


\section{THE LIBRARY}

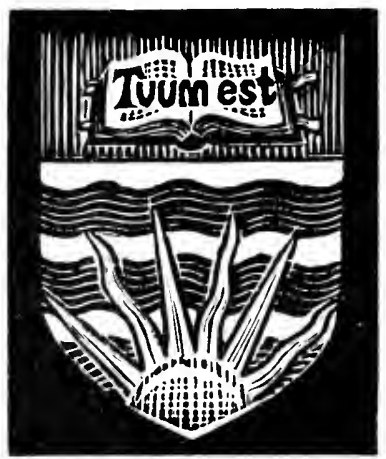

THE UNIVERSITY OF BRITISH COLUMBIA 


\section{Digitized by the Internet Archive in 2010 with funding from University of British Columbia Library}




AMERICAN

\section{DIPLOMATIC QUESTIONS}


Thes $>1 \times 0$. 


\section{AMERICAN}

$J \times 1416.45$

\section{DIPLOMATIC QUESTIONS}

JOHN B. HENDERSON, JR.

Now 17ork

THE MACMILLAN COMPANY

LONDON: MACMILLAN \& CO., LTD.

I 901 
COPYRIGHT, I:HII,

BY THE MACMLLAN COMPANY. 


\section{CONTENTS}

I

THE FUR SEALS AND BERING SEA AWARD

I

Resian and American Claims in Bering Sea . . Page

II

Tile Life History of tile Ftr Seal . • • . . . 10

III

The Beginming of Pelagic Sealing . . . . . . 13

IV

Protests and Diplomatic Corregloninence • . . . 14

r

Tue Paris Award and Regilations. . . . . . 34

VI

EFForts for Monjfication of Regilations . . . . 42

VII

The Present Situatiox +. . . . . . . . . . . 61

I I

THE INTEROCEANIC CANAL PROBLEM

I

History of Canal Schlames. . . . . . . . . 65

II

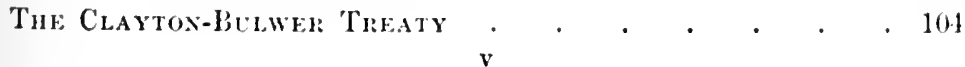


1550-1860-A Decade of Discession . . . . . . 123

IV

Tine Blane-Frelinghuysex-Granville Debates . . . 137

V

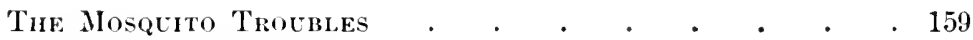

VI

The Hay-Pauncefote Treaty . . . . . . . . 167

\section{VII}

Tile Three Problems. Neutralization . • • . . 176

\section{III}

THE UNITEI STATES AND SAMOA

I

The Islands - People - Government . . . . . 209

II

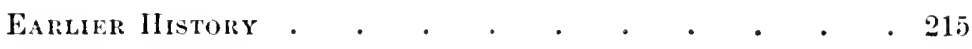

III

Social Coxmitions in Aria - 1581-1589 . . . . . . 219

I

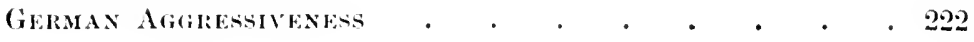

V

The Waimfitox Conferences . . . • • • • . 228

VI

The Reign of Dissexisuns . . . . . . . . . . . 232 
VII

The Berlin Conferface axi Convention . . . . 212

VIII

TrilMPH OF MALietoA . . . . . . . . . 257

IX

The Trial for tue Kingam- Partition of Samoa . . 262

\section{I}

THE MONROE DOCTRINE

INtroduction . $. \quad . \quad . \quad . \quad . \quad . \quad . \quad . \quad . \quad . \quad 289$

I

J Foreign Relations of tile United States from 1783 to 1823994

II

Tile Revolting Spanish Colonies $\quad$ • • • • • • 299

III

$\checkmark$ The Holy Alliaxce . . . . . . . . . . $30 t j$

IV

Framing the Monbof Doctrine . • • • • • . 316

r

Receptuon of the "Doctrine" • . . . . . . . 3:36

VI

Pandma Congligst . . . . . . . . . . 342

VII

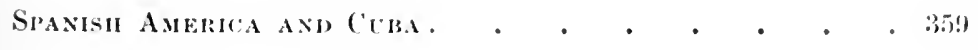




\section{VIII}

PAGE

IX

Ýcatax . . . . . . . . . . . . 385

$X$

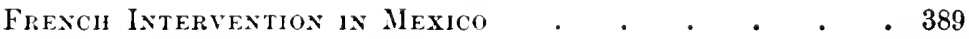

XI

From 1866 To 1896 .

XII

Great Britain and Vexezuela

\section{XIII}

Conclusion

THE NORTHEAST COAST FISHERIES

Introdction . . . . . . . . . . . . . . 451

I

The Innestry . . . . . . . . . . . . . . . 454

II

The Eally Exgilis axd Frexch Fisheries . . . . 459

II I

The farly American Fishemies. . . . . . . 472

IV

From the Auericax Revoluten to 1812 . • . • . 486 
V

PAGE

The Convextion of 1818 . . . . . . . . . 488

VI

1818 то 1854 . $. \quad . \quad . \quad . \quad . \quad . \quad . \quad . \quad 497$

VII

Reciprocity aNi Treaty of 1854 . . . . . . 508

VIII

The Treaty of Washington . . . . . . . . . 513

IX

Retern to Conithons of 1818- Mones Vivend . . . 519

X

Situation is 1901 . $\quad . \quad . \quad . \quad . \quad . \quad . \quad . \quad 526$ 


\section{I}

THE FUR-SEALS AND THE BERING SEA AWARD 



\section{THE FUR-SEALS AND THE BERING SEA AWARD}

Br treaty of March 30, 1867, in consideration of the sum of $\$ 7,200,000$, Russia ceded to the Lnited States all her possessions in North America. 'These included the present territory of Alaska, the Aleutian chain, and some isolated groups of islands in the Bering Sea. The western boundary of the territory so transferred to the United States was deseribed in the first article of the treaty as follows: -

The western limit within which the territories and dominion conveyed, are contained, passe's through a point in Bering's Straits on the parallel of sixty-five degrees thirty minutes north latitude, at its intersection by the mericlian which passes midway between the islands of Krusenstern, or Ignalook, and the island of Ratmanoff, or Noonarbook, and proceeds due north, without limitation, into the same Frozen Ocean. The same westem limit, bginning at the same initial point. proceeds thence in a comrse nearly southwest, through Behring's straits and behring's Sea, so as to pass midway between the northwest point of the island of St. Lawrence and the sontheast point of Cape Choukotski, to the meridian of one humbed and seventy-two west longitude: thence, from the intrisection of that mericlian. in a southwesterly direction, so as to pass midway betwen the island of Atton and the Copper island of the Komondorski complet or group, in the North Pacific Ocean, to the meridian of one hundred and ninetythree degrees west longitule, so as to include in the territory conveyed the whole of the Alentian Islands east of that mericlian.

An unusual example was here presented of a divisional line between two empires passing almost midwa though a great ocean. The boundary in question marks the uestern 
limit within which the territories and dominion conveyed are contained. This terse deseription may be regarded as a shorter and more convenient mode of expression than the separate enumeration of a bewildering number of islands, yet it involved a confusing implication - that Russia intended by these words to convey to the United States, not only all the islands lying east of the imaginary line so designated, but, indeed, the actual sea itself, with full and exclusive dominion over the same. This construction of the intent and purpose of this elause of the treaty, however novel or in ill accord with the usages of nations, gained apparent weight from the fact that through a period of many years Russia had persistently claimed extraordinary rights of navigation and fisheries in Bering Sea, - rights which even at that time were regarded by eivilized nations as beyond the sanction of international law. The important question - had Russia, by her assertions, gained a valid title to the waters of Bering Sea, and then, had the United States really acquired by purchase a dominion over this extensive body of water, or even greater privileges of navigation therein than are enjoyed in common by all nations?formed one of the issues in the Bering Sea arbitration trial, held in Paris, in the spring and summer of 1893.

As early as the year 1800, Russia had established in Alaska a chartered company, with exchusive rights of hunting and fishing in its waters and of trading with its native population. In order better to protect the interests of this flourishing business organization, the Emperor Alexander the First, in 1821, issued an ukase, or proclamation, in the following words: -

Section I. The transaction of commerce, and the pursuit of whaling and fishing, or any other industry on the islands, in the harbors and inlets, and, in general, all along the northwestem ceast of Ameriea from behring strait to the fifty-first parallel of northern latitude, and likewise on the Aleutian Islands and along the eastern coast of Siberia, and on the Kurile Iskands; that is, from Behring strait to the sonthem promontory of the Island of Urup, viz., as far sonth as latitude forty-five tlegrees and fifty 
minntes north, are exclusively reserved to subjects of the Russian Empire.

Sectiox II. Accordingly, no foreign ressel shall be allowed either to put to shore at any of the coasts and islimils unter Russian dominion as specified in the preceding section, or even to approach the same to within a distance of less than one hundred Italian miles. Any vessel contrarening this provision shall be subject to confiscation with her whole cargo.

At the time of the promulgation of this law (1821), the prineiple of absolute freedom of navigation in the open sea was generally reeognized, and no nation could rightfully assert her sovereignty over the ocean further than three marine leagues from her own shores. This distance was considered the average range of a camnon shot. and, therefore, the limit within which a people could protect their marine jurisdiction from the land. Seven years before that time the American commissioners at Ghent had made the attitude of the United States fovermment in this mattel quite clear by their determined opposition to Englands threatened assertion of jurisdiction over the Newfomdland hanks. Alexander the First either considered himself superior to the operation of international law, or he may have reganderl the entire Bering Sea as a elosed sea, or mo clumsum. over which he eould properly exercise sole control, even to the total exclusion of all foreign vessels. The fact that in 1820 the waters of the Bering Sea washed only Russian shores, which, in some respects, snggesterl a closed sea, probably led the Emperor Alexander to regard his assertions of enlarged dominion over the whole or any gart of it as not only just and right, but fully in lieeping with the principles of international law. Bering sea is in reality a vast orean, communicating with the larger Pacific ocean thromgh many channels of great width. It is, indeerl, a part of the greatere oeean, and shomld properly be so comsirlered, being separated from it only by a line of islanels that often lie many miles apart.

The violation of legal principles comerming the extent of marine jurisdiction, made by the Russian Emperor's ukase of 
1821, might have gone unchallenged by the world for many years; for, in those early times, very few merchant vessels had occasion to visit those distant waters, and in general little interest attached to their inhospitable shores; nevertheless, fleets of American whalers lad even before that time found their way north of the Aleutian Islands, following the custom of making annual summer cruises thereabouts in pursuit of whales, which were abundant in the cold waters of the Bering Sea. The Russian restrictions upon navigation in the northern Pacifie Ocean seriously embarrassed those hardy sea-rovers from New Bedford and Nantucket. Through their complaints to the State Department in Washington, an American protest appeared against these Russian assertions of sovereignty over so large an expanse of ocean. Secretary of State John Quincy Adams, in a communication of February 25, 1822, to Mr. Poletica, then Russian Minister at Washington, said:-

I am directed by the President of the United States to inform you that he has seen with surprise, in this edict, the assertion of a territorial daim on the part of Russia, extending to the fiftyfirst degree of north latitude on this continent, and a regulation interlieting to all commereial ressels other than Russian, upon the penalty of seizure and confiseation, the approach upon the high seas within one hundred Italian miles of the shores to which that claim is made to apply. . . . It was expected before any act which should define the boundaries between the United States and Russia on this continent, that the same would have been arranged by treaty between the parties. To exelude the vessels of onr citizens from the shore, beyond the ordinary distance to which the territorial jurisdiction extends, has excited still greater surprise.

Mr. Poletica replied February 28, only three days after the receipt of Mr. Arlams communication:-

... I onght, in the last plaee, to request you to consider, sir, that the Russian possessions in the Pacific Ocean extend, on the northwest eoast of America, from Behring Strait to the fifty-first degree of north latitude, and on the opposite side of A sia, and the islands adjarent, from the same Strait to the forty-fifth degree. The extent of sea, of which these possessions form the 
limits, comprehends all the conditions which are ordinarily attached to shut seus (mers fermess), and the Russian Government might consequently jurlge itself authorized to exereise ujon this sea the right of sovereignty, and espeeially that of entirely interdicting the entrance of foreigners. But it preferred only asserting its essential rights, without taking any advantage of localities.

It thus becane evident that the Emperor considered as belonging to him alone, not only the Bering Seal, but also, as a closed sea, all that portion of the Pateific Ocean which lies nortl of latitude $51^{\circ}$; and that he further considered it a generous aet on his part to leave all his imperial domain of sea, exeept a mere humcled-mile belt abont its shores, free to the world for its commerce and navigation. Mr. Adans replied to Mr. Poletica's note on Mareh :30:-

This pretension is to be considered not only with reference to the question of territorial right, but also to that mohibition to the vessels of other nations, including those of the Uniterl states, to approach within one hundred Italian miles of the coasts. From the period of the existence of the Uniterl States as an independent nation, their vessels have freely navigated those seas, and the right to navigate them is a part of that inclependence. . . .

The Russian kmperor's position, in asserting mar dausum over the Pacific Ocean as bounded by his own possessions on either side, was made absurd by Mr. Aclans" simple statement that "the distance from shore to shore on this sea in latitude $51^{\circ}$ north is not less than 90 degrees of longitude, or four thousand miles."

England had no important interests direetly violated by the Russian ukase of 1821 , but she possessed territory vaguely and indefinitely bomded in the northwest part of North Ameriea, and she detected in linssian chaims of enlarged jurisdiction over so great an extent of sea a precerlent that might in the future operate ardversely to her own interests. Her protest, which was quite as vigorols as the one from Washington, is fomel in the Inke of Wellington's letter of November 28, 18\%2, to the Russiun Ambassarlor at London :- 
... The second ground on which we object to the ukase is that His Imperial Majesty thereby exclucles from a certain considerable extent of the open sea vessels of other nations. We contend that the assmuption of this power is contrary to the law of nations; and we camnot found a negotiation upon a paper in which it is again broadly asserted. We contend that no power whatever can exclude another from the use of the open sea; a power can exclude itself from the navigation of a certain coast, sea, etc., by its own act or engagement, but it cannot by right be excluded by another. This we consider as the law of nations. . .

These protests from the eagle and the lion succeeded in enlightening the bear, for Russia immediately began to recognize the feebleness of her asserted right to eontrol the North Pacific Ocean. After a short period of correspondence, Russia yielded all these exaggerated pretensions and made a treaty with the United States (April 17, 1824), in which it was agreed:-

... that, in any part of the Great Ocean, commonly called the Pacific Ocean, or south Sea, the respective citizens or subjects of the high contracting powers shall be neither disturbed nor restrained, either in narigation or in fishing, or in the power of resorting to the coasts, upon points which may not already have been occupied, for the purpose of traling with the natives, saving always the restrictions and conditions determined by the following articles.

The "conditions and restrictions" referred to illicit trading and the formation of settlements.

By the fourth article of this convention Russia granted to United States vessels, for a period of ten years, the privilege of frequenting " without any hindrance whatever the interior seas, gulfs, harbors, and creeks upon the eoasts mentioned in the preeeding article for the purpose of tishing and trading with the natives of the country." By this treaty also Russian possessions in North America were limited on the south by the $54^{\circ} 40^{\prime}$ parallel of latitude.

When the stipulated period of ten years had elapsed, the United States sought to renew the privilege of trading with the natives of Alaska and of navigating the inner waters of 
the coast north of latitude $54^{\circ} 40^{\prime}$. 'This faror liussia olstinately refused to grant, although the remining articles of the treaty continued always in force. It seems to have been suspected in the Lnited States that Riussia would consider her jurisdietion over a hundred-mile marine belt reëstablished by the expiration of the fourth article of her treaty, notwithstanding the fact that that part of the treaty surendering all elaims to exclusive navigation of the Great Ocean or South Sea remained operative. John Adims at the time expressed himself in his diary as able to down Riussian argument, but unable to silence Russian camnon. Anerican vessels eontinued, however, to navigite the Bering Sea with perfect freedom, and Russia never again actually asserted the right of mare clausum over that body of water, nor alparently considered it otherwise than as a part of the great l'ucitie Ocean, or" "South Sea."

Such, then, was the situation in 1867 , when the Cnited States purehased the territory of Aliskia and came into possession of all Russian rights of trule and navigation in Bering Sea. Beyond its several thousand miles of coast line, this great territory was practically a terra incogneitu to all but a few adventurous exploress and traplers who had penetrated its vast wilderness. Its purelase was largely brought abont through a friendly feeling on the part of the Enited States to meet half-way liussiats desile to dispose of her American possessions, while at the sime time she hoped rather than expeeted that the future might develop valuable natural resourees in this far-away rechion, when civilization, in its westward progress, should gain its shores and ascend its great river.

The description of the western boundary of the cession, already referred to, led to some ambiguity, even at that diy, as to what extent of jurisdietion the United sitates might rightfully claim over the waters of Bering Sea. The question whether Russia intended to eonvey, or even could convey, within the limits of law, dominion over the waters of Bering Sea, outside the ordinarily reeognized three-mile limit of marine jurisdiction, did not at once assume great importance. 
In framing laws for the territory the following year (1868), Congress did not elearly signify the extent to which the United States elaimed jurisdiction in Bering Sea, but simply enacted that the "laws of the United States relating to customs, commerce, and navigation, are extended to and over all the manland, islands, and waters of the territory eeded to the United States by the Emperor of Russia ...", and further enacted that, "no person shall kill any otter, mink, martin, sable, or fur-seal, or other fur-bearing animals within the limits of Alaska teritory, or in the unters thereof. . . ."

Thus the Uniter States asserted its dominion over Alaska and the waters thereof, the phrase "waters thereof" unfortunately being left to the various interpretations of public opinion, as shaped or fashioned by future national interests. This ambiguity of expression was destined finally to play an important part in a serions international complieation.

Two great industries at once developed in Alaska, - the salmon fisheries and the eapture of fur-bearing animals. Of these by far the most important was the pursuit of sealing. 'The fur of seals is exceptionally fine, and being always in demand, has eommanded high priees in the markets of the world.

The fur-seal, known to zoologists as Callorhinus ursinu, resembles biologieally a form of marine bear, and should not be confomnded with the true seal of om Pacific coast, from which it differs in several respeets.

There are three herds of these marine creatures that annually visit the islands of the North Paeifie. These herds do not mingle, hut have each their own particular breedinggromm, to which they ammally repair. One herd inhabits Robin Island, in the Okhotsk Seat one the Commander Islands which lie on the Russian sile of Bering Sea; and the thirel (in point of numbers the most important, and known as the "American herd" in contrarlistinction to the other two, or "Asiatic herds"), inhabits the Pribyloff Islands - a gromp of small islands on the Ameriean sidte of Bering Sea. To these islands the soals resort in great numbers during the latter part of Maly or the first part of June. The males 
arrive first, and taking positions along the shore, each preempts, so to speak, a certain space saered to hinself, and there awaits the coming of the females. As they appear, arriving day by day from the sea, great confusion reigns along the shores of the rookeries. Desperate struggles for the females follow, and when a degree of peace is restored in the course of a few days, there results an establishment of many approximately permanent polygamous family grouls more or less densely erowded along the littoral of the islands. The younger male seals, known as "bachelors," are unable to eope with the older and stronger ones in their fierce contests for possession of the females. They retire and lierd together, a discontented throng, at some distance from their jealous elders. The old males keep eonstantly on the alert to protect their homesteals from the intrusion of other males, or to prevent the members of their own households from deserting them. So jealoms are they of their "wives" that they" dare not venture away from their positions on shore during the entire breeding season, not even in search of food. The females, soon after landing, give birth to their young, each bearing a single "pup." These helpless little ereatures are earefully nurtured by their mothers mith they learn to swim and ean shift for themselves. The females in seareh of ford make frequent excursions to sea during the breeding season, often going as far as two lundred miles from the island rookeries, at which distance they have been frequently observed disporting themselves, or quietly sleeping unon the surface of the water. 'They always retmrn to the care of their young and to the protection of their watehful lords and masters.

Thus the seals constitnting the "Ameriean herd" live upon the Pribyloff rookeries forn the time of their ammal coming in May and June until the late antmmu, when the forees of Boreas besiege the islands and the northern soris beeome tempestuous. The seals then slip into the surf forl' their long amunal swim to the sonth. They migrate leisurely through various passes hetween the Alontiun Islands. thence southward in the open Pacifie to about latiturle :5\% (opposite San Franeisco), then making a long sweep inland they 
follow a northerly course along the American coast. No landing is made until the following May or June, when, in obedience to their instinets, they once more return to their common rendezvous on the Pribyloff Islands. The life habits of the seals of the Asiatic herds are in all respects identical, their winter migrations being south along the Asiatic coast to the neighborhood of Japan.

Under the organized sealing industry of the ehartered American Company, a fixed number of " baehelors " only were killerl, the fenale seals being left unmolested along with old males, the pelts of the latter being quite useless for commereial purposes.

Shortly after the diseovery of the Pribyloff Islands in 1786, the number of fur-seals annually eaptured at the rookeries has been variously estimated among the millions. The mnlimited slaughter of the seals and the consequent danger of their extinetion obliged the Russian Govermment to enact prohibitory laws from time to time for their protection. At the time of the Ameriean aequisition of Alaska, the Russian-Ameriean (ompany (chartered by Russia and which enjoyed the monopoly of the Alaskan trade) was shipping annually to New York and London upon an average forty thousand skins. Notwithstanding this seemingly large yearly capture, seals were vastly inereasing in numbers.

In 1868-69 attention at Wrashington was espeeially direeted to the great value of the sealing inchustry, and also to the wisclom of taking active measures to prevent a wholesale slanghter of seals by rival companies that quickly oceupied the field when the Russian company went out of existence. Cnmindful of the future and eager for immediate gain, these irresponsible lunters sought to kill the goose for her golden eggs. Aceordingly the islands of the Pribyloff group were declared to be a governmental reserve, and by virtue of an Aet of Congress, July 1. 1870, the killing of "any fur-seal upon the islands of St. Panl and St. George or in the waters adjacent thereto, excepting during the months of .June, July, September, and Oetober in each year" was prohibited. It was also dechared mulawful to kill such seals at any time by the 
use of fire-arms, or by any means which tended to drive them away from those islands. The Secretary of the Treasury was further empowered to lease to proper and responsible parties, for a period of twenty years, "the right to engage in the business of taking fur-seals on the islands of St. George and St. Paul"; Secretary Boutwell therempon granted to the Alaska Commercial Company the sole privilege of eapturing seals.upon those islands. The company aecording to the terms of this lease was obliged to pay annually into the Treasury of the United States the sum of $\$ 55,000$, besides the sum of 6.2 eents for each skin taken. Under proper restrietions such eare was taken by the company in killing only the "bachelors," - the two to four year old males, - that the number of seals sojourning upon the islands each year showed no signs of diminution, despite the fact that the company was authorized to take anmully one hundred thousand pelts. During the twenty years' operations of the Mlaska Commercial Company in the Pribyloff Islands, the prices of sealskins advaneed from $\$ 2.50$ in 18158 to $\$ 30$ in 1890 . At the expriration of its lease, the eompany had paid into the 'Treasury of the United States the large sum of $\$ 5,956,065.67$.

'The contract proved to be an exceedingly profitable one for' the eompany as well, and the reports of its suceess soon spread far and wide. Expeditions were fitted ont by shipowners in British Columbia, in Iawaii, and even in Australia, to engage in the hunt for seals. As the Alaska ('ompany' was protected in its monopoly of seal catching on the islands of St. Paul and St. George of the Pribyloff group, and as the few Russian islands, to which the other seal herds repaired, were similarly proteeted ly Rinssian laws, the methor followed by these free rovers was to drift about in the ogen waters of the sea, of ten in the neighborhood of the pasises between the Alentian Islands, and thus intercepting the seals in their anmual migration north or sonth, capture them in the water. This method of attack was execerlingly destructive to the herd. It was impossible that a discrimination could be made between the males and females, and in lilling the females a double slanghter was effected. besides this, 
many of the animals were wounded and lost, and it was apprehended by the American sealer's that the continuation of the practice of pelagic sealing would soon result in the extermination of the speeies.

The Collector of the port at San Franciseo, Mr. Phelps, having been apprised of the dangers threatening the industry so comfortably prospering in St. Paul and St. George, wrote to the Secretary of the Treasury in $187^{2}$, asking permission to despatch a revenue cutter to the scene of action for the purpose of preventing pelagic sealing. Mr. Boutwell, the Secretary of the Treasury, in reply said, "I do not see that the United States would have the jurisdiction or power to drive off parties going up there for that purpose unless they made such attem,ts within a marine league of the shores." This was the first official expression touching upon the doubtful words, "or in the waters thereof." It elearly indieated that the government in Washington at that date interpreted those words of the Aet of Congress of 1868 to mean the ordinary three miles of marine jurisdiction. Destruetive to American interests as pelagie sealing might prove to be, the United States in 1872 did not see its way elem in preventing it by foree; aceorlingly no revenue cutter was sent to Bering Sea.

Each sneeeding year witnessed an increase in pelagic sealing. New vessels were being fitted out every season to engage in the exceedingly profitable oeeupation of seal hunting in and about the passes of the Aleutian Islands, and frequent ineursions were made for the same purpose into Bering Sea. Contimed protests from the Alaska Company found their way to Washington, and evidence of the gradual diminution of the herd through the wanton slaughter of seals by the pelagic hunters was repeatedly furnished to the anthorities of the Treasury Department. It soon beeme distressingly apparent that unless seal hunting in the open sea could be prevented, the total extinction of the animals was a question of only a few years.

Now if the United States could establish a elaim of mare clausum over Bering Sea, the problem of ways and means of preventing pelagie sealing in Bering Sea would be solved. 
Could the same exelusive dominion be established over that sea that the Enited States exercised orer ('hesapeake Bay or Long Island Sound, her right to control its waters woukd be complete. Then, with Revenue eutters on guard during the season of the migration of the seals, maranders could be warned away or their vessels seizerl and condemmed under the statute law's of 1868 and 1870 (Supros). The temptation to set up a elaim of mare clausum wats great.

In 1881, I), A. d'Ancona. Collector of the Port at Sin Francisco, disturbed by reports of sealing expeditions which were being fitted out in British Cohmbia. wrote to the Treasury Department (as had his predecessor. Mr. Phelps, in 1872), asking for more definite information regarding the extent of Ameriean dominion in Bering Sea. The reply of Mr. French, Acting Seeretary of the Treasury, March 1:, 1881, marks a complete reversal of the position assumed by the government in 1872 , as expressed in Mr. Bontwells letter already referred to. Mr. French wrote as follows:-

You inquire into the interpretation of the terms "waters thereof" and "waters adjacent thereto." as used in the law, and how far the juriselietion of the Cnited states is to be mules"stuod as extending.

Presuming your inquiry to relate more pepecially to the waters of western Alaska, you are informen that the treaty with liussia of Mareh 30, 1sio, by which the terretory of Mlaska wals cented to the United States, defines the boundialy of the territory so resterl. The treaty is found on pages bit to bi: of the volume of treaties of the Revised statutes. It will be sespll the peffom that the limit of the ression extends from a line starting from the Aretie oram

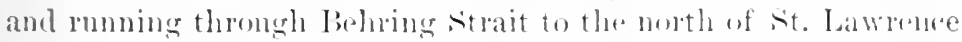
Istands. The line lons then in a soutlowesterty direetion, sols as pass midway between the istand of 1 ttom and (opper istand of

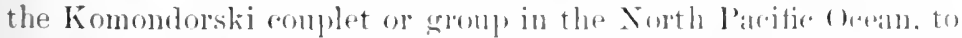
meridian of 19.3 of west lomeritulte. All the motes within thet

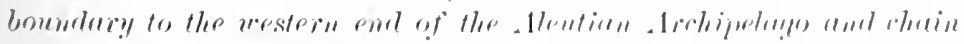

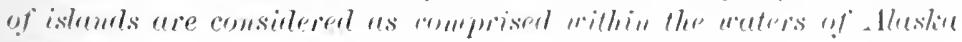
territory."

Thus it will be seen that in order to grain the right to protect seals while in Bering Sea, the United states yiekded to 
the temptation and assumed jurisdiction over the entire stretch of its waters (east of the imaginary line designated as the boundary line of Alaska), claiming it to be a mer fermée, or closed sea, in the same category indeed as any coastwise harbor, notwithstanding the fact that Bering Sea is of vastly greater geographical extent than any harbor. While believing herself justified in so doing, the United States made no actual captures of sealing vessels at that time. Pelagic sealing nevertheless continned. In $1886 \mathrm{Mr}$. Manning, Secretary of the Treasury, addressed a letter to Collector Hagan of the port of San Francisco, affirming the ruling of Acting Secretary French, as follows :-

I transmit herewith for your information a copy of a letter addressed by the Department on the 12th of March, 1881, to D. A. d'Ancona, concerning the juristiction of the United States in the waters of the territory of Alaska and the prevention of the killing of fur-seals and other fur-hearing animals within such areas as prescribed by chapter 3 , title $2: 3$, of the Revised Statutes. The attention of your prerlecessor in office was called to the subject on the the dyril, 1ss1. This communieation is addressed to you, inasmuch as it is understood that certain parties at your port contemplate the fitting ont of expeditions to kill fur-seals in these waters. You are requested to give due publicity to such letters, in order that such parties may be informed of the construction placed hy this Department upon the provision of law referred to."

Fortified by this further statement of the government's position regarding United States control of the waters of Bering Sea, the Treasury officials on the Pacific coast determined to take a stand against further poaching in what had been declared by their ehief to be American waters. Accordingly the United States revenue cutter Corwin proceeded to Bering Sua, and in August of that year (1886) seized three British vessels, - the Omeard, Carolina, and Thornton, - all being at the time of their seizure considerably more than three miles from shore. They were engaged as alleged, in capturing seals in violation of Section 1956 of the Revised Statutes of the United States, which made it unlawful to kill seals "within the limits of Alaska territory or in the uaters thereof." These three vessels were taken to Sitka, tried 
before the District Court of Alaska, their masters found guilt $y$, and the vessels were accordingly confiscated and condemmed to be sold. In the trial of these vessels their owners advanced the following argument in defence of their rights :-

The first question then to be decider is what is meant by the "waters thereof." If the defendants are bound by the treaty between the United States and Russia ceding Alaska to the United states, then it appears that Russia in 18:2 claimed absolute territorial sovereignty over the Behring Sea, and purported to conver practically one-half of that sea to the United States. But are the defenchants, as men belonging to a countrr on friendly terms with the United States, bound br this assertion of Russia:" And ean the United states claim that the treaty eonvers to them any greater right than Russia herself prossessed in these water's?" In other words, the mere assertion of a right contrary to the eomity of nations can confer on the grantees no rights in excess of those recognized by the laws of nations.

It also appears that the Enited states in claiming sorereignty over the Behring Sea is claiming something beyond the well-reconnized law of nations, and bases her claim upon the pretensions of Russia, which were successfully repmliated by loth Great britain and the United States. A treaty is valid and binding between the parties to it, but it camnot affect others who are not parties to it. It is an agreement between nations, and womld be construed in law like an agreement between inchivhuals. Great Britain was no party to it and therefore is not bound ly its terms.

The American position, on the other hand, mat well be presented in the following words taken from the charge to the jury, made by Judge Dawson of the District Court of Alaska in the libel proceeding against these ressels:-

All the waters witlin the bomulary set forth in this treaty to the western end of the Dentian arelipwago and rhain of islinds are to he considered as comprisen within the waters of Mlaska, and all the penalties prescriber by law atatinst the killing of fonbearing animals must, therefore, attarle against any violation of law within the limits herestofore describerl.

If, therefore, the jury believe from the evidenee that the defourlants by themselves or in conjunetion with other's did, on on about the time chargorl in the information, kill suly oftor, mink, mastm, sable, or fur-seal, or other fur-baring amimal or aminals, on the 
shores of Alaska or in the Behring Sea, east of the one hundred and ninety-third degree of west longitude, the jury should find the defendants guilty.

In delivering this eharge to the jury, Judge Dawson acted under the advice of the Attorney General in Washington, and the United States was now fully committed to the policy of maintaining at any eost its position of absolute ownership of the Bering Sea east of the line deseribed in the treaty for the cession of Alaska as marling the western boundary of that dominion. The seizure and condemnation of these three British vessels were immediately followed by a formal protest from the British Minister in Washington, Sir Lionel SackvilleWest (letter of October 21, 1886).

An issue, accordingly, was squarely presented for future diplomatic negotiations. Pending further disenssion, President Cleveland very properly ordered all proceedings against the three vessels stopped. The following summer, however, the United States revenue entter Richarl Rush arrested more British sealing vessels, - the W. P. Sawyard, the Dolphin, the Grace, the Anna Beck, and the Alfied Adams. These, like the vessels eaptured the year before, were all taken outside the ordinary zone of marine jurisdiction, and their seizure intensified the feelings of resentment against the United States that had already been manifested in Canada after the condemnation proceedings of the previous year. Another British protest quickly follower (Sackville-West to Bayard, October 12 and 19, 1887), and the question, now fairly lannehed into the sea of diplomatic discussion, became the subjeet of a spirited eorrespondenee.

In the meantime, however, Seeretary of State Bayard had made an attempt to find a settlement of the difficulty in an international agreement for the regulation of the fur-seal industry. Notes were addressed to Great Britain, France, Cremany, Russia, Japan, Norway and Sweden, inviting those powers to "enter into such arrangement with the Govemment of the [nited States as will prevent the eitizens of either eountry from killing the seals in bering Sea at sueh times and places and by such methods as at present are pursued, and 
which threaten the speedy extermination of those animals and consequent loss to mankind." It was ordered that no seizures of sealing vessels be mate during the season of 1888 , and the negotiations for international agreement seemed promising for a suecessful issue, when, in June of that year, the Marquis of Salisbury annomeed lis intention of withdrawing from the proceeding. This was owing to a request received by him from the Canadian government to await the completion of a memorandum it was preparing upon the subject of Ameriean and Canadian interests in Bering Sea. As England's coöperation in any seheme of settlement of the difficulty was absolutely neeessary, the negotiations for an international agreement, so happily begun, were unfortunately abandoned.

During the autumn of 1888 , a careful examination of the "Bering Sea Question" was undertaken by a House eommittee, and an attempt was also made to obtain from Congress a revision of the laws of 1868 and 1870 relating to Alaskan fisheries, that should define more strictly the meaning of the phrase employed in the old statutes, - " Alaska and the water's thereof." There was lacking an unamimity of opinion in Congress regarding the right of the Lnited States to prevent pelagic sealing by making cattures of offending foreign vessels when operating outside the ordinarily accepted threemile limit of marine jurisdiction. The press of the comntry, and perhaps the greater weight of popular sentiment, inclined toward the belief that a legal sanction eould he fomnd to jistify the seizures of these British vessels and Judge Dawson's decision was generally indorsed. Nevertheless, an imitating louht as to the authority of the United States to maintain jurisdietional claims in the Bering sea haunted the Senate corridors. The extent and genelal configuration of that body of water seemed to prechure the idea of a closed sea. - especially in the light of the well-known fact that the morlern tendency of international usage was to restrict the seope of marine jurisdiction. All agreed that pelagic sealing was a pernicions practice and highly detrimental to American interests, and although the attempt to stop it by force seemed to many a 
questionable proceeding, yet the policy, _ "when in doubt, err on the side of your country's cause," - prevailed. At all events, any definite expression of Congress defining the vague words, "or in the waters thereof," was most desirable.

The House passed a bill declaring that: "That section 1956 of the Revised Statutes of the United States was intended to include and apply, and is hereby declared to apply to all the waters of Bering Sea and Alaska embraced within the boundary lines mentioned and described in the Treaty with Russia, dated March 30, 1867, by which the territory of Alaski was ceded to the United States. . . " Senator Sherman, Chairman of the Committee of Foreign Relations, objected to the measure on the grounds that it "involved serious matters of international law . . . and ought to be disagreed to and abandoned, and considered more carefully hereafter." The House resolution was, however, amended and passed the Senate March 22, 1880, as follows:-

"That Section 1956 of the Revised Statutes of the United States is hereby declared to include, and apply to, all the Dominion of the Lnited States in the waters of Bering Sea."

The measure then, as finally passed, was no more explicit in its object of determining the extent of United States jurisdiction in Bering Sea waters than was the law of 1868 , for what the State Department had especially called for and desired was a definition by Congress of the very words "Dominion of the United States in the water's of Bering Sea."

In March, 1889, the Iarrison administration fell heir to the responsibilities of maintaining the American position in this controversy. Ex-Secretary Foster, in the North American Review of December, 1895 , thus clearly states the situation as it existed at that time:-

Three courses were open to President Harrison, and one of them must be chosen without further delay. First: He could abandon the claim of exclusive jurisdiction over Bering Sea or protection of the seals beyond the three-mile limit, recele from the action of his predecessor as to seizure of British vessels and pay the damages claimed therefor. Such a eourse wonld have met with the general disayproval of the nation, and would have been 
denounced by his political opponents as a base hetrayal of the country's interests. Second: He could have rejected the arenments and protests of the British Government, and continnet the policy initiated by his prederessor in the seizure of all liritish ressels engaged in pelagic sealing in liering sea. Jut this course had already been proposed to P'resident ('leveland and decided to be improper. The Hon. E. J. Phelps, who, as Minister to (ireat Britain, had conducted the negotiations with Lord sislisbury growing ont of the seizures of 1886 and 1S87, in a lengthy despatch to Secretary liayare, reviewing the concluct of c'anala which had prevented an adjustment once acopted by Lord salisbury, made the following recommendation: " L noler these circumstances, the Govermment of the Cnited States must, in my olinion, either submit to have these valuable fisheries destroyed or must take measures to prevent their destruction by apturing the vessels employed in it. lietween these two alternatives it does not appear to me there should be the slichlest hesitation. . . . I earnestly recommend, therefore, that the vessels that have been seized while engaged in this business be finmly lield, and that measures be taken to capture and hold every one hereafter found concerned in it. . . There need be no four that a resolute stand on this subject will at once put an end to the mischief complained of." But this recommendation of Ml. I'leels was not approved by Mr. Bayard, who was nuwilling to arlopt a course which might bring about a rupture with (ireat Britain, the probable ontcome of which would have been an armed couflict. In view of this decision and the state of publie sentiment, with a prevailing opinion in a large part of the press and with public men that the attitude of the government was leally momol, and that the interests involved did not mule the cirromstaners stated justify the hazard of a great war between these two English-speaking nations, the adoption of this second alternative by l'esirlent Harrison would have been the height of malness. The only remaining alternative was arlitration.

The idea of arbitration came only after a desperate attempt through a diplomatie correspondence with the british foreign office to establish the legality of the Ameriean position and to justify United States seizures of the British vessels that had alrealy been made on the high seas.

No arrangements having heen marle to abandon the sealing operations pending a final settlement of the question, several captures of British sehooners were effected in the summer 
season of 1889, and the friendly relations between England and the United States became very much strained. The British Government resolved to take a firmer stand against further molestation of their subjects engaged in catching seals upon what they contended were the high seas, and before the summer of 1890 opened, it presented through the note of Sir Julian Pauncefote of June 14, 1890, the following vigorous protest:-

The undersigned, Her Britamnic Majesty's en roy extraordinary and minister plenipotentiary to the United States of Ameriea, has the honor, by instruction of his government, to make to the Hon. James G. IBlaine, Secretary of State of the United States, the following communication:-

Her Britannic Majesty's Govermment have learned with great concern, from notices which have appeared in the press, and the general accuracy of which has been confirmed by Mr. Blaine's statements to the undersigned, that the Government of the Unitel States have issned instructions to their revenue cruisers about to be despatched to Behring Sea. under which the vessels of British subjects will again be exposed, in the proseention of their legitimate industry on the high seas, to mlawful interference at the hands of American ofticers.

Her Britumic Majesty's Government are anxious to eoöperate to the fullest extent of their power with the Government of the United States in such measures as may be found to be expedient for the protection of the seal fisheries. They are at the present moment engaged in examining, in eoneert with the Government of the United States, the best method of arriving at an agreement upon this point. But they eannot admit the riglit of the United States of their own sole motion to restrict for this purpose the freedom of navigation of Behring Sea, which the United States have themselves in former years convincingly and successfully vindicated, nor to enforee their municipal legislation against British vessels on the high seas beyond the limits of their territorial jurisdietion.

Her Britamie Najesty's Govemment are therefore mable to pass over withent noticr the public announcement of an intention on the part of the Government of the United States to renew the acts of interference with British ressels navigating outsicle the territorial waters of the United States, of which they have previously had to complain. 
The undersigned is in consequence instructed formally to protest against such interference, and to declare that Her Britannic Majesty's Government must hold the Govermment of the ['niter] States responsible for the consequences that may ensue from ants which are contrary to the established principles of international law.

Mr. Blaine, the Seeretary of State, hat in the meanwhile entered upon a lively eorrespondence with Lord Salisbury in defence of the American case. Every argument that could be brought to bear upon the subject in support of the American position was marshalled by this brilliant statesman in opposition to the English contention of a full legal right to catch seals in the Bering Sea, or indeed in any other sea not mer fermés outside of the three-mile limit from shore.

Casting aside for the time all elaims to mare clausum, Mr. Blaine urged that, "In the opinion of the President, the Canadian vessels arrested and detained in the Behring Sea were engaged in a pursuit that was in itself controlumos mores, a pursuit which of necessity involves a serious and permanent injury to the rights of the Goverument and people of the United States." In support of this argument he reviewed the history of sealing, alleging that "Those fisheries had been exchsively eontrolled by the ( iovernment of Russia, without interference and withont question, from their original discovery until the cession of Mlaskat to the Cnited States in 1867. From 1867 to 1886 the possession in which Rusidit had been undisturbed was enjoyed ly this government also. There was no interruption and no intrusion from any somree. Vessels from other mations passing from time to time throngl Behring Sea to the Aretic Ocean in pursut of whales hart always alsstained from taking part in the eapture of seals. This uniform avoldance of all attempts to take firl-seal in those waters latl been a constant recosnition of the right held and exereised first ly linsia and sulseguently by this Government." He lwelt with partienlat emphasis upon the destructive character of pelagic sealing. ." l'he killing of seals in the open sea involves the destruction of the female 
in common with the male. 'The slaughter of the female seal is reckoned as an immediate loss of three seals, besides the future loss of the whole number which the bearing seal may produce in the successive years of life. The destruction which results from killing seals in the open sea proceeds, therefore, by a ratio which eonstantly and rapidly inereases, and insures the total extermination of the species within a very brief period. It has thus beeome known that the only proper tine for the slanghter of seals is at the season when they betake themselves to the land, because the land is the only place where the necessary cliscrimination ean be made as to the age and sex of the seal. It would seem, then, by fair reasoning, that nations not possessing the territory upon which seals can increase their numbers by natural growth, and thus afford an annual supply of skins for the use of mankind, should refrain from the slaughter in open sea, where the destruction of the species is sme and swift."

"The entire business," he continued, "was then (before 1889 ) condncted peacefully, lawfully, and profitably - profitably to the United States, for the rental was yielding a moderate interest on the large sum which this government had paid for Alaska, including the rights now at issue; profitably to the Alaskan Company, which, under governmental direetion and restrietion, had given unwearied pains to the care and development of the fisheries; profitably to the Aleuts, who were reeeiving a fair peemiary reward for their labors, and were elevater from semi-savagery to civilization and to the enjoyment of schools and churches provided for their benefit by the government of the United States; and, last of all, profitably to a large body of English laborers who had constant employment and received good wages." Led on by the impetus of his own reasoning, he attempted to set up a preseriptive right aequired ly Russia through the acquieseence of all nations in her large elaim of jurisclietion over Bering Sea. He asked, "Whence did the ships of Canada derive the right to do in 1886 that which they had refrained from doing for more than ninety years? Upon what grounds did Her Majesty's Govermment defend in the year 1886 a course of 
conduct in the Behring Sea which she had carefully avoider ever since the diseovery of that sea? By what reasoning did Her Majesty's Govermment conelude that an act may be committed with impunity against the rights of the United States which had never been attempted against the same rights when held by the Russian Empire?" T'o justify further the Ameriean assertion of right in this ease to seize foreign vessels, when outside the three-mile limit and engaged in the pernicions practice of pelagic sealing. he called Lord Salisbury's at tention to parallel cases where England asserted the same puivileges. "It is doubtful whether Her Majesty's Government would abide by this rule if the attempt were male to interfere with the pearl fisheries of Ceylon, which extend more than twenty miles from the shore line, and have been enjoyed by England without molestation ever since their acquisition. . . . Nor is it creditable that modes of fishing on the Giand Banks, altogether practicable but highly destructive, would be justified or even permitted by Great Britain on the plea that the vicious acts were committed more than three miles from shore." No laws of the sea or land, however supported by the approval of nations, should be used to protect acts in themselves vicious or harmful to the world's best interest. To quote again: "In the julgment of this government the law of the sea is not lawlessness. Nor can the law of the sea and the liberty which it confer's and which it protects, be perverted to justify acts which are immoral in themselves, which inevitably tend to results against the interests and against the welfare of mankind. One step beyond that which Her Majesty's Govermment has taken in this contention, and piracy finds its justification."

In reply to Mr. Bhaine's argument, Lord Salishury, in behalf of England's position, stontly maintained that in times of peace no nation was privileged to seize and search upon the high seas the private vessel of a fliendly nation, save upon the suspicion of piracy, or in pursuance of some special agreement. Continuing: " liut Iler Majesty's (iovermment must question whether this pursuit can of itself be regarded as contra bonos mores, unless and until, for special reasons, it 
has been agreed by international arrangement to forbid it. Fur-seals are indisputably animals ferce nature, and these have miversally been regarded by jurists as res mullius until they are eaught; no person, therefore, can have property in them until he has actually reduced them into possession by eapture. It requires something more than a mere declaration that the govermment or citizens of the United States, or even other comntries interested in the seal trarle, are losers by a certain course of pruceeding, to render that course an immoral one. Her Majesty's Govermment would deeply regret that the pursuit of fur-seals on the high seas by British ressels should involve even the slightest injury to the people of the United States. If the ease be proved, they will be ready to consicler what measures can be properly taken for the remedy of such injury, but they would be unable on that ground to depart from a prineiple on which free commerce on the ligh seas dejends.'

In answer to Mlr. Blaine's contention that Russia had gained a prescriptive right, through her exelusive control of the Bering Sea fisheries. from the discovery of Alaska until 1867 , and that the United States had since that date come into possession of, and had contimued to enjoy, these same exchusive rights (thereby establishing more firmly her own prescriptive title), Lord Salisbury referred to the numerous American and English official protests (already mentioned supra), against the early Russian assumptions in Bering Sea. Ile quoted as well the words of many prominent Ameriean statesmen, that had been nttered in condemnation of Russia's illegal claims over the high seas in excess of the ordinary three-nile limit of marne jurisdietion. In further refutation of Mr. Blaine's argument, he furnished a long list of British vessels that hal been engaged in the pursuit of sealing in Bering Sea since the aequisition of Alaska by the Inited States. To Mr. Blaine's assertion that "The F'resident is persualed that all friendly nations will concede to the United States the same rights and privileges on the lands and in the waters of Alaska which the same friendly nations always conceded to the Empire of Russia" - he frankly 
replied: "Iler Majesty"s Government have no difficulty in making suel a concession. In strict aceord with the views which, previous to the present controversy, were consistently and successfully maintained by the United States, they have, whenever occasion arose, opposed all claims to exclusive privileges in the non-territorial waters of Behring Sea. The rights they have demanded have been those of free navigation and fishing in waters which, previous to their own acquisition of Alaska, the United States declared to be free and open to all foreign vessels."

"That is the extent of their present contention and they trust that, on consideration of the arguments now presented to them, the United States will reeognize its justice and moderation."

Not in the least disconcerted by these arguments from London, nor by Lord Salisbury's seemingly clear exposition of the prineiples of international law touching the eise, Mr. Blaine again entered the lists with his adroit pen. IJe critically reviewed the history of Russian and American claims in the Bering Sea, and by an ingenions aromment to substantiate his eontention of a prescriptive right in the Lnited States to control the waters of bering Seil, he endeavored to prove that the protests of John Quiney Arams, and of other American statesmen referred to by Lord Salisbury, against the Russian claims of the ukase of 1821 , were direeted, not against Russian claims in Bering Sea proper, lnt only against the Russian assertions to exclusive juristlietion from Bering Strait along

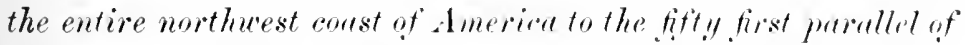
latitude. "Against this larger claim of autlority," he urgerl, (viz., extending farther south on the Ameriean eoast to the $51^{\circ}$ north latitude), "Mr. Adams vigoromsly protested." Mr. Blaine, therefore, drew a distinction between the "Bering Sea," as such, and the "Pateifie Ocean," maintaining that the Inited States had never oplosed hy word or deed Russia's claim to exclusive jurisdiction north of the Aleutian Islands, i.e. the Bering Seal, hut hard only denied Russia's right to exercise such control of the waters sonth of the Aleutian Istands, i.e. the Pacific Ocean, and as expressed 
in the ukase of 1821 by the words, "All along the northwest coast of Ameriea, from Bering Strait to the 51st parallel of latitude." IJe endeavored further to show that the English protests against Russian sovereignty over the Paeifie Ocean were made with a similar intention and meaning, and therefore coneluded, - Why should not the United States enjoy the same exclusive jurisdiction over the waters of Bering Sea, that Russia had asserted and maintained without opposition during so long a period of years?

Lord Salisbury denied the correctness of Mr. Blaine's interpretation of the words "Pacifie Ocean," and insisted that by the terms of the ukase the "Paeific Ocean" extended to Bering Strait, and included the Bering Sea, and that, therefore, the American and English protests before referred to were actually directed against Russian elaims in the Bering Sea, as well as against her elaims over the ocean south of the Bering Sea. He attacked the implied American contention of mare clausum as applied to the Bering Sea, and offered in the end to arbitrate the whole matter.

The drift of these arguments had brought the Ameriean and English eontentions to a single issue, - the question whether the protests of both the United States and England against the hundred-mile limit of Russian sovereignty in the Pacific Ocean from Bering Strait down the northwest coast of America to $51^{\circ}$ latitude, and down the Siberian eoast to the $45^{\circ} 50^{\prime}$ latitude, were direeted against those Russian elaims in the Bering Sea, or only in the Paeific Oeean exelusive of the Bering Sea. Ilad Russia really been ummolested in her extraordinary assmmption of sovereignty in the waters of Bering Sea, or had her claims been met and opposed by foreign protest? Obvionsly, the diseussion hinged upon the meaning of the worls " Pacific Ocean." Mr. Bhaine, accepting this issme, went so far as to say: "If Great Britain ean maintain her position that the behring Sea at the time of the treaties with Russia of 1824 and 1825 was inchuled in the Pareifie Oeean, the govermment of the United States has no well-grounded complaint against her. If, on the other hand, this government can prove beyond all doubt that the Behring Sea, at 
the date of the treaties, was understood by the three signatory powers to be a separate body of water, and was not included in the phrase 'Pacific Ocean,' then the American case against Great Britain is complete and undeniable."

Further argument was useless. Both power's stood firmly by their respective positions, and the ease, stripped of nonessentials by the exhanstive pleadings of the English premier and the American Seeretary of State, had been narrowed down to comparatively simple issues. The question called for an immediate settlement. 'That same year, 1890, the twenty-year lease of the Aliska Commercial Company expired, and the North American Commercial Company suceeeded with a fresh twenty-year lease. 'The seal herd had by this time become greatly reduced in numbers, and ample evidence was furnished by the alarming annual deerease of the size of the herd to demonstrate that the total extinction of the species was already a promise of the near future, unless some arrangement with England could be made to prevent pelagie sealing. Camadians were determined to exercise their right of eatching seals upon the high seas, and the United States Government had become equally determined to seize and condemu any ressel found "poaching" in Bering Sea. It was feured that the following season's operation in Alaskan waters might bring the dreaded clash between the two great powers. Their interests in the North Pacifie seemed hopelessly to conflict: their determinations to proteet their own subjects in the exereise of their so-believed respective rights were firmly fixed, and their patienee and good will were already sorely tried. It was at this eritical stage of the controversy the two nations happily agreed to submit the matter to a tribunal of arbitration.

Owing to this rapid decline in numbers of seals resorting to the islands, the North American Company was restrieted by a Treasury order to a catch of only 20,000 pelts for the year 1890 , and pending the negotiation of a treaty of arbitration, the following agreement with England was effected June 15, 1891 :- 


\section{Modes Thende.}

1. Her Majesty's Govermment will prohibit, until May next, seal killing in that part of liehring sea lying eastward of the line of demarkation described in Article No. 1 of the treaty of 1867 between the United States and Russia, "and will promptly use its best efforts to insure the observance of this prohibition by British subjects and ressels."

2. The United States (iovermment will prohibit seal killing for the same period in the same part of Behring Sea, and on the shores and islands thereof, the property of the United States (in excess of 7,500 to be taken on the islands for the subsistence and care of the natives), and will promptly use its best efforts to insure the observance of this prohibition by United States citizens and ressels.

3. Every ressel or person offending against this prohibition in the sait water's of Behring sea ontside of the ordinary territorial limits of the United States, may be seized and detained by the Naval or other duly commissioned officers of either of the High Contracting Parties, but they shall be handed over as soon as practicalle to the anthorities of the nation to which they respectively belong, who shall alone have jurisdiction to try the offence and impose the penalties for the same. The witnesses and proofs necessary to establish the offence shall also be sent with them.

4. In order to facilitate such proper incuiries as Her Majesty's Government may desire to make, with a view to the presentation of the ease to that gorermment before arthitrators, and in expectation that an agreement for arbitration may be arrived at, it is agreed that suitable persoms designated by Great Britain will be permitted at any time, upon applieation, to visit or to remain upon the seal islands during the present sealing season for that purpose.

Signed and sealed in duplicate at Washington, etc.

The adoption of the modus viendi put off, for a time at least, all danger of eollision in Bering Sea, and the diplomatic agents of England and the United States set about framing a treaty and preparing a way for the trial of the eause. In the meantime English and Ameriean ressels were sent to Bering Sea to control the waters wherein seals were to be found and to enforce the molus rivendi. The commanders of these vessels were given full liberty to search suspected ships moler either flac, and to arrest all offenders.

In accordanee with the agreement in the modus vivendi, 
Great Britain appointed Sir George Baden-P'owell, M.P., and Professor George Mercer I awson commissioners to proeeed to the Pribyloff Islands for the purpose of examining into the fur-seal tisheries. On the part of the United ritates, Dr. C. Hart Merrian and Professor Mendenhall were selected in like capacity the following February.

Diplomatic efforts were immediately directed to shaping the disputed questions for inclusion in the proposed treaty, and to preparing the issues in suceinct form for presentation to a tribunal of arbitration. In this matter some slight difficulty was experienced hy Sir Iulian Pauncefote, Mr. Wharton, and Mr. Blaine, especially in reference to questions touching the liabilities of each for injuries alleged to have been sustained by the other by reason of killing seals in bering Sea, or through arrests, ete. In November a compromise agreement was reached upon the phraseology of this troublesome eount; having framed all the issines, the negotiators were finally alle to sign a treaty at Washington on February 29, 1892.

The instrument opens with an expression that "The United States of America and Her Majesty the (Muesn of the United Kingdom of Great Britain and Ireland, being desirous to provide for an amicable settlement of the questions which have arisen between their respeetive governments concerning the jurisdietional rights of the United States in the waters of Behring Sea, and concerning also the preservation of the fur-seal in, or habitually resorting to, the said sea, and the rights of the citizens and subjects of cither commtry as regards the taking of fur-seal in, or habitually resorting to, the said waters, have resolved to submit to arbitration the questions involved. ..."

The parties then determined upon a tribunal to be eomposed of seven arbitrators, two to be appointerl by the President of the United States, two to he named by her Britamido Majesty. one to be named by the president of the French liepmblic, and one each by the King of Italy and the King of swerten and Norway. The arbitrators were to meet in Paris within a stipulated time. 
The following five points. conceived to be the real issues in the case, were expressed als follows, the award to embrace a seprarate decision mpon each : -

1. What exclusive jurisdiction in the sea now known as the Behring's Sea, and what exclusive rights in the seal fisheries therein, did Russia assert and exercise prior and up to the time of the cession of Alaska to the United States?

2. How far were these claims of juriscliction as to the seal fisheries recognized and conceded by Great Britain?

3. Was the body of water now known as the Behring"s Sea inchuded in the phrase "Pacific Ocean," as used in the treaty of 1825 between Great Britain and Russia ; and what rights, if any, in the Bering's Sea were held and exclusively exercised by Russia after said treaty?

t. Did not all the rights of Russia as to jurisdiction, and as to the seal fisheries in Behring's Sea east of the water boundary, in the treaty between the United States and Russia of the 30th March, 1867, pass unimpaired to the United States under that treaty?

5. Has the United States any right, and if so, what right of protection or property in the fur seals frequenting the islands of the Uniterl States in the Behring's Sea when such seals are found outside the ordinary three-mile limit?

The question of regulations was treated in the seventh article of the convention as follows:--

If the determination of the foregoing questions as to the exclusive juristiction of the United States shall leave the subject in such position that the concurrence of Great Britain is necessary to the establishment of regnlations for the proper protection and preservation of the fur-seal in, or habitually resorting to, the Behring sea, the arbitrators shall then determine what eonenrent regulations ontside the jurisdictional himits of the respeetive Govrmments are neressary, and over what waters sueh regulations should extend, and to aid them in that determination the report of a joint commision to be appointed by the respective (iovernments shall be lair bofore them, with such other evilence as either Govermment may submit.

The high contracting parties furthermore agree to coöperate in securing the adlesion of other powers to such regulations. 
The eighth article of the treaty left the question of liabilities for injuries alleged to have been sustained by the eitizens of either country in connection with the arrests and condemmation of the English sealing vessels to be determined by the arbitrators npon the submission to them of all the facts.

Agreeably to the terms of the ninth article of the treaty, by which " Each government shall appoint two commissioners to investigate conjointly with the commissioners of the other government all the facts relating to seal life in Bering Sea, and the measures necessary for its proper protection and preservation," Sir George Barlen-Powell, Member of l'arliament, and Dr. Dawson were retained by Great Britain, as were 1)r. Merriam and Professor Mendenhall by the United States, to act as such commissioners. With full instructions to investigate thoroughly the conditions of seal life and to ascertain what permanent measures were necessary for the preservation of the fur-seal speeies in the North Pacific Ocean, the joint commission proceeded to Bering Sea and set to work gathering material for the use of their respective governments in the arbitration trial to be held in Paris. It is not a little remarkable that side loy sicle four seientists prosecuting the same line of inquiry, considering together the same evidence, and reading together the same incontrovertible facts, should have arrived at such widely different conclusions. The impartial observer must yield to the suspicion that the conclusions of the commissioners were colored by a desire to further the interests of their comtries, and that their scientific investigation had not been wholly free from a trace of diplomacy. The American eommissioners fonmd overwhelming evidence to establish in their minds beyond all questions of doubt the fact that the seal herd had greatly diminished in size, and that such condition had been ehiefly brought abont by the destructive practice of pelagic sealing. They consequently recommented its entire suppression. Subsequent history has proved the correctness of these condusions, and it is to be regretted that the case in l'aris was eomplinated by the radically differing report of the british commissioners. They, on the other haml. somewhat bougludgingly andmitted a 
falling off in seal life, for whieh eircumstanee they insisted that the killing on the islands by the American company was the main cause, and they also discovered that pelagic sealing in itself was not necessarily destruetive to the herd. As a remedy, if indeed a remedy were called for by existing conditions, they proposed severe restrietions in relation to the number of seals ammually taken upon the islands, and as an area of protection to the seals, recommended a marine belt of ten miles about the Pribyloff Islands, within which no pelagic sealing should be permitted.

These two very contradictory reports necessarily formed the basis for the consideration of the Paris tribunal, whose office it was to determine a future eourse of action looking to the preservation of seals in Bering Sea.

The tribunal met in Paris in the spring of 1893, and continued its sessions well into the summer. The arbitrators chosen were Baron de Courcel (France), Marquis Emilio Visconti-Venosti (Italy), M. Gregario W. W. Gram (Sweden and Norway), Lord Hannan and Sir John S. D. Thompson (England), and Justice John M. Harlan and Senator John T. Morgan (United States). The American case was conducted through the agency of the Hon. John W. Foster (who had sneceeded Mr. Blane as Secretary of State), together with Edward J. Phelps, James C. Carter, Frederick R. Coudert, and Henry Blodget as eounsel.

Although it had been expressly disavowed by Mr. Blaine that the United States put forth any claim to mare clausum over the Bering Sea, it is nevertheless impossible to eonsider the American position before the tribunal in Paris as otherwise than an attempt to justify such a contention. While $n 0$ direct and formal allegation of the applicability of the prineiples of mare alousum appear in the proeeedings, the United States nevertheless songht to make grood its position in Bering Sea by maintaning the propriety of early Russian assertions of dominion over those waters, - or over at least a hundredmile belt abont their shores. These Russian claims in Bering 
Sea cannot well be regarded other than assertions of mare clausum; and the attitude of the United States, taking shelter behind these early Russian assumptions, neeessarily committed her in defence of those claims and principles. Again, the United States, in attempting to justify herself for having exercised an alleged right of seareh upon vessels of a friendly nation outside of her own legally recognized territorial waters, and in the absence of treaty stipulations authorizing her to do so, necessarily elaimed sovereignty over the sea wherein the acts of visit and search had been committed. There can be no right of police over the high seas in times of pence other than as directed against suspected common enemies or pirates, and its exercise must assmme proprietorship.

In the early days of Spanish and Portuguese exploration and conquest, vast oceans were demanded as the property of the State. With the growth of the British navy, certain exaggerated claims to marine proprietary rights were, for a period, advanced by England; but the spirit of modern times has been so decidedly hostile to all attempts to establish dominion over the sea that to-day eivilized nations are disposed to tolerate no infraction, however slight, of the broad principle of mare liberum. The nltimate extent to which "territorial waters" may be urged in accordance with the present law of nations, includes only a marine belt of three miles along the open coast, and all harbors and bays whose openings to the sea do not exeeed in width ten to twenty miles, or in general, such inland bodies of water, the narrowness of whose entrances from the sea and whose configuration clearly indicate them to be enclosed seas. The Luited States has always been conspicuously foremost in the advoeacy of freedom of the high seas; she was indeed the first to protest against Russian unwillingness to accept these enlightened principles in the l'atcific. It is to be regreted that in this matter the Lnited States should have appeared before the tribunal and the cirilized world in the unfortmute light of taking a step batek warl in order to resuscitate and reclothe a defunct merliacral doetrine.

The American case supported the contention that Russia had acquired dominion over Bering Sea by preseription, - a 
right or title gained by immemorial use. Alexander I. had

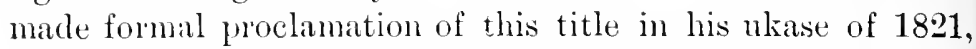
and counsel contended that Russia had ever after enjoyed full and undisturbed possession of her asserted proprietary right over Bering Sea mitil by treaty of 1867 she had parted with such rights to the United States. And it was urged that the long period of time that Russia had remained in open adverse possession of those waters, exercising all the privileges a nation enjoys over a territorial expanse of sea without protest or hindrance, had given her a full and complete prescriptive title, - which title passed mimpaired to the United States.

The question of Russia is undisputed exercise of her alleged rights in Bering Sea came before the tribunal as an issue of fact to be proved or disproved by weight of evidence, and the legal aspect of the question of prescription, its applicability to the present case, and its scope and force as a prineiple of the law of nations, were not tonched upon by the arbitrators. It may well be doubted that even had Russia really been left undisturbed, as allegred, in her occupation of Bering Sea for a century or more, a prescriptive right to its water's would consequently ensne. There is abundant authority in international law to demonstrate that rights gained through immemorial usage do not appertain to the sea. All rights of navigation, fishing, ete., upon the high seas are of a nature that do not depend upon constant use for their validity. 'They may be used at will, or never used at all, - for non-use cannot imply relinquishment. Beeause a nation never sailed a vessel across the sea may she forever be denied the privilege? Because a nation has alone fished in a distant sea may she forever bar her neighbor from fishing there as well? Again, it is conceived that preseriptive titles may be acquired only in such things as are inherently eapable of acquisition, always implying an original or prior grant constituting at least a eolor of title. It is incompatible with the doctrine of the freelom of the high seas to suppose any one nation is eapable of acquiring rights therein alove, or greater than, the eommon rights of all nations. Few in time past, and no one to-day, ventures to assert that Bering Sea falls within that class of enclosed 
waters which form an exception to the general rule of mue liberum, or open free sea. Such then being the case, it is almost certain that, even had the fact of universil acquiescence in Russias claims of dominion north of the Alentian Islands been satisfactorily proved, a resulting pescriptive title would not have been aceoreded by any impartial tribumal.

It appeared at once that the American contention of Rousia's exclusive sovereignty conld not be maintained. Reliance had been placed in evidence afforded by certain Russian documents to establish Russia's prescriptive right to juriscliction over those waters, and as a natmal sequitur the similar American rights aequired by purchase. The testimony in question, upon closer scrutiny, was found to be false, and the American case, unsupported by proof, failed upon the first and second points.

The third point in the case, involving the true meaning of the term "Pacific Ocean," as employed by Russia and England in a treaty of 18.5 , and which in the full comprehensiveness of its meaning includer the Bering Sea, was decided unanimonsly in favor of the English contention. This refuted Mr. Blaines argument that English and American expressions of protest against Russian assumptions in the North Pacifie had never been directed against Russian operations north of the Alentian lslankls or in Bering Sea. 'The object of this comt was to strengthen the American preseriptive title to the waters of the Bering Sea in the event of deeision favorable to the United States. lint this issue luaring already been disposed of adversely to the United States in the first two counts, its value and importance were consequently lost.

Failing, then, in the first thee proints in the case, the fourth one became meaningless to the Enited states and was dropperl without comment. This left the fifth and last issue in the ease, the only one npon which the American eommissioness could take a firm stand: the main force of the Amcrican argument was bronglit to bear 11 on it in an endleavor to establish a right of poperty in, or actual ownership of, the seals, and a consequent right of the United States to protect its own property upon the high seis. 
The right of property in animals ferce naturce ordinarily held or eapable of aequisition by individuals or communities was discussed at great length in an exhaustive argument by Mr. Carter who endeavored to demonstrate the rightful Ameriean ownership of the seals. On this question, he urged: . The United States hold that the ownership of the islands upon which the seals breed; that the habit of the seals in regularly resorting thereto and rearing their young thereon; that their going out in seareh of food and regularly returning thereto, all the facts and incidents of their relations to the islands, - give to the United States a property interest therein...."

The common and civil law was ransacked for cases to support this elaim, and a remarkably ingenious argument was presented. The question was practically a unique one in the field of international law, and no precedent could be quoted either to sustain or defeat the American contention. The common and civil laws recognized two classes of animals, - first, those that are domesticated and tame, such as cattle, horses, dogs, etc., and in whieh man may possess absolute ownership; and secondly, those animals which wander about at free will and are of a wild disposition, designated as ferce nature. In this latter class, man might enjoy, under certain conclitions, qualified property rights. When such creatures are captured and detained, they become personal property so long as they may be kept in aetual possession; but the moment they escape and gain their liberty, property light in them instantly ceases, nuless, indeed, they wander away animo revertendi, an intention acending to habit of returning, in which case a certain qualified ownership may still exist. But the exact extent and seope of this property right in animals fore noture that have left their eonfues but purpose eventually to returu are not altogether clear. The particular and peculiar natures of the many species of animals that may serve man and still he considered under the heal of animals fere nuture, are questions well ealculated to confuse jurists and tend to make generalization upon the subjert impossible. Thus, the owner of a swarm of bees 
loses no property rights in the bees when they fly away to gather honey in fields other than his own; but, upon the same principle, it might be pertinently asked could Canada claim in the United States the flocks of wild geese and ducks that are hatched and bred about the northern Canadian lakes but pass the winter seasons in the United States; or, could the United States elaim in Canada the deer, elk, or buffalo that eross for a day the northern frontier?

The seals could be considered domestic animals only by a strain of the imagination, and as animals fere nuture they are born and live for a period of time each year on American soil, and when they take their departure it is always with the intention of returning. By analogous arguments, therefore, from common law sources, the United States might have been shown to possess a qualified property right in these animals, sufficient even to warrant their protection when outside of American jurisdiction upon the high seas. But to have established such a right in the United States would have been to recognize and to tolerate a violation of much better established principles of international law, - the absolute freedom of the high seas.

The arbitrators (the American commissioners dissenting) decirled against the American contention, holding, "That the United States have no right to protection of, or property in, the seals frequenting the islands of the United States in Brring Sea, when the same are found outside the ordinary three-mile limit."

Thus the American case was lost upon each and every legal point involved. The United States was held to possess no greater right in Bering Sea than was possessed in common by all nations. The seals were considered to be animals strictly ferce nature, and eonseqnently, res mullius, or incapable of ownership when outside of national jurisdiction, or upon the high seas.

Therefore all nations had a natural and perfect right to catch these animals in any open sea, and consequently if any restrictions upon these rights, or any regulations of sealing. were to be effected, such could properly be made only through 
mutmal consent and agreement of the parties concerned and by treaty stipulation.

Ilaving thus disposed of the legal question involved in the dispute in a manner adversely to American interests, the commissioners took up the report of the scientific experts upon the conditions of seal life in the North Pacific and upon the Pribyloff Islands. They sought diligently through the labyrinth of contlicting testimony for a solution of the practical question which was to preserve the seal herds.

Their deliberations finally took form in a set of regulations which. by the terms of the treaty anthorizing the tribunal, should be binding equally upon the United States and England. Briefly, the regulations were, first, there shall be no killing of seals at any time or season within a zone of sixty miles around the Pribyloff Islands; second, from May 1 to July 31 shall be considered a closed season, within which time subjects or citizens of neither power shall engage in pelagic sealing in Bering Sea and the North Pacific Ocean within the area described as " the high part of the sea in that part of the Pacific Ocean, inchusive of Behring Sea, situated north of the 35 th degree of north latiturle, or eastward of the 180 th degree of longitude from Greenwich until it strikes the water boundary deseribed in Article 1 of the treaty of 1867 between the United States and Russia, following that line up to behring Straits;" third, at other times, or during the open seasom, only sailing vessels shall be permitted to take part in sealing operations within such area: fourth, these vessels shall be provided witl a proper license, ete.; fifth, masters will record all catches in a $\log$; sixth, the use of nets, fire-arms, or explosives are positively forbidden, though the use of shotguns in the Pateific Ocean south of Bering Sea is permissible. The regulations were to remain in force until wholly or in part abolished through common consent of the United States and Great Britain, - and "Said concurrent regulations shall be submitted enery five years to a new excminution in order to enable both governments to consider whether in the light of past experience there is occasion to make any modification thereof." The method of enforcing 
these regulations was left to the respeetive governments, with the obligation of enacting each succeeding year such legislation as might be neeessary to the proper enforcement of the award. A recommendation was also mate, in view of the "critical eondition to which it appears certain that the race of fur-seals is now reduced," that the two governments should agree to abstain from all lilling of seals, either on sea or on land, for a period of two or three years. This excellent suggestion, to be acted mpon only by the will of the two powers, unfortunately was not aceepted.

Despite all adverse criticism, there can be no doubt that the arbitrators, in thus framing a series of regulations for the protection and preservation of the fur-seals, acted conscientiously and to the best of their knowledge. In performing their duty of establishing a cole of laws for the protection of the fur-seal speeies, the task of the commissioners was a peculiarly difficult one, far more so indeed than had been the burden of adjudieating upon the purely legal questions involved in the controversy. The arbitrators were at once confronted and overwhelmed with a hopeless mass of variable and conflicting testimony concerning every feature of seal life, and as jurists their steps were uncertain in the provinces of natural science. They desire first and foremost to proviste a system of laws that shomld be effective in protecting the seals from extermination, and they wished as well, in accordance with the natural impulse of a judicial body, to place the deprivations of enforeed abundonment of a profitable industry equally and equitably upon the subjects of hoth nations, so far as proper and consistent with the primary and main objects of the regulations.

The award and regulations were acepted with becoming grace by both eomtries. For a time mummes of discontent were heard from the Camarlian scalers, who at first helieverd that the restrictions on pelagic sealing wonld forever luin their industry. A certain amount of bitterness against the award and the legal conchision of the arbitrators was also apparent for a season in many American newspapers, comtributed by those who could not recover too suddenly from 
their mare clausum convictions regarding Bering Sea, and who perhaps regarded all boards of international arbitration as but sorry exponents of justice.

An Act of Congress was passed April 5, 1894, enforcing the award as to American citizens, and some slight friction between the two powers was caused by the delay of the British government in effecting concurrent legislation in relation to British subjects. Orders in Couneil were shortly after enacted (April 18, 1894), and the sealing season of 1894, the first under the new r'égime, opened.

Notwithstanding the general feeling of satisfaction with the award that soon succeeded a period of doubts concerning its justice, it beeame apparent, at the close of the sealing season the following autumn (1894), that the regulations were inadequate, and that they had evidently been made without that accurate and scientific knowledge of seal life and conditions which the authors of the articles should have possessed. The pelagic catch was unusually and alarmingly large. Including the captures made on the Asiatic side during the closed season of May, June, and July, the number of skins taken at sea amounted altogether to about 142,000 - a figure greatly in excess of any previous year's catch.

Actual operations in Bering Sea soon developed the fact that the sixty-mile in hibitive zone about the Pribyloff Islands was entirely insufficient in extent to protect the seals. The females, and occasionally the young males or bachelors, as already shown, are in the habit, during the breeding season, from May until December, of wandering away in search of food, even to a distance of 200 miles at sea; they do not, as the commissioners evidently presumed, remain on or near the shores of the islands. They are driven to make these long excursions on account of the scareity of food near the shore, a result naturally arising from the presenee of so great a number of animals subsisting entirely upon fish and other forms of marine life. On the first of August, and the end of the elosed season, the sealing schooners appeared in foree in the Bering Sea and reaped a rich harvest just without the proteetive zone of sixty miles that had been established by 
the regulations about the Pribyloff Islands. A majority of the animals thus taken were females, and at that particular time every female has dependent won her a young seal. The death of the mother invariably results in the death of the "pup" who awaits her return on shore. The musually high mortality of the young seals on the rookeries during the season of 1894 gave silent testimony to the destructive character of pelagic sealing in Bering sea, for having deducted from the total of dead " pups " found on the breedingground whose deaths liad resulted from overerowding and aecident, an alarming proprortion remained to indicate starration as the principal eause. The diflieulty also of enforcing the observanee of a line of demarcation between protected and unprotected waters, sixty miles at sea and entirely ont of sight of land, beeame apparent, and especially in this region of dense and almost perpetual fog.

The main objeetion to the regulations, however, was discovered to be in the shortness of the elosed season (May 1 to July 31), during which time no seals were to be eaptured within the geographical limits alrady given. The fleet of sealing vessels ordinarily begins its operations in Jannary, when the seals are at the southern extreme of their anmul migration, and follows the herd in a northerly direction along the coast, during the early spring months. Stationing themselves in and about the passes of the Mlentian Islands, to which points the seals eonverge on their long swim to the Bering Sea, the hunters were enablerl vastly to inclease their catch. At the begimning of the closerl season, the sealing captains erossed over to the Asiatic side of Bering sea and preyed upon the mprotected herds of the Comminder and Robin islands, to return again about Angust 1 to the vicinity of the Pribyloff rookeries, where they hovered about, cansing great destruction to the herd, until the approaching storms of autumn warned all sailing craft to leave those open waters. 'The statistical results of the first season's operations in Bering Sea and the North Pacific furnished ample gromuls for belief that the regulations had fallen far short of ateomplishing the object for which they had been mate. Seeretiny 
of the Treasury Carlisle, in answer to a House resolution, said that from the statisties of the pelagie catch of 1894 , "it becomes evilent that during the present season there has been an unprecedented increase over preceding years in the number of seals killed by pelagie sealers, both in American and Asiatic waters. This increase has cansed an alaming decrease in the number of seals on the islands.... The alarming increase in the number of seals killed by the pelagic sealers.. emphasizes the conclusion expressed in my annual report to Congress that long before the expiration of the five years, when the regulations enacted by the tribumal of arbitration are to be submitted to the respective governments for reëxamination, the fur seal will have been practically exterminated." Mr. Gresham, Secretary of State, expressed to the British Ambassador his anxiety concerning the future welfare of the seals in his letter of January 23, 1895: “. . . It would appear that there were landed in the United States and Victoria 121,143 skins, (operation of season 1894), and that the total pelagic catch, as shown by the London trade sales and careful estimates of skins transshipped in Japanese and Russian ports, amounts to about 142,000 , a result unprecedented in the history of pelagic sealing. . . This startling increase in the pelagie slanghter of both the American and Asiatie herds has convincer the l'resident, and it is respectfully submitted camnot fail to convince Her Majesty's Govermment, that the regulations enacted by the Paris Tribunal have not operated to protect the seal herd from that destruction which they were designed to prevent, and that, mless a speedy change in the regulation be brought about, extermination of the lierd must follow."

Furtler cause for American dissatisfaction in the matter was found in the alleged indifference manifested by the English Govermment in assmming its full share of obligation in the enforcenent of the regulations. In the Act of Congress (April 5, 1894), enforcing the Paris award for that season, a section had been introduced to the effeet that if any licensed sealing vessel should be found within the 
waters eovered by the award " having on board apparatus or implements suitable for taking seals, but forlidklen then and there to be used (fire-arms), it shall be presumed that the . . . apparatus or implements. . . Were user in violation of this act until it is otherwise sufliciently proved." Thus the burlen of proof was placed npon all master's of Ameriean sealing craft, when arms were forbidelen, to show when found in their possession, that the same had not been used for the purpose of killing seals. When enteting laws for the enforcement of a Russian vivendi in 1891, the British (iovernment hat deemed it proper to adopt this rule of evidenee, ${ }^{1}$ but in 1894, in the Orders in Comncil enrying into effect the Paris award as to British subjeets, this inportant provision was omitted. In the absence of such equivalent legislation on the part of Great Britian, the American sealing captains were placed upon an mequal footing with their Canarian brethren, and manifestly at a great clisarlvantage when brought before the eourt eharged with violation of the law forbidling the use of fire-arms in the capture of seals. In his letter of May 10, 189i, to Sir Julian Panncefote, Mr. Uhl, then Acting Secretary of State, sain in referente to this question of evidence :-

“. . Experienee has shown it to be ahmost a pratical impossibility to deteet a sealing vessel in the act of using firearms for this one probibited purpose. Although the searching offieer may be morally certain that firearms have been used, and may properly consider the mere presence of firearms on the vessel, if accompanied with bodies of seals, sealskins, or other suspicious evidence, sufficient justification (even apart from the provisions of Section 10 of the Aet of Congress of April 6, 1894, which is applicable only to American vessels) for the seizure of such a vessel, it must be apparent that in proceedings for eondemuation bronght in a court thousands of miles away from the place of seizure it

1 "If a British ship is found wilhin Bering Sea having on board therenf fishing or shooting implements or sealskins, or bollies uf seals, it shall lie on the owner or master of such slip to prove that the ship was not used or employed in contravention of this Act." - (June 15, 1891, 58 and 54 Victoria, Chapter 19.) 
would be almost impossible to seeure conviction and forfeiture on the ground of illegal use of weapons. Furthernore, under the procedure neeessarily following the seizure of a British vessel the United States officer delivers the vessel, with such witnesses and proof as he can procure, to the senior British naval officer at Unalaska. At the trial no representative of our Government is present, and the British Government must conduet the prosecution and must trust to sueh proofs and witnesses as the American officer eould colleet and furnish at the time. Under such eircumstances forfeiture of the ressel could not be seeured except in the elearest eases of guilt."

Suspicion also arose that England did not fully meet the United States in the desire and determination to protect the seals, because she had deemed a single war vessel sufficient for the purpose of patrolling the North Pacifie and Bering Sea during the closed scason of 1894 , notwithstanding the fact that the Canadian fleet of sealing sehooners was almost twice as large as the American fleet. The United States, on the other hand, had despatched twelve armed vessels to the seene of aetion, and so zealous had been their commanders in the performance of their duties, that a score or more of eomplaints from ontraged shipowners for the too frequent, needless, and fussy overhauling of their sehooners were filed in Washington.

At the close, then, of the first season's sealing operations under the regulations of the Paris award, the "Bering Sea question" again became aente. The most noticeable effect of the enforcement of a elosed season upon the Ameriean side of the Pacific had been to drive the entire American and Canadian sealing fleets across the ocean during the months of May, June, and July, to take advantage of that favorable period in attacking the Asiatic herds in and about Japanese and Siberian waters. 'The resulting increase in the slaughter' of the Asiatic herds startled Japan and Russia. They inmediately expressed a desire to have the restrictive measures of the Paris award extended to their side of the Pacific, and a eorrespondence ensued with that end in view.

Thoroughly convinced of the inadequacy of the laws 
which had been framed to protect the seals from threatened extermination, a strong appeal was made by Secretary Gresham for English assent to a revision of the regulations. His desire was to enlarge the closed season and also to prohibit all pelagic sealing in Bering Sea.

The statistics of the year's catch, gathered from Canadian sources, differed from the American estimates, making the total somewhat less; the English Government, seeing no immediate cause for alarm for the future welfare of the herd, were not favorably inclined to making any changes in the existing laws governing sealing operations. While still engaged, however, in discussing the situation, the spring months advanced, the sealing fleets cleared from their winter ports, and the season of 1895 opened without any modification of the regulations.

The statistical returns from the North Pacific and Bering Sea at the end of the season of 1895 (the second moler the award), were not of a character to relieve apprehension; they served only the more firmly to convince the American Government that its fears for the future of the seal herds were well grounded, and that appeals for British consent to a modification of the regulations were reasonable and proper. Mr. Olney wrote Sir Julian Pameefote, March 11, 1896.

... I desire also to call your attention to the murecedentedly large eatch of seais in Bering Sea during the past season. The total was 44,169 , as eomprared with $31, \pi 55$ during the season of 1894. This is by far the largest catch ever male in Bering sea, and it is believed that another catch of similar size for the coming season will almost completely exterminate the fur-seal herel. I am advised that the greater portion of the seals killerl at sea were females.

The total catch during the last season in the North Pacific and Bering Sea from the American herel was 56,291 , as compared with total for 1894 of 61,838 , the small falling off being due to the inelemeney of the weather between . Jaminy and May along the northwestern coast, and also to the diminution of the seal herd. ... .

In the spring of $18: 16$ Russia again displayed some anxiety for the welfare of her own sealing industry on the Asiatic 
side of Bering Sea, and broached the subjeet of an agreement to extend the provisions of the Paris award to her side of the Pacific Ocean. The Secretary of State eagerly seized this opportunity to gain an ally, and Mr. Bayard, the American Ambassador to Great Britain, was instructed to coöperate with and aid the linssian representative in London in his endeavors to secure England's consent to such legislation. These laudable efforts on the part of Russia were not destined to meet the suecess they deserved. Lord Salisbury received the orertures with indifference and proposed to send two scientific experts to the Bering Sea to make further investigations into the conditions of seal life as affected by the regulations and award, and incirlentally to extend their researehes to the Commander and Robin islands. Accordingly Mr. D'Arey Thompson and Mr. Macoun, on the parts of England and Canada, proceeded to Bering Sea, to remain throughout the season of 18:6. Professor David Starr Jordan, a biologist of great ability, was sent on the part of the United States to coöperate with these English scientists and to make with them a thorough and exhaustive study of the subject.

It was sincerely hoped in Washington that this scientific commission, unlike the former one of 1892 , would be enabled to agree upon findings of fact, and that it might also reach harmonious conclusions in relation to proper remedial legislation. By proofs furnished through her own experts it was expected, as it was greatly desired, to convince the English Government of the necessity of a revision of the rules governing pelagie sealing, and to overcome, if possible, their stolid determination to stand for the full five years on the letter of the law regardless of consequences.

The season of 1896 opened with no changes in the regulations; the mixed Canadian and American seientific commission were at the Pribyloff Islands, and several American and British armed ressels patrolled the seas in search of violators of the sealing laws.

Professor .Jordan's report appeared early the following winter, disclosing facts truly alarming to the government that had struggled so earnestly to protect the herd. After noting 
carefully the gradual decrease in the size of the American herd from the beginning of pelagic sealing in 1880 to about the year 1856, then showing that since that period the steadily increasing rate of diminution of the number of seals was in a direct ratio to the increasing size of the sealing fleets, and further calling attention to the continuous and rapid decline of seal herds in the last few years, - Dr. Jordan was forced to the conchusion that "pegalic sealing... has been the sole canse of the continued decline of the furseal herds. It is at present the sole obstacle to their restoration and the sole limit of their indefinite increase. It is therefore evident that no settlement of the fur-seal question as regards either the American or Russian islands can be permanent unless it shall provide for the cessation of the indiscriminate killing of fur-seals, both on the sealing grounds and on their migrations. There can be no open season for the killing of females if the herd is to be kept intact."

Dr. Jordan recommended that Congress should enact laws absolutely prohibiting Americans from engaging in pelagic sealing at any time or season. Such legislation, he believed, would furnish an excellent example to England, and would place the United States in a strong position for pressing her arguments against the capture of seals at sea. As a final resort, in case no understanding could be effected with Great Britain looking to the prevention of all pelagic sealing, he recommended the expediency of branding with hot irous all the female seals upon the Pribyloff Islands, thereby rendering their pelts commereially worthless, but in no manner injuring the seals. This, he thought, would protect them from the onslaughts of the pelagic liunters and enable the l'ribyloff herd to maintain itself by keeping up the yearly average birth-rate.

The President was much concerned by the seriousness of the situation as depicted by Dr. Jordan. He was again moved to make strenuous efforts to induce Lord Salisbury immediately to enter upon negotiations for a revision of the existing regulations. The latter, however, wonld not accede to the President's wish. Professor D'Arey 'Thompson, in his report soon 
after made public in England, found substantially the same facts and conditions as were reported by Dr. Jordan, but he deduced therefrom a less startling conchusion. He saw no immediate cause for alarm in the continuation of pelagic sealing, but believed the killing of young males, - the "bachelors," - on the islands, as practised by the chartered American Company, to be highly destructive to the herd and altogether a pernicious method. Basing its action upon these findings and conclusions, the British Government failed to see any urgent necessity for a modification of the regulations before the end of the stipulated five years; it declined flatly to consider the matter at that time.

This refusal of the British Government to heed the warnings so plainly written in all the statistical reports of sealing operations since 1894 , and their stubborn determination not to yield to the solicitations of the United States for a revision of the laws, caused much disappointment at Washington. Being thoroughly convinced that the Paris regulations were ineffectual, - indeed, that they utterly failed to fulfil the expressed object of their creation, — the United States. received with less grace each year the refusal of Great Britain to consent to their revision. There was little consolation in the reflection that Great Britain, in thus declining to act, stood squarely upon her rights under the Paris rules. 'These only called upon the parties to submit the regulations "every five years to a new examination in order to enable both govermments to consider in the light of past experience if there is any occasion to make any modification thereof." England was consequently under no legal obligation whatever to reopen the question before the close of the season of 18.18, and by that time it was feared in the United States. there would be no seals left to consider in any light whatsoever.

Apart from her legal exemption, it was felt in Washington that Creat Britain was at least under a moral obligation to consent to an immediate rëxamination of rules that were manifestly so defective. It was urged that the rules were ereated for a definite purpose; they had sinee been proven to. 
be not only useless, but positively harmful, in that they served to protect a nefarious practice. Hence the duty was plain to alter them as soon as possible. England's reply, to the effect that in her estimation the laws were not defective and could well await the proper time for revision, seemed to the American officials an extraordinary conclusion to draw from the facts, - a conclusion so little in accord with all reasonable deductions that it seemed unaceountable. The administration was perplexed and annoyed. With some show of feeling, the Secretary of State, Mr. Sherman, wrote to Mr. Hay, the American Ambassador in London (May 10,1897):-

... On the other hand, I think I have shown that the British Government has from the beginning and continuously failed to respect the real intent and spirit of the Trimmal or the obligations imposed by it. This is shown by the refusal to extend the regulations to the Asiatic waters; by the failure to put in operation the recommendation for a suspension of the killing of the seals for three, for two, or even for one year; by the necrlect to put the regulations in force until long after the first sealing season had been entered on; by the almost total evasion of the patrol duty; by the opposition to snitable measures for the enforcement of the prohibition against firearms ; by the omission to enact legislation necessary to secure conviction of the guilty; and by the refusal to allow or provide for an inspection of skins in the interest of an honest observanee of the regulations. . . A conrse so persistently followed for the past three years has practieally aceomplished the commereial extermination of the fur-seals and brought to naught the patient labors and well-meant conclusions of the Tribunal of Arbitration. ...

Congress displayed a similar feeling of resentment by eonsidering a bill providing for the slaughter of the entire Ameriean herd on the Pribyloff Islands the following season. This very radical suggestion might be regarded as the flomrish of a trump eard. It probably was intended to demonstrate in a striking manner the faet that the United States could speedily end the controversy over the hearls of all concerned, and it was thereby hoped to arouse the London foreign office from its attitude of indifference toward the question of the seals. The measure seems, nevertheless, to have been seri- 
ously considered; it actually passed the Lower House, though it failed to reach a rote in the Senate.

However discouraging the failure to gain English consent to modify the sealing regulations for the season of 1897 , a hope still lingered that some form of action might yet be taken by the two govermments during the summer and autumn of 1897 , which would anticipate by one year the revision of the sealing laws, and spare the diminishing herds the last or fifth season's (1898) slaughter. Mr. John W. Foster and Mr. Charles S. IIamlin, whose familiarity with the Bering Sea questions espeeially fitted them for the duties involved, were appointed in April, 1897,_ "Seal Commissioners"; they were instructed to bring about, if possible, and at an early date, a general conference of delegates from the various powers interested, to meet in Washington for the purpose of coming to some understanding and settlement of the seal question. Russia and Japan promptly accepted the invitation to participate at such a conference, but Great Britain demurred. The foreign office granted a willing consent to a joint meeting of scientific experts to take place in the autumn, "in order by due consideration of the reports drawn up by the said experts to arrive at correct conclusions respecting the condition of the seal herd frequenting the Pribyloff Islands." It will be remembered that Professor Thompson and Dr. Jordan were again in the field making final observations upon the conditions of seal life, and their return to their respective countries was expected in the autumn. The British Government, however, was decidedly opposed to a meeting at that time of regularly appointed diplomatic agents with plenary powers to make a treaty - as it objected to a convention of agents whose armissions would be in any manner bincling npon their govermments. Even at such a meeting of experts, Lord Salisbury objected to the presence of delegates from Russia or Japan, which nations he declared harl no experts "in a position corresponding to that of the eommissioner's who lave been carrying on their investigations upon the Pribylolf Islands during the past two years." IIe further asserted as a suffieient reason for the exclu- 
sion of their delegates from the proposed technical conference, that "neither of the two countries in question possess any direct interest in the herd frequenting those islands" (Pribyloff).

The folly of seeking a settlement of the sealing question without England's coöperation was at once recognized. The sympathy of third parties might be grateful, but what the United States really desired was England's consent to amend or alter the conditions of a bad contract. The British Government were espeeially unwilling to discuss the merits or faults of the regulations with Japan or Russia, for the simple reason that neither of these powers was in any manner bound by them. Great Britain very properly declined, furthermore, to confer upon an equal footing with parties outside the compact. The English Secretiry for Foreign Affairs no doubt shrewdly suspected that England would be ontroted in the conferences where Russian, Japanese, and American interests would be identical and likely opposed to those of Great Britain.

Upon the failure to secure English coöperation, the first impulse of the American commissioners was to abandon the projected conferences altogether, and to recall their invitations from St. Petersburg and Tokio; but the enthusiasm which was displayed by Russia and Japan in the cordial responses of those powers to the American invitation male the withdrawal of the United States from the negotiations extremely awkward, if not impossible. It was also lioped by Mr. Foster and Mr. Hamlin that England might yield at the last moment and send a diplomatic representative to the proposed convention. This hope proved a disappointment, for the conference opened in Washington (October, 1897), with the vacant chair of the English delegate foreboling an impotent conclusion to the meetings.

The agents of the three powers (Russia, Japan, and the United States), soon came to manimons conclusion that under existing regulations the fur-seals inhabiting the North Pacific Ocean and Bering Sea were "threatened with extinrtion, and that an international agreement of all the interested 
powers is necessary for their adequate protection." To make these conclusions more effective, the three powers entered into a written agreement, calling for an international conference to devise a new system of laws for the protection of the seals. The agreement also prohibited pelagic sealing, so far as their own subjects were concerned, until such prospective regulations could be brought into foree. This convention, signed November 6, 1897, was of course made conditional upon the alherence of Great Britain; accordingly the instrument was at once presented to the British Govermment, with an urgent plea for its consent to become a party thereto.

Without awaiting a reply from Great Britain, Congress passed a bill in December, 1897, prohibiting the killing of seals by American citizens in the North Pacific Ocean, except as they may be taken by the North American Commereial Company on the Pribyloff Islands. The act also prohibited the importation of sealskins into the United States, whether "raw, dressed, dyed, or manufactured," except under most burdensome conditions. The object of this legislation was not only to prevent Americans from engaging in pelagic sealing, but also to discourage this practice in others by destroying the American market for the skins. Its anthors no doubt hoped to force Great Britain into a treaty prohibiting pelagic sealing.

Lord Salisbury declined to give his sanction to the provisional treaty of Russia, Japan, and the United States. He wrote to Mr. Hay (December 23,1897 ) “ . . . in the opinion of Hel Majesty"s Govermment, no useful purpose could be served by their taking into consideration at the present moment the question of their alhesion to this convention"; and again (Jannary 12, 1898), "It has been the wish of ller Majesty's Government that an agreement should be arrived at on the seal fishery question as well as on other matters pending between the United States and Canada, but they camnot in the present ciremustances adhere to the convention, which would inflict a serious injury on Her Majesty's Canadian suljeets, and which in their opinion is not required for the protection of the seals in the open sea, while it makes 
no provision for restricting the destruction of the seals on the Pribilof Islands by the American Company."

The provisional treaty, therefore, found an early grave in the waste basket. In the meanwhile, however, events of seemingly greater importance toward a final settlement of the troublesome questions were transpiring in Washington. Immediately following the conclusion of the convention between the United States, Russia, and Japan, the proposed joint meet. ing of the English, Canadian, and American scientific experts took place (November 18. 1897). At this auspicious meeting, the scientists were enabled to agree, and the resulting joint statement of their conclusions in regard to sealing conditions promised well for future suceessful negotiations with Great Britain. At last there was a common basis of fact upon which the two nations could stand in their deliberations for a new set of regulations. Most important of all for American interests, these conclusions of the experts virtually sustained the American position, calling for the very remedial measures which the United States Govermment had been striving to bring abont for four years. The commissioners agreed that there was ample evidence since the year 1884 that the fur-seal herd of the P'ribyloff Islands had declined greatly in numbers, but at a varying rate from year to year: that from given data, the former yield of the islands was from three to five times as great as in 1896 and 18.47 ; that the death anong the young fur-seals was very great: that actual count of these and of the females upon the ishauds confirms the belief in the diminution of the herd; that a marked decrease was to be noted in the twelve months from 1 sin; to 1897 ; that the method of driving and killing practised on the islands by the American Chartered Company calls for no criticism or objection; that pelagic sealing involves the killing of males and females alike ; that the reduction of males effected on the islands causes an cnhaneed proportion of lemales to be found in the pelagie eateh ( 62 to 84 per cent): that a large proportion of females in the pelagic catch incluctes not only adult females, both nursing and pregnant, but also young seals; that the polygamous hab it of the animal compled 
with an equal birth-rate of the two sexes permits a large number of males to be removed with impunity from the herd; that the killing of females far in exeess of the natural yearly increment is the cause of the reduction of the herd; that actual extermination of the herd is not threatened so long as the seals are protected on the island; that the diminution of the herd had already reached the point when the sealing industry either at sea or on the islands had become unprofitable.

Sir Wilfred Laurier, the Canadian Premier, and Sir Louis Davies, Minister of Marine from Ottawa, happened in Washington during the course of the meetings of the seal experts. Negotiations of an informal character were then and there entered upon with them for the purpose of temporarily settling the sealing question upon the basis of the joint findings of the scientific commission, the object being to bring about as soon as possible a formal consideration of the question by the British and the United States Governments. Mr. Foster's proposal, however, for a modus vivendi "providing for a complete suspension of the killing of seals in all the waters of the Pacific Ocean and Bering Sea for one year from December, 1897, and for a suspension of all killing of seals on the Pribyloff Islands for the same period," was not favorably received by the Canadians. "There are difficulties in agreeing to that proposition which I fear will be found insuperable," wrote Sir IVilfred Laurier to Mr. Foster. "The fleet is preparing as usual; the prohibition of pelagic sealing for a year would practically destroy the business for several years, because the masters, the mates, and the erews, for the larger part belonging to other parts of Canada, would leave British Columbia. The sum which would likely be demanded as compensation is far beyond what it would be possible for us to induce Parliament to vote, even if we conld recommend it.... I am in hopes that you will not press for the immediate suspension of pelagic sealing." So tliese efforts toward a preliminary diseussion of the regulation proved after all to be fruitless.

This last attempt, like the many others on the part of the United States to induce Great Britain to modify the Paris sealing regulations of $18: 1: 3$ before the end of the stipulated 
five years, having failed, the Secretary of State had no alternative but to fall baek upon the five-year clause in the award. The sealing season of 1898, the fifth and last uncler the Paris regulations, was entered upon with no ehange in the laws.

Mr. Sherman wrote to Sir Julian Pauncefote February 1, 1898: "The President has learned with deep regret that the British Government has deelined to adhere to the provisional convention and has shown an indisposition to agree to any appropriate measures for the suspension of the killing of seals for the current season. He has therefore directed me to bring to your attention the provision of the award of the Paris Tribunal of 1893 , which fixes the period when the regulations adopted by that tribunal should be subjected to a revision, and to ask that an arrangement be agreed upon with as little delay as possible for such revision."

The sealing season of 1898 being the fifth and last under the regulations, Great Britain at length consented to a review of the laws, in aceordance with the provisions of the awarl. Instead, however, of conducting the negotiations directly between the two powers, it was determined by mutual agreement to carry on proceedings between Washington and Ottawa, Canada assuming the responsibility of protecting ler own interests.

As an outgrowth of the visit of the Canadian Premier to Washington in the autumn of 1897 , a plan was diseussed for a joint Canadian and American commission whose members should be appointed by the exeentive branches of the two governments. It was proposed to place before this commission the numerous subjeets of eontroversy which had arisen between the Dominion and the United States. One of the most important subjects was the sealing question, involving the adoption of a new set of regulations. The scheme was favorably received by both parties, and an agreement was signed in Washington on May 30, 1898, for the creation of the commission; its members were announced in July, and the first meetings were held in Quebee the following Angust. In October the commission adjourned to reassemble in Washington on Novenber 1; sessions were then 
continued, with some slight interruptions, into the early spring of 1899, when a further adjournment was made to the following summer. The meetings, however, were never resumed.

Unfortunately, the subject of pelagic sealing soon became involved in the adjustment of other important questions before the commission. An idea was at first entertained that the United States might do well to purchase from the Canadian sealers their entire outfits, and thus nullify the very pertinent argument of the Canadians that complete cessation of pelagic sealing would bring financial ruin to a number of British subjects who had already invested their capital in vessels and in the paraphernalia needed for catching seals in the open sea. 'This plan, however, was rejected, and another method of settlement had to be sought.

The most important question before the commission, and the one which presented the most stubborn difficulties, was that of commercial reciprocity. The Canadian agents were quick to seize upon the opportunity of securing a good bargain through the eagerness of the United States to secure laws absolutely prohibiting pelagic sealing. Accordingly, they valued their "concession" in this respect the more highly, and demanded in return what appeared to the Americans to be an unreasonably large price in the shape of a free list of American importations from Canada. The more this question was discussed, the more hopeless of solution it appeared to be. Finally the commission encountered an unsurmountable obstacle to all negotiations in the Alaska boundary dispute; when adjournment took place (February, 1899), the Bering Sea question - as, indeed, all the other issues before the board - were left entirely unsettled.

It will be recalled that one of the points of disagreement between the two powers in framing the Washington convention of February 29, 1892, hat been in the matter of british claims against the United States for the seizure and condemnation of Canadian vessels in Bering Sea. In 1886-87, when the evils of pelagic sealing were first noticed by the United States Government, a number of vessels hailing from 
British Columbian ports were seized, through orders from Washington, by American revenue cutters, and afterward condemned in libel proceedings at Sitka. These captures had been made in what their masters maintained to be the open high seas, - i.e. outside the ordinary three-mile limit of marine jurisdiction. The case of the sealing schooner W. P. Sayuard was appealed by her owners, and eventually reached the United States Supreme Court, where, as a test case for all the other vessels similarly libelled, it was expected to obtain a definition of the term, "ligh seas." The case wats dismissed in Washington upon a technicality, and no decision upon its merits was rendered. The owners of the condemned vessels were, nevertheless, determined to obtain redress, and the matter of dimages for wrongful seizure and confiscation by the United States authorities having been taken up by the British Government, the question drifted into diplomatic channels and became a part of the greater "Bering Sea controversy."

When it was finally agreed to arbitrate the whole question, the claims of these Canadian shipowners naturally came forward for recognition by the tribunal. In the convention of lebruary 29,1892 , with Great liritain, - in which the jurisdictional rights of the United States in Bering Sea waters were submitted to a tribunal of arbitration, - it was stipulated that either party might submit to the arbitrators any question of fact "involved in said claims and ask for a finding thereon." The question of the amount of liability of either government on the facts found was, however, left subject to further negotiations.

The british agents aceordingly presented to the arbitrators at Paris all the facts in comneetion with the confiscation by the United States of the Canadian sealing ressels. These facts, which gave the exact locality of each vessel when captured, its distance from shore, the number of skins on board, ete., were agreed to $b y$ the Lnited States agrents, and the arbitrators unanimously found the same to be true. With the facts in each particular case thus accepted by both the British and the American agents, and the jurisdiction of 
the United States in Bering Sea having been limited by deeision of the tribunal to the ordinary zone of territorial waters, the seizure of these vessels outside of such territorial waters stood acknowledged as illegal; the United States could therefore no longer evade the liability for damages to their owners. The only question left to deeide was the amount of compensation due.

The following year (1894), the Seeretary of State, Mr. Gresham, signed an agreement with the Canadian authorities to pay to them the lump sum of $\$ 425,000 \mathrm{in}$ satisfaction of these claims, but Congress refused to appropriate the money, notwithstanding the fact that the full British claim amounted to about $\$ 850,000$.

During $1895-96$ efforts were continued to fix the amount of compensation due satisfactorily to both sides. A treaty between Great Britian and the United States was finally signed in February of the latter year, providing for the appointment of a tribunal to adjudicate upon all these claims. It was to be composed of two members, - a Canadian and an American, and. in ease of disagreement, a third and neutral member was to be called in as umpire. William L. Putnam of Portland, Maine, Judge of the First Judieial Cireuit of the United States, was chosen by the President as commissioner on the part of the L'nited States, and George E. King, a Justice of the Supreme Court of Canada, was likewise seleeted at Ottawa.

The commission met in Victoria, B. C., and later in San Francisco, where testimony was reeeived orally as in open court. No umpire was found necessary, and in December, 1897 , the commissioners submitted their joint report to their respective governments, their award being final. 'The total amount of damages to be paid by the United States to the injured shipowners was placed at $\$ 473,151.26$. In finding this sum, the commissioners included not only the value of the ressels, their outfits and the skins confiseated, but also the value of the probable catch which wonld have been made had not the ressels been prevented from continuing their operations throughout the sealing season. Each vessel 
estimated a prospective cateh of 3500 to 5000 skins at a value from $\$ 3.50$ to $\$ 12.50$ each. On June 14,1898 , a joint resolution of Congress appropriated the sum of $5473,151.26$ to pay the award, and two days later, the Assistant Secretary of State, Judge Day, delivered a check upon the Treasury to Sir Julian Pauncefote. Thus closed in amity the question of the Bering Sea claims.

Deep regret was felt that the Joint High Commission had been unable to frame a new set of regulations. Cunler the five years' regulations of the Paris award, the seals were to a eertain extent protected, although that protection was admittedly inalequate to preserve the herd; but since the termination of those laws and the failure of the Canadian commission to create new ones, the seals have been left wholly and absolutely without protection while in the sea; the same distressing conditions which existed in Bering Sea before 1894 prevail once more. Dnring the seasun of 1899 and the statson of 1900 pelagic sealing was and is to-day free to all withont let or himbance.

If the seals were in danger of extermination, even muler the proteeting laws of the Paris awad, as is generally believed to have been the case, that danger must now be vastly increased since all restrictions have been lemoved. Now, still further to agoravate the situation, while Canalian vessels are accorded perfeet freetom to kill seals in bering Sea waters, American vessels alre barrecl from all participation in pelagie sealing. The laws to this efferet passed by Congress in the winter of 1897 remain in force, and thus, in the final slanghter which is promiserl, the ('andians will realp) all the profits.

The herd lad beeone so diminished in numbers in $18: 9$ that the industry for that year was quite muprotitable. 'The Canadian sealing fleet of $18: 9)^{1}$ was smaller than that of the previous season. but eonsidering the depletion of the herel, an alarmingly large eatch of suals was marle.2 A larger theet sailed last year ${ }^{3}$ and the outlook for the present season is a

1 Twenty-six British vessuls. 2.5, $846 ;$; $5.21 \%$ fermales.

3.3. British vessets. Catch :5,191, with a large excess of females. 
discouraging one. Apparently nothing can be done to save the animals from total extinction. Could the industry be properly regulated, there is said to be no doubt that it might flomish for all time. But the seals belong to no one when outside the ordinary limits of marine jurisdiction, and the high seas must be free to all. There is no legal remedy. Possibly a balance will be found, and the yearly diminution of seals will cause a corresponding falling off of hunters, as pelagic operations become less renmmerative. But the chances are strongly in favor of a total destruction of the herd within a few years, unless some immediate understanding can be had with Great Britain to check the onslaught.

The American eompany on the Pribyloff Islands took in 1899 and $1900,16,812$ and 22,470 skins respeetively, the increase in 1900 indicating a desire to gain as much as possible from a dying industry.

In consequence of the unequal laws governing their operations, American pelagic sealing vessels have been driven from the field. Danger of further conflicts in Bering Sea is lessened, but the unjust conditions whieh are imposed upon the Americans remain as a sequel to the closing of a diplomatic incident which from first to last has been disastrous to American interests. 


\section{II}

THE INTEROCEANIC CANAL PROBLEM 



\section{II}

\section{THE INTEROCEANIC CANAL PROBLENI}

THE problem of interoceanic communication at some Central American point is by no means a new one, as it finds its origin in the very eauses that led to the diseovery of America. The repeated voyages of Columbus were for the purpose of finding an open waterway to the East Indies. The early Spanish navigators explored every bay and cove and ascended every river of Central and South America, in the hope of discovering a passage through which their vessels might reach those lands of boundless wealth of which Mirco P'olo hat given account. Their object was to find a short and direet route "from Cadiz to Cathay." Since the days of the earliest explorers, the history of Central Ameriea las been closely associated with this question of an interoceanie waterway, first, to discover the natural one, if it existed, and in its absence, to construct an artifieial one.

A wagon road across the isthmus from P'orto Bello to Panama was constructed early in the sixteenth century for transportation to and from the "El Ioralo" that P'izarro had discovered in Peru; indeed, as early as 15:30, Peelrariats Davila, governor of Niearagna, wishing to divert the transit trade of Peru from l'anama to his own flomishing colony, conceived the plan of constructing short canals aloout the rapids of the San Jnan River, in order to make a waterway between the "North" and "South" seas. The prssibilities and advantages of this open water comnection betwern the great oeeans was also thoroughly appreciated by the Spanish home authorities, for Charles $V$ of Spain, in 15.36, ordered an exploration of the Chagres River (at Colon) for the purpose of ascertaining whether a ship canal eoull be practically substituted for the wagon road; and Philip II, in 
1561, sent his engineer to explore Nicaragua for the same purpose.

From the earliest days of Spanish discovery and settlement in C'entral America, down to the present moment, canal schemes have originated, flourished, and died. Although never quite abandoned, they have at various times been laid aside, - as during the times of struggle between Spain and the English freebooters in the West Indies, times when pirates roamed the seas and infested the lagoons of the mainland, and marauding expeditions laid waste the towns along these coasts. But whenever a lull in hostilities occurred, Spanish interest in the great eanal was sure to spring up anew, to be followed by further investigations and new projeets. These earlier efforts, however, amounted to very little, praetically.

With the decline of Spanish power and influence, other nations became interested in this faseinating canal problem, notably Holland, Belgium, Franee, England, and finally the United States. Volumes of maps and descriptions of favored routes have been filed away in government archives and in the records of private eompanies, among whieh are great numbers of extravagant statements coneerning the wonderful topographical advantages offered by various favored sections, along with astonishingly cheap calculations for eanal construetion.

It would be useless to the purpose of this review to examine all the numerous schemes for the building of isthmian canals from the beginning of the sixteenth eentury. Suffice it to say, they furnish a history of failure and blighted hopes. It might not be uninteresting, however, before proceeding to the politieal and diplomatic history of the United States in connection with this eanal problem, to make brief reference to some of the more prominent isthmian eanal schemes which have been projected during the present century.

No less than eight routes of supposed practicability have elaimed the attention and approval of engineers and those interested in the construction of a waterway across Central America. The six important ones are:- 
I. The Tehuantepec Route. The isthmus of Tehuantepee forms the narrowest portion of Mexico, it being about 150 miles across, from ocean to ocean. Cortez established a line of transit at this point, which was maintained for a number of years; but it subsequently yielded in favor to the admitted superiority of the Niearagua route. As early as 1550, Galveo, a Portuguese navigator, deelared the 'lehuantepee route a feasible one, and urged Philip of Spain to consider it. No further notice seems to have been taken of it until about 1770 , when Charles III of Spain ordered the viceroy of Mexico to locate a site for a eanal across this istlmus. The result of the viceroy's survey was diseouraging, and the plan thereafter was abandoned as unfeasible.

II. The Nicaragna Route. This leads from the mouth of the San Juan River to Lake Niearagua, thence by several proposed lines (preferably by way of Brito) to the Pacifie Oeean, a distance of 169.2 miles. Of all possible routes, this seems to have claimed the most farorable attention of American engineers. It is said to possess the best conditions for the location of a lock-system eanal, elijef of which is the existence of Lake Niearagua, which, with portions of its outlet (the San Juan River), provirles many miles of natural waterway, and an abundant and eonstant supply of water for the loeks. The elimatie eonditions of this loeality are also excellent. It is not unlikely that P'hilip of Spain would have here attempted the work of eanal eonstruetion in 1567 , which, in those days, would have been a labor of Ilereules, had not political complications at home diverted his attention from his ambition across the sea.

La Condamine, the eminent French scientist, who, with a corps of able infénienrs, was sent by his government (in 1735) to South America for the purpose of eonducting certain astronomical observations, marle an examination of Ialke Niearagua and its outlet. Ile heeame much impressed with the many advantages this route offered for the cristruction of a canal, and so reported to his government, but France was not then rearly to mudertake so great a project. Enghand seems always to have reeognized the value of this route, 
and for two centuries persistently sought and held territory near the mouth of the San Juan River, while American interest has always been especially alive to its feasibility and importance.

III. The Panama Route from Colon, or Aspinwall, on the Caribbean Sea, to Panama on the Pacific.

IV. The San Blas Route from the Harbor of San Blas to. the mouth of the Rio Chepo on the Pacific.

V. The Caledonian Route, aeross the isthmus of Darien, from Caledonian Bay on the Atlantic side to the Gulf of San Miguel. This is the narrowest point of land separating the great oceans to be found between the aretie circle and Cape Holn.

To the Panama Route nature has contributed mueh toward the possibility of constructing the work. There is. here a depression in the mountain range, the great Cordillera of the Americas, fumishing a pass only $28+$ feet above the tide. The distance from sea to sea is searcely fifty miles, and there are suitable harbors on either side. The advantages of a canal operated throughout upon sea levels, thus avoiding the eomplications and inconvenienees of locks, are so very great that one turns away from Panama with reluetince. One is inclined to hope that modern seientifie ingenuity may yet find means to surmount the obstacles presented by the floods of the Chagres River, the yielding sands. and soils of the isthmus, and the deadly climate of Colon and Panama. The other two routes near Panama were oneesupposed to be practicable, but careful surveys by more aecurate or less partial engineers have demonstrated the fact that. the monntain ranges crossing them present almost insurmountable barriers against the eonstruction of a canal.

V1. The Atrato Route. The Atrato River has its rise in Colombia, on the eastern slope of the Andes, and flows north. about two hundred miles, close to the foot of this great range of mountains, fmally debouching into the Gulf of Darien. So fearful was Philip II of Spain that the Atrato River might furnish to his enemies the coveted opening to the Pacific, and thereby destroy the profits of his earying trade by wagon road. 
zcross the Panama route to Peru, that he issued, in 1542, a oyal order, imposing the penalty of death upon any one who should attempt to enter that river. A veil of profound nystery long enveloped this region, and for upward of two senturies tradition gilded the unknown with its usual nagnificence. This most alluring river of the Atrato is :eparated from the Pacific Ocean, along its entire course, by t mere strip of land. 'This land, however, is the Cordillera, or summit of the Andes, and although it is furrowed on he eastern side by numerous streams tributary to the Itrato, the explorer has always been confronted, at the ources of these tributaries, by towering walls and impassble heights. This, therefore, has been a region of brilliant nomise and of sad disappointment.

Each of these rontes possesses its own good and bad feaures, its own peculiar advantages and disadvantages. Careful urveys of them all, made in the light of modem scientitic nethods, together with comparisons of their orographie, ydrographic, and climatic conditions have resulted substanially in the rejection of all except two from the list of practical ossibilities. 'These two are the Panama and Nicaragna routes. The beginning of the nineteenth century found Alexaner von Humboldt making a eritical examination of the arious Central American routes. He disensserl them at sngth in his "Personal Narrative of Travels," giving paricular emphasis to the superior alvantages offered by the iicaragua route. Humbolit eontributed to the work's nowledge the first valuable information, from a scientific oint of view, concerning this route; his conclusions so inpired the Spanish Cortez that it passed a deeree for the nmediate construction of a camal through Central Ameriea. pain's power and influence in the Western IIemisphere, owever, had by this time beeme far too feeble to carry out ny such undertaking, and this last spasmodic effort to waken her spirit of achievement in the New Workd expired lmost with its conception.

By the year 1824, all of the Sipanish-American colonies and secured their political freedom from spain, and had 
established themselves as free and independent republics, and those whose geographical position and topography warranted them in so doing stood ready to enter into treaty relations with any foreign power thought to be able and willing to construct an interoceanie eanal within their borders. The United States had, at this time, reached a point in its national existence when the entire attention of its government was no longer confined to matters purely internal and domestic. For the first time it was then ready to consider the subject of connecting the oceans at some favorable point between North and South America. The Panama Congress, which had been called to meet in June, 18:6, had for one of its oljects the discussion of this eanal scheme, and the attention of Mr. Clay, the American Secretary of State, was specially directed to the importance of the question. Perhaps American activity was somewhat stimulated by the fact that at the same time British influence was at work in Niearagua, seeking concessions for canal-building purposes.

A company was quickly formed in New York, called the "Central American and United States Atlantic and Pacific Canal Company." Encouraged by an Aet of Congress, this company set earnestly to work to present its bids for obtaining a coneession from Nicaragua before the English eompany could antieipate it and get firmly located in the field. Suceceding in obtaining its eoncession, the American eompany signed a contract in 1826 , with the Govermment of the Central American Confederation, to construct a canal through Nicaragua "for vessels of the largest burden possible." Estimates of eost did not exceed $\$ 5,000,000$. Great interest was excited in the United States and in Central Ameriea, but owing to a lack of funds necessary to the undertaking of so very large an enterprise, this, the first American effort to construct an isthmian canal, served but to add one more eximple to the long record of failures and disappointments.

In 1830 the king of IIolland, at the head of a Duteh canal company, secured from Nicaragua an exceedingly liberal concession, so liberal, indeed, that it called from President Jackson a strongly worded protest, predicated eliefly on those 
political principles so recently enunciated in the celebrated "Monroe Doctrine."

Following the failure of the Duteh company, which was immediate and complete, a number of less pretentious efforts on the part of American, English, and Freneh companies appear and disappear in rapid stlecession in both Nicaragua and Panama. The interest of Lonis Napoleon, then a prisoner at Ham, seems to have been keenly aroused to the imprortanee of the question. He organized a company known as " La Canal Napoleone de Niearagua," and in $184 t$ published a pamphlet advocating the Niearagua route, which remains to-day as a sort of exelamation mark in the history of the eanal. Its publication aroused new interest in Europe, and at the time brought to its author much reputation for practital statesmanship. Napoleon was foreed, however, to bide his time; but his opportunity he supposed had come at last, when from his imperial throne in Paris he watehed with satisfiction the gathering of the war clouds in the United states. When the storm of eivil strife had threatened the dissuption of the Union, he undertook the task of orerthrowing the republican institutions of Mexico and establishing in their place a government dependent on France, which would be at the same time an ally, offensive and defensive, of the Confederate States of America. In this delusive dream his fancy had sketehed the dismemberment of the American Rejublie, the aggrandizement of imperial Frunce, and a final sulpjection of Western interests to the domination and control of Europe. The overthrow of the Southern revolt prevented the possibility of suceess, and his splendirl revery was forever dispelled by the fortunes of war at Sedin. The hulding of a Frenell canal through Nicanagua was probahly but a small fart of Napoleon's great Western project.

About the year 1850 eonsiderable enthusiasm was aromserl in Europe, and espeeially in Fante, over the report of cedtin explowers in the lower istlumbs. At one time there were three parties of engineers (. Imorican, linglish, and finemeh) struggling in the pestilential jumgles and morasses bolow Panama in seareh of reported but imagrinaly depersions in 
the mountains. The English and American surveyors left. the region in disgust, but the French eompany, encouraged by the Société de l'Étude of Paris, and by popular enthusiasm at home, continued to make investigations along the lines of the Caledonian and Sim Bliss routes. Between 1850 and 1855, a wealthy American, Mr. Kelly, who was charmed by the mysteries of the Atrato River, spent a fortune in making a reconnaissance of this region. The result of this active exploration of the lower isthmus during the years 1850-55 was to place the Itrato, the C'aledonian, and the San Blas routes outside the limits of practical canal possibilities.

The "Central American and United States Atlantic and Pacific Canal company," launched with flying colors, and doomed to disappointment, was succeded twenty-two years. later by "The American Atlantic and Pacific Ship Canal Company," which was organized in New York, with Cornelius Vauderlilt at its head. It secured from Nicaragna (September, 1849) a favorable concession to build a canal from any point in the state on the Atlantic coast to some Pacific point, together with a liberal land grant and a monopoly of steam navigation on the rivers and lakes of Nicaragua. With so promising a begiming the company despatched its engineer, Colonel Childs, to make accmate and complete surveys of the route. The Childs survey was the first really technical examination made of the Nicaragua route; and the line adopted by him in 1850 has been practically approved and accepted by engineers in all subsequent surveys. Preparatory to embarking woon the great work of building a complete waterway, the company operated a line of small steamers on the river San Jum and lake Nicaragua, continuing the transit by stage coaches from the lake to the Pacific Ocean. 'The profits of this preliminary enterprise were exceedingly large during the pioneer rush to the gold fields of California. Although the company for some years continned successfully to operate this "temporary line" of transit even after the construction of the P'anama Railroal (completed in 1855), it accomplisherl comparatively nothing toward the declared object and purpose of its creation. 
A series of diplomatic difficulties and entanglements then arose between the United States and Great Britain touching their respective rights in Nicaragua. These diffieulties, together with politieal confliets in the United States, operated to decrease public interest in the great undertaking, and so delayed and erippled the American promoters, that the Nicaraguan ('ongress lost entire eonfidence in their ability to carry out the company surpose. It finally (May, 1858) declared a forfeiture of the franchises of the Ameriean conpany and transferred similar rights to one Felix liclly of Paris. The Belly company, however, was unable to secure the funds necessary, even to legin the work, and its eoneession accordingly lapsed. Ont of this apharently hopeless confusion, the American Company sneceederl in effecting a reorganization under the name of the " ('entral American 'Transit ('om]nuy," and as such continued to clam and exercise the rights and franchises of the former company until 1869, when it sold and transferred the same to an Italian company. After 1800 fmblic interest in the project seems to have wholly subsirled in the Lnited States mitil the year 1872, when President Grant revived the subject by urging that the eamal be built by the government as a national undertaking. In pursuance of his suggestions, he appointed an "Interoceanic ('anal Commission," consisting of the chief engineer of the army, $A$. A. Inmplures, the superintendent of the coast survey, C. P. Patterson, and the ehief of the burean of navigation, Alminal Ammen, moler whose direction a series of exhaustive surveys of the Tehnantepee, Nicalagua, Panama, San Jias, and Atrato routes Wats made. The report of the commission farored the Nicaragua route as formerly surveyed by Colonel Childs, and steps were taken to organize at eompany for the matnagement of the werk.

From the more modest operations of the American promoters in Niearagua one must turn for a moment to lanama, where. by this time, the l)e lessegs sehene was at the loeight of its

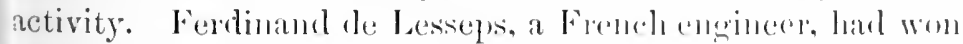
the confidenee and anmintion of the wolld hy his splemdid success in constructing the Sur\% ('anal. Ite hatel revived the old scheme of a tide-Watcle cinal from ('olum to l'anama, and 
having organized a French eompany, and also seeured liberal franchises from the Colombian States, he took in hand the task of raising the necessary funds for its eonstruction. Through the aid of the Paris Geographical Society, he eaused a series of surveys to be made in the lower isthmus, all of which were subsequently found to have been absurdly superfieial; then, in order to decide upon the best route and to stamp the approval of the world upon his ehoice of it, he invited the political authorities of Europe and America, as well as the presidents of many geographic and scientific societies to send delegates to an "International Scientific Congress." By extraordinary cleverness and ingenuity De Lesseps carried every point in this convention, which finally deeided that a tide-level canal could be built at Panama for $\$ 140,000,000$. Hostile eriticism of the unlertaking in the Enited States, foreshadowing a protest on its part against exclusive French control of the work. finally brought De Lesseps to Washington for the purpose of overeoming threatened American opposition. He managed the "preparatory arrangements" for his grand scheme with marked ability, and the enthusiastic and readily excited French people struggled to obtain shares in his company with as much zeal as they had once before manifested in the purelase of stock in the Mississippi sehene of John Law. Work was begun at Aspinwall in 1881, and was continued for nearly seven years, when it was fouml that the canal, though not half finished, had eost upward of $260,000.000$. Further investigation disclosed the hopeless insolveney of the eompany. The scamblats comnected with the enterprise were so great as to compel eximination by the legislative anthorities of France, resnlting in the discovery of eorruption and fraud in its mangement. which fairly astomeder the world. Many millioms had been spent in buying the faror or silenee of the press and in purchasing the support of legishators. The names of many prominent offirials of highest rank and position in Finner were sarly smirched in the process of the investigation. The original intentions of the promoters were, without doubt, honorable: but hefore the work had progressed 
a year, it became evident to those in charge of the operations on the isthmus that the difficulties to be overeome had been greatly underestimaterl. The soft, yiehling eluracter of the soil, the heave rains and flooks. the miasmie climate all arderl new complieations which vastly increased the lahor and expense of the undertaking. To attain suceess it berame necessary greatly to enlarge the capital of the company. and to aceomplish this objeet it became equally necessary to (monrage public enthusiasm hy frepuent and glowing rejorts of the company's sureesisful pogress.

When an utterly hopeless future confronted the officers of the company, when but a breath was neederl to burst the expanding hubble, the promoter's still maintained their struggle to suppress the truth. At last the expense became too great. The crash came, carrying down many thomsands of Freneh investors who had staked all won the reputation and promises of De Lesseps. Even to-dily the great dredges and massive machinery employed in this gigantic molertaking, and representing many millions of cost, lie lalf buied in earth, corroded with rust, and draped in natme's veil of tropieal foliage. They lie at Colon like fallen monnments to the greatest failure of the eentury. This is, of all, the most melancholy event in the somewhat tragie history of isthmian eanal projects.

For a brief time financial success marked the operation of the Ameriean Canal Comprany, in so far only as it undertonk to maintain a trans-isthmian overland rente. In atetual progrress toward the building of the eamal, the revonds of this, as of all other canal eompanies, tell the old story of failure.

Just after the conehsion of the Felingluysen-talialla treaty with Niearagua (1884), a number of prominent business men, encombaged by the liheral concessions promised to the Enited Sitates in that traty, met in New York amb organized the "l'porisional Camal Assoriation." It was the object of the eneregetie promoter's of this assoriation to form a company whose distingmished persommel. Whose tinamoial guarantees, whose advantages in the way of conlessions, and whose command of engineering talont would malie fatilure 
an impossilility. The association was neither chartered nor incorporated ; it had no connection with the government; it was simply a private symlicate. Between two and three million dollars were quickly subseribed, and Mr. Nenocal was sent to Nicaragna to seeure the necessary eoncessions. With an ample bomms paid in arlvance to the Nicaraguan anthorities, lie met with no diffienlty in olstaining for his clients (April 2t, 1887) an exchusive right to build and afterward to nperate a camal for ninety-nine years. The state hound itsell "not to make any subsequent coneession for the opening of a canal between the two oceans during the term of thr fresent concession." and the association pledged itself to expend a certain amomit within a specified time and to complete the work in ten rears.

E pon Mr. Menocal's return to the Lniterl States the syndicate causerl a "Nicangunan Canal Comstruction Company" to be incorperated nuler the laws of Colorado with a nominal cappital of -12 . (1)(1).0(1). As an arljunct to the "Assoeiation" and in conformity with the terms of their eoncession, the Construction ('ompany at once set about making necessary final sureys and eliminating the technical uncertainties that still stool in the way of the commencement of actual construction. Mr. Menocal leal this engineering expedition. The survey covered a period of nearly three years, and was a most exhanstive scientific investigation of the route. 'Throughout the conntry considerable interest began to attach to the progress of Mr. Menocal's investigations, and the Canal Assoriation had the heartiest good will of all for its future suecess; in fact, a genelal belief began to manifest itself that the eompany should have the protection, as well as the dignity, of a national charter. I'noler stress of sudden popnlar enthusiasm, both IIomses of Congress assented to the froposition to datrer the association, and rery soon after the introluetion of the masme into the Senate the company reorived its anteles of incorporation and was christenert the "Nantime C'anal C'ompany of Nicaragna" (February 20 , $1889 !)$.

'The comprany was at once olemanized with $\$ 10,000,000$ of 
stock; new eontracts were made with the Canal Construction Company, and the digging of the Nicaragua Camal aetually began. Hon. Warner Miller of New York was made president of the Construction Company. Having raised funds sufficient to undertake his contratet with the Maritime Canal Company, he pressed the work in Nicaragua with great energy. Within one year the stipulated $\$ 2,000,000$ hat been expended to the entire satisfaction of an exacting govermment in Nicaragua. In three years nearly five millions had been spent. Seemingly insmmountalste diffieulties were overcome in bulluing a line of railroad thirteen miles from the coast to the foot-hills across the lagoon, through the tangled massiss of swampy jungle that intervened. A camal two miles long was dug, breakwaters at Greytown were constructed, the harbol was dredged, and altogether sitisfactory progress wats being male when the financial panic of $189: 3$ eompelled the Construction (ompany to suspend all operations. Despite all efforts to stem the tide of arlverse fortune, it soon after fell into the hands of a receiver.

The officers of the Marritime Canal Company constantly exerted themselves to kere firesh the lively public interest which had been exhibited in their projeet from the hegiming, and their efforts were rewarded ly many demonstrations of public enthusiasm. In ounuary, 1891, the senate committee on foreign Relations framed a bill anthorizing the government to gualdantee an issue of one hmutrerl millions of the Maritime Canal Company's bonk amel to hold as a pledere a entrolling interest in the stork of the annpuny. Althongly the measure, which wats wallmly supperted ly senalors sherman and Moreran, did not herone law, this incident of the committee room served to demomstrate the trent of puldie thought upon the matter of gevernmental control of any ('en-

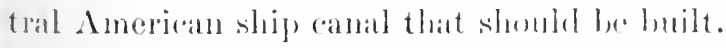

There was one reason in partienlate why the idea of ener-

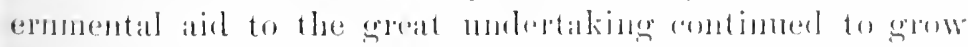

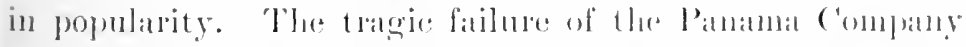
hat made a strong impuresion mpon the minds of investors. 
That lamentalle event had fumished the best proof of the utter futility of any private corporation undertaking the gigantic task of piercing the Central American Cordillera; none but a Ilercules slould attempt a labor of Hercules. Aside from reasons relating to the physical side of the question, the very nature of the project itself appeared to invest. it with a national rather than with a private character. The difficulties, political and economic, as well as technical, which surromiled the enterprise, removed all doubt that the construction of the canal should be under the anspices and protection of the United States Government. The use of the canal when completed would necessarily be most intimately comnected with vital interests of the nation. Would it then be safe to subject to the chances of private ownership an undertaking which involved interests so complex and important? Public opinion then rapidly shaped itself into a conviction that the canal should be built by the government in order that it might at last be controlled by the govermment.

Further reasons induced the stockholders themselves persistently to seek govermmental aid for their project. Periodic political disturbances in Central America had cansed the Maritime Canal Company consiclerable embarrassment. A genuine respect for any body of private citizens operating within her borders eould searcely be expected from Nicaragua's turbulent political factions. At any moment Central America was likely to go to war. Indeed, the efforts of the company to prosecute the work at Greytown had been hampered from the ontset by quarrels between Nicaragua and Costa Rica. The news of the ammoying delays forced mpon the company by these frequent political disturbances reached the United States, and deterred many who were otherwise most enthusiastic in the cause of the canal from risking cappital in its development. Even while active work on the part of the contractors was progressing in Nicaragua, the lack of suffecient fumds greatly handicapped the Maritime Canal Companys operations. In this awkward predicament the promoters were in doubt as to the proper course to be 
this measure, govermmental guarantee of $\$ 70,000,000$ of the comprany's bonds was called for and national ownership of $\$ 70,000,000$ of stock, and the Seeretary of the Treasury was anthorized to control the construction of the work. Thus the idea of absolute govermmental ownership of the camal, together with a governmental responsiloility for its construction, was contemplated by Congress. The measure bid defiance to treaty stipulations of the United States, which should have acted as an estoppel to any such legislation. The bill was lost in the House, notwithstanding the fact that a great majority in both branches of Congress strongly favored govermment ownership and eontrol of the Nicaraguan Camal.

In 1895 Congress again took action in the same direction: but, as before, the House refused to aeeept the measme which the Senate had been willing to adopt. However, on March 2, 1895, Congress authorized the appointment of a commission of three engineers for the purpose of reporting on the feasibility, permanence, and final cost of the company's project; $\$ 20,000$ were appropriated for the purpose, and the company added generously to the amount of the appropriation to help defray the costs of the commission. The ereation of this commission was generally aecepted as evideneing an intention of Congress, sooner or later, to extend its protection over the Maritime Canal Company, by the absorption of its capital, and ultimately to secure full control of the work. The same field had been surveyed and resurveyed many times by competent engineers, and further scientific investigation along the well-known route was liardly neessary; however, the commission (under General Ludlow) entered upon the task with the seeming apploval of the comntry.

The commission reported in November, 1895 , to the effect that the company's project for a ship eanal in Nicaragua was perfectly feisible, save for some detail in the eompany's plans to which the eommission duly exeepted. The report recommended still further investigation in order to obtain certain adkitional dita which the engineers deemed essential for a final conchusion and a correct estimate of cost. 
The measure was not again called up until January 18, 1897, when it became the special order of business in the Senite for nearly a month. A vast amount of testimony, from many sources, had been taken by the Senate eommittee to demonstrate the neeessities for passing the bill, and voluminous clocumentiry reports accompanied the Senate committee's recommendation. But behind the necessities of the case there existed in the minds of many of the Senators an uncomfortable feeling that the passage of the bill might involve a neglect of those moral requirements placed upon the nation by its treaty stipulations. Many advocates of govermmental control of the canal fully believed that the C'layton-Bulwer treaty with England, binding the United States never to secure sole control of any isthmian eanal, had long since beeome a dead letter; yet that treaty had never been formally abrogated, and all past attempts to avoid its terms having failed, the treaty still stood as though fully and unreservedly acknowledged. This treaty, made in 1850 , operated as a check, though as yet a silent one, upon any such legislation as the Senate at that time contemplated. Other influences, notably those of the great transeontinental railways, stealfastly opposed the passage of the bill. It was finally tabled, and the hopes of the Maritime Canal Company again withered.

Before the close of 1897 the President appointed a new commission, eonsisting of Admiral Walker, Colonel P. C. Haines, and Professor Lewis N. Haupt, to make a final and complete survey of the entire Niearaguan ronte. This eommission proceeded to Greytown in November, 1897, with a corps of able engineers and a large force of assistants. It was armed with the most perfect scientific equipment. The sonding of this commission - in this age of commissions wats really to serve a triple purpose. First, it would gather all the information needorl by the government to satisfy Congrorss of either the feasibility or non-feasibility of the Nicaraguan ronte, and it would add one more expert estimate of cost to the many previous ones on file. Secondly, it wonk rive the eneouragement felt to be due those who elamored 
over the ratio of their interests in the Maritime Canal Company. Their mutual dislike had proved unappeasable by war. Did Niearagua desire to oust Costa Rica from her concessionary rights, or did Costa Rica demand a more substantial interest in the canal? Whaterer may lave been the immer motives that prompted her to do so, Nicinagna continued to give evidence of a pupose to declare the forfeiture of the Canal Company coneession. On June 5, 1897, she entered into contract with the Atlas Steamship Comprany, whereby the latter seeured exehusive rights of navigation and raihoad construction on the lagoon at the month of the San .Tuan River and along the bank of that river. Sole privileges of navigation on Lake Nicarigua were also granted to this English company. While it was expressly stated in this contract with the Atlas Company that nothing in the instrument should be considered as an obstacle to the carrying out of any contract the Nicaraguan Government may have previously made in regard to the opening of an interocennic canal, yet the contract certainly bore upon its face an affront to the Maritime Canal Company. 'The latter company made vigorous protests, alleging gross violations of its rights under its eoncession of 1887, and called upon Congress to lend its support in resisting this unwarrantable aet on the part of Nienagua.

The limit of grievances was not yet reached. In 1894 , just after the failure of the Construction Company, which, it will be remembered, had held the contraets from the parent (Maritime Canal) company, for the actual construetion of the canal, a number of wealthy men in New York and Chieago hecame sufficiently interested in the ship-eanal projeet to make an investigation into the eonditions of the work along the ronte, with a view to purchasing neeessary rights and muldrtaling the fulfilment of the contract themselves. Ilaring risited the scene of operations the following year. they leproted that the Maritime Canal Company had been unable, ancolding to the torms of its concession, to keepr pace with fleeting time in the fulfilment of its obligations. 'They discovered that the Nicaragnan Govermment was disposed to agree with them in that the existing eompany could 
October 10, 1899, upon which date the Maritime concession was declared to lapse. It liffered in but few of its essential features from the Maritime concession of 1887. The company paid for it $\$ 100,000$, with a promise of $\$ 400,000$ more, as a pledge of good faith. It bound itself to begin the excavation of the canal within two years, and complete the same within ten years. The concession was in perpetuity, and the govermment bound itself by a declaration that no concession or privilege theretofore granted should, in any manner, "oppose, conflict, embarrass, or prejudice" this one. The free navigation, use, or disposition of all waters in the state were given to the eompany, which was also to retain exchusive control of the management and operations of the canal. 'The final articles set forth that it is "understood that for the purposes of this contract the Cardenas-Menocal contract (1887, to Maritime (ompany) shall cease to have legal existence on the 9th day of Oetober, 1899, and therefore all the foregoing stipulations shall take effect without further action, dectaration, or law, on the 10 th of October, 1899, or sooner, should Messrs. Eyre and Cragin, their heirs or assigns, obtain the rescission of the Cardenas-Menocal contract. . .

A forfeiture of its concession from Nicaragua was naturally the greatest ealamity that could possibly befall the Maritime Company, and now the very worst had happened. But the company still had to its credit nearly a year of grace before the contract came to its end, and the company's directors, undaunted by evil fortune, deeided to make a final and desperate effort to sive the company's life. Their best manner of secking redress for the outrages which they felt had been perpetrated upon them by a fickle, irresponsible govermuent was through interposition of the State Department at Washington. The right of the company thus to fall back mon national potection was found, first, in its national charter, which gave to Congress a privilege of supervision orer all its aftairs; and secondly, becamse its concession from Nicaragua and Costa lica, ly virtue of the quasi international charater of its provisions. partook, in a measure, 
f the nature of a treaty. There can be no doubt that the mpany had need of every resource at its command to extriite itself from the awkward position into which it had ulen, and it certainly played its strongest card in an appeal , the Department of State (December 2, 1898). A corresondence ensued, calling upon Nicaragua to show cause for s summary action in cancelling the contract of the Marime Company, and further asking for an opportunity on the art of the company to make a defence.

The year 1899 therefore opened with two rival canal commies, each holding exclusive concessions from Nicaragua, d each clamoring for public recognition.

Now a third company, operating in I'anama, suddenly ume forward with a flomish of concessions and a budget seductive arguments, further to confuse the already beildered Senate and IIouse committees who had in elange 1 matters pertaining to Central American canals. When te old Panama company reached its disastrous encl in 389, its scattered weckige was put through a process of anipulation by the courts of justice in Fance. Singulary lough, there remained some assets after the disaster, which, f the careful management of the "liquiclators," or receiss, were converted into a nest-egg for a new and more salthy company : this was duly organized moler the genesal nporation laws of France on October 20, 1894. Lis deceree court, all the canal and canal works, the concessions, ete., the old company were transferred in full right to the new se. An extension of time to 1904 , and then to 1908, within hich to complete the l'anana ('anal, was oldained from the olombian Govenument, and the new company set to work riously and hopefully, thomgh morlestly in the matteg of ependitures, as compared with the reckless extravaranee of e previous management.

'The suchen intrusion of this new filctor' on the commercial de of the canal problem led comgress into making an instigation into the morits and prospects of all three comprates. From Janulyy 17th to the 25th, 1899, the ('omnittee 1 Interstate and Foreign Commeree of the IIouse heard a 
presentation of the elaims to govermmental recognition and encouragement by the agents of the three rival companies.

The Panama Company presented an unexpectedly strong. case. They had to their eredit one fairly good and one excellent harbor upon the Atlantic and Pacific sides of the isthmus, nearly one-half of the entire work of excavation completed, an existing railroad paralleling the ronte of the canal, good concessions, and a force of three thousand men actually at work in the field. The company was shown to be solvent and its prospects bright. It asked for no finaneial aid, only to be spared adverse legislation. "We have a right to assume." concluded the attorney for the company, "that the Panama canal is a necessary, if not the controlling, factor in the solution of the isthmian canal problem."

The representatives of the Maritime Canal Company devoted their testimony largely to a defence of the company's rights under its concession from Niearagua, and to explanations why it had failed to eomplete the canal within the ten year's' limit as therein speeified. 'They stoutly maintained that their concession had not properly lapsed, notwithstanding their own failures. As against the Panama route, they urged the superior advantages of their own, alleging a better larbor on the Atlantic side, fewer miles of actual canalization, shorter canal termini for vessels with northern port terminals, better advantages in the matter of trade winds; and finally, as a convincing argument, they showed that the Panama l'oute involved diplomatic difficulties in the way of exploitation, which marle it far less deserving of public notice than their own project in Nicaragua. IIaving referred to the financial panic of 189.3 , and its effeets npon the eompany, Mr. IIram ITitclicock, president of the Maritime Company, said: "This condition of affairs has necessarily led to a waiting attitude on the part of the company, during which time its franchises and possessions have heen actively coveted by aspiring rival routes and interests, sometimes under the indileet inspiration of foreign powers: and it has encountered eriticisms and direct opposition of enemies in the United States and ('entral America. In the face of all this, the com- 
gany has remained solvent and faithful to its trusts, and it has rotected the enterprise and preserved it for the people and govsmment of the Lnited States." Rieferring to the Grace consession, he said. * It was entered into by Nicaragua in riolation If the rights and interests not only of this eompany (Maniime ('ompany), but of the United States and of Costa Riea." The representatives of the Crace-Cragin syndieate a\}roached their examination by the Honse committee in the unty manner of rictors fresh from the fray, and hearing the poils of rietory - in the shape of a remarkably liberal eomession from Xicaragna. They believed the Maritine conession to have alreatly beeome a worthless instrument, and ssisted upon their own paramount rights to begin work Ocber 9, 1899. Epon that day, they asserted, the Maritime 'ompany would be called upon by Nicaragna to open the mal to navigation, which, needless to siy, the Maritime ompany would be unable to do; then the latter comprany ould be obliged to stand forth and acknowledge its failnre , earry out the terms of its eontract and aecept its forfeiture ithout further parley; then the Grace (ompany, as a private rporation, woukl step in with a clear field, and, with the st of eoneessions from Nicaragua, it wonld enter upon e task with every assurance of suecess. In sulstintiaton of their claims in regard to the forfeiture of the Marine franchise, they pointed out how the Nicaragnam Gorernsnt had granted the Canal Association a generons (onnession mg with ample time allowance, which shonld have assmed e opening of the canal for miversal commerce before the se of the century. "They waiterl. . . Their chatgrin amel appointment may lee imagined as the weeks and months led into years without the tuming of a wherel upon the nk. . . The drerlges have for years been wreeks, restip on the bottom of fireytown Lagoon: the railway is 1 ted out and overgrown; the buildings are mere shells s nding npon rotter timbers: the hathen is fillerl with sid, and the entrance from the sea is mever, at the most, (ar three feet in depth. Sineh of the property as has not l:n destroyed has been realized upon. Much of the crm- 
pany's property has been sold under judgments. Piers, buildings, telegraph and telephone lines, steamboats, and dredges are gone. 'The remmant of railway that remains reverts to Nicaragua next Oetober. We were told that the last sale of the company's assets was of hand tools, surveying instruments, etc., sold to the Nicaraguan (iovernment for a few thousand dollars, part of which was paid to the company. The company's representative is now pushing the Government for the balance, in order to pay his salary and that of the watchman. To the Nicaraguans, at least, the attitude of the company, claiming ability to carry out an enterprise involving $\$ 100,000,000$, pressing a claim of a few thousand dollar's against a Government which is the company's ereditor, is ridiculons."

Surh, then, being the deplorable condition of the Maritime Company. the representatives of the Grace Company believed that any chaim on the part of the former to an extension of its franchises beyond Oetober 9 of that year " would be treated by the Covernment of Nicaragua as the merest effrontery."

Before the rommittee examination into the status and prospects of the three canal companies had terminated, the sumate took into consileration a hill to amend the old alet incorporating the Maritime C'anal company, its purpose being, as in the previons yar, to plate the company more completely muler the amspices and control of the national govermment. Inder this bill all the stock of the company originally issmed was to be recalled, and new shares in place of it were to be issued to the I'nited States Grofermment, to viearagual. amel to costa Rica. Thus the finmeial burean of the comprany would be transferred to an oflice in the Treasury lopartment. In the senate bill at gnillantere of nentrality of the canal was inserted with the following froriso: " The Nicaragnal ('amal being a necessary comnection between the castern and western coast lines of the United States, the right to protect the same against all intermptions am at all times, is reserved and excepted ont of this derelarition of the atentrality of said camal and its free use bo other nations." 
While this bill was pending, the examination of the three rival companies was progressing in the committee room, and the facts developed there tended very eonsiderably to modify the ideas held by many in ('ongress upon the subject of the canal problem. The original draft of the senate bill was entirely stricken out, and an amented form, entitler, " $A$ Bill to provide for the construction of a canal comnecting the Waters of the Atlantic and Pacific Oceans," was reported. This amencied bill male no mention whaterer of the Maritime Company, nor of any existing sehemes in Centrai America, but provided simply for the govermental purchase of a portion of territory along the proposed canal route in Nicaragua, and called for an appropriation of the funds necessary for the Inited States Govermment immerliately to undertake the work as a national project, irrespeetive of the saims or rights of any private company. llere, then, for she first time, the Senate had reached that point to which it ad for so many years been tending,- a declanation for an American canal to be constructed by the govermment ats a ational undertaking. The bill passed the Senate by a safe margin, and, attached as a rider to the River and IIarbor Bill, was turned over to the mereies of the House. 'There, however, it encomntered the unyielding opposition of sipeaker Reed, and immediately beame involved in the meshes of an sudless controversy over matters political, diplomatic, and technieal. It was consigned to the waste-basket on the last lay of the session.

In the meantime, the Nicaragnan Cinal ('ommission, of which Admiral Walker was the chatman and which had hecon

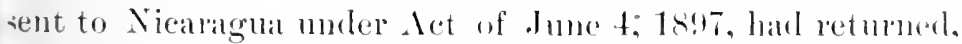
and submitted to the l'resident a proliminary report relative to its progress a in investigating the fluestion of the propel ronte, the feasibility. and aost of comstrotion of the Niearat-

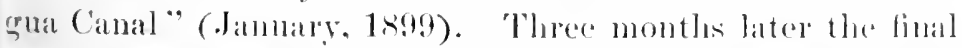
report was prepared : a syoposis of it, furnished ly the State Department (May 31, 1859), wate the rosilts of the

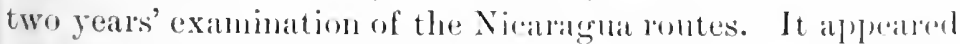
by this synopsis that the three commissiomers agreed as to the 
best route through Nicaragua (differing in some particulars from the route selected by the Menocal survey), but they disigreed seriously in their estimates of the cost of construction. Acmiral Walker and Professor Haupt calculated the sum as not exceeling $\$ 118,119,790$, while Colonel Haines believed the probable cost would reach quite $\$ 16,000,000$ more. These figures were deduced from a generous estimate of the expenses of actual construction ; nevertheless, there was left to the imagination a formidable array of mknown quantities which might call for extra millions.

The effect of this report, marle by the most competent and disinterested engineers, and after a prolonged and most careful survey of the region, was, in one sense, encouraging to the friends of the Nicaraguan Camal, amrl, in another sense, it was quite the contrary. The feasibility of the Nicaragua route was thoroughly established; there could be no further question mon that score, and the best course for the canal from Greytown and brito, as well as the most adrantageons disposition of locks and dims, were definitely fixed ; but the amomint of treasure the monster would consume was, after all, lighly prohlematic.

The recent appearance of the Pamama agents in the conferences of the senate and I lomse committees, and the sudden awakening to new life and vigor of that once hopelessly discredited French project, prolneerl a marked effect upon Congress. Itad all heen progresing smoothly in Nicaragua, the case night lave been different; but the Nicaragua callal project was becoming anch year more and more entangled in a wele of conflicting eoneessions, claims of rival companies. and the rexations of diplonntic mismderstamelings. The Maritime Comprany, that step-child of the finate and exponent of the. Nicaragnan ronte, was lying on the street for want of the fimancial nourishment the sienate hanl constantly striven to supply, but had always failed to give. Your by year the determined efforts of its friemes to makd the builing of the Nicaragua Canal ¿novernmental projeet had also lailed. In both branches of Congress, and esprecially in the IIonse, a strong moler- 
urrent of opposition to all Nicaraguan eanal measures nded to prevent snccessful legislation; now came the eliminary Walker report, which, though eheerful and speful in tone, told a diseonraging story of costs and diflialties to be met. Congress begin to look to P'innamal srhaps, after all, it would be mwise to ignore the enticing omises of the French company.

Panama had not been eximined for many years : indeed, it ad never been investigated in the thoromgl and complete anner in which the Walker commission had surveyed icaragua. The same eould be said of the other Central merican rontes, formerly consinlered within the realms of ssibility, but long since abintoned. Possibly Nitaragua, ith her load of amnoyances, could he east aside, anul anotleer ad better route discorered. At all events, it were better to it upon full knowledge of all the conditions mon the isthus, than to eommit the nation to a route which might rentually prove less desirable. A further and more comrehensive investigation of all the possible routes was felt to ? the proper course to pursue.

The State Department was embarrassed. Each year, when re eanal bills were under discussion, the Secretary felt the whwardness of the diplomatic sitnation in which the eountry as likely to be placed. Congress hatd a way of framing bills I matters relating to the canal question, and of giving nterace in the freest manner to policies, which were not in aceord ith the legal obligations of the comntry placed npon it ly eaty stipulations. In short, the legislative branch of the overnment in this respect often worlied to cross purpuses ith the executive, - while Great Britain anxionsly looked n with a protest rearly for filing the monent congress aceeeded in converting its ship) cantal theories into litw. 'learly, if Congress were detemined noon buikding, owning. rtifying, and controlling a Central Anerican eanal, somehing must first be done in the mattor of andenling the layton-bulwer treaty. Delaty wats neecssary, - obvinmsly nother commission was the thing:

On the list day of the session, the day upon which the 
Senate bill for the construetion of the Nicaragua Canal, as a rider, was stricken from the River and Harbor Bill, a elause was substituted in its place as follows:-

The President is authorized to make investigation of any and all practicable routes for a canal ... with a view to determining the most practicable and feasible route for such canal, together with the proximate and probable cost of constructing a canal at each of two or more of said routes: And the President is further authorized to investigate and ascertain what rights, privileges and franchises, if any, may be held and owned by any corpora. tions, associations or individuals, and what work, if any, has been done by such corjorations, associations or individuals in the construction of a canal at either or any of said rontes, and particularly at the so-called Nicaraguan and Panama routes re. spectively; and likewise to ascertain the cost of purchasing all of the rights, privileges and franchises held and owned by any such corporations, associations and individuals in any and all of such routes, particularly the said Nicaraguan route and the said Panama route; and likewise to ascertain the probable or proximate cost of constructing a suitable harbor at each of the termini of said canal, with the probable annual cost of maintenance of said harbors, respectively. And generally the President is authorized to make such full and complete investigation as to determine the most feasible and practicable route across said isthmus for a canal, together with the cost of constructing the same and placing the same moler the control, management and ownership of the United states.

To enable the P'resident to make the investigations and ascertainments herein provided for, he is hereby authorized to employ in said service any of the engineers of the United States Army at his discretion, and likewise to employ any engineers in civil life, at his discretion, and any other persons necessary to make such investigation, and to fix the compensation of any and all of such engineers and other persons.

So the session of 1899 elosed with the canal question resting easily under the certainty of at least a year's delay.

The President at onee appointed the members of the new eommission. They were Armiral Valker and his two colleagues of the former commission, ex-Senator Paseo of Florida, Alfred Noble, George S. Morrison, and Professor William II. Burr of Columbia University, - three well-known and 
distinguished engineers, - General (then Colonel) Ernst, U.S.A., and Professor E. R. Johnson of the University of Pennsylvania, a noted student of commeree and economics. With the generous sum of a million dollars to defray expenses, the new commission organized and proceeded to Central America.

After this final series of crushing blows, only that hope which springs eternal in the human breast could have indueed the promoters of the Maritime ('ompany to eontinue their fight for existence. Their only chance for success had been in the fidelity of Congress to their eause: now, in their darkest hour of adversity, the Senate had all but deserted them. It was upon the Senate they had chiefly relied, but now that body had passed a Nicaragua eanal measure which utterly ignored them, and Congress had adjourned in March with the creation of a new commission whose duty it was to examine and report upon other routes as well as upon their own. Their one course to pursue was to induce Nicaragua to extend their privileges beyond the 9th of the following October - the fatal day upon which that state had arranged to celebrate the eompany's obsequies. Now, by the last article in the Maritime Company's eoncession, it is provided that:-

Any misunderstanding that may arise between the State of Nienagua and the company in regaid to the interpretation of the present stipulations shall be submitted to a court of anlitrutors composed of four members, two of which shall be appointel hy the state and two by the complany.

These arbitrators shall be designated by each of the maties within the period of four months from the day on which one of the eontracting parties slall have informed the other in writing of the want of agrement on the proint at issue. Should one of the parties allow the aforesainl rem to pass, it shall be considered as assenting to the opinion or elain of the other:

The company's last hope lay in this clatuse, and t? le dircetors sought to strengthen their prosition hefore Nicaragua by pressing their clains for a hearing through the State Department. The latter assumed the burden with some hesitation, and a 
correspondence upon the subject was opened with Mr. Merry, the United States Minister at Costa Rica, there being at that time no diplomatic representative from Washington at Managua. The company's claim to an extension of time, under the terms of its concession, was based upon the assertion that the revolutions in Nicaragua within the last ten years - in reality a protracted reign of political disturbances - and enforced cessation of work caused by the investigations of the varions governmental commissions, together constituted "events of main force," that are "duly justified and sufficient to impede the progress of the work." Negotiations looking to the settlement of the company's grievances progressed slowly, and the 9 th of October arrived before the formal protest of the company, as set forth and required in the bond, reached the Nicaraguan capital. By the company's failure to make proper and due protest, and to present its ease before the time limit set upon the company's franchise had expired, the Maritime Company lost its right to a tribunal; but in deference to an expressed interest in the company, shown by the United States Government, Nicarigua waived her rights in the premises and agreed to arbitrate. She at once appointed two natives of Nicaragua to serve as jurors, and invited the company to name two albitrators; the company selected two men who were personally interested in the company, and whom Nicaragua challenged, coupling her challenge with a demand that all four arbitrator's be Nicaraguans. To this the company firmly objected, and with this hiteh in the proceedings the matter remained unsettled.1

The future of the Maritime Canal Company was far from bright. It clicl not seem likely that, if a tribunal of arbitration were agreed mpon, its deeision could be otherwise than adverse to the company. Senator Morgan warmly championed its anse in 1899, but the following year Congress showed a more decilled tendency to sever itself from all private or corporate canal schemes, and to retain a free hand

I A tribunal was eventually agreed upon which decided, in the autumn of 190n, adversely to the eompany. Aramst this riecision the company excepted

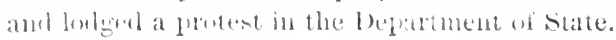


to prosecute the work, when the proper time should come, is a purely national undertaking.

The Grace Company also eneountered numerous diffizulties. According to the provisions of its very liberal consession, it was to begin its corporate existence on October 3, 1899. Six months from that day, i.e. April 9, 1900, it was expected to be fully organized and equipped for work, and four months from the date of its complete organization $t$ was expected to pay to Niearagua the balance of the $\$ 500,000$ deposit. The member's of this syndicate felt secure $\mathrm{n}$ their rights and reasonably satisfied with the outlook. Chey awaited judgment upon the Maritime Company case, onfident that their rivals woukd be forever silenced by decree if the improvised eourt. They asserted perfect organization as company, and their ability to fumish the funds necessary to omplete the construction of the canal; and they dechared hemselves to be ready to pay the sum of $\$ 400,000$ still due o Nicaragua, the moment a demand should be made for it. neidentally they considered their franchise worth $\$ 5,900,000$. On the other hand, the syndicate was embarrasiced by nurerous difficulties. The good will of Nicuragua herselt, n essential to success, wats apparently lost. A decirled solness toward the eompany on the part of the eoneesonary government developed into ontspoken disfinson. icaragua maintained that she bundered into granting the ragin-Eyre franchise though a false belief that the symliite represented a governmental project, and that it hab the ipport of the Presislent and the Congress of the Lnited tates. To-day Nicaragua expresses her desire to deal with te United States directly and to rid herself of private mpanies, in all of which she has lost faith. In the seeond ace, the Grace Syndicate never won the support, nor even re confidence, of the men in the United States ('ongress ho control the canal committees. Indeed, Congress was sposed to regard the symlicate as a speculative concern hose elaims might be safely and properly ignored, should ongress deeide to luilu the canal as a covornmmit work. he growing conviction of congress that the government 
should undertake and maintain the work upon a national basis promised an uncertain future to this Syndicate as it augured ill for the moribund Maritime Company. ${ }^{1}$

Despice the excellent showing made by the representatives of the Panama Company in the Congressional investigation of January, 1899, and the resulting appointment of a scientific commission to examine that route, the star of that illfated project lost lustre as the new year (1900) approached. Every one remembered too well the brilliant promises of the old company, which had never been fulfilled; indeed, the whole distressing story of failure and fraud was too fresh in mind to permit even the chance of its repetition.

Suspicion began to attach to the sudden revival of this Panama scheme, and the impression gained ground, and finally prevailed, that its sudden advertisement was, after all, but a clever move, on the part of the transeontinental railroad lobby, to divert public attention from the only feasible canal ronte. Despite the prejudice it eneountered in the United States, the Panama Company continued its strenuous efforts to impress the eountry favorably with its prospects. The latest move of its promoters has been in the direction of "Americanizing" the French eompany. As an initial step, it organized in New Jersey, at about the beginning of the year 1900, the "Panama Canal Company of America," to which the rights of the French company should eventually be transferred. In this manner the l'anama promoters hoped to place their projeet upon an equal footing with the other two Ameriean companies in the race for governmental recognition.

Althongh the scientitic commission was still in the field at the opening of the stith ('ongress (December, 1899), the canal committees in both branches decided not to wait for Admiral Walker's leport, which was not due for many months. A more propitious moment for carrying through a canal mensnre har never before existed. 'The private companies having suffered themselves to become involved in diffienlties from

1 The Grace Symdicate failed to mert its obligation to pay the balance of st00.000 11001 the stipulater date; the Nicaraguan authorities aceordingly declined its franchise cancelled. 
which they could not extricate themselves, conld be safely gnored. The country at large favored the scheme of na:ional construction, the executive entorsed it, Niearagua lemanded it, and the surplus in the Treasury, for the first ime in years, was in a condition to meet the financial obligations necessary to undertake the work.

A "Bill to provide for the Construetion of a ('inal comneetng the Waters of the Atlantie and Pacitic ()eams," was iccordingly introluced into the Honse hy Mr. Iteplum. on December 7 (1896), aud a bill of similar funport was saced before the Stenate ten days later hy Mr. Sullivan. Both measures provided for the immerliate purehase of a atrip of territory from Nicaragua and (ista Rical and caller or appropriations - one lill, of $\$ 8: 30,0000,000$, and the ot lecer, of $\$ 140,000,000$ - to meet the exprenses of construntion. The Senate bill anthorized and requested the Prosident to regotiate with the (iovermment of (ireat Britain for the brogation or modifieation of the claytom-bulwer treatr. - so far and to sueh an extent as to enable the lnited Sitates o own, construct, maintain. and operate moler its exclusive urisoliction, a canal. . . .

It also provided for the purehase of any valid ontstanding

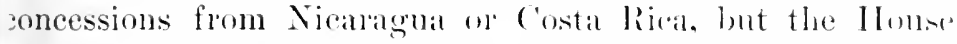
sill not only ignored the treaty rights of (imalt britain, bun

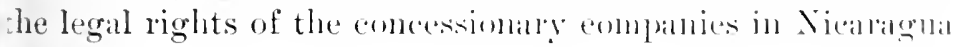
is well.

In his report acemplanying the llomse bill (11. R. 2.; : Mr. Iepburn expressisy stated, in reforemente these andzessionaries, that $\cdot$ it is not heliereel that any one of these - has any right or interest that he (and enerey to the

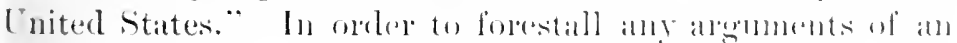

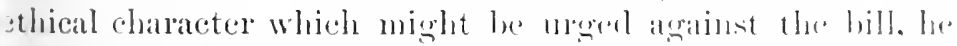
set forth, with eonsideralule positiveness. his belief that the Nicaragua Camal, when finally built, would be rutitlod to me place in the field of international law. and furthor. that all

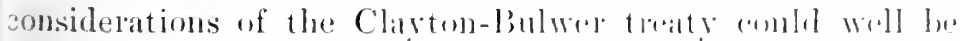

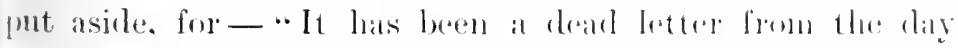
the treaty was signed to the jursent noment." 
The passage of such a measure in Congress was at that time consilered by many to be particularly indiscreet, in riew of the fact that the Walker eommission, for whose experses $=1.000 .000$ had been appropriated, was still engaged in the examination of the varions routes. An international scientific commission of high authority had recently pronomned the Panama project entirely feasible and had placed the cost at only $\$ 102.000 .000$; it seemed, therefore, highly desirible that Armiral Walker's coming report should be received before either Mr. Hephurn's or Mr. Sullivan's bills should become law.

Buth bills were amended in committee, and as amended were reported back to their respective Houses in Jannary and Febuary. Comsideration of these bills for the moment was delayed by the stress of other and more important business, but the friends of both of them felt confident that early action would be taken, and that some sort of a eanal bill wromlil receive the sinction of both Houses before the end of the trm: the sudclen aplearance of the Hay-Panncefote treaty, with its unexpected provisions, effeetually blocked for a time all further aetion upon the pending bills. Although it seemed higlily improbable that final action on either muasure comkl be reached during that session of Congress, the Ilephurn hill nevertheless passed the IIouse by the werwhehning majurity of 2.25 to :35 rotes (May 2).

The bill ignowerl all the private complanies. and enacted that the [ nited states Crovernment should " acquire from the states of C'ustat Rica and Nicaragua, for and in behalf of the linted states, control of such portion of territory now ledomging to Costa Rica and Niearagnal as mal be desirable and nexestilly on which to excivite. eonstruct, and defend a rillal of surde drepth," otc. It provided for such fortifieations alonger the lonte " als will he reguired for the safety and pro-

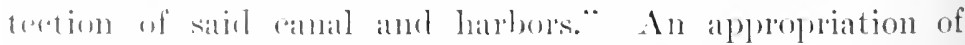

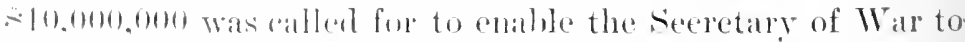

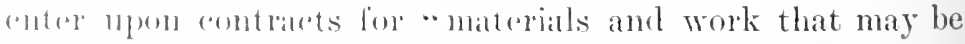
frement meressiry for the proper excavation, construction, defence and completion ol said canal, to be paid for as appro- 
priations may from time to time be hereafter made, not to exceed in the agoregate $\$ 1+0,000,000$."

The passage of this hill in the Honse marked the desire so generally folt throughout the comntry that the [nited States Govermment should construct an isthmian canal; but its passage was also ill timed, in view of the fact that the Hay-Pameefote treaty was then before the sunate awiting confirmation. The provisions of the treaty and of the bill, in so far as they related to the political control of the canal, were diametrically opposed, and the sudlen passage of the bill in pointed contempt of the treaty was a measure well caleulated to impugn the good faith of the nation. 'The bill failed to pass the Senate.

On February 13 (1900), another canal bill was introdnced into the Honse by Mr. Levy of New York, which differer essentially from all previons measures looking to the construction of a Central American canal. Following the tenor of the Iay-Panncefote treatr, which was then hefore the Senate, it provided for negotiations between the Inital States and other maritime nations, with a view to securing international coöperation and contribution acomeling to the ship tomnage of the varions nations in the construetion of a neutralized ship canal. This bill was far too radical to meet with favor in the IIouse.

A comprehensive glance at the history and development of the canal problem in Central America discloses the following facts:

First, it was the objeet of the early navigator's to find at natural strait connecting the two oecans.

Second, when the absence of such a matmal waterwat wats definitely determined, the purpose wats endeedred to construet an artificial one.

Thirrl, a number of projects were amsidered atul discussed looking to this end doring the sixteenth, serenternth and eighteenth centuries.

Fourth, the Lniterl States learine interested in the ylles- 
tion in the early part of the nineteenth century, after the independence of the Central American states had been established.

Fifth, other nations then became interested in the project, and numerous surveys were made covering not less than six possible rontes. The early surveys were superficial, and wholly worthless in the light of more modern engineering science.

Sixth, the result of later surveys has been to reject all except the Panama and Nicaragua routes. French interest hecame foeussed upon Panama, and the United States favored the Nicaraguan route.

Seventh, the failure and collapse of the French Panama Company had left for a time a elear field to the American companies in Niearagua; but when the latter companies were driven to insolvency and inactivity, nothing less than govermmental aid seemed to promise suecess.

Eighth, the result of recent surveys, combined with the experience of those who have attempted construction of the work, has been to demonstrate that the physical difficulties in the way and the probuble cost of construction are greater than formerly supposed. While the advanced skill of engineering seience las devised improved means of overcoming physical diffieulties, it has at the same time developed many obstacles hitherto undiscovered.

Nintl, a recent phase of the question is a growing distrust in the ability of any private company to complete the work of enstructing a Central Ameriean canal. For ten years past congress has tended toward a poliey of placing the work upon a national basis. 'This tendency reached its culmination in the 5fith congress by the introduction of bills into both llouses looking exchusely to governmental construction of the earrel.

The great majority of the people of Europe and America lave always believed that hlis convenient doorway to the Paeifie shombl be opened to the world's commeree. The query natmilly arises, Why, after three hundred years of effort, has it never been done? In spite of the physical difticulties, the work has at all times been considered 
feasible. The great advance in the efficieney of scientific investigation has not tended to lessen these difficulties, but the admitted resources of modern engineering are acknowledged to be sufficient to overeome them. It would, of course. require many millions to accomplish the task, but a greater amount of private eapital each year finds means of investment in other directions, while large sums prefer inactivity to an investment so hazardous. There is lack of neither skill nor capitil. The majority of the people of the United States are probably of the opinion that the ship canal would pay dividends upon its eapital within a few years after its completion, yet every company that has undertaken its construction has failed for lack of funds. For ten or fifteen years politieal parties in the eomntry have been united in the belief that the government should undertake this work as a national projeet; and each year bills have been introdueed into Congress looking to that end, yet none of these bils have become law.

It is true that a large transeontinental railroad interest has steadily opposed these measures, but that opposition could not by itself prevail year after year, against the desire of the country at large. One must then look elsewhere for that mysterious influenee which seems to prevent the realization of these hopes of triumph over the obstacles of nature. It is probably to be found in the fear and distrust of each other entertained by the commercial nations of the world. While each one hesitates to make the enormous expenditure necessary to the construction of a Central Anierican ship canal, each would no doubt promptly condemn exchsive ownership or control by one or even several of the other nations. So far, the lowers interested have been unahle or unwilling to fix among themselves the politieal status of the canal when it shall have been built. It is necessary, therefore, that preliminary to the commencement of the workwork that will finally suceeed in its ol)jeet - some diplomatie questions of a relicate and serions charater calling for adjustment must be met. For the l'nited States, these questions have beeome more eomplicated by reason of the recent 
development of public sentiment which indicates a purpose to claim, and possibly to demand, full and absolute political, if not commercial, control of any Central American canal wherever and whenever it may be built.

A review of the diplomatic aspects of this canal problem must be taken, and to make its history the more intelligible, it must be treated in comnection with early events in Central America, out of which these international questions arose.

The earliest Spanish discoverers and explorers in the Western Hemisphere were followed almost immediately by numbers of their countrymen who eame to win fortune in the New World. Considering the many perils of unknown seas and the many risks ashore, these Spanish pioneers founded flourishing colonies in Central and South America in a surprisingly short time. The Anglo-Saxon navigators, for the greater part, limited their field of exploration to the mainland of North America, and the colonists from the colder chimates of Northern Europe sought regions where the winter's brought snow and ice.

For quite a hundred years the Spanish enjoyed an unlimited monoproly of the trade connected with the Gulf of Mexico and the Caribbean Sea. In the sixteenth century Spain, at the zenith of her power and strengtl, grew opulent upon the rich returns from her transatlantic possessions. But her fleets of galleons, which took home the treasures of America, offered great temptations to piracy by certain adventurous spirits in Europe and America. In the carly part of the seventeenth century, the famous "Bnccaneers of the Spanish Main" apprared like so many happies to prey 11 on these richly laden vessels of sinain. They came in stealily increasing numbers, sometimes fonnding settlements of their own in the West Intian Islands, whence they made excursions for robbery and phunker. Among these companies of roving freebooters a band of Englishmen fomnd for themselyes a safe and convenient rendezvous in the lagoons of the Mosquito Coast of Nicaragua. 
They cultivated the friendship of the native Indians, and, though unrecognized and unauthorized to do so by England, they established mon these swampy shores an English settlement, thus forming the nucleus of a future English possession. In like mammer, though many years later, another band of English adventurers, who may doubtfully be sprared the name of pirates, took possession of points along the coast of Yucatan, and appropriated to their own use certain islands lying off the coast of Honduras, thereby fomding the settlement of Belize, later known as British Honduras, and more recently created into a British colonial possession.

The terrible assaults of these desperate men upon Spanish commerce led to many angry protests from Spain, which only drew from England an equal number of denials of responsibility for her castaway and disowned subjects. Yet, with her accustomed diplomatic shrewdness, England lost no occasion to make political recognition of her settlements on the mainland of Central America. 'This was palticularly evidenced in her treaty with Spain of 1670. All Spanish efforts to dislodge these unweleome neighbors of her colonies, either by diplomacy or foree, proved mavililng. In course of time, however, and possibly through pressare of civilization, the character and aims of these pilutical ettlers gradually assumed a hetter phase, and even before the seginning of the eighteenth century the descendants of these uccaneers became substantially honest and peaceful meu. They betook themselves to cutting logwood, eultivating the ioil, teaching morality to the Indians, and maintaining a. prowing and profitable trade with the English colony of .Janaica. The early history of these two settlements of liedize .nd Mosquitoland is but the story of a ceaseless struggle by ingland to maintain her questionalle foothold on the contirent against the efforts of the Surnish in C'entral Ameriea o loosen it. The degree of security enjoyed by these linitish ettlers in Central America depenuled larerely ujom the varyng fortunes of England and syan in the European wass in wich both powers were almost constantly involved. 'Thus, s late as 1814 , by the treaty of Madrid, Eugland was com- 
pelled to disarow all colonial claims in Mosquitoland, and by the same instrument the English settlement of Belize was reducer to the status of a mere tenancy at will. The claims of her subjects amounted to a bare lumbering privilege granted to a company of Englishmen by the Spanish Government.

In the future course of events, however, England found further occasion to reëstablish her lost prestige in Central America. A few years after the ratification of the Madrid treaty, and just after Spain had lost her sovereignty over the Central American states, the English again appeared on the Mosquito shore. With much pomp and eeremony they crowned the chief of the Mosquito Indians, "King of Mosquitia," and established an English protectorate over the newly created kingdom. Under the sheltering wing of the great British power, the southern boundary lines of Mosquitia suddenly expanded so as to include the mouth of the Sim Juan River, that vital spot of Nicaragua's territory. In quite the same manner, and as suddenly, Belize ripened into an English "possession," with a governor and other officers of state, under" the title of "British Honduras," which now as a colony continues to flourish, time having eured the weakness of its tenure upon the land, and cleared away the doubts formerly cast upon its rights of existence.

The purpose of England's tenicious hold upon the mainland of Central Ameriea became clearer when, in 1847, the King of Mosquitia annomeed to the Nicaragman Government that, on and after lanuary 1, 18t8, he would "reassume his lawful control" over the San Juan River. In pursuance of this notice, he duly appeared at the river's mouth with a force of English marines, and raised the colors of Mosquitia. Some skirmishes with the Nicarignan soldiers resulted, but in the course of a few months, when the excitement had subsider, the English were thoroughly established in the old town of Sin Juan del Norte at the month of the San Juan River, which they changed to the name of "Greytown," and they were moreover strengthened in their enlargerl possessions by a new treaty with Niearagua, which 
purported to recognize actual rights of sovereignty in the Mosquito king.

These English encroachments upon American soil were regarded with growing apprehension in Washington, not only beeause it seemed to be a clear and open defiance of the Monroe Doctrine, but also because it was foreseen that English acquisition of territory, through which the proposed Nicaraguan Canal must pass, would likely give rise in the future to many serious diffieulties. Prompt alction on the part of Congress was demanded by the Ameriean press to check this dangerous advance of British influence in Nicaragua. The isthmus routes were as yet unaploropriated, and to gain an equal adrantage with Great Britain, President Polk at once concluded a treaty with New Gimala, now known as the Lnited States of Colombia, serming to the United States exchusive rights of transit across the isthmus, in return for onr promise to maintain the alsolute neutrality of the transit line, and a further pledge to guard, against all attack, New Cirmadas complete political sovereignty over any line of transit the Cnited States might eonstruct within her territory. While securing these rights and privileges over the lower isthmus, President Polk despatched Mr. Elijah Ilise to Niearagua to investigate and report upon the reeent acts of the british in connection with the Mosquito king, and also upon the extent of their encroachments, if any, upon the rights of Nicaragua. He was not chothed with powers to enter upon any negotialtions whatever, the purpose of his mission as rharge d'affuires being, besides one of investigation, to use his influence in establishing more cortial relations with Nicaragua. Ilaving arrived upon the scene, however, Mr. Ilise became convineed that his duty was to obtain for his country the most liberal treaty possible from Nicaragua. He soon discoverer ample evidences of a British purpose to secure possession of ports upon both cousts of Nicaragua. which would enable them alsolutely to control the canal that it was hoped might some day comnect the oceans at that point. The recent aequisition of California with its promises of 
future wealth convinced him of the utmost importance to the United states of maintaining the route free from foreign influence. The canal was lestined no doubt to be the main ligh way comnecting the two distant sections of the country. In those early days tile all but impassable deserts and unexplored monntain ranges of the West prechded the idea of a direet overland communication by rail to the Pacifie coast, and consequently the imprortanee attached to the Central Anerican route was then much greater in the publie mind than in later years.

Cognizant of these conditions and fully confident that the government at Washington, when once it hat been led to appreciate the extent and motives of British aggressions in Central America, would ratify them, he proceeded, though unathorized to do so, to conelude the articles of a new eonvention with the very willing Niearaguan Congress. The treaty which he signed in Jume, 1849, gave to the United States, besides the usual privileges of such an agreement, the right to ereet fortifications along the course of a proposed canal, and to hold and fortify the ports at either end of the route. In return for these privileges, the United States undertook to guarantee Nicaragua's sovereignty from sea to sea over all the territury she claimed. Such a compact, of course, not only completely ignored British chims at Greytown, threatening at once to draw England and the United States into a dispute, but it also involved an extravagant application of the Monroe Doctrine which was far too radical to meet with the views of President Taylor. A reaction from the aggressive foreign policy of the Polk atministration had set in; Mr. Hise wats recalled, and in his place Mr. E. G. Squier was despatehed with all haste to Nicaragua to grapple with the situation.

Mr. Squier's instruetions were extremely conservative. Ile was cautioned against all rash measures ealculated to infringe upou the rights of others or needlessly to provoke hostility. Ile was assured that while the govermment was at all times ready and willing to maintain the "Monroe Doctrine," that doctrine was not intonsistent with the idea and pulpose that an interoceanic canal should "concele equal 
rights of transit to all nations," and that it " should not be hampered by any restrictions, either from local government or the company builling it." Mr. Siquier at once drew "l a treaty with Nearagna which granted the Lnited States a right of way from sea to sear, and the Lnited States in return guaranteed Nicaragnat sight of sorereignty over the romte and at both terminal ports; the right was reserved to Nicalargua to make similar treaties with any other nation or nations that cared to share this open right of way. ()bviously, by entering into such a compart with the Lniterl States. Nicinalgua again violaterl lee treaty of the year before with England, and in guaranteeing Nieatraglats sovereignty over both ports at either terminns of the proposed canal, the linited States necessarily stamped her disapproval upon the British seizure of Greytown.

While Mr. Squier was negotiating this very liberal treaty, the Eughish resolved to strengthen even more firmly their grasp' upon Nicaragua and the canal joute by obtaining landed intersests at the Paeificterminus of the canal. A British experlition, accordingly, started for the finlf of Fonseca, in the territory of Honcturas, which was the sulposed future Pateific entrance to the inland waterway, for the purpose of seizing the istancts in this gulf, - points of the grealtest strategie value. Mr. Siquier hurried to Ionduras, and in oreler to forestall these british encroachments, he hastily eoneluded a preliminary treaty with Honduras (September, 1849), wherely, pending final negotiations, the Island of l'igre, in the (iulf of Fonserat, was cerled to the Lnited States for a limited period. Now, strumerly enough, Mr. Squier's hasty mission to llomduras had surecely been aceomplished, when the British expedition alpealled, and upon the transparent excuse of an mingid dobt seized lhis

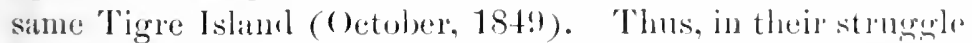
for the control of the territory through which the interoeeanic cantal was likely to pass, the two jowers atme fatce to

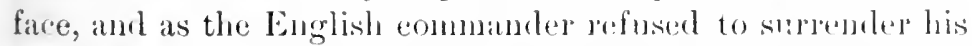
newly acquired island, it seemed that war was inevitable. In the meantime, the british had been no less active along the Atlantic coast; under pretext of definitely fixing the boun- 
daries of the Mosquito kingdom, its domain had been eonsiderably enlarged. The extent and eharacter of the Hise treaty (though never ratified by the United States) had become known to England just before this time, but fortunately the sulthe forees of diplomacy had already been utilizerl to avert an armed conflict, which the publication of the Hise treaty would certainly have preeipitated; suddenly the news of the Tigre Island incident eame to intensify the existing excitement in the Lnited States.

In 18 in) the American people had just come to a realizing sense of the fact that Great Irritain and the United States were rivals for a eontrolling influenee in Central America. The Lnited States had oecupied itself in reclaming its vast domains and in ereating new states in the wilderness which lay heyond the Mississippi without thought of the effect upon the world at large, or a care for the "balance of power" in the Anericas, territorial expansion westward had steadily continuel. Texas was absorbed into the Union, and California, an empire in itself, was alded to the growing body of the nation. (Oregon and Washington were definitely marked ont, and a lasting check was therely placed upon British hopes of further expansion on the Pacifie eoast. Contact with the western ocean awakened thoughts of Oriental commerce, and here, for the first time, the influenees were felt that had been operating to draw apart the two great powers, and that laad mate them rivals in Central America. Great Britain enjoyed nonopoly of Indian and Asiatie trade, and when once that somes of her eommereial vitality was jeopardized, her disfaror and emmity were aroused.

The snecess of Anerican alms in Mexico had in a measure intoxicated the people, and every antrance in territorial gain seemed more than ever to prove the truth in those early frophereses that "a manifest destiny" would eventually place the whole continent muler the Ameriean flag. This eagerness for territorial agramdizement was no more than the cuteome of a race between the North and sonth for extension of the slaveholding and free-soil area of the United states; but liritish statesmen saw in this mania for expan- 
sion only a surer prospect of the extension of the Cnited States north into Canalda and south into Mexico and Central America. In the interest of her American colonial possessions, Great Britain sought to oppose such advances. The British Government foresaw the importance to England of a neutral Central American eanal, and it anticipated the movements of the United States that should seek to place Central Ameriea under North Ameriean dominion, and deprive England of those joint proprietury rights in the canal which her trade interests demanded.

When the British first latil elaim to Mosquitia, the American people, ummindful, eontinued to attend to their own domestie affairs; but when the british reocenpied the east coast of Niearagua, and seized Greytown, the Lnited States became aroused. The causes that for years had been silently operating to estrange the two nations now came to the surface, and a spirit of jealonsy shatowed the populan mind in both England and the Lnited States, and no doulst influenced both governments. The American people resenterl these recent acts of british aggression in Nicaragna, which they believed to have been inspired thromgl feelings of enmity toward the Lnited states. The mutnal feelings of sisspieion and distrust were enhanced by the determination of Great Britain to stand by the assumptions of the Mosipuito chief who obstrueted the building of an Anerican canal through his territory. 'The belief had become general throughout the country and especially in the Southern states, that an open waterway through Nienagna was absolutely essential to the integrity and welfare of the United States. The demand for a neutral canal had become so urgent, its importance so vital, that the people themselves were realy to risk wa for it if need be; then came the British seiznre of Tigre Istand, which eompleted the chain of events that had hronglit abont the bitter jealousies of the two nations. The danger of war in 1850 had beeome alarming.

Mr. Clayton, the Secretary of State, fully appreceiated the gravity of the situation. As a pratctical statesman, he believed that the benefits arising from a great tom- 
mercial enterprise belonged rather to a state of peace than to a state of war, and perhajs already realizing, above and beyond the excitement and passions of the moment, that an interocemic canal should be as free as the high seas themselves, he proceerlen to open the way with the English Minister at Washington toward the negotiation of a treaty, which would not only lie the means of preventing an immediate war, but which woulil also outline those practical and eonservative suggestions which he believed it would be neeessary to arlont to insme the completion of this great work.

The conchusion most earnestly sought was to induee England to withdraw from Greytown, for in that occupaney the Secretary saw the certainty of armed conflict. On this point it was linown that American sentiment was fixed and irreversible. In return for such a eoncession, however, Mr. Clayton was willing to share with England in the politieal control and use of the canal, for he saw no reason why any one country should enjoy exchusive rights and privileges in what was designed to be an international highway, which, to be profitable and to subserve the purposes of its ereation, must be always open and always neutral. In this spirit of friendship, and desirous of making the canal a "bond of interest ancl peace" between the two nations, rather than a "sul,ject for jealousy," he approached Mr. Crampton, the British Minister in Washington, and invited his coöperation in consislering the terms of a treaty that would harmonize British and American interests.

The dinger in the situation was two-fold; first, England harl seized ntew territory upon the American continent in open defiance of the "Monroe Ioctrine," which, in itself, might be comsidered by Congress as a casus belli; and, secontly, the territory so seized was the country about the month of thrs san Juan livirr, which, of course, meant nothing less forliklding than buglish ownership of the Atlantic entrance to the propeserl cantal, — a condition of affairs manifestly intorlemable to the I'nited states.

To induce Englam to yield all her rights in Nicaragua would lave been a most desirable consummation, but to oust 
her at once from her position of vantage at Greytown was a sine qua non of peace.

Mr. Clayton, blinded perhaps to the importance of the first object by his extreme eagerness to aceomplish the second. entered upon the negotiation withont feeling quite justified in placing before Englind as an ultimatum the complete relinquishment of her claims over Mosquitia. He was prepred to yield community of interests and joint eontrol in the canal. but feared to present this as the ultimate and only quir pro quo for total abandonment of British territorial elaims in ('entral America. British statesmen were fully advised that exclusive English control of the canal would not be tolerated by the United States. A share in its management at best was as much as England coukl reasonably expect, and as a means of securing that share she already held Greytown, in the name of the Mosquito king.

In the correspondence that took place between the Secretary of State, Mr. Clayton, and Messrs. Baneroft and Lawrence, successive American Minister's in London, and also in the records of interviews between Mr. Clayton and Mr. ('rampton, the British Minister in Washington, preparatory to the actual negotiations for a treaty, the attitude of Mr. ('layton and of the Taylor administration toward the question of a Central American canal is fully and most clearly set forth. The Secretary of State was thoronglily in aceord with the popular view that under no ciremstances should the United States permit Great Britain or any other power to exereise exclusive control of any isthmian transit route. $\mathrm{U}_{1}$ mon the other hand, he did not seek for his own country the exclusive control he denied to others, and in assmming his position he followed the universally accepted theory of the complete neutrality of ship canals. The doetrine of international freedom of transit as applying to artificial waterways had been defended by Mr. Clay in 1826, and supported by manimous resolutions of Congress in $18: 35$ and again in 1839 . P'esident Polk had not fomel this doetrine inconsistent with his notions of an aggressive Momroe Doctrinr, and his sureessor, in his annual message to Congress of 184 !) had derlared that "no 
power should occupy a position that would enable it hereafter to exercise so controlling an influence over the commerce of the world, or to obstruct a highway which ought to be dedieated to the common use of mankind." The eonvention conclurler with Colombia three years previously contained a special clause calling for a guarantee of neutrality of the proposed isthmian transit route. No other ideas of the political status of an interoceanic ship canal had ever been entertained, - indeed, the very essence of the dispute that at that time bade fair to involve the two nations in war, was fear on the part of each that the other was seeking to gain for itself the monopoly over the Nicaraguan route.

When once it was mulerstood by both Mr. Clayton and Lord Palnerston, as revealed by their correspondence, that neither power actually songht this monopoly over the canal, the way was at once cleared of the most formiclable obstacles to the conclusion of a treaty. England's stubborn determination to maintain her foothold upon the east eoast of NicaJagua was still an annoying factor in the negotiations; yet Mr. Clayton had reason to believe that, as soon as both nations had given a pledge not to seek exclusive eontrol of the proposed route comneeting the oceans, Great Britain's object in mantaining her territorial interests in Central America wonld ranish, and she would then voluntarily and gladly disembarrass herself of her eharge.

Ilaving in mind a policy thus broad and liberal, yet subservient to his eomntry's hest interest, Mr. Clayton entered upon the negotiations of a treaty with Great Britain desirous of obtaining no exchusive privileges in Central America that should be incompatible with the just rights of other nations; he was intent only on preparing the way for the eonstruction of a great international highway that should be open to the worldis commeree upon terms equal to all.

Final negotiations were immediately begun upon the arrival in Washington of sir Henry Bulwer (January, 1850). At first Mr. ('layton persisted in his representations that unless (ireat britain were willing to abandon her Mosquito protectorate he did not believe the neutrality of the canal could 
ever be thoroughly effected, and without this concession in faror of a common ideal, and possibly as an earnest of good faith, the treaty would likely prove to be an instrument of empty words. But it seems never for a moment to have been the intention of Great Britain to relinquish her holdings in Central Ameriea, notwithstanding the fatet that she was perfectly willing to join with the Inited States in a guarantee of neutrality of the canal. With considerable shewrness the British commissioner argued that as the Lnited States could have no real interest in existing lbitish possession in Central America exeept in so far as they might appear to affect the neutrality of any future transit ronte, all coneern upon that score woukl be at onee removerl hy the signing of the proposed treaty, wherein, he alleged, England was entirely willing to pledge herself never to make use of her territorial possessions in Central America, or even to avail herself of her intluence over any Central American state, to gain a dominion over the route inconsistent with the strictest terms of nentrality.

Politieal conditions in the United States very considerably favored Sir Henry Bulwer in the aecomplishment of his purpose to conchule a treaty without yielding any of his country's territorial clains. Alarming reports of the events connected with reeent British encroachments in Central Ameriea were just legimning to spreal about the country, and, in consequente, feelings of lostility toward England were daily growing more outspoken and intense. The press demanded the reasons for delay in the building of the canal, and further demanded the immerliate publication of the Hise treaty. Congress also yichled to the popular clamor and ealled for all the correspondenere prottaining to the Central American eamal. Mr. Claytom fidt keenly the danger in making pulslie these doemments at that partieular moment, and furthermole he betrayed his anxiety to Sir Henry Bulwer; the Presirlent, too, folt much embarrassed in continuing to withlolel the desired correspontence from Congress. Lulwer was quick to talke advantage of his opponent's confusion, and he played upm 
Mr. Clayton's nervousness and evident desire to adjust the matter speedily as possible.

In the very midst of these diplomatic troubles, news of the Tigre Island incident arrived, and instantly popular excitement thronghout the Lnited States arose to feverish height. Indeed, Mr. Clayton himself, who hitherto had been struggling to overcome the natural suspicions aronsed in his breast by Great Britain s persistent determination to cling to Mosquitia, was thoroughly angered. His hopes for a satisfaetory conelusion of a treaty were wholly dispelled by this unfortunate event. However, Great Britain's prompt disavowal of the act restored hamony in Washington, though it left the country in a passively sullen mood. Negotiations were resumed and hurried along, and on April 19 the treaty was signed. In brief it provided :-

(1) Neither the United States nor Great Britain shall ever ohtain or maintain for itself any exchusive eontrol over the proposed ship canal.

(2) Neither power shall ever erect or maintain any fortifications commanding said canal or in the vicinity thereof.

(3) Neither power shall ever occupy, fortify, colonize, assume, or exercise any dominion over Nicaragua, Costa Rica, the coast, or any part of Central America, nor shall either make use of any alliance or protection that either affords or may afford, or make use of any intimaey, connection, or influence that either may possess, to gain that end.

(t) Great Britain and the United States shall mutually gnat the safety and nentrality of the eanal, and invite all other nations to do the same.

(i) Great Britain and the United States will extend their aid and protection to any eanal company, laving proper anthority and working under fair and reasonable ter'ms.

(i) In order to establish a principle the two powers will also extend their aid and protection to any other practical monts of transit across the isthmus, either by canal or rail.

Neither Mr. Clayton nor Sir IJenry Bulwer was fully satisfed with the convention. The Secretary of State felt troubled by his failure to persuade Great Britain openly 
Ind unreservedly to relinquish the Mosquito protectorate. ret the main object of the treaty - the assured neutralizaion of the canal, was satisfactorily aceomplished. With that question settled, the Mosquito claims of England, so far ats he United States was concerned, had lost their greatest ignificance. In fact, Bulwer wrote to Pahmerston tlat, " We lave no longer any interest in mantaining the Mospuitos Indians] where they are, nor our protection over them in hat locality;" but as Creat Britain coukl not " honorably bandon" her ties with the Indians, Bulwer frankly sugested to the British foreign secretary that some arrangesent be made whereby the Mosquito Indians "eonlel he rithdrawn from the vicinity of the canal, and therelsy emove all cause of dispute [with the Lnited States]." Jpon the whole, then, the satisfactory features of the treaty - among which must be counted the probable exemption of he country from a war with Great Britain - seemed at the ime to outweigh its omissions.

'The instrument was severely criticised in the Cabinet, and fterward met with strong opposition in the Senate, notwithtanding which, however, it was soon ratified by a vote of 42 ) 11 .

The treaty was immediately endorsed by the British iovernment. Before the exchange of ratifications was ffected, however, Palmerston becane disturbed by the mbiguous nature of the phraseology of the first article, nd being, moreover, desirons of removing any misilppreensions that he feared might still exist mon the sulject, e ordered Bulwer to amnounce to Secretary ('layton that iritish interpretation of the language of the treaty left naffected existing English possessions in ('entral Aneriea. iulwer accordingly met the Seeretary of State with the eclaration that " Ier Majesty's Govermment does not umlerand the engagements of that convention to apply to Her Iajesty's settlement at Ionduras, or to its deferrlencies." he word "dependencies" was somewhat vague, and as it ointed ominously to the Mosquito reservation, it no koubt neovered to Mr. Clayton's rision the skeleton which he laal 
been so anxious to eoneeal. There ean be little doubt that the great majority of senators, if not all of them, who had voted for ratification, had assmmed that the treaty called for relinquishment of Greytown and all of Mosquitia, - that being but part of the agreement whieh they hoped would inangurate a new era of friendly coöperation of the two great powers in the construction of the canal.

Even without a definite statement in the instrument to the effect that Mosquitia would be abandoned, Mr. Clayton believed that that result would very soon be brought about when once the treaty was in force, and he was undesirous of surrendering the other adrantages to his combry, which he supposed the treaty offered, simply on account of this new assertion of Englind's mwillingness to yield her Mosquito pretensions. But the sulnjeet was a peeuliarly delicate one; the Secretary's colleagues in the Cabinet (with the possible exception of Reverdy Jolnson, the Attorney (reneral), and those of his personal friends, in whose confidenee the negotiations reposed, felt it to be a mistake to conclude a treaty without a positive promise on the part of Great Britain to withllaw entirely from Nicaragua.

Possibly Mr. Clayton entertained similar misgivings. 'The political sitnation in the United States, however, which threatened at any moment to spring the mine of anti-British fecling at liome and thus wreck every effort he had made to (check further English aggression in Nicaragua, and to secure a nentral waterway, impelled him to continue in his efforts to reach an molerstanding, even though an ambiguous one. I'erlalps a half loaf were better in this calse tham none at all; at hest. the treaty represented a mutnal yielding of interests which both nations considered vital and were extremely loath to concede. From a first formed determination, then, to refuse an exehange of ratifications npon the basis of Sir Inenry Buber's declation and to abandon all further mogotiations, Mr. Clayton finally decided, as a last resort, to try the plan of placing a construetion npon Sir Henry linlwer's leservation that might be more satisfaetory to himself and yet acceptable to Great Britain. Mr. Clayton acord- 
ingly approached Sir Henry Bulwer with a proposition for a counter-declaration, in which he proposed to limit the term "dependencies" by making special mention of the islands along the Honduras coast, expressly omitting reference to Mosquitia. Sir Ilenry Bulwer angeed to this with the understanding that " it was not the intention in the treaty to embrace whatever is Her Majesty"s settlement at Honduras, nor whatever are the dependencies of that settlement."

To leave no room for "charges of duplieity against onl government," Mr. Clayton addressed a note to Mr. King, Chairman of the Senate Committee on Foreign Affairs. aequainting him with Sir Henry Bulwer s deelaration, but he onitted to mention in lis note to $\mathrm{Mr}$. King the worl "dependencies." Mr. King was probably not surprived by receipt of the Secretary"s letter, for he had never supposed that British IIonduras was to be abandoned by (ireat Britain under the terms of the treaty; he replied the same day (July 4) that "The senate perfeetly molerstood that the treaty did not include British Honduras, - but," he added, in a tone of arlmonition to the Secretary of State. "yon should be careful not to use any expression which would seem to recognize the right of England to any portion of Honduras [i.e. ontside of British I Iondunas]." L Lon receipt of Mr. King's answer, Mr. Clayton sent a note (it hard been already prepared) to Sir Ilenry Bulwer, in which he silil:-

The language of the first article of the convention concluded on the 19th day of $A$ pril last, between the United states and (iveat Britain, deseribing the country not to be oecupied, ate., by aither of the parties, was, as gou know, twice approved by the gorednnent, and it was neither understood ly them nor by either of 11. the negotiators), to include the Pritish settlenent in Homduras 'commonly ealled British Houduras, as distinet flom the state of Honduras), nor the small islands in the neighborlhoor of that settlenent which may be known as its dependencies.

To this settlement and these islamds the treaty we negotiated sas not intenterl by either of us to alply. The title to them it s now and has besen my intention thronghont the whole negotiation to leave as the treaty leaves it, withont denying or aflirming or in any way meddling with the same, just as it stood previmsly. 
The chairman of the Committee on Foreign Relations of the Senate, the Honorable W. R. King, informs me that the Senate perfectly understool that the treaty did not include British Honduras.

With this last presentation of "leclarations," ratifications were exchanged the same day (July t), and the treaty was proclaimed as law the day after.

It appear's to have been understood by both Mr. Clayton and Sir Ilenry bulwer that any amendments, alterations, or qualifying statements in the treaty subsequent to its ratification by the Senate would be considered of no foree whaterer. Such being the ease, these various statements on the part of the negotiators, male just before the final exchange of ratification, will serve only to show the intention of the parties who framed the instrument, but may scarcely be accepted as part of the res gestce of the negotiation. From the varying shades of meaning expressed throughout these negotiations, - partieularly as both negotiators were not only sparring to gain adrantage one over the other, but were also endearoring to shield their designs from publicity - it is not easy to interpret the precise understanding of either. lint it now seems reasonably certain that Mr. Chayton did not anticipate British withdrawal from Mosquitia as obligatory under the terms of the treaty, though lie expected such action to follow as a natural consequence of the British promise not to fortify, ete., any point in Central America, and also because he conceived Great Britain's sole object in retaining her hold upon Nicaragua to have departed upon ratification of the treaty. It is equally certain that the Senate did anticipate an immediate withdrawal of all British claims on the Nicanguan coast. Sir Henry Bulwer's acceptanee of Secretary Clayton's "counter-declaration" would indicate that he had wavered in his determination to save Mosquitia for Great Britain; and yet, on the other land, his whole attitude, from the opening of the negotiations to their close, demonstrates a fixed and dogged purpose to the contrary. There can be but little doubt that the Bay Islands were considered by both Mr. Clayton and 
Sir Henry Bulwer as part of the dependencies of British Honduras. As for British Ilonduras itself - the former Belize - there was no question in any quarter, not even in the Senate, but that it was excepted from operation of the treaty. This is confirmed by an official exposition of the convention which appeared in the National Intelliyenrer but three days after its promulgation; it was there asserted that "the British title to the Belize the treaty does not in any manner recognize, nor does it deny it or meddle with it. That settlement remains, in that particular, as it stood previously to the treaty." No mention, however, was here made of the dependeneies, and the people of the Lnited States were still left in ignorance of the uncertainties which existed in official circles conneeted with that work.

President Taylor's death oceurred on July 9, and about one week later his suecessor in office, President Fillnore, transmitted a communication to Congress, with which he submitted a copy of the treaty itself. "Its engagements," he said, "apply to all the five states which formerly eomposed the republic of Central America and their dependencies, of which the Island of 'Tigre was a part. It does not reeognize, Iffirm, or deny the title of the British settlement at Belize, which is, by the coast, more than five humbled miles from he proposed eanal at Niearagua. The question of the Britsh title to this distriet of eountry, commonly called liritish Honduras, and the small islands adjacent to it, claimed as ts dependencies, stands precisely as it stond before the reaty. No act of the late President's anministration las, n any manner, committed this government to the British itle in that territory or any part of it."

Thus it seems elear enough that whatever mismolerstandng there may have been between the negotiators of the reaty, that mismulerstanding was in reference to Mospuitia, and not to Belize, known as british IIomlunats, nor to the 3ay Islands. Furthernore, whatever maty have been the beief in Congress as to the meaning of the ahnegatory elamses If the first article (whether or not prospective in character, equiring Great Britain to abandon her Central Anerican 
possessions, or permitting her to retain them), the Senate accepted the above message without protest, and would thereby seem not to have been surprised or disappointed as if by a new and astounding revelation.

Had Mr. Clayton been enfowed with a keener sense of that political foresight which was possessed to such a marked degree by Wrashington and Jefferson, he would have recognized his error in not holding out firmly against British asserted rights in the "dependencies" of British Honduras, and making British abandonment of the Mosquito protectorate a condition of all negotiation. There ean be little donbt that Palmerston eventually would have yielded, and Mr. Clayton would have spared his eountry many unfortunate misunderstandings with Great Britain, and years of eontroversy between Wrashington and London.

With due respeet for Mr. Clayton's skilful management of a difficult international situation and for the ability which he may have displayed in delivering the nation from possible war, an unpleasant appearance of double-dealing with the Sienate is inseparably eomnected with his correspondence on the subject. Just why Mr. Clayton did not ehoose to make Congress eognizant of the exaet meaning of Bulwer's qualifying note can now be understood, and his motives alpreciated; yet the questionable eourse which he saw fit to adopt at a critieal moment was a temptation to which he should not have yielded - an error he should not have committed. Had Mr. Clayton been less actuated by fear, he might have utilized for his own benefit those very threats of war which terrorized him into eoneluding a bad bargain. 'That both Bulwer and Palmerston were alarmed by the prospect of war, and that they were willing to direet their eomse well within the lines of discretion, is made manifest from certain portions of their correspondenee while the treaty was in course of negotiation.

Nir Ilenry Bulwer's tacties in the making of the treaty have been a frequent theme of censure against English diplomaey in this country. That he played his hand skilfully, reserving to best advantage his largest trump until the 
last, cannot be denied; yet the method employed by that shrewd statesman, in all fairness to both sides, camnot be characterized as dishonest. It was "elever" in so far as lie outwitted his antagonist by playing upon his fears and profiting by his errors in jurlgment. Mr. Buchanan, then in private life, wrote to a friend shortly before the eonclusion of the treaty, - "If Sir Henry Bulwer ean suceed in having the first two provisions of this treaty ratified by the Senate, he will deserve a British peerage."

Outside the ranks of the administration's most stanch supporters the treaty met with general condemnation. No objection was raised against those provisions of the agreement which ealled for international guarantee of the nentrality of the canal, but the fatal omissions in the instrument, when deteeted, brought forth the severest criticism upon the document, and on Mr. Clayton fell the aceusations of a cowardly weakness. "The Nicaragua treaty is even worse than I had supposed." again wrote Buchaman in May, 1850.

Buchanan's words were true and his eriticism just. The United States had pledged itself never to seek or exereise exclusive control over any C'entral American canal, nor to acquire any territory on the isthmus. Great Britain, on the other hand, had received a recognition of her elaims in Honduras and all of its vagnely defuned dependencies. Without actual surrender of anything, England hat really secured an excellent footing for subsequent territorial expansion in Central America.

\section{III}

Aside from the misunderstandings muler which the Clayton-Bulwer treaty was concluted, both Sir llenry Bulwer and Mr. Webster, the newly appointerl secretary of Sitate under President Fillmore, realized that the instrument wats imperfect, ambl, in many mespects, firr from sattisfartory. They accordingly entered upon negotiations looking to the ettlement of several importint questions left open by the reaty. One of these questions was to determine the actual 
status of Greytown - a matter rendered perplexing by the chronic boundary disputes between Nicaragua and Costa Rica. Indeed, this old-time quarrel had just then broken out afresh. The negotiations dragged along wearily for quite a year with the unhapy result of demonstrating to both men the impossibility of a mutually satisfactory conclusion.

A series of unfortunate events now took place, which seemed to sharpen the ill feeling already existing between the two power's, and, because of the mutual jealousies and suspieions therehy aroused, a deallock resulted, making the reconciliation of American and British interests in Central Ameriea impossible for some time to come. Perhaps the distressing political conditions in Central America, at that particular time, were, in a large measure, responsible for numerous British and Ameriean follies; but, at all events, both Englind and the United States were led into committing acts in Central America which were in open violation of their treaty stipulations, and seemed to indicate bad faith upon the part of both.

With the evident intention of making it perfectly clear to all concerned that she still eonsidered Mosquitia a part of the dependency of British Honduras, Great Britain proceeded formally to ocenpy Greytown with a military force, and profited further by the occasion to reassert her protectorate over the Indians. Having aecomplished this, the British commander urged upon the Nicaraguans the advantages they would reap by abandoning their "pretended friends" (the United States), and coming "to an understanding withont delay with Great Britain," for only in London could sufficient capital and "spirit of enterprise be found for earying out a lurject (the huilding of the eanal) of such magnitude." Thus were the Nicaraguans impressed with the fact of unimparied Mosquito control of their Atlantic coast and over the prort of Greytown. The United States was expected of conre to take notice. This new assertion of British sovereignty over Freytown soon bronglit American and British subjects there resident into direct conflict. A crisis was reached in November, 1851, when an American vessel, be- 
longing to the Ameriean Canal Company, the Prometheus, was fired upon by a British man-of-war, for refusing to pay certain port dues to the Anglo-Mosquito authorities.

The matter being reported to Mr. Welster, he promptly renewed his efforts to reach an understanting with the British Minister regarding Central American affairs. 'The atet of firing upon the Prometheus was at once disavowed by Eall Granville; but the issue which Secretary Clayton had earefully avoided was now sharply presented, and the Seeretary of State appreciated the urgent necessity for eoming to a elear and perfect understanding as to the construction of the term - "dependeneies of British Honduras." The boundary dispute between Nicaragua and Costa Rica had beeome violent, and in this quarel the sympathies of the United States and of England were arrayed upon opposite sides. Costa Rica, which had always cultivated hritish favors, elaimed the right bink of the San Juan River, inchuding Greytown and a small adjoining settlement of Amerieans who operated the temporary trinsit ronte across the state. Niearagua, on the other hant, insisted upon the inclusion of Greytown within her limits, and she natmally resented the English ocenpation of that port; she also denied her neighbor's territorial rights to the south bank of the san Juan liver. In these contentions she was encomaged and upheld by the sympathies of the Enited States.

Mr. Webster and Mr. ('rampton, the English Minister (Nir Henry Bulwer having returned to England) entered upun the settlement of the new disputes by attempting first to locate the true boundary line between the two little repulslies, thus lopping to eliminate one imitating factor from the total of their differences. To aceomplish this, of comses it would be necessary to formulate a plan which wonld pore aceeptable to both republies ats well as to themselves. On April 30, 1852, an agreement was signed in Washington which, as a tentative arrangenent, provided that Gregtom and "Mosquitia" should be recerled to Nicaragnga and a reservation set apart for the Indians. The Costa Rican territorial elaims were acknowledsent as far north as the 
San Juan River, and full rights of navigation in the great lake were also accorded her. The plan was ostensibly a compromise measure, which would likely have relieved the situation had it been accepted; but Nicaragua not only rejected the agreement with a show of indignation, but curtly announced her displeasure at this instance of foreign meddling in her domestic affairs. Costa Rica's acceptance of the plan was not in itself sufficient; so the efforts of Webster and Crampton came to naught.

With matters in this msatisfactory condition in Nicaragua and "Mosquitia," the attention of the United States was suddenly directed to Honduras. English eapital had recently become interested in a railway project to connect two Honduran ports on the Atlantic and the Pacific oceans, and thereby to establish a transit route which would compete with the American transit route across Nicaragua, and also with the Panama routestill falther south. The Bay Islands - a group lying off the IIonduran and Gruatemalan coasts - had formerly been appropniated by Great Britain and constituted, according to her assertions, a dependency of her settlement on the mainland (Belize or "British Honduras"). IIer sovereignty over these islands had negligently been permitted to lapse, but in the interests of her projected schemes in Honduras, the British Govermment decided to reoceuly them. Accordingly, on June 17, 1852, the London foreign office ammonnced that the islands of Ronatan, Bonacen, Brabant, Ilelma, and Morant shonld constitute a colony, "to be known and designated as the Colony of the Bay Islands." In August following the islands were formally oceupied by crown officials.

Whatever may have been the merit in the British contention of ownership of the Bay Islands, the moment ehosen for the overt atet of their seizule was a most unfortunate onc. The amicable relations of the two mations harl at all times been more or less strainerl since the Tigre Island ineident; and since the prommlgation of an mostisfactory treaty each governund had continued to view the acts of the other in Central Anerica with a high degree of suspicion and dis- 
trust. The numerous failures thereafter to harmonize their conflicting interests had only aggravated the situation; hoth governments were more than ever ill disposed to grant favors or yield a point in Central America. In fict, the situation called for the most careful diplomacy, if their differences were to be settled upon a peaceful footing; but with an offensive bluntness, the British Government committed an act which, it must have foreseen, could only be accepted by the United States as one of unwaranted aggression and in direct violation of the Clayton-Bulwer treaty. The people of the United States were filled with indignation. The election of 1852 had bronght the Democratic party into power, and the new administration - if for party reasons only - was strongly anti-British.

When Congress convened in l)ecember, the Senate at once called for all the correspondence relating to British alvances in Central America, and General Cass of Michigan introduced a resolntion, asking, "What measures, if any, latve been taken by the Executive to prevent the violition of Article I of the Treaty of July 4, 18.00\%", On .January 4 (1853), the President sent a coly of such eorrespondence to the Senate, which included the letter's exchanged by Mr. Clayton and Sir Henry Bulwer just before the concluding ceremonies of the treaty. Then, it alpeared for the first time, that the full meaning of that instrument, with its fatal reservation, was moderstoor in the Senate. The scene that followed in that chamber was sensitional. (Jue after another of the senator's arose to denounce, in the most vigorous language, the treaty, Mr. Clayton, the preceding Whig administration and Great Britain.

A resolution was drafted by the Foreign $\Lambda$ ffairs Committee to the effeet that England's title to Belize was wrthless, and that her oceupation of the bily Islands, and her position in Mosquitia were in direet violation of the terms of the treaty and in defance of the principles of the Monroe Iortrine. The debate which followed npon the presentation of this resolution was characterized by an intemperate displity of partisan feeling that has not often been equalled in the sen- 
ate. There can be no doubt that the bitterness of personal abuse, and the feelings of hostility against England that developed in this debate were induced, to some extent at least, by political reasons, for the discussion soon assumed a party cast. 'The Democrats, led by Douglass and Cass, attacked the treaty; the Whigs, under Sumner and Seward, generally smprorted it. The committee resolution was adopted, and the fury of the Senate finally spent itself in a declaration reasserting the principles of the Monroe Doctrine.

'The storm at the eapitol spread over the country, and the feelings of enmity toward England became more than ever pronomeel. With an alministration in power whose platform was essentially anti-British, a vigorous diplomatic tampaign against England was expected. Mr. Marey, the Secretary of state, had already expressed an opinion, that the Mosquito protectorate was roid; that the erection of the Bay Islancls into a British colony was unwaranted and in clear violation of the terms of the treaty, and that with the exception of Britisl Ilonchuas, to whose occupation by England he mate no objection, Great Britain should at once alanton all her territorial chims in Central America. He Wats not to be shaken from his conviction that the American interpretation of the pluaseology of the Clayton-Bulwer treaty. as held hy the Demoeratic party, was a eorrect one, and that its aceptance by England should therefore be insisted II wh. With such positive instructions Mr. Buchanan, the Anerican Minister in London, was directed to enter upon negotiations with Lord c'larendon.

The earnest efforts of these two men to hamonize their conflieting views of the true meaning and intent of the Clayton-Bulwer treaty resulted in a total fallure. Lord C'litrendon marle a lengthy statement in defence of his posifion, in which he matintained that belize was not a part of Central Americal, as mulerstood by the negotiators of the traity, as it had for many gears been a British possession, acknowledger by Spain, later by the Central Ameriean states, and, finilly, recognized by the United States, as evidenced by the fate that an American eonsul had been sent to Brit- 
ish Honduras in 1847 and had been permitted to carry on the duties of his post mider a British exequatur. As to the Bay Islands, he maintained that they also had for some years before the treaty been British territory, and were considered a part, or rather a dependency, of Belize. To Mosquitia, he maintained, the treaty in no way referred, but that it only prohibited further colonization. Existing English possessions were in no way affected by the treaty, the inhibitory clauses relating merely to future acquisitions. Further to sustain the correetness of his views, Lord Clarendon eallerl attention to the fact, that although this was fully evirlenced in the words of the treaty itself, yet, to remove all pussible doubt, the negotiators lad thought it well, before final ratification, to exchange witten declanations npon the subjeet, the purport of which har been to except british Homrluals and its dependencies from the operation of the treaty. Contimned ocempation of these territories, therefore, by England, or any alterations in their political relations toward the British Government, conld not be regarded as an infraction of the treaty.

Mr. Buchanan was equally firm in his views, which were upon every point diametrically opposed to those of lam Clarendon. With eonvietions so ratically divergent, the futility of compromise onglit to lave been foreseen, and the Clayton-Bulwer treaty should then have been abumboned for one more specifie in its terms. The controversy wats finally closed by Clarendon's somewlat impatient statement that Great Britain conld not acerept the Monse Inotrine ats an axiom of international law, and that he would declime further discussion of his comutry's original rights in C'ont ral Ameriea. Thus enderl the matter for a time, leaving (intril American affars in the sane unsatisfactory eomdition ats before.

About this time an Ameriean Canal Company was operating a temporary transit route ateross Nicaragua orer the siu Juan River and Lake Nicangua, and thenee, by an overland stage road from the lake, to the Parific Ocean. Just inmerliately south of Greytown an Anerican settlement, mate "11, 
of the company's operators and that flotsam and jetsam of wanderers who gather at pioneer posts, had sprung into existence.

In an altercation between some Mosquito Indians and Amelicans an Indian was killed, and the smonldering antipathies of the two towns began to blaze. An Anglo-Mosquito mob attacked the house of the American consul, and the sailors of an American ship in the harbor came to their countryman's rescue. A pitched battle ensued. When the news reached Washington a gunboat was despatehed to the scene and indemnity was demanded from the Anglo-Mosquito anthorities. Upon their refusal to consider sueh a proposition, the Ameriean gunboat proceeded to bombard and destroy Greytown. This passage at arms did not help to relieve the diplomatic situation between England and the United States; nor, indeed, was the general situation in Niearagua improved by events whieh immediately followed. An Ameriean eitizen named Walker gathered about himself, in the Southern states, a band of followers who were desirous of adventure, and, finding his opportunity in one of the periodical civil was in Central America, he made a boll dash for the eity of Granada, and soon placed himself in control of Nicaragua. He was supported for a time by nne of the warring faetions of this turbulent republic, but his filibustering expedition, ostensibly carried out in the interest of the United States, was, in reality, for the purpose of extending the area of African slavery.

In every possible manner Walker antagonized British interests in Nicangua, and the belief became general in England thit the United States sought to acquire a Central Ameriam state. A comber military demonstration, on the fart of Costa Rica, ereated the suspicion in America that England was covertly taking a part in these struggles along the cant ronte; and this belief elieited for Walker a larger mosme of sympathy thromghout the United States than he womld have otherwise received. The Government at Washington finally wont to the length of reeeiving a diplonatic agent, representing the Walker govermment at 
Granada; the incident also stimulated the mnfriendly feelings between England and the Lnited States, and served ats well to estrange from ourselves the good will of the Central American states. Walker was eventmally deported and tried; but before his death he made several warlike expeditions into Central Ameriea, and succeeder in almost hopelessly entangling the United States in a triple contest, full of ill will, between herself, Englind, and Nitaragua.

These events in Central Americar reopened all the old wounds which the Clayton-Bulwer treaty had been designed to heal, and another series of acrimonions disenssions in the Senate, levelled against British interference in Greytown and in Nicaragua, tended in no way to assuage the popular anger.

Mr. Buchanan had been succeeded in Londom, in the fall of 1855, by Mr. Dallas, and the latter was directed by the President to make a stremous effort to secure a settlement of these Central American questions. These, along with other grievanees against Great Britain, were rupirlly assmuning a dangerous aspect. The comtry was already deeply agitated by the drift of internal political issues, and party zeal was alarmingly strong. In the excitement and fassions of the period, there was no skill of propheey that conlil foretell the length to which either party might go, should foreign complication offer relief from the strain of that fearful domestic diffeulty - the slavery question.

The Dallas-Clarendon negotiations were hurrerl along, and, on October 17 (1856), an agleement was reached, which was immerliately sent to Washington for confirmation. It providerl: (1) for the freerlom of the port of Greytwwn under nominal Niearagnan sovereignty; (2) the establishment of a reservation for the Mosquito Indians, thus abandoning the British protectorate; (B) the limiting of the Belize settlement within certain fixed lines; $(t)$ the eession of the bay Islands to Honduras. The eonvention was male conditional upon the ratification of a eertain treaty just drawn np between Honduras and Great Britain. This latter treaty' had been made in August, 1856, and constituted the Bay- 
Islands a free territory, coming partially under the sovereignty of Honduras, and yet free in the sense that it could not be taxed, nor its subjects be called upon to perform military duty, other than in their own exelusive defence. It will be seen, therefore, that the ratification of the DallasClarendon agreement wonld oblige the United States to acknowledge the Bay Islands to be a free territory, over which a British protectorate would continue virtually to exist.

It has been thought not a little remarkable that the executive, representing a party so radically anti-British, and so positive in its demands that England should abandon, under the terms of the Clayton-Bulwer treaty, all her Central American possessions, should have accepted this convention with favor. In his last annual message the following l)ecember (1856) President Pierce said that the "occasion of controversy on this point [British pretensions in Central Americal has been removed. . . Shonld the proposed supplemental arrangement be concured in . . the objects contemplated by the original convention [Clayton-Bulwer treaty] will have been fully attained."

Obviously, this eonvention was a eompromise which left. Great Britain firmly established in Belize, doubtfully so in the bay Islands, but did away entirely with her influence in Niearagua. The Senate did not share the President's optimism, but promptly condemued the instrument, though finally, after eonsiderable diseussion, ratified it with certain amendments. The most important of these amendments. struck ont the clanse making the treaty conditional upon the acceptance of the British-Honduran treaty of August, 18.56. This particular anendment, however, was unsatisfactory to lomel Clarendon, for, by making an meonditional. surender of the Bay lskands to Honduras, he alleged it would leave unproteded a large number of British subjects. who hat taken up, their abode there with the natural expectation of protection from the home govermment; however, since the Senate conld not accept the conditions placed upon. the retrocession of the Bity lslinds, as already set forth, he: 
would propose a new basis of settlement, which was, cession of the Bay Islands to Honduras, according to certain conditions to be incorporated in a new treaty between Great Britain and Honduras.

If the Senate had been unwilling to agree to conditions already known, it was not to be expected it would aceept conditions that were unkmown. Nothing short of the unqualified retrocession of the Bay Istands to IIonduras was acceptable; and, as Great Britain declined to aceede to that proposition, the Dallas-Clarendon convention failed of ratification (May, 18.57). Thus the two powers were thrown back once more upon the unsatisfactory Clayton-linlwer treaty, with British officers at Greytown, a British protectorate over Mosquitia, together with British oceupation of the Bay Islands, and full sovereignty over Belize.

In the fall of 1856 Mr. Buchanan was elected President upon a Democratic platform extolling the Momoe Doctrine, and calling for a vigorous foreign policy. He appointed General Cass, Secretary of State, whose rallical views upon the subject of the Clayton-Bulwer treaty were well known, as he had upon former occasions in the semate led his party in fierce opposition to that compact. Mr. C'ass immediately concluded an agreement with Nicaragua which male secure American rights along the route of the proposed camal, and further accorded the Enited States the murestricted right of transit for troops and munitions of war. The nentrality of the canal was guaranteed, and the influence of both parties pledged toward sceuring international coöperation toward that desirable end. Great Britain objecterl to this agreement upon the ground that it violated the Clayton-Bulwer treaty of 1850 . It was never ratifierl.

Such was the diplomatic situation of the "canal problem" in the fall of 1857 , and in accordance with the spirit of his party's platform, the President deeided to remove embarrassment, at once and for all time, by abrogating the ClaytomBulwer treaty and procesding thenceforth nyom an entircly new basis. "The fact is," the President urgerl upon Congress, "when two nations, like Great Britain and the United 
States, mutually desirous, as they are, and I trust ever may be, of maintaining the most friendly relations with each other, have unfortunately concluded a treaty which they understand in senses directly opposite, the wisest course is to abrogate such a treaty by mutual consent and to commence anew. Hat this been done promptly," he continued, "all difficulties in Central America would most probably ere this have been arljusted to the satisfaction of both parties. The time spent in disclissing the meaning of the Glayton-Bulwer treaty wonld have been devoted to this praiseworthy purpose. and the task would have been the more easily accomplished betause the interest of the two countries in Central America is identical, being confined to securing safe transits orer all the routes across the isthmus."

Lord Napier, the British Minister in Washington, scenting danger in the hostile attitude of the Buchanan administration, approached the President with a new plan of settlement which he said his government was desirous of suggesting. An arbitrary abrogation of the Clayton-Bulwer treaty, he believed, would surely lead to acts in Central America which would disrupt the diplomatic relations of the two countries; this he was anxious to prevent. II is proposition included two alternatives: a mutual abandonment of the treaty with a return to the status quo ante, in which case both powers would be left free to act in Central America just as if no treaty lad ever been male; the other alternative was to lay the treaty, with its ambiguous phraseology and misunderstood provisions, before some European court of arbitration.

'The President could aceept neither of these propositions. That portion of the treaty which especially called for revision involverl principles relating to the Momroe Doctrine, and the President suspected that those prineiples would not stand the test of a European tribunal. And, on the other hand, a formal recoguition by the United States of the complete validity of English rights, as previously claimed in Central America, would be wholly impracticable.

With these avenues closed, Lord Napier then presented to 
the President a third scheme for the settlement of the diffculty. He explained that the British Government was abont to despateh an agent to Central Ameriea for the purpose of concluding a series of treaties with those states. In these prospective comprats he declared his government intenderl to make a disposition of Mosquitia and of the Bay Islands, in accordance with the wishes of the United States, as expressed in the amended form of the Dallas-Clarendon convention. Now, if this conld really be aecomplished, the President would have no eause to feel otherwise than satisfied. "To him it was indifferent," the President said, "whether the enncession contemplated by Her Majesty's Government was eonsigned to a direct engagement between England and the United States, or to treaties between the former and the Central American republies." After a period of argumentative sparring, into which he entered with abundant caution, in order to make it clear to Lord Napier that only a settlement of those vexed Central American matters upon a basis of the American interpretation of the Clayton-Bulwer treaty, would be acceptable to the United States, the President eonsented to await the results of British negotiations in Central Ameriea before making any further move toward its alorogation.

Sir William Ouseley, the British agent in question, after a preliminary sojourn in Washington, proeeeded to Central America upon his diplomatie mission. Je was for a time delayed by a series of misadventures, brought about ly the turbulent condition of affairs existing in Nicaragna; and it was not until 1860 that Lord Napier was finally enabled to submit to Mr. Buchanan the three treaties which Great Britain had concluded with Gratemala, IIonduras, and Nicaragrna respeetively.

The first of these treaties was designed to arljust the boundary lines of British IIonduras, which were liberally enlarged in favor of England, so as to inelude nearly all slie lat ever claimerl in that region. As the original settlenent of belize had never figured as a canse of serious eontention between the United States and England, the President was inclined to accord his approval to this agreement. 
The second treaty - the one with Honduras - retroceded to that republic the Bay Islands, with the conditions that the recipient should never part with them to any other nation, and that British subjects, continuing to reside there, should be unmolested in their property rights and religious freedom. By this same instrument, England abandoned her territorial claim along the shores of IIonduras, occupied by the Mosquito Indians, on the sole condition that Honduras should pay to the Indians an annual indemnity of $\$ 5000$ for ten years. This treaty also met with the President's approval, although he would have preferred the release of English territorial rights less hampered by conditions.

The third treaty (with Nicaragua) was the most important one to American interests. By this compact England withdrew from her protectorate over Mosquitia, but Nicaragua was required to establish a reservation along her shores for the Indians, permitting them to exercise local self-government, and also allowing them at any time to incorporate themselves absolutely into the body politic of Nicaragua, should they so desire. In this contingency, the reservation would be abandoned. Nicaragua was also obligated to pay annually to the Indians the sum of $\$ 5000$ for a period of ten years, in defanlt of which Great Britain reserved the right to interfere in behalf of her former charges. Greytown was to become a free port under Nicariguan sovereignty.

At last it seemed that all went well in Central America. I Iad England absolutely and unconditionally surrendered all her territorial claims in IIonduras and Nicaragua, it would have been more satisfactory to the United States; yet, upon the other hand, this arrangement was a long move in the right direction, and it appeared to be a victory for the American interpretation of the Clayton-Bulwer treaty, and a vindication of the Monroe Doctrine as well. In his last annual message (1)ecember 3, 1860), President Buchanan expressed his satisfaction in the happy results of his diplomacy. "Our relations with Great Britain," he said, "are of the most friendly elaracter. Since the commencement of my Administration the two dangerous questions arising from the Clayton and 
Bulwer treaty and from the right of seareh claimed by the British Government have been amieably and honorably adjusted. The diseordant eonstruction of the Clayton and Bulwer treaty between the two Governments, which at differsnt periods of the diseussion bore a threatening aspeet, have esulted in a final settlement entirely satisfactory to this Government."

The country at large acquieseed, and it was confidently roped that the matter was forever settled, and that the roublesome Clayton-Bulwer eonvention wonld be permitted o rest peacefully in the archives of the State Department.

Thus closed in reace and coneord a decale of bitter conroversy growing out of this treaty. Fundamentally, the notives of these disagreements may be langely traced to susicion. While neither party actually sought a monopoly of olitical control over the eanal route, ench power distrusted he other, and was ready to deteet in every move of its oppoent, a covert attempt to secure those forbidden advantages. iut the lope that the controversy was forever ended proved ain. Twenty-one years later, Great Britain fomm her susicions verified. The United States did eovet a monopoly of re camal, and openly proclaimed her intention of aequiring

The Clayton-Bulwer treaty was scamned anew for its nperfections, and the old-time quarrel wals fought over nce again, but upon new lines of argunent.

\section{IV}

From 1860 to 1865 the United States was engaged in a ruggle at home that rendered Central Ameriean affairs imparatively of little importanee; nevertheless, the suljeet a canal was never entirely lost sight of. In 18 in a series riots at Panama interfered with the freedom of transit over e isthmian railway, and the United States found liesself uder obligation to use military foree to relieve the inferrupted ute. Upon this oceasion the Seeretary of State. Mr. Marey, sclaimed any desire for exclusive ardvantage in that line of unsit; he went so far as to amonnce tle Ameriean inten- 
tion of inviting other nations to join in a "guarantee for the neutrality of that part of the isthmus." Six years later, revolutionary movements in Colombia again menaced the safety of the railway, and the Gorermment at Bogota called upon the United states to lend aid in suppressing the rebellious uprising that endangered the freedom of transit between Colon and Panama.

Mr. Seward, the new Secretary of State, felt that the burden imposed upon the Cuited States to maintain alone and singlehanded the integrity of the Panama route against the numberless revolutions of a Latin-American state was unjust. The route was open to the world's commerce, and the responsibility of its protection, he believed, should rest equally upon the shoulders of all beneficiaries. The interest of the United States was in no manner " different from that of other maritime powers." He instrueted Mr. Adams and Mr. Dayton, Ministers to London and Paris respectively, to ascertain whether Great Britain and France would "unite with the United States in guaranteeing the safety of the transit route and the anthority of the new Granadian confederation."

At the close of the Civil War, a more lively interest in a ship canal was manifested, and steps were soon taken to encourage more friendly relations with the Central American states. American interests in Central America had been permitted to decline, and they were greatly in need of the stimulus which fresh treaties would give them.

The United States emerged from its four year's' conflict with enlarged ideas of her position in the world; the seeds of a new and more agressive foreign policy had been sown. The progress of those ideas is marked by the Alaskan purchase, the attempts to secure naval bases in the West Indies, the expulsion of the French from Mexico, and by the evidences of a belief, then gradually forming in the minds of the people, that the Initerl States should exercise sole political control over any ('entral American canal that should ever be built.

Mr. Sewarl first gave expression to this new eanal policy in 1860, when he directed Mr. Mdams, the Mmeriean Minister in London, to broath the subject to Lord Clarendon of the 
United States purchase of Tigre Island as a coaling station the same island that had figured so prominently in BritishAmerican relations in 1850$)$. Wrould such aetion on the part If the United States be eonsidered by Great Britain as a vioation of the Clayton-Bulwer treaty? In his letter to Mr. Idams, Seeretary Seward hinted that the clayton-Bulwer reaty was void becanse it related to the bnilding of a certain anal which had never even been undertaken. "It may be a uestion," he said, "whether the renunciatory clauses of the reaty are to have perpetual operation." The matter was not messed by Mr. Adams, but the episode is important here, as 'emonstrating the birth of a new sentiment, which was in iter years destined to expand into a national poliey.

The Dickinson-Ayer treaty with Niearagna, which stands I force to-day, was ratified in June, 1868. It cedes to the Inited States a right of way, though not an exelusive one, or canal building purposes; it guarantees freelom of ports nd neutrality of eanal, subject to the political sovereignty of iicaragua. The United States also agreed to use its influence , induce other commereial nations to coöperate with it in uaranteeing sueh neutrality.

This treaty, therefore, like the one conchuled with Colomia, twenty years previously, enutemplated the nentrality the canal; in this respect it was in full accord with the rovisions of the Clayton-linlwer treaty. A new treaty as also made with ('olombia (1868), in the negotiations II which Mr. Seward exhibited a deeirled change of sentient from 1862, touching the nentrality of the isthmian ute. He inserted a clanse in the rlaft of this Colombian eaty which provided that enemies of the Inited sitates rould be excluded from the use of the proposed canal in mes of war. 'The Colombia Govermment rejerted the artie, adding in its place a clanse faroring intermational comol. The treaty was given full discussion in the Sinate, it failed of ratifieation. Harl the Senate accepted this greement with Colombia, it is quite certain that Great ritain would have protested against it as a violation of the layton-liulwer treaty. No doubt Mr. Seward well knew 
this, and he was probably intending to hasten an issue with Great Britain by this practical exposition of his theories.

Cpon the inauguration of Presiclent Grant in 1870, a keen interest in the interocemic problem was revived, and the new policy ealling for exclusive American control of a Central American canal rapidly gained adherents. It was strongly urged by General Grant, and soon found many champions among the public men of the day.

There were several causes for the rapid development of this poliey during the Grant administration. Many, who theretofore had never considered the question of canal neutralization in the light of a national issue, had their interest suddenly aroused by the French operations under De Lesseps at Panama. The prospeet of European influence in the lower isthmus brought many converts to the extreme views of the administration, - and they, as is usual with most converts, exhibited great zeal in their new cause. The Monroe Doctrine, which had recently been fittingly and successfully applied in Mexico, had left its impression in a general revival of those principles which led the American mind to protest against any form of foreign aggrandizement on this continent. Indeed, the maintenance of these principles seemed sufficient reason in itself to warrant a demand for an exclusive American control of any ship canal enterprise in the Western Iemisphere. As most Americans, aceording to their own varying interpretations, believed in the wisdom of the Monroe Doctrine, they came perforce to aceept what appeared to be a mere corollary or incident of that well-established faith.

After the period of reconstruction and the consequent remion of the states, the need of such a canal continned to grow in importance, especially as the Pacitic seaboard states rapilly developed a marvellous commereial growth. With two coists to defend, the military value of such an American waterway, from the Atlantic to the Pacifie, eame more than ever to be appreeiated. Consequently many began to argue that there conld be no safety in a canal whose international guaranty should keep it at all times open as the high seas. 
Thus the idea that the interoceanic eanal should be constructed, owned, and then solely controlled by the Lnited States, came so generally to be aceepted by all political parties that it may be said in 1880 to have become erystallized into a definite national policy.

The most formiclable obstacle, however. which stood just in the way of realizing this ideal was the C'layton-Bulwer treaty. Consequently each administration, since that of President Grant, hats in turn made some attempt to remove this obstruction. With the general acceptance of the more radical theories of American monopoly of the canal route, it has been diffieult for many legislator's to comprehend how their predecessors could have entertained dissimilar views upon the subject; for this reason the Clayton-Bulwer treaty has been frequently denouneed in Senatorial debite within the last twenty years, as a monument to American imbecility. These critics are apparently ummindful of the conditions under which the treaty was originally mate and of the diplomatic negotiations which followed its ratification. Actuated by the conviction that the agreement is a prejurlicial one, senators have for twenty years periodically sought to abrogate it.

Prion to 1880, however, no systematic effort, betanse of its supposed antagonism to Ameriean interests, harl been marle to repudiate the (layton-Bulwer treaty, for although the growing sentiment in the United States, ealling for American control of the canal, conflicted with the provisions of that treaty, up to that year the instrument itself was generally accepted as a binding agreement, and no actual attempt was male by those who regaded it with disfaror to abrogate or otherwise avoil it. On the eontrary. great solicitude was at times manifesterl lest (ireat Britain slonuld violate its provisions. When Belize was transformed from a british settlement to a molomial possession, Ameriean protests were marle predicated upon the provisions of the Clayton-bulwer treaty. Upon other oceasions as well, when Great liritains motives in "arljusting" her Centmal Amrian bomblary" lines were brought into question, the C'layton-bulwer treaty" 
was quoted to the British Minister in Washington as a sufficient condemnation of England's conduct.

As already noted in the development of this new theory of American political control of the canal, the operations of the French company under De Lesseps, at Panama, played an important part. Fearing that the French might realize their Central American objects and thereby gain for themselves an undue military advantage over the United States, President Hayes, in March, 1880, sent a special message to Congress declaring the policy of this country to be "An American canal under American control." lle said: "The United States cannot consent to the surrender of this control to any European power or combination of European powers. If existing treaties... stand in the way of this policy .. suitable steps should be taken.. . to promote and establish the American policy. . . . It is the right and duty of the United States to assert and maintain such supervision and authority over any such interoceanic eanal across the isthmus . . . as will protect our interests." At another time President Hayes asserted that the [nited States should consider the banks of the Nicaragua Canal as a continuation of the American shore line, which doctrine would, of course, claim the right in the Lnited States to hold, fortify, and defend the same.

Following this exposition of the executive's position on the canal question - which was the first official and public declaration of the new policy - C'ongress passed several resolutions recommending the repudiation of the ('layton-Bulwer treaty. These resolutions were inspired by the same fear that had actuated Presirlent Iayes, and were also aimed at France and her l'anama canal scheme.

The growing opposition to the Clayton-bulwer treaty and to the principles for which it stood reached one of its crises in 1881-82. In the early part of that year rumors were circulated in Washington that several European powers, at the request of Colombia, were considering the advisability of arlopting some plan of concerted attion looking toward a joint guarantee for the neutralization of the French canal at 
Panama. Colombia had again declined to make a treaty with the United States which would bind her to aceept the sole guarantee of the latter for the nentrality of the isthmian transit route; the situation in Central America seened unsatisfactory. President Garfield, in his inaugural address, Mareh 4, 1881, touched upon this question, though with eonsiderably more calmmess than had been displayed by his predecessor. While declaning that the Uniterl States wished to follow no narrow or exelusive policy, nor sought exclusive privileges, yet on the other hand, it was the "right and duty of the United States to assert and mantain such supervision and authority over any interoceanic eanal across the isthmus . . as will protect our national interests."

But the Secretary of State, Mr. Blinine, was more deeply moved by the threatened danger to Ameriean interests. He was wholly in sympathy with the popular movement demambing the abrogation of the Clayton-Bulwer treaty: he felt that the time had arrived for action, and he preeipitated a controversy with Great Britain hy a bold and altogether defiant stroke. On June 24, 1881, quite in disregard of the obligattions imposed upon the eomintry by the Clayton-13ulwer trealty, he issued a circular letter to the powers of Europe, informing one and all that the Enited States would in future tolerate no foreign interference in the matter of political eontrol of any isthmian canal; assmance being given, however, that the United States would itself "positively and effieacionsly" guarantee the neutrality of any such route: also, that no assistance or aid from any other powel to this end was necessary; furthermore, he gave notice to all that any insistence on the part of European nations to have a shalle of responsibility in the neutralization of the canal would "plartalke of the nature of an alliance against the Enited States." In further elabonation of this recently adopted and somewhat novel attitude of his combty toward the subject of camal squalization, Mr. Blaine espectally desired that the rarions liplomatic envoys of the Initer States. to whom he hat arlIressed his cireular letters, should " not represent this position is a development of a new policy." He alleged, on the con- 
trary, that it was "nothing more than the pronounced adherence to principles long since adopted."

It is difficult to see just how Mr. Blaine had been enabled to justify to himself the correctness of this last statement, especially in view of the fact that the American canal policy, as set forth in his circular note, had been but the actual outgrowth of the previous decade, while the theory of a conpletely neutralized canal, on the other hand, had obtained in the United States for more than half a century.

No doubt the British Government was surprised by the receipt of Mr. Blaine's circular letter. The full statement of the new American position had been made in complete disregard, if not in open contempt, of the Clayton-Bulwer treaty. 'The British Minister for Foreign Affairs, Lord Granville, was pointedly brief in reply, and his answer bears a hint that he suspected Mr. Blaine felt the weakness of his own position. He merely said that the matter in question had already been settled by the engagements of the Clayton-Bulwer treaty, and that "Her Majesty's Government relied with confidence upon the olsservation of all the obligations of that treaty."

Mr. Blaine anticipated the issue to be presented, and before the receipt of Granville's note, he despatched to Mr. Lowell, the American Minister in London, a lengthy communication upon the subject (November 19, 1881). The letter is no less remarkable for its plausibility than for its lack of logical consistency.

1. "This convention [Clayton-Bulwer]," he said, "was male more than thirty years ago, under exceptional and extraordinary conditions which have long since ceased to exist, - conditions which at best were temporary in their nature and which can never be reproduced. The remarkable development of the United States on the Pacific coast since that time has created new duties for this government, and developed new responsibilities mpon it, the full and complete discharge of which requires, in the judgment of the President, some essential modifieations in the Clayton-Bulwer treaty."

2. "The interests of IIer Majesty's Govermment, [in a 
Central American eanal] . . . are so inconsiderable in comparison with those of the United States, that the President hopes" for a readjustment of the treaty.

3. At present the treaty "concedes to Great Britain the control of whatever canal may be constructed." This is necessarily the ease beeause of England's great sea power.

4. The Lnited States (owing to its position in the Western Hemisphere) "will not consent to perpetuate any treaty that impeaches our rightful and long-established elain to priority on the American continent."

5. Great Britain practically holds the route to India, her fortifieations at all the important strategic points secure to her the mastery of the Mediterranean and the Serd seas, and this, together with the controlling interest in the Suez ('anal. practically converts those waters into a mure clunsum 'Therefore, he argued, "If a hostile movement should at any time be made against the l'acific eoast, threatening danger to its people and destruction to its property, the Government of the United States would feel that it lad been unfaithful to its duty and negleetful toward its own citizens, if it permitted itself to be bound by a treaty which gave the same right through the canal to a warship bent on an errand of destruetion that is reserved to its own navy sailing for the defense of our coast and the protection of the lives of our people. And as England insists ly the might of her power that her enemies in war slatl strike her Indlian possessions only by doubling the (arpe of Good Ifope, so the fovernment of the United States will equally insist that the interior, more speedy, and safer ronte of the eamal shall be reserved for onrselves, while our enemies. if we slall ever lue so unfortunate as to have any, shall be remamled to the royage around ('ape Horn."

6. ". . . Only by the United States exereiving smpervision ean the Isthmus eanals be definitely and at all times seeured against the interference and olstruction incident to war. A mere agreement of nentrality on paper letween the groat powers of Europe miglit prove ineffectual to preserve the canal in time of hostilities. The first sound of a cannon 
in a general European war would, in all probability, annul the treaty of neutrality, and the strategic position of the canal, commanding both oceans might be held by the first naval power that conld seize it." 'This would likely embroil the United States in foreign wars.

7. The United States is less likely to be engaged in foreign wars than are the European powers. Therefore to her should be entrusted the care of the canal.

8. Other powers are extending their Central American trade, while France is building a canal. 'The Clayton-Bulwer treaty leaves the United States powerless to assert her just rights on the isthmus, while these other powers are free to control the situation.

9. "One of the motives that originally induced this govermment to assent to the Clayton-Bulwer treaty, not distinctly expressed in the instrument, but inferable from every line of it, was the expected aid of British capital in the construction of the Nicaraguan Canal. 'That expectation has not been realized, and the ehanged condition of this comntry since 1850 has diminished, if it has not entirely removed from consideration, any alvantage to be derived from that source."

Therefore the United States asks that "every part of the treaty which forbids the United States fortifying the canal and holding the political control of it in conjunction with the country in which it is located should be cancelled; "that "every part of the treaty in which Great Britain and the United States agree to make no aequisition of territory in Central America should remain in full force;" and that a nentral zone about each terminus of the canal, of liberal extent, should be preserved by agreement of the great powers of the world.

'Ten days later, Mr. Blaine despatehed another letter to $\mathrm{Mr}$. Lowell, upon the same subjeet. The argument of " Tempora mutuntur" was further elaborated. Mr. Blaine did not hold the ('alyton-Bulwer treaty to be a void, but rather a voidable, instrmment: it had always been a cause of friction between the two governments, a compact "mismulerstandingly entered into, imperfectly comprehended, contradictorily interpreted, 
and mutually vexatious," for which reasons, he inferred, its provisions could not properly be accepted as a guicle to the action of either party in C'entral Ameriea. A full historical account of these many eontratictory interpretations of the vexatious treaty, throughout the period of Sir William Ouseley's mission to Central America, down to 1859 , is given. The numerous quotations presented demonstrate clearly enough the dissatisfaction felt in the Luited sitates throughout that period. IJe conchudes, that for harmuny s sake, the objectionable features of the convention should be removed by the common consent of the parties.

The weakness in Mr. Blaine's position is at once apparent. His argument amounts to a statement that the Lnited States, having found the obligations of its contract irksome, and antagonistic to its new politieal policies, it therefore leems it fitting and proper to avoid them. The particular reasoris anvanced in support of his contention are, for the most part, quite unsatisfactory. The rast growth of the l'acifie states, connected by numerous railway systems with the Eist, harl been made under the very restrictions he eomplainerl of, and the ability of the West eoast to proteet itself hal heen strengthened by its mavellous advanee in population and wealth. It is true, the interests of the I'nited states were probilly. greater in a Central American canal than were the interests of Great Britain, yet the measure of interest cannot affeet the legality of the contract. England might easily have asserted her own great interests in the ronte by simple reference to her merchant marine, which exceeder many times in value that of the United States; her own territorial possessions on the Nonth Ameriean eontinent, having a l'acific const line as well, though less in extent than that of the Cuited Sitates. demanded protection of their interests. The ronte from Halifax to Vanconvel would be shoptened as well as the route from New York to Siln Fruncisen.

Mr. Blane's contention that the terms of the ClaytonBulwer treaty, uniting Great linitin and the luited Sitates in joint protection of the Isthmian Cimal, would grive to the former virtual control, is searcely true - and if true. coukl 
have no weight as an argument in this discussion. If Great Britain could gain control of the canal, to the injury and prejudice of the United States, it would not be by virtue of any provisions in the Clayton-Bulwer treaty, but by reason of her superior naval strength, - a fact lying wholly outside the issue in question. On the contrary, the very obligations from which Mr. Blaine sought relief, being equally binding upon both governments, prevented the "control" of England over the canal. The treaty called for a joint guarantee of neutrality - a guarantee, it must be remembered, which tied England's hands, as well as our own. There is no pardonable excuse for avoiding a contract because of the superior strength of one of the parties.

The claim to priority on the American continent, and to that position of vantage which gives to the United States a greater right in the management of all the political ventures in the Wester'n Hemisphere, is a claim only to be upheld by military strength; such asserted right can be maintained only by force - it cannot be supported in the law. If this argument of Mr. Blaine were to be brought forward as a positive finale of the discussion, it could only indicate that the United States had decided to abandon its treaty pledges, to assert its control of the canal, and then stand by the consequences. But Mr. Blaine had no intention of thus conveying an ultimatum to Great Britain; his argument concealed no threat, - it was made solely in the hope that it miglit convince the British Minister that England's interests were not sufficiently important to give her any part in the maintenance of an open waterway comnecting the Atlantic and Pacific oceans. As such, it could only be considered a political argument, possessing but little of legal force.

'The exposition of Great Britain's position along the route to Indial, and her alleged control of the Suez Canal, as an argument for a similar comse to be followed by the United States, ahong her route from the East to the West, was not sufficicntly gromuled on fact, even had it been relevant, to invest it with argumentative force. At that time the neutralization of the Suez Canal had not been thoroughly effected, 
but Great Britain was the central figme in the attempt then being made, and later earried out by treaty of constintinople, to secure the perfeet neutrality of the Snez Canal. liy this agreement Great Britain estopled herself from acyuiring the control of that eanal which her great navil strength might have given her. Her position along the route, throngh, the Meditermean and Red seas, hard nothing more to do with the legal status of the Suez Canal than our own naval stations along the Atlantic and Pacifie eoasts might have with the Isthmian Canal.

Mr. Blaine's assertion that "only by the United States exercising supervision, ean the Isthmian Canal be definitely, and at all times, seenred against the interference and obstruction incident to war," is a statement much more suseeptible of refutation than of proof. It is manifestly easier for two to stand guard than for one, and still more easy for three to protect than for two; when all are willing and are plerlged to stand guard, there becomes no further need for the sentry. With the United States alone roing guard duty upon the banks of the eanal, what is there to prevent any two warring powers from blockarling the route? What is there, even to prevent their elosing the way against American ships? The force of this eontention by Mr. Blaine can be better appreeiated in the ferveney of patriotic sentiment, but logically it fails. As an argument for abrogation of that part of the Clayton-Bulwer treaty ealling for international guarantee, it was of little force, for there is every reason to suppose that no single nation can perpetually maintain the reedom of an interoceanic ship canal.

Mr. Blaine's fear that France might gain entire control of he Pamama Canal was without reasonable fommlation. De Lesseps made no claim for his conutry exchusive intrests n the result of his lahor's. He himself deminded intronaional agreement for the protection of the ronte: and had he: int done so, or had france assumed a right to evelude all ther nations from a share in its politioal manacement, it is ertain that Great Britain womld have protested as vignomsly is the United States. Indeed, there is no reason to suppose, 
judging from the attitude of the commercial powers toward the subject, that the other nations of Europe would have permitted France to control the P'anama Canal to their disadvantage.

It is difficult to see, as contended by Mr. Blaine, wherein the Clayton-Bulwer treaty gives promise of British eapital for the construction of the canal. English money had never been solicited for the purpose. Mr. Webster, as Secretary of State, two years after the ratification of the treaty, declared that the necessary means could easily be obtained in this country. There is no evidence to show that the United States ever expected to draw upon English sources for a proportion of the funds necessary for the building of the canal.

Lord Granville replied in two despatches, dated January 7 and $14,188 \%$. At the outset, he arraigned the principles upon which Mr. Blaine had founded his arguments as "novel in international law." Denying the charge of Great Britain's control of the snez route, he hastened "cordially [to] coneur in what is stated by Mr. Blaine as regards the unexampled development of the United States on the Pacific coast . . . but Her Majesty's Govermment cannot look upon it in the light of an unexpeeted event, or suppose that it was not within the view of the statesmen who were parties on either side of the Clayton-Bulwer treaty. The declarations of President Monroe and of his cabinet in 1823 and 1824 . . show at least ... twenty-six years anterior to the treaty . . there was a clear prevision of the great futme reserved to the Pacific coast. It is . . a an inadmissible contention that the regular and successful operation of causes so evident at the time . . . shonld be held to have completely altered the condition of affairs to the extent of vitiating the foundations of an agreement which camnot be supposed to have been eonchuded withont careful thought and deliberation." Great Britain, as well as the United States, has important interests comeeted with the waterway between the Atlantic and Pacific oceans. Such a canal, he urged, " is a work which concerns not merely the United States or the 
American eontinent, but the whole civilized workd... . Her Majesty's Government are as anxious as that of the United States that, while all nations should enjoy their proper share in the benefits to be expected from the undertiking, no single country should aequire a predominating influence or eontrol over such a means of communication." Its universal and umestrieted use should be secured upon an international basis. This, he reminded Mr. Blaine, was the attitude of the United States in the past, and to save all annoyance and trouble, and to subserve the best interests of all alike, this should be their attitude in the future.

To the historical objections presented by Mr. IBaine, Lord Granville replied at much greater length in his second despatch of Jannary 14. The substance of the letter is condensed in its elosing paragraph, which sets forth that the various differences which arose between the two governments out of the Clayton-Bulwer treaty, and to which Mr. Bhaine refers, related, not to the general principles of the treaty, (neutralization, international control, ete..) but to that portion of the instrument forbidling new aequisitions of territory in Central Ameriea. 'These old quarrels fomm their origin in allegations that Great Britain was rolating the provisions of the treaty by acquiring ('entral American territory. This portion of the treaty Mr. Bane does not now attack, but desires, on the contrary, to retain intart; indeed, it was in defence of those very principles of nentralization that the United States objected to (rreat Britain's novements in Central America. In his historical review, Mr. blaine stops at the very point where the controversy should begin. In 1860, upon the conthision of the thee Intish treaties with the Central Ameriran fitates, the old disputes between England and the Enited Sitates were entirely settled, and President Buchanan, in his ammal mossige of that year, said: ". The disorolant eomstrurtions of the ('latytom-Bnlwer treaty between the two govermments, which at different periods of the discussion bore a threatening aspeet, have resulted in a final settlement entirely satisfactory to this grovermment." 
Here then was an estoppel to Mr. Blaine's "historical arguments."

The Garfield administration soon after coming to a tragic end, President Arthur's Secretary of State, Mr. Frelinghuysen, resumed the controversy with Lord Granville. His first letter upon the subject (to Mr. Lowell, May 8, 1882) is a state paper of considerable strength.

Mr. Frelinghuysen maintained that the construction of an isthmian canal, open to all ships, at all times, would expose our Western coast to attack, destroy our isolation, oblige us to improve our defences, increase our navy, and compel us, contrary to our traditions, to take an active interest in European affairs. The physical conformation of this continent is whe of our greatest safeguards, and any change made in it might most injuriously affeet the interests of the Republic; hence the severance of the isthmus must be effected in hamony with those interests. Relating to the canal, there is no conflict between American political claims and the material interests of other nations. The Panama Railroad and the Suez Canal, without any international pledges of neutrality, have remained open and in service during the most turbulent times. If no protectorate were found necessary for them, it can scarcely be required for the Isthmian Canal. He therefore considered it "unnecessary and unwise, through an invitation to the nations of the earth, to gualantee the neutrality of the transit of the isthmus, to give their navies a pretext for assembling in waters contiguous to our shores, and to possibly involve this republic in conflicts from which its natural position entitles it to be relieved." Such international agreements - calling for interference by force - are apt to breed dissension and trouble. In times of peace they are harmless and useless, and in times of war they often cammot be cnforced. Besides this, such an agreement would lead to foreign intervention in American affairs, which the tralitional policy of the United States would make it impossible to tolerate. A protectorate of Enropean nations over the isthmus transit would be in confliet with the Monroe Doctrine. 
The treaty had two primary objects, — the construction of the Nicaragua Canal, and the dispossession of (ireat Britain from her Central American settlements. To this end, the parties agreed not to exercise any dominion over, fortify, or colonize, Nicaragua, Costa Rica, the Mosquito eoast, or any part of Central America. Yet Great Britain exereises dominion over Belize or British Iondmras, - an area equalling Massachusetts, Comnecticut, and Rhode Island, - and the impression prevails that since 1850 Great Britain lats eonsiderably increased the region in Central America over which she assumes control. Such dominion seems inconsistent with the provisions of the treaty. At the time of the conclusion of the Cliyton-Bulwer treaty, English dominion in Belize consisted merely in a privilege to cut worl and establish saw-mills in a territory established by metes and bounds. It was referred to by sir IIenry Bulwer in 18j0, as a "settlement" at Honduras. I lis letter to Mr. Clayton, excepting this settlement and its dependencies from operation of the treaty, was made after the conclnsion of same, and was unknown to the President and Senate. In 1859 Great Britain made a treaty with Guatemala, in which her "settlement" was referred to, as "Her liritanic Majesty's settlements and possessions," and the commissioners appointed to mark the boundaries diseovered the British area to lave greatly expanded. The United States nevol gave assent to this conversion of a British settlement into a british possession under full British sovereignty. "Tnder treaty of 1850, while it is binding, the Inited States have not the right to exercise dominion over or to eolonize one foot of territory in Central Ameriea. Great Britain is under the same rigid restriction. And if Great Britain has violated and continues to violate that provision, the treaty is, of eomse, voidable at the pleasure of the Inited States."

Referring then to Lord (inurille's mention of l'resiblent Buchanan's message of Iecember 2,1860 , in which the exeentive expressed his entire satisfaction with the ontrome of negotiations arising under the Clayton-Bulwer treaty, Mr. Frelinghuysen said: 
"It is well known that the parties to the Clayton-Bulwer treaty anticipated that a canal by the Nicaragua route was to be at once commenced. Inder the assumption of a proteetorate of Mosquito, British authority was at that time in actual and visible occupation of one end of the Niearagua route, . . and it was intended by this treaty to dispossess Great Britain of this oeeupation. This objeet was aceomplished in 1859 and 1860 hy treaties between Great Britain, Guatemala, Honduras, and Nicaragua. . . It was to this adjustment, which was one of the prime objeets of the treaty, and not to the eolonization of British Ionduras, that $\mathrm{Mr}$. Buchanan alludes. ..."

An ample review of the negotiations between Sir Henry Bulwer and Mr. Clayton, which led up to the treaty, was then given, in order to show that the primary object of the parties was to insure, at the earliest possible moment, the completion of the particular ship canal for which a concession had alleady been marle by Niearagua to eitizens of the United States (Angust 29, 1849). It is to this particular canal, (Nicaragua Canal) Mr. Frelinghuysen urged, that all the provisions of the first seven articles of the Clayton-Bulwer treaty apluly.

C'oming then to the seventh and eighth articles of that instrument, which provide for the eourse of action to be followed by the two governments toward any other Central Ameriean seheme for connecting the oceans, Mr. Frelinghuysen insisted that reference was only male therein to such projects as were then in contemplation, i.e. at the time the treaty was signed. All that part of the treaty (Artieles 1 to 7 ) relating to one particular canal (the Nicaragua Camal) had lapsed by failure to construct the eanal to which it espeeially referred. 'The canal "now (185.2) in question" was the Promama Canal, and the position of the United States in reference to that is determined by a convention between the United states and New Granala (Inited States of (olombia), concluded in $\mathbf{1 8 4 6 ,}$ and still in force. In this treaty, the United States is placed in the position of sole grmarantor of the nentrality of any route across the Isthmus of Panama. 'The United States 
protectorate is therefore exelusive in its chanacter, and should Great Britain claim, under the Clayton-Bnlwer treaty, a right to join the Lnited States in the protection of this route, "the United States would submit that experience has shown that no such joint protectorate is requisite: that the Clayton-Bulwer treaty is smbject to the provisions of the treaty of 1846," between the Lnited states and Colombia.

Furthermore, the United States having successfully exercised her protectorate over the Pamama Railuad route, for upward of thinty years, during the most tmbulent times, Great Britain has no right, at this late date, to demand any share in the guarantee of any canal hereafter to be built across the isthmus.

In conclusion, Mr. Frelinghuysen maintained that both history and theory support him in his position against a joint protectorate with Great Britain over the Panman transit ronte, and finally that the United States cannot take part in extending an invitation to the powers of the world to cooperate with them upon the basis of the clayton-linlwer treaty; and that the United States " would look with disfaror upon any attempt at a eoncert of political ation by other powers in that direction."

This letter of Mr. Frelinghursen is, perhalps, the lest exposition of the Ameriean case that hats ever been mate for the abrogation or modification of the ('layton-bulwer treaty. The arguments are set forth with great earnestuess and much plausibility; but despite the elaborate preparation of the brief, it was completely traversed by Lord Granville's reply to Mr. West (December :30, 1882).

To offset Mr. Frelinghuysen's contention that the Clayton-liulwer treaty had reference only to the interoceanic routes then in contemplation, Lord Ganville soeded lut to offer in quotation the treaty itsell, which declared "tlat neither the one nor the other of the high eontrationg batices wonld ever ohtain or maintain for itself any pxohsive control

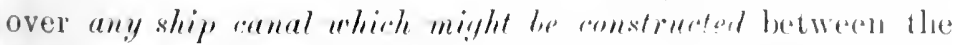
Atlantic and Pacifie ()eeans, he way of the river siln llan." Having then declared for a prinerple, as well as for the ateen- 
plishment of a particular object, the parties agreed " to extend their protection by treaty stipulations to any other practicable communications, whether by canal or railroad. aeross the isthmus whieh connects North and South Ameriea, and especially to the interoceanic communieations, should the same prove to be practicable, whether by eanal or railway, which are now proposed to be established by way of Tehuantepec or Panama." The use of the words "general principle" and "especially," in reference to Tehuantepec and Panama, seem to remove all doubt as to the construction of the treaty. Granville's position was still further strengthened by the general acceptance of this construction of the treaty in the United States for many years following its ratifieation.

General Cass, while Secretary of State in 1857, had asserted to Lord Napier that " the United states demanded no exclusive privileges in the interoeennic passages of the isthmus." All of the treaties made since 1850 , by Great Britain and the United States with Central American states, acknowledged the principle of joint protection. From one of these American treaties (that of June 21, 1867, with Nicaragua), Lord Granville called attention to the fact that the United States not only "agreed to extend their proteetion to all such routes, guarantees," ete., but it did further "agree to employ their influence with other nations to induce them to guarantee such neutrality and protection." Therefore, as the United States had seen fit to pledge itself to the earrying out of that "general principle" established by the Clayton-bulwer treaty and opposed to all ideas of exclusive control, by treaties since marle, they conld not now eonsistently fall baek upon the Colombian treaty of 1848 , as giving them exelusive rights upon the isthmus.

It was to $M \mathrm{H}$. Frelinghuysen's contention that certain acts of Great Britain, in violation of the terms of the Claytonbulwer treaty, had voided the treaty itself, and liberated the United sitates from its operations, that (iranville especially turned his attention. These alleged acts on the pait of Great britain, it will be recalled. were the conversion of a more restricted right of settlement in Ilombluras to a full- 
fledged colony, and to the unlawful extensions of the boundary of this British possession. Lord Granville furnished an historical account of Belize, showing that while originally the occupation of this territory by Englishmen was maintained under the sovereign laws of spain, yet by conquest it had subsequently beeome English territory, as acknowledged by Spain, and later by the Central Ameriean states. All these acts, which secured to Great Britain the sovereignty over lier Central Ameriean territory, had been committed before 18;0. In that year, and while the Clayton-linlwer treaty was awaiting ratifieation, Mr. Clayton, the Secretary of State, acknowledged this British possession. Finally, to elose the discussion, Lord Granville pointed to the postal convention of 1869 , between Great Britain and the United States, which formally reeor. nized British Honduras as a "colony" of Great Britain.

Mr. Frelinghuysen returned to the discussion, and the controversy with Lord Granville was urged along, though with signs of diminishing vigor on the part of the Uniterl states. Nothing new was developed in what miglit be termed this supplementary correspondence, - the old lines of argunent were preserved, and the same facts reiterated. 'The end of the debate was only brought about when the line of argument returned once more to Mr. Frelinghuysen's former charge of Great Britain's bad faith in creating a "colony" in IIonduras since the ratification of the Clayton-Bulwer treaty, lord Granville's curt reply to this repeated assertion was simply. that the United States, through its offieial mouthpiece, har expressed its satisfaetion and reeognized English rights in Honduras. The Monroe Doctrine, which hat erept into the discussion, he dismissed with a query, - Why had it not applied during the past thirty years? If the lefenders of the Monroe Doctrine could accept the clayton-linlwer treaty in 1850, they could equally reeognize it in 1883.

The only effect of this two years' controversy was to establish all the more firmly the validity of the ('laytonBulwer treaty. Whatever ills its provisions maty have imposed upon the Initerl States, there was no eseape from the treaty through the avenues of logic or by recourse to 
legal arguments. The merits of the case belonged to Great Britain. There was no position which either Mr. Blaine or Mr. Frelinghuysen had taken, which was not disproved by admissions elsewhere made; at every turn there appeared to be an estoppel.

The reason for this utter failure of American statesmen to free the nation from a burclensome treaty is at once clear. For twenty-five years after the conclusion of the treaty the principles embodied therein had been accepted by the United States as sound and wise. On such a basis other treaties had been negotiated, authoritative endorsements had been made, and the whole course and tenor of the nation's thought and attitude toward the question had apparently built an impregnable bulwark about the treaty itself, as it had consecrated the principles for which it stood. Whenever the Clayton-Bulwer treaty shall be attacked, another diplomatic vietory will be given to British statesmen, and another defeat scored at home. The treaty is not void, and camot be avoided upon purely legal ground.

If the conviction which has apparently seized upon the public mind that full American control of any Central American canal is necessary to the safety and welfare of the United States, and must be a condition of any waterway to be constructed, and if this conviction persists, the time will soon come when the United States will feel itself justified in adopting the only rational plan for dissolving the obligations of the Clayton-Bulwer treaty. 'That plan is, - boldly to proclaim its abrogation and take the consequences of a breach of faith, whatever those consequences may prove to be. One way short of so radical a procedure would be to offer to Great Britain some manner of compensation for the relinquishment of her rights under the treaty. But the assumption should not be made that the United States is so great a sufferer under the provisions of that treaty. The subject will be discussed under the title "Neutralization of the Canal." 
The results of the Blaine-Frelinghuysen-Granville controversy greatly displeased the executive: it was mosatisfactory to Congress; it was regurder as a humiliating deleat by the country at large. The conviction was general in Washington that the United States had been duped in 1850, and had been afterward sednced into the damaging admissions, which now arose like ghosts, to frighten the nation into the olservanee of a self-sacriticing compact. Many believed it to be an exaggerated sense of virtue that bonul the nation to the fulfilment of those agreements. Tethnicilly, perhalps, it was thought, Great Britain's position in belize was justified; but honestly, as the hmman heart appreciates the worl, it was not; Granville's arguments did not seem to ring quite true.

But especially discontented with the onteome of this correspondence was a numeroms group) of ('ongressmen, who persistently asserted that the salration of the Lnited states depended upon the immediate eonstruction of an isthmian canal that should be entirely American in every particulats. President Arthur himself had been of this opinion, and he at once entered upon the task of putting his enrictions into execution, notwithstandung the unfarouble outcome of the recent diplomatic encomber with (ireat Britain. Ilaving convinced himself that the Panama Canal (then in process of construction) eould never eome under the full American control, which he felt to be a neressary conclition to his country's safety, he determinerl that the Lnited States shomb construet a canal of its own in Nicallatgra. Mr. Frelinghuysen prepared the way by conchuling a new treaty with Señor Zavala, Speetal Euroy from Nicalragra (18st).

This treaty was male in total discegatrd of the romsen-

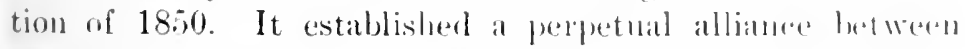

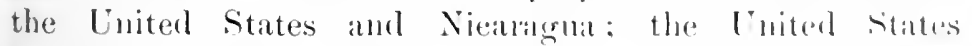
should constluct a canal and thron maintain an axolnsive control over it. A strip of territory 11 mon cither sille of the ronte was transferred to the Uniterl States in fee simple. 
Nicaragua's territorial integrity was guaranteed, and the Inited States placed itself in the position of protector of the smaller republic.

It may readily be surmised that the ratification of this treaty would certainly have reopened the Clayton-Bulwer controversy. It would necessarily have provoked a contest between the Monroe Doctrine and the treaty obligations of the United States. The Senate, however, was unwilling to incur the risk of such a debate, and a vote of thirty-two yeas to twenty-three nays left the treaty unconfirmed. A reconsideration was then ordered, and the matter, still unsettled, continued over into the cleveland administration.

The new Democratic President entered his office with ideas on this question differing radically from those of his predecessor, or rather from those of his last four predecessors. In his first message of December 8, 1885, Mr. Cleveland took occasion to make pullic these views. Referring to the Frelinghuysen-Zavala treaty, which he had previously withdrawn from the Senate, he said:-

My immediate predecessor caused to be negotiated with Nicaragua a treaty for the construction, by and at the sole cost of the United States, of a canal through Nicaragna territory, and laid it before the senate. Pending the action of that body thereon, I withlrew the treaty for re-examination. Attentive consideration of its provisions leads me to withhold it from re-sulmission to the Senate.

Maintaining, as I do, the tenets of a line of precelents from Washington's day, which proscribe entangling alliances with foreign States, I do not faror a policy of acquisition of new and distant territory or the incorporition of remote interests with our own.

I am mable to recomment propositions involving paramount mivileges of ownership or right ontside of our own territory, when roupled with absolute and mlimited engagements to defend the territorial interrity of the State where such interests he. While the general project of connecting the two oceans by means of a canal is to be encouraged, I am of opinion that any selieme to that end to be considered with lavor shomld be free from the features alluded to. . . 
Whatever highway may he constructed across the barrier dividing the two greatest maritime areas of the world must he for the world's benetit - a trust for mankind, to be removed from the clance of domination by any single power, nor become a point of invitation for hostilities or a prize for warlike ambition. In engagement combining the constrution, ownership, and operation of such a work ly this government, with an offensive and defensive alliance for its protection, with the foreign state whose responsibilities and rights we would share is, in my julgment, 1uronsistent with such dedication to miversal and neutral use, and would, moreover, entail measures for its realization heyoul the scope of our national polity or present means.

The lapse of rears has abumlantly confirmed the wisctom anct foresight of those earlier Administrations which. long before the conditions of maritime interconse were changed and enlared by the progress of the age, proctaimed the vital need of interocennie transit across the American Isthmus and consectated it in anvance to the common use of mankind, by their positive declarations and throngh the formal obligation of treaties. Towarl such realization, the eftorts of my Administration will be applied, ever bearing in mind the principles on which it must rest, and which were declared in no uncertain tones by Mr. Cass, who, while Secretary of state, in 1sis, ammomerei that "what the United States want in Central America, next to the happuness of its people, is the security and nentality of the interoceanic rontes which lead through it."

The attitude of the executive throughout both of $M \mathrm{r}$. Cleveland's administrations served to eheck the attempts to repudiate the ('laytom-Bulwer treaty which were demanderl from influential sources; indeed, the earnest efforts of $\mathrm{Ml}$. Blaine and Mr. Frelingluysen to abrogate that eonvention have never since been revived, althongh the clayton-Bulwer treaty has never ceaserl to be reginded in other than a most unfavorable light. On two oceasions, indeed, since 1888, the provisions of the treaty have been invoked in such a minner as to indicate onr renewerl adherence to it.

It will be reealled that ly the treaty of Managua, between

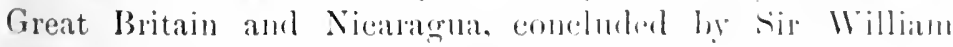
Ouseley in 1860, the former albundoned her protectorate oser Mosquitia - that strip of territory lying along the sulf contst 
of Nicaragua. By the terms of this instrument, Nicaragua had guaranteed to pay a certain indemnity to the Mosquito Indians. Probably inspired by the hope that the United States would support her against any British quarrel she might stumble into, Nicaragua persistently refused to pay the promised yearly stipend to the Indians; the latter clamored for their pay, and called upon Great Britain to enforce her treaty rights. Aeeordingly, in 1880, a demand to this end was made upon Nicaragua; but in consequence of the latter's continued refusal to abide by the terms of her contract, the matter in dispute between the two nations was submitted to the Emperor of Austria for arbitration. At first the administration felt that the United States had been slighted, and that the Monroe Doctrine had been violated as well. It appeared to be a clear case of "foreign interference" on the Western continent; but for several reasons the President believed an American protest would be ill advised. Great Britain was elearly acting within her own rights as a party to a treaty, and the United States had fully approved of the convention when first concluded (Buchanan Message, 1860 ). Although a foreign tribunal of arbitration threatened the renewal of British claims in Mosquitia, there was simply no help for it, except in the use of force. As apprehended, the arbitration proceedings ( July, 1881) resulted in the reëstablishment of the English protectorate over the Mosquito reservation; but consolation was sought by the Senate in reaffirming the prineiples of the Monroe Doetrine. The episode called forth no direct piotest from either Mr. Blaine or Mr. Frelinghuysen.

The commercial and moral effect of the restoration of British influence carying enlightened Anglo-saxon rule along the Mosquito shore, was almost magical. Immigration set in, business revived, and the dilapidated village of Bluefields became a commercial centre where British and American capital sought investment. A large fruit trade was opened with New ()rleans, and American capital began the exploitation of Mosquito resourees upon a eomparatively large scale. 'This rapid development of Mosquitia operated adversely to 
Nicaragua's prospects in the race for wealth. Jealousics soon arose, and Niearagua appealed to the Enited states to protect her in her efforts to regain control of the Indian reservation. Acts were committed by Nitaraguan officials in contempt of Mosquito and English authority at Blnefields and elsewhere within the limits of the reservation. A crisis was reached in 1888, whieh renewed the old controversy, in which the United States again reprimander Great Britain for violation of the Clayton-Bulwer treaty. Mr. Bayard, the Secretary of State, opened the new diplomatic skimish by a shap remonstrance. His letter of November 29. 1889, to Mr. Phelps, American Minister at London, took the position that a continuance of the protectorate of Great Britian orer the Mosquito territory would be regarded by the Lniterl States as conflieting with the provisions of the Clayton-Bulwer treaty. He maintained that Great Britain was using her Managna treaty as a mere cloak to slield her in the eontinued exprcise of sovereignty along the Central American eoast: that the United States, being no party to the Austrian arbitration poceedings, was not bound nor committed to an artmission of British right of interference between Nicaragua and the Indians within her borders; he therefore insisted that the United States was free to oppose a British proteetorate in Central America, as being wholly inconsistent with her general views and political policy.

Mr. Bayard's appeal was to the Monroe Doctrine quite ats muel as to the clayton-Bulwer treaty; but his somewhat elaborate argument had the fatal weakness of many $\Lambda$ merican state papers - the presentation of a political theory or policy againsi generally aceepted tonets of intermational law. Whatever objections the Lnited sitates might interpose to British actions, they were remeleed mugatory by the simple fart that Great Britain was acting consistently within the limits of at treaty which the Lnited States herself loul salletioned; and finally, she was clearly justilied under the award of a tribmal assented to by Nicaragua.

Lord Salistury replied to Mr. Bayard some months later (March 7, 1889). He denied any English claim of sovereignty 
over the Mosquito Indians, and asked only for the Nicaraguan observance of the Managua treaty to offer Great Britain the opportunity she desired to withdraw from the affairs of the Indian reservation.

For some years Mosquitia continued to prosper under British rule. The increasing number of American inmigrants to Bluefields contributed a decided American flavor to Mosquito polities. Although British influence remained paramount, this fact was mole than ever manifested in $\mathbf{1 8 9 2}$, when the Mosquito authorities placed a duty upon importations received at Bluefields in excess of speeified rates previonsly fixed by treaty between Nicaragua and the United States, - Niearagua having beeome unable to abide by her tariff pledges to the United States, as her own sovereignty along the coast had been entirely suspended. The Mosquito tariff act presented an auspicious occasion to Nicaragua to reopen the old eontroversy with Great Britain; a correspondence ensued, in which the United States was necessarily soon involved. In a letter to the American Minister in London, the Secretary of State, Mr. Foster, declared with great emphasis, that Nicaragua sovereignty over Mosquitia had not been impaired; her concessions to Great Britain being, in their nature, tribal and not territorial. "A supposititions Mosquitia is not to be arbitrarily substituted for the territory allotted to and reserved for the residenee of the Mosquito Indians by the sovereign." "The United States emmot look with favor upon any attempt, however indirect, on the part of Great Britain to render illusory the sovereignty of the Republic of Nicaragua over the Mosquito Indians and the territory reserved for their dwelling." $\quad \Lambda$ lengthy discussion might have resulted, which would no doubt have brought forth much learning upon the subject of suzerain rights, had not more stirring events in Mosquitia suddenly diverted attention, from acarlemic debates between London and Washington, to the consideration of an immediate military interference on the spot. In the usual course of C'entral American history, Nicaragua and I Honduras, along with most of the adjoining states, beeane involved in war. 
Mosquitia remained neutral, whieh in the estimation of Nicaragua, claiming sovereignty over the reservation, was nothing less than disloyalty. Aeeordingly Nicaraguan troops swept into the reservation, seized and ocenpied linefields (February, 1894) against the combined protests of the native Indian Chief, Clarence, and his political supporter, the British Consul. The L. S. S. Kenrstrge was weeked while hastening to the scene; but upon the arrival of a British war vessel, and the landing of marines, the Nicaragnan troops retired, leaving, however, a Nicaragun commissinner in the hands of the foreigners at Bluefields. This sudden flurry at arms had a sobering offect upon the English anthorities, who, sinee the Anstrian anbitration, had been inclined to disregard in toto Nicaraguan elaims to sovereignty over Mosquitia. The Nicaraguan commissioner was therefore areeptert ats a factor in a new provisional govermment formed for Mosquitia. The infusion of the Nitaragnan element into the governmental affairs of the reservation soon brought disonteut among the foreigners, which resulted in a nocturnal "mup détat overthrowing the provisional government and anain placing Chief Clarence in control. In consequence of this, Niearaguan troops soon appeared near. Bhnefields, in fighting array, and demanded the restoration of the Niearaguan authorities.

Such was the crisis when the Uniter States fully awoke to the importance of events taking plate in central Aneriea. Explanations were demanded: the ('layton-Bulwer treaty was carefully reread at the State Department: American citiz sus in Bluefields were cantionerl to take no part in acts violating Nicaraguan sovereignty in Mosquitia, and Great Britain was asked to withelraw her troops. England yielderl, the manines departed, and a deplonable eondition of political confusion resulted in Mosquitia. A resumption of Nicalagnan sovereignty in Bluefields, with its attemlint abnses and extor-

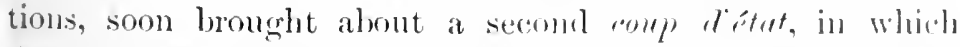
American, English, and Indians all combined to cast ont the intolerable rule of Nicaragna. The Inited states was thus placed in the awkward position of favoring the lecritinate 
rule of Nicaragua over Mosquitia, which the business interests of American citizens there resident had twice prompted them to overthrow.

The Indian (hief (Clarence) was scarcely established in office, with a "council of state" of American and British eitizens to aid him in directing the affair's of Mosquitia, when the Nicaraguan army again appeared. England having already abaudoned hope for the fulfilment of her Mosquito projects, held aloof. The United States, to be consistent, encouraged Nicaragua. Blnefields was taken, Clarence fled to Jamaica, all American and British subjects including the British ('onsul, who were suspected of complicity in the last Mosquito uprising, were seized, and witl scarcely a pretence of trial, were summarily banished.

Through the exercise of an musual amount of tact by the United States authorities, Nicaragua relented, and pardoned the exiles, many of whom retmrned to Bluefields to resume their former occupations; but further efforts to maintain a Mosquito nation were seen by all parties to be useless, and in November, 1894, the Indians voluntarily deelared for incorporation into Nicaragua. "Mosquitia" became the Nicaragnan state of " Zelaya," with which change the last remnant of Great Britain's grasp upon it faded.

England's demand for indemnity growing out of the banishment of her Consul, Mr. Hatch, resulted in the seizure of the Nicaraguan port of Corinto (April, 1895). The event cansed some excitement in the United States, but it marked the final episode of British interference in Nicaragua. The claim was paid, and the British warships sailed away, leaving behind, for the first time in a century, no shadow of English anthority in Nicaragna.

since 1895 a number of American eitizens lave continued under Nicaraguan anthority to live and do business in Bluefields; lut frequent signs of their irritation lave come to the surface, inclieating their disrespect for a governmental system that thrives upon revolution and permits many deeds of injustice muder excuse of military necessity. Could Great Britain be induced to sanetion the abrogation of the Clayton-Bulwer 
treaty and free the United States from the ban of territorial expansion in Central America, it is probable that, sooner or later, $a$ fourtlı coup a' étut in Bluefields might transfer the State of Zelaya to the United States. Such a consummation would be pleasing to those members of Congress who faror the inmediate construction of the proposed canal as a national undertaking.

\section{VI}

As already noted, the views of President Cleveland, touching the political status of the Central American (anal, being more in accord with those entertained by the comntry previous to 1870 , precluded the possibility of any definite action looking to the abrogation of the Clayton-Bnkwer treaty under his arministrations. From 1885 to 1889 and from 1893 to 1897 no renewal of Mr. Blaine's and Mr. Frelinghuysen's efforts in that direction were undertaken, notwithstanling the fact that the treaty received several denunciations in Congress, and public opinion throughout the country was becoming more and more fixed against the toleration of foreign influence in the management of the canal.

President Mckinley at first gave to the public no hint of his own position in the matter; but in his second annual message (December 1898), moved by the new conditions which had arisen within the short space of a year, he recorded himself a champion of the doctrine of an "American ('anal." Ile siad in reference to the Nicaragnan ('amal:- "T'he construction of such a maritime highway is now more than ever indispensable to that intimate and rearly intereommmication between our Eastern and Western seaboards demanderl hy the annexing of the Hawaiian Islands and the prospective expansion of our influence and commerce in the l'ateific, and that our national policy now more imperatively than ever calls for its control by this govermment, are propositions which I doubt not the Congress will duly appreeiate and wisely alot upon."

Thus Presirlent Mchinley time to entorse the ultra-American principle of the political status of a central American 
canal as supported by Presidents Hayes, Garfield, Arthur, and Harrison. The position of the executive was coneurred in by Congress, and approved by the country at large.

Events growing out of the Spanish War went far to convince a conservative minority, who doubted the wisdom or expediency of abrogating the Clayton-Bulwer treaty, that they had probably erred in judgment. The long voyage of the Oregon from San Francisco to Santiago, at a time of national peril, furnished the only proof still lacking to demonstrate the necessity of a canal connecting the oceans which should be under the military protection of the United States Govermment. The expansion policy of the United States in the West Indies, and the acquisition of a Pacific empire with its promises of trade and of a greatly enlarged American merchant marine, further stimulated the desire of the country for a ship canal under American eontrol. Shipping subsidies were uncler discussion in the Senate; a greatly increased navy was called for to protect distant possessions; new and unlooked-for conditions suddenly transformed the nation into an alert and aggressive power. With these ehanges of national sentiment, public interest became more than ever aroused in the completion of the Nicaraguan Canal. Unanimous conmittee rejorts in both houses of Congress favored prompt eonstruction by the United States Government; a growing disposition in Congress manifested itself for the acquisition of a strip of Nicaraguan and Costa Riean territory, in order that the canal might lie wholly within American soil. Resolutions of Congress again deelared the ClaytonBulwer treaty to be void. The press was musparing in its attacks upon the old eompact, and never before had all parties so persistently clamored for the immediate undertaking of the work upon a national basis, although in defance of treaty obligations.

In Jammary, 1900, a rumor became eurrent that negotiations were in progress to conclude a new treaty with Great Britain relative to the ship canal. Knowing the sentiments of the administration on the subject, the proponents and friends of the canal rejoiced in the prospect of final delivery from the 
diplomatic entanglements which for fifty years had prevented the realization of their hopes. The preple at list concluded that the Clayton-Bulwer treaty was to be abandoned. I (onngratulatory tone pervaded the puesis comments, while the appearance of the new treaty was eargerly awaited. Surmises were rife that Great Britain, having encomntered evil fortune in South Afriea, and being in danger of Enropean intervention, had consented to withdraw her ('entral American pretensions for the salke of assured American frienchlip. It was also suspected that in order to hmmor ('anada, England might ask of the Lnited States concessions in Alaska, am give in retmm all that was demanted relative to the eamal. On February 5, the Hay-Panneefote Convention was signed, sent to the Senate, read and immediately refered to the Committee on Foreign Relations. It was entitled, " I ('onvention letween the United States and Great Britain to Faldilate the Construction of a Slip (anal to Comnect the Atlantic and I'acitic Oceans, and to Remove any Objection which Might lrise ont of the Convention ('ommonly (alled the Clayton-linlwer Treaty." The agreement called for the construction of the canal under the auspices of the Enited States (ioverument, to be done at its own expense and to carry with it the enjoyment of all the rights ineident to such onstruction. The " General Principles" of neutralization as establisher in the righth article of the Clayton-linlwer treaty were to be preserved, and to that purpose a set of rules analogors to those enortained in the Constantinople treaty (October 20.1888) were adopted. These rules called for-(a) frecolom of transit in times of war or peace to all vessels of all nations: (b) a freedom from blockade; (c) a corle of procerlure for war vesseds entering and leaving the canal; (d) no fortilioations along the route. The high contrating parties shomk call upon the other powers to unite with them in grmantering nentrality of the camal.

When the text of the convention was made prublic a few days later, it be wildered the ermutry. Those who combrowl the principles of nentralization, for which the new treaty itood, were amazed, because the administrition had alrealy 
pledged itself to quite the opposite theory in reference to the canal. All others who read the words of the treaty were no less disappointed than astonished. The Clayton-Bulwer treaty was not abrogated in the instrument, as they thought would be the case; on the contrary, its principles were reaffirmed. The new agreement did not abandon the old; it supplemented and enlarged upon it. Those features of the old convention relating to the neutralization of a canal, which had been denounced for so many years as objectionable, were emphasized and perpeturted in the new instrument. 'The disabilities placed upon the United States by the old convention, in the matter of acquisition of Central American territory, not being expressly removed, were, in consequence, recognized by the new. And finally and above all other considerations, the despised Clayton-Bulwer treaty was acknowledged to be binding and in force, - creating thereby a new and effective estoppel to future efforts seeking British consent to its abrogation.

In the committee-room the following amendment to the treaty was appended to the instrument by Senator Davis:-

It is agreed, however, that none of the immediately foregoing conditions and stipnlations in sections, Nos. 1, 2, 3, 4, 5, of this article, shall apply to measures which the United States may find it necessary to take, for securing by its own forces the defense of the United states and the maintenance of public order.

This amendatory clause was based upon a provision in the Constantinople treaty of 1888 tonching the neutralization of the Snez Canal, and was meant by Senator Davis to supply an omission which had occurred through "oversight" of the negotiators. It will be seen that the Davis amendment at once mobed the instrument of its main purpose - the neutralization of the route, - and, if adopted, would virtually nullify the treaty.

The appearance of the Iny-P'anncefote agreement brought the subject of neutralization of the canal to a final and definite issme, and its acceptance or rejection by the Senate would indicate the course the United States must finally adopt. 'The altermatives were: - 
(1) A canal neutralized to the use of the worlil's eommerce by a joint guarantee of all nations, and

(2) A national waterway belonging to the Lnited states, and over which it exereises full control.

The sudden presentation of this issue in so positive a form brought forth many virulent criticisms by the more ratical advocates of American exclusiveness in a canal policy. 'The apparent change in the President's sentiments from 1898 to 1900 on the subjeet of canal equalization gave to the opponents of the Ilay-Pauncefote treaty the hamlle of a whip wherewith to flay the administration. It was inevitable that the "canal question" should develop" a political aspect, and before the close of the session it hegan to aceommolite itself to party needs. The Republiean supporters of the President were openly acensed of seeking to perpetmate a vicious anti-American compact. Railroal interests, the Trusts, and a snobbish catering to British polieies were alleged as the causes. In the House, the Ilephum bill, which wholly ignored the C'layton-Bulwer treaty, and was in direct opposition to the principles of the agreement awaiting confirmation in the Senate. was passed by at large majority of votes to the discredit of Americun methods of negotiation with foreign nations.

The 1st Session of the 51st congress came to a hurricd adjournment in early Jume withont lating ratified the Hay-Pauncefote treaty or even having acterl upon the I aris amendment; and the matter was postponed to the following December. On aceomst of the dehy, the period for ratification of the treaty wats extender by mutual argeement to March 4, 1901.

Both party platforms, arlopterl in the National ('onventions immerliately after the arljommment of Congress, contorsed the policy of absolute and exclusive Ameriean eontrol of the eanal. The aceeptanes of such a llank in the liepululiean

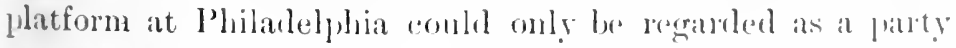
expression of disapproval of the position assument hy the executive towarl a nentralized waterway commerting the oceans. This protest from the party, which had been presmm- 
ably won over to a neutral canal, and which was supposedly backing the ratification of the treaty, greatly lessened its chances for adoption by the Senate the following session.

An unusual degree of interest in canal legislation was manifested at the opening of Congress on December 4, 1900. Two important events were looked forward to, - the appearance of the canal commission's report' ${ }^{1}$ and an early vote upon the Hay-Panncefote treaty. The preliminary report of the Isthmian Canal Commission was submitted to Congress with the President's message. It contained in a condensed form the onteome of one and a half years' exhaustive study of all the possible canal routes across Central America. The advantages or disadvantages of these various routes were considered from their physical, political, and strategic points of view. The probable costs of construction were estimated, and the location of each possible route with reference to full and complete ownership by the United States was investigated.

Basing their calculations upon the statisties of entrances and clearunces at European, North and South American ports, the commission came to the conclusion that the freight tomnage passing through the canal would be suffieient to warrant its commercial suceess. To meet the requirements of molem sea-going vessels, in view of their constantly increasing size, the report recommended a greater depth and width of channel than ever before proposed. The uniform low water depth of 35 feet, with a bottom width of 150 feet, together with a double system of locks, furnished a more extravagunt basis for estimates of cost than had ever before been eomsidered.

Abandoning all other routes as impracticable, the commission found the probable cost of the Nicaragua and I'anama canals each to be about $\$ 200,000,000$. In the ease of the latter, the estimated cost of completion was placed at $\$ 142,342,579$, but this :momnt, added to the sum required to buy ont the French company alrearly in the field, would make the final cost of the two mutes abont equal.

1 For creation of this commission, see page 94. 
A careful comparison of the advantages offered by these two waterways led the commission into a close examination of the rights and privileges owned under franchises by the various canal eompanies interested in Central America. All such franchises of course stood directly in the way of the government undertaking the construction as a national project. The report concludes as follows : -

"1. 'The estimated cost of building the Nicaragua Canal is about $\$ 58,000,000$ more than that of eompleting the l'anama Canal, leaving ont the cost of acquiring the latter property. This measures the difference in the magnitude of the obstacles to be overeome in the acutal construction of the two canals, and covers all physical considerations, stteh as the greater or less height of dams, the greater of less depth of cuts, the presence or absence of natural harbors, the presence or absence of a railroad, the exemption from or liability to disease, and the amount of work remaining to be done.

"The New Pamama Canal Company has shown no disposition to sell its property to the United States. Should that company be able and willing to sell, there is reason to believe that the price would not be such as would make the total cost to the United States less than that of the Nicaragua Canal.

"2. The Panama Canal, after eompletion, would be shorter, have fewer locks and less eurvature than the Nicalagui Canal. The measure of these alvintages is the time required for a ressel to pass through, which is estimaterl for an average ship at twelre hours for l'anama and thirty-thice hours for Nicaragua.

"On the other hand, the distance from San Franciseo to New York is :377 miles, to New Orleams 579 miles, and to

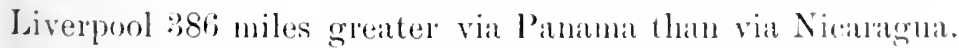
'The time required to pass over these distances being greater than the difference in the time of transit thomgl the canals, the Niearagua line, after completion, wotald be somewhat the more anvantageous of the two to the Uniter States, notwithstanding the greater cost of maintaining the longer canal. 
"3. The Govermment of Colombia, in which lies the Panama Canal, has granted an exclusive concession, which still has many years to run. It is not free to grant the necessary rights to the Lnited States, exeept upon condition that an agreement be reached with the New Panama Canal Company. The commission believes that such agreement is impracticable. So far as can be ascertained, the company is not willing to sell its franchise, but it will allow the United States to become the owner of part of its stock. The commission considers such an arrangement inadmissible.

"The Governments of Nicaragua and Costa Rica, on the other hand, are untrammelled by concessions and are free to grant to the United States such privileges as may be mutually agreed upon."

And the report in conclusion says:-

"In view of all the facts, and particularly in view of all the difficulties of obtaining the necessary rights, privileges, and franchises on the Panama route, and assuming that Niearagua and Costa Rica reeognize the value of the canal to themselves, and are prepared to grant concessions on terms which are reasonalble and acceptal,le to the United States, the commission is of the opinion that 'the most practicable and feasible route for' an isthmian eanal to be 'under the control, management, and ownership of the United States' is that known as the Nicaragua route."

The report, being so thoronghly in aecord with the established American preference for the Nicaragua route, gave great satisfaction. The charater and ability of the commissioner's and the thoroughness of their investigations have no doubt settled for all time the choice of routes. The field is clear in Nicaragua, the eoncessionary companies have been disposed of, and, with abundant means in the 'lreasury and popular favor to hasten the eonsummation of the project, there remains but one obstacle to postpone or clefeat the undertaking. 'That obstacle is the C'ayton-Bulwer treaty. Soon after the eonvening of Congress in December 1900 , 
the Hay-Pauncefote treaty was called up for consideration, and for some diys the Senate in executive session consiclered the adoption of the Davis amentment, along with numerous other amendatory clauses offered hy various senators. The Davis amendment was agreed to on I)ecember 1:3 (65 to 17), - a clause which, as already shown (1) 170), completely transformed the eharacter and purpose of the treaty. On December 20, two additional anendments presented by Senator Foraker were adopted. (Ine of these eonsister of the insertion of the words "which convention is hereby" superseded," just after the words " ('layton-Bulwer Convention," in the seend article of the instrument. The seetonr amendment provided for striking ont the entire thind artiele of the convention, which abandoned article had called n]on the parties to bring the convention to the notice of the other powers, and to invite them to arluere to it.

The ratifieation of the treaty so amended by the Senate took place the same day (December 20, 1500), and the instrument was immediately returned to the President for delivery to Lord Pauncefote.

As the treaty now stands, it is virtually a compunise between absolute nentralization and complete American control. It provides for the construction of the route als a purely American project under the anspices of the government, and gives to the government full management of the waterway, the fixing of tolls, etc. The "nentralization" of the ronte is then effected, so far as the two powers concerned are able to guarantee its neutralization. It shall be olen in time of war as in time of peace to all vessels of all nations, without discrimination, save when there is war against the I'nited States; then the Lnited States may take such measures ats it may find neessary to proteet itself, even to the chlosing of the canal against the vessel:; of the enrmy. 'This reservation of conrse defeats the absolute nentrality of the romte, and the denial of the rights of the other great powers to ariplesate in such a guarantee also removes the eitual from the (diss of nentralized waters. Should Great Britain decile to datify the treaty as already accepted by the Senate, the status of the 
Nicaragua Canal would be that of a private waterway, with provisons, however, relating to its control, which give to it the semblance of a neutralized channel.

\section{VII}

The "Canal question" involves three sets of problems, all of which call for definite solution before the actual work of excavation shall begin. These problems relate, first, to the physical features of the undertaking and its cost; second, to its commercial aspects and probable value to the United States; and third, to the political status of the waterway - in other words, shall it be controlled by the United States alone, or shall it be neutralized ly common consent of all nations? These three questions are of paramount importance.

1. To the first of these questions (the engineering features and cost), much attention has aheady been given. It may be assumed that reasonably correct estimates have been made by the United States Government through the exhaustive researches of its recently appointed scientific commissions. The civil engineer and the geologist are enabled to base their calculations upon actual facts ; with the utmost precision they have measured the amount of earth to be renoved; they have aseertained the hardness of rock to be encountered, and have probed the underlying strata to great depths with a view of obtaining a perfect knowledge of their character. The water-levels of the lakes and river's have been accurately measured, and the most advantageous sites for dams and locks have been located. 'The harbors have been sounded, and their approaches most carefully studied. From the engineer's standpoint, then, the problem has already been solved. The conclusions are defmite, and the Nicaraguan Canal is beyond all douth a pliysical possibility.

In so far as it is possible to compute the cost of so gigantic an enterprise, this has also been calculated. It is true that these estimates vary, yet their differences are not discomagingly great. The most expensive of them all in no way

${ }^{1}$ Great Britain declined to accept the treaty as amended. 
removes the undertaking from the limits of a financial possibility. The last phase of the problem eomnected with the physical aspects of canal eonstruction relates to the choice of routes. This has been narrowed down to Panama and Nicaragua. It was the ehief ohject of the last isthmian connmission, which has already submitted its preliminary report, to make a final seleetion. American preference has so long inclined toward the completion of the latter route. that the adoption of the other is extremely unlikely; howerer, in case of any future change of sentiment to Panama, the physical features of that route have been as thoroughly investigated, and its feasibility equally demonstrated.

2. The seeond elass of considerations involves the commereial aspects of the proposed ronte, - Will it pay" This feature of the canal question has perhaps been too little considered. The people of the United States have been rather inclined to assume that so splendid a trimmpli of engineering seienee must surely receive the reward of commereial success; and for proof of this, the satisfactory earnings of the Suez Canal have been offered in evidence. The contemplation of huge enterprises affeets the mind somewhat after the manner of wine, and eare should be taken lest the splendor of achievement shall dim the jurlgment. It must be borne in mind that ships follow the shortest and hest routes, and that freight seeks the cheapest highways. It shoukd be noted thit the Nicaraguan ('mal does not fmmish the shortest ronte from New York to the Philippines, nor from the ports of ('hinat and the East Indies to London or New York: the fact must also be eonsidered that the sinez route offers greater inducements to steam vesisels in the way of coaling stations and shorter lapss between ports.

Again, the five competing railionl systems ancoss tle continent of North Ameriea have so rerlacerl the freight rates in the last fifteen years that assertion has been frequently malle. if not thoronghly proved, that any all-water ronte fom the Pacific to the Atlantic coasts camot compere with the allrail routes. The products of the l'acific slope whirh womld have to be shipped first by rail to the coast and then trans- 
shipped to a vessel, might be enabled to reach their Atlantic destination at less cost by the all-rail journey. Indeed, when railroads have come into direct competition with water rontes, the latter have often declined in commercial importance. The canal and river systems of the United States, once the commercial highways of the nation, have, in many instances, become virtually abandoned in the presence of competing railways.

On the other hand, there is a great unknown quantity of trade that may be promoted ly this "marriage of the oceans." With the Suez isthmus aheady pierced, there remains but the breaking of the Central American barrier to complete an open road to vessels around the world in a comparatively straight course. How far the realization of this prospect, so pleasing to the imagination, is likely to prove commercially successful, should be the subject of thorough, accurate, and scientific investigation. An original outlay of two hundred millions is too great a sum to be hazarded withont at least a fair promise of return, - a return that is susceptible of demonstration by better evidence than mere conjecture or sentiment.

The commercial aspect of the question is somewhat neutralized, if not overshadowed, by military considerations. If the canal is necessary for national defence, its probable success or failure, as a commercial venture, is of little relative importance. The original cost and the yearly outlay thereafter would be charged to the legitimate expense columm. Ilowever, estimates of the strategie value of the canal to the United States involve inquiries which come more fittingly under the third class of considerations relative to the "Canal problem."

3. With the physical elements of the problem removed, and the practicability of the molertaking determined, there still remain problems of utmost importance to be solved before connecting the oceans. These considerations are of a fulitical natme. What shall be the legal status of the canal when constructed? Shall it be open, like the high seas, to the world's commerce? Shall it be neutralized by common lledge of all nations, or shall it be regarded as a private waterway belonging to the United States? 
Whenever the work is actually begun, this question will necessarily become vital: indeed, it has already become so. It eamot be evaded. The commercial powers of the world are too alert to permit their trade interests to be jeopardized. and these interests must be reckoned with. To avoid all future complications in this respect, the political status of the canal should be determined in advance.

One of the following plans must be adopted :-

1. Exchusive American political control.

2. An "understanding" with Great Britain to divile the responsibility of maintaining the wnal and securing its nemtrality.

3. A treaty or arrangenent with the great commeroial nations of the world whereby the absolute nentrality of the eanal shall he guaranteed to all ships of trarle or war.

The second of these schemes may be eliminated from the list, for the advantages and disadvantages growing ont of dual control in such a waterway are practically identical with those of the first scheme - sole Ameriean control. 'This narrows the problem of the political character of the canal to the alternatives of exclusive American control or eomplete nentralization.

There is some confusion as to the true meaning of the word "neutralization." Statements are frequently met in the press, in party platforms, and in the declarations of Congress that the Nicaragua Canal should be a "nentral "waterwy, and open to all vessels of any flag, but that the Juited States should at the same time reserve to herself the right of elosing the canal in times of war against the vessels of an anemy. Again, it has been frequently asserterl in Washington that the United States is willing to "guamantee the neutrality" of the canal, but for reasons involving her own safety, she cammot consent to the participation of other nations in such guarantee. This position was taken by $\mathrm{Ml}$. Blaine in his anrespondenee with Lord Silistury in 1881, when he serimosly maintaned that there was no need of international soöperation to this end becanse the Cnited Sitates was herself willing and eompetent "positively and efficancinsly" to gutl- 
antee" such neutrality. In a vague sort of way this has ever since been the canal doctrine in the United States.

The reservation of any special privileges for American ships in time of war is considerably at variance with the idea of a neutral canal; and the belief in the sufficiency of American guarantee indicates a decided misconception of the meaning of "neutralization." Cuited States guarantee of neutrality really means nothing more than her promise to defend the open waterway against attack. No nation can give a guarantee against the attack of another; it can only pledge its resistance against such attack. No nation can "positively and efficaciously guarantee" neutrality, unless, indeed, it be sufficiently strong and powerful to enforce the guarantee, - even then it could not really give more than a promise to defend the canal route in case another sought to hold or destroy it.

Neutralization means an exemption from all warlike operations, and this condition can only be effected by an agreement of all parties to abstain from such warlike operations. It consists of that immunity from attack that can only be secured by general consent. "Nentralization is the assignment to a larticular territory or territorial water of such a quality of permanent neutrality in respect to all future wars as will protect it from foreign belligerent disturbance. This quality can only be impressed by the action of the great powers by whom civilized wars are waged, and by whose joint interposition such wars could be averted" (Whartou Digest, $§ 1+5$ ).

It thus becomes evident that if the United States is really sincere in its determination to accomplish the neutrality of the Central American ('anal, it defeats its own object by declining to accept international coöperation to that end for by that means only can nentralization be secured.

The "American Canal doctrine" of to-day, generally advocated, does not in reality contemplate neutralization. It promises merely to keep the canal open in times of peace; to rlefend it in times of war; and to close it against enemies of the country. 
With this understanding of the word "nentralization," (and it admits of no other interpretation) the issue is sharp and clear between an American-owned canal, eontrolled by the United States, and a neutralized canal as desired by the commereial nations of the world and called for by the Clayton-Bulwer treaty.

The question resolves itself into this, - sionld the Nicaragua or Panama Canal be neutralized?

Arguments for or against this proposition may spring from three sources, viz. :-

(a) International Law. Are there any legal duties imposed upon the Inited States as owner of a ship canal passing through the territory of another state, and comnecting two high seats, - in other works, is the Cnited States moler any legal obligation to accept the neutralization of such a anall?

(b) Precedents. Is the United States obliged by any precedents relating to ship anals in general, or to the Central American Canal in partieular. to mite with other nations in a joint guarantee of canal equalization?

"Precedents" as here used would naturally include all the treaties, agreements, or official deelarations of the Inited States which can be taken to indieate not only its intermational obligations but also national sentiments npon the subject.

(c) Self Interests. Do the hest interests of the Inited States require her monopoly of the central American Canal, or are they better subserved by a neutralized Central American canal?

International law does not throw direct light mpon this question, aud there is in eonsoquence much confusion among the various anthorities as to the status of a ship eanal in the domain of public law. It is only in companatively reeront years that the alvances of scienee have made possible the construction of great artificial chamels commecting aceans, and the very few such waterways aldeaty in rexistenter have not had suffecient time to establish for themsel res a legal code. 
The application to them of legal principles is indirect; they can only be made through the inore or less doubtful analogies of natural straits, arms of the sea, territorial waters, and the high seas. The value of such comparison is not always to be relied upon; but the general advance of liberal sentiments relative to the freedom of the seas, as developed in the progressive erolution of international ethics, is far more signifieant. This would indicate a decided tendency toward impressing an international character upon ship canals connecting open seas.

The protracted controversy concerning mare clausum and mare literum, which lasted for more than a hundred years, long since resulted in complete victory for the adherents of the latter doctrine. The high seas are free to all vessels, but natural straits eonnecting the high seas, when narrow, and lying within the territory of a single power, may or may not be entirely free, aceording to eircumstances. Their exact position in law has not yet been satisfactorily determined, though it may be conficlently asserted that the trend of modern usage is to withlold from nations, through whose territory such waterways pass, exclusive control over their navigation.

It is to-day generally agreed that bodies of water answering to the description of a strait ought to be free because they are in a greater or less degree necessary to navigation; and only snch limitations upon their full freedom of navigation are allowable as the seenrity of the state through which the strait passes seems to demand. When the interior waters of a state terminate at either end in the open sea, the resulting freelom of navigation in them, in times of war, might operate as a serious menace to the welfare of such state; hence it is that certain modifications of the free rights of navigation in such waters maty be made by special compact. Yet the fact is not altered that they do in a measure belong to the world's commeree. A sovereign may not debar alien vessels from innocently using sueh courses, and his own sovereignty over them has been practieally limited to the extent of collecting only such dues from passing vessels as 
may reimburse him for the expense of keeping the way lighted, buoyed, and properly charted. Inenmark no longer can colleet revenue from the somd dies she formerly exacted. Such is the ease in regard to the (int of Canso, the straits of Magellan, and, theoretically at least, to those at Cibraltar. The Dardanelles and the Bosphorus are anomalous, in that their navigation continues to be regulated entirely by treaty. These straits do not, however, conneet two open seas - the Black Sea being a boly of water "neutralized" by international agreement, and its free navigation being in some respects restricted; henee the Bosphorus and the I)ardantlles do not, strictly speaking. fall within the class of natural chamels connecting the high seas. In regard to artificial watelways commecting two open seas, a number of elements enter which would seem to remove them at once from the operation of international law, and to exelude them from the elass of natural waterways.

It has been asserted by high anthorities that an artificial canal, linking two open seas, and being also a navigable waterway, should therefore be open to the world; that it should be regarded as a part of the high seas, and that its freedom of use is a corollary to the rule governing the open oceans it comnects, it being a necessity to navigittion. A canal, therefore, beeomes a public way. like the arms of the sea, and should be regulated by the same laws that direct the world's shipping. On the other hand it hats been as freely asserted by equally good anthority, that the fact of an artificial chamnel not having been granted hy nature to the use of man, but being wholly the work of man himself, invests it with the eharater of private or national ownership. One cannot well aroid this condusion. To assert that a nation may not construct a watroway through its own territory withont eoncerling its free navigation, is to assert that a nation is not sovereign within its own limits. There is no public law that permits a nation to seod its armies across the territory of a neutral power, or in any manner to assume a right of transit ovel its domains. ('onvenient routes of overland transit, such as railways, are obviously 
under the protection and control of the sovereign power whose teritory they traverse. A great transcontinental railroad might be considered necessary to the world's commerce, yet no one would seek to invest such a route with an international character. Should the nations of Europe claim a voice in the management of our transcontinental railroads, we should at once resent the suggestion as an assumption wholly without reason or law. If railroads are subject only to the munieipal law, why should canals when substituted for roads become international in character? The approaches to a canal are a part of the territorial waters of a state, and the waters of the canal must necessarily be under the jurisdiction of the territory within which they lie.

Again, no ship canal necessarily involving great labor and cost of construction will ever likely be built by any one nation for philanthropic reasons, and the builders must of necessity have the right to levy tolls. If it were a natural waterway, no nation could derive profit in such a mamer; nor coukl a company of stockholder's frame a constitution for its government. There can be no rules or regulations conflicting with the freedom of ressels upon the high seas: therefore, if the waters of a canal are a part of the ligh seas there would naturally be no need of treaty regulations governing them.

Again, no nation or even combination of nations has the right to construct a ship canal through the territory of another without the latter's consent. This fact necessarily implies the right of a sovereign to construct a canal of his own, for he could not well transfer to another a right he himself does not possess. If he constructs a canal through his own territory, it would seemingly then belong to him, and not to the world at large: and if he transfers such a privilege to another, the latter should stand in the place of the seller.

In the municipal law, the government is anthorized, under certain restrictions, to condemn private property for the use of the state. International law has not reached in its development so advanced a state : ret it may reasonably be supposed that at some future time there will be an understanding 
between the great nations of the world, allowing them, under proper conditions, to condemn territory for the use and interests of the world in general. Such a canal conld offer no question as to its position in public law, for the element of private ownership would be entirely eliminated.

Reasoning on this subject is much confused, becanse a slip, canal, partaking of the nature of an arm of the sea and also of any artificial transit route through the territory of a state, admits of the conflieting arguments which a double analugy must ahways furnish. One is, however, enabled to maintain with fewer violations of reeognized legal principles that a canal built by a nation through its own territory and comnecting two open seas is not a public highway, meconditionally open to the world's use. It would be going too far to assert that when a nation at great expense comects two oceans by a channel within its own domain, it possesses 110 more right over its transit regulations than does the world in general.

Considering, then, the various attributes of ship canals, as compared with those of natural waterways, one is led to assume that if the Nicaragua ('anal shall be comstructed by the United States, it will not beeome "an arm of the seal ": and that the United States will not necessarily be deprived by international law of the superior rights of the builder and private owner.

If international law has not get fully extended its system over artifieial channels connecting open seas, commereial powers have already felt the need of sneth an alvance. Experience has partially, if not fully, lemonstrated the advisability of such control over ship eanals. and the tendeney therefore is to invest them with international ahilateder. 'This scems to call for some definite muderstanding on the suljoet among the various nations interested.

Although the qualities belonging to an antifirial waterwaty do not entitle the nations of the workh, as a right, to a volce in its control, yet for the silke of harmony, for the best interests of the builder, and in oreler bette: to serve thrse whose patronage is desired in the use of the chammel, it hals been 
found desirable to guarantee the safety and neutrality of the passage by treaty stipulations. The importance of a canal which will shorten by many hundreds of miles the usual commercial routes, is coming to be considered too great to be left to the control of any one nation. In the struggling competition of tracle, nations are indisposed to tolerate any handicap which tends to interfere with its equality. In time of war, it would beeome necessary for a belligerent to blockade or to hold against the enemy a point so important as a ship canal. Commeree would be interrupted, and the very object for which the canal was constructed would be defeated. It is natural. therefore, that mations have come to look upon ship canals as subjects of international regulation. Indeed, from the moment the construction of the Suez Canal was contemplaterl, this idea of international concert for its guarantee of neutrality was consilered a sine qua non of its finaneial success. Prince Metternich had declared that its suceess must depend upon contirlence in its neutrality, and De Lesseps himself fully appreciated, as he acknowledged, the truth of his statement. In the Act of Concession given by the Viceroy of Eigypt, and endorsed by the Sultan in 1856, a promise was solemnly made that "the Grand Maritime Canal from Suez to Pelusium and its dependent ports would be open forever, as neutral passages to all ships of commerce passing from one sea to the other, without any distinction, exclusion, or preference of persons or nationalities. . ." The mere promise of Egypt in 1856 (then, as now, under the suzerainty of the Sultan of Turkey) to maintain this status was regarded as inarlequate, and the principal nations of Europe, except Russia, signed a treaty in 1873, agreeing that the Suez Canal should be open to the warships of all parties to the agreement. Even this treaty was deemed insufficient to determine Clearly and positively the international character of the eanal; and in 1887 the ('onvention of Constantinople was signed by all the great European powers, again excepting Russia. This convention declared that the eanal shall forever be open and free, in time of war as well as in time of peace, to the ships of all nations. Its approaches shall never be block- 
aded; no act of war shall take plate upon it: and hostile ships leaving from either terminus must allow a period of twenty-four hours to elapse between departmes. No permanent fortifieations are permitted; no nation may mass its naval strength within the waters of the eamal nor land troops or material of war along its shores. When the neutrality of the canal is threatened, the Khedive or sultan may call upon the signatory powers for assistance. Turkey, in whose territory the eanal lies, is entitled to exercise sovereignty over it, but no contracting power ma enjoy any special advantages or privileges in it. All powers are invited to join in this comprehensive guaranty.

Although Russia has never been willing to join in the general European guaranty, her attitude was mate clear when, in the Turko-Russian War she assured the powers that she had no intention of threatening the neutrality of the canal, as she regarded that route as belonging to the world and sacred to its commerce.

It is safe therefore to conclude that international law of itself places no restrictions npon American control of a central Ameriean Canal; further inquiry, however. develops the fact that nations have come to look "pon interoceanic ship canals as a proper sulject for treaty stipulations. 'The powers could not as of right demand the nentralization of the ('antral American Canal; but they will surely expert the United states to admit it for the common interest of all.

This expectation is in accord with the general theories accepted by the United States mutil rerently. This is fully demonstrated by a long line of precedents. Indeed, the neutraization of the canal is the traditional policy of the United States. From 1825, when Mr. Clay declarred that the benefits of a trans-isthmian canal "onght not to be exrolusively appropriated to any one nation," mutil 1851, when $\mathrm{Ml}$. Blaine alvanced the opposite theory, American statesmen of all parties were intent on securing a passageway for ships across the isthmus, whose absolute freedom of transit should be secured by international guarantee. Every administration from that of President John Qnincy Alanms, to that of Presi- 
dent Grant, who first favored exelusiveness on the isthmus, has indorsed these broad theories favoring the international character of ship canals. Since the Grant administration, President Cleveland and President MeKinley have also supported this traditional American policy. During that period of heated controversy over the Clayton-Bulwer treaty from 1850 to 1860 , it was not the object of the United States to obtain exclusive proprietary rights in the canal. On the contrary, it was to the mantenance of the neutrality of the proposed route that American argument was wholly directed. From 1860 to 1880 the only concern manifested in respect to isthmian matters was lest Great Britain should violate her agreements by acquiring Central American territory, thereby threatening the nentrality of the route, and lest France might insist upon monopoly of control at Panama.

A glance at the history of the interoceanic transit problem in Central America reveals the fact that all nations interested in its solution, including the United States and the Central American states themselves, have inviriably insisted upon the strict neutrality of any Central American canal. This condition has at all times been demanded. In its treaties bearing upon this subject the United States has fully recognized this principle; and in its diplomatic correspondence relating thereto, it has so frequently reaffirmed these views that no confusion or doubt can exist as to its position. 'This is finally set forth in three canal treaties now in force; the Claytonlinlwer treaty with England, the Dickinson-Ayers treaty with Nicaragua, and the treaty with Colombia of 1846 . All previous United States treaties and all preliminary drafts of treatius with Central American states concerning a canal, kept in riew this principle of nentrality. In the Colombia treaty the Uniter States, by its 25 th article, "guarantees positively and effacionsly to New Gramada, by the present stipulation, the perfoct nentrality of the before-mentioned isthmus, with the view that the free transit from one to the other sea may not be interrupted or embarrassed in any future time while this treaty exists."

The I)ickinson-Ayer's treaty with Nicaragua (1867) in its 
fifteenth article declares that " The United States hereby agree to extend their protection to all such routes of communication as aforesaid, and to guarantee the neutrality and innoeent use of same. They also agree to employ their influence witl other nations to induce them to guarantee such neutrality and protection."

The Clayton-Bulwer treaty of 1850 recites that neither government will ever "obtain or maintain for itself any exclusive control over the said ship camal." The purport and aim of this instrument is to place a safeguard of guarunteed neutrality over any isthmian canal. After going to the length of asserting that neither power shall amnex central American territory, the two partics agree to ask all other nations to unite in similar engagements.

The change of sentiment in regard to neutralization, first officially championed by Messrs. Blaine and Frelingluysen, was not intended as a complete reversal of the former doctrine on the subject. This new American policy contemplated a guarantee of neutrality to be given by the United Sitates alone. As both these statesmen believed that an American guarantee was sufficient to that end, their views become rather a modification of the generally accepted theories of neutralization, as secured by concerted action of the powers. Both were entirely willing to pledge the United States " positively and efficaciously to guarantee," etc. They camnot therefore be said to have fully repurliated the ideals of a neutral passageway through the isthmus, although the methor they advocated to effect that end wonld have been inaleguate.

It is only within the past few years that arlvocates of an unqualifiedly American canal have enme forward. This ultra-American theory is exemplified by a llonse docment presented in Mareh 1900, loy Mr. Hepburn of Iowa, who argues in favor of a Nicaraguan (anial so controlled by the United States that discrininations against foreign vessels may be made even in times of peace.

An adherence to the principles of neutralization is also evidenced in the numerous charters and concessions which have been granted during the past twenty years to various 
American canal companies. In most of these instruments a neutral waterway is called for. Indeed, neither Nicaragua nor Colombia could grant the exclusive right to control a canal through her territory without violating treaty stipulations with European powers.

Thus it appears that the doctrine of canal neutralization is the traditional policy of the United States, as well as of Great Britain, the European nations, and the Central American states; that the doctrine changed in American diplomaey to neutralization as secured by American guarantee alone; and it further appears that the theory of sole control as opposed to nentralization is of comparatively recent origin.

To-day the idea seems to prevail that the geographieal position of the United States in eonnection with its commereial interests, its safety in time of war, its politieal relations with its neighbors, and lastly, its obligations to its commereial marine, all combine to warrant a disregard of precedent and to justify the demand for complete political control of the Central American eanal. In other words, Ameriean interests in the isthmian canal are so great that the United States camnot afford to be governed simply by precedent. In determining, therefore, the political attitude toward the projected camal, the elements of self-interest will no doubt figure far more prominently than considerations of preedent.

It is not unreasonable to assme that in the development of national needs and eonditions, eases may arise where it would be unwise to adhere to ancient customs merely for the silie of consistency. The mind is apt to eling, as by instinct, to the traditions of the past. Well-grounded precedents in law have often so effectually blinded the eyes to reason that a century of progress has scarcely been sufficient to efface them from the statute books. Hoary abuses, when dignified by age, have defied correction for eenturies.

l'recodents cease to have validity when the eireumstances on which they are hased cease to exist. The obligations to follow them ase purely theoretical. In this particular case there may be special reasons why the past should be disregarderl. As observed, the subject of ship eanals connecting 
high seas, being eomparatively modern, has not yet foumd a definite place in public law, though evidence tends to prove that ship canals do possess a fluasi-intemational chanactel, and that their owners are under some manner of obligation to the world to keep them inviolable from hostile attack. At best, the precedent is but doubtfully fixed in law, and might be fittingly ignored should self-interest so demand. Inteed, an exchusive American control of the Nicaragua Canal might in itself establish a new precedent more valuable than the old.

Abandoning, therefore, all thonght of the last, the sulject may be considered solely from the standpoint of the futme, - Is it to the best interests of the Lnited States to comstruct the canal as a national undertaking and to maintain over it sole financial and political control? I)o those interests favon the repudiation of all existing treaties bearing npon the subject? Do they call for a denial of the spririt of puldic law? The preponderance of public sentiment in the Lniterl States is in the affirmative.

'The advocates of American monopoly of the canal route contend that the safety of the Lnited States demands this course; that the protection of the country being of the first importance, all other considerations shombl be regarded as secondary. They maintain that a nentralized eanal would expose both of the American coasts to hostile attack. In case of war, the United States would be compelled to permit an enemy's fleet, while bent upon an errand of destruction, to pass unchallenger through a nentral canal. In time of peace, it would be obliged to maintain a largedy angmented flect in both Pacifie and Atlantic waters: in shorte to domble its navy. Now, on the other hand, were the Inited states to fortify the banks or the entrances of the route, a lostile these eould lee debarred from its use a the same tim. the Imerican navy would be vastly inereased in effectiveness ly "Xelusive freedom of passage. In this manner a squatron rould be quickly transferred from the Atlantio to the Parcific, while the enemy would be relegated to the long vorage by waty of Magellan. 
Furthermore, a neutralization of the canal by general compact would likely prove, when the test came, to be nothing more than a paper agreement. The route not being fortified, an enemy might seize the canal and hold it as a base, greatly to the prejudice of the United States.

They further maintain that there are circumstances conneeted with the neutralization of the Suez Canal which should serve as a warning to those who advocate an equality of interests in the isthmian canal. Great Britain holds the control of that route. Her occupation of the territory through which the passage has been ent furnishes all the proof necessary that England would not hesitate to seize the canal, if the defence of her Indian possessions seemed to eall for such action. The same conditions and necessities would drive the United States to a similar eourse in Niearigua. How much better it is, they say, to avoid all cause of future misunderstanding, by promptly asserting the right to fortify and hold the eanal.

They also maintain that eommercial interests demand an American monopoly of the ronte. Efforts are being made, throngh smbsidy and various other measures, to restore the prestige of the American merehant marine. To-day the seacarrying trade of the world is almost wholly commanded by Englishmen. The discrimination in tolls that eould be made in favor of Ameriean shipping through the isthmian canal would no doubt furnish a deeided stimulus to this growing American industry.

Possibly the strongest arguments for an "American Canal" are found in the application of the Monroe Doetrine to the subject of emal equalization. While those principles, as enunciated by President Monroe in 1823, only denomeed foreign interference in the domestie affairs of the American states, they have since been extended into a broader doetrine which gives to the Inited States this very right of interference. The result of nearly seventy years of varying interpretations of this political ereed has tended to remove the Western continents from the sphere of European influence, and to spread the mantle of a United States protectorate over their whole 
extent. The Nicaragua Canal, by virtue of its geographieal position, and also because of the American interests, which it is particularly designed to serve, seems to fall appropriately under the operations of this doctrine.

The nations of the Old World have already completer their short cut to the Orient, and opened the way to their colonies. They are entirely free to make any disposition of their own route. The United States claims no right to interfere, and asks no voice in its management. Therefore, when the Lnited States shall construct her short route from the Atlantic seaboard to California, Alaska, and Pacifie islands, she has a right to insist upon its exclusive eontrol. A joint guntantee of the Nicaragua Canal would reduee the Lnited States to the lower plane of importance and influence in Central America ocenpied by the nations of the Old Wordd. This should never be permitted; by her position in the Western Ifemisphere, the United States shonld enforee the claim to those privileges which her paramomnt interests there clealy entitle her to enjoy. The United States is heir to the Westem Iemisphere. The same "manifest destiny" which impelled the fathers to reach forth to the Pacific Ocean will likewise nrge their soms to follow a scheme of rational expansion which will extend the shore line of the United States to the Niearatgua ('anal. This course, they say, is inevitable. The first step in this direction has been taken in Cuba and the West Indies. 'The unlooked for acquisitions in the Pacific will make the second step more than ever necessiry. The territory intervening between the Rio Grande and the Sin Juan rivers, they insist. must eventually come under the controb of the great nortleren state. This farr land is mistuled by a number of irresponsible governments, the merest travesties upon republican institutions. 'They are mable to maintain order, or to protert United States eapital seoking investment there. Peaceful conditions in Mexico will polathly end with the resignation or death of President Diar, and a return to tumultuons politics may be eonfirlently expecterl. Amerion interest will sooner or later demand the aequisition of these states, when the canal will be actuilly upon Americin soil. 
With such a future of expansion in mind, it would be unwise, they believe, to hamper the government by pledges of neutrality or promises against fortifying the canal. Suppose, for instance, that Jefferson had been confronted by a previous agreement never to acquire territory west of the Mississippi River, or that Polk had been prevented by some former treaty stipulations from establishing full American sovereignty over the narrow entrance to San Francisco Bay.

Let there be no future mistakes such as the Clayton-Bulwer treaty. The parting of the ways is at hand; there ean be reconeiliation between the doctrine of American control of the canal as dictated by self-interest, and enjoined upon us by the Momroe Doctrine, on the one hand, and the doctrine of canal equalization as demanded by European interests on the other. 'The United States, therefore, must abandon all its treaties which eall for international control of the channel. It should acknowledge its breach of faith, and take the consequences, whatever they may be. This action would prove less serious than to abandon the Monroe Doctrine, and accept European dictation in any part of the IVestern Hemisphere, and open a convenient passageway to the fleets of Europe.

The advocates of a policy of neutralization hold, on the contrary, that the greatest good demands the entire freedom of commercial transit. They found their theory upon the broad principles of mare literum, and in accordance with the development of international law. The inviolability of the canal is a condition contemplated in all fairness by the world at large, and it is also a condition wholly consistent with the best interests of the United States. It is a policy dietater by practical wislom.

Wars are not the outgrowth of open and free competition, but too often result from trade restrictions of one kind or another. 'The tendency of modern times is to remore as far' as possible, all barriers to free and untrammelled commerce. The progress of international law has been in the direction of securing and safeguarding the common interest of the whole family of nations in opposition to the tendencies of local greed and aggression. The same policy that calls for an 
"open door" in China, for universal freedom of trade competition, for the removal of protective tariffs, also ealls for the unrestricted use of all commereial highways. The eommercial isolation of the Lnited states shomld not be maintained. The great extension of her commerce lats aldeally brought her so intimately in connection with other powers, that her own commereial interests have in a great measure become indentical with theirs. To elose so important a lisghway as the Nicaragua ('anal involves the aroption of a policy opposed to progress and eivilization; it wonld remove the United States from the commervial fellowslip of mations, and bring upon her every form of retaliatory legislation. With the enmity and jealousies engendered by so nalrow and selfish a policy, the way would be eonstantly open to disagreement and war upon slight provocation. The symunthies of the world would be against the United States, ant other nations would find eommon cause against her.

The neutralization of the canal is an inevitalle result, and it does not comport with the progressive eharacter of Western ideas to delay or seek to avoid it.

The principles of the Nomroe Doctrine are in no mamer violated by equalization of the ronte. It would not introdnce the political system of the ()le Worlel into thr New, nor give to Europe a right of interference in the affairs of the American continent. On the eontrary, a guarantee of nentrality is the very opposite of interference. It is a plerlge of noninterference. It places a lasting eheek npon the antrance of foreign influence at a particularly vital spot in the Western continent.

Such an agreement does not contemplate the yirleting of the United States to any foreign influence or control of thes canal, but expressly removes all posibility of such interforence or control by any one or more nations. It loses not, then, even violate the spinit of the Monpoe Inotrine: it is rather direetly in line with it. It exals a formise from the most powerful and most lapacious nat ions of the wolld. mate firm and binding by treaty regulations, to alstain from any kind of interference in the affains of the isthminn rant. 
But even shoukl the dogma of Montoeism be infringed upon by the proposition of a neutral Central American waterway, there is no reason why that doctrine should not be disregarded in the furtherance of a better cause. It would be folly to cling to a doctrine simply for the sake of the doctrine itself, or for any other sentimental reason. The object of every general policy is for the general good. If, in any particular case, the application of a theory, however sound in a broader sense, is found to be unwise, it should be cast aside. If logic and reason show that the best interests of the United States are subserved in assuming the entire responsibility of managing the political affairs of the canal, and a consistent observance of the Momroe Doctrine equally demands it, then it is proper to follow the Momroe Doctrine, - otherwise, as in this case, by all means abandon it.

Assuming further that the Momroe Doctrine would be encroached upon by conceding a joint guarantee of neutrality, it may be asked: By what right does the United States deny the privilege European nations claim to look after the welfare of their eommercial interests in the IVestern Hemispliere? There can be no reasonable doubt that foreign nations will be solicitous about the arlvantages to accrue to their commerce by maintenance of the freedom of transit through the Nicaragua Canal. The United States has not only commercial but territorial interests in the Eastern Hemisphere, and is also demanding an open door in Asiatic ports. How may she be justified, then, in denying to foreign nations in America what she herself claims elsewhere?

The nentralization of the canal would moreover avoid those dangerous aggressive tendencies which must surely be engendered by commercial advantages retained only through force of arms, both in defiance of the rights of other's, and contrary to the better instincts of justice prevailing at home.

The imposition of differential tolls would excite universal disapproval, and would eall upon the United States the denumciation of all commereial nations. The commereial and political interests of several Enopean nations in the Far East, aside from the desire to defend a vital principle of justice, would 
force them to combine against the Cuited States, should the latter persist in elaiming the privilege to elose the canal against their ships. Each maritime power would immediately eall upon Niearagua or Colombia, as the case might be, for the observance of those treaty rights secured to them by "most favored nation" elauses. There need be no occasion for self-deception in this matter. Eugland's determined resistance to Ameriean attempts to avoid the obligations of the Clayton-Bulwer treaty demonstrates her probible attitude toward the freedom of transit through the Nicaragna Cimal.

Franee is solicitous eoneerning the maintenance of this principle, as plainly shown by her Central American treaties; and one eannot well suppose that Germany or Russia would permit itself to be handicapped by any navigation disabilities that other nations escape. The Cnited States might, indeerl, defy the nations of the world, were the cause a just one. In this case she would be defending, against overwhelming olls, a prineiple which has been condenned by the civilized world, including herself. Nations, like individuals, cannot afford to ignore the good-will of their fellows. 'To persist in this poliey is simply to invite troubles which would far outhalance any temporary trade benefits which might at first acclue through a monopoly of the waterway.

At all events, the policy would have to be abandoned sooner or later; but while upholding this position of supposed vantage in Central America, the Lnited States would he subjected to the greatest amonnt of needless expense, anmoynce and risk. Lpon the United States alome wonld devolve the duty of preserving order and protecting the eanal. In times of the profoundest peace the Lnited states would be obligerl to police the route in a thoronghly effective manner: in time of threatened disturbance al large military forre womld be required upon the scene. The Lnited states wonld have to be prepared always to despateh troops to the line of the canal. Foreign vessels departing upon long jomneys ric Niearagua or Panama must be assured of finding the way "leits. No Central American revolution must be permitted to interfere, no political disturbances, riots, or threats of lawlessness in 
the neighborhood of the channel could be tolerated, which would in any way render hazardous peaceful passage through the canal. 'The danger of hostile acts committed when unfriendly relations exist between two nations would have to be provided against. For all "accidents" the United States would alone be responsible under her sole guarantee. Thus the United States would undoubtedly be forced to assume a more or less active, though unwelcome, interest in the never ceasing revolutions of those turbulent Central American states.

The liabilities of the United States would only begin here. 'To fulfil her promise alone and unaided to maintain the "strict neutrality" of the camal, she would needlessly burden herself with a task which under the most favorable conditions of universal peace would prove irksome and expensive, and which, upon the outbreak of hostilities at home or abroad, might become onerous in a high degree. But granting immmity from foreign intervention, in times of peace, what would be the extent and character of her obligations toward nations in time of war? The political complications in Eastern Asia, consequent upon territorial changes, have already sown the seeds of jealousy and bitter feeling in Europe. It is not unlikely that conflicts of European powers will result. In case of any war between two or three great maritime powers, and particularly in the event of one growing out of interests in Eastern Asia, the isthmian canal would, beyond question, become involved. This would naturally lead to a naval demonstration at one or the other entrance to the canal. Suppose, for instance, that England, free from treaty obligations to observe the neutrality of the eamal, should attempt to blockade the Atlantic entrance, to prevent the entrance or exit of French, German, or Russian vessels. Would it not become the duty of the Lnited States at once to raise the blockarle?' The injured party might come to her assistance, but would that not inevitably daw her into a foreign war? - a war in which, in all jrobability, the United States would not have the slightest material interest. Then, it may safely be assmmed that from the moment the United States consti- 
tutes herself the sole guardian of the open route from the Atlantic to the Pacific, she takes upon herself a grave responsibility, - a responsibility which may prove exceelingly burdensome. The almost inevitable eonclusion presents itself that the first European war would thus eonvert the United States from a neutral power into an unwilling participant. This should be reckoned a large price to pay for the advantages to be gained from an "Ameriean Canal."

The return for so great a price - a price that means no less than a departure from a eherished and time-honored policy - should indeed be great. It should be a national advantage, so great and valuable that it is absolutely indispensable to her safety and welfare.

Is the advantage, then, of fortifying the eanal and elosing it against foreign measures of aggression worth so great a sacrifiee? - for only in time of war against the United States would she desire to bar the route against naval ressels, and then only against the ships of an enemy. Cnder present conditions this might indeed be eonsidered a doubtful advantage. The value to the United States of exclusive control of this route in periods of hostility will depend very largely upon the relative size of her own and her adversily's lavy. 'The peculiar nature of a long narrow ehanel through a region of tropical jungle is such as to render it extremely doubtful whether a large protective force could secure its use, - even against an inferior foe.

A eanal with its series of locks, dams, and artificial embinkments, presents many vulnerable points to methorls of morlern attack. A resolute eneny equipped with eflicient appliances might easily destroy the use of the passage for months, an at which the most extrardinary vigilance could not prevent. In case of war, when a superior navy might invest the plice, the advantages to the United States of the prosession of the passage might be turned into an actual disidtrantatge. A blockade might then be effected at either terminns of the route, and maintained to the great injury of the I'nitenl States. The imprisonment of Amerienu war vessels in the canal, either by blockate or ly the destrution of a dim or 
lock, might easily result in the most serious calamities. In fact, the fear of this very eontingeney, and of the loss of vessels by explosion of mines placed in the ehannel, would likely render its use impracticable in times of war.

Assuming that it were possible so effeetively to guard the chamnel that its use could be preserved to the United States in times of conflict, and closed against the enemy, the fact yet remains that the United States is wholly unprepared to maintain with safety the exclusive control over the route. The protection of the American eoasts depends, after all, upon the strength of the navy, and all outlying posts which must be guarded are of value only as they may be defended withont too great a division of strength.

While the policy of the United States calls for an annual increase in the navy, there are other powers whose needs will require them, not only to keep pace with the general advance in armament, but to maintain for many years to come larger naval fleets than that of the United States. Such being the ease, Ameriean efforts to retain a position of exclusiveness on the isthmus may prove, after all, to be of doubtful expediency.

It may often be asserted that England's military occupation of Egypt and her fortifieations along the route to India, together with her ownership of a controlling interest in the Snez Canal itself, virtually invest her with politieal proprietorship of that ehamnel. But while it is true that the freedom of transit into the Red Sea has not been subjected to the test of a general European war yet, there has been no act of England so far that violates the terms of the Constantinople agreement. She elaims no extraordinary politieal rights over the canal itself, and makes no attempt to fortify the route. Her line of possessions and naval stations from Gibraltar to llong Kong, are permitted in no way to threaten the neutrality of the eanal. On the eontrary, England has always taken the initiative steps in bringing about international agreements to secure its neutral charaeter. Her superior naval strength undoubtedly would give her the power, in ease of war, to effeet a bloekade of the Suez Canal without entering 
within the zone of neutrality. This fact, however, cannot be regarded as an evidence of England's bad faith, or cited to disprove her belief in the neutrality of interoceanic highways. The position of the United States, with islands and coaling stations on either side of Central America, would place her in somewhat the same attitude toward the Nicaragua Canal.

By following, therefore, the spirit of international law, by observing her treaties, and by inviting the nations of the world to join in keeping open the canal, the United States deprives herself of one doubtful advantage, and at once relieves herself from a host of perplexities.

With the neutrality of the canal guaranteed by international agreement between the great maritime powers, there would be no need of fortifications; because in the face of so powerful a combination none would dare to violate the freedom of the route. American armies would not be needed to defend its banks; American ships would not be called upon to raise a blockade or disperse a threatening squadron. 'The United States would eseape the many pitfalls of foreign entanglements which the selfish policy of sole political eontrol must inevitably place in her path; and thus, - the adrocates of neutralization maintain, - by the adoption of a more liberal policy in Central America, " an inexhaustible source of international conflict" would be avoided. 



\section{III}

THE UNITED STITES AND S.MOO. 



\section{III}

\section{THE UNITED STATES AND SAMOA}

Differexces between nations are neeessarily of a serious character, because the settlement of such disputes affects directly or indirectly the fortunes of many individuals. They are also attended with danger. because close behind international misunderstandings lurks the spectre of wir. In every heart exists a belligerent chord, and the most impartial of men will magnify the shorteomings of other nations while they laud the virtues of their own. Rince prejudices are always more or less acute. War quickly appeals to popular favor when quarrels over personal rights or privileges expand into national issues, and then patriotism is likely to assume the form of blind passion withont reason or forlearance.

However trifling, then, an international dispute may appear. it possesses, nevertheless, a hidlen element of danger. It is partly on this account that the Simoin imbroglio, though now happily relieved, is worthy of attention. In the world's history the story of Samoa can never expeet to find a more prominent place than a footnote. In the anmals of diphomacy it must figure as a faree. Robert Lonis Stevenson aptly charaeterized the Samoan wars as an " infinitesimal affray"; Samoa was like a tea-pot in which a tempest raged while three great nations jostled each other in fussy endearors to keep the little pot from boiling over.

If the Samoan episorle appears trivial to the grenteral observer, it possessed nevertheless a pathetie sirle to the philanthropist, who eould not fail to see in this south tea enterprise of England, Germany, and the Lnited States, another demonstration of the withering influence of civiliza. tion upon semi-barbarous peoples. 'The assumerl hurden of the white man to protect and edueate the black one often results in the undoing of the latter. The result comes naturally, 
for, in the long run, the law which proclaims the survival of the fittest regulates human affairs as it controls all organic life. When the lion is hungry the lamb dies; when the man with a rifle takes to expansion, the man with the spear yields his estate. In Samoa the operation of this law was unique. The unfortunate natives were only saved from immediate extermination through the jealous watchfulness of three protectors. 'The duty in Samoa of each protector was ostensibly to shield the natives from the rapacity of the other two. In the meantime, the Samoans lost all control over their own affairs, and were crushed under the weight of an "autonomous government," created by their kindly disposed friends. The inevitable end - the loss of their territory - has just recently been effected, and their ultimate race extinction is simply deferred.

The history of American political relations with Samoa is primarily of interest because it reveals the first genuine instance of departure from a time-honored policy of nonintervention in the domestic affairs of alien nations. In assuming the responsibilities of fashioning and maintaining a system of government for this little group of islands in the mid-Pacific, the United States entered into treaty relations with two great powers, pledging itself to protect a people it had not accepted into the Union, and in whose interests it had not the least concern.

Since the famous farewell address of President Washington, until quite recently there have been few public officials of the United States who have not expressed belief in a doctrine of non-interference in the political affairs of other nations. This principle, which had become as much a tenet in the American political ereed as any enactment of the constitution, was forcibly expressed by Washington, who realized that his comntry was destined to attain great wealth and influence, could it be spared the exhausting drain of needless wars. Ile foresaw the great danger of meddling in the chronic quarrels that tormented the nations of Europe. Similar sentiments were expressed in the strongest language by John Adams and Thomas Jefferson. President Fillmore, in 
his annual message of 1851 , pithily characterized the nation's maxim, "Friendly relations with all, but entanghing alliances with none."

Frequent temptations have been lield out to the people of the United States to depart from their traditional poliey, - and especially when the sympathies of the country were aroused by appeals from weak nations suffering impositions, or when neighbors of the Western world were strugghling to obtain their independenee, and asked for aid or moral support. But every appeal to assume an interest or to share a responsibility in the domestie concerns of alien nations has been consistently refused by the govermment.

Mr. Seward, when Secretary of State, in deelining an invitation from France to join in the exereise of a moral influence upon the Emperor of Russia, said :-

Our policy of non-intervention, straight, ahsolute, ind frecouliar as it may seem to other nations, has thus become a raditional one which could not be ahandoned without the most urgent ocrasion, amounting to a manifest necessity.

Mr. Frelinghuysen, Secretary of State, instructing a diplomatie representative in ('hili (January 9, 188:), sald:

The President wishes in no manner to dictate or make any anthoritative utterance to either Peru or chili is to the merits of the controversy existing between those repullias. . . Wre the United States to assume an attitude of dictation towards the Sonth Ameriean republics, even for the purpose of poremting war, the greatest of evils, or to preserve the antonomy of nations, it must be prepared by army and navy to enforce its manklate, and to this end tax our people for the exchusive benefit of forminn nations.

This fundamental principle of the American government was observed for nearly a eentury.

It is true that in its earlier history there are mumeroms instances when the govermment sent ont military expeditions to attack bands of pirates, or to redless wrongs enmmitfrel upon the rights of American citions. Several naval denemstrations were made in the Meditermancan in the lirst part 
of the century, for the purpose of suppressing the buccaneering propensities of the Barbary pirates who flaunted the black flag from various strongholds on the North African coast. A letter from the Dey of Algiers, in 1815, to the "happy, the great, the amiable James Madison, Emperor of America, may IIis reign be happy and glorious," was answered by a broadside from Admiral Deeatur's fleet, for the Dey had been tolerating acts of piracy upon American commerce. But none of these examples of interference could be quoted as exceptions to the rule of non-intervention. On several oceasions the operations of the Monroe Doctrine have seemingly led the United States to swerve from this same policy; but in those instances there was the reason of jeopardy to American interests - reasons sufficient to exclude those acts of threatened belligerency from the category of wilful and uscless meddling.

The Samoan affair, indeed, marks the beginning of a new epoch in the history of American foreign relations. Commenting thereon, Mr. Gresham, the Secretary of State, in a report to the President, May 9, 189t, said:-

This duty is especially important [of reviewing the facts of the ease], sinee it is in our relations to Samoa that we have made the first departure from our traditional and well-establisled policy of avoiling entangling alliances with foreign powers in relation to objects remote from this hemisphere. Like all other human transactions, the wistom of that departure must be tested by its fruits. If the departure was justified, there must be some evidence of detriment suffered before its adoption, or of advantage since gained, to demonstrate the fact. If no such evidence can be found, we are confronter with the serions responsibility of having, without sufficient grounds, imperiled a policy which is not only coeval with our Govermment, but to which may, in great measure, he ascribed the peace, the prosperity, and the moral influenere of the United States. Every nation, and especially every strong nation, must sometimes be conseious of an impulse to rish into difficulties that do not coneern it, except in a highly imaginary way. To restrain the indulgence of such a propensity is not only the part of wislom, but a duty we owe to the worlh as an example of the strength, the moderation, and the beneticence of popular govermment. 
Whether or not the signing of the treaty of Berin in relation to the Samoan matter actually planted the seed of a new political religion must be left to inclivilual opinion, yet the fact is eertain that since the making of that treaty in 1889, a "new sehool," advotating a more generons forrign policy, has sprung into existence. Suplorters of an aggresisive foreign policy argue that conditions have changed, and that the United States, being no longer a fledgling among mations, must assume its proper share of responsibility in furthering the common welfare of mankind.

\section{I}

The term "Samoa" is applied to a group of twelve small islands whose combined area seareely exeeeds that of Rhode Island. It is one of the many island systems of Polynesia, which, like eonstellations won a map of the heavens, wot the Southern Pacific ehart, eonverting that vast region into a veritable island world. The position of this particular (rroup) is approximately between latitudes 13-15 south, and longitudes 168-17:3 west, and it lies upon the direct route talien by vessels from Western American ports which ply win IIonoluhu to the Australasian colonies. The principal port, in fact the only port worthy the name, is Mpia, sitnaterl on the ishond of Upolu. At that point foreign mereantile interests in the archipelago eentre, and there for many years the consular representatives of several comntries resided.

The islands are of volcanie origin, and rise boldly from the sea, - the isolater momtain-tops of a great sulmergerd lange. From summit to eolal-fringed hase, they are blessed with hxuriant tropieal vegetation, and charm the ege with surpassing loveliness.

'The eentral position of the gromp, with its fine rlimite and the amiable chancter of iis people, attrated many wanderers to its shores. In the earlier part of the century Samoa was visiterl ly a fow roving tranlern who rame to barter their calico prints and chapl baubles for anplat and tortoise shell. Numeroms arlventurers of a reongnizerl South Sea type, mostly eseatped convicts from Australia, 
deserters from ships, and the nondeseript ne'er-do-wells who infested the Pacific islands in the earlier days, drifted in the conrse of their wanderings to Samoa. They eame from time to time, either for gain or adventure, or else to eseape the consequences of erimes committed in more civilized parts of the world. At that early day in the far-away haven of the Central Pacific, retribution followed slowly the misdeeds of men. Missionaries came and found in Samoa a congenial field. Whalers from New Bedford and Sydney touched at the islands for fresh supplies, and to enjoy a period of revelry. Those are recorded by South Sea chroniclers as the romantic days of the small trader and the ubiquitous "heach-eomber," - the days of native simplicity and welcome that preceded the modern period of organized eommereial enterprise. With German, English, and American trading firms soliciting business upon the islands, Samoa entered upon an era of foreign interference and arrogance, - an era of mischievous political plots and counter-plots, of bitter jealousies and war. The Samoans then discovered that the white men, whom they had revered as superior beings, were morally no better than themselves, if, indeed, they were quite as good. The natives were wholly disenchanted when they found at last that the white man's anxious solicitucle for their welfare was a negative charity bised on greed. Finally the Samoans realized that they must accept willy-nilly the invincible white strangers who lad settled among them, and whom they could never drive away.

Is early as 1850, England, Germany, and the United States were represented by commercial agents in Apia; and in 1854 the great South sea trading firm of Godeffroy and Company, of llamburg, a chartererl monopoly, established itself upon Uprlu. For many year's thereafter the history of Samoa was the history of this well-organized trating company. Under the able learlership of its first manager, Theodore Weber, who, it appears, was both chief of the firm and German Consul, the eompany prospered marvellonsly. By a mortgage system admitting of skilful manipulation of titles, which was quite 
beyond the native understanding, large tracts of land fell to the company's portion, and these were industriously converted into plantations of cocoanuts. The methods of Godeffroy and Company, from a purely commereial point of view, have been denounced as unscrupulous, but the testimony of rivals should be carefully weighed. One must also beat in mind that the honor line is exceedingly larel to trace in all dealings of civilized with semi-civilized peoples. In course of time rival American and English trading concerns sprang into existence at Apia. Fierce competition between these companies, where the rolume of business could scareely support one, often induced their zealons managers to adopt unfair methods for the purpose of gaining native faror and trade. The efforts of the three consuls, who were usually strongly prepossessed in favor of their kinsmen, to protect the trader's of their own nationality, led to many official blunder's. Several hundred foreigners - principally German, English, and American - resided at Apia. The jealons competition of the traders reacted upon these, and each partisan faction esponsed with intense enthusiasm the cause of its own nationality. Seemingly incapable of regulating their own aftairs within the municipality of $A$ pia, the sterner interferente of home governments was often invoked, for the purpose of restoring order where claas reigned. Commercial rivalry ripened into national jealousy, and all within the confines of a mile of ocean beach. When the situation at Mpia lecame lopelessly involved, and wholly beyond the possibility of local anljustment, England, Germany and the Lnited States took the matter in hand. Therein lay the motive of Simoris woes. and the perplexing problem of her relief. Therein also lay the causes of the United States" abandonment of her timehonored poliey of non-interference.

The native Samoms are genemons, emotional, aniblule in disposition, of pleasing and even comtly manmers. anml mmoh given to ceremony and merriment. There is much of groul and little of evil in them. They are willing to kill white men only because white men kill them. Natmre hats so fully responded to their simple wants that they are inclined to 
indolence and rasy enjoyment of nature's bounty. They possessed no real property in fee. A political economy based npon communal irleas wealiens the incentive to acquire large private wealth, hence it was difficult for the "government" to tax its subjects. Their own system of government was essentialiy of the patriarchal type. Every community or elan hat a "royal" family, the chieftainship being hereditary as to the family, but elective as to the individual. When a chief was selected by rote of his neighbors, he was usually dignified by honorific titles. The well-known name of "Malietoa," the "Pleasing Hero," is one of these. In a measure the chief was a sacred being, of greater influenceif he proved popular - than of actual power over his people. His son succeeded to his mame and position only when elected to do so. A chief having attinined very great popularity or military suecess might have honorific titles bestowed upon him by clans other than his own; and should he receive in this mamer the recognition of five different clans, he was considered the Supreme or Highest Chief, and accorded lingly honors. The idea of royalty, as understood in Europe, seems rather to have been a foreign innovation in the islands.

When Samoa became a treaty-making power, the neeessity for a stronger central government with a definite and responsible head was felt. The step from a patriarchal form of government was easily taken under the tutelage of the whites, but true conceptions of a king apparently never sank deeply into the Samoan consciousness. To revolt against the de facto king becanse he had enjoyed an inning of several years and should therefore give other worthy men a chance to realize their ambitions, was entirely proper and legitimate aceording to Samoin eustom. The people therefore had little idea of "government," as understood by moleru civilized nations, and eonsequently a strong central power levying taxes and atually enforcing judicial decrees was not properly comprehended. The Samoans were unable to appreciate the ntility of contract obligations; they rejoiced in peace, but tribal disturbanees were more or less frequent 
throughout the islands. The white man was given the heartiest weleome, and has never since fomnd an ene'ny among the Samoans, except when his own miscleeds hate driven the simple natives to desperate retaliation.

Previous to the year 1872 no interest whatever in the United States attached to these distant islands. Ther were of neither political nor commereial importance. In that year, however, Admiral Mearle, who was cruising abont the Central Paeifie in the C. S. S. Norragunsett. antered into an agreement, quite upon his own antherity. with a "relain ehief on the Samoan island of Tutuila, "lereby the local ehief granted to the I'nited states the exchusive privilege of establishing a naval and coaling station in the harter of Pago-Pago. In return for this favor the chiel expected the friendship, and if need be the protection, of the lnited States. The value of a coaling station in that locality wats appreeiated, especially in the event of the completion of an isthmian eanal. When Admiral Meades arreement with the chief reached Washington, the Senate hesitated to sinetion the "friendship and protection" part of the baldgain. and no aetion was taken upon the matter. Soon after this (15i:), having been urged by "certain highly respectable persons" who represented to the govermunt the innortance of the growing trade between the Inited Sitates and the South Sea Islands, President Grant sent Col. A. B. Steinberger as United States Commissioner to Simma, with instructions to make a full report concerning the conditions, commercial possibilities and general inpmetane of the istimds.

A report was soon made, and Mr. Stembererer Was ansilu invested with authority (187t) to revisit the islands for the purpose of "observing and leporting 11 pen silnum alfairs, and impressing those in anthority there with the lively interest which we take in their happliness and welfare." Jnstranl of returning at once to Samoa to carry out the oljeert of his 
mission, it is alleged that Mr. Steinberger proceeded directly to Hamburg, and there entered into contract relations with the president of the great trading firm of Godeffroy and Company, pledging himself to their interests. Mr. Steinberger, who seems therefore to have become an adventurer, and unfaithful to his trust, proceeded thence to Samoa under the mask of Enited States Commissioner, but in reality to carry out the terms of his Godeffroy contract. He arrived in Samoa in the early part of $\mathbf{1 8 7 5}$, and devoted his energies to the interests of his new business. He soon became involved in Samoan polities. Internal dissensions convulsed the islands, the primary cause of disturbance being the rivalry of two members of one family, who elaimed each the coveted title of "Malietoa." Under a new form of govermment, but lecently adopted, Malietoa Laupepa, the "king" was in retirement, and the country was ruled by Councils of State. Mr. Steinberger gained great favor among the natives; and with the aid of some other white men, who were in sympathy with his projects, he prevailed upon the Samoans so to alter their constitution that Malietoa Laupepa should beenme, for a limited number of years, the recognized king, and he, Steinberger, should be made Prime Minister. While acting in such a capacity, he represented to the Sanoans that their islands were under the protection of the United States.

In course of time rumors of this condition of affairs reached IV ashington, and Congress speedily called for information in relation to Stemberger, his mission and his powers, which resulted (May, 1876) in the Seninte's repudiating any considerations of a Inited States' protectorate over Samoa, and disarowing all interference in Samoan domestic eoncerns. In the nleantime, hovever, a British war vessel happened along, and the enemies of Stemberger took the opportunity of having that reputed alventurer seized and deported. By the same movement, Malietoa, the king, was dethroned and hell prisoner. Instantly the islands blazed into war, and the vacant throne beeane a prize for several contending chiefs. The prospect of never ending tumult which followed the downfall of Steinberger (encouraged by the interference of 
several rival foreign factions in $\Lambda_{\text {pial }}$ ), finally indncerl the Samoans to pray for an English protectorate over thrir distracted comtry. When the fact beeane known to the foreigners in Apra, the German and American repenesentattives and residents were greatly alamerl. For oner they forgot their commercial rivalries, and acted togethere their interests being united in a common callse agaimst knglish annexation. With the eomnivance of the Cieman Comsnl. as is supposed, the American commereial agent at Mpia hoisted his flag over the city, and prorkimed a Lniterl States protectorate. A similar acemrence took place a year later. when an English commissioner arrivel at Apia for the prrpose of extorting certain treaty concessions from the ling. L lon this occasion English persuasion was pendered the more potent by a squad of marines from a ressed lying in the harbor; and the American flag was again hoisted lyy the anent over the government hulding, in orter to proctain to the workd, and especially to the british commissioner, that any treaties relative to Samoa shombl be marle in Washington. Both of these somewhat latsty acts were disilvomal.

The efforts made by the natives for Eustish amexation proved unsuccessful, and the disappointed chiefs rement from their mission abroal only to find the land still in the

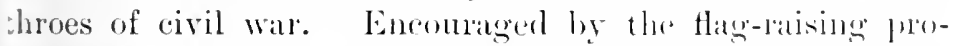
rensities of the Anerican Consul, they turned to the loniterl states, in the hope of fincling relief in an Aneriann furoteretoate. Mamea, a ligh chief, proceederl to Washington (1-7i), sut there lie found no disposition on the palt of the uthorities to depart from a policy that opposed all chlangling allianees with foreign nations. The genteroms offer of his realm was declined by the l'resident, but the objeret of is mission to the United States wats not wholly deferaterl. Ie conclurled a treaty in Washingtom, Jammary 16, Ists. wereby the United States was granted "the priviluge of 'ntering and using the polt of l'adgo-l'agro, and establishing herein and on the shores thereof, at station for conal and of her laval supplies"; the treaty further gnaranteed, that therefter Samoa would "neither exereise nor anthorize any juris- 
diction within said port adverse to such rights of the United States, or restrictive thereof." In return for these concessions it was provided in the treaty, that:-

If, unhappily, any differences shonk have arisen, or should hereafter arise between the Samoan Government and any other government in amity with the United States, the Government of the latter will employ its good offices for the purpose of adjusting these differences upon a satisfactory and solid foundation.

This treaty was made by the United States more in the desire not to appear wholly indifferent to the friendly advances of the Samoans than for any importance it attached to Samoa, or ardrantage to be gained by close political or commercial relations with her. It was indeed felt by many that the mere offer to use friendly offices in case of difficulty was a rash promise that might some day call for fulfilment, especially as Germany, with her preponderance of commercial interests in the islands, would probably sooner or later seek forcibly to acquire the group.

The Samoans, however, proceeded to make treaties of similar character the following year with England and Germany, granting to each exelusive rights in certain harbors for naval and coaling stations. In the case of the German treaty the Samoans were far more generous, through coercion it is said, and granted to the energetic German representative certain concessions that appeared to be incompatible with the favored nation clanse in the Ameriean treaty. 'This fact excited some feeling of displeasure, which was no doubt more keenly felt in the Amcrican consulate at Apia than in the State Department at Washington. To Ameriean citizens in Samoa it suggested imposition on the part of Germany, and convinced them of Germany's intention to secure a grasp upon the islands that would lead to ultimate annexation. There can be little doubt lad Germany then made a coup rétut, and formally seized the islands with a graceful recognition of American and English rights in their respective harbors, the world would not have been profoundly moved or the United States greatly shoeked, But the American Consul, who hoped for an 
American Samoa, beeame alarmed by the evidenees of German intrigue, and he decided it to be his duty to thwart Tentonic ambition in the island. The breach between the United States and Germany in Samoa was thus begun, and English subjeets in Apia took sides with the Anericans against the greater rival.

Civil dissensions between various native factions continued anabated throughout the year 1878. The followers of Malietoa Telavu and the allherents to the old regine of the - Councils of the Chiefs" took to the bush, Samoan fashion, o glare at each other over their rude fortifications, to brandish iereely their arms and to fill the forests with their warries. It was during this long period of strife that the oreigners in Apia for their own sifety oltained from both rarring factions the reeggnition of a strip of territory, inluding the municipality of Apia, as nentral and sacred from 11 hostile attack. Over this tract of land the three nations, hich were in treaty relations with Samoa, were anthorized sexercise the rights of extra-territoriality. In regard to se native wars, the three eomsuls in $A_{\text {pia }}$ proclained ofcially the strictest neutrality; but notwithstanding their etermination to hold aloof from any participation in the oubled affairs of Samoa, their languishing trade interests impelled them to intervene. In the light of later Samoan story, it is not a little rematkable that all three consuls, teked by the eoneurent opinions of several natal captains the harbor, were enabled to mite in the selertion of alietoa Telavu as the ruler of Samoa. They thereupon rew the weight of their inflnence in his faror. Desultory phing continued, nevertheless, for over a year, when peate is finally restored only by the interposition of captain sinhart of the German cruiser Bismarek.

Though peace had been aceomplished by no less vigorous asures than a bombardment of native villages, Samoan lities continued in a most msettled condition. The three nsuls decided to take a still more active part in the manement of local affairs, if for nothing more than to insure e stability of the government they had united in establish- 
ing. Accordingiy they entered into a compact with Malietoa Telarn, agreeing to support his govermment, he to accept three arrisers, - a German, an Englishman, and an Ameriein. The successor of Telaru was to be chosen "by the three protecting powers" (March 나, 1880). Such an agreement as this hore all the earmarks of a protectorate; but both England and the Lnited States declined to regard the agreement as more than a "scheme of arrangement between the consular borly and the government of the islands for the protection of the foreigners." Malietoa Telavu, however, was explicitly recognized as head of the Samoan Government, and upon his death in 1881. Malietoa Laupepa was recognized as his successor. On March 19, 1881, Laupepa was duly anointed king, according to native custom, and installed at Mulinum, the royal seat of Samoa.

In some other islands of the goup there was opposition to Laupepa. Possibly his too close association with the foreigners who sustrined him displeased some of the "old party." At all events, a native anti-administration faction crowned a certain high chief Tamasese as opposition king to Malietoa Laupeja, and the rifles and spears were again bronglit into use. Captain Gillis, of the U.S. S. Lackawana, happening in port, snceceded in quelling the rebellion by bringing about a compromise. Malietoa Laupepa was to remain king: and Tamasese was ereated vice-king (July 12, 1881).

At last all native factions were appeased, and the consuls were reasonably in accord. Peace continued for several years; no one heard of Samou's troubles; and seemingly all was well.

Those who profess to comprehend the untutored savage mind, maintain that prinitive peoples camnot long remain in peace. We that as it mily, the period of rest from July, 1881, to the early part of 1885 proved to be only the calm that preecdes the storm. With all due allowance for native vacillation and the savage's readiness for an affray, the foreigners in Apia must be leeld guilty for bringing about the troubles which followed, and the Germans must accept a little more than equal share in the guilt. 
A glance at the somewhat eomplex social conditions which existed at Apia in 1884-89, the years of greatest disturbince, is necessary to an understanding of the series of erents which, beginning about that time, culminated in the tripartite treaty of Berlin.

The munieipality of Apia was governed wholly ly the sonsular representatives of England, Germany, and the United States; and the private property within this neut ral trea generally belonged to eitizens of one or the other of hese three powers residing and doing lunsiness in the islands. To the Samoans, Apia was, to all intents and purposes, a forign eity, over which they exereised no control whatever. Iere was coneentrated the wealth of the islands, and within he nentral zone at Mulinum resided King Malietoi Lantepa and his Viee-King Tamasese, the mominil hroarls of a eculiarly weak and mistable goverument. In the enviroms f Apia in every. direction the painterl sign-pusts of foreign roperty holdings stealthily advaneed, sometines moving on $y$ night into the widerness that sumounds the nentral strip the municipality.

In Apia proper the foreign population was composen of aree distinet elements, that fuirrelled anomg themselves or nited in frienelship as their own separate and rivil interests ictated. Of these three elements the German was the most gressive and commanding. Their conmmereial interests in tmoa, embodied in the (xorleffroy firm (reoreranized into

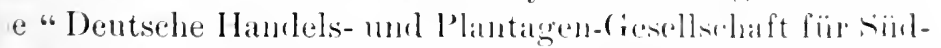
e-Inseln zu Inamburgo"), greatly exrecerled tloses of the merican and English residents combined. I vast ammont eapital had been expenderl in improving their landere planta-

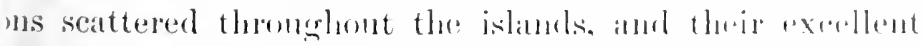
ade hat been established by thirty years uf anstant ving-

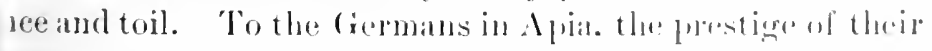
"untry and the suecess of their gleat " firm " hald almost leome synonymous terms. Nothing should be pernitted to 
check their company's growth, - not even an unfriendly native king. To "aid" in framing laws for Samoa, to ineite a revolution, or to depose a hostile government, must be accepted as legitimate aets if the company's interest demanded them; in short, any means were permissible to that end. It is not to be wondered that the Germans regarded the American and English traders somewhat in the light that a gamekeeper regards a poacher within his preserves. When the latter evinced a tendeney to adopt their own tactics for influeneing native legislation, the Germans resented their boldness, and bitter feelings were aroused; when they hinted at annexation, the Germans lost their equanimity of temper. The predominance of their commereial interests was their exeuse for all aets of interference in native affairs, and in the passively hostile attitude which they sullenly maintained toward the other foreigners in Apia.

The English element was a smaller, but in some respects a no less active, one. On the veranda of the British consulate and at the eounter of MeArthur and Company they discussed with much feeling the growing influence of the Germans, and plotted for the advancement of their own business affairs. England was known to favor imperialism, and she was constantly alive for the absorption of new territory. Her ships ranged the seas, and her commanders were quick to act. With an avowed policy of expansion in London, the English residents felt their strength in Apia. They watehed the Germans narrowly, and resented their medlling with the natives. They also had eonsiderable influenee over the latter, by reason of the activity of the London Missionary Society, whose workers in Samoa lad suceeded in favorably impressing the religiously inelined aborigines.

The Ameriean element in Apia consisted of a mere handful of nen who rallied aromel the premises of an American firm to denomnee the German and English attempts to gain greater influenee in the islands. 'Their trade was a growing one, but they felt hampered by the knowledge that the United States would probably never eare to annex the group. It would be unfair to say that they always held aloof from 
the purely domestic affairs of the Samoans, or that they constantly maintained that attitude of strict nentrality toward warring factions in the islands that the tralitions of their country should liave prompted them to observe. 'Theirs was the position of eager spectators whose interests led them from time to time to take a part in native politics, chicely to thwart the machinations of their English and (ierman neighbors.

In general, therefore, the one motive in Samoa was to aequire commereial advantage. When competition is fiece between citizens of sevelal nationalities, in a neutral land and under a weak and dependent government, the temptation to secure a controlling influence in the eomeils of the nation beeomes too great to withstand. It was impossible, umler such eonditions, for these commereial strugglers to eliminate the sense of patriotism from their efforts to increase their trade. Race prejudices were fed by business rivally, and a clash was always imminent.

Each foreign faction was headed by a consul who was quick to rliscern the right and slow to detect any wong in the aets of his "subjects." Inder the laws of extraterritoriality these officials enjoyed considerable anthority and power. They exereised judicial fumetions and supervised the govermmental affairs of the municipality wherein those of their own nationality resided. In an alvisory eallatity they exerted a decided influence over the native government. As might be supposed, where all the elements were so faroralile, politieal feelings were intense, and oceasionally ran riot. The atmosphere was eonstanty charged with rumor's of intrigne. The movements of native factions were keenly watched in the light of possible arlvantage to be gained by any threatenenl political ehange. Every act of the king or his vice-king was examined under the lens of a jealous interest, to dotermine whether it sarored of preference for Ciemun, linglish, or Ameriean.

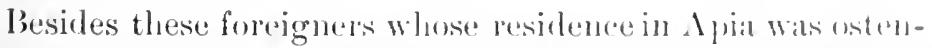
sibly for legitimate purposes of trade, men of at lower social stratum, a bar-loom riffraff of deciledly uncertain clatale- 
ter, infested the place. The South Sea Islands appear to furnish the conditions neeessary to the development of an unprincipled class of men who are always ready to breed dissemsions among native peoples, whom, by glibness of tongue, they influence to evil. Thieves profit by confusion. These arlventurers, like stormy petrels seenting the tempest from afar, were a constant menace to peace in the islands.

King Malietoa Laupepa, installed in a shanty at Mulinuu, gloomily contemplater the shatow of his slender authority. He was thoroughly dependent upon the coopperation of the comsuls to repress the little rebellions that sprang up like weeds in his garden. He was nevertheless much loved by his people. Laupepa has often been described as a gentle, lovable old man, of the most generous impulses, but pitifully weak. Tamasese, the vice-king possessed no distinctive qualities, either good or bald, and his popularity among his people was but lnke-warm.

()ut in the bush, a great chief and warrior, a man of high conlage and principle, of large and enthusiastic following, Mataafa by name, rested mon his alms. He may be said to have been at that moment in a quieseent state. He was ambitious for the throne, disliked Tamasese and bore a strong fremolnip for his kinsman, Malietoa Laupepa.

Mataafa's personality was very striking, eombining great vigor with a kindly, generons nature. He possessed a elear sense of justice, and was a good friend and a bad enemy. From ehildhood a curse rested upon this ambitions warrior. For some uncivil act he committed toward his elders he had been denomnced by a relative who, as a prophet of evil fortune, cast upon him a future of great disappointment. Never shomld he rule Simma, yet never should he rest from his vain efforts to reach the throne.

\section{$1 V^{*}$}

Inring the earlier cighties the plantations of the German

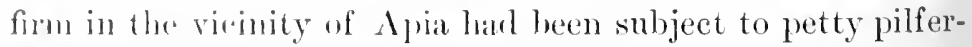
ings of the natives. The managers of the company had narke frequent complaints about these thefts; the German 
Consul had demanded of Malieton that he should warn his subjects more positively against midnight raids upon the German fruit trees. A mmmber of light-fingered citizens lad been caught in the act of making away with an armful of green cocoanuts or a bunch of bananas; they had been duly tried and senteneed to imprisomment, but it was discosered hy the watchful Weber, the head of the firm, that the back loor of the jail was open: Weber's convicts were not paying the full penalty of their mistemeanors. In ()ctober, 188t, the (ierman Consul addressed a letter to King Malietoa, calling lis attention to this lapse of justice, and smggested to him in no uncertain language that a continuation of such a condition of affairs would be accepterl as an insult to the (iemman (iovermment. The Arcadian simplicity of Simom life did not develop that fineness of discrimination between menm and tumm that the Teutonic rejuesentative in Apia believer shonld be observerl. The king no doubt felt the delicacy of his position; it required more tact than Malietoa possessed to serve two masters at the same time. lle attempted to reform his judiciary at a ruinous expense of popmlarity among his subjects, lut his reforms were not sufficiently complete to meet the requirements of the exacting fiermans: so Mr. Weber of the firm decided to constitute limself both judge and jailer of the realm. In the alsence of the German Comsul he arrangerl for a troaty between the berlin and the Samoan governments which would virtually place the management of native affairs into his own lamels. 'This doeument he placed before the astomished Malieton, with a demand that he sign it blindfolded, or, to put it more clarly, bofore its provisions conld lecome known to other foreigners in Apia. Some frerman men-of-war were in the harbor. 'The' unfortmate monach was at his wits end. He hastily allpealed to the reforesentatives of England and thr L'nited States for protection: and to the queen of Eingland he despatched a formal applieation for immonliate ammexation. The Germans in $A_{\text {pra }}$ were ontraged by this display of imlependence on the part of the king; they pressed him the harder to sign the paper, and demanded an abject apology for 
his delay and impertinence in consulting the English and Americans. Sorely harassed by threats, Malietoa yielcted. In Norember he ant his companion, Tamasese, appeared at the German consulate, mate public hmmiliation in the dust, and signed Mr. Weber's treaty. Doubtless feeling himself to be between two evils (the German man-of-war on the one hand and the wrath of his subjects on the other), he appealed in his distress to the Emperor of Germany (December 29, 1884): -

I write to inform your Majesty that I am deeply distressed on account of the troublesome acts done by subjects of your country in Samoa.

I humbly beseech your Majesty to listen to my complaint.

The first matter of complaint of which I have to inform your Majesty is the agreement which was made on the 10th of November between the Government of Germany and the Govermment of samoa. The method in which it was brought about was very improper, for we did not desire to make it because we were not allowed to see the documents so that we could consult about it and consider it.

I wrote to the German consul to ask him to give me a copy of the agreement, in order that we should thoroughly understand its meaning. He replied that he refused to give me or my government a copy of the agreement until after we had accepted it.

I assented to the agreement, and our names, Malietoa and Tupua, were signed to it on account of our intimidation by threats. I also inform your Majesty of onr withdrawal from the agreement on aceount of its containing many impracticable clanses.

I therefore beg your Majesty will not assent to that agreement.

I also apural to your Majesty with reference to the troublesome acts of Mr. Wreber, a sulject of your country.

Ito is continually trying to canse divisions among the people in ordep to bring ahout disturlanes and war in Simoa. I have repeived much information respecting his working for the purjese of eansing troubles to arise in Samoa arain.

II" is continnally seheming and offering bribes to some Samoan chiefs to induce them to comply with his wishes, and thus cause a rewellion in my country.

I complatin to your Majesty on account of this improper conduct of Mr. Weler, so that he may be compelled to desist from acts by which the blood of the people of my country may be shed. 
I hope and pray that God will bless your Majesty and your Government.

I am, your Majesty,

Malietoa, King of Samoa.

No more effective state paper has ever been written, but the German Consul-(ieneral, Herr Steubel, was not the man to permit the advantage he had just gained to slip from his grasp. Resolving upon an extreme poliey, at an opportme moment (emulating the example of a former Aneriean cimsul), he hoisted the German flag over Mulinmu ( Jannary 2:3, 1885), and nailed to a tree the following interesting proclatmation: -

Let all the people of Samoa observe during the long period that Malietoa has been king, the Govermment of Gemany has hern treated with unkindness and injury, and all agreenents that have been made between the Governments of Germany and simma havo been repeatedly violated. For that reason I must now make arrangements necessary for the protection of the smbjerts of my government and their possessions. This is my view of that which is necessary to be done: that I shonld take possession of the lands of the village and district of $A$ pia, in which are included Mulinmu and the Harbor of $A$ pia, to hold possession moler the supreme control (that was muler the ciovermment of llalinton) for the Govermment of Germany. This is the sign of this- I have hristed the flag of His Imperial (irmman Majesty in Mnlinum. This is the meaning of it (the losisting of the flag), that only the Govermment of Germany will rule for the present over that prition of territory.

Samoans, I tell you now plainly, that it is only the trutitery that is called the Ilunicipality that is taken possession of. but no other portion of land in samoa is taken pessession of.

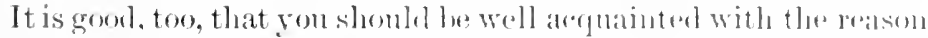
of that which is dome. It is momkinhluess at all to simulat. The

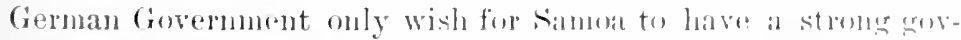

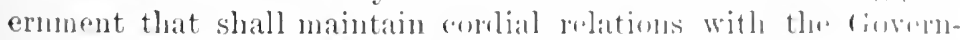
ment of Germany. When a peareful solution of these diftionltios

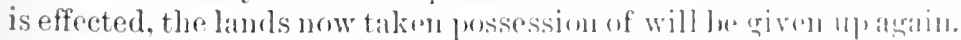

I beseech you to be at patce and to have contidnenere in the Government of Germany and myself; then Sannoa will indmed be prosperous.

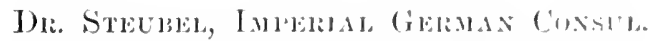


It might be presumed that Dr. Steubel needed rest after such an effort, but those lacking in humor seem never to tire; besides, this was Dr. Steubel's busy day. To Malietoa, he wrote: -

Already, on the th of November [1884] your Highness wrote to me that the prisoners who in February, last year, escaped, in conseqnence of the order of your Government, out of the German prisons, would be brought back. Subsequently I made an agreement [the blindfold episode already referred to] with your Highness' (iovermment. I supposed that difficulties which arose formerly would be removed thereby. Your Highness' Govermment, however, remewed the old inimical attitude towards Germany. Not all the prisoners were bronght back, and those who were escaped again soon after, and your Highness' Government did not think of taking the trouble to return the prisoners. In a letter which your Highness wrote to me on the 20th of November you say that it is generally known that Samoa was to be taken by force by the German Government.

Since then the followers of your Highness . . Semmanu and Lanati lave repoatedly, in meetings, designated Germany as a rohber lauk, and a comitry of slavery, and as a country without religiom. ... (xermany "an no longer look upon this state of affairs with expanimity. . .

Hence the German flag-raising over the municipality. To the American and liritish consuls, who had at onee protested against 1)r. Stenlel's assmuption of authority, he wrote that by way of leprisal he had attached, in the name of the Imperial German Govermment, all the territory forming the municipality of Apia, as far as the rights of sovereignty of King Malistor and his government are concernerl, and that lte womld hold the simse as security for the due fulfilment of existing treaty obligations by the Samoan Govermment.

Malietoats apparent complacency in pielding to the importumities of the now cordially disliked Germans injured him in the eyes of lis subjects. Tamasese hoped to profit by his diseraro, for anbition had flowered in his breast. The viceking sukfenly annommerl his separation from Malietoa's government, and he proceded at onee to set up his own emblem of sovereignty in a near-by village. A German mil- 
itary offieer, Captain Brandeis, arrived on the scene as a elerk of the German firm. Ile took up lis residence with Tamasese, and begin the process of tutoring that hopeful candidate for the throne.

In far-away Berlin, the Kaiser may possibly have been tonehed by Malietoa's pathetic letter. - at all events, he fold that his representatives in Samoa hat gone tou far. 'The' German Government quickly disavowed any resumsibility for the events of the past few months and for the conduct of Consul stenbel. Of the improper comsere of 11 . Weber (in reality a private citizen) it fully alisalploved. Had the Germans in Apia therempon prompty restorerl the statu quo of November, 188t, and then sot about waining their desired reforms in a less aggressive manner, posibly the humbling of the Samoan Government and the flaceraising incident at Mulinum would have blown over as a hanmless political squall; but they were not so disposerl. Int. Stenbel kept his flag waving defiantly for twelve months, - thronghout the entire year of 1885, - rhring which time the social relations of the three comsuls and the citizens of the three

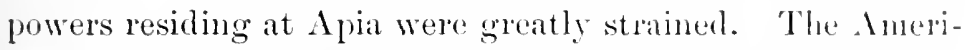
can and English residents generally gave their sympathy to the much-abused Malietoa, and the (iermans were nore amb more openly supporting Tamasese. Among the natives murmurings of diseontent were hearel on all sickes. 'Two plitties were formed - the followers of Malietoa and the followers of Tamasese. The position of the former at Mulinum, so near the irrepressible Weber, who "rested not," becatme tor delieate even for the semsibilities of a barbarian, and he therefore moved into $A_{\text {piat }}$ froper, and raisent his thang in mone friendly surroundings. The (iomman ('omsul at omer pullud it down, and then the docile Malietoat guiesty moved ont of the foreign eoncession into one of his own nattive villages, and there once more raiser his colors. Protests of the ansuls becime the orkler of the diay.

In April, 1886, Admiral Knorr, commanding a squallon of three ferman vessels, arrived in port and openderl nowntiations with Tamasese, signifienutly igmoring Malietuil, whom 
he addressed simply as "High Chief." Mistaking the object of the almiral's mission, Malietoa addressed to him a letter reviewing at great length the story of his sorrows. "Your Excellency," he conchuled, "let the righteous dealing and the kind regard of the (iovernment of Germany be manifest towarl om islands, so feehle and so few." But the admiral's ear belonged to I)r. Steubel and not to Malietoa, and it was to Tamasese that he fired a royal salute.

The hokless Malietoa, now wholly discouraged and believing that the Germans seriously meant to crown his rival, directed anotler appeal to the American Consul for protection; and in reply to this the sympathetic Mr. Greenebaume mufurled the American colors over Apia, and proclaimed an American protectorate (May 14, 1886). An American and an English man-of-war arrived; the German flag was flying at Mulinun over a proclamation setting forth that the municipality of Apia was under German control ; the American flag fluttered over $A$ pia above a document which warned all passers-by that Samoa was an American possession. Tamasese was in open revolt, with German encouragement behind him. Malietoa was gathering about him his elans on the other side of $A_{p}$ ia, and the Americans and English were griving him eonsolation and selling him arms. The outlook was theatening.

The summary aetion of Consul Greenebaume in proclaiming a protectorate over Simoa disturbed the State l)epartmont at home. The situation seemed to eall for the fulfilment by the Lnited States of its obligation under the traity of 1878, to nse its grood offices in behalf of the Samoan Corernment, althomgh that obligation could starcely be arried to the cxtent of lending its flag to the threatened maler. Instructions were accordingly sent by the United Sitates to its representatives at London and lierlin, to annouce that the protectorate over Samoa set up by Consul Greenehamme was manthorizerl. Reeognizing, however, the seriousness of the sitnation in Apia, and desiring to remove all 
causes of irritation between Germany and the Lnited States, Secretary Bayard suggested a conference to the German and English ministers at Washington. This was made with the view of reaching some mutual moderstanding for the reëstablishment of order in Samoa. 'The secretary of sitate cannot be said to have gone too far in thus secking to redieve the unfortunate condition of affairs in A pra. He recogmized the dangers of a eivil war in the islands where American and German sympathes were so keenly arrayed on different sides ; and he probably realized the difticulty of kecping Imerican residents at Apia in the straight and natrow fath of nentrality should the threatened war break out. He not with a hearty response from both England and fiermany, both of which powers probably shared with him a belief that their umruly subjects in Samoa were camsing altogether too much trouble.

It was therefore agreed that before any definite steps should be taken, a commission, composed of an agent liom each government, should visit the islands for the purpose of investigating and reporting upon their political and social conditions; thus, after more perfect knowledge ladel lean gained of the needs the situation might all for, lepresentat tives of the interested govermments womld mest and take such action as seemed necessary. Mr. Bates, Mmerican, Mr. Thurston, English, and Mr. 'Travers, German, visited Simmor in the summer of 1886 as an international rommission, and their reports were returned to their respective govermments in the following spring.

News of the action of the three powers came to Apria none too soon. The teusion was relicved hy the shithing of lesponsibility beyond the seats. P'repatations had to be hastily made for the aroval of the commissiomes: the (icrman flag came down, the American llag was lobled and put

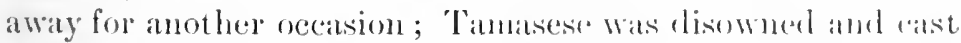
aside by his German protectors; Madietoat Wan Mreroul into an agreement to keele the peare, which he was pludengl to

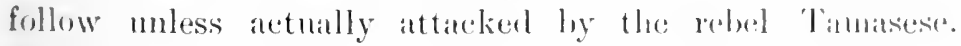
Finally, after much persuasion, the "liepresentatives of 
Malietoa and his Government" and the "Representatives of Tamasese and his Party" were induced to sign an agreement of perpetual peace, to live " in friendship and cordial relations." When the commissioners stepped ashore on the beach at Apia, the temple of Janus was elosed; outwardly, at least, the consuls had resumed friendly social relations.

The reports of the three commissioners were somewhat tinged by the prejudices which infected the air of Apia, but in essential details they agreet. The unanimous conclusion was reached that the natives were wholly incapable of maintaining a stable or efficient government. Their interests, as well as the interests of foreigner's residing and doing business in simoa, would be better served, they all declared, by the establishment of a form of govermment in which the three powers might exercise supervision. Armed by these documents, the secretary of state and the British and German ministers at Washington, met in conference (June and July, 1857 ), to take up the task of "preserving order in Samoa."

The United States entered into these negotiations "to establish peace and a better understanding" with feelings of some hesitation, if not of diffidence, as if eonstrained into committing a second error in oreler to mitigate a former mistake. The administration had no desire to embarrass the comntry by assuming responsibility for good government in Simoa. The weak and helpless little nation had granted the linited states a firor, and had asked in return the merest shadow of American protection; the time had come when the rights and the independence of this nation were threatened with extinction, and the grood offices of the President had qeen invoked. American trate interests were not of suffieient importance to warrant a very large share of attention to the sureial or political affatirs of Samoa.

(iermany, whose paramount commereial interests gave her a livelier reand for Samoan affairs, was far more eoneerned in the politieal comditions of the islands, and she was, moreover. less hampered by conservative notions in her foreign relations. It is more than doubtful if she was genuinely interested in the welfare of Samoa. Her desire was mani- 
festly to establish some form of governmental machinery in the islands that would not operate adversely to her commercial interests.

England regarded with disfavor Germany"s growing influence in Polynesia, and entered into the negotiations with the sole idea of protecting her own tracle in that part of the world. She may have desired as well to checkmate some of the suspected colonial sehemes of the Kaiser.

Diseussions at the eonference which followed, soon developed wide divergencies of opinion. The Greman Minister farored a scheme to place the management of Samoan atfitis in the hands of one foreign official, who should be chosen by the power having the greatest commereial interests in the islands, and who should be designated. "adriser" to the king." This would of course establish German control ; but Herr von Alvesleben contended that this was only proper in view of the larger German investments in the group. The plan proposed by the seeretury of state was that of an executive comneil, composed of the king, the viceking, and three foreigners - an American, an English, and a German subject; but to this the Cierman objected, as being no solution of the diffieulty whaterer. In this he was 1 mdoubtedly correet, as subseruent events have fully demonstrated, for the trouble, being antirely eaused by the rival interest of three sets of foreigners, eonld in no wise be reliered by the addition of a seeond offieial head to each faction. For obvions reasons the (ierman Minister's plan, though apparently farored by the English Minister. eombl not be accepted by the I nited States beeanse of its somewhat false prosition of intermediary. Mr. Bayant clectaren that the German proposition was not in acord with the principhes upon which they were to proceerl, als it amonnted to the reduction of Simoa to at German pusiession.

Failing to come to a conclusim, the conferences wore closed for the time being (July 26,1557 ), with the moledstanding that the politioal affirirs of the islands should remain in stretu quo until the menbers of the commission could meet again after having consulted further with therr 
home governments. Thus the matter rested, it being believer in Washington that the question would be readily adjuster within a few months, when the commissioners were again ts meet.

\section{VI}

News of the adjoumment of the eonferenee without a defi nite conclusion no sooner reached Apia than the old reign 0 : dissension began anew, and so vastly complieated becam the situation in those turbulent little islands, that hac not the greater forces of nature intervened at a most eriti cal moment, it is possible a war between Germany and the [nited States might have resulted. For their hasty aets of the previous year, Consuls Steubel and Greenebaume hac been dismissed, and were replaced by Herr Becker and Mr. Harold M. Sewall respectively. The former entered upor his duties as German ('onsul with a determination to follow to its rational conchsion the poliey Stenbel had inaugurated: his aim was to complete the task that his predecessor had been forced to abandon. This he set about doing with a lofty disregard for the Washington agreement just entered into by the representatives of the three powers. Malietoa had already been marked as a victim by Steubel, on account of his supposed unfriendly attitude toward the Germans: but eircmstances hat prevented the former consul from perfeeting his plans; he was still recognized as the lawful sovereign by England and the Lnited States, and Tamasese had perforce been abundoned by Stenbel at a moment when his scheming had almost succeded in making lim king.

Mr. Becker immediately cast about him to discover a good excuse for stripping the unfortmnate Malietoa of the last vestige of lis power. Some glaring misleed, still better an atrocity, was needed. It was found, thongh a slender one. Abont six months before this time, in a bar-room brawl, some Creminn salors haul fallen into an altercation with a few natives, and a rough-and-tumble fracas ensued, ont of which all parties emerged with bruises. The natives who had, participated in this "riot" were found guilty of assault, 
by the German municipal jurlge, and although the event had taken place within the linits of Apia. and therefore without the jurisdiction of the native ling, Malietoa was held responsible for the outrage of " trampling upon the (ierman Emperor." This event harl taken place previous to the Washington conference, but at the time it was not serionsty considered. It was now suddenly revived. before the king could more than eateh his breath to reply; Berker leclared war upon him "by order of llis Majesty, the Emperor of Germany." Like the opportume happenings of a fiary tale, four German men-of-war appeared in the harbor. In less than a month from the elosing of the conference in Washington, war was declared by Germany upon Malietoa, martial law was proelaimed in Apia, and Tamasese was heralded as king.

Mr. Sewall and the English Consul at once cane forward to protest: -

Whereas the Govermment of Germany has this day froclaimed Tamasese King of Samoa,

Now, therefore, we, the undersigned representatives of the United states of Ameriea and Great Britain. herehy give notice that we and our governuents do not and never have recognized Tamasese as King of Samoa, but continne as heretofore to recengnize Malietoa.

We adrise all Samoans to submit quirety to what they cammot help; not to fight, whatever the provoration, but to await freareably the result of the deliberations now in progress, whinh alone an determine the future of samoa.

The stroke having now been griven in earnest, the (iemman Consul determined to proseente his campringu with the utmost igor. In the hope of winning recruits by means of oratory, lamasese stump speakers were conveyed on (inpman vissels to different ishands to hatrangue the natives: in ortain owns where the orators were collly resedved. the tiscourta-

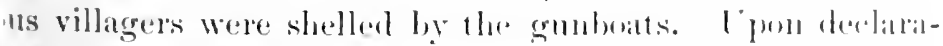
ion of war, Malietoa lastily took to the bush, and his upporters began to rally abont him. ('aptain linambeis roceeded to lortify 'Tamasese's position an Mulimu. The 
chief Mataafa with his warriors then emerged from his solitude and went to Malietoa's aid.

With such important and exciting events in progress, if corld scurcely be expected that the foreigners in Apia shoulc remain calm. As Becker made no concealment of the objec of his sehemes, - to get rid of Malietoa and to crow Tamasese as his own puppet king, - the American and Eng lish spectators soon became bluntly outspoken ; the employee of the German firm assumed a swaggering demeanor; th Americans and English used insulting language.

The first object of the German Admiral, as ranking office among the Germans, was to capture Malietoa. He issued ar invitation to him to surrender, coupled with threats of ren geance upon his people if he declined the invitation. In Sep tember (1887), the thoroughly cowed king answered th summons in person, having first turned over the care of hi people to his powerful ally, Mataafa. The entrance of th sorrowful Laupepa into Apia as a prisoner of war was a teal ful event. In a farewell address to his followers he said :-

On account of my great love to my country, and my gres affection to all Sanoa, this is the reason that I deliver up $m$ body to the German Government. That Govermment may do : they wish with me. The reason of this is because I do not desir that the bloor of Samoa shall be spilt for me again. But I $i$ not know what is my offence which has caused their anger to n and to my comntry... Taumasanga, farewell; Manono an family, farewell. So, also, Salafai, Tutuila, Ansa, and Atu farewell.

'To Mr. Sewall, who he believed should have more vigo onsly exerted the "grood offices" heretofore mentioned, I wrote:-

When the rhief Tamasese and others first moved the prese trouhles, it was my wish to punish them and put an end to tl rebellion, Jut I yelded to the alvice of the British and Ameries consuls. Assistance and protection was repeatedly promised the and my government if I abstained from bringing war upe, my rountry. Relying upon these promises, I did not put don the rebellion. Now I find that wal has been made upon me I 
the Emperor of Germany, and Tamasese has been prodaimed King of Samoa. I desire to remind you of the promise so frequently made by your govermment, and trust that you will so far remlepm them as to canse the lives ami liberties of my chiefs and reolle to be respecter.

As a hero, then, anid the lamentations of his people, Nalietoa Latupepa was deported in exile to distant lands. For several years he disappears from view.

These events occurring in the face of the agreenent to leave Samoa matters in stutu quo were not overloolierl at Waslington. The action of the Germans wals clearly in (ontempt of this mutual understanding. There is a positiveness in German manners, which, althougl not interded to give offence, is sometimes as irritating as an unfriendly ant. The Secretary of State wias amoyed by the dash Mr. Buclier hat taken into forbidden tickls, but lie felt more offended hy the arrogance of his anthority. In the ensuing correspomlence, Bismarck persistently laik the blame upon the Americin consuls, one and all, whose comduct in Apia, he declared, harl always been hostile to German interests. Secretary liarard could only reply that it was the (ierman and not the Anerican consuls who had hrought abont simmois trouble's.

With Malietoa ont of the way, the main obstatele to the success of Becker's plans was removed. Martata, lowerer, was amming; but Tamasese was alrealy anmed, the alert Brandeis having looked to that. The next step was to silence the American and linglish comsuls who wore openly hostile to his schemes. It will be remembered that the port

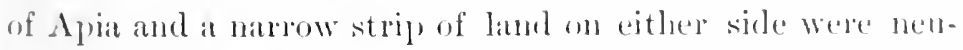
tral territory over which the three guwers exereised the right

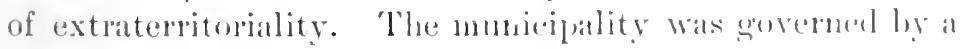

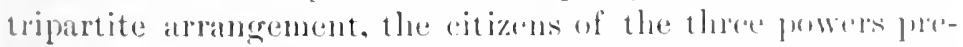
sumably shating about equally the comtrol of arban allatrs,

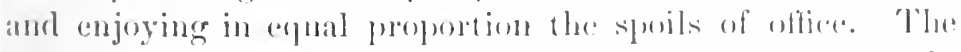

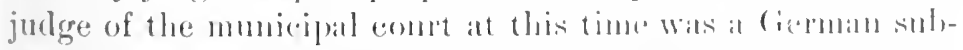

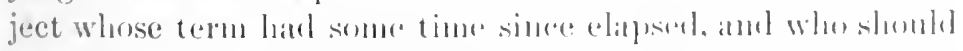

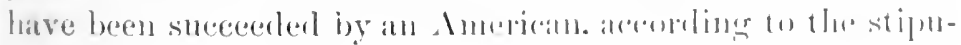

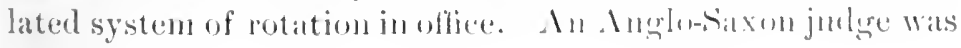


not what the Germans in Apia wanted at that particular juncture, so $\mathrm{Mr}$. Becker began a process of elbowing out the foreigners from the comneils of the munieipalicy. To accomplish this task satisfactorily required some very skilful manceuving, but Mr. Beeker was fully equal to the occasion. For some weeks, with various excuses, he absented himself from the regular consular meetings, thus preventing the necessary quorum for the consideration of municipal affairs. Finally appearing at an appointed meeting, he took advantage of the fact that the Ameriean Consul, Mr. Sewall, was not present, although it is believed he knew that the belated official was hastening to the meeting. He quickly left for his home to write a letter to Mr. Sewall, in which he said that he regretted to be obliged to eonsider the municipal government to be in abeyince, "since you have refused to take part in the meeting." By resort to such a doubtful method, he succeeded in abrogating the neutrality of A pia, while he instantly became deaf to all the protests and demuciations showered upon him by the indignant Amerieans. lle duly annonnced that Apia was Samoan territory, over which Tamasese ruled.

The German flag still flying at Mulinum no longer trespasserl therefore upon neutral territory; the king himself resided in a German house on German land; the king governed A pia, and the Germans controlled the king. 'To cilp the climax, Tamasese appointed a German judge to presicte orer the courts of Apria. Captitin Bundeis was made Prime Minister, and Mr. Weber, of the German firm, was the power behind the throne. At last German persistence wats crowned with full and eomplete suceess.

The Tamasese-limaleis (iovermment eontinned in aetive operation from the latter part of 1887 until Septembe: 1888 , when its carecr drew to a sanguinary elose. After the excitements of revolution were well over, and the ruflled tempers of the foreigness in Apia had had time to subside, it was fommel that the new govermuent was not a wholly bat ome after all. Brambeis appears to have been a man of comsiderable ability amd, for a professional instigator of 
revolution, one possessing a fair sense of justice. It seems to have been his aim to administer his government with strict impartiality towarl the business interests of the several nationalities. Roals were built; taxes, though sonewhat excessive, were well applied, and many needed reforms were instigated. Indeed, many of the foreigners in Ipia who had bitterly opposed the change gradually became reconciled to the new conditions. But the fault of the TamaseseBrandeis Govermment lay in its origin. In the natme of things it conld not last. The seizure and deportation of Malietoa never ceased to rankle in native breasts, and hack in the forests plots were continually hatching against Tamasese and German rule. No government, in fact, that strictly enforeed its decrees eould long remain populat with the zasy-going Samoans. From day to day dissatisfied natives lrifted into Matalafa's camp, for Matalafa had Malietoa blood .n his veins, and stood for the vindieation of his exiled zinsman.

The ambitions 'Tamasese, within the linits of his circun,cribed powers, like the beggar on horseback, rode too hard. Ie lat gained honors, and he craved distinetion. Ile began sssuming honorific titles, finally dubbing himsell with the ighest of them all, the satered name of "Malietoa." The llegianee of many of Tamasese s own best supjorters was at rest none too sure, and a host of these became indignant vith their monareh for this molnoly folly. Tle retnsmen of Ialietoa, who regarded 'Tamasese as a mere usurper, shiehled y German forees, felt their temlerest sentinents outragerl. The one consistent and nuenumbmising enemy to the new egrime in Apia was the Ameriean ( onsul, Mr. Semall. The

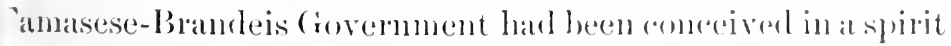
f unfriendliness to his eonntry, and hanl heen phanned and xecuted by the Fremans in discegard of their obligations. 11 fact, it was being mantained in dotiance of his own rotests, and the complaints of his Seromtary of State. He alt himself to have ban hookwinker in the abougation of

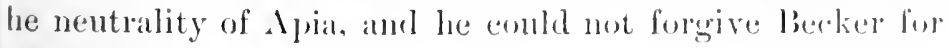
is duplicity. 
In August. 1888, Mataafa suddenly beeame aggressive and made an attick, though unsuceessful, upon Tamasese at Mulinum, and then retired to marshal his strength for another assault. Instantly all the suppressed antipathies of the two parties in the islands rekindled, - the Tamaseses rallied about the king at Mulinum; Brandeis dug trenehes in aetive prepration to meet the eoming assaults. From neighboring islands the sympathizers of Mataafa eame in their eanoes to share in the threatener conflict. In Apia the priee of arms and ammunition reached a fabulous figure, and eould only then be bought by the natives upon a declaration showing on which sicle they were to be ased.

To strike terror" into the hearts of the "rebels," the German warship Adler proceeded to bombard native villages along the coist that were known to favor Mataafa. It was then that Commander Leary of the U.S.S. Adams addressed a letter to the German captain which was ealenlated to remove all doubt as to which side in the coming contest he and the American eitizens in Apia had given their sympathies. He said: "The revolutionists had an armed force in the field, within a few miles of this harbor, when the vessels under your eommand transported the Tamasese troops to a neighboring island with the arowed intention of making war on the isolated homes of the women and children of the enemy. Being the only other representative of a naval power now present in this harbor, for the sake of hmmanity, I hereby respeetfully and solemmly protest in the name of the United States of Aneriea, and of the civilized world in general, against the use of a national war vessel for services as were yesterday rendered by the German corvette Adler." This well-directed protest was followed by a series of thrusts on the part of Commameler Leary that stmog the German Captain's temper. The best of jokes may be pushed too fur, and in this respect Commanter Leary probably transgressed. Ilis final offence, by inviting throngl inferenee or implieation, the commander of the Allep to meet lim in eombat, in no way relieverl the tension. Epon this partieular oceasion the German man-of-war had talien position to bomband a native village, and Leary 
steamed in between him and the shore, annomeing that if the German commander intended to carry ont his purpose he would be obliged to fire through the Alums.

In September, 1888, Mataafa, having been erowned king by his own supporters, led another attack mon the gorermment forces under 'Tamasese and Brandeis which were intrenched upon either side of Apia. The battle of Matautu (September 12) raged all day and well into the night, and was perhaps the greatest battle ever fomght upon the islands. The amount of ammunition expenderl is sald to have been something quite extraordinary, and " the noise deafening"; when the smoke cleared awa the govermusut forees were found to have been driven back into their stronghold of Mulinum. Only abont forty dead were left upon the field, no doubt a hmmiliating disappointment to both sides.

With American and English sympathy avowedly in faror of Mataafa and hostile to the Germans, social relations in A pia were rapidly reaching an uncomfortable stage. Those ordinary amenities that remder endurable the association of men of opposing interests were cast aside. Opportunities cime daily for the commission of unf riendly acts which served to inflame further the growing enmity of Germans and Anericans. For example: one Scamlon, an American half-cast, owned a house near Mulinm whieh was raded by Tamasese men, more for the purpose of adding Scanlon's pigs to their rations than on aceomnt of any especial ill-fecling towad Scanlon limself. The matter ame before Commanter Leary, who welcomed an incident that furnished another exeuse for an adventure. With military pomp and a show of force he oceupied the Scanlon honse and deelared his intention of shelling Tamasese across the way. The (irlullus were greatly ontraged hy this "medhling" in Samoan altials, but they nevertheless alvised the king to shift his gmateror. It was thus by American theats that Tamasese and his warriors were obliged to abandom their fortified position at Mulinum and take to the hush. Then it maly be saill the point of war was ahmost reached between the suplporter's oi 
the two native factions, - the Germans and Americans in Apia. So critical incleed had the situation become, that the various consulates were converted into veritable fortresses for the refuge of their eitizens.

After a series of inconclusive skirmishes between the forees of Matarafa and Tamasese, Dr. Knappe, the German Comsul (Becker had been recalled), decided upon a final stroke, - to lisarm and probably capture Mataafa. In the small hours of the morning of I ecember 18, 1888, a force of 150 marines was silently landed from the German war vessel and was proceeding inland when suddenly the woods became alive with Mataafa warriors. The squad of bluejackets only retired after a desperate struggle, leaving 50 dearl and wounded in the jungle. The following telegram reached Washington soon after :-

Three war ships umdertaken to disarm Mataafa. Landed at night force to prevent retreat. Mataafa's men fired on and forced to fight. Ciemans ronted. Twenty killed, thirty wounded. Germans swean vengeance. Shelling and burning indiscriminately regardless of Amerian property. Protest mheeded. Natives exasperated. Foreigner's lives and property in greatest danger. Ciermans respeet no nentral territory. Americans in boats Hying. American flag seized in Apia harbor by armed German boats, but released. Admiral with squadron necessary immediately.

The Mataafans were jubilant. They had made a great and valuable diseovery, as hat the Caribs of Porto Rico when they held a Spaniand moler water to discover whether or 110 white men bore a charmed life.

If the relations between the Anglo-Saxons and Teutons in Apiat had been bat before, they now beeane worse. Herr Finaple acensed the Anerican and binglish consuls of complicity in the masisere of Germatn soldiers, and a volume of native trestinmy was arlucesl to prove the eharge. Whatever might be the value of a native atth, it is certain that the English Comsul. Mr. de Coetlogom, did not give a signal to the natives at the time of the anding of marines from the Adler. 
and it is equally certain that the American Vice-consul, Mr. Blacklock, did not set a trap for the luckless German blue-jackets. The infuriated linapere goaled to rlesperation by the miscarriage of his plans, determined npon immerliate revenge, and he prepared for an active campainn against Mataafi. He began by proclaiming martial law over Apia, including Amerieans and English moler its operation. They declined to heed the prodanation. Sucl, were the social conditions in Apia at this trying perionl, that when the British Consul protested aganst Geman mantial law over his subjects, Dr. Finappe replied: .- I have hatd the homor of receiving your Exeellency's agreeable communicition of to-day. Since, on the ground of received instructions, martial law has been declared in Samoa, British subjects, ats well as others, fall umler its application. I warn you, therefore, to abstain from such a proclamation as you ammonnce in your letter. It will be such a piece of business as shall make yourself answerable under matial law. Besicles, gom lonlamation will be disregarded."

Aceounts of the desperate condition of affairs in Apia needed none of the usual colorings of sensitional jommalism to exeite the people of the Inited states. In its plain. mvarnished recital it was suffieient to creite alanm: Cremuluy had broken her pledge; the Amerian flag had prat toally been fired upon. War with Germany was sepionsly discusserl. The truth of the war rumos's which spreat orer the anmutry was apparently corrobomated, both hy the firm attitmle of the government at Washingtem, and by the immerliate reänforeenent of the Anerican fleet in Simoa.

In answer to Vire-Consul Blacklorkes stirring able, Adminal kimberly was lomriedly sent to Apiat. Ile ar-

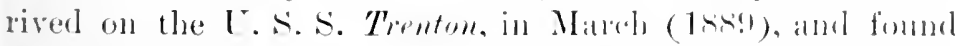

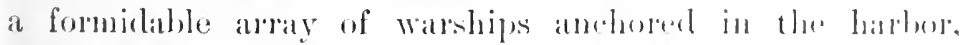
all cleared for action and awaiting terelopments. I poun

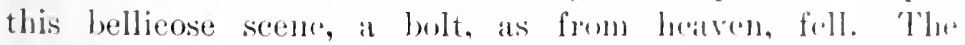

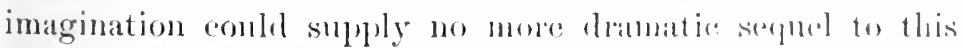
gathering of warships. A hurricane (March la) destroferel all the vessels in the harbor salve one, the G'alliope (English), 
which, after a memorable battle against the elements, succeeded in safely steaming out to sea. In the common disaster, all belligerents forgot their quarrels and animosities; Mataafans hastened to the relief of German sailors, and Tamaseses heroically rescued Americans. The power of Germany and of the Lnited States in Samoa was thus suddenly and utterly broken. The great storm cleansed and sweetencel the torrid air of Apia. Seemingly, providence, according to its own methods, had undertaken to cure the Samoan distemper. Before this terrible catastrophe had arrivel. however, the Samoan imbroglio had again fallen into the hands of the three powers for adjustment.

\section{VII}

It is pleasing to note a prevailing calmmess of tone in the official correspondence between Washington and Berlin during this period ( $1887-89)$, relative to Samoa. It contrasts strongly with the feverish and hysterical temper of the commmications between the consuls in Apia, and in letters to their home govermments. Mr. Bayard and Mr. Blaine on the one hand, and Prince Bismarck on the other, were contimually prodded by communications from Apia sounding many alarms and craving sanction for many deeds of doubtful propriety. The communications passing between these premiers indicate, almost without exception, a desire for moleration. Eath hopes that the impetnosity of his excited officials in Samoa may be pardoned, in order that the questions at issme may amicably be settled. Between the lines of these formal despatclies a trace of wariness may often le detected, which might rencler a farrly correct reading, despite the actual words used, to be, "They are at it again; will they never stop? Your men have done wrong; control them lettro, and I shall try to control mine:" and finally, "It is of no use: we must ourselves settle their difficulties, and over their lreals, - let us meet for the purpose."

In ()etoler, 1887, Mr. Barard calbled to Berlin that the state of aftairs in samoa " is rery distressing, and can only 
be made worse by a continuation of the war" ; that Mr. Sewall has been instructed to "preserve a strict neutrality" : and suggests the "adrisability of the immediate eleetion of a king and a vice-king, as agreed to in the conference." The reply that "all the important chiefs who had atsisembled had formally recognizet Tamasese as king," indlicates a misconception in Berlin of the true situation in Samoa. "The conduet of Malietoa," said Bismarck, "harl beecome unbeal. able, maltreating the Germans, and finally permitting outrages upon those who were properly celehrating the lirthlat of the emperor [the prince referred to the bar-som hal bil before mentioned]; that the German Govermment harl detel-

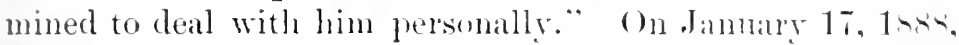
Mr. Bayard forwarderl to the Eniterl States Minister in berlin a long eommmication, reviewing in detail the events. in Samoa following the atjourmment of the commission, and complaining of the course of the fierman representative in Apia. This unwarranted eomse consisted in forcihly treat ing Tamasese king, in abrogating the neutrality of the pert. and in ignoring the protests of the American ('omsul - all alleged to be in derogation of the mulerstanding of the three powers to leare the sitnation in stote quo until a tinal settlement. Mr. Bayarel continued :-

The conclusion at which I an foreel to arrive from the revien of recent events in samon is that the present unfortmate situation there is due not to any action on the part of the representation of the Uniterl states. but to the fomentation be interesterl for. eigners of native dissensions, and to the desire exhibiten in a marked degree ly those in charere of local dieman interests to whtain personal and commereial adrantages and politioal supermaley.

Closing the despatch, he sait :-

Owing, doubtless, to her ammerejal prepomleranoe in the

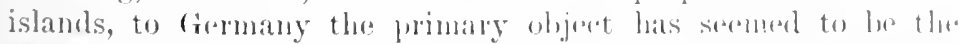
establishment of a stronger enoremument. To the lonted status.

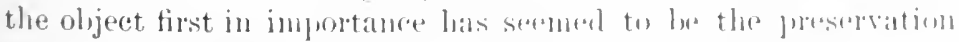

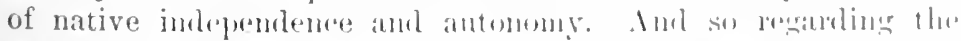

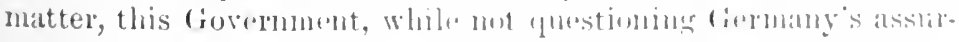


ances of the absence of any intention on her part to annex or establish a protectorate over the islands, has been compelled to dissent from propositions which seemed to subordinate all other considerations to the strengthening of the German commercial and landed interests in the islands, and correspondingly to diminish, if not entirely to destroy, the probability of the establishment of a Samoan Government, and of the neutralization of the group, at least in respect to the powers now immediately concerned.

During the peaceful continuance of the Tamasese Government, until the autumu of 1888 , but few despatches of real importance concerning Samoan matters passed between the powers. Both England and the United States felt dissatisfied with the situation: and while resenting the action of Germany in overturning the native govermment and setting up a king of their own choosing, they appeared to be adverse to further interference, so long as affairs in the islands moved along smoothly, and the new govermment gave reasonable satisfaction to all parties. In the autumn of 1888 , however, when Mataafa entered upon the seene in open rebellion against Tamasese and the German regime, the questions of nentrality and of German aggression were reopened. Mr. Bayard wrote to Berlin, November 21, 1888, that as often stated theretofore, "the desire of this Govermment is to see a lawful and orderly condition of affairs established in Samoa, under a govermment freely ehosen by the Samoan people. As to what chief may be at the heal of that government, it is to this government a matter of indifference. . . If any cause of complaint should arise out of differences between the consuls at $A$ pia, the matter shonld be taken up by their respective govermments, and settled at onee directly between them and not lie left to be the subject of contention in Simo:."

As the revolution progressed, and the situation in Apia became more acote, the commmnications between the powers took on a slight degree of pretmance. Count Areo-Valley, the (ieman Minister in Washingtom, reported to the State Ieprotment, Jamulay 10, 18s?, that :- 
The German forces were landed after the German commanter had given notice of his intention to the commanders of the American and british men-of-war, the reason for landing being that some German plantations were in clanger.

Epon so landing, the ciermans were attacked hy the Samoans under the command of Klein [a newspilpel correspondent], an American citizen, and lost fifty men killed and wommled. A state of war with Samoa is therefore annemmed by (iemmany, amel as an American is alleged to have been in command of the attanking samoan force, count Areo is instructed to make complaint to the United States.

Count Arco is also ordered at the same time by his govermment to say that the treaty rights of the Cnited States shall he respected under all circumstances, and all the rights of the treaty power's.

The German Government also begs the Cnited States to join them in an active way to restore calm and quiet in the island equally for the three treaty powers.

Mr. Bayard disclaimed any responsibility for Klein, and called Count Arco-Valley's attention to the argrement of the three powers in 1887 to leave to the simmons the free alection of a king according to their own will and constom. He adderl (January 12, 1889):-

It would seem most opportme if such an elertion could now practically be held, and I feel assured that it would do much towards ending the turbulent and hittre discontent which has led to the shocking internecine wafture anmong these islanters, and finally involved them in a loeply regetetable conflict with firman forces, which is sincerely deplored by the United states.

Prince Bismarck was less complatisint. () Jamulury 18, (1889), he wrote, in reference to the mishight raid of the German blue-jackets: -

.. This mprosoked attack is siticl to hatre taken plines

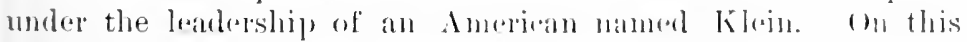

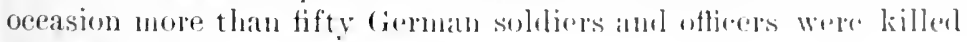
and wounded.

In conseguence of this we have beren tramsplanterl from the trorritory of mediatorial negotiations, hy whell the imperial cemsul in 
Apia was trying to reconcile the contending parties, and for which he had sought the coöperation of his English and American colleagues, into a state of war with the assailants, to our regret.

We shall carry on the contest which has been forced upon us by Mataafa and his followers, with the utmost consideration for English and American interests. Our military measures have in view only the punishment of the murderers of German soldiers and the protection of our countrymen and their property. As they, on their part, are at war with Tamasese, onr interference will necessarily assume the character of assistance to Tamasese. . . .

The worts "unprovoked attack" and the "murder" of German soldiers, are especially interesting, in the light of the fact that the armed marines were admittedly landed with hostile intent. It seems almost unworthy of the man of blood and iron to refer to the defeat of his troops in legitimate warfare as a "murderous crime." What if, in the darkness of that night, those same marines had succeeded in surprising their enemy, and had fallen upon the guard of Mataafa? Would it have been a "murderous erime" or merely a "legrettable inciclent"?

Count Areo-Valley complained that the task of settling these difficulties by amicable arrangement "has been rendered difficult by the fact that the officer in charge of the American consulate and the commander of the American war vessel [Leary] have, during the present revolution on the Samoan Islands, openly taken part against Chief Tamasese, who is recognized by the imperial govermment, and have supported Mataafa." In this the comnt may not have been so very far lrom the truth, and Mr. Bayard in his reply was also substantially correct in saying that "neither of these officers has assumed on behalf of the Govermment of the United States, to recognize Chief Mataafa, or to do any aet contrary to the i ival elains of Chiel Tamisese, other than to take neeessary stejs to protect Americans and their interest in those islands." In the same commmnication (Jannary 18, 1889) he sommded the key-note of the American poliey in Samoa as follows:- 
Deep as is the regret felt by this Government for the lamentable conflicts which have lately taken place between Grmans and the adherents of one of the native factions in samoa, and however sincere our hope that the unfortunate occurrence may be satisfactorily settled, this Government continues to feel it to be its duty to maintain its attitude of consistent neutrality, and not abandon the belief professed and acted upon for three rears or more, that the best assurance of peace and gnaranty for the equal protection of the rights of the three treaty powers in Samoa will he fomnd in permitting and assisting the natives freely to choose their own king, who should be recognized by the three powers and assisted by them in the administration of good govermment.

\section{In elosing the letter, he urged that:-}

The objection to Tamasese is wholly on the part of the preponderating number of his own comtrymen who deny that he was ever chosen by popular will, or that he is acceptable to them; to insist, therefore, upon his rule is to substitute the will of foreigners for the Samoan native government for which the majority have manifested their strong desire and which the treaty powers had certainly agreed to respect.

When news of Dr. Kuappe's proclamation of martial law reached $\mathbf{W}$ ashington and Berlin, Seeretary Bayalrd protested vigorously, and Bismarek realized that his energetic oflicer in Apia was orer zealous. On February 1 he arldressed the State Department: -

When the state of war was declared against Matana the commander of the German squadron issued a prociamation by which the foreigners established in samoa were subjected to mitrtial law. International law wouk, to a certitin extent, not prevent such a measure, but as Prinee bismarek is of the opinion that our military authority has gone too far m this instanee, the mili-

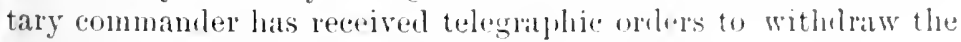
part of his proclanation concerning foreiguer's.

In negotiation with Matafa our consul at Simua has atsken

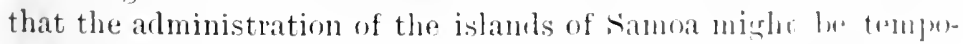
rarly hander over to him, which demand not heines in wnformity to onr previous pomises resanding the mentrality and independence of Samoa, Mr. Knapure has been ordered by telegram to withdraw immediately his drmant. 
This seemed indeed to be a very large concession from Prince Bismarck; clearly he was not in accord with Dr. Knappes scheme to gain political control of the group, or, if so, he lisapproved of the consul's methods. Becker and Knappe had played a high-handed game in Samoa, and had lost, and Bismarek seems to have beeome weary of the sham that was being conducted in the name of Germany. On February 4 , he instructed the minister in Washington to represent to the Secretary of State that:-

The present situation in Samoa regarding the interests of the three treaty powers renders it necessary to renew the attempt to bring the future of those islands to an understanding.

The position of the three treaty powers in the civilized world makes it their duty to stop the bloody combat accompanied by barbarous customs of those not numerous tribes, for whose welfare, according to the jumbment of the civilized workl, it is a duty of the treaty powers to provide.

Prince lismarck, in conserquence, considers it a duty of the participating goremments to put an end, by the agreement of the treaty powers, to the troubles which have originated in Samoa, and by restitution of peace among the Simoans themselves, and so make an end of futme bloolshed and the horrors of a civil war conducted with barbarons cruelty among the natives.

The best remerly seems to be a resumption of the consultation which took place between the representatives of Germany, Englaml, and the United States, in the year 1887 , at Washington, and at that time adjonrned without any possibility of their representatives coming to any agreement.

In consequence, I have heen requested by Prince Bismarck to propose to you to resume with Germany and the British Government the consultation regarding the samoan question. . . .

Thus Germany opened the door and the United States most willingly entered. Mr. Bayard's reply was ready the following day (February 5th): "The l'resident. . requests me to saty that he fully shares in the desire expressed by the prince chancellor to hring the blessings of peace and order to the remote and feehle community of semi-civilized people inhahiting the islands of Samoa; and that he elearly reeognizes the duty of the powerful nations of Christenclom to deal with these 
people in a spirit of magnanimity and benerolence." .. The sooner this conference can be resumed, the better." he amled.

John A. Kasson of Iowa, William Walter Phelps of New Jersey, and George II. Bates (the former commissioner to Samoa) were appointed United States commissioners to nneet in Berlin similarly qualified plenipotentiaries of Germany and Great Britain. The spirit of their instruetions Wis embollied in two short sentences: ". The olnligation of the United States in the Sonth Pacifie is to protect the rights and interests of American citizens who may be resillents there, and engaged in lawful pursuits. We lave no slesire to dominate." The commission was instructerl hy Mr. lialine:-

First, To ask the restoration of the stutus quo. While the President was unwilling to consider that at tion of (iermany, which immediately followed the snspension of the conferences at Washington, as intentionally clerogatory either to the dignity or the interests of the other treaty powers, yet he conld not but regard it, moler the ciremmstances, as an abrupt breach of the joint relations of the three powers.

Second, To seek for the organization of a stable governmental system for the islands, wherely native independence and antonony should be preserved free from the control or the preponderating influence of any foreign government: and also free "from all occasions of tromble arising from and fostered into mischievous activity hy the avarier and eacerness of competing merchants and land spexulators, and the irregular conduet of forcign officials, who are, perlaps naturally and excusably, hut most injulicionsly sympathetic with the prejudices and immediate interests of their resident sountrymen."

Third, 'To effect some system of aljustment and rewistry" of lanel claims.

fourth, To seek the adoption of some form of regulations or the impertation and sale of fire-ams amel alcoholic lignors, hat fatal combination where peace is lesireet.

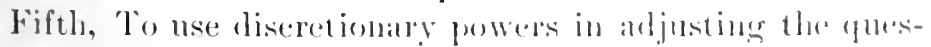
ions of neutrality and govermment in the municipality of Ipia. 
The commission met in Berlin, April 29, 1889. Prince Bismarck was chosen to preside orer the meetings, which eontimerl mntil June 1t, on which day the General Aet of Berlin was signed by the plenipotentiaries. During the course of the disenssion (at the 5th session, on May 22d), Mr. Kasson introdueed the subject of restoring the status quo in Samoi. Prince Bismanck replied that the prineiple of election in the choice of a ling by the natives was aceeptable to him, but that he was bound to make one exception in the person of Matiafa, on aceount of the outrages committed by his aclherents, and unler his authority, upon dead and wounded German sailors lying on the fiele of action. Sir Edward Nalet, (English) thought the exeeption fair and reasonable, and suggested that as Malietoa had been released by Germany, "we, therefore, propose that in the interest of the peace and the prosperity of the islands, it should be intimated to the Samoan people that if they will take Malietoa as king, such act on the part of the Samoans shall receive the sanetion of the treaty powers."

This seemed to all parties a good solution of the diffieulty. With two rival chieftains in the field (Mataafa and Tamasese), it was felt that if the first selection of a ruler under the new system were left to the natives, it would certainly lead to a renewal of eivil war. As Mataafa was persona non grata to the Germans, and Tamasese's influence among the natives was waning, the restored Malietoa appeared to be the logical candidate. His former popularity in the islands would no doubt be enhanced by the martyrdom he lad suffered in his country's cause, and he was morcover entirely acceptable to the three treaty powers. Sir Elward Malet's proposal was referred to a committee on revision, and subsequently arlopted.

This first restriction in the "antonomous" scheme of govcrmment for Samoa proved a mistake, as future erents slowert. It would probalbly have been wiser in the end hat Bismarek overcome his very natmal prejulice to Mataafa and permitted the natives from the begiming a freer rein in the choire of their king. 
The treaty as finally ratified provided an elaborate system of government for the islands, and the Inited states stood pledged, for the first time in its history, 10 share the responsibilities of good govermment in another mation and to assume, in a measure, the rôle of protector.

It will be seen that a variety of canses. leading step by step, in the settlement of the Samoan diffienlty, induced the Enited States to ignore those precedents which the wistom of its earlier statesmen larl establisherl. American trarle relations in Samoa were companatively insignificant, and the number of Aneriean citizens resicling there was rielienlonsly small. From a politieal point of view, the Sammans were like children, and it was recognized, hoth at Washington in 1887, and at Berlin in 1sse, that a purely native govermuent conld not maintain itself. No two of the powers would consent to invest the other with exthsive entrol, so the only possible solution of the problem seemed to be a tripartite agreement to establish and support some form of government at Apia in which all thee powers womlel pat tedipate.

but just there lay the wealiness. perhalss the folly, of the American attitule toward the whole glestion; it was fear that the rule of another nation in Simmos would operate atversely to the private interests of American citizens in Apia. It would have been far mose anomminal, if expense s a consideration, to have bought ontright all the Ambram mivate interests in the islands. or indeed, from a sentimental itandpoint, if the sense of ownership is ploasint. lo have argained with Gelmany and lingland for Ameritan ammexaion of the group. Posisibly an altruistir desire to fromote he happiness and welfare of the natives ly arling them in he establishment of gord government may have influnemest he United states to some extent, lut this sulpmestion will not vear tou close analysis. Nations do not suatlere the soents of hilanthopy broadeast, lut are far mole likely to plant llecir rops where the soil is good or the pusition is alvantalgams or military or other good reasons. At all events, the l hiterl tates drifted ont of an old r.annel inte a new ane. In igning the treaty of berlin, the Anerican nation contereal 
into an "entangling alliance" with foreign powers that at once involved it in foreign political affairs that concerned it the very least.

In sulstance the General Act of Berlin provides as follows:-

\section{Article I}

A dreduration respecting the imlependence and neutrality of the islamls of somod, and assuring io the respective citizens and subjects

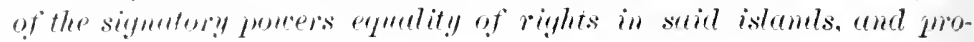
viding for the immediate restoration of peace and order therein.

It is declared that the islands of Samoa are neutral territory, in which the citizens and subjects of the three signatory powers have equal rights of residence, trade, ant personal protection. The three fower's recognize the independence of the Samoan Govermment and the free right of the natives to elect their chief or king and choose their form of gorermment according to their own laws and customs. Neither of the powers shall exercise any separate control orer the islands or the government thereof.

It is further declared, with a view to the prompt restoration of peace and good order in the said islands, and in view of the difficulties which wonld surromnd an election in the present disordered condition of their government, that Malietoa Laupepa, who was formally mate and appointerl king, on the 12th day of July, $18 s 1$, and was so recognized by the three powers, shall again be so rerognizel hereafter in the exercise of snch anthority unless the three powers shall by common aceord otherwise declare; and lis successor shall be dhly elected according to the laws and customs of samoa.

\section{Article II}

A deduration respecting the morlifiention of existing treaties and the assent of the Samoten Goremment to this act.

\section{AnTILLE III}

A decturation resperting the estallishment of a supreme court of justire for sermene and defining its juristliction.

Secetion 1. A supreme eourt shall be establisher in Samoa, to eonsist of one judge, who shall be styled chief justice of samma, and who shall appoint a clerk and a marshal of the court. . . 
Section 2. With a view to secure judicial independence and the equal consideration of the riglits of all parties, irrespective of nationality, it is agreed that the chief justice shall be namerl by the three signatory powers in common aceord; or, failing their agreement, he may be named by the King of sweden and Norway. He shall be learned in law and equity, of mature years, and of good repute for his sense of honor, imprirtiality, and justice.

His decision upon questions within his jurisdiction shall be final. He shall be appointed by the Samoan Government upon the certificate of his nomination as herein provided. He slall receive an annual salary of six thomsand dollars (s(i)00().00) in gold, or its equivalent, to be pair the first year in enfual proportions by the three treaty powers, and afterwards ont of the revenues of Samoa apportioned to the use of the samoin Government, upon which his compensation shall be the first charge. . . .

Section 4. The supreme court shall have juristiction of all questions arising under the provisions of this general act, and the decision or order of the cont thereon shall be conchusive upon all residents of Sanoa. The court slall' also have appellate juristiction over all municipal magistrates and officer's.

Section 6 . In case any question shall hereafter arise in Sinnoa respecting the rightful election or appointment of king or of any other chief claiming authority over the islands, or respecting the validity of the powers which the king or any ehief may clain in the exercise of his office, such question shall not lead to war, hut shall be presented for derision to the chief justice of Samoa, who shall decide it in writing, conformably to the provisions of this act and to the laws and rustoms of samoa not in confliwe therewith; and the signatory governments will acept and aldike by such decision.

Section 7 . In case any difference shall arise betwoen either of the treaty powers anel Simoa whinh they shall fail to arljust by mutual aecord, such differenes shall not be held anse for war, but shall be refereed for arljustment on the principles of justiere and equity to the chief justiee of Siambal, who shall make his derision thereon in writing.

Section 9. Lpon the organzation of the supreme ront thers shall be transferred to its explusive juriscliation :-

(1) All civil suits comerning real preperty sitmater in simoa, and all rights affecting the sane.

(2) All civil suits of any kind betwon natives and foreigners or between foreigner's of different nationalitios. 
(3) All crimes and offences committed by natives against foreigner's or committed by such foreigners as are not subject to any consular juristiction. . . .

Section 10. The practice and procedure of common law, equity, and admiralty, as administered in the courts of England, may be - so far as applicable - the practice and procedure of this court; but the court may modify such practice and procedure from time to time as shall be required by local circumstances. The court shall have anthority to impose, according to the crime, the punishment established therefor by the laws of the United States, of England, or of Germany, as the chief justice shall decide most appropriate; or, in the case of native Samoans and other natives of the South sea Islands, according to the laws and customs of samoa.

Section 11. Notling in this article shall be so construed as to affect existing consular jurisdiction over all questions arising between masters and seamen of their respective national vessels. . . .

\section{Article IV}

A declaration respecting titles to land in Samoa and restraining the disprosition therent by matices, and prociding for the investigation of daims thereto and for the registration of calid titles. . . .

Section 2. In order to adjust and settle all claims by aliens of titles to land, or any interest therein in the islands of Samoa, it is declared that a commission shall be appointed, to consist of three (3) impartial and competent persons, one to be named by each of the three treaty powers, to be assisted by an officer, to be styled natives' adrocate, who shall be appointed by the chief executive of Samoa, with the approval of the chief justice of Samoa. . . .

\section{Article $V^{\top}$}

A dectaration respecting the municipal district of Apia, moviding a local administration therefor, and elefining the jurisdiction of the municipal magistrate. . .

\section{ArTicle Vi}

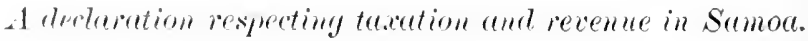

Sertion 1. The port of $A_{\text {p }}$ ia shall be the port of entry for all dntiable soorts arriving in the Samoan Islands; and all foreign goods, wares, and merehandise landed on the islands shall be there entered for examination. ... . 


\section{Article VII}

A declaration respecting arms and ammunition and intoxicating liquors, restraining their sole and use. . . .

\section{Article Vili}

\section{General dispositions.}

Section 1. The provisions of this act shall continue in force until changed by consent of the three power's. Cpon the request of either power after three years from the signature hereof, the powers shall consider by common ateord what aneliorations, if any, may be introtuced into the previsions of this semental act. In the meantime, any special amendment may be andopterl by the consent of the three powers, with the allherence of simnoil. . .

The assent of samoa to this general act shall be attesterl by a certificate thereof signed by the King and executerl in tripliciate, of which one copy shall be deliverent to the consul of earch of the signatory powers at Apia for immediate transmission to his Gurernment. . . .

It will be observed that the first article of the act sets forth the reeognition of the *- imlependence of the simman Government and the free right of the natives to elewt theil chief or king and choose their form of gorermuent aceorling to their own laws and customs." The ate then proceeds to evolve a system of "autonomous government "for the patient Samoans as follows: First. the king is to be clected and supported by the natives (salary later fixed at 81 son al year); then in the same elanse it is reciterl that the provers will select the king. Next comes a chief justice to be alponinterl by the three powers jointly at a salary of sligon: let is juovided with a clerk and a marshal, whose compensition is to be derived from offieial fees. The juristiction of the silpreme

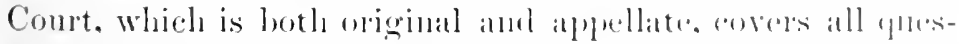

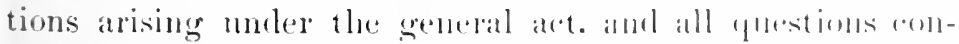

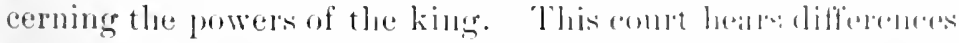
between native Samoans, reviews the qualrels of forcoingers, and exereises a right of appellate jurbiliolion were all land titles and litigation arising theref rom. In auldition to this and 
to the police courts of the municipality of Apia, duly provided for, the eonsuls of the three natious represented in simoa continued to maintain judicial functions aceording to the various laws of extraterritoriality.

The business of the ishonds is conducted at Apia, at which port the vessels that keep alive the trade of the nation arrive and depart, and it is there that the bulk of the revenues is collecterl. Accordingly a municipal council with a chairman or president is established. The president draws \$5000 a year. He is the chief executive of the district, and advises the king "in accordince with the provisions of the general act, and not to the prejulice of the rights of either of the three treaty powers." This comncil has upon its table the affairs of the municipal district of Apia, which in fact must virtually be the affairs of Samoa, as it collects the eustoms revenue as well as the taxes at the only point of export and import in the nation, and where the great majority of the tax-payers reside. The council appoints its own subordinate officer's for the district. All its legislative acts, howerer, are inoperative and of no effect until approved by the consuls of the three treaty powers in simmoa.

A land commission is established for the examination of all claims and titles to real property, their holdings being subject to review by the Supreme Court.

The salaries of all these officials, none of whom, exeepting the king, were likely to be native islanders, are to be paid the first year by the eontrating power's, and thereafter from the native treasury.

liosides this corps of officials and their lists of rules and regulations, the act provides a system of revenue eontaining a sehedule of export and import luties, and embracing a code of laws covering internal taxation.

On the face of the treaty it plainly appears that the gorermment provided for simom by the three powers was a joint protectorate pure and simple, - that the words "antonomous govermment" contained in the paper" were devoid of all meaning, while the act itself, in recognizing the "independenee of the Simoan (iovermment, and the free right of the natives to 
elect their ehief or ling and choose their form of government aecording to their own laws and customs," was a faree. There is no word in the treaty that left to the king any alctual power in his own realm. Every function of legislative or judieial govermment was to be performed by foreignors, who were appointed, and maintained if need be by the power of foreigners. The nation's revenues were to be collected. held and disbursed by the agents of the three contrateting powers: and finally, the eonsular representatives of the three powrs, whose sanction is necessiry to every legislative act, manifestly controlled the nation s policy. An examination of the treaty therefore discloses the fact that instead of securing to the native Samoans an autonomons government, as it julported to do, it simply stationed a cordon of foreigners alwnt the native king who should conduet the business of the nation in a manner not prejudicial to the interests of their home gorermments; and lastly it confirmed in the consuls their superior rights over all to control the destinies of the islands.

\section{VIII}

When the fury of the famous hurreane was spent, the war elouds that had hung low over simoa for more than a rear dispersed, and the islands were left distresserl, hut in pater. News of the efforts of the three powers at berlin to solve the Samoan social problems had reached Ipia, and all, natives and foreigners alike, remained expectant, - the latter no doubt vastly relieved. 'T'amatiese's straw palace fell, and that disappointed monareh, bereft of (iemman support, sulked in silence in his native village. The German and Amerienu flags were lowered, and the angry-worled prodamat inns were torn down to be burned and formotten. Dr. Kintple, the

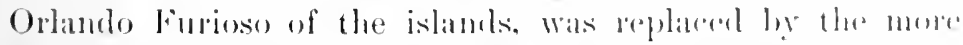

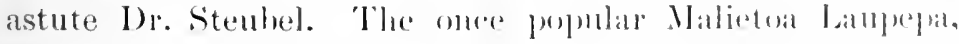

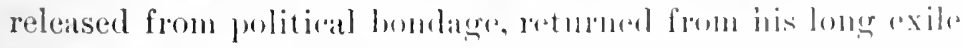
in the Camerooms to find his power and prestign belonging to another, his old ally and kinsman, Matalal. Matalial hat fought in the trenches, and had sulfered and bed lon the 
cause of Samoa against the aggressions of the "invincible strangers." He was the hero of the wars, and richly deserved all honors. But when the Berlin treaty reached Samoa, it was Malietoa, to the amazement of the natives, who was recommended as sovereign. The two chiefs found themselves in a most embarrassing and aggravating attitude of rivalry. Probably no other candidates for royal honors in the world would have kept the peace under such cireumstances. 'These two remarkable persons began a contest of civility, each pressing upon the other the acceptance of the crown. It was only by the extraordinary complaisance of Mataafa (a rare piece of good fortune for the foreigners who stood by the treaty) that Malietoa was at last accepted as king, and Mataafa, the Warwick, was content with the lesser dignity of vice-king.

The Samoans in due time gave their formal adherence to the treaty, and the foreigners in Apia celebrated the event. Chief Justice Cedarcranz (appointed by the King of Sweden) and Baron Senfft von Pilsach, the president of the municipal board, arrived, and took up the burden of their duties. The land commission set to work upon its seemingly endless task, and the wheels of the massive govermmental machine were set in motion. For about one year all went well, or at least aplarently so; but the seeds of dissatisfaction were in the soil and were maturing slowly. Now and then the natives betrayed rebellions symptoms, - the powers, they cried, recognize our independence and sovereignty, and accord us the right to elect our own king according to our own fashion, - a fair election would make Mataafa king; we, the majority, want Matalaf, why must we be sadrled with Malietoa, who is not our choice? The Supreme Court entered upon the usual routine of judicial duties, issuing warrants and other writs, which were duly served upon the people according to civilized custom. Wut which were as duly misunderstood and disregarded by the matives. The tax gatherers under the foreign rogine appeared on time to collect the governmental duess but they entered empty houses.

The relation of the native kings to the offeial foreigners 
was far from satisfactory. Malietoa's salary, out of which he paid all his own expenses, amounted, all told. to scalreely s:1.; a month - a beggarly allowance for even a Samoan prince - while the monthly stipends of the ehief justice, the president of the municipality, the chief of police and the private secretary of the chief justice were, respectively, sion, $\$ 15$. $\$ 140$, and $\$ 100$ a month, - in all $\$ 1155$. The difference wats too apparent. The natives had so often taster the bitter fruits of deceit in their dealings with foreigners, that suspicion quite naturally stole into their minds that they were again being duped. The treaty in one sentence accorterl them rights which in the next sentence it took away. The government was almost entirely an alien one which they, the natives, were obliged to maintain upon a scate of generous salaries. 'They realized that their own king, the only native officer, was a mere figurehead. Is an additional cause of grievance they were being taxed to support a gorernment not of their own creation, and were being promptly prosecuted by the courts if they failed to pay. It also appeared that the land eommission was confirming too many dubious titles in the German, Enghish, and American traters to seem entirely just to the Simoans-surely, they were being pluckerl.

While Malietoa was nominally king. all the pomp amel ceremony of that Gilbertian office, as well ats the management of the few affairs left to the native government. fell to the share of Mataafa. The latter having the stronger personality of the two, and being all the time consedous of the

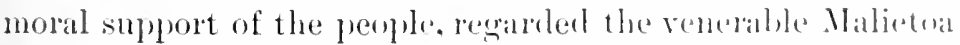
as "his poor brother," and maintained towarl his superion"

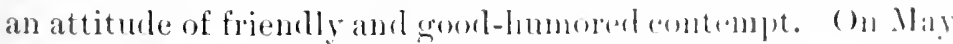

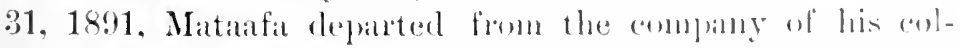
league and took 11 , his aloole at Malice at town some miles to the west of Apia, where he continmal to live in royal manner attended by retaners amb entertained by the visit-

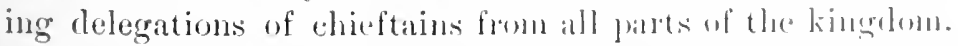
To the apprelensive foreigners of Apra the departure of Mataafa from his post of duty hy the siste of Malietoin at 
Mulinu was no less than a signal for a revolutionary ontbreak. The govermment officials trooped en masse to Malie, to persuade the disaffected monareh to return; and though they plied him with argmment, he politely, but none the less firmly, declined to resmme his former status of viceking. In Apia preparations were again made for war; but to the forbearance of Mataafa himself, be it saicl, peace was maintainerl, - this, too, in spite of the fact that the government declared Mataafa a relel, and his estates eonfiseated.

'The position of the latter at Malie was an anomalous one. While enjoying the ontwarl signs of royalty, and to all intents and purposes exereising the offices of a ruler over the native leoples, he conducted himself, nevertheless, in a manner wholly consistent with the scheme of government estahlisherl by the power's. Ile recognized Malietoa as king, obliged his followers to pay their proper dues into the legitimate treasury, and he sent his subjects, when arrested for any canse, to the Apia courts for trial. Still his attitude was an oninous one, and a nervous apprehension rested over Apia, lest at some mexpeeted moment the rebel forces would sweep into the eity. 'That such an occurrence did not take place surprised every one.

As might very naturally be expected, such unsatisfactory relations between the two rulers could not long continue. Malietoa became jealons and threatening; Mataafa gradually became offensive. On Decembel 6, 1892, United States Vice-Consul Blacklock, reporting upon the condition of affairs in the islands, wrote:-

Evor sincre Mataafa's establishment at Malie he has endeavored to gather strength, and there is not the slightest doubt had he bern suceessful in getting snfficent following, he would have makle war upen Malietoa. He has done every thing in opposing the (iovernment except making war' he has defied its courts, obstructol its oflucials in the exerution of their duties, harbored refingers from justice, sncored and supported prisoners escaped from frison, and at the present moment is living in open defiance of the king amd covermment amb all the laws of the combtry, keeping 11 : an armed fores and plundering foreigners plantations for subsistence. Time and again have white officials, who went 
to Malie with warants for the arrest of offenders, heon driven away by Matanfa's soldiers, and wamed against attempting any arrest under penalty of leath.

The expediency of sending war vessels to Apia to assist the government in enforeing its decress became a subjeet of correspondence in Washingtom, for the situation in the islands changing from bad to worse, the question had arisen as to the arlvisability of taking active measures to disarm Matalalia. June 19, 1898, Mr. Gresham wrote to Sir Julian P'anncefote :-

The Government of the Cuited States. while hepetofore inclined to confine its artion to participation in the maintenaner of the system of govemment devised ly the General Aet to the axecution of the process of the supreme cont and to keeping np such naval representation in simum waters as should suffice for the protection of Amprican life and property in those islands, is now prepared to go further, in view of the reported relmllious attitude of Mataafa and his followers, and will join in an all tive demonstration for the purpose of surromding and disanumg them.

Sir Julian in reply, a few days later, reported that " IIer Majesty's Government will heartily coüperate with the othur two treaty powers in the mamer and for the purposes mentionerl."

Accordingly, with the ready consent of fiermany, another

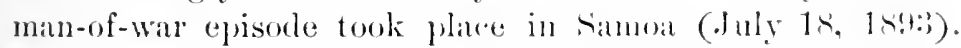
Before the arrival of the L. S. S. Philadelphie. Which had been hastily despatehed to the islands to assist in the dentonstration, Mataafa surrendered to the combined (icerman and English forees and was deported, as had formerly berou Malietra, to the Marshall Iskmels, where, with a mumber of chiefs who bore him company he was maintained in exilo at the joint expense of the three powers.

With the powerful Matalat ont of the way, and Malietoat

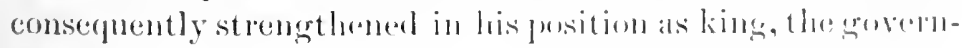

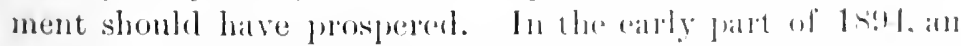
uprising of Tamaseseites distmberl the repose of the king, but the three comsuls, and king Malintoin stond longethele 
through the crisis. The revolution, after a series of skirmishes, and a rast deal of parleying, came to a close in September. This revolt was led by young Tamasese, the son of the former king, and a new eandidate for royal honors. Its object was the overthrow of Malietoa: because "he lias done much evil"; because "it is now more than twenty years since he has beeome king and he has done nothing for these islands"; and because "Samoa is completely drained by the payment of taxes." The latter reason was perhaps the urgent one. for accorling to most reliable authorities, any tax at all is too much for the Samoan natives. This rebellion was suplressed with a severity which called from Robert Louis Stevenson, then resilling at Vailina, the bitterest reproaches upon the three powers. Still another of those distressing man-of-war episodes took place, in which native villages were shelled and defenceless women and children killed. The ferocity of white men seems at times to be little less than that of more primitive people.

\section{IX}

After a period of a few years the "autonomous government" of Samoa, as provided by the Berlin treaty, was found to be a failure. At first the evident frietion between parts of the govermmental machine had been charitably overlooked, as the result of newness, and it was hoped, when once the pace was set, the system would prove satisfactory. As time progressed, all who were in a position to know became convinced that the scheme adopted for the islands was not only ineffective but actually pernicious. The discord which seemed inevitable among the various hearts of that triple dominion soon became manifest. 'The authority of the rhief justice and that of the president of the municipality came into more or less eonfliet. The land commission toiled faithfnlly, hut with exasperating interuptions, while its decrees bred dissensions as they displeased this or that faction in Mpia. The three consuls and the numerous officials of different nationalities interpreted the provisions of the 
Berlin Act as best suited their own or their eountry's politicil and commereial interests. It is not surprising, therefure. that the old racial enmities cropled out anew. It beraluse apparent, even to its most radical supporters. that the treity government could never fultil expectations. 'Tlue nativis soon came to ignore the authorities. The prosess of the Supreme Court was selilom served, and when served, it wats of little arail. The influence of King Malietor gramtually declined, until the last vestige of his power as native ruler of Samoa left him king in name only. The government hat no, authority whatever outside the settlement of Apia, and even within the little municipality itself, its impotent chalacter, combined with its cumbersomes structure, matle it serem like the creation of a comic oprera. The testimony of travellers, the reports of consuls, and the dismal complaints of the matives operated in a very short time to prejulice the antuinistration in II ashington against the maintenance of the Berlin Act.

At one of the sessions of the eonference in Bertin (1s-s:1), Count Bismarck harl sail, with full alplurval of the other plentpotentiaries, that the allugements would * be limited to at period of three or five years, to put them to the test." The act also provided for amendmest ( 1 rt. S. Sea. 1 ) alter three

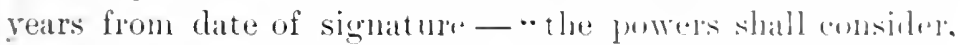
by common aceord, what aneliomations, if ans. maty le introduced into the provisions." Taking anvintinge of these

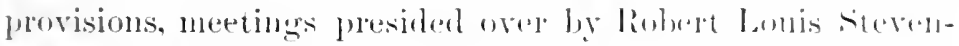

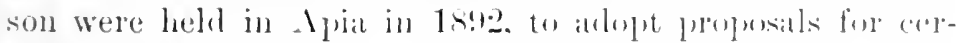
tain desirable ehathges in the ate These propmsals were forwarled to the thee signatory pumers. with the expleseserl hope that "they, the powers, might be willing to romainlep the opinion of persons on the spent. and intimaltely aleplatintal with the interests involved." The Amerian ('msul, . Mr.

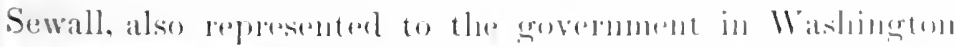

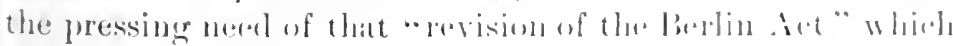

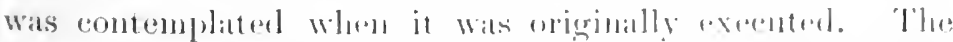

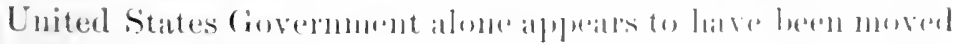
by the Stevenson memorial. for it. at leatst, matle some effort 
to bring about a convention for reconsideration of the act. Both Gemany and Great Britain declined to entertain the proposition, and the unsatisfactory governmental system, as originally adopted at Berlin, continned to exist, to the distress of the natives. and to the annoyance of all concerned.

Referring to the many tronbles of Samoa since the Berlin Act had gone into force. President Cleveland said in 1893, . This incident. and the events leading up to it [American interposition in Samoa]. signally illustrate the impolicy of entangling alliances with foreign powers."

The next year President Cleveland repeated his views upon the subject :- -

The present government has utterly failed to correct, if indeed it has not aggravated, the rery evils it was intended to prevent. It has not stimulated our commerce with the islands. Our particjpation in its establishment against the wishes of the natives was in plain defiance of the conservative teachings and warnings of the wise and patriotic men who laid the foundations of our free institutions, and I invite an expression of the judgment of Congress on the propriety of steps leing taken by this Government looking to the withdrawal from its engagements with the other powers on some reasonable terms not prejudicial to any of our existing rights.

In December, 189.;, the President was moved once more to touch upon the Samoan matter in his third annual message to Congress :-

In my last two annual messages I called the attention of the congress to the position we oreupied as one of the parties to a treaty or agreement by which we became jointly bound with England amd Germany to so interfere with the government and control of samoa as in effect to assume the management of its affairs. (Hu the 9th of May, 1894, I transmitted to the Senate a special message . . and emplasizing the opinion I have at all times mntertained, that our situation in this matter was inconsistent with the mission and traditions of our goverument, in violation of the principles we lnofess, and in all its phases mischievons and vexations. I again press this subjert. won the attention of the Congress, and ask for sureh lecrislative action or expression as will lead the way to our relief from obligation both irksome and unnatural. 
Notwithstanding the dissatisfaction felt in Samoa and in the capitals of all three of the contracting powers (expecially in Washington, where more conservative ideas of foreign relations existed than in either London or Berlin), no further attempt was ever made to alter the Berlin Act. The Samoans continnel to complain; the foreigners in the islands controlled their jealousies as hest they could. and all waited and hoped for some change. Relief came suddenly and in a most unexpected manner.

In 1898 news of the death of one of the chiefs who hat accompanied Mataafa in his exile to the Marshall Islands distressed the Samoan natives. A large majority were dissatisfied with the rule of Malietoa Lampepa, as they hat condemned the manner in which that monareh had been thrust upon them. They had never ceased to hope that justice womhl yet be done their favorite chieftain, the great Matalifa. The fear lest he, too, might succumh to the mulcalthy climate of the Marshalls, and suffer the disgrate of dying in exile, brought about a persistent clamor for his parton, and for his restoration to his own people. Even Laupera. his rival, joined in the petition to the power's for the pardom and return of Mataafa. The old hero was releaterl, and he soon after reappeared in his native province, anim the rejoicings of his devoted followers. He was under striet promise to keep the peace, and to respect the rights of Ling Malietua Laupepa-there should be no more revolutions.

Matalfa had searcely arrived in Samoa when hing Malietoi Laupepa died. This wils in August, 1sis. Aerording to Samoan customs, there is no direct suceession to the crown, nor can the king appoint his sulecessors. "The minner of selecting a ruler is peculiar. Only those belongring to certain clans or families are eligrible; and of these. the one who hats had bestowed mpon him. by the gerophe of his own or of other provinees, a certain number of homorifie titles, is alcerpted ats

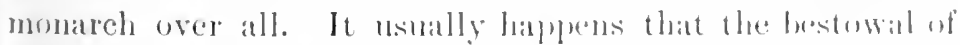
honors is carried to an mowarlantable dexpere doring an election period, and numberless disputes anise lectwren claimants as to the atuthority of a tribe to graut titles, and 
the rights of the recipients to receive them. Thus the last step in a Samoan election, according to native eustom, is a war of succession.

With the throne left vacant by Laupepa's death, three eandidates for royal honors at once presented themselves: Mataafi, the veteran, fresh from his enforeed retirement; Malietoa Tanu, a young boy, son of the dead ling; and 'T'masese, who, it will be recalled, had been ereated, by the Germans, king of Samoa in opposition to Malietoa Laupepa, in 1888. Each aspirant was of royal blood - i.e. belonged to families who were eligible to the kingship, and had, therefore, substantial elaims for the honor of sueeeding Laupepa. Tamasese hat a comparatively small following of several hundred men. Tanu was popular in Apia, and was supported by many foreigners, especially by the Americans and English, and supposedly by the Protestant missionaries; Mataafa had practically the solid backing of all native Samoa. He was the popular idol. Delegations of natives from all parts of the island rallied to his support. 'Thousinds of his adherents came to Apia in the hope of witnessing the trimmph of their favorite chief, and to assist in the ceremonies of his anointment as king. The result of the native eleetion (November 14, 1898) was in favor of Mataafa, both Tanu and Tamasese showing a pitiful weakness in face of the overwhelming strength of the Mataafa party. 'Tamasese had been induced at the last moment to withdraw in favor of Tanu. The latter, despite the inequality of the contest, and no doubt influeneed by his foreign friends and supporters, deeided to contest the clection with Mataafa. He maintained that Mataiafa was not eligible to the offiee, owing to the fact that he harl suffered exile, and that he had returned to Samoa only with the express understanding that he should never seek to gratify his royal ambitions.

The sixth section of the third article of the Berlin Act provicles that: -

In rase any question shall hereafter arise in Samoa respecting the rightful election or aplpointment of $\mathrm{King}$ or of any other chief claiming anthority over the isliuds... such question shall not 
lead to war, but shall be presented for decision to the chief justice of Samoa, who shall decide it in witing, conformaly y to the provisions of this Act and to the laws and customs of samoa not in conflict therewith; ...

The choosing of a king, therefore, fell at last to the supreme Court, according to the stipulations of the tripartite licrlin Act; but the selection of a ruler from the candiclates was, nevertheless, to be made by the comt in strict accordance with the laws and customs of Simoa. William L. ('hamber's, an Ameriean, was elief justice, moler anthority of the three signatory powers, and unom him, therefore, fell the responsibilities of the occasion. An excited popular interest, both native and foreign, became inflamed during the period of the trial. The Tentonic element in Apia wamly esponsent the cause of Mataafa, and his case was vigomously comducted in court by Herr von Bnlow, a German lawger well versed in Samoan traditions.

The American and English residents suspected that the lively German interest in Matalafas sulecess was owing to some secret molerstanding with that chicf by which, in the event of his election as king of simno, he wats to sulmit himself to the will of the German Govermment, and even aid in securing for it the ultimate control of the islands. Inelecel,

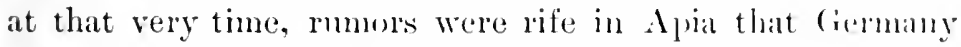
contemplated a decisive novement towarl that end. The usual jealonsies and racial antipathies in M pia were therefore greatly stimulater. The fermans did not eonecall their desire ultimately to win Simoa for themselves; hut for the present they had no hesitaney in asserting that Matatifil hald been rightfully and properly clected king, and that they supporterl him solely thromgh a sense of justice. Matalafa, it will be remembered, was the former arch ememy of the firlutins. He was in command of these forces which, in the politioil disturbances of 1857-85. harl ambusherl and killent some fifty German marines from the dollor. This act hat ralled down

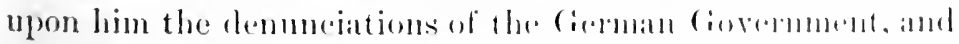
had left him barred from ruling over Samoa bỵ a potored of the Berlin Aet, - a eondition insisted upon, ats almauly statenl, 
by Count Bismarck before the signing of that instrument. The attitude of the Germans in suddenly befriending their former enemy in Samoa served all the more to arouse American and English suspicion in their motives.

It was upon the operation of this protocol that the Tanu party based its claims in court; - but thereupon Herr Rose, the German Consul-General, eame forward and officially withdrew his government's objection to Mataafa upon that score. Seemingly, then, Tanu was left without ground to stand upon. The eligibility of Mataafa having been acknowlerlged by the Germans, - the only party who might rationally object to his choiee, - and his cligibility having been aceepted ly Judge Chambers in writing, the result of the judicial investigation seemed to be fully assured in Mataafa's favor. Pending the trial, an agreement was signed by the representatives of Tann. binding themselves and their elients to abide by the lecision of the chief justice. Mataafa, firmly convinced of his rights, refused to enter upon such an agreement.

"After a trial of eleven days of patient investigation," wrote Judge Chambers afterward to his brother in New York, "two sessions each day and a hard study every night of Samoan genealogies, customs, titles, and praetiees, I eame to the eonclusion, from a legal and conscientious point of view, besides upon the treaty and the laws and eustoms of Samoa not in confliet therewith, that Tanu, the son of the late King Malietoa, and who, by the gift of the people, had been endowed with the name of Malietoa, was the duly elected king." By the same decision Tamasese was ereated vice-king.

Jurlge C'hambers' deeision was based, first, upon the protocol, which, he held, for all time barred Mataafa, and therefore left no other candidate in the field but the young Tanu; and, secondly, upon the fact that upon young Tamu only had been conferred, hy the natives, the requisite number of honorific titles which, according to their enstom, would entitle him to the kingship. The indignation of the Germans, and of the majority of natives, was very great when the result of the trial was proclained; indeed, when the opinion was first read, December 31, 1898, a riot was only averted by 
an armed force of marines landed from an English man-ntwar, - a denonstration in which the justice was hinsell fully prepared to join.

The decision was at mese aceepted by the Eunglish and American consuls-general. Messis. Maxse and ()slums. lun was indignantly seorned by the German ('omsul. Mrrle liske. With the Germans solidly opposed to the luling of the eom the and in open and avowed sympathy with the defeaterl party, Mataafa was encouragerl to lesist this decree of the court. Conditions were favorable for a revolt. A Ciemalln vesisel was in the harbor, and Matalafas warrinds wele restless and hard to restrain: for weeks they lad bern prephing to defend the cause of their chicf. and the moment was mow at hand. It was a period of intense excitement, and the Mataafins felt that their leader had been greatly wronged. For one day only was there hesitaney and suspense, and then the Mataafa forces hroke from their cambl at Mulimum and swept into Apia, headed, as the Americans allegred, by German officers, one detachment of the "leduls" artmally" being led hy the puesident of the municipality, Itran Johaness Raffel. The 'Tamu sulporters enuld not withstanul the "rebel" assitult: they thal in "very direction, many" taking refuge upou the british grmbots at anchor in the harbor, while the chief justice was himself ol, liged to seck safety in tlight. Mataafil was at once in eontrul. amel. With some pomp, crownet himself king.

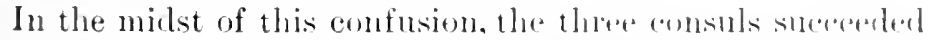
in effecting a truce (.Jammary 5. 1sig). ly the mmanimmos

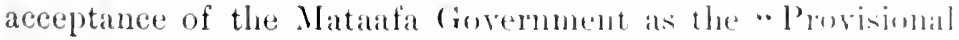

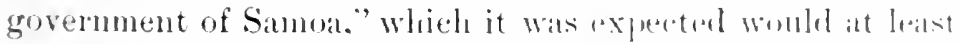
keep the peace until a way ont of the difficultios amble lmo

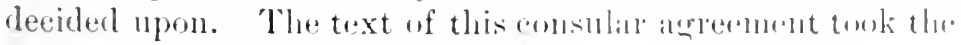
form of the following prorlamation:-

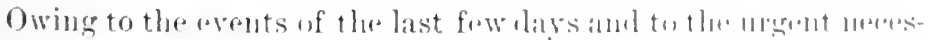

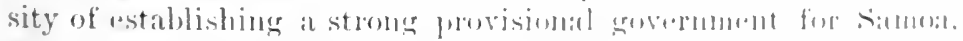

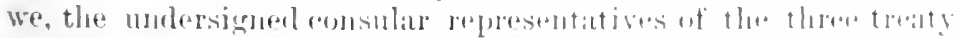
powers, derelare ats follows: -

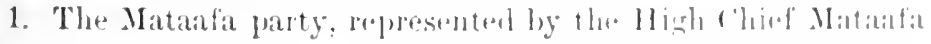


and the following thirteen chiefs . . . who lately acted in behalf of sairl party, and who are now in de facto possession of the gorernment, are recognized to be the provisional government of Samoa, pending instructions from the three powers.

2 The I'resiclent [of the Innicipality] to be the Exeentive of the saic Provisional Gorernment.

8. Tothing in this proclamation shall be taken as modifying or abrogating the rights of the three treaty powers in Samoa, either individually or collectively, or of their Consular representatives as now existing.

Given at Apia this 4th day of January, 1889.

Ruse,

Imp. Gov. Consul Gen.

L. W. Oslowis,

U. S. Con. Gen.

Elixest G. B. Maxse,

H. 13. M. Consul.

So far as the affairs of Apia were concerned, the president of the municipality, Herr Raffel, was thereby placed in control as the exeentive officer of the provisional government.

'This action was a decided victory for the German Consul, Ilerr Rose, as it gave the color of virtue to the revolution against the legally chosen Tam. With Herr Raffel in control, and with the sympathy of nearly all Samoa behind them, the Cermans in Apia were in a position to bring abont peace with the probable acecptance of King Matanfa by the powers. To accomplish these ends, moderation and a very keen appreciation of what was fitting and proper to do under the cireumstances were necessiry. However, both Herr Raffel and Consul Rose, being men of uneertain temper and somewhat wanting in taet, permitted their better judgment to be so far overeome by the exeitements of the moment that the very next dily after the proelamation they seized the conthomse, barred the doors, and issued a notice that the supreme comrt hat adjommed until further notice from the purisional government. In reply to this startling notice, Captain Sturdee, of the Enghish man-of-war, Porpoise, upon which the rhicf justice had taken refuge, issned a statement to the effect that the supreme Court having been "illegally 
closed by the provisional government, and the orders of the chief justice posted at the courthouse torn down by armed troops of the government, the chief justioe, sulporterl by the United States Consul General and IJer british Majesty"s Consul, under the protection of the armed forces of the Porpoise, will hold a court to-day at moon. If resistance is met. which it is hoped will not be the ease, fire will be opened to support the rights of these two great powers."

Thereupon Herr Raffel, no dombt recalling the words of Louis XIV, declared limself to be the Suprence ('ourt. and encouraged by the Gierman Comsul, he took formal possession of the building in the name of the provisional govermment. According to his threat, Captain Sturdee sent astore his marines, who accompanied Mr. Chambers to the comrthomse and assisted hin in taking forcilule pessession of the prenises. In this attempt to oust the (iemmans, jersomal encommters between high officials took place, amb Mr. ('himbers resumed his seat and the mingled cheers and jeers of the divided speetators. An indignant fieman resident violited the sanctity of the eourthouse by wilfully smashing its windows, whereupon . Justice ('hambers orelered him to be arrested, fined and eommitted to jail. Herr haffel thereupon released his emplatiot, and the German Comsul portested against the action of the American julge in lining a German subjeet. The Ameridan and English consuls returned sharl answers to Herr liose. and therafter eren the semblanee of peaceful relations ceased between the rival factions. As among the natives themselves, wall hetweren the whites in Apra was virtmally decelared, and the marines

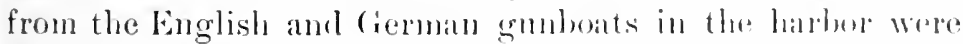
quite rearly to respond to any rall. In the meantine. Mattaafa with a force of several thousinul warriors helel Mulium, the royal seat, and barle clefinuer to all who shomld sere to dislorlge him. In Apia a reign of terror was inturgmated; throughont the island at seatson of riot and pillange lexean.

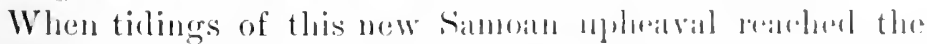
outer world, the three treaty jowers serement at a lose to know just how to atet. The oceasion was an atupicions one for the 
American press to open an assault upon Germany. Criticism of Germany was at that moment aceeptable to all parties, as the Admiral Diedrich episode at Manila Bay was still fresh in mind. The history of German intrigue in Samoa was fully reviewed in highly colored accounts, and the story of the lively careers of consuls Stenbel and Knappe were glowingly rehearsed to demonstrate Germany's hostile attiturle toward the United States. In these proceedings was found another link in that chain of evidence which proved the emmity of Germany. The German Government, it was insisted, should be called upon to answer for a gross violation of the Berlin Aet. That Consul Rose and President Raffel were wholly in the wrong there could be no doubt, for had they not refused to aceept the final decision of the Supreme Court, in violation of treaty regulations; had they not furthermore encouraged the defeated party into open revolt against the law of the land; had they not seized the courthouse, broken the jail, and were they not to be charged with having instituted a reign of anarchy? The valor of the Amerieans and English in upholding the deeision of the chief justice against great odds was highly commended, and a desire was generally manifested for a warship to be sent at once to the scene.

The German side of the ease was simply that the decision of Chief Justice Chambers was biassed, and deeidedly unjust; incleed, it was so outrageous it could not be tolerated. In justification of their conduct the Germans insisted that they had only songht to prevent the imposition of a weakling upon the people who was not the choice of the Samoans, and whose sueression to the throne would inevitably lead to war. They charged the missionary party with eomplieity (Mataafa being a Catholie), and .J ustice Chambers with corruption. If they had exceeded the bounds of propriety in their methods to relieve the situation in $\Lambda_{p}$ ia, it was because of their zeal to right a woug as quiekly as possible.

Much anxiety was nevertheless felt upon all sides lest the signatory powers would seek to mphold the acts of their agents in simoa, and thus expand the disturbanees in the 
islands into an international quarrel. Obvimsly the courso of wisdom lay in disregarding the reeent happenings in Apia. and proceeding at once to a review of Justice chambers decision.

Germany first relieved the tension hy a disavowal of the course which had been followed by her comsul-gemeral in Apia, and by the bestowal of a reprintme upon llerr Raffel. which caused that indignant official to resign his pusition. The Parliamentary Secretary for Foreign Affairs ammoned that England was awating further information before recogrnizing Mataafa as king of Samon. This evidence of a conciliatory policy on the part of (ireat britain further eatsenl the situation.

The first move of the Lnited States after a hasty diphlomatic parley in Washington between secretary llay aml the representatives of (ireat britain and (ivemany (where assurances were given that the matters would be peareably settled) was to (lespateh a war vessel with a eommandrer of high rank to the scene. Aceordingly the L.S. S. Philmelphie, Admiral Kintz in command, was immediately ordered

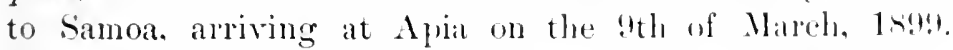
The admiral was instructed to enforce order, but to take mo decided steps in upholding either party withont urgent necessity.

The situation that Admiral Kitutz disovered upon his arrival in Apia was a tromblesone one with which to deal. An official deallock existerl. Matala Marriors were actire. and desultory fighting continued in all the islands. The ant-

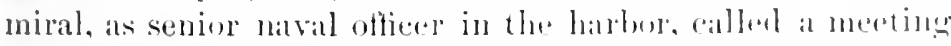
of the three comsuls and of the natral ammanturs then in

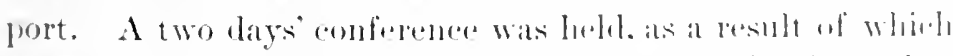
Admiral Kantz issued a proclanation on Mareh 11, sotting

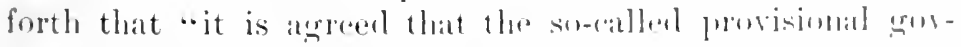
ernment, under the High ('hief Matiafit amel thirteren where

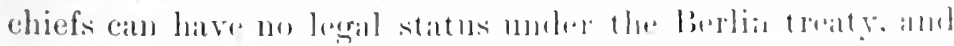

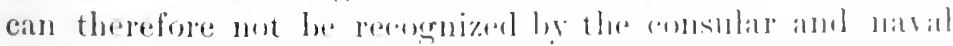

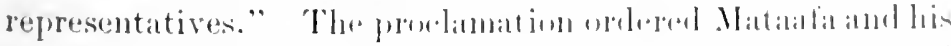

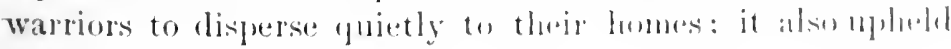


the decree of Chief Justice Chambers, and ordered that the chiefs of the Tamu party, who had been deported to other islands, should be returned to their own homes; it ordered that the decrees of the court should be respected, and ended in a threat that muless these things should be done, military force would be employed to earry out the purposes of the instrument.

Admiral Kantz, no doubt, assumed that a majority vote of the consuls was sufficient to authorize any such proceeding -an opinion which was not shared by the German Consul. 'The latter held that manimity of eonsular agreement was required to order the dissolution of the provisional government. Two days later he met the admiral's proclamation by a counter-proclamation which gave-

Notien to ald Samoaxs: By the proclamation of the Admiral of the Cnited States, dated March 11, it was made known that the three comsuls of the signatory powers of the Berlin treaty, as well as the three commander's of nen-of-war, had been unanimous in deciding to recognize no more the provisional government eomposerl of Mataafa and thirteen ehiefs.

I, therefore, make known to you that this proclamation is quite false. I, the (ierman Consul General, continue to recognize the provisional govermment of samoa mil I have received contrary instructions from my government.

A pia, March 13, 1899.

Rose, German Consul General.

Instead of dispersing, as ordered by Admiral Kautz, the: Matalafa party became more aggressively defiant and bold. They ocemped and fortified positions within the nentral area of the municipality. More 'Tanu supporters were captured and deported to other islands. The trimmp of Matalifa seemed to be complete when Admiral liantz interfered ly foree of arms. His ultimatum to the rebellious. chicftain to cease losstilities carried with it the threat of a bomlardnent to begin at one ordock, Mareh 15. When that moment arrived, the Matalans refused to yield their positions in Apra, and the shelling process began. American and English manines were landed, and fought side by 
side, the Germans taking no part. The war was carried on in all the islands. The Philadelphia. and the English vesisels, Porpoise and Royalist, began a systematic hombandunent of the coast villages which were known to be in symuathy with Mataafa. This method of warfare upon the detentedest natives, the women and children of the villages along the coast, hat been romully denoumeed by (antain beary when

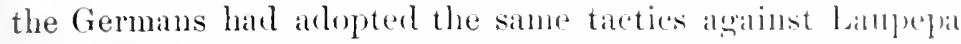
and Mataafa in 1888 ; and it is difficult to fimel justification for it at any time, whatever may be the puromation. To fire upon non-combatants is not only oppused to all pules of civilized warfare, but in these particular cases it womll soem to be the refinement of inhmmanity. The worst oftence of the natives was the desire to elect a ling according to their own custom, - a privilege accorderl them in the treaty, and for some mysterions reasum denied them. In me eneomuter (April 1), a squal of Amerioan and English salilor's. Jed by several officers from the Philadolphie, were smprised hy Mataafans, and a number killed and decapitaterl, inclurling two American officers.

Mataafa was, however, soom obligerl to retire from Mulimm, and Tanu was thereupon erowned king ( Mancl, :-?) in the presence of some natives and the Americam and linglish officials. Matalafa contimned in open rebellion, with hearlquarters in the bush, and a mumber of andingements of more

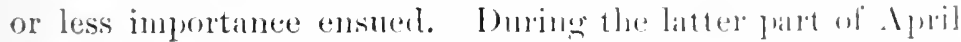
news reached Apia of the alpointment hy the these signatory powers of an investigating eommission. ()nly then was a

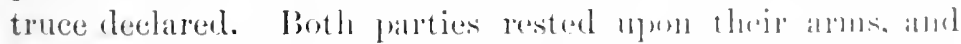
in at sullenly expectant mom the opposing foreding fintions in Apia consented to await the cominge of the ammonision.

As soon as it was possilule. the diplomany of the thene

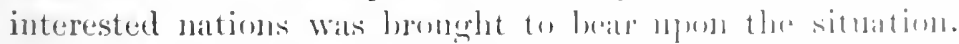
Fortunately all three powers assimed an mexperterlly andu-

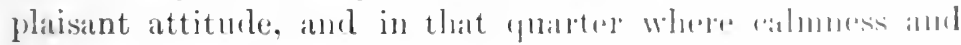

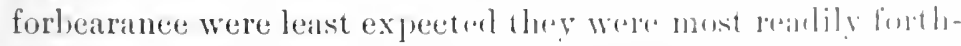

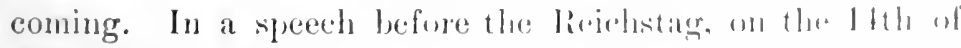
April, Herr von bulow declared that it "would be simply 
criminal to let loose war between three great and civilized mations" because of such a quarrel. From Germany, the traditional offender in samoa, came a proposition for a Joint High Commission, representing the three powers, to proceed at once to the scene of disturbance. The proposed commission should restore order in the islands, ascertain the causes of the present trouble, and report to their home government its recommendations for future legislation.

No more promising method of a settlement could be devised. The Lnited States and Great Britain at once accepted the proposition from Berlin, and general satisfaction was felt when the State Department announced the appointment of such a commission. The personnel of the commission inspired confidence, and the fact that the German and English nembers were selected by their respective governments from among the diplomats residing in Washington, and who were presumably in tonch with American opinion on the subject, gave further promise of a satisfactory conclusion. The commission departed from San Francisco April 25, on the L.S.S. Badyer, arriving in Apia on May 13.

The three commissioners were, - for the United States, Julge Bartlett Tripp, of South Dakota (elected Chairman); for Creat Britain, Sir Charles Eliot, Second Secretary of the British Embassy at Washington; and for Germany, Baron Sieck ron sternberg, First Seeretary of the German Embassy in Washington.

'The commission carried full authority to establish a provisional govermment in Samoa, and to enforce order. All ofticials under the lierlin treaty, or those representing their moremments in Apia, were instructed to smrender their anthority to the commission. Thus by aequiring full jurisdiction over the islands, the commission would not be hampered in the fulfilment of the more important duties with which it was charged. 'These duties were a careful inguiry into the social and political eondition of the islands; an examination of rival claims to the throne, and a review of the chief justices decision. The commission was further 
charged to make investigation into the eamses that led to the recent riots and disturbances, as well as to the bombarelments that followed on the part of the Anerienu and Enchish war vessels. and to the rarious arrests and acts of violence which had taken place. Finally, the commission was instructed to "consider the provisions which miglit be neeessary for the futme govermment of the islankls or for the modification of the final act of berlin," and report accordingly.

On their arrival, the commissioners found a condition of nervous excitement existing in Apia. Matalafan forces surrounded the municipality; native and white soldiers patrolled the streets of the town, six men-of-wal lay at anchor in the harbor, and all business was suspenderl. 'Their' reception by the usually demonstrative natives, as well as by the whites, was nnexpectedly cold. This lack of cordiality was owing to the fact that the natives distrusted the competeney or ability of a committee wholly ignomant of Simmoan customs to satisfactorily adjust their diffieulties. The commission lost no time in entering upon its double task. The first step was to disarm the natives, which was suceessfully aceomplished within two weeks by promises of restoration of the arms or their equivalent in money after peace hat been seeured. After a series of meetings with the residents, native and foreign, the commission reathed the eontehsion that the decision of the chief justice was raliul. "The decision deelaring Tanu to be king was the law of Samoa, and all who refused obedience to it violated mot the deeision alone, but the treaty upon which it was hased "wrote Mr. Tripp. Hence, a vinlieation of Arminal Kant\%.

The provisional goverument of Mattatat and IIerr Raffel which hat been inanguated by the thee eomsuls in ommary, having ceaser to exist, the commision derlatred 'T'anu to be king; but that young man, alleady wearierl of the uncertain glories of political life, and being, moreorer, ambitious to arlopt the career of a missionary, pumptly ablicated: 'Tlen arose the question as to the advisalsility of abolishing the kingship. The various islatuds wele canvassed, amb many 
meetings held with chiefs in various parts of the group, which resulted in a discovery that the larger sentiment of natives and foreigners farored the plan of the eommission to do away entirely with that office. In the wisdom of this reform both 'Tann and Mataafa agreed, the latter chief no doubt concluting to almandon his struggle against what now seemet to him to be the decrees of fate. Another provisional government was thereupon established consisting of the three consuls, with the presiclent of the municipality, Dr. Solf (Herr Raffel had resigned), as adviser. Pledges of pace between the rival native factions were secured, and harmony reigned when the commission departed upon the lomeward joumey, July 18. Mr. Chamber's left the islands, Mr. (Sborn was designated Chief Justice, and Dr. Solf remained president of the munieipal comneil. There was 110 king.

Before leaving the islands the commissioners reached an agreement recommending a new form of govermment for Samoa. Their eonelusions were embotied in a preliminary draft of treaty before the three powers for the amendment or the molification of the Berlin Aet. Accompanying the draft of treaty was a joint report explanatory of the proposed reforms.

The conclusions of the commissioners had been arrived at in a logital manner. First, the ills of Samoa and the evils which cansed them were investigated and classified, and then to each eategory of evils were proposed such remedies as seened to the commission best ealculated to remove or at least to minimize them. "These "evils" were grouped under" forr heads.

1. 'Thuse evils which appear inevitably to attend the eletion of a king in Samoa, and his subsequent efforts to exert his authority.

2. 'Thuse evils due to the rivalry of foreign uationalities and to the disposition of the whites to take sictes in native polities.

3. A class of evils having origin in the fact that there is no law or govermment in the istands ontside of Apia other than native eustoms. 
4. The evils arising from the insufticient enforement of the customs regulations allowing the distribution of anms among the natives.

To offset these fom prime camses of dissension in simma, the joint report poposen, - first, the abolition of the lingship. That, it was believerl, conld be effected withone eron the regrets of the natives. The oftice was a "complantively modern institution," of which it was " impossible to say any good whatever." In place of the kingship a "system of mative government analogous to that which works snceessfully in Fiji" was proposed. This system of native govermment contemplated a division of the islambls into arministrative distriets, corresponding to those recognized by samoan usige, and over each of which a native chief would presirle. These chiefs were to meet ammally in comeil: native compts womld be established with jurisdiction over minor 'rimes, and in accordance with native laws and customs.

The second elass of evils which found origin in the jealousies of the foreign faetions in Apia were reongnized to be the most difficult of all to meet. Hustility amomg the foreigners "permeates all departments of life." ". The traders on the one side combind against those on the of here.

The municipal comeil is divided." lieforms were declared never to be judged upon their merit, but always "by party considerations," - all offieer's were lomml to be partisans. As a cure for these evils three measmas were proposed: (a) the appointment of an arministrator to lee chosen by a neutral power, and who shomld posisess a larero measure of authority; (b) the alpointment of thre delegates by the signatory powers to assist the alluinistratur and also to exereise such eomsular powers as may locemene meressary. 'They, together with the athministrator, formu a " locrislative conneil"; (a) the abolition of enmsulat juriseliction and the consequent abambmuent of extraterritorialit 5 , thro being no real need of three separate jurlicial syotroms in the

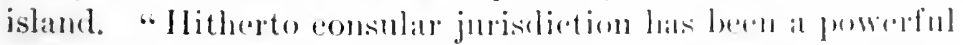
means of embittering intronal strifo in Apiat. Giall nationality has its own law, and the consul who adninisters that 
law was popularly regarded not as an impartial judge but as the protector of his own nationality. We believe that by abolishing this outward sign of separate internal institutions, and by submitting all nationalities to one court and one law, a great advance will be made in the direction of removing petty rivalries and jealousies, and restoring good relations between the various white colonies."

To meet the third class of evils - the lawlessness prevailing outside the municipality of Apia-the joint report proposed the enlargement of the jurisdiction of the chief justice over all the islands, so as to include all cases between natives and foreigners.

The strict enforcement of customs regulations according to law it was believed would remedy the evils of the fourth class, and such reform was therefore urged.

In brief, the recommendations of the commission for the alteration of the Berlin Act were for the abolition of the kingship and of consular jurisdiction, the extension of the jurisdiction of the Supreme Court and the establishment of native courts, the creation of a neutral administrator of large anthority and the appointment of a tripartite council which should act as a legislative council, each councillor being eharged at the same time with consular duties.

These recommendations were made as offering the best possible solution of the difficulties so long as the three interested nations should continue to maintain their positions in Samoa, but the commissioners frankly admitted that no wholly satisfactory arrangement could be made while the trijle-dominion contimmed.

We do not think it will ever be possible to do away with this state of things uncler a tripartite administration, and we take this opportunity of recording our opinion that the only natural and nomal plan of goremment for these islands, and the only system which can assme permanent prosperity and tranquillity, is a govermment by one lower. We regard it, however, as beyond our province to make any lut a general statement on such a subject, and we have endeavored to amend existing arrangements in such a mamer, that they may prove, if not entirely satisfactory, at least workable. 
The action of the Joint High Commission was generally approved in the United States. Those who had followed the course of Samoan history found in the proposed abolition of the kingship the removal of the chief cause of dissension in the islands. Most of the quarrels in Apia had no donbt originated in the more or less open attempts of one or another foreign faction to create a puppet king, who would do the bidding of his masters. With this source of dissension removed, the rival factions would have far less cause of disagreement.

In October, 1899, negotiations were begm in Washington for a joint consideration of the proposals made by the commission, and for the amendment or alteration of the Berlin Act. In Samoa, the probable partition of the group had for some time been hinted at, the current opinim being that Germany would insist upon the retention of [ [ polu, and that Great Britain would take the lirger but less important island of Savaii. Neither Great Britain nor the United States seems to have contemphlated such at tion at this partienlar moment, nor to have comsirlered the possibility at that time of abrogating in toto the Berlin Aet. From (rormany again came the rational proposition of the hour. All three powers had been impressed by the assertion of the Joint Commission that " the only system of govermment that can assure permanent prosperity and trampuillity is a government of one power"; but the difficulty lay in making a sattisfactory arrangement to that end. Indeed a division of the islands among the three powers alp peared to both England ind the United States a hopeless atecomplishment, however desirable such a solution of the difficulties might be. The rival interests of Germany and Great Britain in the Pateific soemed to preclude any such action - at least upon a thormughly friently basis. Inwever, the German foreign oflice insisted that the time for pratition hald come, and upwn no other basis comble the Samman difliculty he anljusterl. Ultimate apportiomment of the islambls was inevitalde, and no time, it maintained, comld be more anpmoprate than the present for such attion. The tripartite government 
hat proved a failure and a source of danger in the past; it would likely be the same in the future, were it permitted to exist.

In a scheme of partition the interests of the United States clearly entitled her to the retention of Tutuila and its valuable harbor of l'ago-Pago, and perhaps to no more; but the interests of Germany and Great Britain in the Paeifie were far more complex ; neither power eould well retire from Apia. In the first attempts to reach a conclusion in the matter of partition of the islands, it beeame very apparent that the group was, after all, too small for a satisfactory division, and the question soon narrowed itself down to whether Great Britain or Germany should retire from Samoa, in consideration of benefits to be granted, and leave the other in sole possession. The extent of land owned in Samoa by the Germans greatly exceeded the holdings of other nationalities. Their investments were larger, their trade greater. They had been the first to exploit the islands commereially, and had always taken a more direct and active interest in the govermment and polities of the Sumoans. Their claim to the group was probably stronger than that of England.

An understanding was reached in November, and it was quite fitting that Great Britain agreed to withdraw entirely from the islands. By Anglo-(ierman treaty, signed November 14 (18:9) $)$, Germany retained full possession of all the islanels of the Samoan group west of longitude $171^{\circ} \mathrm{W}$. This included the entire group, with the exception of Tutuila and some near-by smaller islands of little or no importance. As a eompensation for her abantomment of all Samoan claims, Great Britain aceepted from Germany the latter's jights in the Tongan Istands, a gromp lying several hundred miles south of Sannoa: England also reepived the German islands of Choisenl and Sin lsolel, of the Solomon gromp. Germany also marde certain other concessions to England in Africa.

()n lecember 2 (1899), a treaty was aceorlingly signed in IIslington by the representatives of the three powers. As this document marks the final episode of American complicity in Samoan affairs, it is quoted in full. 
A Convention signed at Washington, December "2, 1599, hetworn the United States, Germany, and Grat Britain, to aldust an inably the questions between the three ciovermments m respect to the Samoan group of islands.

The President of the Enited States of America, IIis Imperial Majesty the German Emperor, King of P'russia, and Her Majesty the Queen of the Lnited Kingdom of Great Britain and Ireland, Empress of India, desiring to atjust amicably the questions which have arisen between them in respect to the samoan sronp of lslands, as well as to aroid all future misunderstanding in resperet to their joint or several rights and claims of possession or jurisdietion therein, have agreed to establish and regulate the same by a special convention; and whereas the Govemments of Gemany and Great Britain have, with the concmrence of that of the United States, made an agreement regarding their respective rights and interests in the aforestici group. the three Powers before named in furtherance of the ents above mentioned have appointed respectrvely their Plenipotentiaries an follows:

The President of the United States of Amerua, The Henorable John Hay, Secretary of State of the Inited states;

His Majesty the Geman Emperor, King of P'mssia, II is Ambassador Extraordinary and Plenipotentiary, Jerr von Holloben; and

Her Dajesty the Queen of Great Britain and Ireland, Empress

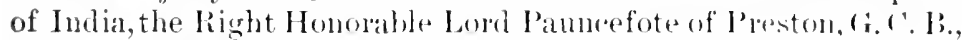
G. C. M. G., Her Brittanic Majesty's Ambassador Extraordinary and Plenipotentiary:

who, after having communicated carh to the other their respeetive full powers, which were fombl to be in preper form, have agreed upon and conclnded the following alticles :

\section{ALTILLE I}

The general Act concluded and signed by the aforesaid lowers at Berlin on the 1.th day of Jume, A.1. 1ss?, and all previnsts treaties, conventions and agreenents relating to simoa, atre antiulled.

\section{AlTHL: H}

Germany renounces in favor of the luited states of Amrion all her rights and rlaims over and in lespert to the Islamb of 'Tutnila and all of here islands of the Samoan grouy east of Longitude $171^{\circ}$ west of Greenwich. 
Great Britain in like manner renounces in favor of the United States of America all hel rights and claims over and in respect to the Island of Tutuila and all other islands of the Samoan group east of Longitude $171^{\circ}$ west of Greenwich.

Reciprocally, the United States of America renounce in favor of Germany all their rights and claims over and in respect to the Islands of Upolu and Savaii and all other Islands of the Samoan group west of Longitude $171^{\circ}$ west of Greenwich.

\section{Article III}

It is understood and agreed that each of the three signatory Powers shall continue to enjoy, in respect to their commerce and commercial vessels, in all the islands of the Samoan group privileges and conditions equal to those enjoyed by the sovereign Power, in all ports which may be open to the commerce of either of them.

\section{Article IV}

The present Convention shall be ratified as soon as possible, and shall come into force immediately after the exchange of ratifications.

In faith whereof, we, the respective Plenipotentiaries, have signed this Convention and have hereunto affixed our seals.

Done in triplicate. at Washington, the second day of December, in the year of Our Lord, one thousand eight hundred and ninetynine.

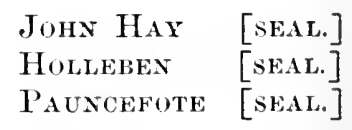

The treaty was ratified by the Senate, January $16,1900$.

The trials of the Samoans, which they had endured for many years moler the administration of three jealous protectors, are enlerl. Whether they will in future fare better or worse under the single rule of Germany is a matter that concerns only then and Germany, - the United States is happily reliever from all further responsibility in the matter. The cutangling alliance so freely eriticised by l'resident Cleveland and by Secretary Gresham has heen broken, not hecause of Washington's advice, but becanse it proved burdensome 
and dangerous to the peatee of the United States. After a trial of ten years the outeome of the berlin let may be viewed in the light of Mr. (rreshan is prophesy. The tirst departure of the Cnited sitates from a traditional and well. established policy of aroiding entangling alliances, was not a successful venture. No evidence can be fomml of detriment suffered before, nor of substantial advantages afterward gained, to demonstrate, in this partieulal calse. the wisdom in the elange of that national policy of nom-interference. The responsibilities imposed upon the Inited states, as a party to the berlin Act, brought only vexatious aures. expense, the loss of several natal ressels, and many lives. Several times it threatented to involve the comntry in wall.

Among the assets, if there are any may possibly lue combed the acquisition of Tutuila, and its vatuable harbor of PagoPago; but the acquisition of this can hardly be aseriberl to the results of the lerlin treaty. American riglits in this harbor antedated that treaty, and were held in abeynoeso long as the triple dominim existed. Inited states" trarle with Samoa is at best very small, and its increase in the decalle from 1889 to 18 . was but a meagre return for the amoment of energy expended in its behalf.

The disposition of the islands, according to the recent treaties, is wholly satisfatery to all proties. (iermany has a coveted satisfaction of ruling supreme over simon (barring Tutuila). A strong mational sentiment, possibly the ontgrowth of an early interest folt in eolonial explansion in the South Seas, has placed the (Berman raluation upon Sianom fal in excess of its real value. For the gratification of this sentiment, Gelmany was willing to give England substantial compensition elsewhere. with which eompensation England is apparently perfectly enutent.

The Enited states has atequired all it has aver dresired al

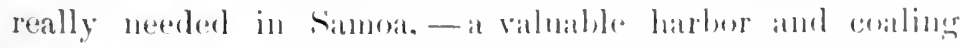

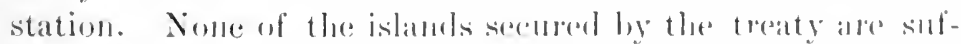

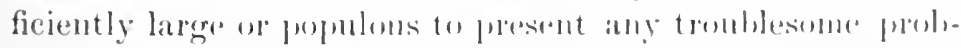

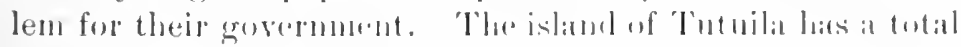
superficial area of something ovel two lammleel squate miles, 
and has an estinated population of about three thousand. The natives are peaceful, marmed, and well disposed to the Cnited states. 'The harbor of Pago-Pago is an ideal one, said to be the best in the Pacific; it is, moreover, susceptible of easy defente. Its strategic value is very great. Several much smaller islands to the east and south of Tutuila (of no particular importance) fall to the share of the United States; but as these are of no real value to any one except their own native inhabitants, they are not likely to become a burkensome care.

Contracts have been made for the improvement of PagoPago harlor, for coal-sheds, docks, etc. On February 12, 1!100. the President formally placed the island of Tutuila uncler the administration of the Navy Department, and Commanter l'. R. Tilley, U. S. N.. became first military governor.

Here, the "Samoan episode" closes. 


\section{IV}

\section{THE MONROE DOCTRINE}





\section{IV}

\section{THE IIONROE DOCTRINE}

THE instinct of self-preservation is the first law of nature. As a natural law governing all living creatures, it takes precedence over the social or artificial regulations of matnkind. Under whatever municipal code an individual exists, he may freely ignore it when necessirly to preserve his life; his only solicitude, if placed on trial, need be to prove that his alleged wrongful aets were committed in self-defence. And so it is, to a eertain extent, with nations. Like individuals, they stand before the publie law - the law of nations - with definite rights and duties. First and fundamentally, they possess the right of sovereignty and independence, and a freedom of action that is limited only by the obligation to respect similar rights in other nations. As in the case of individuals, the exercise of their own rights must be without injury to others.

The international law permits one nation to violate the sovereignty of another in but few exceptional instances. Thus, for humanity's sake, a continued eourse of cruelty or needless bloodshed on the part of any one powere may arouse international eoncern and justify intervention. But any atet intending to destroy the existence of a nation of to limit its sovereignty, when eommitted muler the plea of solfdefence, must find its justification in a coole liggher tham international law. In the common law, homicide in silfdefence is justifialule. In this respeet, throfore, there is a distinetion between the enmmon and the public laws. the latter not yet having fully come to recougnize silforleforme as a justifialsle eause of action. But though the public 
law has not distinctly provided for acts committed under the plea of self-preservation, it is constrained to tolerate them.

The propriety of all defensive acts must be judged by the peculiar circunstances surrounding them, for it is obviously impossible to frame definite and specific rules to govern all cases, as it is impossible to measure, with accuracy, the amount of dinger that, at any given time, may threaten a state from without.

It may be said, therefore, that the duty of states to respect the sovereignty of their neighbors is subordinated to their natural right of self-preservation, - all social laws being in abeyance when existence is in question. History furnishes a long list of infringements upon the sovereignty of states by others which, appearing to have been committed in a spirit of self-protection, have been allowed to pass as excusable. Such extreme cases as the actual invasion of foreign territory, in order to protect persons or property, to suppress insurrection, or to put down race rebellions, are upon record, and often they have been regarled as entirely proper. 'Thus, under certain circumstances, one state ma actually assert its sovereignty to the extent of using violence to accomplish ends within the territory of another, and still not run counter to the dictates of law. The doctrine of self-protection may take such extremes, but it is unfortunate that some international arbiter has not yet been constituted to determine the good faith of the nation or nations so intervening. In Enrope the greater nations exercise a watchfulness over each other by a quasi agreement, expressed or implied, known as the "Balance of Power," whereby all are pledged to prevent any one power from encroaching too greatly upon another, and thereby unduly acquiring a strength and influence that miglit prove dangerous to the welfare of the others. 'To this general policy may be attributed the present integrity of the Ottoman Empire. In the same manner was Belgium established, and now npheld and maintained as an inviolable state; for such reasons have the Balkan states been shifted to and fro at the will of the greater powers. 
It is impossible to anticipate what course of action maty suddenly be made necessary by national eompliations, and it would be useless, therefore, to attempt a definition of all the extraordinary powers a sovereign state may excet in a moment of extreme langer. Sultice it to say, it may do anything within reasmalble hounds; the conscionsmess of right that exists in all learts will give sinction. provicled it is elear, and above all donlis, that the danger is real and that the act done is in good faith, and not prosecuted beyond the strict requirements of self-clelence.

The celebrated Monroe Doctrine of the Cniter Statrs finds its origin and its justification in principles of a similat character. In this instance there was no artual interention, no overt aet on the part of the Enited States in rerogition of what, in the public law, had been alecepted as the sorereign rights of other nations. In this case Mr. Monroe dirl not choose to wait until the actual emmission of threatened acts which, in lis julgnent, would endanger the intrgrity and peace of the Enited States, but grave notice to the European powers that certain enmmerated acts, if perpetrated, would be resisted by forcible intervention ly his government. The doctrine in its chanacter is rather proplyylactic than enrative, - preventive rather than remedial.

In so far as the Monroe Doctrine forloils otler sovereign powers to do what properly belongrs, as of right, to all sorereign powers, it can find no place in intemational law. It is useless to seek, through ingenious argument, to imest it with the sanction of an international corle. It was purely, and simply one of those measmres of self-defence which, falling outside the legal presogatives of a sorereign state, is justified anong eivilized nations only by virtur of an necessity. This has been essentially the Anmerian view. It is quite certain that the other civilized nations of the work have not aceepted the principles enunejated in this doetrine as a part of the pullic law, num do they arbut ilsat its existence is, or ever was, necessitry to the siffety of the l'nitul

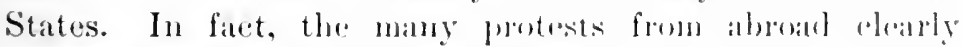
indieate that the workl in greneral hats reganded this mational 
policy of the United States as wholly beyond the public law or the requirements of national self-defence.

In respect to colonization, all authorities seem to agree that territory, unoccupied and belonging to no one, may be appropriated and held by any nation when its subjects enter it. with the intention of remaining. So far as the Monroe Doctrine relates to colonization, the question at once arises was there any territory properly res nullius, or belonging to no one, in either of the American continents when President Monroe issued his edict against colonization in 1823? If not, the interdict was useless ; if there were territory capable of appropriation at that time, the declaration, under the international code, was clearly illegal. It proposed a third requisite to the right of colonization, to wit; the consent of the United States. No amount of argument can reconcile the proposition with the public law, nor can any considerations of self-defence invest it with strict legal authority. If such were the case, the United States would be justified in seizing Canark, and Great Britain would be wrong in seeking to defend a colony that threatened the United States with a contiguous boundary line of three thousand miles.

Now, to what length a nation may go in throwing off its obligations to respect the sovereignty of its neighbors on the score of self-preservation, or even of protection or immunity against less serious attack, is a question of politics rather than of law. In the nature of things there can be no exact and ascertainable measure of danger or of security ; it is. manifestly difficult to say at just what point one may bid another cone no nearer.

Bearing in mind, then, that forcible intervention in the alfairs of other nations is excusable only when committed in self-rlefence and when the danger is real, imminent, and direst, - not speculative and contingent, - and only when the interference is itself actually necessary, and is kept within the limited bounds anthorized by the circumstances of the case, ancl, furthermore, when the interference is not resorted to with a view of aggression or spoliation, - then, and from such standpoint only, ean the so-called "legal aspects" of 
the Monroe Doctrine be examined. Was the Lnited States threatened from abroad in 182:3? If so. do the danger's which threatened the United States in 1823, and called into being the principles of the Monroe Doctrine, threaten the country now? Would a new eolony of European origin in South America be a menace to the best interests of the United States to-day? If a doctrine that found its origin in a gennine call for self-preservation is no longer upheld and sustained by that necessity, is its continuance as a national policy longer justified?

The widest divergence of opinion is to be found in the United States upon this subjeet, no two writers to-day agreeing precisely upon the propriety, the wislom, or the value of the Monroe Doctrine as a defensive measure. Inteed, all phases of the doetrine, from its allegert origin in the political conclitions of our earlier national existence. its authorship, its applications, in fact, its very meaning, lave furnished ground for endless diseussion. Suffice it to say, the principles involved grew ont of certain eonditions of our national growth, and the doetrine was then inroked ats a defensive measure to meet what seemed to be a menace to our institntions. That which spmang ont of an emergency lass heecome a vital principle in the foreign policy of the lnited Sitates: indeed, it seems to have become a sort of fetish for mationil worship, - the ignis fatums of Aneriean prolities. Created as it was to meet the exigencies of the time, it has heen expanded into a national letermination that the new workd must be kept sacred from all European colonization or use. In the course of ehanging arlministrations, and with the consequent changes of opinion at the White Howse amd the Capiltol, the doctrine has too often been distorted from its origrinal meaning, and sometimes rised to sirve the ents of pilly warfare. It has been quoted as anthority for constituting the Lnited States Crovernment the gutmolian and protector of all the nations of the Ameriean eontinents. liy some it is limited to defensive measures: by whers its interpletation would justify all sorts of foreihle ingeression. From a mere right to protect ourselves, the Monroe boetrine hats been 
converted into a right to annex Cuba and any other of the West India Islands. In it is found the right to construct the Nicaragua Canal on foreign soil, and subject its shores to American juriscliction; for, by seizing and controlling these outposts. and, in faet, all other contiguous or adjacent lands, it is urged that the Liniter States would be following a consistent policy of self-rlefence. There is a danger that the more prowerful and formidalsle the United States becomes, and the more grasping and insatiate its policy of expansion, the more unrestrained will beeome the Monroe Doctrine. It may, in time, be too frequently construed to justify acts which never entered the conceptions of its author.

A clearer understanding of the principles embodied in the Monroe Doctrine may be obtained by glancing at a few incidents in the history of our foreign relations from the ending of the Revolutionary War (1783), to the close of President IIonroe's administration (18:24).

Although the Monroe Doctrine itself, as announced in 18:3:), was ostensibly a lefensive measure against the threatened aggressions of a powerful European alliance, there can be no doubt that it was also the annomeement of a general poliey that had been gradnally forming in the American mind for a number of years. This sentiment was the natural ontgrowth of the antagonism between the principles of clemocratic govermment, as adopted in the United States, and the ofposing doctrines of monarehical government, which obtained upon the continent of Europe.

When the Revolutionary struggle was over, and England hanl acknowledged the independence of the United States (traty November $30,178: 3)$, the newly created nation was exhausted and disorganized ; its resonrees were small, and the country was great only in its future possibilities. 'The territory it ocenpied was a mere strip along the eastern const of the rast and little-known American continent. On its entire northern frontier lay English colonies that 
were more than passively unfriendly; British fortifications and hostile Indians along the lakes and upler Ohio Rivel impeded expansion to the west. On the sonth and the southwest, France and spain overshatowed the pioneer republic in extensive domain.

Under these conditions, the earlier American statemen were tempted to protit by the rivalries of European nations, and thus obtain by foreign allinnces, the strength neeessiry to carry the republic through the critical perion of infuncy. A single venture in this direction (the treaty with France. of 1778) taught the fathers a nseful lesson. It was but a few years later that France, finding herself involved in wall with Great Britain, promptly ealled upon the Lnited States to fulfil her treaty obligations. This the Cnited states was unable to do. To invite another war with Eugland womlel have been suicidal; to remain neutral was to offend France. In either case, the legitimate result of medhling in the affairs of Europe seemed to be war; and although actual watr wats in this instance aroided, a bitter party-spirit, aloused by French sympathizers, produced dissonsioms threatening the peace of the nation. From the first, however, the wisel statesmen of the period realized not merely the alvisability. but the necessity, of holding aloof from ail foreign entanglements. This sound principle found its best expression in Washington's farewell arldress, and long continmed to be the watchword of suceeeding administrations, and the cornesstone of the nation's foreign policy. Each l'resident in turn guarded this rital principle of nom-intervention, and the young nation greatly prosperen in its callecer, paying no tribute to the clemands of neenlless wats. Cimbledying the reasons usually griven for mantanining an isulated politiond position in the world. namely, the weatkuess of the conntry.

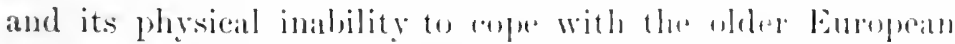
rations, a subtle motive is asily talcenl. It wat fint that the system of popmlar governumblt inamerntated ly the loniterl States wonld be watrhed with some appledension hy the crownel heals of Europe. If the experinent in romstitntional government shombl prove sureessful, its effeet on 
European forms of govermment was obvious. Indeed, in some of the European nations a decided hostility had already been manifested against tyramnieal institutions. 'The belief that absolutism was divinely ordained, or that it represented the best form of government, was being rudely shaken throughout Europe. Royalty was naturally suspicious of all movements toward popular institutions, and the fear that monarchical Enrope would regard somewhat sullenly the success of clemocracy in America, was not unreasonable. Here, then, was a somree of danger to be guarderl against; the liberty so dearly bought was truly worth the price of eternal vigilance.

A clouble peril was therefore presented to the struggling young nation at the very beginning: First, the danger of being tempted into unfortunate alliances with stronger powers; and secondly, that of unprovoked attack by the forces of monarchical government from purely political motives. In those days royalty eommanded stronger armies and navies than the United States eould possibly support. The ideas of popmlar sovereignty and the divine right of kings wele essentially antagonistic; and the notion that the erowned lieads of the old world might seek to strangle the infint giant of the new, was not altogether unreasonable.

Mr. Jefferson expluessed this apprehension as early as 1785 , when he wrote to Monroe from P'aris, urging him to add his "testimony to that of every thinking American, in order to satisfy our countrymen how much it is in their interest to preserve minfected by eontagion those peeuliarities in their government and mammers to which they are indebted for those blessings." In his seeond ammual address of Deeember, 17!8, John Adams said :- -

To the usual suhjeets of gratitude I cammot omit to add one of the first importance to our well being and safety; I mean that spirit which has arjsen in our eomtry against the menaces and ascression of a foroign nation. A manly sense of national honor, dignity, and independence has appeared which, if meouraged and invigurated by avery branch of the government, will enable us to view mulismayed the enterprises of any foreign power and become the sure fomdation of national prosperity and glory. 
But it was Jefferson who grasped the irlea of foreign antipathy more definitely, perhays, than had any of his contemporaries. Although a strict construetionist, he violated his eonvictions of constitutional interpretation and purehased the Louisiana territory to lieep it ont of the hamels of fiance or England, either of which he regarderl as a dangerons neighbor. "Previous, however, to this periol." he mrged npon a hesitating Congress "we had not been malwalle of the danger to which our preace would he perpetnally exposed whilst so important a key to the eommeree of the Westem country remaned under foreign power." This sudden acquisition of a large contignous territory, bringing inte the nation an empire to be settled and prepared for statehood, strengthened the bonds of the ferleration, and garce fresh vigor to the Republic. It also furnished additional reason for the strict observance of the principles of mon-interferenee, and for redoubled watchfuhness against all manncr of foreign aggression. With new ares and responsibitities, these principles developed still more ripirlly, and fomml final axpression in President Momroes famoms messige twenty years later.

The purchase of Lonisiana gire to the Inited States a :olor of title to the Spanish juovine of 11 est Florirlat, and xisting eonditions at home and in Spain male it likely that he Lnited Sitates conld acquire this rahnalle strip of enat and. The title in question wats gerhaps less complete than he determination to secure it ; for after a proclamation to he effect that the Lnited sitates would hohl the territory sending future settlement, President Madism anlliessed the ienate, January 3,1811 , as follows:-

Taking into view the tenor of these seyeral rommumbations,

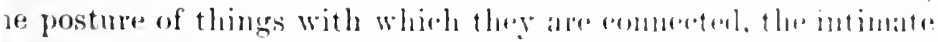

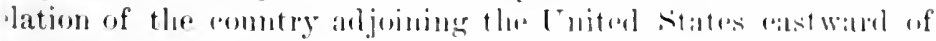

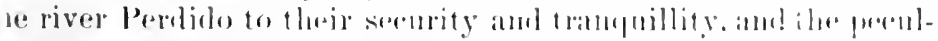

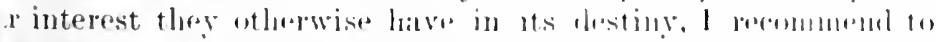

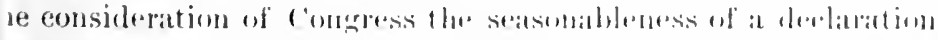

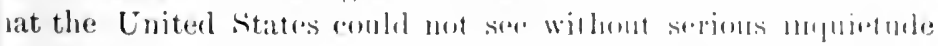
ry part of a neighboring territory in whinh the? have in differ- 
ent respects so deep and so just a concern pass from the hands of Spain into those of any other foreign power. . . . The wisdom of Congress will at the same time determine how far it may be expedient to provule for the event of a subversion of the Spanish authorities within the territory in question, and an apprehended occupancy thereof by any other forergn power.

Two months later Congress indorsed the policy of the President in a resolution declaring :-

Taking into view the peculiar situation of Spain and of her American provinces, and considering the influence which the destiny of the territory adjoining the southern boundary of the United States may have upon their security, tranquillity, and commerce, . . the United States, under the pecular circumstances of the existing crisis, camnot, without a serious inquietude, see any part of the said territory pass minto the hands of any other foreign power.

Here then was a shadow of the Momroe Doctrine cast before. The "destiny" of the Republic was proving itself; it figured here as a factor in determining a question of foreign policy. The acquisition of East Florida (the remaining portion of the old Spanish province that constitutes in part the present state of that name) was made in quite the same spirit, i.e. to remove the liability of attack from contignous territory. In point of fact, Florida had long been a refuge for ontlaws: it was the rallying-point for many filibustering expeditions, both Spanish and English, against the United States. In the War of 1812 it had been used by Enghand as a base of hostile operations. The resolutions of Congress of 1811 could with equal propriety be applied to the case of East Florida. Gentural Jackson was sent to clear the way for annexationa task le accomplished in his own vigolous way.

In relation to these earlier accessions of territory, the spirit amd purpose of the Momroe Doetrine is apparent, - thongh ill defined and emblely expressed. The nation, however. had not yet rached that point of development and strength when even in self-rlefence, it could proclaim a policy seemingly antagonistic to European interests. When the War of 1ri2 hard rosed the Inited states entered upon a 
new era. Old party lines were dissolving. and the riolent issues of the past twenty years were obsolete. The formative period of its existence was over, the experinent of demoeratic govermment was succeeding atmirably. The nation had greatly expanded in territory and wealth, and wis assuming a degree of self-contidence, a sense of power, that enabled it to study its own foreign policies in a calm, philosophic light, and to speak of them, if need be, more anthoritatively. For forty years a nebulous public sentiment harl been steadily approaching the positive form it subsefnently took; in 1828 a definite threat coming from withont, it surldenly crystallized into a elearly and an openly expressed policy.

The immediate causes leading to the enunciation of the Monroe Doctrine in 18:2: are to be fommel in a series of events beginning with the revolutionary movements in sonth and Central America and enminating in the threat on the part of a European alliance of strong powers to intervene in behalf of Syain and in the interests of monarehieal government.

The operations of Napoleon in spain had left that alrealy palsied nation in a dephrable eondition of helplessness. Profiting by her weakness, her American dependencies began, one after another (from 1s1:2 to 1s:ol) to set up) their own standarels, and establish themselves as indromendent

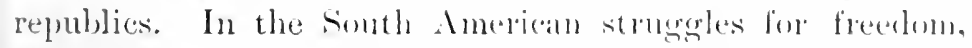
North American sympathy was strongly amouserl. Neutrality was duly proclamed, but material aid was contimally furnished by eitizens of the Lnited Sitates to the Somt and Central Americans, while frepluent explussims of stuplatly were made by congress. Evon hefore the coldonies latil

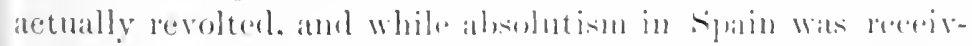

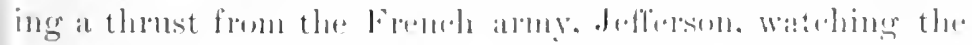
eontest from afar. mulerstand well the import of aromts and

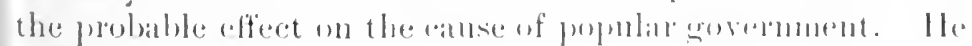

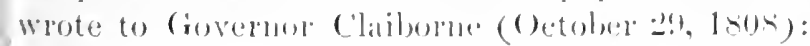


The truth is that the patriots of Spain have no warmer friends than the administration of the United States; but it is our duty to say nothing and to do nothing for or against either. If they succeed we shall be well satisfiect to see Cuba and Mexico remain in their present dependence, but very unwilling to see them in that of either France or England, politically or commereially. We consider their interests and ours as the same, and that the object of hoth must be to exchde all European influence from this hemisphere.

In this statement from high authority the historian Schouler finds the germ of the Monroe Doctrine. When the spanish dependencies began to declare their indepen. dence, and the grasp of the Old World upon the new one began to loosen, Jefferson's bolel statement found active support in all directions. Henry Clay, the leader of his party in Congress, exerted himself to the limit of his oratorical powers in the "emaneipation of South America." The continnal assaults upon the administration of Monroe by this opposition leader ma have caused the President to reeognize the independence of the revolted colonies sooner than he otherwise would have done, although it is elear from the words of nearly all his amnual messages, that Monroe had his heart in the sneeess of freedon's canse in the Western Ilemisphere quite as fully as had Clay, but he moved more cantiously and with far more deliberation than the elopuent and inpetnous member from Kentucky. In the autumn of 1817 , the first year of Monroe's presidency, he sent a commission to South Ameriea for the purpose of investigating the political conditions and of determining if there were any bon ful revolutionary govermments worthy of reeognition. The ammission was composed of men well-known for their radieal views of republieanism, yet in this respect they differed in regard to the proper conse to be prusued by the Inited States in the matter of recognizing the sovereignty of the seceding Spanish colonies.

In the minlst of alninet disenssions regarding this question, news smdilenly came from alnoad (during the early part of 1818) that a movement had been inaugurated in 
Europe to intervene in the affairs of South America. Further confirmation of these first reports came from several foreign ministers resident in Washington. John (2uincy Adams, the Secretary of State, instantly became alive to the situation, and somewhat curtly amounced that " if the European alliance undertook to settle matter's which enncerned us so closely, and without consulting us, they should not be surprised if we acterl without comsulting them." Momre shared in these apprehensions of the secretary of State and feared that the rumors of a European eombination to aid Spain in mantaining her old-time supremaey in the Americas might prove true. Mr. Arlams at onee sommled the british Minister in regand to England's attitude toward the Sinth Ameriean question: incleerl, the President desired freat Britain to join with the Lnited States then and there in reeognizing the independence of the South American colonies.

Across the Atlantic, the American Minister in Lomron, Richard Rush, was instructed to watch closely the intentions of the reported European alliance, one of the alleged objects of which was to interfere in behalf of spatin in Ameriar. Rush approached the English l'remier, Cistlereagh, whose sympathies were thought to be with the European alliance, though the commercial interests of his comntry callod for a greater freedom of trade with the West Indies and C'entral Ameriea than Spatin had heen willing to grant. Castlereagh, however, believed this end comld be effectod by burope:m mediation, and that by seroming to siatin her complete supremacy over her colonics. she might be coelered into adopting more liberal trate regulations as a just compen-

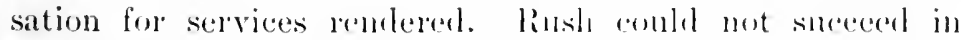
winning over the conservatior ('astheleagh to his original proposition, that of cherking all futnre jugrerling with lhe question by a prompt areknowledement of the imblemendence of South Amrerica.

Great relief was felt in Wathiugton 11 mon the derelaration of the allied powers of Eomple, Whose interforence in sentl Ameriea was so much featred by Mentroe and his cabinet, 
that they did not eontemplate using force to subjugate the revolting Spanish eolonies. In his annual message of November 16, 1818, President Monroe said : -

From the riew taken of this subjeet, founded on all the information that we have been able to obtain, there is good cause to be satisfied with the course heretofore pursued by the United States in regand to this contest, and to conclude that it is proper to alhere to it, especially in the present state of affairs.

Only two months later, however, the President ealled together his cabinet to discuss the subject of reeognizing the independence of Buenos Ayres, a measure he proposed and defended vainly against the adverse eounsels of his advisory board. Ahout this time Adams refers in his diary (May $\mathbf{2 9}$, 1819) to an episode that again places on record his views relating to the poliey of the United States toward foreign interference in the affairs of the Ameriean states. The Russian Minister, Mr. Poletiea, had been instrueted from Petersburg to use all his influence with the administration to keep the Enited States from rupturing the bonds of amity that existed between them and Spain. The snapping of tender ties of conrse related to the reeggnition of the South American states, and Mr. Poletica went so far as to intimate that unless the Lnited States followed a poliey in harmony with the aims of the European alliance she would find herself, however" unwilling, obliged in the end to "follow the impulse of Europe eombined."

I related to him [Mr. Poletica] all that has been done by us concerning the Sonth American question; told him we were convinced that Buenos Ayres at least wonld maintain her independence of spain; that sooner or later they must be recognized as an independent power; that we har thought that the time would before now have arriver when they might justly claim this as a light, but from the time when we learnt that the allies had detrminerl, that whatever might be the event of their mediation, not to use fore arainst the South Americans, the President had conchuded that we might also forbear to take an immediate, decisive part in their favor.

At the opening of Congress in December, 1819, nothing 
further had been done toward the recognition of the south American states. The l'resident said in his ammal message (December 7,1819 ) :

This contest has from its commencement been rery interesting to other powers, and to none more so than to the Cnited sitates A virtuous people may and will contine themselves within the limit of a strict nentrality; but it is not in their powes" to behold a conflict so vitally important to their neighbors withont the sensiblity and sympathy which maturally belong to such a case.

At the reading of the next anmual messige. November 4 , (1820), the situation was little changed. No further threats from the European alliance having come across the seal, the Lnited States had not been moved to act. The President said : -

No facts are known to this Government to warrant the bohef that any of the powers of Eurne will take part in the contest, whence it may be inferred, cousidering all ciremustances which must have weight in producing the result, that an aljustment will

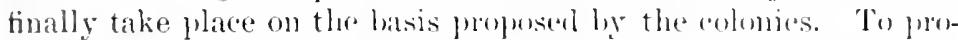
mote that result by friemdly ommses with other powers, imelurting spain herself, has been the mifom pulicy of this ciovernment.

Henry Clay never ceased his attacks upon the andministration for what he eomsintereal its almost aminal negligence in abandoning the great callse of liberty. Dis extending our recognition of their sovereignty it would not only give allcomragement to the states strogerling to free themsel bes form the clutehes of tylammy, hat it womld give as well "alditional tone, and hope, and commentance to the frionds of liberty

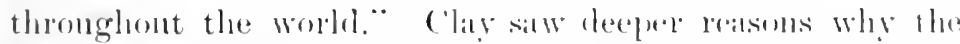

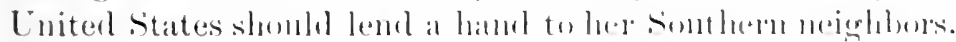

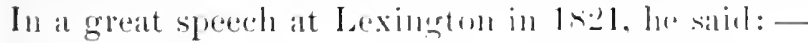

It was evident after the orerthow of limaparto that the

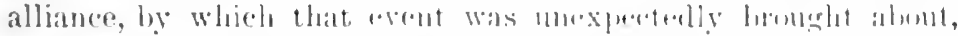

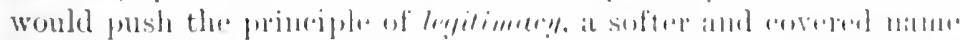

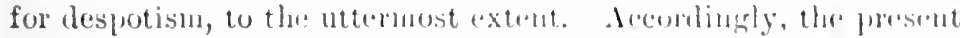


generation has seen, with painful feeling, Congress after Congress assembling in Europe to decide without ceremony, the destiny and affairs of foreign independent states. And if we, the greatest otfencler of all against the principle of legitimacy, har not been brought under their jurisuliction, and subjected to their parental calre, we owed the exemption to our distance from Europe and to the known bravery of our countrymen. But who ean say, that has observed the giddiness and intoxication of power, how long this exemption will continue? It had seened to him desirable that a sort of counteruoise to the holy alliance should be found in the two Americas in favor of uational independence and liberty, to operate by the force of example and by moral influence; that here a rallying-point and an asylum should exist for freemen and for freedom.

Adams agreed with Clay in the broad principles, but differed with him only in the course the United States should practically arlopt before occasion called more loudly for action. Ile told Mr. Claty that he never doubted the final isstie of the struggle in Sonth America, and that he believed it to be better policy to take no active part. "The prineiple of nentrality," he continued, "to all foreign wars was, in my opinion, fundamental to the continumee of our liberties and our Lnion." Wishing well to the canse of freedom in South America, he had yet to see better evidences that the Sonth Americans meant to establish "free or liberal institutions of govermment."

As events turned ont, Clay's vision seems to have proved the clearer, lout Arams comservative action was probably the wiser. Ilowever, no nore alarming threats from abroad cance, and onr recognition of the South American states was mot effectert mutil May, 18:2.

The perions year sian had ratified the treaty eeding the Floridas, and with that vexed question off the programme, the State Dopartment fomme itself greatly reliever. With these pressing retails ont of the way, the administration was free to turn its attrintion to a more remote but much more important matter. 'The solicitude of the President and Siceletry Arlans was at once directed to the consideration of premanent opposition to Enropean intervention in the 
Americas. As already noted, the idlea had been more or less steadily evolving for a number of yeatrs, and hat foumd occasional expression as one cireumstance or another hal inspired it in the writings and speeches of Jefferson. Marlison, Adams, and Claty, and member's of Congress. At last the nation had arrived at the point when its own sense of power, that gratifying feeling of self-entidence gave the assurance of weight to any foreign policy it might choose to adopt, and esperially in reference to snch matter's ats related purely to the allvancement of Western-World interests. With one exception the newly created states of ('entral and South Ameriea, established republican forms of government, and it seemed more than ever to be true that the political world was dividing itself into two camps, - the one in Enrope following the older conservative irleas of government. and the other in the Western IIemisphere embarang the more progressive idleas of repullicanism.

The President and his callinet were fully aware of the natural antagonism between these diannetrically onposing political systems. Alrealy from an alliance of pwerfin nonarehs, mumurings of hostility to populate gevermunent haid come from almoacl. No direet conflict was in prespect, lunt it was well to prepare for it. In his anmual messige of Derember 3, 1822, l'resilent Itouroe went to work upon that structure whose foundations had already been laid and cementerl. and which, in the following year, he completerl in all its towering propertions.

Whether we reason from the late wars [in linrope or from these:

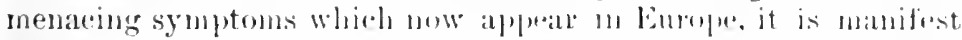

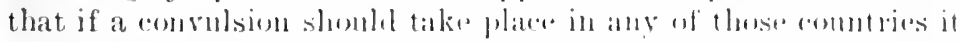

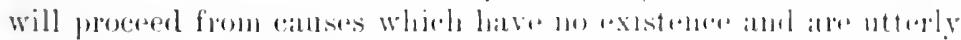

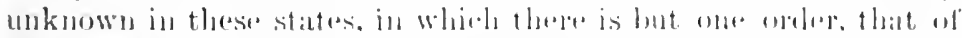

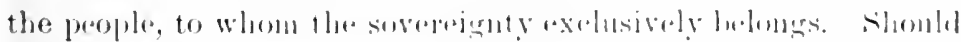

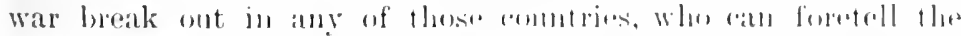

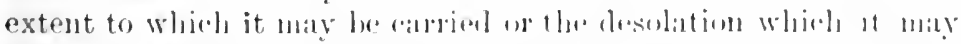

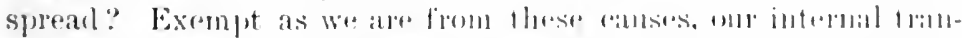

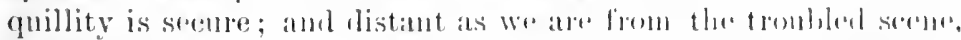

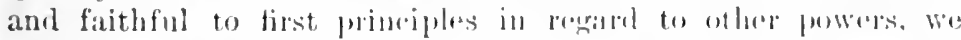

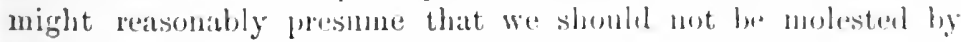


them. This, however, onght not to be calculated on as certain. Unprovoked injuries are often inflicted, and even the peculiar felicity of our situation might with some be a cause for excitement and agrression. . . . The United States owe to the world a great example, ancl, by means thereof, to the cause of liberty and humanity a generous support.

The following rear the anticipated threat from Europe came. The allied sovereigns amed a blow at the new exponents of democracy, and the protesting answer of the Lnited States was given shar'p and clear in the President's message (18:3).

\section{III}

After the fall of Napoleon at Waterloo, the four powers Austria, Russial, Prussia, and England, that had previously allied themselves for the purpose of opposing the advance of the "man of destiny," met by their representatives in Paris, in the fall of 1815 , and there renewed their political ties by a fresh treaty (November 20). In this convention the four allied monarehs, expressing their desire to "fix beforehand the principle which they proposed to follow in order to guarantee Europe from danger's by which she may still be menaced," adopted four resolutions : first, to prevent Napoleon from regaining power; second, to maintain the govermment of France; third, to keep their army of occupancy in France safe from attack, and fourth, to meet again at the expiration of three years in order to consult further, and "take such measures as should then scem to be hest fitted to preserve the peace and happiness of Europe."

This quarlmple alliance has been erroneously referred to by authors as the "Itoly Alliance." The real "Holy Alliance" was quite a different combination, and originater in this way. 'The (zall of linssia was much elated by the defeat of Napoleon. To him the trimmph of the allies - of which he was one - orer this seemingly invincible foe, appeared to be $n$ o less than a direct act of God to save the righteous, 
and to eonfound the wiekerl. He became so impressed with the truth of this remarkable manifestation of Dirine Providence, that, in order to better melit the favor's of the sirpreme being, he determined, thereafter, to rule his empire strietly in aceordance with the principles of the Christian religion, and still further, to induee his neighbors to do likewise. In this happy resolve the king of Prussia and the Emperor of Austria joined with the Czar, and the leagne was christened the "Holy Alliance." England, when invited, deelined to become a party, - Castlereagh, the English seeretary for Foreign Affairs, reporting to the ministry that the Czar was no doubt mentally unbalancerl. Even Metternich ealled the treaty " verliage." It all events, the league was formed, the signers dechuring that they " in consecpnence of the great events [those leading to the rlefeat of Nilpoleon] . . . and of the blessings which it has pleatsed loivine Providenee to sherl upon those states. . . Deelare solemnly. that the present act has no other object than to show . . their mwavering determination to adopt for the only rule of their eonduct. . the precepts of their holy religion, the precepts of justice, of charity, and of peace. . . " The three sovereigns would " remain miteel by the homls of a true and indissoluble fraternity." Considering themselves "only the member's of one ('hristian nation," they lonkenl upon themselves as "delegated by l'rovidence to gurern three branches of the same fandy, to wit: Austria, l'russia, and Russia." They confersed that there was really mo other sovereign than "Ilim to whom aholle puwer belonges of right." etc. The title of the leagne is deriverl from the chosing gratatgraph of the treaty (Septemler 2 $1,1,1515)$ : -

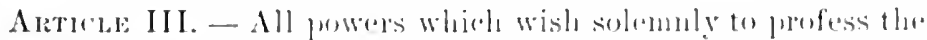

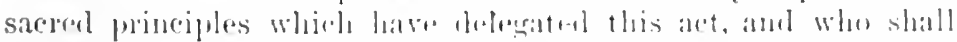

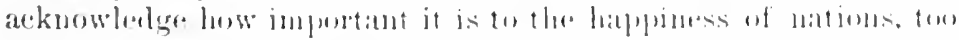

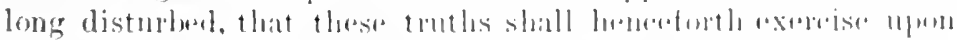

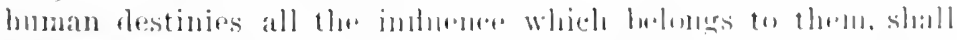

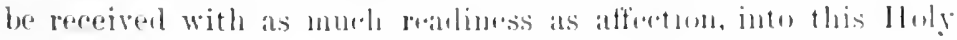
Allance.

Into this eombination France, Sigan. Naples and Somblinia 
entered. 'The Holy Alliance accomplished nothing, and there is no reason to suppose that its nembers intended to use other than their own good examples to accomplish the ends in view. It was a foolish pledge, conceived in a moment of religious fervor, and as completely disregarded in the practieal lives of the signers as though it had never been made. There is no evilence whatever, tending to show that the allies had combined for the purpose of opposing the growth of liberalism. It is the other league, - the Quadruple league that had organized to defeat Napoleon, and that had renewed its bonds in the treaty of Paris, November 20, 1815, - wherein the propaganda of absolntism was afterward born. Now it so happened that this quadruple alliance, a few years later, quite lost its original identity. England had withdrawn from it, and France and Spain had entered. With the fall of Napoleon, the original purposes for its existence naturally became extinct; but instead of dissolving, the alliance continued to live, and to take to itself entirely new objects and ideals in accordance with the changing political conditions in Europe. Now because these new ideas seemed to be in hamony with the vague ideas expressed in the Czar's Christian Family Compact of September 26, 1815, the alliance took shelter uncler the wing of that forgotten assoeiation, and borrowing its title, which, to the zealous monarchs appeared a good one, plumed itself the "Holy Alliance."

Napoleon had stood before the world as an exponent of liberal ideas, notwithstanding the fact that he filled the thrones of Europe with his relatives and created himself Emperor of France. Lpon his final defeat and exile, a rerival of absolutism set in throughout Europe, except, perlaps, in England, where liberal idleas had gained too firm a footing evor to be uprooted by the mere changing tides of popular sentiment. In Franee, the same people, who fifteen or twonty years before had idolized benjamin franklin, the apostle of democrater and who had followed Napoleon in his mardh against absolntism, now welcomed the restoration of the Boullons with wild acclaim. 
Every where rovalist mols tore down the emblems of popular govermment: friemls of liberilism were silencert of shot; the nation was purgerl of its demoreratic semtiments, and absolutism was rampant. The bonrlons were resurrected, and with great pomp and ceremony Lous XVIII Was crownel ling. In Austria, the reation was efually pronounced. Metternich, the menupromising enemy of poogressive ideas, eamestly exerted himself to stamp ont every restige of liberalism, both at home and abroul. Ile indmed ferelinand, king of Sicily, to withelaw his promises of granting a constitution to his perple, and created himself the momal protector of the precioms aloctrines of divine right.

In Spain this same reaction against constitntional gurernment was carred to a most astonishing extent. Fordinimd VII reëntered Spain in 1814 , and was received by the penple with the most extravagant demonstrations of welenme. The immediately proceeded to umlo, with the heartiest apluroval of his subjects, all that had ever been previonsly areomplished in Spain in the way of progress. The eonstitution wats bumed in the market-place of Mardrid: the Cortes wals dissol real and abolished, and all of its decrees were dectared roid. Those suspected of liberal taint were exiled, and their writings destroyed. The prisons were crowdel with those who failed to manifest proper enthusitsm in the batkwart movement. The lands of the ('hurel were restored, the clergy exempted from taxation, and the inguivition resstalshishert. The remarkable feature of this movenent in spatin lises in the fact that it found its heartiest support in those, whos, so few years before, harl eagerly chamonerl for eonstitutional sovernment. In the short spatce of two valls silitin fell bitck into the lap of the lark ages, hut leer tramsatlantic colonies breather a purer atmospliere. 'Tluep were alromly in perolt.

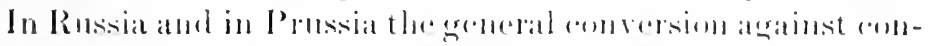

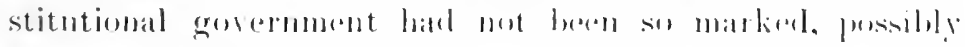

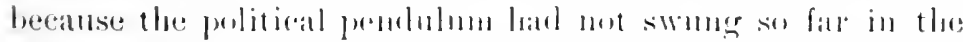
other direction, and the returning swing was antespendingly short. The politions sistems of these two nations, howerer, were wholly antociatic. 
Sneh was the color of political creeds in Europe when the ambassadors of the four power's forming the Quadruple Alliance, in aceordance with their agreement of 1815, met in conference at Aix la Chapelle, October 1818. At this meeting it was deeided to withdraw the allied army of oceupation from France, that country having been thoroughly won back to the principles of alssolutism, and having a legitimist on the throne. France was therefore taken into the alliance that was originally formed against her, making thereby a quintuple alliance. At Aix, the allies made a declaration that the tranquillity of Europe depended largely upon the united action and watehfulness of the five sovereigns composing the league, and that the league "has no other object than the maintenance of peace and the guarantee of those transations on which the peace was founded and consolidated." "The repose of the world will be constantly our motive." Thus it will appear that the allies had virtually constituted themselves into a soeiety for the regulation of European politics. The league had not yet declared the speeific object of suppressing all popular movements against alsolutism, but the reactionary movement in that direction throughont Europe had left its impress upon the hearts of the legitimate rulers, and, barring the English, the five rulers in question were firm atherents to the theory that royal power is based on divine right.

The exact meaning in the decharation of the allies at Aix was not altogether elear, but it pointed in the direction of assuming control of all European politieal affairs, and of insuring monarehical institutions. To this the English cabinet looked askance, remembering that "we have a parliament and a public, to whom we are responsible, and that we cannot permit ourselves to be drawn into views of policy whieh are wholly incompatible with the spirit of our government." Soon after the aljournment at $\mathrm{Aix}$, the allies were called upon to act, and therefore to interpret, the true mean ing of their vague rleclarations. It then became fully evident that they considered themsclves the guardians of Europe, - of its peace, its progress, its religion, and its 
morals; that it had beeome a society whose main object wats the perpetuation of monarchical institutions, and that its paramount duty was to suppress, wherever found, all pojular movements against such forms of govermment.

Great popular movements reeur in the lives of nations with a strange regularity. Like the waves of the sea, with corresponding depressions between, these movements hurl themselves against the buwarks of conservatism, and as quickly subside. So have the waves of liberalism risen and fallen in Europe; but, as in the swelling tides of the ocean, eateh suc. ceeding wave reaches a higher point. The trementous enthusiasm in Spain that greeted the reeistablishment of Ferdinand VII when at its very elimax, in 18:0, suddenly cooled. The revolt of her American colonies had begun about eight years before, and had depleted spain of her resources. The last dollar had been squeezed from the trealsury, the last available man had been forced into the army, the last ship had sailed away with arms and ammmition, and all to no purpose. In 1820 , the last regiment that could be mobilized for transatlantic service relselled. and in a moment all Spain was in a ferment of revolution against the tyramny and oppression ol lerdiname. An incoming wave of liberalism swept over Spain, over Naples and sicily, lhen over Portugal, and threatened to inmolate France. Ferrlinand was forced to grant a constitution to the penple, and absolutism in Naples, fieily, and l'ortugal collapsed. Frighte. ened by the signs, Lomis XVIII hastily ablled upon the allies

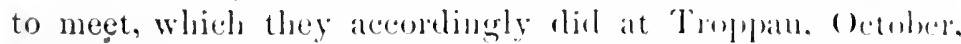
1820. The English ambassinlor' at 'Truppan wats a silent

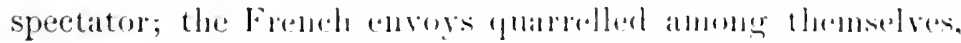

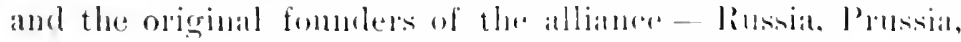
and Austrial - were beft to ald ats they saw tit. Now. il the

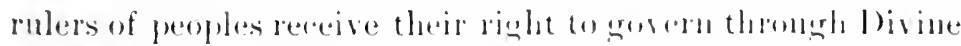

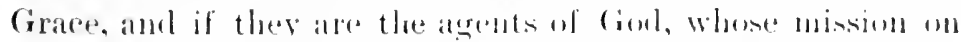

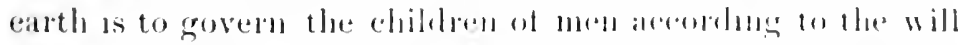
of Heaven, then it must meressitrily follow that all atrompts

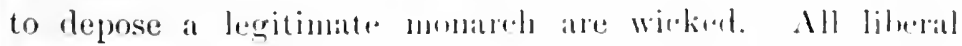
movements, therefore, are unholy; all revolutions against 
the old hereditary families are sacrilegious. Such was the line of argument advanced at the conference. The three powers declared that, having erushed ont the arch fiend of military tyranny and oppression (Napoleon), they now found themselves called upon to "put a curb on a force no less tylumical, and no less detestable - that of revolt and crime."

Suiting their actions to their words, the allies ealled upon the aged king of Naples to meet them in Leybach in January, 1821, and take council with them concerning the suppression of a revolution which had forced him to accept a constitution and a parliament. While that old monarch was theorizing in Leybach, the king's son joined the popular party against him. The allies sent an Austrian almy into Italy which defeated the prince, suppressed the rebellion and restored the old king mpon the throne of Naples as an absolute ruler. Insurrections in Piedmont and in freece were in the same mannel crushed by the forces of the allies.

At Leybach, a new declatation of principles was issued, whieh was, in effect, a repetition of the Troppau circular. It annomced that they (the allies) had "taken the people of Europe into their holy keeping, and that, in future, all useful and necessary ehanges in the legislation and administration of states must emanate alone from the free will, the reflected and enlightened inpulse of those whom God has rendered responsible for power."

The next year the allies met in Vienna, adjourning thence to Verona (October, 182.2), when the matter of the Spanish revolution was taken into most serious eonsideration. Spain was distressed by eivil dissensions, Ferdinand harl been driven into reassembling the Cortes, and the cause of liberalism was again anvancing. It appeared mole and more improbable that the exhansted nation conld succeed in holding her transatlantic colonies, all of which were in revolt, and most of which had, to all intents and purposes, already acquired their independence. Ferdinand begged the aid of the alliance to regain his American possessions, and the great powers hesitated. Russia, Prussia and Anstria, which stood firmly 
by their anti-liberal doetrines, declared they would never recognize the seceded colonies unt spatin herself hald done so.

English sentiment had not yielded to the principles of the allies. The notions of divine right were distasteful to a people who had prospered for eenturies under eonstututional government, and the prineiple of toreible intervention adopted by the allies seemed to the English ministry to be wholly improper. In the course allopted by the allies toward the revolutionary movements in Italy, England had no interest. directly affected, but she had nevertheless protested andinst the unwarrantable interference of the powers in the affairs of Naples. But in the proposed movement against liberalism in Spain, to be discussed by the allied agents of the powers at Verona, England had a more direct and more sulstantial interest.

In earlier days, Spain's eeonomic policy with her transatlantic colonies had been a rigidly exchusive one, but during their revolt, many of the tightly drawn commereial lines hat been cut, and old barriers of trate hroken down. English merehants had greatly profited therely, and within a frow years they had built up a large and growing tmole in somth America and the West Indies. In a eontinnance of these favorable eonditions lay the motive of Englands action. It the time of the meeting of the allies at Verona, the statesmen of Englaud had about deeded to send (ommenerial agents, if not consular representatives, to the larerer aities of somth Ameriea - a comrse of antion which ill aterobled with the policy of the allies toward Sinth Aurerial. Eugland was not prepared, on the otles haurl, to go to the extremity of

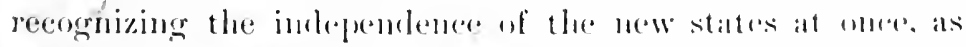

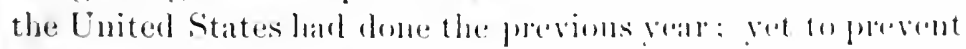

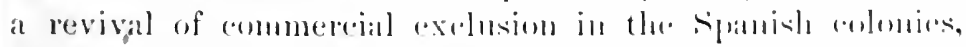

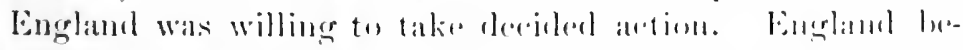

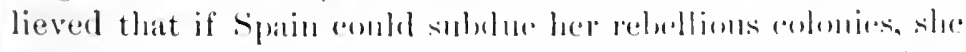

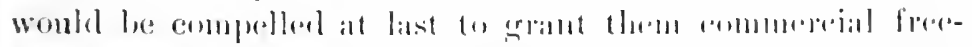

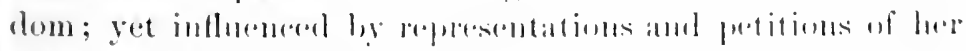

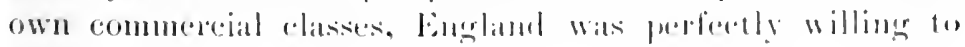


see the colonists secure their independence, in the belief that political relations could be equally well established with them. "Again the English had," wrote M. Beammarchais, anthor of "La Doctrine cle Monroe" (1.6), "the rare good fortune of finding their own particular interests conform to the noble cause of liberty, and they furthered well their real purposes by posing before Europe, either hesitating or hostile, as disinterested champions of Justice and Right."

Lord Castlereagh, the P'me Minister, was chosen to represent England at the Congress of Verona, and the ambassador drew his own instructions, which were to oppose strenuously any proposed intervention in Spanish affairs. He further instructed himself to make known the intention of his country to follow her own commercial interests by sending diplomatic agents to South America.

The death of Castlereagh, before the meeting of the allies, brought Mr. Canning forward as Prime Minister, and he appointed the Duke of Wellington in Castlereagh's place to represent England at the Congress. At Verona the allies signed a seeret treaty (November 22, 1822) to which only the names of Metternich, Chateaubriand, Bernstet (Prussia) and Nesselrode appear. The first two articles of this instrument are of especial interest.

The undersigned, specially authorized to make some additions to the treaty of the Holy Alliance, after having exchanged their respective creflentials, have agreed as follows:-

AlTule I. - The high contracting powers, being convinced that the system of representative government is equally as incompatible with the monarchical principles as the maxim of the sovereignty of the people with the divine right, engage mutually, in the most solemn mamer, to use all their efforts to put an end to the system of representative governments, in whatever comntry it may exist in Europre, and to prevent its being introduced in those comntries where it is not yet known.

ArTucre II. - As it camnot be doubted that the liberty of the press is the most fowerful means used by the pretented supporters of the rights of nations, to the detriment of those Princes, the high enntracting parties promise reciprocally to aropt all proper measures to suppress it, not only in their own states, but also in the rest of Europe. 
It will be noted that in this treaty of November 2.2. 15:2, in which England took no part, the allies, "malie some additions to the Treaty of the Holy Mllince." Thus it appears how these four powers (the original (2ualduple Mlliance), by assuming to amend a treaty not originally of their own making. had appropriated to themselves the title and doctrines of the former IIoly Alliance. ()ne important step was taken at Veronia. The congress adjourned with the understanding that France, in the name of the lobly allies, should send an army into sipain, " to put an end to the system of representative govermment" which was struggling for existence beyond the l'yrences. A Fiench army, moler the Due d'Angouleme, crossed the frontier, and after a fecble resistance from the revolutionists, restored Ferdinand to a despotic throne (April, 18\%2). The next step of the allies seemed to be reasonably certain, - a movement against fouth Ameriean revolntionists. Their efforts against liberalism in Europe had been eminently suceessful, as demonstraterl in Naples, in Sicily, in Piermont, and listly in Sinin. Ferdinand, having been reinstated upon his throme, begrged lustily for help to subjugate his colonies, hoth in the interest of Spain and in the eanse of absolutism. The anlvisability of taking sneh a step hat alrealy heen hroateded at Vienula, and freely discossed at Vermat. Repums of these contemplated movements in the Americats harl reateluol Washingtun, and had impressed the athinistration with a deep fereling of concern. It was feared that France might demand ('ubat as a price for restoring Ferelinand, and it was puite rertain that if the allies disl interfere in Ameriois, the newly croited republies would inevitably fill inte the hambs af the moret powerful Europen nations. In wreler to determine npon a

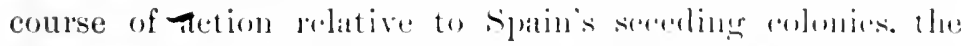
allies agreed to neet ingain in the antmm of $18.8:$ : In the

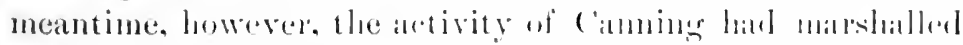

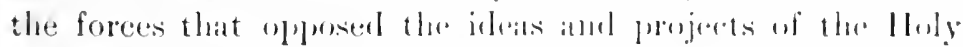

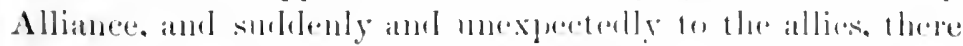

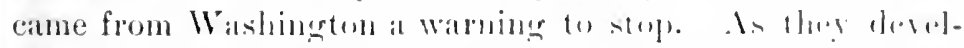
oped in strength and resummes, the ponple of the l'nited 
States had for many years been preparing a mine to be sprung when the proper time came. It was Canning who signalled the danger from abroad; it was Adams who placed the charge in position and adjusted the fuse, and it was Monroe who applied the match. The statement that the United States would resist the advance of the allies into the new world, as hinted in President Monroe's Message of 1823, together with the knowlerge that England's sympathy was plerlged to the United States, was quite suffieient to check any designs which the Alliance may have devised to stifle the canse of liberalism and eonstitutional government in the Western Hemisphere.

\section{IV}

When Canning became Minister of Foreign Affairs he was perplexed in regard to the proper attitude he should take toward the struggling Spanish-Ameriean colonies. Englaml's commercial classes inchined toward the independence of these newly ereated republics; but true to her conservative notions, as well as to treaty pledges to Spain, England was unprepared, even in her own interest, to welcome immediately the seceded Spanish colonies into the brotherhood of sovereign states. An mwillingness to leap as far as her strength will permit is a characteristie of British foreign relations, yet in this particular instance, a leap too far might have proved a leap into the dark, as the strength of all combined Europe seemed to favor the reduetion of Spanish-America in the canse of absolutism ; such a politieal error might have isolated Great Britain. Camning was willing to go much further in this direction than had been his more temporizing predeeessor, Lord Castlereagh. Ite protested vigoronsly against the proposed interference of Europe in America. Ile was willing that the new states shonld remain Spanish ol be free, indeed it is saicl that he almost preferred them to return muler a modified Spanish rule; but in orler to satisfy the requirements of English eommercial interesti, they must, under no eireumstanees, pass 
under other European sovereignty. "Neither justice, nor" humanity, nor the interests of Europe or of America," he said to Polignac, "allow that the struggle . . should be taken up afresh by other hands." Again, England was far in advance of continental Europe in the development of constitutional government; having progressed in her ideas farorable to popular suffrige, she too, it may reasonably be inferred, viewed with some disfavor the resubjugation of a people who had practically aequired their emaneipation from the tyranny of absolute monarchy. Mr. Camning was, in no sense of the word, an enthusiastic admirer of the people of the United States. From his own writings, expressions are not wanting indicating an actual aversion for the keen, aggressive people across the Atlantic, but in the impending danger that threatened both, the one commercially, the other politically, he turned to the Lnited States. lle well knew that the people of the United States sympathized with the Spanish colonies in their struggles for freedom ; indeed, they had already recognized several of them as sovereign states. He knew, also, that Americans regarded the advance of despotism and the action of the allies with no little suspicion and disfavor. Why not, therefore, utilize this sentiment to his own adrantage? He began his reconnoitering tactics at once by seeking Mr. Rush, the American Minister, in London. On August 16, 18:3, while discussing with Mr. Rush matters connected with the northwest houndary of the United States, the conversation drifted into Spanish affairs. Mr. Rush spoke of a recent statement made by Mr. Canning, to the effect that England dischaimed all intention of seizing any Spanish colony, and hoped France entertained no such purpose. Mr. ('imning seizerl the occasion to sound the Anerican Minister as to what he helieved the Covernment of the lnited States wonld say to a project of groing land in hand with Enghand in order to prevent France, or the other powers of the alliance, from interfering in Spanish America. Mr. Rush wrote:-

He did not think that concert of action would become necessary, fully believing that the simple fact of our two comtries 
being known to hold the same opinion would, by its moral effect, put down the intention on the part of France, if she entertained it. This belief was founder, he said, upon the large share of the Maritime power of the world which Great Britain and the United States shared between them, and the consequent influence which the knowlerge of their common policy on the question involving such important maritime interests, present and future, could not fail to procluce on the rest of the world.

Without instructions from home, Mr. Rush did not feel at liberty to commit himself upon so important a matter. Several days after this conversation, Mr. Camning wrote to Mr. Rush that his government had nothing to conceal on the subject. It conceived the recovery of the colonies by Spain to be hopeless, and the recognition of them to be a question only of time and circumstance. He asserted that the English Govermment was "by no means disposed to throw any impediment in the way of an arrangement between them and the mother country by amicable negotiations." England, he maintained, desired for herself no part of their territory, but he added, "it could not see any part of them transferred to any other power with indifference."

Such being England's views, urged Mr. Canning, why not, if the United States acceded, publish them to the world? "A proceeding of such a nature," he continued, "would be at once the most effectual and the least offensive mode of intimating the joint disapprobation of Great Britain and the United States of any projects which might be cherished by any European power, of a forcible enterprise for reducing the colonies to subjugation on the behalf or in the name of Spain ; or of the acquisition of any part of them to itself by cession or by conquest." Mr. Camning supplemented his note by another a few days later, calling Mr. Rush's attention to the fact that additional reasons for haste had developed. France expected shortly to accomplish her military objects in Spain, and notice had been sent to lingland that when this was done "a proposal would be made for a Congress in Enrope, or some other concert and consultation, specifically on the affairs of Sonth America." 
Mr. Rush still hesitated to answer, fearing to complicate the United States in the political broils of Europe, - a nost undesirable step, he believed, for his comntry to take; moreover, he felt certain that the President would sanction no such radical departure from the fundamental principles of American polities. He cantiously replied to the British Seeretary that he could safely saty the Lnited States agreed with Mr. Camning in all he had said eoneerning the future status of the Spanish colomies. He concluded, lowever, with the following vigorous words: "We slould regald as unjust, and fruitful of highly disastrous consequences, any attempt on the part of any European power to talic possession of them by conquest, by cession, or on any other gromed or pretext." Lack of instructions from Washington did not warrant him in joining with Mr. Camning in an open declaration to that effect. A little later, Mr. Rusli wrote to Canning, that his govermment "would regard as objectionable any interference whatever in the aftairs of spanish Americat, unsolicited by the late provinces themselves, and against their will. It would regard the convening of a Congress to deliberate upon their affairs as a measure mncalled-for, and indicative of a poliey highly unfriendly to the trancuillity of the workd. It conld never look with insensibility upon such an exercise of European jurisdiction over eommunities now of right exempt from it, and entitled to regulate their own concerns mmolesterl from abroall."

Mr. Canning eontinued to mege Mr. Rush to join lim in an open declaration, becanse the eongress of the powers would soon meet, and England was desiroms of arming herself beforehand with an Ameriean declaration, in order that she might not enter the lists alone and single-handed against the designs of the allies. Mr. Rush still hesitated. C'ommmnimation with the Enited States reguired many weress and hy that time an answer from Washington womb be of little arail. Again the british secretary prodled Mr. Rash. "lluey [Cnited states] were the first power establisherl on that continent, and now confessedly the learling power: " they were conmester with sonth Ameriea hy their geograplite 
position, and with Europe by their relations. Was it possible that they could with indifference see their fate determined by Europe? Had not a new epoch arrived in the lelative position of the United States toward Europe, which Europe must acknowledge? Were the great political and commercial interests which hung upon the destiny of the new continent to be canvassed and adjusted on the Eastern Hemisphere without the coipperation or even knowledge of the United States? These were flattering suggestions to $\mathrm{Mr}$. Rush; and finally moved by such representations he consented to rely upon his general power as a Minister Plenipotentiary, and to take the desired stand with Mr. Camming, provided England would first recognize the independence of the South American states. To this ('aming would not agree, and the project of a joint Anerican and English statement fell through.

Annoyed by his failure to secure the coöperation of the United States, Camning decided to proceed alone. Turning to France, he made known to the French Ambassador, Prince Polignac, England's determination to oppose the interference of the allied powers in Spain's behalf to subdue her colonies. To his surprise, no doubt, Polignac declared that France entertained no such intention, and, furthermore, that France fully agreed with England in that the South American states were, to all intents and purposes, free and should not be molested. Polignac further disclaimed any intention on the part of his government to seek any exclusive commercial advantage in Spanish America. To Canning these statements of Polignac were too extraordinary to be true; he distrusted the French diplomat, as the latter appear's to lave clistrusted the Englishman, so kush was not made acquainted by Camming with the results of the Polignac conferences in time to forward them to Washington before the end of the year (1823). As it was largely against France that the animus of the Monroe deelanation was directed, it is not mulikely that had such a disclaimer from Polignac reached President Monroe before his message had been framed, its tone might have been considerably modified. 
When Rush's despatches relating his interviews with Canning reached Washington in September (18.25) the President was plunged into a sea of dombt and perplexitr. He fully realized the importance of the question as he saw plainly the approach of the dreaded elash; it was the spirit of absolutism, angered and jealous, which was seeking to arrest the progress of democracy in the Western Ilemisphere. To him the subjugation of the South American colonies by France, or by the combined forces of the Holy allies, pointed directly to the alssorption of those colnmi by the great powers and their forcible return to the swity of imperialism. It meant the hedging in of the Luited States by its natural enemics, and the possible overthrow of republiean institutions at home. He was tetermined from the first to act, but in just what mammer was the question. To unite with Great Britain in a joint declaration to the powers for the furtherance of any end whatever, wonkl be to enter upon an entangling alliance; incleed, to subvert a sacred poliey of his country. To issue a declaration such as the oeeasion called for would involve an interference in the affairs of foreign nations, and if issued alone by the Lnited states it might a vail nothing against the forees of combined Europe.

Jefferson was then in retirement at Monticello, remover from the cares and rexations of public life, but to this agerl statesman, Momroe tumed for alvice. 'To Madison as well, also in retirement at his Virginia home, the Presiclent forwarted copies of the Rush-Caming eorrespondenee, soliciting his counsel in this critial matter. The replies of these two men are valuable historical toemments. That of Jefferson is as follows : -

\section{Monteriso, octoher 21, 182:3.}

Dear Sur, - The question presenterl hy the letters you have sent me, is the nust momentons which has ever heen offered to my contemplation since that of Independenees. That male us at nation, this sets onl (ommpass and points the eonrse whirh we are

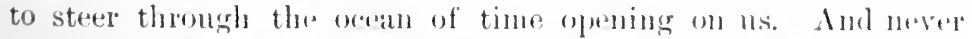

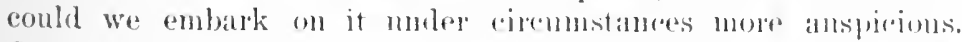
Our first and fombannental maxim shomld be, never te antangle 
ourselves in the broils of Europe. Our second, never to suffer Europe to intermeddle with cis-Atlantic affairs. America, North and South, has a set of interests distinct from those of Europe, and peculiarly her own. She should therefore have a system of her own, separate and apart from that of Europe. While the last is laboring to become the domicil of despotism, our endeavor should surely be, to make our hemisphere that of freedom. One nation, most of all, conld disturb us in this pursuit; she now offers to lead, aid, and aecompany us in it. By aeceding to her proposition, we detach her from the band of despots, bring her mighty weight into the scale of free govermment, and emancipate a continent at one stroke, which might otherwise linger long in doubt and difficulty. Great Britain is the nation which can do us the most harm of any one, or all on earth; and with her on our side we need not fear the whole world. With her then, we should most sedulously cherish a cordial friendship; and nothing would tend more to knit our affections than to be fighting once more, sicle by sicle, in the same cause. Not that I would purehase even her amity at the priee of taking part in her wars. But the war in which the present proposition might engage us, should that be its consequence, is not her war, but ours. Its object is to introduce and establish the American system, of keeping out of our land all foreign powers, of never permitting those of Europe to intermerldle with the affairs of our nations. It is to maintain our own principle, not to depart from it. And if, to facilitate this, we ean effect a division in the borly of the European powers, and draw over to onr side its most powerful member, surely we should do it. But I am clearly of Mr. Camning's opinion, that it will , prevent insteal of provoke war. With Great Britain withdrawn from their seale and shifted into that of our two continents, all Europe combined would not undertake such a war. For how would they propose to get at either enemy without superior flects? Nor is the occasion to be slighted whieh this proposition offer's, of declaring our protest against the atrocious violations of the rights of nations, by the interferenee of any one in the internal affairs of another, so flagitionsly begun by Bonaparte, ancl now eontimued by the equally lawless Alliance, calling itself Holy. .

I could honestly, therefore, join in the declaration proposed, that we aim not at the arepuisition of any of those possessions, that we will not stand in the way of any amicable arrangement between them and the mother comintry; but that we will oppose, with all our means, the forcible interposition of any other power, as anxiliary, stipentiary, or meler any other form of pretext, and 
most especially, their transfer to any power by conquest, cession, or acquisition in any other way. I should think it, therefore, advisable, that the Executive should enconrage the British government to a continuance in the dispositions expressed in these letters, by an assurance of his concurrence with them as far as his authority goes; and that as it may lead to war, the declauation of which requires an act of Congress, the case shall be laid before then for consideration at their first meeting, and under the reasonable aspect in which it is seen by himself.

Madison's reply is no less interesting, and merits free quotation :-

Oст. 30, 1823.

Dear Sir, - I have just received from Mr. Jefferson your letter to him, with the correspondence between Mr. Canning and Mr. Rush, sent for his and my perusal, and our opinions on the sub). ject of it.

From the disclosures of Mr. Caming it appears, as was otherwise to be inferred, that the success of France against spain would be followed by an attempt of the Holy allies to reduce the revolutionized colonies of the latter to their former dependence.

The professions we have made to these neighbors, our sympathies with their liberties and independence, the deep interest we have in the most friendly relations with them, and the conspquences threatened ly a command of their resonrees by the cireat Powers, confederated against the rights and reforms of which we have given so conspicuous and persuasive an example, all mite in calling for our efforts to defeat the meditated crusade. It is pirrticularly fortunate that the policy of Great Britain, though sniked by calculations different from ours, has presented a coijperation for an object the same with ours. Wilh that coijperation we have nothing to fear from the rest of Europe, and with it the best assurance of suceess to our lambahle views. There ought not, therefore, to be any backwartuess, I think, in meeting her in the way she has propesed ; keeping in view, of comrse. the spirit and forms of the Constitution in every ster taken in the roald to war. which must be the last step if thuse shont of war should be without avail.

It caunot be doubted that Mr. Caming s propesal, though marle with the air of comsultutiom as well as concert, was fommes on a pre-determination to take the course marken ont, whaterer might be the reception given hare to his invitation. Int this consinlerattion onght not to divert us from what is just and proper in itself. 
Our coopperation is due to ourselves and to the world; and whilst it must ensure suecess in the event of an appeal to force, it doubles the chance of success withont that appeal. . . .

In Norember (1823) the eabinet meetings began, and it may well be imagined that the principal topic of interest was the subjeet of the Holy Alliance and its suspected IVestern schemes; just low to express the defiance of the United States in the most judicious and practical manner, brought forth eonsiderable divergenee of op inion.

In the calinet were John Quincy Adams, Secretary of State, Calhoun, Sonthard and Wirt. Mr. Calhoun advised following the advice of Jefferson, and giving to Mr. Rush discretionary powers to join with Great Britain in the declaration referred to. To this proposition Adams vigorously objected, in which opinion he was supported by the President, who, aceording to Mr. Adams" own diary, "was averse to any course which should have the appearance of taking a position subordinate to that of Great Britain." Mr. Monroe then suggested the idea of sending a special representative to the proposed congress of the allies to protest against all interference in Sonth America, but this plan found no favor in the cabinet. On November 13, Adams entered in his diary :-

I find him yet altogether unsettled in his own mind as to the answer to be given to $\mathrm{Mr}$. Caming's proposals, and alarmed far beyond anything that I conld have conceived possible, with the fear that the Holy Alliance are about to restore inmediately all Sonth Amerim to Spain. ('alhom stimulates the panic, and the news that c'adiz has surrendered to the French has so affected the President that he appeared entirely to despair of the canse of South Anerica. . .

To Molington, the British Minister in Washington, who pressed hin for an answer to Cannings proposition, the fecretary sain that the measure "was of such magnitude, such paramomt comsequence as involving the whole future policy of the Inited States. . . that the President was 
anxious to give it the most deliberate consideration, and to take the sense of his whole cabinet upon it."

News suddenly arrived announcing the suecess of the French troops in Spain, of the fall of Cadiz, and the restoriation of Ferdinand to absolute power, which, aceording to Adams' diary, thoronghly dejected the President, and caused widespread alarm throughout the country. The press viewed the situation somewhat hysterically, and populat feeling turned decidedly in faror of an English alliance. Adams held firmly to his original position that the Lnited States should stand alone. He seemed to doubt Camning's sineerity; it perhaps appeared to him, who was more familial than his colleagnes with the methods of foreign diphomacy, that possibly Camning had, after all, by his cries of wolf, only been trying to frighten the Lnited States into guaranteeing Cuba to Spain. Somewhat caustically lye wote in lis diary: "I soon found the source of the P'resident's despondency with regard to South American affairs. Calloun is perfectly moon-struek by the surrender of ('adiz, and says the lloly allies, with ten thousand nen, will restore all Mexico and all South America to the Spanish dominion."

Calhoun's proposition to instruct Mr. Rush to act in conjunction with Mr. Caming "in aise of any sudelen emergeney of danger," was arcepted by the President, though in opposition to the riews of the Seeretary of state. A draft of instructions was actually drawn up by the unwilling $A$ dams, and was brought before the ablinet, muels ancmeled and interlinerl, for examination. Mr. Arlams then insister that if the United States must join (ireat Britain in surh a movement, or in such a declatation of principles, the English Government should first acknowledge the independence of the South Ameriean states. The Lnited States, he insisterl, having acknowledger the independence of the SprnishAmerican states, "latel a right to object to the interference of foreign powers in the affatrs of those territories. To Great Britain, it might be objected that althongh possessing the option, she hat no distinet right so to do. She regarded those territories as still depentencies of Spain, and in that 
character she might allow, not only Spain, but pro re nata other powers, as allies of Spain, to interfere in reducing them by force, to obedience. Such a proceeding was impossible to the Unitel States, from the mere fact of their recognition of the independence of the territories in question.'

While discussion was proceeding in the cabinet over the form of instructions to be sent to Mr. Rush, a new phase of the question suddenly dereloped and called for consideration.

Baron Tuyll, the Russian Minister in Washington, read to Mr. Adams certain despatches he had received from Count Nesselrode. One of these was the exhibition of "passionate exultation at the counter revolution in Portugal and the impending success of the French army in Spain; an 'Io Triomphe' over the fallen cause of [popular] revolution, with sturdy promises of determination to keep it down. . . ." Mr. Adams believed the expression of these sentiments ealled for some sort of answer from the United States: "My purpose would be," declared Mr. Adams " in a moderate and conciliatory manner, but with a firm and determined spirit, to declare our dissent from the principles avowed in those communieations, to assert those upon which our own government is founded, and while disclaiming all intention of attempting to propagate them by force, and all interference in the political affairs of Europe, to declare our expectation and hope that the European power's will equally abstain from the attempt to spread their principles in the American hemisphere, or to subjugate by force any part of these continents to their will." 'The President algreed with Mr. Alams in this respeet, and at the next meeting of the cabinet he rearl, from a lough draft, the ammal message to Congress he was preparing to deliver to that body on December 2. In this draft he had inserter not only lis views upon the matters in question, but had also added some lines covertly intended for the ('zar as a reply to Nesselrode's despatches to Baron 'Tuyll. Of this preliminary draft of the message Mr'. Adams wrote in his diary under date of November 21, 1823:- 
... Its introduction was in a tone of deep solemnity and of high alarm, intimating that this country is menaced by imminent and formidable dangers, such as would probably soon rall for their most vigorons energies and the closest union. It then proceeded to speak of the foreign affairs, chiefly according to the sketch I had given him some days since, but with occasional variations. It then alluded to the recent events in Spain and Portugal, speaking in terms of the most pointed reprobation of the late invasion of spain by France. It also contained a hroad acknowledgment of the Greeks as an independent nation, and a recommendation to Congress to make an appropriation for sending a minister to them.

The members of the eabinet generally accepted the draft of the message with approval, but Adams objected to its whole tone as one of combined fear and aggression. It alypeared to him to be the cry of an alarmist; it breathed an air of direct defiance which he believed to be wholly mnecessary; and at last it might precipitate a war,- - the most unfortunate of possibilities. Adams desired to "talie the ground of earnest remonstrance against the interference of the European powers by force with Sonth Ameriea, but to disclaim all interference on our part with Europe; to make an American cause, and adhere inflexibly to that." He wished particularly to avoid mention of the allies, or reforence in hostile manner to any nation, his idea being solely the enunciation of a principle.

Notwithstanding Arlans' desire to deal circumspectly with personalities in public ntterances, he still elung to the idea of issuing a manifesto of some sort to Baron 'Tuyll in answer to the Russian despatches. A comment in his diary upon a paper he had prepared for this purpose and had introduced in the cabinet meeting of November 25, is a raluable extract as showing not mly his own views at the moment, but also to what extent he was the real anthor of the "rleclatration" in the President's messigge to appreal later.

"The paper itself," low wote, "was drawn to correspond "Xactly with a paragraph of the l'msident's messigre which he harl read me yesterday, and which wis entirely conformable to the 
system of policy which I have earnestly recommended for this emergency. It was also intended as a firm, spirited, and yet conciliatory answer to all the conmunications lately received from the Russian Government, and at the same tine, an mequivocal answer to the proposals made by Caming to Rusl. It was meant also to be eventually an exposition of the principles of this govermment, and a brief development of its politicul system as henceforth to be maintained: essentially republican - maintaining its own independence, and respecting that of others; essentially pacific-studionsly avoiling all involvements in the combinations of European politics, cultivating peace and friendship with the most absolute monarehies, highly appreciating and anxiously desirous of retaining that of the Emperor Alexander, but declaring that, having recognized the independence of the South American States, we coukl not see with indifference any attempt by European power's by forcible interposition either to restore the Spanish dominion on the American continents, or to introduce monarchical principles into those countries, or to transfer any portion of the ancient or present American possessions of Spain to any other European lower."

Only a week before the message of the President was due, the question of how to proceed against the threatened dangers from Europe was by no means settled; indeed, Adams seems to have had the only clear conception of the true necessities of the oceasion. The form of instructions to Rush was not determined upon; the President's draft of message met with the vigorous opposition of the Secretary of State, and Adams' suggestion of a manifesto to Baron Tuyll found no supporters in the eabinet. Monroe considered Adams' sentiments in lis proposed letter to Baron 'Tuyll to be too vigorous, and to Europe, too offensively republican; they might even estrange Great Britain, whose friendship in the impending crisis was absolutely essential. Calhoun also doubted the necessity or even the advisability of publishing "so ostentations a display of republiean principles." Adams defended his manifesto by urging that " as the IJoly allies had come to edify and instruct us with their principles, it was due in candor to them and in justice to ourselves, to return the compliment." Again Calhom averred that as the President's message, which covered this very subject, was 
directed to the people of the United states and not to any foreign sovereign, it would be less likely to give offence. Southard agreed with Mr. Adams. "- If the Czar and the Holy allies ehoose to sing to us the praises of despotism," he said, "they annot take umbrage at om chorus for free institutions, even thongh directed to them."

$\mathrm{U}_{\mathrm{p}}$ to this time (abont a week lefore the convening of Congress), Mr. Wirt, the Attorney (rencral, who had been absent from these important cabinet meetings, now appealred upon the scene, and with a mind muinfluenced hy the former spirited diseussions, he proceeded to examine Mr. Arlams' draft of manifesto from a purely common-sense point of view: Might it not, after all, seem to be mese bombast, for if the allies should actually begin hostile operations against fouth Ameriea, would the Lnited States hatek up Mr. Arlams' leelaration with men and guns? 'To this Arkans could only reply, "It is, and has been to me, a fearful question." Epon that point he said in his dialy :-

My paper and the paragraph wonhl rertainly commit us as far as the Executive constitutionally could alet on this point; and if we take this course, I should wish that a joint resolution of the two Honses of Congress should be proposed and arlopted to the same purport.

Five days before the ammal messige became due, the sitnation in the calbinet was still one of emllusion. Alams insisted upon pouring hot shot into the ('zatr by a letter to 'luyll containing a most thorough indorsement of republisan institutions. To this the Presinlent still demmered, fearing that England miglat take offence at the rabid republieanism of the document, and withlaw from her position of harmony with the Lnited States. Monroe was conservative, and Adams extreme; but on the other hand, the Presidnut desired in his message to seore franee and the Holy allies losth for theor interference in syatin and their contemplated interforence in America. He wisherl to reagnoize the imblependence of Greece, to all of which Arlams ohijecterl, insisting that he should "disclain all intention of interfering with these, and 
make the stand altogether for an American cause; and that at the same time, the answer to be given to the Russian communications should be used as the means of answering also the proposals of Mr. Cieorge Camning, and of assuming the attitude to be maintained by the United States with reference to the designs of the Iloly Alliance upon South America." At this point their relative positions were reverserl, the President assuming a bold and defiant attitude, and his Secretary counselling him to follow a more conservative course. Mr. Wirt did not believe that the people of the Enited States sympathized with the South Americans sufficiently to fight for their cause, in which case he questionerl the propriety of issuing any menace whatever, - at least he thought the temper of our own people should first be ascertained by consulting Congress. Calhoun supported the President; the people would fight, he believed, and should fight rather than permit the Spanish colonies to be reclneed by the allies; but he objected to Adams' plan of manifesto to Baron 'Tuyll, to which, on the other hand, Southard and, strangely enough, the eantious Wirt gave full approval.

All of this wrangling seems now to have been quite needless, for it really made but little difference whether the principles the administration wished to proclaim to the world should find expression in a letter to the Russian Ambassudor or should be embodied in the President's message to Congress. Almost at the very last moment, President Monroe seems to have adopted the changes in the draft of message so urgently insisted upon by Mr. Arams. The message, as finally prepared, expressed sympathy with the eonstitutional manifestos of Spain and Greece ; but it diselamed all intention of interfering abroad, and refrained from censuring either Fiance or the Holy allies.

The protest anainst interference on the part of the allies in Sonth Ameriea constitutes, however, only one part of the "Monroe lootrine." In the same messige, though in a precerling part of the doemment, oecurs another exposition of a foreign policy, which the president took oceasion to 
propose as one worthy of future recognition by the Lnited States. This related to the attitude which, for its own safety, the United States should thereafter assume towarl all foreign sehemes of colonization won the American continents. It was a policy emborlying a principle so thoroughly in hamony with the general view ammonced l,y the President in reference to foreign aggressions in the western world, that it his been accepted as a part of the "Monroe Doetrine."

In the early part of the century, an American exploring experlition had deseended the Columbia River to its month, and visiting the coastal regions of (O)egon, had established over a very consiclerable, though ill-defined region of territory, an Ameriean claim of title. Spain also had territorial elaims along the Pacific eoast, as far north as Vancourel Island, which, however, she yiekled to the Lnited States (north of $42^{\circ}$ ) by treaty of 1819 . English claims in the northwest were exceedingly inclefinite, but all eause of friction between Fngland and the Lnited states, arising from disputed boundary lines on the l'acific const, was removed by the agreement of 1818 , leaving for a tem of years the territory claimed by both parties free and open to the subjects of each. Far to the north and west, an immense and vaguely bounded territory, betonged to Russia. Even in those early days, some trate relations existed between citizens of the United States and the mative Alaskin Indians. Mismulerstandings arose, and Russia took oecasion in a correspondence which followed, to make known her claims along the Paeific coast of Nortl America, from Bering Sitraits to the mouth of the Columbia liver. In 1810 a linssian chatered eompany marle settlements and established a resulan trabling

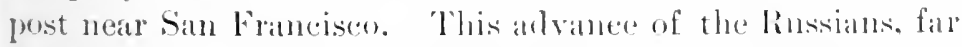
to the sonth, canserl some lissatisfaction in W:alnimgton: hnt so doubtful were all territorial titles along the l'arific const in those early days, that mo prositive stamel was mate anginst

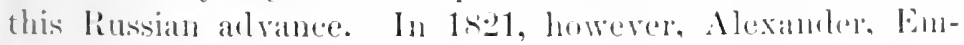
peror of Russia, issued an ukase, in which he anmomment his chaim to the northwest eorst of America, down to the inst 
degree of latitude, and forbade the approach within one hundred miles of his shores by any foreign vessel. This extraordinary assumption of marine jurisdiction met with instant protests from both $\mathrm{W}$ ashington and London. Mr. Adams bestirred himself to gather arguments to disprove this exaggerated claim of Russia, which Mr. Poletica, the Russian Minister in $\mathrm{W}^{\text {a }}$ shington, sought to defend upon the gromnds "of first discovery, first occupation, and upon that which results from a peaceable and nucontested possession of more thin half a century." Mr. Poletica was suceeded by Baron Tuyll, who brought the diseussion to a close by asking that the matter be settled in St. Petersburg by negotiation with Mr. Midlleton, the American Minister at that capital. Mr. Alams, in July, 18:3, told Bimon Tuyll "that we should contest the right of linssia to any territorial establishment on this continent, and that we should assmme distinctly the principle that American continents are no longer subjects for any European colonial establishments." He then instructed Mr. Middleton that:

There can, perhaps, be no better time for saying frankly and explicitly, to the Russian Government, that the future peace of the work, and the interest of Russia herself, camnot be promoted by Russian settlements upon any part of the Ameriean continent. With the exception of the British establishments north of the United States, the remainler of both the American continents must henceforth be left to the management of American hands. It camnot possibly be the purpose of Russia to form extensive colonial establishments in America. The new American republies will be as impatient of a Russian neighbor as the United States; and the claim of Russia to territorial possession, extending to the ist paralle of north latitute, is equally incompatible with British pretensions.

The very sime day he wrote to Mr. Rush, acquainting lim with the latest phases of the northwest-territory dispute. Ilesaid:-

$\Lambda$ necessiry consequence of this state of things [independence of the Sinnish Imericin colonies] will be, that the Ameriean continuts, leneeforth, will no longer be subjects of colonization. 
Occupied by civilized independent nations, they will be accessible to Europeans and to each other on that footing alone, anct the Pacific Ocean in every part of it will remain open to the navigattion of all nations in like manner with the Atlantic.

Incidental to the condition. of national independence and sovereignty, the rights of anterior narigation of their rivers will belong to each of the American nations within its own teritories.

The application of colonial principles of exclusion, therefore, cannot be admitted by the United States as lawful upon any part of the northwest coast of America, or as belonging to any Enopean nation.

Fortunately the dispute was amicably settled by the negotiations in St. Petersburg. In the treaty of 1s-2t, linsial accepted the parallel of $54^{\circ}+0^{\prime}$ as the southern limit of her Ameriean territory.

The statement of Mr. Arlams, that the American eontinents would no longer be subjeet to colonization, was seized upon by President Monroe. It dovetailed perfectly with the policy he and his calbinet had determined upon as a check against the Holy Alliance.

The words of the anmual message of December $2,182:$, which constitute the " Monroe Doctrine" are as follows. those aimed at Russia eming first :-

At the proposal of the Russian Imperial Government, made through the minister of the Eunperor resiling here, a full power and instructions have been transmitted to the minister of the United States at Sit. Petershurg to arrange br amicable negotiation the respective rights and interests of the two nations on the northwest coast of this continent. A similar proposal haut

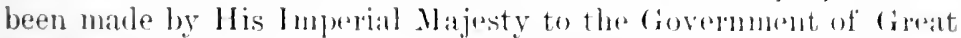

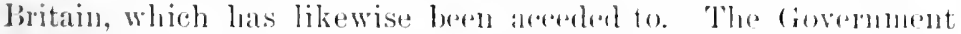

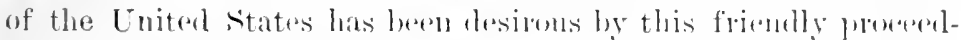
ing of manifesting thes ereat value which they latre invariably

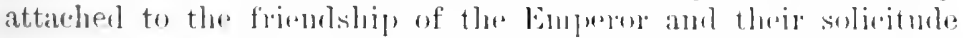
to cultivate the best molerstandine with his ciovermment. In the discenssions to which this interest has griven rise and in the antange-

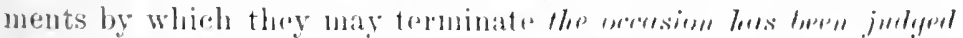

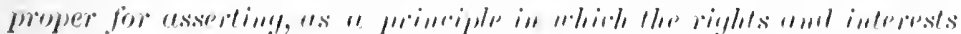

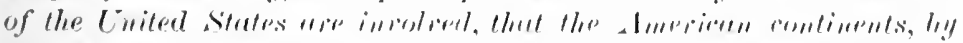

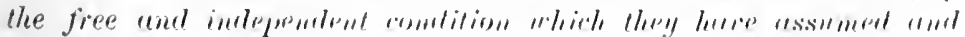


maintain. aie henceforth not to be considered as subjects for future colonizution by any Enropean poxers. ${ }^{1}$

After a digression upon other topics, the President turns to the subject of the threatened interference in South America by the allied powers of Europe:-

-It was stated at the commencement of the last session that a great effort was then making in Spain and Portugal to improve the condition of the people of those countries, and that it appeared to be condueted with extraordinary moderation. It need scarcely be remarked that the result has been so far very different from what was then anticipated. Of events in that quarter of the globe, with which we have so much intereourse and from which we derive our origin, we have always been anxions and interested speetators. The citizens of the United States eherish sentiments the most friendly in favor of the liberty and happiness of their fellowmen on that side of the Atlantic. In the wars of the European powers in matters relating to themselves we have never taken any part, nor does it eomport with our poliey so to do. It is only when our rights are invaled or seriously menaced that we resent injuries or make preparation for our defence. With the novements in this hemispluere we are of necessity more immediately comnected, and by canses which must be obvious to all enlightened and impartial observers. The political system of the allied powers is essentially different in this respect from that of Aneriea. This difference proreeds from that which exists in their respective Governments; and to the defence of our own, which has been achieved by the loss of so much hlood and treasme, and matured by the wistom of their most enlightened citizens, and moler which we have enjoyed mexampled felicity, this whole nation is devoted. Wr one it therefores to andor and to the amicable relutions eristing betwen the United States and those pouters to derlace that we should consider any attempt on their part to ertemen their system to any portion of this hemisphere as danger-

1 Italics not in the message. 
ous to our peace and sufety. With the existing eolonies or dependencies of any European power we have not interfered and shall not interfere. But with the Governments who hatre declared their independence and mantained it, and whose independenee we have, on great consideration and on just principles, acknowledged, we could not view any interposition for the purpose of oppressing them, or controlling in any other manner their destiny, by any European power in any other liyht than as the manifestation of an unfiriendly disposition toumd the Cnited States. In the war between those new Governments and Spain we deelared our nentrality at the time of their recognition, and to this we have adhered, and shall eontinue to adhere, provided no change shall oceur whieh, in the jurlgment of the competent authorities of this Government, shall make a corresponding change on the part of the United States indispensable to their security.

"The late events in Spain and l'ortugal show that Enrope is still unsettled. Of this important faet no stronger proof ean be adduced than that the Allied l'owers should have thomght it proper, on any principle satisfactory to themselves, to have interposed by force in the internal eoncerns of sian. To what extent such interposition may be earried, on the same principle, is a question in which all independent powers whose govermments differ from theirs are interesterl, even those most remote, and surely none wore so than the Inited States. Our poliey in regard to Europe, which was arlopted at an early stage of the wars which have so long agitated that quarter of the globe, nevertheless remains the sance, which is, not to interfere in the internal concerms of any of its lowers; to consider the government he forto as the lesitimate goverument for us; to cultivate frienclly relations with it, and to preserve those relations by a framk, firm, and malnty policy, meeting, in all instances, the just elatus of every power, submitting to injuries from none. But in resind to

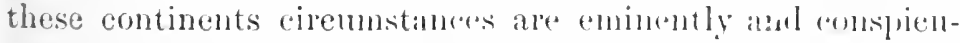
onsly different. It is impossible that the allied powers should extend their politieal systrom any antion of either

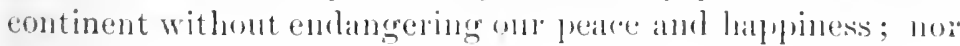


can any one believe that our southern brethren, if left to themselves, would adopt it of their own accord. It is equally impossible, therefore, that we should behold such interposition in any form with indifference. If we look to the comparative strength and resources of Spain and those new Governments, and their distance from each other, it must be obvious that she can never subdue them. It is still the true policy of the United States to leave the parties to themselves, in the hope that other powers will pursue the same course." 1

\section{V}

Reviewing the course of events that culminated in the declarations of President Monroe in his ammual message to Congress of 189:;, several facts are to be noted :-

1. The United States by adopting a republican form of government brought upon itself the enmity of absolutism.

2. Physical weakness obliged it to follow a policy of political isolation. Intermedalling in the affairs of others was likely to invite troubles, and the young republic could not endure the strain of useless wars. By frequent expressions of its statesmen the nation substantially pledged itself to abstain from interference with the concerns of Emope.

3. With this determination to hold aloof from the politieal affiairs of the old world, a dominant feeling prevailed, that the old world should not interfere in the affairs of the new.

4. It became apparent in the summer of 1828 that certain power's of Emrope, allied together for the purpose of suppressing rebellion and perpetuating the theories of divine right of kings, were about to extend the scope of their operations to South Aneriea, by airling Spain in crushing rebellion in her colonies.

5. George Camming, the English Minister for Foreign Afinirs, Was embarrassed as to the proper comrse to pursue in relation to the Sonth American eolonies of Spain. British commercial interests demanded the reeognition of the new, 
states, while other consilerations opposed such a combe. Finding a solution of the difficulty in American evöperation against the Holy Alliance, he sought to enlist the United Stat tes in a plan he had devised to oppose the scheme of the allies.

6. Interference on the part of the allies in Sonth and Central Ameriea, it was featred, would leal to territorial grants to them, followed, in all probability, by the (sital)lishment of monarehical rule, ant eventually the overthow of republiean institutions in all the new world, inchuling the Linited States.

7. Previous to 18:2:), Russia had by proelimation and actual settlement somght to acquire title to portions of the Pacifie coast of North America, elamed by both England and the United States. Penting negotiations for settlement of these diffienlties, the President took occasion to express in his message of 1823 , his belief that thenceforth the I'nited States could permit no European colonization in North or South America.

The Monroe Doctrine inchules several distinct statements, as follows:-

(a) The Ameriean continents are henceforth not to be considered as subjeets for futme colonization by any European powers.

(b) The political system of the allied powers is essentially and radieally different from that of America, and boing dre voted to the defence of onr own system, we owe it in amdor to those powers to dechare that we shonlel "o (onsider any attempt on their part to exteml their system to any jortion

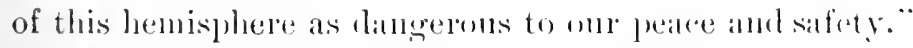

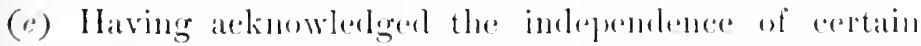
govermments (in Amerial), we romlel mot view interposi-

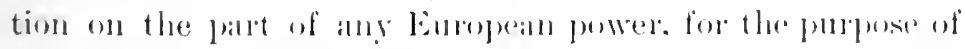

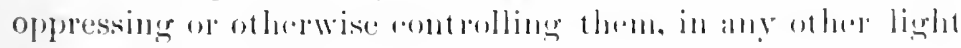

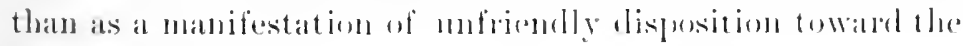
United sitates.

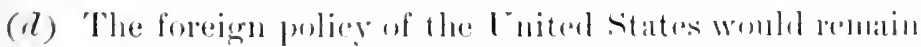
the sanc; that is, not to interfere in the internal affindes of any European power. 
(e) Circumstances being raclically different on these continents, it is impossible that the allied powers should extend their political systems into either of them without endangering our peace and happiness; therefore it is impossible that we shomld behold such interposition with indifference.

Barring the first statement in regard to colonization, which expressly lays down a principle for future guidance, the declaration was a lefensive measure, directed against the threatened interference of the Enropean powers constituting the IHoly Alliance. There has since been endless discussionas to whether the President intended by these words to establish a prineiple that shoulı ever afterward be followed by the people of the United States. Whether the President intended this or not, the principles enunciated at that time have frequently been appealed to since, and the "doctrine" itself has been aceepted as the corner-stone of America's foreign policy. There can be little doubt, however, that President Monroe had no intention of proclaiming to the world an inviolable principle for all time to come. Being confronted by a definite threat, he met it by a definite statement. He mentions in his message the particular reasons for his oplosition to the "Allied Powers," and refers in particular to "these powers" constituting the Holy Alliance, as the object of his attack, hecause they represent, and seek to perpetuate, a system of govermment from the evil influences of which we hat escaped and the revival of which we regarded with ablorence.

Momroe's liographer, Daniel C. Filman, says :-

It appears to me probable that Monroe had but little conception of the hasting effect which his works would produce. . . . It was heramse he fromounced not only the opinion then prevalent, but atratition of other days, which haul been gradnally expanded, that his words carried with them the sanction of pmblic law.

The message was received in the United States with feelings of deepest satisfaction. The danger had been squarely met, and the people were relieved in the knowledge that the president could be dependerl upon to act property should the anticipated erisis oceur. The spirit of the doetrine had been 
struggling for expression for a number of years, and, in voieing it, the President tonched a chord which vibrated in every American heart. From all political parties the arhministration reeeived the wamest commendation, while a most friendly feeling made itself apparent throughout the Lnited States toward England, which had now become a silent politieal partuer. In England that portion of the message which related to interference in America on the part of the allierl powers of Europe was enthusiastically receiverl. and the English press was fulsome in its praise of President Monroe. The British Government felt relieved of a burden by the positive attitude of the Inited States. The message lam come at a most opportune moment; the allies were pressing Great Britain to meet them in convention at Paris, with a view of settling the Spanish-Anerican question. Mr. Canning, though hesitating to isolite his country from the rest of Europe, knew that the proposed settlement would lie unsatisfactory to England. Mr. Monroe's message relieverl the situation and settled the matter in just the way Great Britain desired. Canning afterward boasted, "I callerl tle New World into existence to redress the balance of the Old."

The other part of the message, relating to colonization. was not so acceptable to Great Britain. There being at that time much uncertainty as to the extent and ownership' of unoecupied land in the great Northwest, Camming maintained that England "comld not acknowlerge the right of any power to proclaim such a principle, much less to bind other countries to the observance of it. If we were to be repelled from the shores of Americal, it womld mot matter to us whether that repulsion were effected by the r'katse of Russial, exchuding us from the sea. or hy the new doetrine of the President, prohibiting us from the land. lint we cannot yield oberlience to either." 'The recelaration was " very" extraordinary"; one which His Majesty"s Govermment was "prepared to combat in the most meequivocal manner." The right of colonization was one that, as heretofore, may be exercised "without affording the slightest umbrage to the United States." 
The powers of Continental Europe were surprised and indignant; Monroe was a dietator of the worst eharacter, while the United States was an upstart nation, that maintained unwarantable pretensions, and sought to establish wholly inadmissible principles in eontempt of the eivilized nations of the world. The declaration of this presumptuous people slould be resisted by all powers possessing interests in the Western Hemisphere. But just back of the outstretched wings of the noisy American eagle, France and Russia believed they detected the British lion. If England harl, after all, joined the allies in their schemes, it is much to be doubted whether the President's message of 1829 , would have seriously embarrassed them in the ultimate perfection of their Spanish American plans; but the realization that Great Britain, with her powerful nayy, endorsed, in the main, the sentiments of Presilent Monroe, cast a gloom over the propagandists of divine right, and the great South American project was abandoned.

Although the Colombian Congress resolved that the doctrine of the North American Presirlent was "an act eminently just and worthy of the elassie land of liberty," the message does not seem to have been welcomed with lond acelaim in Sonth America. Events following soon after convinced the people of Spanish America - suspicious by nature, and at heart distrustful of the Anglo-Saxom - that the Lnited States dirl not intend to mpholl the doctrine, and that if it were meant as a promise of protection to them, it was false.

Som after the realing of the President's amnual message, Ienry C'lay, Speaker of the Ilouse of Representatives, caused to be introduced the following resolntion :-

Rirsolved by the Senate and Honse of Representatives of the Uniten states of Amerior in comgress assembled, That the people of these states wonld not see, withont serions inquietmle, any forrible intervention by the allied Powers of Europe, in behalf of syan. to bethere to their former sulijection those parts of the continesut of America which have prerdiamed and established for themselves. respectively, independent governments, and which have been solemmly recognized by the United States. 
This attempt to place the seal of Congressional approval upon the Monroe Doctrine, and give it thereby a more authoritative character, failed in less than two months after its enunciation by the executive. Several reasons have been assigned for this failure; one is, that Congress considered the alleged threats of the allies as empty vaporings, unworthy of notice; another is, that members of Congress, believing the danger to be past, were umwilling, in the absence of clear evidence of hostile intentions from abroal, to lay down a prineiple so wicle and sweeping in its character. and one that might possibly be regarded by friendly nations as offensive. Still another reason is adranced why Mr. Clay's resolution was consigned to the table. Mr. Clay was well known to be a candidate for the presidency. His strength was great throughout the Sonth and the IVest, and his influence as Speaker in the House was a powerful one. Joln Quincy Adams also was looking in the same direetion as Mr. Clay; General Jaekson was a possible candirlate, and the same may be said of Calhoun. The " Iomroe I)octrine" earried within it the elements of unbounded popularity ; its champion in Congress might become a political hero. The opponents of Clay therefore combined against him, and he found himself in the awkward attitude of fathering a measure which was doomed in advance. He yielderl to necessity, and consented to the shelving of his resolution.

Mr. Poinsett of South Carolina also moved a similar resolution, which met the same fate, but political jealonsy can hardly be eharged for the failure of Mr. Ponisedt's motion.

In his last annual messige to Congress. the following year (December 7, 182t), President Monroe again tonk oceatsion to reaffirm the policy anmonneed in his previons message.

. Separated as we are from Europe ly the great Atlantic

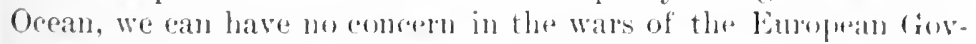
ermments nor in the canses whinh predure them. The hatance of power betweren them, into whicherer seale it may tum in its varions vibrations, camnot affect us. It is the interest of the United states to preserve the most frimully relations with every

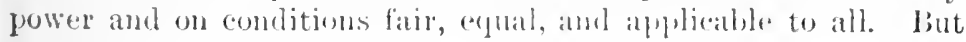


in regard to our neighbors our situation is different. It is impossible for the European governments to interfere in their concerns, especially in those allucled to, which are vital, without affecting us; indeed, the motive which might induce such interference in the present state of the war between the parties, if a war it may be called, would appear to be equally applicable to us. It is gratifying to know that some of the powers with whom we enjoy a very friendly intercourse, and to whom these views have been communicated, have apleared to accuiesee in them... .

An occasion was about to be presented to the United States Govermment which would indicate the extent to which the country was willing to go in pledging its material support to the Monroe Doctrine. In the negotiations and debates relative to an invitation from the South American states to send delegates to a general Congress of the Americas, every shade of sentiment touching the Monroe Doctrine is found. So widely divergent were opinions in Congress upon this subject, that the doetrine, after rumning the gantlet of the Senate and House, emerged sadly disfigured. But in these debates, as with Clay's resolution, a series of political eonsiderations became involved. The reluctance of Congress on this occasion to endorse the policy was, after all, scarcely a test of popular sentiment on the subject.

\section{PANAMA CONGRESS}

i Simon Bolivar was the Washington of South America. It was his roice that stimed the people to patriotic ardor; it was his martial skill that brought them victory, and won for then the prizes of liberty. His statue alorns the public squares of South American cities; his menory is revered from l'anama to Buenos Ayres; lie is declared to be the hero, the liberator of Sonth Anerica. At his instance, the states of ('olombia in 18.2. (then New Granada) began making treaties of alliance, offensive and defensive, with other Sonth American states, whose independence from Spain hat been practically won. In that and the following year, the 
various independent states of South America formed a ferteration, bound together by the elosest ties of friendship and common interest.

The central object of this confederation was to maintain independence by mutual aid and smpport, and to shield themselves against all harmful foreign influence. Like thein North American neighbor, they had watehed with considerable apprehension the threatened movement of the Enropean allies to aid Spain in their resubjugation, and they reengnizerl the necessity of standing firmly together. It was therefore agreed among them that "a general assembly of the American states shall be convened," for the purpose * of cementing . . . intimate relations." and Panama was suggested as a convenient meeting place. There seems to have heen no original intention on the part of these "formerly Spanish" provinces to ask the Lnited States to coöperate with them when they made their treaties of alliance, but the publication of Presillent Monroe's message, of I ecember, 18:3, with its eneouraging words for all newly created repulblics in the Western Ilemisphere, seemed elearly to entitle the Lnited States to a voice in their proposed Congress, should such a desire manifest itself at Washington. In the spring of 18.2. the ministers of Colombia and Mexieo, Messiss. Salazar and Obregon, eautiously aploroached thr. Secretary of State with a proposition from their respeetive governments, to the effect that, shonld the Enited States desire to participate, her delegates would find welcome at the Congress of the Americas, soon to convene at Pamama. 'This invitation eame immediately after the inanguration of President Arlams (March, 1825). The President was known to be at hearty supporter of the principles of the Monroe Inetrine: he had been Secretary of State muler Monroe, and hat rnjovert. as smoh, the full confidenee of the l'resident during the preparation of his famons messige. The secretary of state wats llenry Clay, and he hat always been the champion in Comgress of the South American states: indreerl. some of his greatest speeches harl been mate in their eathse. It was then reasonable to suppose that the arlministration would be faromable 
to this plan of a greneral Congress. Knowing now that Adams, to a very large extent, was the real author of the Monroe Doctrine, one looks with considerable interest to the reply of the President to Messis. Salazar and Obregon, because it is, from the lighest somrce, an official and authoritative interpretation of the Monroe Doctrine. During the cabinet discussions of 1829 , when the phrasing of that portion of the President's message relating to foreign affairs was moler discussion, and Mr. Adams was urging the acceptance of his own coly, Mr. Wirt, the Attorney General, had asked him if he intended that the country should sustain, by force of arms, the somewhat aggressive policy he advoeated. Mr. Arams could only then reply that that very question had given him no little concern, and he could not fully answer it. Now the same question was subtly asked by South America, - Would the United States confer with those who had joined in arms against European aggression, or perhaps, would she go a step further, and ally herself with them?

The Presillent replied to the invitation of the two ministers through Mr. Clay, saying:-

That of course the United States could not make themselves a party to the existing war with Spain. The President believed such a Congress as was proposed night be highly useful in settling several important disputed questions of publie law, and in arranging other matters of deep interest to the Ameriean continent, and strengthening the friendship and amicable intercom'se between the American powers: but, before such a Congress assembled, certain conditions should he complied with, namely, the fixing of the subjects to be discussed at the Congress, the powers to be given to the commissioners, and the mode of organizing the Congress....

A cantions reply. In the following November (1825), these same diplomatic agents of Colombia and Mexico reported to Mr. Clay, renewing their invitation upon this oceasion, by formal notes from their home govermments. They stated that while it was impossible to enumerate, 
definitely, all the topies which would likely be juesented for consideration, at the proposed Panama Congress, they conkl at least state that the discussions would inclucle the mamer of resistance to any attempted eolonization by European powers on the American eontinent, and would inclucle also the methods of resistance against possible interference in behalf of Spain against her former colonies. They would also discuss certain matters of international law, the abolition of the slave trade, and the independence of IIaiti. Numeroms other subjects were to be brought up, which more particularly concerned the South American states, and which the Initer States delegates would not be required or expected to discuss. It was particularly apllopriate, as these representatives lelieved, for the American states to assemble in Congress, in order to eonsider their own interests - the nations of the Old Irorld had long since been doing the same thing.

Mr. Clay thought that the ministers who extender this invitation to the United States laak not even yet been sufficiently explicit as to all preliminary arrangements, to satisfy the l'resident. The l'resident wisherl to know exactly to what extent diseussions at P'anama might go, and just how far the Lnited States might be placed under obligations by the resolutions adopted at the Congress. Botl Arlams and Clay felt the neeessity of caution. It is far safer to declate a poliey than to pledge oneself to abille by it. The l'resident deliberated well; he believed that preliminary matters could be satisfactorily arranged later, so he dismissed the plenipotentiaries from ('olombia and Mexico, with the statement that he womld send eommissioners to the Congress at lanama, if the Senate, which was shortly to convene, would consent.

In his annmal messigge the following month (1)ecomber b,

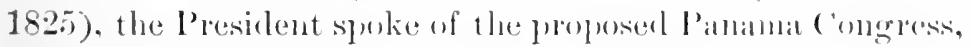
and of the invitation to the l niterl sitates to participate. "The invitation has been alerespted," he wote. "and minister's on the part of the l'niterl states will be ammissioned to attend at those deliberations, and to take part in themeso far as may be eompratible with that nentrality, fonm which it is 
neither our intention, nor the desire of the other American states, that we should depart."

To the Colombian and Mexiean ministers, the President had said he wonld send delegates to the Congress, "should the Senate of the Cnited States . . . give their advice and consent"; to the Senate he simply said, "Ministers on the part of the United States will be commissioned to attend."

It was generally supposed to be the eustom, as well as within the law, for the executive, in the ereation of a new mission, simply to nominate envoys for the purpose, in which case, if the Senate did not agree with the President in the expediency of the suggested mission, it could exereise its authority by declining to confirm the nominations. The President's numerous political enemies in the Senate ehose to avail themselves of this oplortmity to attack the administration, and a bitter diseussion of the eonstitutional right of the Presirlent to create the mission to Panama followed. On December 26 (18.5), the President sent a speeial message to Congress on the subject, in which he remarked :-

Although this measure was deemed to be within the constitutional competency of the Executive, I lave not thought proper to take any step in it before ascertaining that my opinion of its experliency will concur with that of both branches of the Legislature, first, by the decision of the Senate upon the nominations to be lail before then, and, secondly, by the sanction of both Houses to the appropriations, withont which it camnot be carried into effect.

In defence of his policy he went on to say :-

It will be seen that the United States neither intend nor are experted to take part in any deliberations of a helligerent character' that the motive of their attendance is neither to contract alliancess nor to engage in any mulertaking or project importing hostility to any other nation.

The President further suggested that the South Ameriean nations "in the infancy of their independence" and through mere inexperience, had failed in some of their duties to other nations; that throngh the friendly means of a general Con- 
gress, such mistakes against the Lniterl States miglit be corrected. In this doemment from the White louse, a number of other reasons were urged - all semingly sufficient to the President - that the Lnited Sitates should he represented in a general Congress of the Amerieas. The following significant words are notewortly: -

An agreement between all the parties represented at the meeting that each will guard by its own means against the establishment of any future European colony within its borders may be fom advisable. This was more than two years since announced by my predecessor to the world as a principle resulting from the emancipation of both the Anerican continents. It may be so developed to the new southem nations that they will all feel it as an essential appendage to their independente.

The message closes with the nomination of Richard $C$. Anderson of Kentucky, and Joln Sargent of Pennsylvania, "to be envoys extraordinary and ministers plenipotentiary to the assembly of the American nations at Panama."

A storm of disapproval met the rearling of this message. In the Senate many expressed indignation at the President's assumption in nominating delegates to the lanama convention, withont first having asked the consent of Comgress, and were moved to expressions of greater wath by the President's bold assertion of his constitutional right to semd such envoys as he proposed. They railed against his "patronizing effrontery" in asking if Congress did really concur in his opinion of the expediency of the lamana mission, when he had aheady signified his intention to send delegates.

A bitter prejulice was engendered in both hanches of Congress, against the l'resiltent's jnojeet, quite asille and aprart from the merits of the question itself.

There were also many in Comgress who did not favor sending commissioners to Panama, for any reason whatever, as they distrusted the volatile chanacter of the spanish descendants; and as they doubted their eapacity for selfgovernment, they wished to have no political connections with them. It would be unwise, they said, to entangle ourselves 
in their affairs, - we should be free to use our own discretion how and when to apply our recently advanced foreign policy. The United States, they urged, had nothing to gain and everything to lose by sending representatives to such a gathering.

In reviewing the long and particularly acrimonious debate aroused by the President's special message of December 26 , one can hardly fail to be struck by the persistency and vindictiveness of the opposition. It seems indeed to have been out of all proportion to the importance of the issue. A hidden eause for so much venom may be found in the fact that the enemies of the measure were all from the South, and represented slave-holding eonstituents. The Spanish-American states had abolished the institution of slavery, and were desirous of conferring with the United States at Panama, as intimated by Messrs. Salazar and Obregon, "pon the propriety of abolishing the slave trade. Haiti was a negro republie, a nation of former slaves, and these southern members of Congress wished no official notice to be taken of them, and they resented the suggestion of conferring with them in any manner whatever. Randolph, Hayne, Van Buren, Buchanan, Polk, Calhoun and Burton, led an opposition that seemed invincible; "other states will do as they please," said Hayne, "but let us take the high ground that these questions belong to a class which the peace and safety of a large portion of our Union forbids us to discuss. Let our government direct all our ministers in Sonth America and Mexico to protest against the inclependence of IIaiti; but let us not go into conncil on the slave trate and laniti." White, of Temnessee, exchimed, "Let us cease to talk of shavery in this llouse, let us cease to negotiate "pon any subject connected with it." Shadows of conning erents were here cast before. Callom appointed the Committee on Foreign Afrairs, and he selected its member's with a purpose. The committee retumed an manimous report, to the effeet that it was not experlient for the Cnited States to he represented at Panama. The Senate then went a step farther, and passed a resolution eensuring the President. 
On the 15th of March (18:6), Mr. Adams, still undismayed, sent a special messige to the House of Representatives, in which he sought to demonstrate to that body the great importance of the Panama mission. The message is too redolent of the flowers of rhetoric, but it is a remarkably vigorous paper. Here and there occur expressions that throw considerable light upon Adams' conception of the extent and scope of the Monroe Doctrine, and which, coming from a. joint author of the doctrine itself, are of great value:-

But objects of the highest importance, not only to the future welfare of the whole human race, but bearing directly upon the special interests of this Union, will engage the deliberations of the Congress of Panama whether we are represented there or not. Others, if we are represented, may be offered by our plenipotentiaries for consideration having in view both these great results our own interests and the improvement of the condition of man upon earth. It may be that in the layse of many centuries no other opportunity so favorable will be presented to the Government of the United States to subserve the benevolent purposes of Divine Providence; to dispense the promised blessings of the Redeemer of Mankind; to promote the prevalence in future ages of peace on earth and good will to man, as will now be placed in their power by participating in the deliberations of this congress. . . .

The late Presillent of the United States, in his message to Congress of the 'd December, 18::3, while announcing the negotiation then pending with linssia, relating to the northwest coast of this continent, observed that the oreasion of the discussions to which that incident har given rise harl been taken for asserting as a principle in which the rights and interests of the United States were involved that the American continents, by the free and independent comblition which they had assumed and maintained, were thenceforward not to be considered as subjects for future colonization by any European power. The principle lad first been assumed in that negotiation with Riussia. It rested upon a course of leasoning equally simple and (onnelusive. With the exception of the existing European alonies, whin it was in nowise intenderl to ristmrl, the two continents consisterl of serveral sovereign and independent nations, whose territories covered their whole surface. By this their independent condition the United States enjoyed the right of "ommore ial intrereourse with "rery jart of their possessions. 'Tuattempt the establishment of a colony' in 
those possessions would be to usurp to the exclusion of others a commercial intercourse which was the common possession of all. It conld not be done withont encroaching upon existing rights of the United States. The Govermment of Russia has never disputed these positions nor manifested the slightest dissatisfaction at their having been taken. Most of the new American Republics have declared their entire assent to them, and they now propose, among the subjects of consultation at Panama, to take into consideration the means of making effectnal the assertion of that principle, as well as the means of resisting interferenee from abroal with the domestic concerns of the Ameriean Govermments.

In alluding to these means it wonld obvionsly be premature at this time to anticipate that which is offered merely as matter for consultation, or to prononnce upon those measures whieh have been or may be suggested. The purpose of this Government is to concur in none which would import hostility to Europe or justly excite resentment in any of her States. Should it be deemed advisable to contract any conventional engagement on this topic, our views would extend no further than to a mutnal pledge of the parties to the compract to maintain the principle in application to its oun teritory, and to permit no colonial lodgments or establishment of European jurisdiction npon its own soil; and with respect to the obtrusive interference from abroad--if its future character may he inferred from that which has been and perhaps still is exercised in more than one of the new States - a joint declaration of its character and exposure of it to the world may be probably all that the oreasion would require. . . .

The condition of the islands of Cuba and Porto Rico is of deeper import and more immediate bearing upon the present interests and future prospects of onr Union. The correspondence herewith transmitted will show how earnestly it has engaged the attention of this Government. The invasion of both those islands by the mited forces of Mexico and Colombia is avowedly among the ohjects to be matured by the belligerent States at Panama. The convulsions to which, from the peculiar composition of their population, they wonld be liable in the event of sneh an invasion, and the danger therefrom resulting of their falling ultimately into the hants of some European power other than Spain, will not almit of on looking at the consenuences to which the Congress at l'anama may lead with indifference.

After giving assurances that the "assembly will be in its nature diplomatic and not legislative - merely consultative," 
Mr. Adams takes up the question of whether "the measure might not have a tendency to ehange the policy hitherto invariably pursued by the Lnited States of aroiding all entangling alliances and all unnecessiny foreign connections." "Mindful of the advice given by the father of "ml tomtry," he declares that the connsel of $W$ ashington in that instante, "like all counsels of wistom," was founded upon the fact that "Europe lat a set of primary interests" all her own, and having but a remote relation to us, conld only inrolve us in needless dispute, did we eoncern ourselves about them, but now. having " more than realized the anticipations of this admirable political legacy," by our growth and expansion we have arriverl at a point when ". America las a set of primary interests which have none or a remote relation to Europe; that the interference of Europe, therefore, in those concerns should be spontaneously withlield hy lier upon the same principles that we have never interfered with hers, and that if she should interfere, as she may, by measures which may have a great and daugerous recoil upon oulselves, we might be called in defence of onw own altans and firesides to take an attitule which would cause ou neutrality to be respected, and choose peace or war, as on interest, gruided by justice, should comnsel." Following the same idea he continues:

To the question which may he asket, whether this meeting and the prineiples which may he adjusted and settled by it as rules of intercourse between the Anericaln nations may mot give umbrage to the holy league of Eurojern powers on offence to Spain, it is deemed a sufficient answer that our attendinee at Panama ean give no just conse of unbrage or oflences to either, and that the United States will stipulate nothing there which can give such canse. Here the right of impliply inte onr purposes and measures must stop. 'The holy leagure of Enope it self was formed without infuiring of the Euited sitates whether it

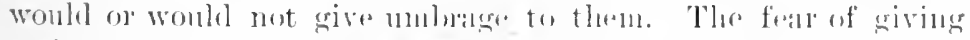

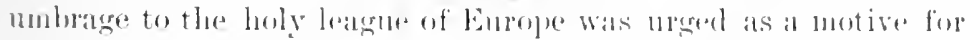
denying to the Amerim nations the areknowlangment of their

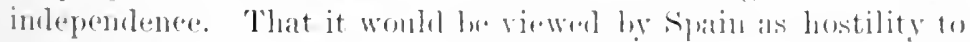
here, was not only urged, but dirently decliared by herself. 'The 
Congress and Administration of that day consulted their rights and chuties and not their fears. Fully determined to give no needless displeasure to any foreign power, the United States can estimate the probability of their giving it only by the right which any foreign state could lave to take it from their measures. Neither the representation of the United States at Panama nor any measure to which their assent may be yielded there will give to the holy leagne or any of its members, nor to Spain, the right to take offence; for the rest the United States must still, as heretofore, take comsel from their duties rather than their fears.

Considering the lukewarmmess with which Mr. Adams, as Secretary of State, had approaehed the subject of acknowlelging the independence of the South American states, and considering his extreme caution and reserve as President in accepting the invitation to participate in the Panama Congress, one may wonler at the zeal displayed in his appeals to Congress to send representatives to the isthmus. He threw himself against the opposition of Congress with all his strength; he made the matter a personal one, as though the refusal of Congress to approve his scheme amounted to no less than an insult, and a personal affront to him. Whatever may have induced him to experience so decided a ehange of heart, suspieion will remain that a reason of some weight is to be found in the very olstacle itself, - the opposition of Congress. 'Thoroughly aroused by the thrusts of his political enemies, now considered his personal enemies, the President was moved to great earnestness as he pemned this message. Seemingly in a spirit of inspiration he concluded the paper.

That the Congress at Panama will accomplish all, or even any, of the transcendent benefits to the human race which warmed the conceptions of its first proposer it were perhaps inclulging too sanguine a forecast of events to promise. It is in its nature a measure speculative aml experimental. The blessing of heaven may turn it to the account of hmman improvement; accidents unforeseen and mischanees not to be anticipated may battle all its high purposes and disappoint its fairest expectations. But the design is great, is benevolent, is humane. 
It looks to the melioration of the condition of man. It is congenial with that spirit which prompted the declaration of our independence, which inspired the preamble of our first treaty with France, which dictated our first treaty with Prussia and the instructions under which it was negotiated, which filled the hearts and fired the souls of the immortal founders of our Revolution.

The long aerimonious debate in the Senate was elosed Mareh 14, 1826, by the appointment of Messrs. Anderson and Sargent as Ministers Plenipotentiary. 'The P'resident had trimphed then in the Cpper. Iouse, but at a great cost of ill feehing. The Lower House read his messige, and in ten days the Committee on Foreign Relations placed before the House the resolution that, " it is expedient to aphropriate the funds necessary to enable the President of the Lnited States to send ministers to the Congress of l'anama." The Ways and Means Committee immediately reported a bill making the necessary appropriations to defray the expenses conneeted with the mission.

The debate in the House was, perhips, less bitter than it had been in the Senate, but the same opposition to the measure developed that had thatraterized the disedissions of the Lpper House. The Sonthern members arrayed themselves solidly against a projeet that, in their estimation, led the Enited States into forming embarmassing allianees with Sonth Americans, - a projeet that might induce the l'nited states to take aetion with foreign nations upon the slave tranle, and that might disgraee their eountry hy undue familiarity with the negro republie of I Iaiti. Alrealy the Sonthem members sought to tahoo any disenswion touching npon slavery. Daniel Welster eame to the Presirlent's rescue by warmly defending the message of Mareh 15. Ile insisted that it was not the duty of the llonse, nor their constitutional right to decide "what shall he discussed hy partienlar ministers, alrealy appointerl, when they shall meet the ministers of other powers," - that matter, he mintainerl, belonged to exeentive diseretion and responsibility. It was for the House only to vote the neessary appropriation. He deelared 
that he looked " . . on the message of December, 1823, as forming a bright page in our history. I will neither help to erase it or tear it out; nor shall it be by any aet of mine blurred or blotted. It did honor to the sagacity of the govermment, and I will not diminish that honor. It elevated the hopes and gratified the patriotism of the people. Over those hopes I will not bring a mildew; nor will I put that gratified patriotism to shame."

The force of Daniel Webster's logic did not convince the members from the South. The necessary appropriation bill was finally passed, but a heavy tail to the kite was attached by the following resolution :-

It is therefore the opinion of this House that the Government of the United States ought not to be represented at the Congress of Panama except in a diplomatic character, nor ought they to form any alliance, offensive or defensive, or negotiate respecting such an alliance with all or any of the South American republics; nor ought they to become parties with them, or either of them, to any joint declaration for the purpose of preventing the interference of any of the European powers with their independence or form of government, or to any compact for the purpose of preventing colonization upon the continents of America, but that the people of the United States should be left free to act, in any crisis in such a manner as their feelings of friendship toward these republics and as their own honor and policy may at the time dictate.

The way being at last cleared, on May 8 (186), Mr. Clay, the Secretary of State, instrueted the two envoys:-

"The assembly of a Congress at Panama, composed of diplomatie representatives from independent American nations, will form a new epoch in hmman affairs." With the idea before them that the republican nations of the New World shoull meet to examine aml pass upon their own interests, which were now distinct and separate from the interests of the Ohl Worl, the commissioners were to devise means of freserving peace in futme among the American nations. They were to assist in the revision of a number of vaguely expressed ar msatisfactory principles of international law, especially as related to the sea — " to propose a joint decla- 
ration of the several Ameriean states, each, however, acting for and binding only itself, that within the limits of their respective territories no new European colony will hereafter be allowed to be established."

On the question of the interoceanie canal, should it come before them for eonsideration, they were to take the stand that - "If the work should ever be exeented so as to admit of the passage of sea ressels from ocean to ocean, the benefits of it ought not to be exehisively appropriated to any one nation, but slıould be extender to all parts of the globe upon the payment of a just eompensition or reasonable tolls."

The Congress of Panama assembled on the 2.2d of June, 1826, but neither of the American representatives was present. Mr. Anderson, one of the commissioners, was Minister at Bogota at the time of his alpointment to Pamama; he died on his way to attend the meeting. The other American delegate, Mr. Sargent, had been so long delayerd by the lengthy debate in Congress over the experlieney of his mission that he was unable to effect his derarture from the United States in time to be present.

The lamana Congress proved to be a fiasco; neither the United States, Chili, Brazil, nor Bnenos Ayles wis represented, and without the coipueration of these. the largest and most important states of the Western Henisphere, the lesorlutions of the Congress necessarily reacherl a "lame and impotent conchusion." The more sonl-inspiring and magnificent the utteranees of the few delegates puesent at the convention, the more ridiculous they appeared. A treaty of perpetual mion and conferleration, a sort of offensive and defensive allianee, was entererl into by the relegites - the purpose being to pledge all the Anerican states to airl earde otlere in maintaning their own integrity. () all the states repere senterl, Colombia alone ratifierl the treaty. Jurleerl, lard the delegates of the Lniterl states been in attendance at the conference, they could mot lave subseribed to the resolutions that were adopterl.

A resolution to meet argain the following yan in sonth America was only responded to by the two Luited States 
delegates. These men, with bulky instructions in their pockets, found themselves alone at the appointed time and place. Their sense of humor was no doubt severely taxed. In fact, the South and Central American states had already begun their careers of eivil strife; they had neither the time nor inclination to deliberate over matters relating to the common welfare.

As the Panama Congress proved to be a hopeless failure, chief interest in the event, as previously suggested, is to be found solely in the numerous interpretations of the Monroe Doctrine, which it elicited. The many opinions-coming directly from President Adams and his Secretary of State, Mr. Clay, from the most prominent statesmen of the country, and as embodied in the resolutions of both Houses of Congress - throw a flood of light upon the contemporaneous construction of the doctrine.

Althongh in these Panama debates the principles, enunciated by President Monroe, were more or less overshadowed by other political considerations, yet enough was said bearing directly upon the interpretation of the doctrine to illustrate the views of the statesmen of the period on the subject.

First and foremost, Adans, no loubt the actual author of that part of the doctrine bearing upon futurc colonization by European powers in the Western Hemisphere, and probably a joint anthor of the rest of the message included in the "Doctrine," was the one who, of all others, conld speak. most anthoritatively mon the sulject. In reference to the ennnciations of his predecessor in office, he said: "Our views would extend no further than to a mutual pledge of the parties to the compact to maintain the prineiple in application to its own territory, and to permit no colonial lodgements or establishments of European jurisdiction upon its own soil." The hesitation of the President to accept the invitation of the Sonth Amerieans, and afterward his insistence that the functions of the plenipotentiaries should be diphomatie only, and in no sense legishative or binding upon the govermment, shows definitely that he was not of a mind to pledge the eomintry to exeente a policy which he had him- 
self taken so prominent a part in framing. 'This, too, Wats in spite of the fact that he believed the Americas had a system and interests of their own, removed from and perhaps opposed to those of Europe. When called uprom to act, therefore, President Adams narrowed his former position amel declared a new doctrine. "Let every state defend the integrity of its own territory." That, after all, was a useless suggestion.

Clay followed the sentiment of his chief, - the United States shonld not be oluliged to guamee the execution of the principles of the Momroe Doctrine.

The Senate and House passed resolutions, reaffirming the poliey of non-interference, asserting the hroal principle that the people of the Lnited Sitates should be left free to act, in any erisis, as their own homor and policy might dictate. Momoe Doctrine or no Momme Doctrine, in case of foreign aggression, the Govermment of the Lnited ritates should always be at liherty to follow the comse of action that the necessitios of the orcasion called for". There shoml be no fixed rule to govern futme contingencies and ambarass the nation. Daniel Webster seems to have voiced the majority opinion of Congress luring this Panama debate, when he said :

It [Monroe's Declaration] dir not commit ns, at all events, to take up arms on any indication of hostile feeling by the powers of Enrope towarts sonth America. If. for example, all the states of Europe had refused to trade with Sonth Amorica mutil here states should return to their former alle gianere, that wonld hatve furnished no canse of interferenere to ns. (1) if an armanent har bern fur- nished by the allies to aret anamst furovineses the most memote from us, as Chili or buenos Ayres, the distance of the serne of artion diminishing our appehension of danger, and diminishing also on means of effertnal interposition. might still have left us to (on-

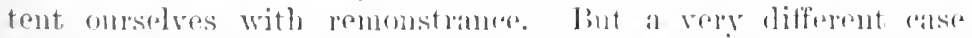

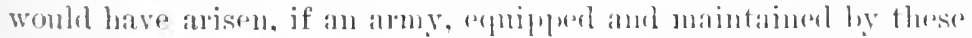
powers, har been lanked on the shores of the Gulf of thexion,

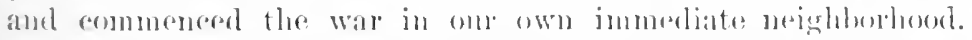
Such an event might justly be rengumled as daugroms to omrselves, and, on that gromnd, call for decided and immediate interferente 
by ns. The sentiments and the policy announced by the declaration, thus understool, were, therefore, in strict conformity to our duties and our interest.

In this same debate, James K. Polk, member from Ten. nessee, declared :-

When the message of the late Presiclent of the United States was communicated to Congress in 1828 , it was riewed, as it should have been, as the mere expression of opinion of the Executive, submitted to the consideration and deliberation of Congress, and designed probably to prodnce an effect upon the councils of the Holy Alliance, in relation to their supposed intention to interfere in the war between spain and her former colonies. That effect it probably had an agency in producing; and if so, it has performed its office. The President had no power to bind the nation by such a pledge.

With the close of the year 1826, the Monroe Doctrine is found to be limited by the following qualifications:-

1. No future eolonization on the Western Hemisphere by the European powers can be permitted to take place. The United States will ask the new Spanish-American repulslics to adopt this rule so far as their own territory is concerned.

2. The Lnited States shall remain free to adopt any course its honor and poliey may dictate tonching alliances with foreign nations and tonching the practical operation of the Monroe Doctrine.

3. The republies of the New World have a set of primary interests of their own, but the Lnited States will not join with any of them in a dechation against interference from alsoad.

In slort, therefore, the statesmen of the diy believed the primary object of the Monroe I oetrine had been aceomplished - the Holy Alliance was dearl, and Russia had abandoned her West coist colonization schemes. The measure being protective only, its principles might revive as occasion ealled them into life; but it was distinetly to be understood that, beyond a point of self-defence, the United States had no 
intention of assuming a rôle of guardianship over the Western Hemispliere, nor of eonstituting herself the protector of South America.

\section{SPANISII AMERICA AND CUBA}

From the close of the administration of John Quiney Adams, in 18:29, to the beginning of Polk's adninistration, in 1845 , there oceurred a series of events comnected with spanish-Ameriean interests which apparently called for action on the part of the Lnited States Government involving the principles of the Monroe Doctrine, lut which were, nevertheless, permitted to pass mnoticed. It has been said that during that period the doctrine was dormant. All attempts to seeure legislative action upon the sulpject failed in Congress, and the Monroe Inotrine was renembered only as the policy of a past administration. It was, however, universally endorsed as a gool policy to revive, shomld oceasion demand it. In those days the words of l'resident Monroe did not aplanentiy receive the broad interpretation that lats been given to them in more reeent years. The attitude of the eomutry toward Europe, during this period, was one that would likely have heen assumed, even had no Iloly Alliance ever threatened to merlulle in Anerican aflairs, and had no defiant messige been sent hack aldoss the seal. The position assumed by all those who controlled the foreign policy of the Enited States was simply one of self-rlefence, and in the absence of definite threats from abroad, the doetrine was not invoked.

The feelings of corrial sympathy in the United States toward South Americams, which had been so freely extendad when those people were strugnling for their liberty, sensibly

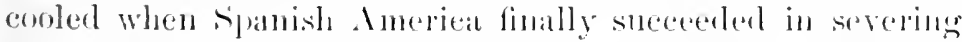
its politial relations with sipain. In a very short lime the Soutle American states gatre evillence of a woful larek of political stablility. Any sort of permanent anforlolation among the varions states was som slown to be imposiblele. A regular sureession of revolutions distressed the land, and 
the insatiate cupidity and reekless extravagance of their political leaders augured ill for the perpetuation of republican gorermment in South Ameriea.

Althongh the Monroe Ioctrine had been intended by its authors only as a defensive measme for the Lnited States, Sonth Americans clamored for its application whenerer they encomntered difficulties with Europe. Believing. as they did, that the doctrine was promulgated as much for their benefit as for the North Americans, they londly denounced the Lnited States as a monster of bad faith, when the latter refused to become a party to their quarrels or declined to give them material aid, or even the full quota of sympathy which they felt to be their due.

In 1829, the Malavinas Islands (Falklands), which belonged to England, were seized upon by the Buenos Ayrean anthorities, who, as snceessors of spain, elaimed a right to the group. The following year, the attention of the Cnited States was drawn to the fact by the arrest of some North American seal hunter's on the Falkland shore. The arrest seemed to be unjustified by the cireminstances, - the fishermen having merely followed a eustomary privilege granted by England, - and the American sloop of war, the Lexington, not only liberated the prisoner's, hut in retaliation deported the Buenos Ayrean governor (18:3). The English thereupon resumed control, and complaint of the Argentine Repullic, that this act involved a gross riolation of the Monroe Doctrine never ceased to be pressed in Washington. The Inited Sitates never almitted a claim for indemnity. and has always maintained that it was no party to the controsersy hetween buenos Arres and rireat liritain, - the rights of the latter having long anterlated those of the former in the Falklands. IIal the same construction been placed upon the words of I'resident Nomroe that has frequently beron applied since, President . Iackison might well have reganded this incident as one demanding the interference of the Initerl Sitates, - at least to the extent of investigating the disputerl claims of Great Britain to the Falklaud Islands. The executive, howerer, appears to have 
entertained no fears of European colonization in the Wrestern Hemisphere, when located at so distant a froint from the Enited States as the Falkland Islands.

In 18:35, Brazil and Buenos Ayres recognized the independence of Crugnay by a treaty mate thromgh the mediation of England. Some rears biter, Buenos Ayes threatened to attack the newly created nation it lad so recently reconghized, and Brazil ealled npon Great Britain and France for a dis in mantaning the integrity of Imomay. In answer to this call those two powers established a naval bockatle along the eoast of Buenos Ayres. The Enited States having no live interest in the dispote, and fecoling itself in no way threatened by such an act of Emrorean intervention, refused to interpose. Again the Lnited viates was romully drnounced in South Ameriea for the alrandomment of her principles.

Through her foothold in ('entral America aloug the Musquito coast and in Honduras. England hade for many gears, been gradually eneroalehing upon Niearagua. (ireat britains claims to territory in ('entral Ameriea dated from the seventeenth rentury, although some of these rlaims were jurlgerl, in the Enited States, to be of doubtlin origin. I lo to 1855, extensions of her Belize bomndary lines had been made gradually and noiselessly; but in that yall the English made so decided a territorial advance into Homburas and Niearagua, that the Contral American anthorities alpealerl

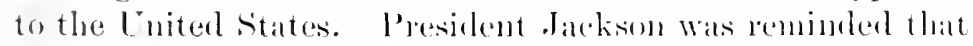
"it had always been the poliey of the lnited states to prevent and resist European settlements in Americar." Gemeral Jackson thought it inexperlient to interfere. From a more

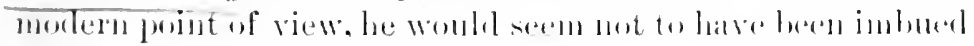

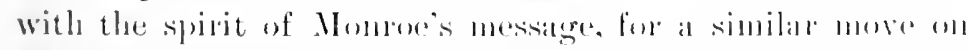

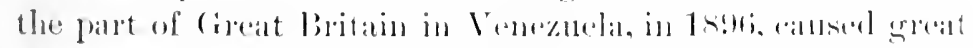
exeitement in the lonited states, motwithatamling the lated

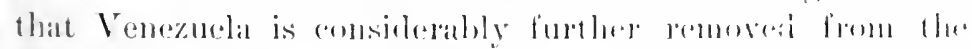

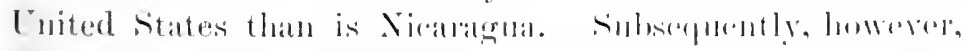

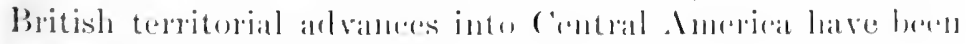

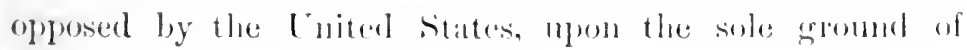


violation of the Monroe Doctrine, but not seriously until the subjeet of an interoceanic canal had come forward more prominently.

In 1842, and again two year's later, England found it necessary to besiege San Juan, for the sake of impressing upon the natives a respect for the validity of her territorial claims. These decidedly aggressive acts were passed umoticed in Washington.

Other instances might be cited which prove to a certain extent that for a number of years after the famous message har been issued, it was not viewed by contemporary statesmen in the same light in which it is generally regarded to-day. 'The particnar danger against which Mr. Momroe had directed his protest had ceased to exist. Its principles were only to be revived in case such acts of aggression or armed interference in America seemed actually to threaten the safety of the Inited States. The idea that the Enited States shomle offer its military forces to Sonth or Central America, at its bidding, was never entertained. It was never denied that European nations had the right belonging to any sovereign power to use force in South or Central America, if necessary, in the collection of debt, or to obtain redress for grievanees. However, while the United States for a considerable period took little cognizance of European intervention in South and Central America, President Monroes declaration was by no means forgotten; this is particularly evidenced in relation to Cuban affairs.

The proxinity of Cuba to the American shores has always marle it the sulject of jealous watehfulness by the United States, and dhring each alluinistration from that of President Momroe, a share of attention has been direeted to it.

As early as 1809, Jefferson looked longingly toward Cuba, although he feared the dangers of a general expansion policy. He wrote to President Madison: "I would immediately erert a column on the sonthermmost limit of Cuba, and inseribe on it a me phes ultre as to us in that direetion. . . Cuba can be defended by us withont a navy, and this develops the prineiple which ought to limit our views." 
President Madison was not so thoromghly in farrer of the annexation of Cuba. Ilis views, ats experessed in a lettel to William Pinkney, in 1810, reflect the sentiment which thirteen years later crytallized into a national doctrine. "The position of Cula gives to the Lnited states so derpe an interest in the destiny, even, of that island, that although they might be an inative, they could not be a satisfied spertator at its falling under any European forermment, which might make a fulcrum of that position against the commereas and seemity of the Lnited States." These views of President Marlison were at that time inore aleceptable to the people of the Lnited states than was the irlea of andual ammexation.

During the two administrations of P'resident Monroe, ereat anxiety was felt in ITashington lest ('ula miglit be seized by some European power. The English press, and some of the more influential British statesmen, anstantly insistenl upon the aequisition of the istand, as an wfliset to the prepmderating influence in West Indian alfaims, which the cossion of Florida had given to the Lnited States. While the British Govermment does not seem to have sorionsly eontemplaterl the oceupation of Cuba, applethension lest it might decide upon such a course kept the arministration not a little angtated. This fear was enhamed by the fanet that numbers of pirates infested the Cuban coast and preper upon England"s commerce. The Sipanish (Foremment was ntterly mable to suppless these malauders, and the threatened british demomstrations against theme if aledully madre, would almost certainly learl to a seizure of the islamel itsell.

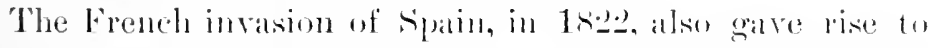
many alarms in the Lnited states, in respeet to the fate of Cuba. It was generally beliereel that syain must, somere or

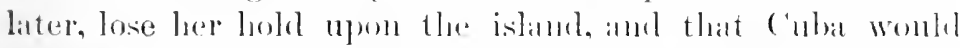

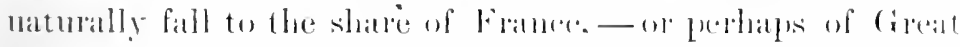
Britain, who was known to be fumbling the means to the

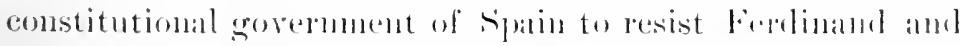
his French allies. It hat always been one of oloh (2uiney Adams' fixed ideas that the acquisition of culat wombleventually become a recessity to the political interests of the? 
Enion. He was moved by the threatened loss of Cuba by Spilin to instruct Mr. Nelson, the American Minister at Mardrid (182:3):-

.. These islandis from their local position are natural appendages to the North Anerican continent, and one of them [Cuba] almost in sight of our shores, from a multitude of considerations, has become an object of transcenclent importance to the conmercial and politinal interest of om Lnion. . . . In looking forward to the proballe course of events for the short period of half a century, it is scarcely pussible to resist the conviction that the annexation of ('nba to our Federal Republic will he indispensable to the continuance and integrity of the Lnion itself.

Mr. Arams dirl not then consider the moment anspicions for the annexition of ('uba to the Lnion, but he believed, nevertheless, that

... There are laws of political as well as physical gravitation: and if an apple, severed by the tempest from its native tree, cannot rhoose but fall to the ground, culna, foreibly disjoined from its own unnatmal connection with spain, and ineapable of self-sulport, can gravitate only towards the North American Cnion, which, ly the same law of nature, cannot cast her off from its bosom.

Jefferson was sill of the opinion that possession of Cuba by Cireat Britain ". would indeed be a great calamity to us," hut he adrocated the acquisition of Cuba by peaceful means only.

The publiration of I'resident Monroe's messige of 1823 may have had a decided influence upon France in checking her allegert Cuban designs: nevertheless, ahmulant rumors of French plots to acpuire the island continued to vex Presidents Mams and bakson. The continued withlolding of Syanish reoggnition of Colombian and Mexican independence determined those states to attempt the seizure of Culna and Porto Rico, shomld Syan persist in her stubborn policy of maintaning war against them. The possibility of thens transferring the theatre of Spanish-American hostilities to Cuba 
aroused Mr. Clay's apprehensions. He accordingly souglit to induce spain to yield at once to the demands of Colombia and Mexico, and he threatened, moreover, toluing about the occupation of Cuba by Lnited states amies, ratler than suffer the dangers of a foreign war in the islands . Whone fortunes have such a connection with the proserity of the Cnited States." At this jumctme a French flect alpeared in Cuban waters (1825), and the fact drew from the Sereretaly of State an emplatic protest. Ile wote to the Ameriaral Minister in Paris: "IVitl the bope of gollarding beforeland against any possible difficulties on that subject that may arise, you will now ald that we would not eonsent to the occupation of those islands [Culat and Porto Rico] by any other European power than Shain muler any contingency whatever." At the sime time, President Arams took occasion to announce througl the varions Amerion foreign Ministers to all European power's that the Initerl States "desired no elange in the political comelition of ('ulat ; that they were satistied that it should remain open, as it now is, to their commeree, and that they combl not with indifference see it passing from Span to any European power.'

Similar statements were freely expressed during the o atckson, Van Buren, and Tyler alministrations. Anxiety upon the subject of European intervention was nerer permitted wholly to relax, eliefly on aceoment of the fact that the Cubans themselves were generally in a ferment of robellion against the extortionate and olperessive rule of the mother comntry. Oppostunities for intervention were therefore frequent, and the prize was musually tempting.

Some disagreements between (ireat britain and Sipain, growing ont of a treaty for the sulplesesion of the slave trate in Cuba, again brought forth rumors of Euglish intention to ocenpy the island. Mr. Vail, the Ameriande Minister in

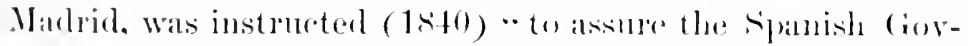
ermment, that in case of any attempt, from whaterer quatler, to wrest from laer this portion of her territory, she may securely depend mpon the military and naval resomres of the Cnited states to aid her in preservinger orecosering it." 
Three years later, Daniel Webster, as Secretary of State, addressed the Cnited States Consul in Havana, to the same effect. his letter being also used as a basis of instructions to Henry Irving, the American Representative in Spain. He sairl: "The Siranish Government las long been in possession of the policy and wishes of this government in regard to Cuba. which have never changed, and has repeatedly been told that the Enited States never would permit the occupation of that island by Britisls agents or forces upon any pretext whatever ; and that in the event of any attempt to wrest it from her, she might securely rely upon the whole naval and military resources of this country to aid her in preserving or recovering it."

Until abont the beginning of the Polk administration, the American policy toward Cuba appears therefore to have heen a consistent one, and wholly in accord with the avowed principles of the Monroe Doctrine. The idea of annexation found a few hearty supporters: but even among its ehampions, that notion was ponpted hy expediency rather than from a resire for territorial gain. Such ideas were especially manifesterl at those times when the safety of the United States was supposed to be imperilled by European intrignes to seize Cuba. To prevent that contingency the United States was willing to go to any length. It would guarantee Cuba to Spain, and pledge to her the use of its army and navy ; if forced to it, it wonld amex the island. Upon that point, the application of the Monroe Doctrine was clear and never disputed. After the close of the Mexican War the policy of the Eniterl states towarl cuba nnderwent considerable change. I feres of expansion seized the people, and the foreign pricy of the nation beeane bolder. Covetous eyes were cant toward the "Pearl of the Antilles." The prineiples of the Monre Dortrine were neither forgotten nor overlooked, but they were eonsiderably distorted and per-b verted to meet polition and seltish ends. The purchase of the island was impossible, first, becanse spatin always indignantly refused to part with "lier faithful colony"; and, secomilly, becanse the slave-holders of the fonthern states, 
and later the anti-slavery party in Congress, successfully thwarted every effort the national government marle looking toward purchase. Indeed, the great slavery controversy that soon came to overshadow alf other questions in national polities affected any aetion respecting Cubis. It colored every discussion on the Monroe Ioctrine, as it tinged every phase of American polities.

From about 1845 to the begiming of the Ciril War, our connection with Cuban affair's is marked hy a desire fofamexation not so much as a measure of self-protection, as too often asserted, but as a means of extending the slaveholling area of the country. 'To maintain itself in Congress, the slave power had need of more representatives. and to get a larger representation in Washington, alditional territory was essential. The land humger which sharpened the alpetite for Texas was equally strong for Cuba, and this perion of fifteen years preceling the Rebellion of the Somtlern states, developed a series of attempts on the part of the Lnited States to obtain the island either by purehase on by force.

In 1845-47, a strong popular semtiment in firor of the purchase of Cuba prevaled in the Western states, which, championed by the press. soon sprear over the entire comitry. The novement was given fresh inpetus by reports that Great Britain was again eontemplating the seizne of ('ulat

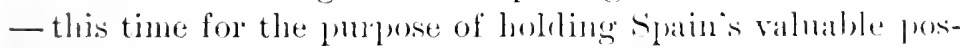
session as a security for the parment of ripanish lomels. The bulk of the Spanish delt was owned in lomelom, and the interest was greatly in arreatr. The l'resirlent was therefore called upon to act immerliately. Mr. Pollis anderesive foreign poliey was relied now by the entintry, expecially by the South and West. to anemmplish this eherished uljeret.

(J) Jatuary 17, 1sts, Presinlent Polk sent longthy and

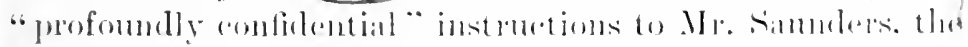

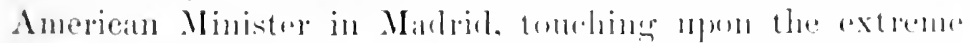
danger of English andexation of the island, which lor

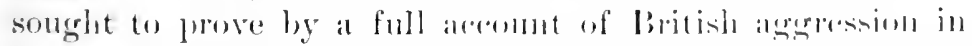
Central Amoriea. He anthorized Mr. Sammetes to mrese 
upon the Spanish Government the advisability of parting with Cuba to the Lnited States, but he hastened to give assurances that the [nited States would not seek to aequire it "except by the free will of Spain." It was to be by "fair purchase" only, and $\$ 100,000,000$ was suggested as a maximum price. Popnlar feeling in Spain was outraged hy the very suggestion of releasing this gem of her few remaining possessions. "It was more than any minister would dare," replied Mr. Saumelers to Mr. Buchanan, "to entertain any such proposition; sooner than see the island transferred to any lower, they wonld prefer seeing it sunk in the ocean." It thus became clear that the purehase of Cuba was entirely out of the question.

In 1849-50, during the presidency of Gen. Taylor, an ineirent oecurred in eonnection with Cuhan affairs which brought to light a new plase of the Monroe Doctrine. Among the many political disturbances and revolutionary movements which illustrate the history of Cuba, one in partieular, the Lopez rebellion of $1849-50$, received its main, if not entire, support, in the United States.

Nareiso Lopez, a Venezuelan by birth, once prominent in Spanish military service, beeane the leader of a revolutionary party in Cuba. In the summer of 1849 , he organized an expedition in New York, mate up for the most part of Mexican war vetelans, and was about to embark in the cause of "Cuba libre" when he was arrested by the United States anthorities. Presinlent Taylor thereupon issued a proelamation (Angust 11, 1849) in which he amounced that "It is the duty of this govermment to observe the faith of treaties and to prevent any aggression by our citizens upon the territories of friendly nations. I have therefore thought it necessaly and proper to issue this my proelanation to warn all citizens of the United States, who shall conduct themselves with an enterprise so grossly in violation of our laws and one treaty obligations, that they will thereby subject themselves to the heary penalties denomeed against them by om ants of congress, and will forfeit their claim to the protection of their ceuntry. No such persons must 
expect the interference of this govermment in any form on their behalf, no matter to what extremities they may he reduced in eomsequence of their comblnet."

There can be no question of the offieial neutrality of the Lnited States Govermment, but the fitting ont of filibustering expeditions emld not he prevented. Imlismayed hy the failure of his first attempt. Lopez trabled through the Southern states, where he fomm loth corlial sympathy and material aid for his project. A second expedition was organized (1850) moler the anspices of some wealthy fouthern planters, but met with reverses in Cuba. Lopez was then prosecuted by the Cnited States for violation of the nentality laws, but lowing escaped conviction. le proceded to organize a third expedition. This time, along with many American citizens mon his staff and within his ranks, he was captured, sentenced, and executed in Ilarma hy the Spanish anthorities. P'nblic indignation in the Initer States, especially in the sonth, was keenly aronsed by the exeeution of the Anerieans in Iavani. Anti-spanish remonstrations took place in New (Orleans. Spain at once appealed to France and England for protection against any Ameriean attack mpon ('uba which now scemed imminent. These two powers despatched naval forces to the Wiest Indies, and declared their intention of repenling any invasion of Cuba. While the Lnited States forrerment disclatimed any purpose of forcibly seizing ('ubat, the natral demonstrittion of England and Fance in ('uban waters wats most offensive. The act homght forth a protest from the anluninistrat ion

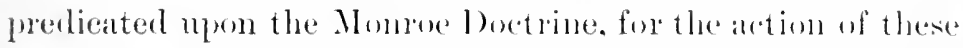
two powers eonlel only be reganderl by the l nited states " with grave disalpuroval, ats involving on the part of European sovereigus combined atetion of protertorshiporer American waters." Great britain and Fuance, being stromgly mered

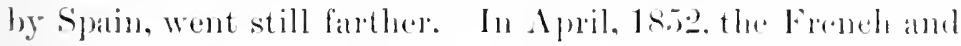

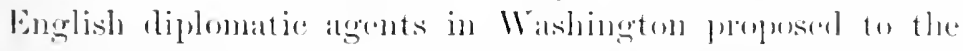

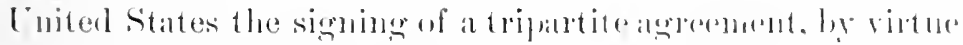

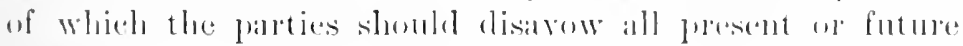
intention to obtain possession of the island of cubas and 23 
should bind themselves to diseomntenance all attempts to that effect.

P'resident Fillmore's attitule toward Cuba was made known in his ammual message of 1852, in which he gave assurance that the Lnited States not only contemplated no designs against Cuba, but that he "shonld regard its incorforation into the Cnion at the present time as fraught with serions peril." Its acquisition by the Lniter States against. Spanish opposition he regarded "as a hazardous measure." Notwithstanding these views, the invitation of France and Cireat Britain was declined by the President for several gurl reasons. While it might have been reassuring to know that both England and France stood pledged to keep their lanuls off Conba, - a pledge falling quite in line with the Monroe I)octrine, — yet it was considered improper to admit Enropean nations into the comcils of the Initer States upon an equal footing relative to the affairs of a territory so essentially connected with American interests.

The Seeretary of State, Mr. Webster, had already given the Spanish Minister little hope to expect the Presirlent to consent to the desired arrangement with Great Britain and Fince. Ilis objections to the measure lay prineipally in the direction of aroilling entangling alliances, and in the desire of the Enited States " to keep, itself free from national obligations, except such as affect directly the interests of the Finiterl Sitates themselves." The death of Mr. Webster, in the summer of $18 . \%$, transferred the entire subjeet to his suecessor, Mr. Everett. The latter, in a eommunication to Comte de Sartiges (December 1, 185\%), reviewer the attiturle of the Lnited states in this matter. and althongh he made no mention of the Monroe Doctrine as such, his referanee is chall when he silys: "The Presirlent does not coret the acepuisition of Cuba for the linited states. It the same time lie considers the condition of Cuba as mandy an Ameri(an question. The proposerl convention proceeds on a different principle. It assimes that the Lnited States have no other or greater interest in the question than France or England, whereas, it is only necessary to cast one's eye on the 
map to see how remote are the relations of Europe, and how intimate those of the [nited States with this island."

The principles of the Monroe Doctrine were not only adhered to by the President, but the interpretation of its words was enlarged into a protest against permitting either European voice or arms to control the destinies of New World territories that lay near the borders of the Lniterl States. Beyond doubt the position was well taken. 'To have entered into sueh an agreement would not only have violated the older ductrine against entangling alliances with Europe, but would have bound American hands in a partienlarly awkward manner. If the Lnited States desired to prevent European annexation of (uba, it would have been consummate folly thus to curtail her freeslom of artion. Of all the Spanish-American states, Cubar came neanest home. A eoneentration of foreign interests there wonld have proved a dinger not to be tolerated for a moment. In ease of any such threat from abroad, the true poliey of the Lnited States would have been to seize the island at once.

On January 4, 18.it, one month after the refusal of the Cniterl States to take part in the proposed tripartite convention, Mr. Cass of Mirhigan introduced into the Senate a joint resolution declaring : -

"The American continents, by the free and independent rondition which they have assumed and maintain, are heneoforth not to be considered as subjects for future colonization by any European power." And while "existing rights should be resjereted," and will be by the Cnited states, they owe it to their own "safoty and interests" "to amomme, as they now do, that no future Europeran colony or dominion shatl, with their consent, be flanterl or established on any part of the Forth Imerion eontinent." And shouk the attempt le made, they thos deliberately declare that it will be viewed as an aret originating in motives lengalless of their "interests and their safoty," and which will brive them free to allopt such neatsures as an inde pendent nation may justly arlopt in refence of its rights and its honor.

That while the Inited states disclatm any designs now the Island of ruba, iuconsistent with the laws of nations and with

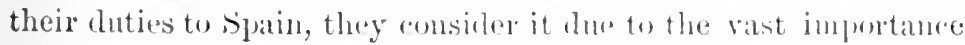


of the subject to make known in this solemn manner that they should view all efforts on the part of any other power to procure possession, whether peaceably or forchly, of that island, which, as a naval or military position. must, mnler cireumstanees easy to be foreseen, become clangerous to their sontheru coast, to the Gulf of Mexiro, and to the south of the Mississippi, as unfriendly acts directed against them, to be resisted by all the means in theil lowel.

John P. Hale, of New Iampshire, moved to amend this resolution ly the insertion of the word "Canada." No aetion was taken on the resolution, hut its introduction proroked a lengthy diseussion upon the subject of European interferenee on the Western continent, in which the prineiples of the Momroe Doctrine were very generally entorsed. The southern members alvoeaterl an extension of the doetrine into a justification for seizing Cuba, while the Northern members, though less decided in their opinions, were still willing to press the words of Monroe into the service of aequiring territory which lay to the north of the United citates. Only Mr. Howat of Texas ventured the belief that the Momroe Doetrine did not mean "that every settlement upon any sand-bank on this eontinent is an offenee which is to result in war."

To succeed President Fillmore, the Whigs failed to eleet their candidate, General scott. He had been the war hero of 1845, but was reduced in 1852 to the "peacoek of politics, all fuss, feathers, and fireworks." 'The Demo"latic party, demanding an agresessive foreign poliey, and decring the "old fogyism" of Taylor and Filhmore, trimomplantly pheed Franklin Pieree in the White Honse. The slavery question had mate the annexation of Cuba a barty issue, and the bemoclats looked to Pieree to carry ont their wishes in this respect. In his inangumal address, the P'esiclent derelared that the poliey of his administration would

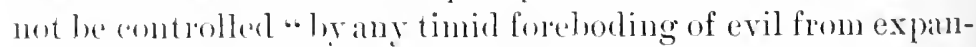
sion." Indeed, he further derelared, "it is not to be disguised that mur attitude as a nation, and our position on the globe, renter the aequisition of certain possessions not within our 
jurisdiction eminently important for our protection, if not, in the future, essential for the preservation of the rights of comnmerce and the peace of the world." This printed cleally to Cuba. The Southern Denmerats were greally encomraged. and a persistent clamor arose for the acquisition of the island. With that purpose in view, the American ministers to England. France, and siatin were chosen. P'jerre Soule of Lousiana was sent to Marblicl. Ile was a ratlical ('uball annexationist, and hat attacked Presiblent fillumere most bitterly the previons year in Congress. for his latek of symparthy with the Lopez tilibusters. Mr. Somle was determined to atequire the islamel, and entered 11 pon his mission to Sian with that single purpose before hin. Presillent l'ierees sereretary of State. William Marey, was the emservative elenent of the arlministration; he frequently instructed Mr. Soule to bring abont a rearljustment of the conmeredial relations between Sprin and the Lniterl States: and althomgh he spolie of purchasing Cuba, he did not believe Sinain would be ${ }^{*}$ at all inclined to enter npon snch a nogotiation." ". Xothing will be done, on our part, to disturl, its [Cul,al s] present ronnection with Spain, unless the chanacter of that connection shonld he so ehanged as to affect omr present on prospective sermity. While the Lniterl States womld resist, at every hazarl, the transference of Cuba to any Europenn nation, they womld exceedingly regret to see spatin lesorting to any power for assistance to uphold her mole orer it. Such a dependenese on foreign ain wonld, in effect, invest the anxiliary with the character of a protector, and give it a pretext to interfore in our affars, and also generally in those of the North American contiment."

These mild instrutetms were not pleasing to Mr. Somle.

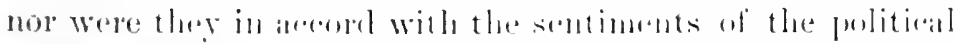

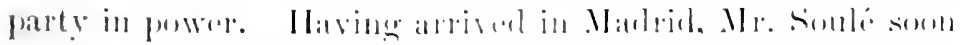

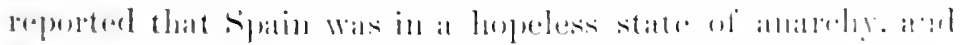

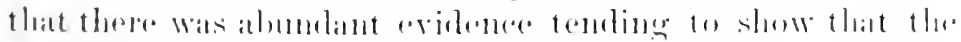

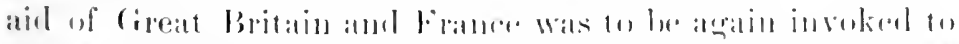

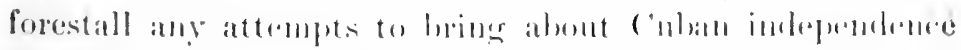
or amexation to the linted states. Mr. Marey therengun 
authorized Mr. Soule to reopen negotiations at once for the purehase of the island, raising, upon this oceasion, the price offered to $\$ 130.000,000$. If, however, the Spanish prejudice to a sale was found to be too strong to orereome, Soulé was authorized to suggest delicately to Spain that she might permit Cuba to detach herself from her dominion, and to become a free nation; in this indirect way the same object could ultimately be accomplished.

Just at that moment, the alleged illegal seizure of the cargo of an American vessel, the Black Warior, by the enstoms anthorities in Havani, suddenly brought the two nations almost to the verge of war. This Spanish assanlt against American shipping was eagerly caught up by the South as an excuse to substitute force for diplomay, and President Pierce was very nearly induced to give way to the passionate appeals of his own party leader's. The slavery party raised the standard of the Momroe Doctrine, and had their comnsels prevaliled, a peculiar adaptation of those principles would have resulted. It had, for many years, been a favorite object of Great britain to do away with the institution of negro slavery in Cubat. Spain hatd. from time to time, displayed a willingness to accede to England's repeated solicitations in this respect, and especially at those moments when English goolwill or eöperation was desiralle in maintaining inviolate her control over the island. The South pretended to regard the emaneipation of Cuban slives as a measure fraught with the gravest danger to the United States. The absorption of a free-soil c'uba into the Lnion was, from their point of view. undesirable. With Cuba as a slave state added to the Union, "slavery might bid defiance to its enemies."

In 18\%, the Richmond Enquirer, a leading Democratic organ, declared that the "menace of a design to Africanize Cuba, or to emancipate the slaves, would be a grievons act of hostility, and would anthorize the United States to talie any means of retaliation, or to wage war." The freedom of the Cuban slaves would leave that island in the control of a vast number of blacks who might at any moment convert Cuba into a second Inati or Santo Domingo. At the very 
least, emancipation in Cuba womlel greatly imperil the policy of the Cnited States tomeluing the question of hmman shrery.

Mr. Soulés diplomaley dial not lning abunt a sat isfartory settlement of the Black Warrior affair. 'The P'resielent was far from being satisfied with the results of Mr. Soulfis lutheaded methods, ame the Demoreats called all the mont; loully upon its President for action - for a swift retaliation upon Spain, and for the immediate annexation of (ubal.

The more conservative Secretaly of State, Mr. Marey, was driven to a new plan for the settlement of the voxatims Spanish-American question, which plan le hopeel wombl bring abont the desired results without a resort to arms. Convinced that contimmance of Soules efforts in Madrid would be umprofitable, he proposed (June, 1sit) the aplpointment of an extrandinary commission, to be composingl of " two distinguishenl (itizens" whoshonhl alet in eonjunetion with .Mr. Sonle in rë̈nforeing the demands of the Lnitod States against Spain. The projoet ereating sueh a commission, however, was abandoned. and as a smbstitute therefor. Mr. Soule wats instructed ( Iugust, 185t) to nueet and eonsult with Messis. linclanan and Mason, the American ministers in London and Paris.

I and directed hy the rresident to suginest to you a partionlau step, from which he anticipates much alvantage to the nugntiat-

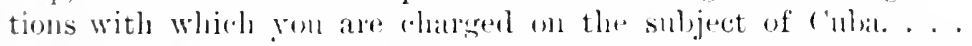
It seems desirable that there should be a full and fure introhamare

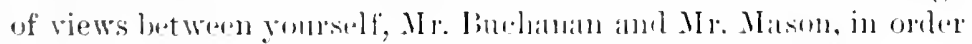

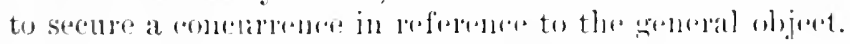

The simplest and only vory applatent means of olitaining this

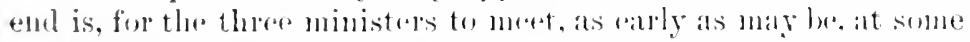

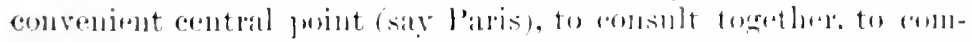

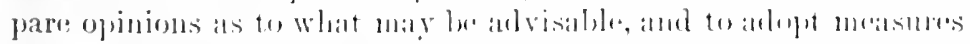

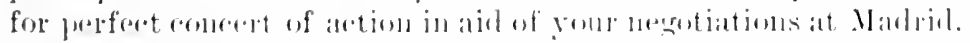

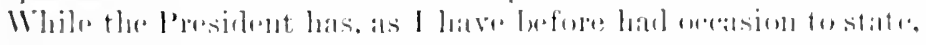

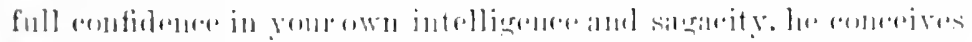

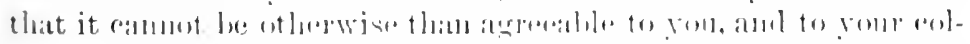

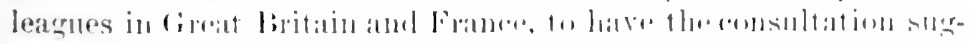

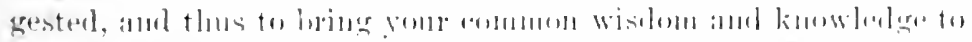

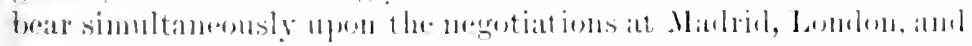
Patris. 
Accortingly, the three American ministers met in eonference at Ostend, Oetober 9,1854 , and adjourning to Aix la Chapelle, there signed a rejurt on the 18th of the same montl. This series of resolutions is known as the "Ostend Manifesto. “

After a lengthy argument in faror of the acquisition of Cubil, and an enmmeration of the many advantages which would accrue to both Spain and the United States by virtue of a transfer of sovereignty in Cuba, the report advises the offer to spain of $\$ 120,000,000$ for the island. Should Spain decline the offer, the use of force is proposed to accomplish the sane end. The advisability of such radical measures was based on the broad principles of self-preservation, - the Monroe Doctrine. "O Our past history forbids," it reads, "that we should aequire the island of Cuba without the consent of Spain, unless justifierl by the great law of self-preservation, but," the authors hasten to add with a flourish of virtue, "we must, in any event, preserve our own conscious rectiturle, and our own self-respect." It beeame a question, they asserted, whether or not the continued possession of Cuba by Spain amounted to a menace "to our internal peace, and the existence of our eherisherl Cnion." If such be the ease, as they believed it was, then we would be justifiet by "every law, human and divine," in wresting it from Spain.

'The position taken by Messrs. Buchanan, Soulé and Mason was certainly many degrees beyonel the farthest limits of the Nonroe Doctrine. The latter called for opjosition to foreign aggression in the IV estern continent, and expressly stated that no action would be taken against those European powers alrealy holding territory in the New World - unless they songht to expand their holdings. The true motives of the Ostend Manifesto were, after all, too thinly veiled. The Words of Mr. Monnroe harl heen obriously tortured into the furtherance of a seheme to extend the slave-holding area of the Inited States. The arlministration promptly condemned the manifesto.

The policy of forcible acquisition, in case amicable nego- 
tiations for purehase should fail, was too ratieal eren for President Pieree. Mr. Marrey referred to it as ' a robber doetrine," which would hring shame nuon the administration, and would disgrace the nation in the eyes of the world. "We camot afforel to get it" (cuba), he said, " by robbery or by theft."

The Ostend Manifesto was left entirely mmentioned in the President's annual report to Congress. The following winter resolutions in Congress calling for the report, and all the correspondence relating thereto, were sulpressed, and every effort was matle by the arministration to prevent the publicity of the document.

From $185+$ to the outhreak of the Civil Win, Cubat eontinued to ocenpy a prominent place in the foreign affarirs of the Lnited States. From the close of the Relellion down to the late Spanish War, this same interest in Cubil Wis kept alive, but in the absence of any definite threats by other nations to acquire the island, there were no distussions in Congress relative to the subject. After the collapse of slarery in the Lnited States, the desire for Cuban annexation largely disappeared, nor was it revived until very recenty.

During the past thirty-five rears, sereral revolutions in Cuba brought abont relations between the Lnited States and Spain which were sulsstantially similar to those which existed prior to the breaking out of the late Spanisl-Aneriean War, - conditions with which every one is familiar. If not actually desiring amexation, the lonited States hats, upon all occasions, manifested a derp) interest in ("uban inflependence, and has sometimes with dillieulty peserved a neutral attitude.

In this relation, one incident is notewortly in its bearings upon the Monroe I oetrine. The Cespides rebellion in Cubal had dragged along for many years, with the enstomary reeord of eruelties and batrarities which seems generally to hase marked Spanish-(uban warfare. The inability of sipain to suppress the rebellion induced l'resident firut, in his annual message of December 7,1875 , to hint at intervention. Spain had stubbornly refused to listen to nediation; and 
as the conditions seemed to warrant the Lnited States in recognizing the independence of the island, intervention was looked to as the only means left for ending a hopeless conflict. In lis note of November 5, 185, to Mr. Cushing, the Amerien Minister in Mathid, the seeretary of State, Mr. Fish, had already anticipated these suggestions of the President. lle wrote:-

In the absence of any prospect of a termination of a war, or of any change in the manner in which it has been conducted on either side, he [the President] feels that the time is at hand when it may be the duty of other govermments to intervene, solely with a view of bringing to an end a disalstrons and destruetive conflict, ant of restoring peace in the island of (uba. To goremment is more teeply interested in the order and peaceful administration of this island than is that of the Lnited states, and none has suffered as the Cnited States from the "ondition whin has obtained there during the past six or seven years. He will, therefore, feel it his duty at an early day to submit the subject in this light, and accompanied by an expression of the riews above presented, for the consideration of ('ongress.

Copies of this note were sent to the American ministers at the various Emopean courts for the purpose of ascertaining the attitucle of these gorermments towarl intervention in Cuba. It seems also to have been Mr. Fish's desire to secure (ireat Britain's coöperation. The replies of all the govermments which had thus been approached, were unfarorable, and the matter was put aside. In a short time, however, the fact that Mr. Fish had seen fit to atmit - incleed, to invite - European conncils upon a matter so essentially Ameriean in all its hearings, brought upon him the odium of having neglectul the proper observance of his country's tralitions, and to having violated the principles of the Monroe Doctrinc. Mr. Fish alpears to have been sensitive to this accusation, and to have evalded an explanation of his course in seeking airl from alloarl to oust Syain from Cuba.

Intervention in behalf of Cuba in 1898 was not predieated directly moon the Monrex I)octrine, although the Senate Committee on Foreign Affairs in April of that year, sub- 
mitted a report upon Lnited States relations with Spain and

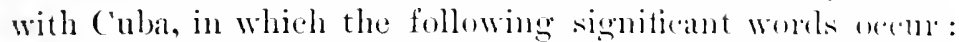
- We cammot consent upon any comelitions that the dremplelated portions of C'uha shall be ionlonized hy suan any more than she should be allowed to foumd a new colony in any part of this hemisphere or islambls thereol. Either ant is regarded by the Luited states as dangerens to ond prare and safety." Intervention was therefore farored upon the gromels of necessity as contemplated by the Mompe Doretrine, - it being justilied by the ('uban situation, which had "beeome a menace to the workh, and esperially to the preace of the Lnited States,"

The resolution of C'ongress declaring war upon Spain for the relief of ('uba ( $\left.A_{\text {pril }} 19,18 ! 8\right)$ was not. however, based upon the Nomroe Doctrine. It merely recited the fitet that the people of Cuha were, and of right ought to ba, free. The Lnited States also rlisclaimed any intention or disposition "to exereise sovereignty, juriscliction, or control orer said island, except for the pacification thereof, and asserts its determination when that is acomplished to leave the government and eontrol of the island to its people."

\section{TEXIS ANI) OREGON}

James K. Polk entered upon the presideney in 18ti;, pledged to his party to eomplete the ammexation of Texas, and to secure the whole of ()resom, to the Russian loontier of $5 t^{\circ} 40^{\prime}$ north latitude. The slavery question mulerlay both propositions, and the principles of the Momroe Dextrine were.aplealled to by the lpesident in both cases.

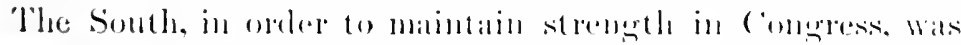

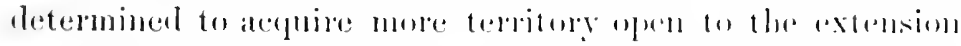

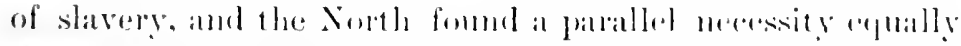

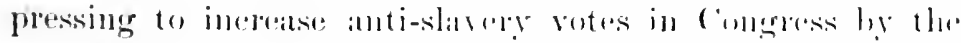

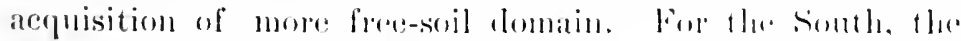

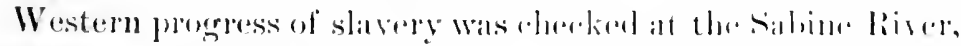

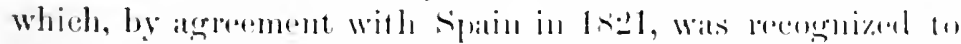

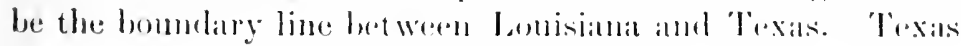


Was then a province or state belonging to Mexico, although a large immigration of Americans from the Southern states, taking their slares with them, gave to it a decidedly American cast, and established in 'Texas a strong political party. orthodox in the slavery creeds, and earnest in its agitation for annexation to the Lnited States. In 18:9 the Mexican Govermment abolished slavery, in consequence of which act Texas revolted, and seven years later established itself as an independent republic.

The Texans at once sought incorporation into the Union, and the Sonthern states elamored for its amnexation against the opposition of the North. 'The issue became a vital one in the camprign of 1844 , and Polk, the Democratic candidate, was on the side of annexation. Mexico had never acknowledged the independence of her seceding state, and was supposedly realy to fight rather than yield it to the Enited States.

The underlying motive for the acquisition of Texas was so apparent that a better reason for annexation had to be found, in order to ciremuvent the opposition of the Nortl. Mr. Calhom, Seeretary of State under President Tyler, had become alarmed by his own zeal for its acquisition, and feared the North would become too rigorously aroused when his real motives were thoroughly milerstood; but Polk was fully equipped and ready to meet the situation. It was known in Congress that France and England were unfavorably impressed with the idea of Texan incorporation into the Union. on account of a supposed disturlance of the "balance of power" on the Western eontinent, which such a territorial change would bring about. In his message of December, 1845, Mr. Polk saicl :

Even France, ... most nnexpectedly, and to our unfeigned regret, took fart in an effort to prevent anmexation and to impose on Traxs, as a condition of the recognition of her independence by Mrxico, that she wonld never join herself to the United States. . . and lately the doetrine has bern broached in some of thren [10wess of Europe] of a "balance of power" on this continent to check our advancenent. The United States . . cannot 
in silene permit any European interference on the North American continent, and should any such interference be attempten, will be ready to resist it at any and all hazanls.

It is well known to the Amerian preople and to all nations lhat this government has never interfered with the relations subsisting between other govermments. We have never male onrselves parties to their wats or their alliances; we have not somght their territories by conquest: we have not mingled with parties in their domestic struggles; and beliering om own form of gorernment to be the best, we have nevor attempted to propagate it by intrigues, by diplomacy, or by force. We may claim on this continent a like exemption from European interference. The nations of America are equally sovereign and independent with those of Europe. They possess the same rights, inlepentent of all forrigu interposition, to make war, to "onclute peace, and to regulate their. internal affairs. The people of the Uniterl states camnot, therefore, view with inlifference, attempts of European powers to interfere with the independent action of the nations on this continent. ...

The President had already said in his inaugural address of the previous March :-

None can fail to see the danger to our safety and future peace, if Texas remains an independent state, or becomes an ally, or dependency of some foreign nation more powerful than herself.

Was it not necessary, therefore, to take Texas, before Europe might intervene between her and Mexico, and, in the eonfusion of civil war, perhays gain a foothold in the Lone Star state?

7 The scarecrow of European aggression in Texas was so obvionsly a pretence that it was never serionsly considered fby the government; lont it disgruised the real sitnation and furnished a soothing halm for the conscience. The aropuisition of 'Texas, sooner or later, both on aceont of its greographical position and the temper of its people, wats a moral certainty ; but to take it in assmed fear that some ot luep nation might do so, was a clear perversion of the Mnnme Doetrine. 
An exemplification of the "Polk Doetrine" was further" given in the matter of the Oregon territory dispute, to which the Presiclent referred in the same nessage of December, 1845 .

The term, "Oregon," was applied to a large distriet of teritory lying between the Rocky Mountains and the Paeific Ocean, and embraced, in part, what now constitutes the present province of British Columbia and the states of Washington, ()regon and Idaho, - a total areal of about six hundred thousand square miles. The Lnited States' chaim to this territory was based upon the Lonisiana Purehase, the explorations of Captain Robert Gray in the Columbia River (1792), the discoveries of Lewis and Clark (1804-06), American settlements at Fort Hall and Astoria in 1808 and 1811, and the treaty of 1819, by which all Spanish title along the Pacific, north of latitude $42^{\circ}$, was smmendered to the United States. In 182t Rissia agreed to limit the southern boundary of her American possessions at latitude $54^{\circ}+0^{\prime}$, and the United States at onee set up a territorial claim to that line. This was contested by Great Britain, but an agreement to exereise joint sovereignty over the territory from the Columbia River on the south to $54^{\circ} 40^{\prime}$ on the north, the disputed portion, temporarily suspented the eontroversy. Immigration of American and British subjects into this disputed territory began, and it was tacitly understood by these early settler's that eventually a majority among the residents would control in tle final determination of sovereignty. With a better knowledge of this great territory eame an appreciation of its value, and the Democratic party in $18+t$ took up the battleery of the "whole of ()regron or none." With "Fifty-four forty or tight" "upon its banners, James K. Polk was elected. He at once entered npon negotiations for the arequisition of the entire extent of his party's territorial claim, as far as the Russian frontier'.

In his inamgual adrlesss, he asserted that the Americam title was " clear and meguestionable" and "already are our people preparing to perfect that title by oeenpying it with their wives and children." An earnest attempt was made by the President in the sumner of 1845 to reach an muler- 
standing through diplomatie negotiation with freat Britain. for as he afterward dectared: "In deference to what haul been done by my predecessons, and espredially in ronsiderattion that a proposition of eompromise harl heen thriae made. hy two precerling administrations to adjust the question an the parallel of $49^{\circ}$. . I I deemerl it to be nuy duty not abruptly to break it off."

Great Britain refused to eonsider any proposition of rompromise settlement that was not based 11 on a free navigation of the Colmmbia liver, which privilege the l'resillent was naturally unwilling to grant. The fourth at tempt therefore to adjust the Oregon bomblary having failed, a determination to make good the entire elaim by force swejt over the comtry, and war seemed inevitable. The l'pesident then fell back upon the Nomroe Doctrine. In his first ammul message to Congress (December 2, 1845), he said : -

Near a quarter of a rentury ago the principle was distinctly amnounced to the worll, in the ammual message of one of my predecessors, that "the American continents, hy the free ancl independent condition which they have assmed and maintain, are henceforth not to be comsirleted as subjects for future colonszation by any European powers."

This principle will apuly with greatly increased force should any European power attempt to establish any new colony in North America. In the existing cirmmstances of the world the presunt is deemed a proper occasion to reiterate and reattin the principhe avowed by Mr. Ironroe and to state my corelial concurrence in its wistom and some policy. The rassertion of this punciphe, expecially in reference to North America. is at this day but the fuomulgation of a folieg which no Enropean frower slombl wherish the alisposition to resist. Existing rishts of erery Eurnean nation

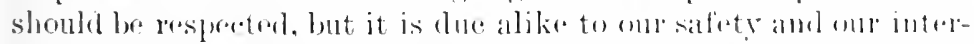

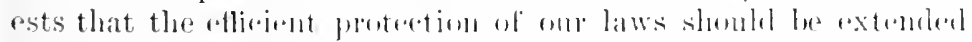

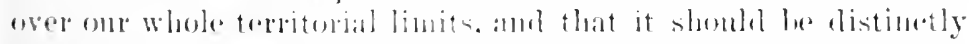

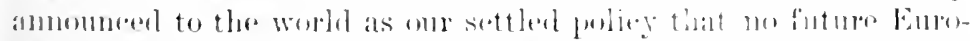
fean colony or dominion shatl with ond consunt le planted or

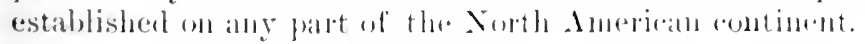

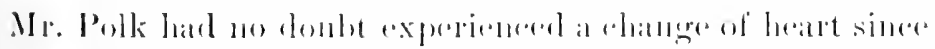
his reelanation in comgress doring the P'anchnat debate that 
the Monroe Doctrine was "riewed, as it should have been, as the mere expression of opinion of the executive . . . designed probably to produce an effect upon the eouncils of the Holy Alliance in relation to their supposed intention to interfere in the wall hetween Srain and her former colonies. The President had no power to bind the nation by such a pledge."

Harl the territory of Oregon been res mullizs, a domain upon which no claim rested, and therefore open to colonization by any nation according to the terms of international law, the application of the Monroe Doctrine to the case would be elealer. In such event, a foreign power would aetually have been seeking colonization upon the American continent, ancl that part of Monroe's message dealing with colonization would have been violated, had any such attempt to acpuire Oregon gone unchallenged by the United States. As it wats, both the Lnited States and Great Britain claimed the territory in question. It was not a domain res mullius. Great Britain rlid not seek to extend her dominion, but only to retain what she considered properly belonged to her. Obriously, then, the only settlement of such a question was to be formel in a minute eomparison of claims, the better one to prevail. In case amieable negotiations failed, an appeal to anms conld only be mate upon the broad principle of the final resort to settle quarrels.

IIappily the controversy was closed by a compromise settlement upon the 4th parallel before the rough arbitrament of war became necessary.

The expressions of President Polk, touching the Monroe Doetrine, as already quoted, modified to some extent the true meaning of the original declaration. The prohibition of European dominion, as well as colonization, would imply that no transfer of territory to European nations conld be permitted, even through voluntary conveyance. The acquisition of territory in North Ameriea by any means whatsoever was interdieted to foreign powers. IIc restricted the principle, however, to the North American continent. By his application of this prineiple in the case of Oregon, an implication follows that mo foreign power alaning territory 
in North America would be permitted to complete its title. should that title admit of doubt in the Enited states.

Notwithstanding the positive attitmile he thus assumed. the President was nevertheless willing to change his attitule when the compromise offer from Enghand reached Washington, - to partition the Oregon territury north of the Colnunbia River, over which he believed our title was " clear and unquestionable."

A few weeks after the reating of the Presilent s message. Mr. Allen, of Ohio, in the face of ensiderable opmositim, introduced into the Senate the following resolution:-

Resolven, That rongress, thus toncurring with the l'resilent, and sensible that this subject has heen forcen mon the attention of the Cnited states by recent events so significant as to malie it impossible for this government longer to remain silent, without being ready to submit to and even to invite the enforenent of this dangerous doctrine, do hereby solemnly derlare to the civilized world the malterable resolution of the Cnited states to allhere to and to enforce the principle, that any effort of the powers of Europe to intermedtle in the sofial organization or politial arrangements of the inderendent nations of Imerial, or further to extend the Europeem systen of govermment upon this ontinent by the establishment of new colonies, wonhl he ineomplatible with the independent existence of the nations. and dangerons to the liberties of the people of Americal, and therefore wouk incur. as by the right of self-preservation it would justify, the permpt resistance of the United states.

The bill expired in the eommitte room of foreign affatrs when the treaty with England, of Jume 20, 1sti, was conchuded, by which the Oregon dispute was settlerl. Thus an attempt to secure Congressional expression upon the Monroe Doctrine again failerl.

\section{YCCATAN}

One other event oecurred towarl the close of Polk's atministration, which is interesting on aceomnt of its bearing

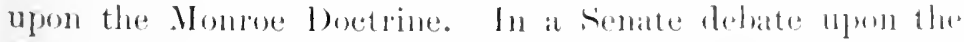

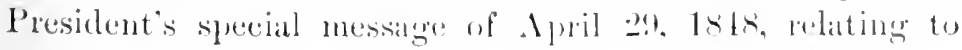


Yncatan. a considerable rauge of opinion eoncerning the applieation of the doctrine was expresserl. The speech of Joln C. Calhom, marle at that time. is an especially valuable contribution to the literature of the subject.

In this messige the Pessident submitted to the eonsideration of Congress certain communications from the governor of Incatan, setting forth the unfortunate condition to which the country had been redueed by an mrising of the native Indians. The Indians were represented as carrying on a war of extermination against the whites, and the latter, "panic-stricken and destitnte of arms," had been brought to a deplorable condition of suffering and misery. In desperation they had appealed to the Enited States for protection, and offered in return the "dominion and sovereignty of the peninsula." A similar apjeal had been made, along with the same offer of sovereignty, to the Spanish and English governments.

The Presirlent adrled: " Whilst it is not my purpose to recommend the adoption of any measure with the view to the aepuisition of the 'dominion and sovereignty' orer Yucatan, yet, aceording to our established poliey, we eould not consent to a transfer of this 'dominion and sovereignty,' either to Spain, Creat Britain, or any other European power." Quoting from Momroes and his own messages of 1823 and 1845 , le contimmes: " On own secmity requires that the established policy thus annomeerl shonld guide on conduct, and this applies with great force to the peninsula of Yueatan. . . . I smbmit to the wistom of Congress to alopt such measures as in their julgment may be expedient to prevent Yneatam from becoming a colony of any Emopean power, which in no event combl be permitted by the Lnited States. . ."

Yroutan Was a state belonging to Mexico, but her inhabitants remained nentral during the wall lotween the Inited states and Mexion, then in progerss. A bill hat been introAneed into the senate to enable the Presirlent to orer military ocompation of Yucatall, which furnished the subject of delate allearly reforred to.

Aside lrom feelings of homanity, that natumally andomsed 
Mr. Polk's desine to send prompt relief to a suffering people, he believerl that an urgent necessity alled upon him to maintain the integrity of the Monme I oetrine. Ite believes the doetrine not only forbarle foreign interference for 1 mrposes of dominion or eontrol, but he further considered that the duty of the Enited States extemed to the prevention of foreign interposition, even when offered in friendly spirit and upon the invitation of Ameriean states. John ('. ('allumm was then a member of the Senate, and the only smrivon of President Monroes cabinet. In his estimation, the true character of the Monroe Doctrine was mismolerstoot both by the chief Executive and by the masses of the penple. Eminently qualified to speak, he delivered a speech in the Senate. May 15, 18+8, carefully reviewing the cireumstances under which the declaration of President Monroe was promulgated. and gave as unavoidable reductions a series of conclusions. It is difficult to qualify them.

1. The declanation was male to meet but one special and particular condition, to wit; - the threatened interference of the Holy Alliance in Spanish-Ameriean affairs, for the $\mathrm{p}^{\prime m}$ pose of preserving the revolting colonies to Fanin, and forcing their contimen allegiance to monarehical institutions. 'The danger soon after ceased to exist, and the warning of the Linted States, supporterl by the sympathetic attiturle of Great Britain, had serverl its purpese. That part of the declaration, therefore, must he considered in ennection with the ciremustances muler which it was anmonnced : otherwise it "would have involverl the alsurelity of asserting that the attempt of any European state to extemel its systrm of gerermment to this eontinent, the smallest as well as the grateste would endanger the prace and safety of our combly ry."

2 . 'The next deetaration, that the interpoxition of any

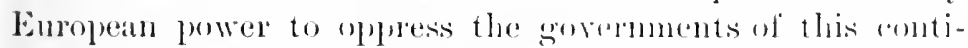
nent, or to control their destiny in ally malner whatevere,

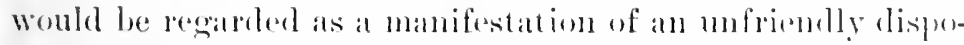
sition toward the Lnited States, arese from the silno rommlitions, and "belongs to the history of that day." It was an atpentage to the last eleclanation. 'The governuments referred 
to were those just freed from Spain, and the Executive made nse of the words "any European power," for the sake of encouraging the young republics.

3. In regard to the use of the word "colonization," as employed by Monroe, it hat a speeific meaning — "the establishment of a settlement by emigrants from the parent country, in a territory either uninhabited, or from which the inhabitants have been partially or wholly expelled." This part of the ductrine was also directed to a certain source of irritation - Riussian eolonization on the northwest coast. 'To inchucle the whole continent as under the ban, was manifestly an impropriety, as a large part of the continent had not asserted nor maintained its independence: British and Russian America then exceeded in area the whole of the United States. This portion of the message originated with Mr. Idams, and had not been freely discussed in the cabinet. "I will venture to sily," asserted Mr. Callom, "that if that decharation had come before the cautious cabinet, (for Mr. Ilomroe was among the wisest and most cautious men I have ever known,) it would have been modified and expressed with a far greater legree of precision, and with much more delicacy in reference to the feelings of the British Government."

t. In another respect as well, Mr. Calhoun believed, President Polk did not understand the famous declaration. "They were but decharations, - nothing more. Declarations amnonneing in a friendly mamner to the powers of the workl that we shomld regard eertain acts of interposition of the allied powers as dangerous to our peace and safety ; interpositions of Enropean powers to oppress the republics. which hat just arisen upon this continent, having become free and independent, as manifesting an mufriendly disposition, and that this continent having beeome free and inde: pendent, wats no longer the sulject of colonization - not one worl in any one of them in reference to resistance."

5. ()ur country, then, is not expected inexorably to follow a simple declaration as though it were a fixed principle. Such a course would make the United States a party, willing or unwilling, to all the wars, just or unjust, of the several Ameri- 
can states. "Wre are not to have quoted upon us, on every" occasion, general declarations to which any and every meaning may be attached." Whether the comitry intends to resist by force any interposition from abroad rests with Congress, and must be decided npon the merits of the case itself. It should be asked - does such interposition affect the safety of the country? Is it to the best interests of the nation to resist it, and if so, are our interests infolverl sufficiently great to make war expedient? In some particular instances this would be proper-proper because wise - and Mr. Calhoun cited the cases of Cuba and Texas. Here he "would resort to the hazarel of war with all its calamities." In the case of Yucatan, the only duty devolving upon the United States was to respond to a cry for help.

From this review of the Monroe Doctrine, the following deductions seem to be clear: -

The safety of the United States did not demand the amexation of Yucatin.

The occupation of this country by Great Britain or Spain would not have been for the pripose of dominion. It womk have been only the friendly interposition of another power at the solicitation of Yucatan herself.

Occupation of this sort conld not properly be called colonization.

The doctrine as enunciated by its authors did not apply in this case.

There was but a slight desire in the United States to ammex Fncatan. The country was regarded as pratically worthless, and its arlmission into the Lnion to be a mistake. It is not easy to determine, however, what final ation the semate might have taken in the matter, hal not the incilent been closed by a treaty between the whites and the holians which put an end to their difficulties.

\section{THE FRENCH INTEREATION IN MEXICO}

There is no event in the history of the Monroe Inotrine in which the principles it emborlies have had such direet and 
muquestioned application as in that of the French invasion / of Mexion. The cireumstances in this case were in many respects strikingly similar to those that called forth the doctrine in 18\%3. In this instance, the threat from abroad was consmmmated by an actual landing of European forees upon North American soil for purposes of dominion. The olject of this invasion was for the very purpose of establishing monarehial institutions npon the Western Hemisphere, and the territory so invaded, bordering upon the United States, brought the movement well within the threatened line of dinger to American interests. All the conditions necessary for an American protest existed. Indeed, the situation in Mexico, brought about hy French intrigue, fully justified the action of the Lnited States on primary principles which authorize the use of force in self-rlefence. The exeuse of a national policy to be followed or maintained, could have earried no argument for intervention half so potent. While the Monro Doctrine. properly considered, is fundamentally a plea for self-protection, there is a magie influence in its pluases which easts a spell upon the American people when they are repeated, - a spell that has at times blinded the eyes to right or wrong in the excess of patriotism it seems to have inspired. In the French invasion of Mexieo, the threatened danger to the United States was so real and aplarent that no juggling with magical words was necessary to satisfy the national eonseienee that interposition was necessary: and it will be noted that in all the official despatehes relating to this international episode, no mention whatever is made of the Monroe Doctrine, no statement refers to a "well established policy," no precedent is exhibited, and no offerings are made upon the altar of a "manifest destiny."

With the establishment of the republie in 1821 , Mexico enterea upon an era of political eonvulsion that is probably umparalleled in the ammals of any other nation, if the example of tmpulent llaiti be excepted. In the course of forty years the fires of as many revolutions were lighted; seventy-two rulers, cither monarchial or repuhlican, were seated and deposer. The printry eanse of the ehronic condition of civil 
war which eharacterized this period of Mexican history is to be found in the controversies between the "elerical " and " liberal" parties of the State.

The Catholic ehurch was supreme in Spain, and its saererl symbols were bromght to the New World emblazoned upon the banners of her conquerors; with them Catholicism invalled Nexico, and the Church beeame the richest and greatest power in the land. The repullic inluerited a colossal and cormut ecclesiastical system that fattened upon the emornoms wealth of its own landed interests, all of whieh were exempted from taxation. So great had become the power of the church in the Mexiean Republic that it overshadowed all govermment, civil and military. Through vast accumulation of wealth, and beeause of its hold upon the minds of a superstitious people, the Catholic chureh became a wholly tyramical institution. The Clerieal party representerl the monarchical, aristoeratie, and despotic elements of the nation, while the progressive Librials stood upon a platform of "equal rights," "freedom of worship," and a general reform of aluses. The bitter struggle betwoen these two parties raged fiercely in 1858-190, with Miranom (Conservative) and Benito Juarez (Liberal) as opposing learlers. The nation hat been reduced by eeaseless war to a comdition of social and political chaos; gonerilla bands wandered about the comitry upon errands of plunder, and the smaller groups of banditi, like wolves, left the momntains and infested the lighloways: every semblance of law and order disappeared: murder and pillage were legitimized, and the term " government " wats a moekery. These deplorable conditions in Mexien invited foreign intervention because, in the turmoil of constant revolution, Mexico lard neglected her intemational obligations. During the Miramon-Jualrez strugrenles, offers of mediation from England and France were declined by Juarez beanse he suspeeted a resign to impose monarehieal institutions upon Mexico.

In 1861 .Jurez emererel from the eonfusion, trimmphant over his enemies, and with the "amy of the constimtion" he entered the capital. Juarez was always considered al gond 
lealer and a just man : in many respects he was a remarkable dhacter, whose memory will continue to be eherished in Mexico; althongh in control of the govermment he was. quite unable to prevent the disorder and riot whieh immediately followed his inauguration as president. Foreign intervention again became imminent, and the Conservatives, - or, in other words, those inclined to monarchical institutims - supported by the church, conspired in its favor. The policy of Juarez, to suppress the monasteries, to confiseate the wealth of the elergy, and to guarantee full religious liberty to all, were measires altogether ton radical in a country so completely dominated by ecclesiastical orders. Envoys of the Conservatives appeared in Europe, in 1861, to induce Sprain to reëstablish an empire in Mexico. Napoleon III of France was also approached, and that ambitious monareh at once grasped this opportunity to launch the great project that lay near his heart; Earl Russell, on the part of Great Britain, was finally induced to assume, though reluctantly, a share in a tripartite scheme of intervention in Iexico.

France, Sipain, and England, no doubt, had each some grounds for interposition. In the ease of France, the collection of a debt long overche gave her, as a ereditor government, a right to take action in her own interests. It appears that during his presideney Miramon had issued bonds to the extent of $\$ 15,000,000$, realizing upon them, according to his fullest expeetations, less than $\$ 1,000,000$ in eash; and the largest holders of this doubtful Mexiean paper were French eitizens. Juarez, on eoming into power, promptly repuliated this deht. Other elaims, amomting to many millions of dollars, were suldenly resurreeted from the waste basket by the French Govermment. Their validity had always been questionable, though some of them were, no dombt, just. Spain relied upon a violated treaty to justify ler artion, and Great Britain fomnd ample cause for armed intervention in rertain atreities committed by Miramon's officers in the british Legation at Mexico. A large sum of money hald been stolen from the legation safe, and varions English consulates had been sacked; for these enormities no 
redress had been offered by the Mexican frovermment, and none could be obtained by Great Britain thomgh amy meams short of foree. The three powers, having decisled to annduct a joint intervention, signed an angeement in Lombon (Oetober, 1861), declaring that:-

The high rontracting parties engagerl not to seek for themselves, in the employment of the correive measures contemplatol by the present convention, ans acpuistion of teritory, nor any special arvantage. and not to exerrise in the internal atfair's of Mexico any influence of a nature to prejuelice the right of the Mexican nation to choose and to constitnte freely the form of its govermment.

Their purpose was ostensibly to secure parment of their claims, and if necessary, to seize certain Mexican ports, attach their customs reeejuts, and hold them as a pledge. Accordingly, on the 7 th of Jimmary, 186;2, an allied fleet of the three nations, supplemented hy a French military foree, appeared at Vera Crmz, and demanded of Juarez, the Liberal. leader and president of the republie, immerliate payment. of the elaims against Mexico. Juarez combl only assert the inability of his govermment to meet such demants; les frankly and trutbfully stated that the treasury was (mpty. The allies then proelaimed to the people of Mexion their intention. They hat not come, they assured them, for eonquest, nor for the purpose of interfering with . Mexican politics; furthermore, their intentions were not prinatrily hostile, - on the contrary, they canne with a fricurlly hamd ontstretehed toward "a people whom l'rovidener hat fatroled with many gifts, but who used their foredes and exhatusterl their vitality in rivil watrs and perpetmal comsulsims."

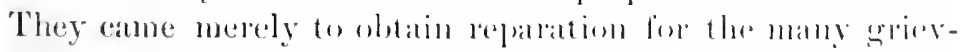

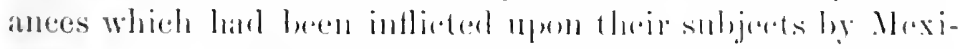

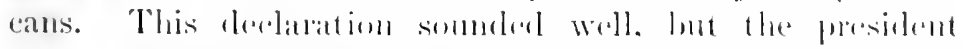

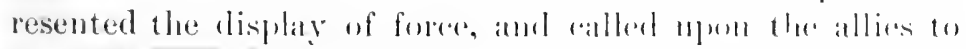

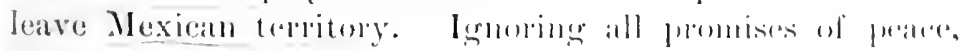

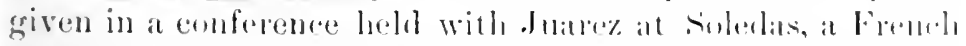

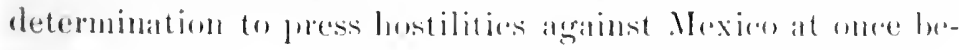


came manifest. This sudden determination convinced the English and Spanish commander's in Mexico that their French ally had motives ulterior to those expressed in the conference at London, and that it was contemplating a course of action in which they could take no part. They accordingly withdrew their forces, leaving the French alone. Then, relieved of his allies, the French commander, unmindful of the pledge given by his emperor, and of his own assurances to Mexico, declared war upon the Mexican Government. Ile issued at the same time a proclamation calling upon all good Mexicans to rally about his standard as it warned all foolhardy ones who should dare to oppose it; with this preliminary flomish he commenced his march to the city of Mexico, expecting an easy and splendid entry. At Puebla, about halfway on his journey to the capital, a Mexican army, under the flag of Juarez, met and defeated the French invalers, obliging the latter to fall back to Orizaba to await reënforcements from home. These, in due time, arrived, with Marshal Forey in command.

Napoleon's instructions to Forey left no further doubt upon the true object of his intervention in Mexico. The emperor was kindly solicitous for the welfare of the Mexicans, but " of comrse," he wrote, " if they prefer a monarchy, it is to the interest of France to support them in that view. ... In the present state of civilization of the world, the prosperity of America is not indifferent to Europe ; for she it is who feeds our manufacturers and keeps our commerce alive. It is to our interests that the Republic of the United States may he powerful and prosperous, but by no means that she should take all the Gulf of Mexico, and hence command the West Indies, as well as South America, and be the sole dispenser of the products of the New World. . . . If, on the contrary, Mexico conserves her independence and maintains the integrity of hor territory ; if a suitable government be constituted there, with the assistance of France, we shall have restored to the Latin race, from the other side of the orean, its strength and prestige; we shall have guaranteed, their security to our colonies of the West Indies and those, 
of Spain; we shall have established om heneficent influence to the centre of Amerial: and that influenee, by ereating immense openings to onr eommeree, will procure for ws the indispensable materials for our industry. Mexien, thus regenerated, will alwals be farorable to us: nut only by acknowledgment, but also beanse its interests will be in hamony with omrs, and it will find a point of support in its good relations with the Enopean powers. Now, therefone, our military honor pledgerl, the exigence of on polities, the interest of om industry and omr commeree matie it omr duty to mareh on Mexieo, to plant there boldly on stamblarle to establish there a monarehy, if it is not jurompatible with the national sentiment of the comntry - but at all events, a govermment which promises some stability."

Napoleon III entertained the brilliant project of reeistablishing the power of the Latin race in the Western Ilemisphere, and of restoring to France her lost prestige in the Americas. IIe felt that he alone might he able to aceomplish this great achievement. Syain was virtually dead; her former colonies in Central America had not fultilled the promises of freetom: the French were the only branch of the Latin race that had griven suffieient evidence of those qualities which insure suceess and progress : they alone had lived up to the glorious destinies of the Latins. I pon him, then, rested the burden of quickening to new life the race that was onee supreme, but which now lent before the masterful energies of the Anglo-sixoms. Eastern puestions belonged to Eugland: Western questions must lonk to France for solution. Mexico oflered the stage for the first aet of his heroic drama. The ('lerieal party, the monarelists, and the many sympathizers of the wh regine in llexion, would come to his support. He would swere aside the quarrelling political factions: he womld extrominate the ban-

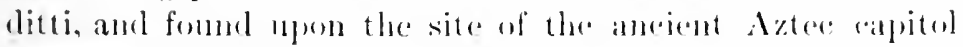
the seat of a new Lattin Empire. which, in the fuluess of time, wonld ontshine the ohl one. The laited states and its Monroe Doetrine perhaps stomel in his way, but he belioved the United States was too busily enerageel in its own desper- 
ate affairs to seriously tromble him: he realized, howerer, that he must act with cantion, and not unduly alarm the watchful anthorities at Washington, - hence, the resurrected French chams, the convention of London, the proclamation of his general in V'era ('ruz, and the Soledad Conference. No doubt Naproleon was encomaged by the mila tone of American protest. lle had well chosen his time, for at that partioular moment it was inexpedient for the United States to malke ememies abroal.

Manshal Forer, with his letter of instructions, arrived at Vera Cruz, in September, 1862, and inmerliately assumed command of a larely angmented French foree. After overcoming the resistance of the Mexicans in several hard-fought battles, Forey entered the capital Jume 10, 186:3, and estab. lisher a frovisional government, consisting of a regeney, in which he hinself was the central figure. A branch of the new govermment, styled the "Assembly of Notables," lost no time in reporting to Napoleon that the Mexican nation "arlopts a monarchical and hereditary form of government uncler a Catholie prinee" who shall take the " title of Enferor" - the choice for ruler being, " Ilis Imperial and Royal Highness, the Prince Ferdinand Maximilian of Austria."

The Areholuke, Maximilian of Austria, was a nember of the House of llapsburg, - a man of ambition, of honest intentions, of small political sagacity, and of little experience in worldly affairs. ITe was a tool in the hands of Napoleon. Before acepting the honor of an emperor's crown in Mexico, he desired nudoubted assurance that the choice of himself was in reality the choice of the Mexican people, and Napoleon's oflieials in Mexico were elever enough to olnain for the archduke every assmance he needed on that score. Finally convinced, and therefore believing himself to have the support of "an immense majority" of Mexicans, he accepted the honor. Ile was crowned at Mirmon, and in June, 1864, was weleomer into the city of Mexico with great demonstrations of joy.

The pleasing personality of the emperor, along with his good sense in recognizing the Liberals in the matter of 
appointments, gave to the opening of his reign promises of a most flattering nature. Many influential men among the Liberals, wearied at last with perpetual was, came to his side, believing that possibly, after all, Nipoleon had better solverl their political problems than they themselves had been able to do. Maximilian in fact became eren popular.

However, all the emperor at first gained in the gered-will of his subjects, was soon lost by a woful lack of julgment in the management of his imperial office. Ite fell reallily into the hands of the C'lerical party, and under the influence of their fawning adulation he entered mpon a stmpidly blind policy of antagonizing the Liberals at every turn, - those whom he had at first conciliated, and noon whose friendship he most depended. Ile finally sealed his own drom hy the astonishingly foolish error of recalling from exile the notorious generals, Miranom and Marquez, the former leaters of the Conservatives, and whose inhuman and baldanons anelties on the field of battle had disgusted even their own soldiers. No more flagrant offence ennld have been offered than the restoration to military power of these two detestal,le and bloodthirsty men.

An emplatic warning from the Inited States in April, 186t, cansed Napoleon to withdral the French forces liom North America, therely depriving Maximilian of his omly real support. Alamdoned to his late by those who had placed him mpon the throne, he carried on a despairing fight against the swelling forces of dnatez, and he finally paid the supreme price of his life for the ghlories of a four years' reign in Mexien, - a reign that was conceived and comblucted in error.

He was exeenterl June 1!), 186iT.

liearing in mind the realiness with which the varions administrations at Washington lat invoked the Monore boctrine whenever adjacent teritory hat been threatened with invasion form abroal, one womld naturally expect to find a prompt and deciderl warning from the L bited sitates, when the three allies signed the lomblon ('onvention, and aspecially when they appeared a lew months later with a demonstration of force at Vera Cruz. Surh, however, wats not the ease. 
There were several reasons why President Lincoln and his. cabinet chose to adopt a cantious pulicy. In the first place, the United States had substantial claims of her own against Mexico, and being thoronghly disgusted with the childish follies of her Southern neighbor, had only herself declined to become a party to the London Convention, because of her established poliey of non-alliance with foreign powers. The Secretary of State, William H. Seward, had not failed, from the beginning, to olstain the most convincing and satisfactory assurances from France that the object of the intervention was solely for the pmpose of collecting a debt, and was in no wise intended to be eonverted into a political movement. Although the Monroe Doctrine had, on previons occasions, been loosely regarded as a general inhibition against foreign intervention of any kind whaterer in the Western continent, a more reasonable construction of $\mathrm{Mr}$. Monroe's words could not give them so broad a meaning. The allies, it was thought, harl an undoubted right to use force in the collection of just elaims against Mexico, and the United States had no right to interpose so long as her own safety was in no manner involved.

Another reason why Mr. Seward chose to adopt a complacent attitude of nentrality, a comse for which he had later to endure the accusation of cowarlice, must be taken into aceount. His responsible position at the head of the Department of State was, at that particular moment, fraught with the greatest difficulties. A mistake in the management of foreign affairs wonld ahmost surely have invited disaster, and this particular matter called for the utmost delicacy of diplomatic treatment.

The eiril war that had been threatening the United States for a quarter of a century had at hast come; -any violation of the Monroe boctrine, howerer offensive to the people of the United States, would probably have been disregarded beranse of other and greater dangers. Mr. Seward nevertheless anxiously watehed the progress of the allies; he sought constantly to conciliate the three powers, though expressing always his comntry's displeasure with any foreign meddling. 
in Mexico which might temd toward an overthrow of its legitimate government. England's attitude toward the Cnited states Govermment he well knew to be unfrimblly. and the unfortunate affair of the Trent was fresh in every mind; a further offence to England, muler the circmustances. would have been inexpedient and possibly muste.

When Napoleon's innel motives eame to light, and the English and Spanish withdrew their forees from Vera Crum. the new dinger thrust itself upon the state Department. Success of the Rebellion, and the division of Anglo-Saxom power in Anerica, was clearly in rlirect line with French interest. That $M r$. Seward was fully alive to the dangerons situation is apparent in the eautions tone of his despatches. It was only when Appomattox elosed this eritical period of American history that the administration was enabled to assume its proper attitude toward the French invasion of Mexico. With a veteran army to batek the demand, Napoleon was requested to abandon at once his project in Mexico. The Momroe Doctrine was vindicated.

A few quotations selected from a voluminoms mass of oflicial despatehes will suflice to indioate the position of the government in this matter, at its varions periods, from 1861 to 1866 , and to present as well a budget of oflicial literature upon the doctrine under discussion.

When the intervention was first deciled nyon by the three powers, Mr. Cass, Secretary of State, wrote to Mr. Mrdalne. September 20, 1860 :-

While we do not deny the right of any other power to cary on hostile operations agalinst Mexiro, for the lentress of its grierances, we firmly olject to its holding prosession of any part of that country, or endeavoring by force to control its political destiny.

This opposition to foreign interference is known to Flaner. Enyland, and spain, as well as the determination of the Cuitrel states to resist any such attempt by all the means in their powre...

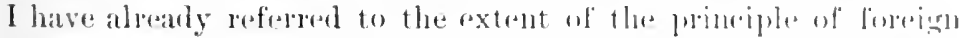

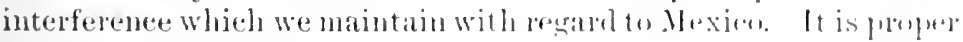
to ald that while that principhe denies the right of any luwe to 
hold permanent possession of any part of that country, or to endearor by force to direct or control its political destiny, it does not call in question its right to arry on hostile operations against that repulblic for the redress of any real grievances it may have suffered. But we insist that such hostilities be fairly prosecuted for that purpose and be not converted into the means of acpuisition or of political contract.

Replying to the invitation extended by the three allies that the Lnited States should become a party to the London Convention, and join them in the recovery of their claims against Mexico, Mr. Seward said:

... the President does not feel himself at liberty to question, and he does not question, that the sovereigns represented have umbubted right to decile for themselves the fact whether they have sustained grievances, and to resort to war against Mexico for the redress thereof, anch have a right also to lery the war sererally or jointly. The Lnited States have a leep interest, which, however, they are haply to believe is an interest held by them in common with the high contracting powers and with all other civilized states, that neither of the sovereigns by whom the convention has been conehuled shall seek or obtain any acquisition of territory "r any advantage peculiar to itself . . . or to exercise "any influence of a character to impair the right of the Mexican people to choose and freely to constitute the form of its own govermment. . . . It is true, as the high contracting parties assume, that the United States lave, on their part, claims to urge against Mexico. Upon due consideration, however, the President is of opinion that it wonk he inexpeclient to seek satisfaction of their claims at this time through an act of accession to the convention.

On March 3, 1862, when Napoleon's duplicity had seareely become suspeeted, Mr. Seward arldresserl Mr. Adams, Minister to Great Britain, as follows:-

The Presiclent, however, deems it his duty to express to the allies, in all candor and frankness, the opinion that no monarchical government which could be foumled in Mexico, in the presence of foreign navies and armies in the waters and upon the soil of Mexico, would have any prospect of security or permanence.

Later in Narch, 1862, the administration became convinced of Napoleon's real intentions in Mexico, and upon Mr. 
Seward fell the burden of opposing French aims withont offending the French emperor. It at once became Mr. Seward's object to prevent Great Britain and France Prom eombining in a common cause against the Eniterl states. The task of the diplomatist was certainly not an easy ane. Both powers were thought to faror the suceess of sonthern arms against the North, and both were actually mited in an aggressive movement against Mexico, which was lostile to American interests. At such a moment the olservaluce of a mere political tenet was of little relative importanee. The Secretary wrote to Mr. Inyton, Minister to France, Mareh 31, 1862, as follows: --

You will intimate to $\mathrm{Mr}$. 'Thouvenel that rumors of this kind [that France is a pirty to the scheme to "subvert the repulblim American system in Dexico"] have reached the Presidnt and awakened some anxiety on his part. Yon will say that you am not authorized to ask explanations, but you are sure that if any can be made, which will be calenlated to relieve that mxinty, they will be very welcome, inasmuch as the United States desire mothing so much as to maintain a goed understanding and the most cordial relations with the government and the people of France.

It will hardly be necessiry to do more in assigning your reatsons for this proceeding on your part than to say that we have more than once, and with perfect distinetuess and andur, informed all the parties to the alliance that we cannot look with indifference upon any armenl European intervention for prolitiral ents in a comntry situated so neall and comnected with his so closely as Mexico.

Mr. Seward sulsequently explained the mildness of his protest by saying, that "nations, no more than indiviluals, can wisely divide their attention upon many suljects at one time." 'The one subject of rivil wall at home was fully ample to oceupy the attention of every branel of the gorermment.

The assurances given that Flance did not intemel to colosnize Mexico or to take Somora or any other section of the country permanently enabled the L Hited States Govormment in defer the definite protest which it held in maliness to pre-

1 Bancroft's Life of Seward, Vol. 2, p. 125. 
sent at a more auspicious moment. 'To Mr. Motley, Minister to Austria, Mr. Seward wrote, September 11, 1863:-

When France mate war against Mexico, we asked of France explanations of her objects and purposes. She answered, that it was a war for the redress of grierances; that she did not intend to permanently occupy or dominate in Mexico, and that she shoulk leave to the people of Nlexico a free choice of institutions of govermment.

But the vigorous campaign of the Freneh had begun to alarm the people of the United States. Mr. Seward adrlressed Mr. Dayton, September 21, 1863 :-

- The United States government has hitherto practised strict neutrality between the French and llexico, and all the more cheerfully becanse it has relied on the assurances given by the French govermment that it did not intend permanent occupation of that romtry or any violence to the sovereignty of its people. The proceedings of the French in Mexico are regarded by many in that eomntry and in this as at variance with those assurances. Owing to this circumstance, it becomes very diffienlt for this government to enfore a rigicl olservance of its nentrality laws. The President thinks it desirable that you should seck an opportmity to mention these facts to Mr. Drouyn de l'Huys, and to suggest to him that the interests of the United States, and, as it seems to us, the interest of France herself, require that a solution of the present complieations in Mexico be made as early as may be convenient upon the basis of the mnity and indepremlence of Mexico. I eamot be misinterpreting the sentiments of the United States in saying that they do not desire an annexation of Mexico or any part of it, nor lo they desire any special interest, control, or influence there, but they are deeply interested in the reestahlishment of mity, peace, and order in the neighboring republie, and exceedingly desirous that there may not arise ont of the war in Mexico any eause of alienation between them and Fince...

A threat is here veiled only by expressions of good-will; but numerous letters written by Mr. Seward to the French Minister about this period, indicate the extreme dissatisfaction felt by the Inited States Govermment against France. which was held in restraint only hy domestie war at home. 
When Drouyn de Lhuys (the French Minister of Foreign Affars) intimated the emperor"s clesire for the Initerl States to recognize Maximilian, Mr. Sewarel adroitly replied that "a determination to err on the side of strict nentrality. if we err at all," was all the emperor could expect of the Lnited States. But he continned more openly :-

Happily the French Govermment has not been left minformed that, in the opinion of the Cnited states, the permanent establishment of a foreign and monarchical government in Mexiro will be found neither easy nor tesirable. You will inform Mr. Dromsm de l'Huys that this opinion remains mohanged. On the other hand, the United states cannot anticipate the action of the people of Mexico, nor have they the least purpose or desire to interfore with their proecedings, or control or interfere with their free choice, or disturb them in the enjoyment of whaterer institutions of government ther may, in the exercise of an absolute freedom. establish. It is proper, also, that Mr. Ihouyn de l'Huys shonld be informed that the Uniterl States continue to regarl Mexico as the theatre of a war which has not yet ended in the subversion of the Government long existing there, with which the Enitert States remain in the relation of perce and sincere friendship: and that. for this reason, the Cnited states ane not now at liberty to consiter the question of recomizing a Gorernment which, in the further chances of war, may come into its place. The Cuited States, consistently with their principles, an do no otherwise than leave the destinies of Mexico in the kepping of hor own people, and recognize theil sovereignty and inderendence in whatrer form they themselves shall choose that this sovereignty and independence shall be manifested.

With the actual erowning of Maximitian. C'omgress could not restrain its indignation, nor longer remain silent. Mexican affairs then began to compel consideration in the Lnited States, and even to assmme importance superior to the engrossing excitenents of the eivil wal. The press chanored for a positive reassertion of the Monroe Inoctrine, and ('ongress responded to the call, heedless of the conseguenters.

On $A_{p}$ ril 4 , 18tit, the Ilomse passed the following resolution without a dissenting voice : -

The Comgress of the I'niten States are muthing he silemere to have the nations of the work under the impression that they are 
indifferent spectators of a deplorable event now transpiring in the republic of Mexico, and they think fit to declare that it does not arcord with the policies of the Uniterl states to acknowledge ans monarchical govermment erected on the ruins of any republican government in America under the anspices of any European power.

The publication of this act, which represented as truly the feelings of the administration as it did the feelings of the comntry, came perilonsly close to cansing war between Fance and the Enited States - a war which, coming at that time, might have very materially changed the future destinies of the Lnited States. The French Minister for Foreign Affairs demanded of Mr. Dayton, " Do you bring us peace or do you bring us war"?"

It required a quick comnter-move on the part of Mr. Lincoln and his Seeretaly of State to repair the dam whieh Congress hat nearly opened to the devouring flood. Mr. Sewad hastened to instruct Mr. Dayton to report, " that the proceedings of the House of Representatives were adopted upon suggestions arising within itself, and not upon any communication of the Executive Department, and that the French Government would be seasonably apprised of any change of policy upon the subjeet which the President might, at any future time, think it proper to arlopt : " and to report also that the question of a policy toward Mexico was an exeentive one unless Congress should agree by a two-thirls vote of both IIouses, and that the oprinions in the Ilonse, as lemonstrater by the resolution, were " not in harmony with the policy of nentrality, forbearanee, and consideration which the l'lesident has so fathlifully pursued"

When the Civil War elosed the hands of the administrattion wore muloosed, and Mr. Seward was then enabled to assume a mole detiant attitude toward French aggression in Mexioo, but he leperl nevertheless to accomplish by peaceful means what fienerals firant and sheridan insisted should be done he the direct theat of military force. In September, 1865. he anmomment in a firm but eomeiliatory mamner, that as France and the Lnited ritates hat armies confronting eateh 
other on the Mexican frontier, "a time seems to have ame when both nations may well (emsider whether the permanent interests of international peace and friemblip do now repuire the exercise of a thought ful and serious at tention to the pulitica! questions to which I have thus reverted."

The "political questions" referred to, were that the Lnited States favored republican institutions on the American continent, and the Firench dirl not.

The Lnited States refused to reeognize Maximilians (forernment; and on Deeember 16, 1865, Mr. Seward garve the direct warning to Napoleon that ended the affair, so far als the Monroe Doctrine was concerned. He instructed Mr. Dayton to amounce that : -

It has been the President's purpose that France slould bo respectfully informed upon two prints, namely : tirst, that the United States earnestly desire to rontinue and to cultivate sincere friendship with France; secondly, that this policy would be brought into imminent jeopardy mless France conld deem it consistent with her interests and honor to desist from the prosecution of armed intervention in IIexico to overthrow the domestic republican government existing there, and to establish upon its mins the foreign monarehy which has been attempted to be inmgurated in the capital of that country.

With the change of condition in the Lnited States which reunited its strength and gave to it a latrge veterim army. ready to proeed at once to Mexico, Napeleon sitw the downfall of his sclieme. Ile awoke at last from his dram of Western Empire.

With the withdrawal of the French tropse from Mexico, a movement was begme in Anstria to raise an army to fureceed to Mexieo in support of the deserted Maximilian. Mr.

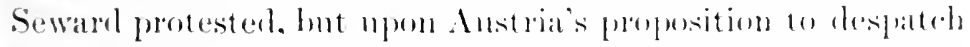
a smalles foree, Sewarel repried that the youstion of militaly aid for Maximilian was not to be discussed, anul slumbl lane Anstran Govermment persist in its determination, the Amori-

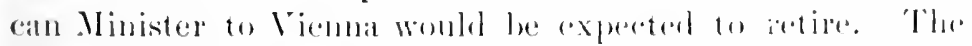

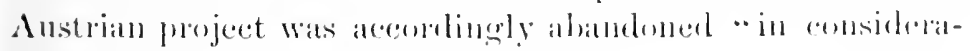
tion of all the. . . circumstances." 
Thus closed the episode with a complete vindication of those principles upon which the original Monroe Doctrine was founded, but without mention of the Doctrine itself, and without the slightest allusion to its author. This was the first overt act in American history looking to the establishment of European monarchy on the Western continent; the only case where the threat was made good by actual invasion - the only case, indeed, which really threatened the interests or safety of the Lnited States. Yet the administration, being fully alive to the situation, preferred to justify American intervention upon those broad grounds of selfdefence that are recognized by all civilized nations, and accepted by all authorities as sanctioned by the public law. It alid not choose to summon specifically the Monroe Doctrine in its defence. No precedent was needed, no appeal to sentiment was necessary, there were no doubter's to be soothed or cajoled by magical words. American intervention in Mexico involved no ulterior political schemes which had to be hicklen under the cloak of a "national policy," or clothed with the appearance of right by the sanctity of a popular slogan. 'The danger to the Cnited States of a new European empire, planted upon her very borders, was too real to call for sleight-of-hand methods to arouse opposition to it. There was no party to be led on by high-sounding phrases.

The principles of the Monroe Doctrine were fully vindicated, as they always must, and always will, be when the proper occasion calls. Those principles belong, not to the United States alone, but to all nations alike. The Monroe Doctrine was not alluded to, because the object of that declaration had long since been fulfilled; because from Mr. Seward's point of view, if it could be regarded as a "national policy" at all, it had fallen into disgrace; and finally, because a purely national policy can have no authoritative place in international law.

To William II. Seward is due a credit, not generally aecorded him, for the able manner in which he defended American interests against the sehemes of Napoleon III, also for lis skill as a diplomatist in eonciliating foreign 
enemies to the Northern eause, while he opposed at the same time their adrance in Mexieo. Mis adroitness in freventing Great Britain and France finding a eommon grievance against the Lnited States during the trying period of the Civil War is worthy of great praise. An equal distinetion is no less due him for his independence and good judgment in declining to justify his intervention in Mexico on the gromml of a domestic political policy when the universal prineiple of selfdefence offered him sufficient argument.

\section{XI. $186618-1896$}

From the close of the Mexican episode in 1866 to the present day, there has been but one important intermational question involving the Monroe Doetrine that has given rise to serions discussion, - the case of Venezuela and Freat Britain in 1896. From time to time, debates in the Senate concerning the revocation of the Clayton-Buber treaty with England (1850) have taken place, in most of which discussions the relation of the doctrine to the poliey of American control of an isthmian canal formed a part; but cluring this period of three decades the enintry has been singularly free from rexatious diplomatic questions, arising from acts of European aggression upon the Western eontinents.

President Grant in his seeond annual message (Decenber 5,1870$)$ proposed the annexation of Santo Domingo. Among other reasons for taking it, he submitted that if the Lnited States did not acquire the island - the natives being prepared to weleome Ameritan sovereignty — "a liee port will be negotiated for by European nations in the laty of Samana." He declared that ". The aequisition of Santo Domingo is an adherence to the Monroe Doetrine; it is a measure of self-protection; it is asserting our just claim to a controlling influence over the great commereial traltic; soon to flow from west to east by way of the lsthmus of Darien. . . .

Like Mexieo, the Dominican Republic hat lerl at checkeder politieal career after its declanation of inderentence in $18 \mathrm{th}$ 
In 1861, Pedro Santana, a party leader and prominent revolntionary general, proposed the retrocession of the island to. Spain, hoping thereby to seeure for its inhabitants freedom from the rexations of continual war.

The Lnited States was just then too busily occupied with home affairs to take very serions notice of Santo Domingo. Nevertheless, hearing of Santana's action, Secretary Sewarel annonnced to shain that "the Govermment of the United States would regard with grave concern and dissatisfaction, movements in Cuha to introduce Spanish authority within the territory of IDominica." Spain was also much ocempied with internal difficulties, yet not wishing to lose so excellent an opportunity to recoup her lost fortumes in the West Indies, she disregarded Mr. Seward's warning and sent a borly of troops to Santana's aid. Spain's welcome in Santo Domingo was less cordial than she had been led to expect. The Dominicans waged a relentless guerilla warfare upon the spanish trons. In 1865, the governor seneral and his military aptain, Maximo Gomez (later of Cuban fame), were obliged to withdraw, with a parting farewell thrust from the lominieans, to the effeet that, "The united Dominiean people, without regard to rank or color, have planted the white cross of the Republie upon the principles enunciated by the great mother of free nations, that Amrerca belongs to Americans, and we will endure all our trials over again, sooner thin desert it."

It the time of President (irant 's message, therefore, the Spaniards had abandomed all intention of subjugating the island, and no actual negotiations upon the part of any foreign power had been made, nor were likely to be made, to secure a port within the bay of Simmana. It is difficult, then, to see just how the doedrine applied to the case.

This, as has been allearly intimaterl, was not the first perrersion of the Monroe Ioctrine; President Polk had emfloyed much the same tacties in furthering the ammexation of Texas. I stuffer hird in both eases harl to be substituted for a living one at which to shoot.

The real merits of the question respecting the ammexation 
of Santo Domingo had nothing to do with the Monroe dortrine, and the atmission of the island into the Lnion wats considered by Congress in reference only to the atetual value or worthlessness of the territory. Lnfortmately the debate in Congress was so characterized by bitterness of personal feeling and antagonism to the President, that the friends of General Grant folt obliged to withdraw the bill before a rote could be talien upon it.

Shortly after the elose of the Civil $/ V^{*}$ ar a movemest was inaugurated in Congress lonking to acpuisition of territory north of the Lnited States. I seriess of conflicts betwersu upper and lower Camala had awaliener the British Corernment to the advisability of miting lex ('analian posiessions into a single dominion. This was ateomplished hy what is called the british Nolth Amerian Act. This act united in close ties of confederation the provinces of Ontario, Qnebee, Nora Seotia, New lormswick, l'rince Edward Island, Manitola. and British Columbia, with a Parliament at Ottawa. More cordial feelings between the provinees were thus brought ahout by the arkowledgment of mutual interests and dejendence.

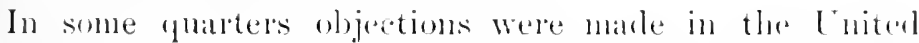
States that this aet of Great Britain was in violation of the spirit of the Nomroe Doctrine, becanse it seened to be antagonistie to the proper fulfilnent of the desting of these provinees, which eventually womld lecome a part of the

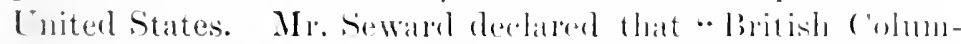

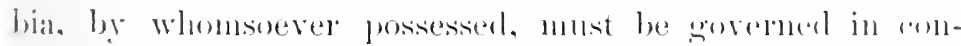
formity with the interests of hel people and of society "1pon the Aneriean continent."

Congress also eonsiblered a resolution whirh volual the uneasiness of the comntry at withessing "sllete at vats congromeration of Anteriean states, establisherl on the monal-

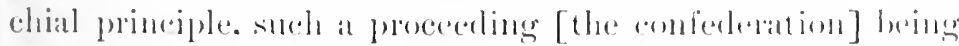

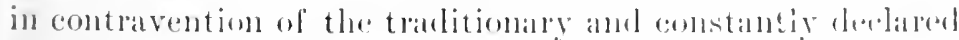
principles of the lonited States, and endingerent their most important interests."

In this case, as in the freceeding one, the application of 
the Monroe Doctrine is not clear. Mr. Monroe expraysly staterl that, "With the existing colonies or dependencies of any European power we have not interfered and shall not interfere."

Certain political distmrlances in South America, from 1864 to 1871 , drew from Washington further statements relating to the Monroe looctrine. An alliance of South American states, including Chili and Peru, were involved in diffieulties with Span, growing out of the musatisfied claims of Spanish eitizens. In the war that followed a Spanish fleet bombarded Valparaiso (Mareh, 1866), and the United States was looked to by the allies for an assertion of the Nomroe Doctrine. Mr. Sewarl wrote to Mr. Kirkpatrick, the American Envoy to Chili (Jume 2, 1866) that the Government of the United States will "maintain and insist with all the decision and energy which are compatible with our existing nentrality that the republican system which is aecepted by any one of those [Routh American] states shall not be wantonly assailed, and that it shall not be subverted as an ent of a lawful war by European powers." However, Ml. Seward declared it was not the intention of the Inited States to go beyond this position. In South American wars, where European powers did not seek the estal,ishment of monarchieal government, the United States could wot be expected to take part.

In the early part of 1895 Great Britain was moved to indignation by the arrest and foreible detention by Nicaraguan anthorities of Mr. Iatch, the aeting British Consul, and certain other British subjects in the Mosquito Reservation. These men were denied a trial, and summarily' expelled from Nicaraguan territory. Nicaragua alleged that they had instigated riots against her sovereignty in Mosquitia, hut she failed to give the prisoners a hearing before a eourt of justice. Great Britain at once presented a claim of 15,000 pounds sterling, and receiving no satisfactory promise of payment from Mamagua, promptly sent a watr vessel to Corinto to enforce her demands.

Nicaragua appealer to the Lnited States. Mr. Greshim 
replied that Nicaragua must deal directly with Great Britain. In a telegram of April 2-4, to Mr. biararel in Lomdon, he said: "The President antrises that yon sily unoftieially and confidentially to Lord kimberley, that while disclaiming any right to interfere in pending settlement of claim for pecuniary reparation, compliance with Nicanagua's request [extension of time for payment] wonld aroist embarrassment to commerce of this and other countries, and be very satisfactory to the Lnited States."

This, Lord Kinberley willingly granted, ant the elaim was soon after settled.

Commenting upon this episode, the President in his annual message the following December, said: "While the sovereignty and jurisdiction of Nicaragua was in no way questioned by Great Britain, the former's arbitrary conduct in regard to British suljects furnished the gromud for this proceeding [seizure of Corinto]."

The landing of an armed British force in Central America provoked considerable comment in the press thronghout the country concerning the duty and probable action of the United States. The matter was closed, however, withont an official appeal to the doctrine.

\section{GREAT BRITAIN ANI) VENEZUELA}

The latest application of the Monroe Doctrine by om. government was male in 18!1j-6!ti. In his third anmul nu(ssage (December 2, 189.j), President Cleveland used the fol-v lowing words : -

It being apparent that the boundary aispute betwoen Great Pritain and the Republie of Veneznela concerning the limits of

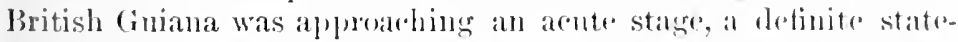
ment of the intrerest aml policy of the United States as regalrds the contreversy seemed to be legulied both on its own alconnt and in view of its relations with the frimolly powers direetly andeerned. In July last, therefore, al despiatwh wats alldressed to our Ambassarlor at Lomdon for commmination to the british ciowernment in which the attitule of the United states was fully asul 
distinctly set forth. The general conclusions therein reached and formulated are in sulstance that the traditional and established policy of this goremment is firmly opposed to a forcible increase by any European power of its territorial possessions on this continent; that this policy is as well founded in principle as it is strongly supported by numerous precedents; that as a consequence the Cnited States is bound to protest against the enlargement of the area of British Guiana in derogation of the rights and against the will of Venezuela: that considering the disparity in strength of Great Britain and Venezuela the territorial disprite between them can be reasonably settled only by friendly and impartial arbitration, and that the resort to such arbitration should include the whole controversy. ...

It had long been known in the United States that there existed a bomdary dispute between Great Britain and Venezuela, but in view of the fact that many of the boundary lines in South America were vaguely defined and had for many years caused more or less irritation between the South American republics, the settlement of this particular one was not considered important to American interest. This was the aase even regardless of the fact that one of the contestants represented a Emopean power. The dispute between Great Britain and Tenezuela originated in conflicting Dutch and Synish territorial claims in the northeastern part of the Sonth American continent, - England being the successor of the I)utch in Guiana, while Tenezuela based her elaims upon spanish title. It became apparent in 1840 that these early territorial elaims were in conflict. Cnsuccessful attempts to detine the lines charaterized half a century of correspondence between the rival claimants. From time to time, as the teritory in dispute becanc better known to settlers, the quarrel broke ont ancw, but as often to be abandoned on failure of an moderstanding.

In 187i, Veneznela alled the attention of the United States to the alleged encroachnents of British Guiana upon her soil, laying (xpecial emplatsis upon English advances in the region lying about the momtle of the Orinoes River. From that time to $18 \% 5$, Venczuela upon several oecasions 
had urged the Enited states as the "oldest of the republies of the new continent." and therefore the one called upon " to lend the others its powerful moral sulport in clisputes with European nations," to intereede in its behalf. Withont exception, the replies from IIashington expressed sympathy with Venezuela in her controversy. In some instances atsonances were given that if (ireat Britain were wrongfully suching to extent the lines of her Guiana colony, snch atetion would be regarderl by the Lnited States as an unjustitiable encroachment upon the Westem Hemisphere, and therefore a subject coming teally within the seope of the Monroe Doctrine. Moved by these representations, Mr. Frelinghusen, in 185. . had offered to propose to creat Britain a submission of the question to the arbitrament of a third power, should Venezmela so request. In a letter to Mr. Baker, American Minister resirlent at Caraeas (January $31,188: 3)$, he ontlined the attitule of the United States - one of strict impratiality. lut farmable to the employment of good olfices toward inclining (ireat Britain to arbitrate. There was a work of caution to Mr. Lowell, the American Minister in Lumbon ( Jnly T, 1sit), not to commit the Enited States '• to any deteminate politionl solution" of the question, which at that time indicaterl clearly the conservative attitule of the government. In this letter Mr. Frelinghuysen stated that ."The moral position of the [nited States in these matters [allegerd foreign

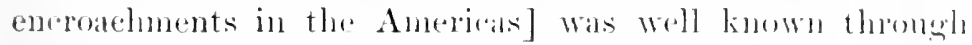
the enmedation of the Momree boctine, but formal action in the direction of alphlying that doretrine to at sureoulative

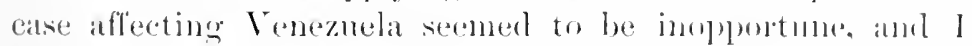
conlal not advise Veneznelat to aronse a discossion of the point."

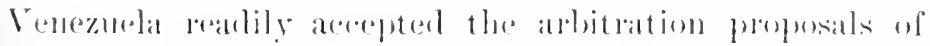

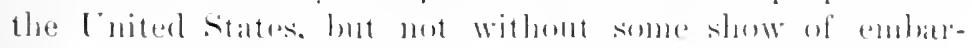

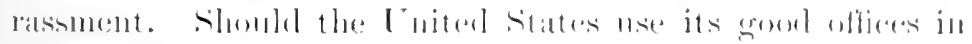

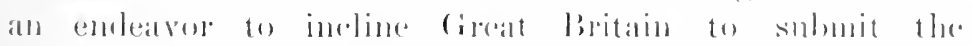

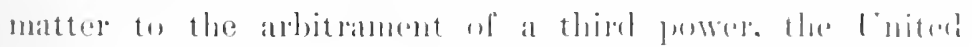
states, therefore. ats mediator in the rase, would likely le 
debarred from acting in the capacity of umpire; and the Lnited States alone was acceptable as an umpire to Venezuela. On the other hand, while the United States was perfectly willing to name an umpire, it eould not do so with propriety, unless a concurrent request came from both parties to the dispute.

Further English advances near the mouth of the Orinoco River in 1886 were viewed with alarm and dismay, and war was almost preeipitater by the despateh of a Venezuelan gunboat to Barima Point with engineers and equipment to construct a lighthouse in that locality of disputed ownership. At this same time a Venezuelan note was addressed to the British authorities that should Great Britain object to this assertion of sovereignty over Barima, diplomatic relations between the two nations woukd instantly cease. Even at this critical juncture, public interest in the United States was not greatly moved. Mr. Bayard, voicing his friendly concern in the adjustment of the dispute, felt warranted in tendering to the British Government the good offices of the United States, in an endeavor to promote an amicable settlement of the respective claims, with which the secretary compled an offer to act as arbitrator, should sueh proposal prove aceeptable to both eountries. In a communication to Mr. Phelps, December 30, 1886, Mr. Bayard toncher upon the responsibility of the Cnited States in relation to the South American republics, in which he mentioned "the doctrine we announced two generations ago": such responsibility he deelared to be entirely consistent and eompatible with an "attitude of friendly nentrality and entire impartiality." He said forther : "It is not smposed for a moment that any ilea of political or territorial expansion of authority on the American continent can control ller Majesty's counsellor's in any action they may take in relation to Veneznela. . . The dispute with Venezuela is nerely one of geographical limits and title, not of attempted political jurisdiction."

With the clash of anthority at Barima Point, Venezuela assumed a more angressive attitude towarl (rreat Britain. 
Her Minister in Washington constanty yeminiled Mr. Baram of the Ionroe Doctrine. ". The violation of the teritory of Venezuela," he mrgerl, " luas been gradnally accomplished by means and moler pretences which, in view of the antecedents of the care, appear searcely eredible. The representative of Great britam at Catrats formally decelated, in 1850, that the acquisition which hats now been so temilemsly insisted upon, was not eren thonglit of. Liy this alcpuisition. Great Britain gains possession of territories which she dis not formerly pretend to elam, and violates the stifmatims male with Veneznela in the eonvention signed at that tine through reliance on the sincerity of those declatations."

Great Britain dechered to aceept the friendly olfices of the Lnited States, and the British Minister at Calateas seemenl his passport preparatory to abandoning his diplomatic post. English men-of-war appeared in the Orinoco and at La Ginira, and for the moment war stemed inevitable. Just at this anxious monent of suspense the unfortmate bumblary dispute was more than ever complicated hy the discovery of gold in the interior district of Caratal. - a region elaimed by Venezuela, and now sudrlenly aecupied by liritish miners, who, with the usual indepentence of gold miners. refused to recognize any sovereignty but their own. The matter was still further agrarated by the firmer attitule assumed toward Great Britain in Washington. Mr. Bayard wrote to Mr. Phelps, February 17, 18x8: "The Govermment of the Enited States has hitherto taken an earnest and friendly interest in the question of bommlaries so long in dispute between Freat Britain and Venezncla, and, so fall as its disinterested emmsels were admissible, has adrocaterl an amicable, final, and homomable settlement of the dispmte. We have follower this andse on the assmmption that the issue was one of historical fare e.minent ly aplathle for admit-

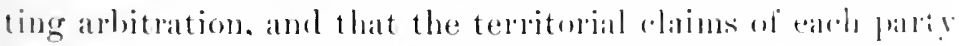
had a fixed limit, the light to whirle womld without liflicollty

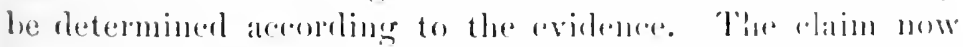
stated to have heen put forth he the anthoritios of liritish Guiana neeessarily grives rise to gratre disquietule, and ereates 
an apprehension that the territorial claim does not follow historical traditions or evidence, but is apparently indefinite. . . It may be well for you to express anew to Lord Salisbury the great gratification it would afford this govern. ment to see the Veneznelan dispute amieably and honorably settlerl, by arbitration or otherwise, and our readiness to do anything we properly can to assist in that end.'

In the spring of 1858 Congress called for the correspondence relating to the Venezuelan controversy, and thus the matter eame more prominently before the country. Although the subject was duly diseussed by the press, even then it did not oceur to the people of the United States that the question of a South American boundary could, to any very great or serioms extent, affect American interests.

From 1888 to December, 1895, amicable relations between Tenezuela and Great Britain were greatly disturbed, although diplomatic intercourse was resumed in the form of several special Venezutan ensoys to London, who labored earnestly, though in vain. for a friendly adjustment of the boundary difficulties. During this period of seven years british subjects continued to emigrate to the Caratal gold district. where they fommled numerous settlements, and so far won the conticlence of the native Indian tribes that the latter were often willing to unite with them in foreibly resisting Veneznelan anthority. In the year 189.5 the boundary rlispute had again reached a dangerous crisis, owing to some hostile encounters. within the disputed area, between British settlers and the Veneznelan police. Venezuela's apprals to the Luited States for protection were so persistent that I'resielent Cleveland was finally induced to step into the arena. A somewhat rigorous correspondence took place between Washington and london, the burden of the discussion between Mr. Olney and Lord Salisbury being the applicability of the Homroc Doctrine to the case.

The ammal message of the l'resictent (1895) was followed, two weeks later (December 17), by a special message to Congless. submitting the (Olney-salisbury letters, and further

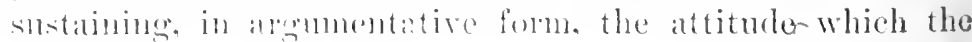


administration had seen fit to take. Then, for the first time. the whole tangled question came before the American penple as a matter of vital importance. For several months it was the absorbing topic of the press. The journals bristled with inflammatory editorials. England was roundly denomured as a nation of robbers and the natural enemy of the Lnited States. The usually quiet antipathy to Great Britain. which would seem to be an inherited Americin instinet. suddenly came to the surface, and the people of the combtry called for a prompt vindication of the Monroe Inotrine. An intensity of bitter feeling against England was exeited, pointing ominously to armed confliet; while the more conservative elements of the comtry stood amazed and alarmed at the seriousness of the situation.

The position talien by Mr. ()hey was sulstantially ats follows: If Great Britain were eneroathing upon Venezuelil, as Venezuela allegerl, by an mwaranted extension of hel Guiana boundary, such liritish aggersion (onstituted an attempt to extend the sovereignty of a Emolean power. along with its system of govermment, to a portion of the Ameriean eontinent; an art which rearly fell within the interdiction of the Momre boretrine. The only way to determine whether (ireat britain was merely ocenpying territory that rightfully belonged to her, or whether she was secking to extend her sovereiguty, was hy means of a eareful examination and comparison of the historical evidences that smplorted the eontlieting elaims: llerefore the Enited states must insist that the matter be submithed to a tribmal of arbitration. Should such a trihnual find that the British elaims w the disputed territory were just, the whole matter wonld fall ontside the opelation of the Mombe I ha-

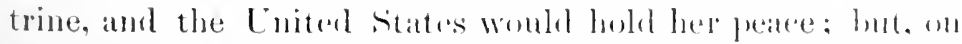

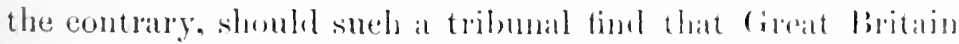
was seeking to alpropriate territory belonging of right to Venezuela, then it would become the duty of the l'nitul States, in the interest of her own safety, and in comformity

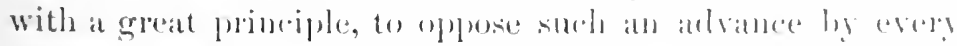
means in her jower. 
The British position was, in substance, that the Monroe Doetrine had no bearing upon the boundary dispute in South America: that that doctrine had been ereated to meet certain ends, and had long since fulfilled its purpose; that the interest and safety of the Lnited States was in no manner threatened; and, therefore, the British-Venezuela quarrel being no affair of the United States, the intervention of the latter was wholly unwarranted.

The two letters of Secretary Olney and Lord Salisbury on this subject are most important documents in the historical development of the Monroe Inoctrine, and free quotation from them cannot well be aroided. Only those parts of the letters relating to the merits of the territorial elaims are omitted.

\section{Mi. Olney to Mi. Bayurd.}

No. S04.]

Departuent of State, Weshington, July :20, 1895 .

His Excellency Thomas F. Bayaro, Etc., etc., etc., London.

Sir: I am directed by the President to communicate to you his views upon a subject to which he has given much anxious thought and respecting which he has not reached a conclusion withont a lively sense of its great importance as well as of the serious responsibility involved in any action now to be taken.

It is not proposed, and for present purposes is not necessary, to enter into any detailed account of the controversy between Great Britain and Venezuela respecting the western frontier of the colony of British Guiana. The dispute is of ancient date and began at least as early as the time when Great Britain accoured by the treaty with the Netherlanks of 1814 "the establishments of Demerara, Esserpubo, and Berbice." From that time to the presint the dividing line between these "establishments" (now "illow British (iniana) and Venezuela has never ceased to be a suligect of contention. The clicius of both parties, it must he confederl, are of a somewhat indefinite nature. On the one hand lenezuela, in every constitution of govermment since she became an independent State. las drebared her territorial limits to he these of the Captainey Cieneral of Venezuela in 1810. Yet, ont of " moderation and puldence," it is said, she has contented her- 
self with claiming the Essequibo line - the line of the Essequibo River, that is - to be the true bomdars hetween Venezuelat and Britisi Guiana. On the other hand, at least an enual degree of indefiniteness distinguishes the elam of Great britain. . .

To the teritorial controversy hetween Great Britain and the Republic of Venezuela, thus brietly outlinet, the Cuited states has not been and. indeed, in view of its tratitional poliey, could not be indifferent. The note to the butish Foreign (office by which Venezuela openerl negotiations in $18 \mathrm{~s}$. was at once com-

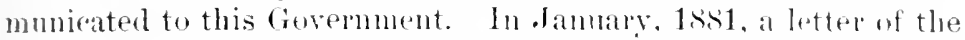
Venezmelan Minister at Washington, respecting ertain allegeri demonstrations at the month of the Orinoco, was thus answered by Mr. Evarts, then seceretary of state: . .

Subsequent communications to Mr. Bayard direct him to ascertain whether a Minister from Veneznela wonld he receiven by Great Britain. In the anmmin Messige to Congress of December id last, the President used the following language:

"The boundary of British Guiama still remains in dispute hetween Great Britain and Venezuela. Believing that its curly settlement. on some just basis alike honorable to both parties, is in the lim. of our established policy to remove from this lamisphere all anses of difference with powers beyond the sea, I shall renew the efforts heretofore mate to bring about a restoration of dipho. matic relations between the disputants and to induce a reference to arbitration, a resort which Great Britain so conspiconously favors in principle and respects in practice and which is earnestly sought by her weaker alversary."

And February 22, 189.5 a juint resolution of comgress deriared

"That the President's suggestion . . that Cirrat Britinu and

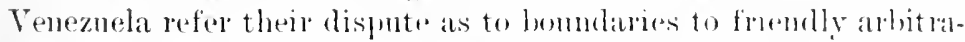
tion be earnestly recommented to the farorable comsideration of both parties in interest."

The important features of the existing situation, as shown hy the foregoing recital, may low biefly staterl.

1. The title to territory of indefinite but confessedly very larase extent is in dispute between (ipeat bitain on the one laminl and

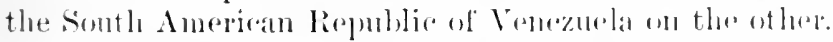

2. The disparity in the strength of the clamants is surte that

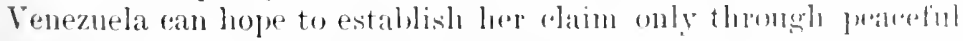

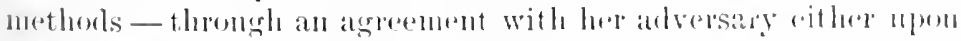
the subjecet itself or 11 , an an allitration.

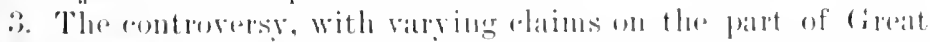

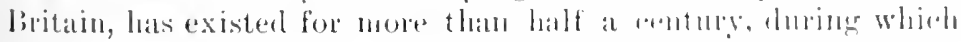


perior many earnest and persistent efforts of Venezuela to establish a boundary by agreement have proved unsuceessful.

4. The futility of the endeavor to obtain a conventional line being reeognized, Tenezuela for a quarter of a century has asked and striven for arbitration.

万. Great Britain, however, has always and eontinuously refusert to arbitrate, except upon the condition of a renuneiation of a large part of the Venezuelan claim and of a concession to herself of a large share of the territory in controvers.

6. By the frequent interposition of its good offices at the instance of Veneznela, by eonstantly urging and promoting the restoration of diplomatic relations between the two countries, by pressing for arbitration of the disputed boundary, by offering to act as arbitrator, by expressing its grave concern whenever new alleged instances of british aggression mpon Tenezuelan territory have been hronght to its notice, the Government of the United States has male it clear to Great Britain and to the world that the controversy is one in which both its honor and its interests are involved and the continuance of which it camnot regard with indifference.

The accuracy of the foregoing analysis of the existing status cannot, it is believerl, be challenged. It shows that status to be such that those charged with the interests of the United States are now forced to determine exactly what those interests are and what course of action they require. It compels them to deeide to what extent, if any, the United States may and should intervene in a controversy between and primarily concerning only Great liritain and Teneznela and to decide how far it is bound to see that the integrity of Veneznelan teritory is not impaired by the pretensions of its powerful antagonist. Are any such right and duty devolverl upon the United States". If not, the United States has alreally done all, if not more than all, that a purely sentimental interest in the affairs of the two eomntries justifies, and to push its interposition further would be unbeeoming and molignified and might well sulpject it to the charge of impertinent intermedhling with affairs with which it has no rightful eoncern. On the other haml, if any such right and duty exist, their elue excreise and discliarge will not permit of any aetion that shall not be eftielent and that, if the power of the United states is atequate, shall not result in the areomplishment of the end in view. The guestion thus pesenterl, as matter of prineiple and regard fring law to the settled national prliey, does not seem difficult. of solution. Yet the momentous practiol consequenees dependent npon its determination require that it shoukd be carefully con- 
sidered and that the grommes of the conchusion arrived at shmul be fully and frankly stated.

That there are eircunstanees muler which a nation may justly interpose in a controversy to which two or more other nat inns are the direct and immediate parties is an ahmitted ranon of international law. The doctrine is ordinarily expressod in terms of the most general charater and is perhajs incapalse of more sjecific statement. It is declared in substance that a nation maly avail itself of this right whenerer what is done or furoused by any of the parties jrimarily concerned is a serious and dimet menace to its own integrity, tranguillity, or welfare. The lumpiety of the rule when applied in goorl faith will not be cluestioned in any quarter. On the other hand. it is an inevitable thomgh unfortunate consequence of the wide seope of the rule that it hats only too often been mate a cloak for schemes of wanton spoliation and aggrandizement. We are concerned at this time, howerer, not so much with the general rule as with a form of it which is peculiarly and distinctively Ameriean. Washington, in the solemu admonitions of the Farewell Alldess, explicitly warmerl his comntrymen against entanglements with the polities or the ("ontroversies of European jowers.

"Emrope has a set of primary interests which to us have nome" or a very remote relation. Hence she must he engares in firequent controversies the auses of which are essentially formign to onr concerns. Hence, therefore, it must le muwise in us to inplieate onselves hy artifiedal ties in the orelinary vicissitudes of her polities or the ordinary combinations and collisinns of her friendships or enmitic's. Our hetached and distant situation invites and enables us to pursure a different conrse."

During the administration of l'resinlent Montere this doetrine of the Farewell dolderess was first consiglereel in all its alsperets

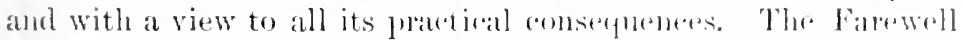

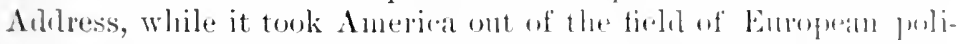
tics, was silent as to the part Eurepe might le promitred to play

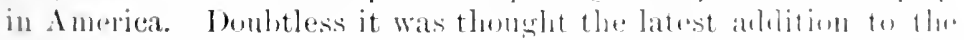

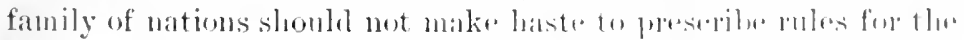

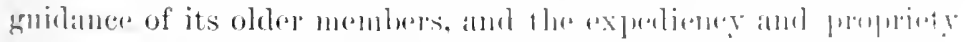

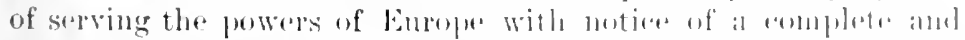
distinctive Anerican policy axebuling them from interforemere

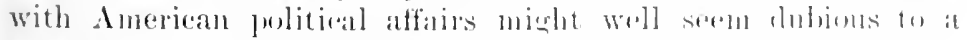

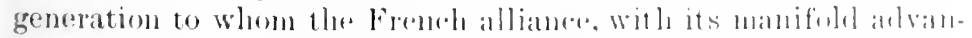
tages to the eanse of American indepremlence, was fresh in miml. 
Twenty year's later, however, the situation had changed. The lately born nation had greatly increased in power and resources, had demonstrated its strength on land and sea and as well in the conflicts of arms as in the pursuits of peace, and had begun to realize the commanding position on this continent which the character of its people, their free institutions, and their remoteness from the chief scene of European contentions combined to give to it. The Monroe administration therefore did not hesitate to accept and apply the logic of the Farewell Address by declaring in effect that American non-intervention in European affairs necessarily implied and meant European non-intervention in American affairs. Conceiving unquestionably that complete European noninterference in American concerns would be cheaply purchased hy complete American non-interference in European concerns, President Monroe, in the celebrated Message of December 2, 1823, used the following language: . .

The Monroe administration, however, did not content itself with formulating a corvect rule for the regulation of the relations between Enrope and America. It aimed at also securing the practical henefits to result from the application of the rule. Hence the message just quoted declared that the American continents were fully occupied and were not the subjects for future colonization by Europrean powers. To this spirit and this purpose, also, are to be attributerl the passages of the same message which treat any infringement of the rule against interference in American affairs on the part of the powers of Europe as an act of unfriendliness to the United States. It was realized that it was futile to lay down such a rule unless its observance could be enforced. It was manifest that the United States was the only power in this hemisphere capable of enforcing it. It was therefore courageonsly declared not merely that Europe ought not to interfere in Ameriean affairs, but that any European power doing so would be regarded as antagonizing the interests and inviting the oplusition of the United States.

That America is in no part open to colonization, though the proposition was not universally admitted at the time of its first enunciation, has long been universally conceded. We are now concernerl, therefore, only with that other practical application of the Monroe doetrine the disregard of which by an European power is to be deemed an act of mnfriendliness towards the United States. The precise scope and limitations of this rule camnot be too dearly apprehended. It does not establish any general protectorate by the United States over other American states. It does not relieve any American state from its obligations as fixed 
by international law nor prevent any European power direetly interested from enforcing such obligations or from inflicting merited punishment for the breach of them. It does not contemplate any interference in the internal affairs of any American stite or in the relations between it and other American states. It does not justify any attempt on our part to change the established form of government of any Ameriean state or to prevent the people of such state from altering that form aceording to their own will and pleasure. The rule in question has but a single purpose and object. It is that no European power or combination of European powers shall forcibly deprive an American state of the right and power of self-government and of shaping for itself its own politieal fortunes and destinies.

That the rule thus defined has been the arcepted publie law of this country ever since its promulgation cannot fairly be denied. Its pronomncement by the Monrue adninistration at that particular time was unquestionahly due to the inspiration of Great Britain, who at once gave to it an open and unclualified adhesion which has never been withdrawn. But the rule was decided upon and formulated by the Monroe administration as a distinctivels American doctrine of great import to the safety and welfare of the United States after the most careful consideration by a Cabinet which numbered anong its members John Quincy Adans, Calhoun, C'raw ford, and Wirt, and which before acting took both Jefferson and Madison into its comsels. Its promulgation was received with acclaim by the entire people of the country irrespective of party. Three rears after, Webster declared that the doctrine involver the honor of the country. "I look "],on it," he said, "as part of its treasures of reputation, and for one I intend to guard it," and he added,

"I look on the messacre of December, 18 "s, as forming a bright page in our history. I will help neither to erase it nor to tear it out; nor shall it he by any art of mine blurred or blotted. It did honor to the sagacity of the Government, and I will not diminish that honor:"

'Though the rule thus highly eulogized by Webster has never been formally aftirmed by ('ongress, the House in 186 it droclatml against the Mexican monarehy someht to he set up hy the Frmeh as not in aceord with the poliey of the (nited states, and in 1 s's? the Senate expressed its disapproval of the ronnection of any European power with a canal across the Isthmus of Darim or Central Aneriea. It is manifest that, if a rule has been openly 
and uniformly declared and acted upon by the executive branch of the Government for more than seventy years without express repudiation by Congress, it must be conclusively presumed to have its sanction. Yet it is certainly no more than the exact truth to say that every administration since Presiclent Monroe's has had occasion, and sometimes more occasions than one, to examine and consider the Monroe doctrine and has in each instance given it emphatic endorsement. Presidents have dwelt. upon it in messages to congress and secretaries of State have time after time made it the theme of diplomatic representation. $\mathrm{Nor}$, if the practical results of the rule be sought for, is the recorl either meagre or obscure. Its first and immediate effect. was indeed most momentous and far reaching. It was the controlling factor in the emancipation of South America and to it the independent states which now divide that region between them are largely indebted for their very existence. Since then the most striking single achievement to be credited to the rule is the evacu. ation of Mexico by the French upon the termination of the civil war. But we are also indebted to it for the provisions of the clayton-Bulwer treaty, which both neutralized any interoceanic eanal across Central America and expressly exchded Great Britain from oceupying or exercising any dominion over any part of Central America. It has been used in the case of Cuba as if justifying the position that, while the sorereignty of Spain will be resprected, the island will not be permitted to become the possession of any other European power. It has been influential in bringing about the definite relinguishment of any supposed protectorate by Great Britain over the Mosquito Coast.

l'resident Polk, in the case of Y'ueatan and the proposed rolun. tary transfer of that combtry to Great Britain or Spain, relied mon the IIonroe doctrine, thongh perhaps erroneously, when he Aecelared in a speeial message to Congress on the subject that the Unitod States conld not consont to any such transfer. Yet, in somewhat the same spirit, Secretary Fish affirmed in 1870 that l'resident firant had but followed the teachings of all our his. tory " in cleclaring in his ammal message of that year that existing dependencies were no longrer regarded as subject to transfer from one Enopean fower to another, and that when the present retation of rolonies arases they are to become independent powers. Another development of the rule, though apparently not neces. sarily resurired by either its leter or its spirit, is foumd in the oljpetion to arhitration of Sonth American controversies by an European power. American questions, it is said. are for Ameri. can decision, and on that gromul the United States went so far as 
to refuse to mediate in the war between Chili and Peru jointly with Great Britain and France. Finally, on the ground, among others, that the anthority of the Monroe doctrine and the prestige of the United States as its exponent and sponsor wonld be serionsly impaired, Secretary Bayard strenuously resisted the enforcement of the Pelletier clain against Hayti.

"The Uniterl States. [he said,] has proclaimed herself the protector of this western world, in which she is by far the stronger jower, from the intrusion of European sovereignties. She can point with proud satisfation to the fact that orer and over again has she declared effectively, that serions indeed wonld he the consequenees if European hostile foot should, without just cause, treat those states in the New Wirld which have emancipated themselves from European control. She has announcerl that she would cherish as it hecomes her the teritorial rights of the feehlest of those states, regarding them not merely as in the rye of the law equal to eren the greatest of nationalities, hut in view of her distinctive policy as entitled to be regarded by her as the objects of a peculiarly grations are. I freel bound to saly that if we should sanction ly reprisals in Inyti the moluless invasion of her territory and insult to her sovereignty which the facts now lofore us disclose, if we approve by solemn Expentive aletion and Congressional assent that invasion, it will be difficult for us hereafter to assert that in the Now World, of whose rights we are the peculiar guardians, these rights have never been invaded by ourselves."

The foregoing enumeration not only shows the miny instances wherein the rule on question has been affirmed and applied, but also demonstrates that the Venezuelan bemmlary controversy is in any view far within the scope and spirit of the mule as miformly

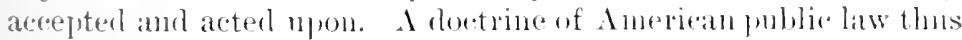
long and firmly established and smpuorted conld not anily he ignored in a proper case for its applieation, "ren were the con

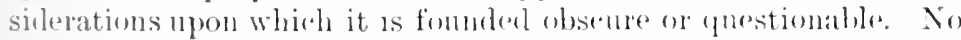
such objection ean be mate, however, to the Monres destrine understoorl and defined 10 the manner al reaty stated. It rests, on the contrary, upon farets and prineiples that are hoth intolligible

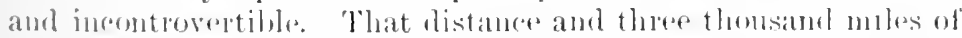

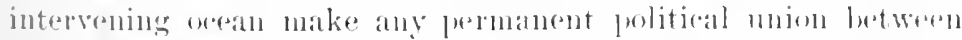
an Enropean and an Ameriean stato muatmal and inexpedient

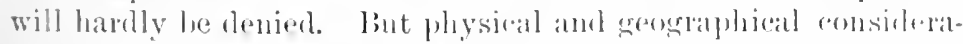
tions are the least of the objections to sueh a mion. Europe, ats Washington observed, has a set of prinary interests which arre 
peculiar to herself. America is not interested in them and ought not to be vexed or complicated with them. Each great European power, for instance, to-day maintains enormous armies and fleets in self-defence and for protection against any other European power or powers. What have the states of Anerica to do with that condition of things, or why should they be impoverished by wars or preparations for wars with whose causes or results they can have no direct concern: If all Europe were to suddenly fly to arms over the fate of Turkey, would it not be preposterous that any American state should find itself inextrucably involved in the miseries and hurdens of the contest? If it were, it would prove to be a partnership in the cost and losses of the struggle but not in any ensung benefits.

What is true of the material, is no less true of what may be termed the moral interests involved. Those pertaining to Europe are peculiar to her and are entirely diverse from those pertaining and peculiar to America. Europe as a whole is monarehical, and, with the single important exception of the Republic of France, is committed to the monarchical principle. America, on the other hand, is devoted to the exactly opposite principle - to the idea that every people has an malienable right of self-govermment anrl, in the United States of Anerica, has fumished to the world the most conspicuous and conclusive example and proof of the excellence of free institutions, whether from the standpoint of national greatness or of individual happiness. It cannot be necessary, however, to enlarge mon this phase of the subjectwhether moral or material interests be considered, it cannot but be unversally conceded that those of Europe are rreconcilably diverse from those of America, and that any European control of the latter is necessarily both incongruous and injurious. If, however, for the reasons stated the forcible intrusion of European powers into American polities is to be deprecated - if, as it is to be depreated, it should he resisted and prevented-such resistance and prevention must come from the United States. They wonlil rome from it, of conrse, were it male the point of attark. Int, if they come at all, they must also come from it when any other American state is attacked, since only the United States hiss the strength adequate to the exigency.

Is it true, then, that the silfety and welfare of the United States areso concened with the matutenance of the imdependence of erory American state as against any European power as to justify and repuire the interposition of the United States whenever that imbinendenee is endangered: The question can be eandidly answered in but one way. The states of America South as well 
as North, by geographical proximity, by natural sympathy, by similarity of governmental constitutions, are friends and allies, commereially and politieally, of the Lnted states. 'To allow the subjugation of any of them by an European power ss, of comrse. to completely reverse that situation and signities the loss of all the advantages meident to their natural relations to us. But that is not all. The people of the United states have a vital interest in the cause of popular self-gorernment. They have secured the right for themselves and their posterity at the cost of infinite blood and treasure. They have realized and exemplitied its beneficent operation by a career unexampled in point of national greatness or individual felirity. They believe it to be for the healing of all nations, and that civilization must either advance or retrograde aecordingly as its supremacy is extender or c $\mathrm{ur}$ tailed. Imbned with these sentiments, the people of the United States might not impossibly be wronght up to an active propiaganda in favor of a canse so highly ralued both for themselves and for mankind. But the age of the Crusares has passed, and they are content with such assertion and defence of the right of popular self-govermment as their own security and welfare demand. It is in that view more than in any other that they believe it not to be tolerated that the political control of an Americam state shall be forcibly assumed by an European power.

The mischiefs apprehended from such a source are uone the less real becanse not immediately imminent in any speeific case, and are none the less to be guarderl against beeanse the combination of eiremmstances that will bring them upon us eammot be predicted. The civilized states of Christendom deal with each other on substantially the same prineiples that regulate the condurt of individuals. The greater its enlightennent, the nore surely every state perceives that its permament interests recpuire it to be governed by the immutable principles of right and justice. Each, nevertheless, is only too liable to snowmb to the temptations offered by seeming speecial opportmities for its own agramlizement, and each wonld rashly imperil its own safely were at not to remember that for the regard and respect of other states it must be largely dependent upon its own strength and power. To-day the United states is practically sovereign on this continent, and its fiat is law mon the subjects to which it confines its interpor sition. Why?" It is not liecause of the pure friendship or grood will felt for it. It is not simply by reason of its high character as a civilized state, nor beeause wishom and justice and equity are the invariable charaeteristies of the dealings of the United states. It is because, in addition to all other grounds, its infinite resources 
combined with its isolated position render it master of the situation aud practically invulnerable as against any or all other powers.

All the advantages of this superiority are at once imperilled if the principle be almitted that European powers may convert Amertean states mto colonies or provnces of then own. The principle would be eagerly araled of, and every power doing so would mmediately accuire a base of military operations against us. What one power was permitted to do conld not be clenied to another, and it is not inconceivable that the struggle now going on for the actuisition of Africa moght be transferred to South America. If it were, the wealier countries would nnquestionably be stron absorbed, whule the nltimate result might be the partition of all south America between the various European powers. The disastrous consequenees to the United States of such a condition of things are obvions. The loss of prestige, of authority, and of weight in the councils of the family of nations. would be among the least of them. On only real rivals in peace as well as enemies 11 war would be found lociterl at our very doors. Thus far in on history we have been spared the budens and evils of 1 mmense standing armies and all the other accessories of huge warlike establishnents, and the exemption has largely contributed to onr national greatness and wealth as well as to the happiness of every aitizen. But, with the powers of Europe permanently emamped on American sult, the inteal conditions we have thus far enjoyed anmot be expected to continue. We too must be armed to the teeth, we too must envert the flower of our male population unto soldhers and sailors, and by withdrawing them from the varions pursuits of peaceful melustry we too must practically annihilate a large share of the productive energy of the nation.

How a sprater calamity than this could overtake us it is difficult to see. Nor are our just apprehensions to be allayed by suggestions of the friendliness of European powers - of their good will towards us - of their disposition, should they be our neighbors, to dwell with us in peace and harmony. The people of the United States have learned in the school of experience to what extent the relations of states to rath other depend not upon sentiment nor principle, But npon selfish merest. They will not soon forget that, in their hon of distress, all their anxieties and burdens were ageravated by the possibility of demonstrations against their national life on the part of powers with whom they had long maintanes the most hamonions relations. They have yet

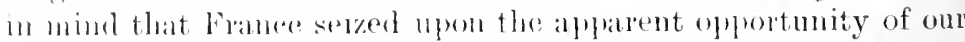
(ivil wall to set up a monalely 10 the arljoining state of Mexico. 
They realize that had France and Great Britain held important South American possessions to work from and to benefit, the temptation to destroy the predominance of the Great Republic in this hemisphere by furthering its dismemberment might have been irresistible. From that grave peril they have been saver in the past and may be sared again in the future through the operation of the sure but silent force of the doctrine proelaimed by President Monroe. To alandon it, on the other hand, disregarding both the logic of the situation and the facts of our past experience, would be to renomnce a policy which has proved both an easy defence against foreign aggression and a prolific sonrce of internal progress and prosperity.

There is, then, a loctrine of American public law, well founded in principle and abmolantly sanctioned by precedent, which entitles and reruires the United States to treat as an injury to itself the forcible assmuption by an European power of political control over an Imerican state. The application of the doctrine to the houndary dispute between Great Britain and Venezncla remains to be made and presents no real difficulty. 'Thongh the dispute relates to a bomolary line, yet, as it is between states, it necessarily imports political control to be lost by one party and gained by the other. The political control at stake, too, is of no mean importance, lut concerns a domain of great extent - the British claim, it will be remembered, apparently expanded in two year's some 33,000 square miles - and, if it also directly involves the command of the month of the Orinoco, is of immense consequence in connection with the whole river navigation of the interior of Sonth America. It has heen intimated, indeed, that in respect of these South American possessions Great Jiritain is herself an American state like any other. so that a controversy between her and Veneznela is to he settled hetween themselves as if it were between Venezucla am lirazl or butween Veneznela and Colombia, and does not eall for or justify Tnited states intervention. If this view he tenable at all, the logical secruence is plain.

Great Britain as a Sonth American state is to be entirely differcntiated from Great Britain gemerally, and if the bommlary question camnot be settled otherwise than by foree, Dritish Ciniana, with her own indegendent resomeres and not those of the british Empire, should be left to settle the matter with Venezuela - an arrangement which very possibly Vemergela might not objeret to. lint the proposition that an Einolean power with an Aneriean dependeney is for the purposes of the Momroe dextrine to be classed not as an Enroperan but as an American state will not 
admit of serious disenssion. If it were to be adopted, the Monroe doctrine would be too valneless to be worth asserting. Not only would every European power now having a South American colony be enabled to extend its possessions on this continent indefinitely, but any other European power might also do the same by first taking pains to procure a fraction of South American soil by voluntary cession.

The declaration of the Monroe message - that existing colonies. or dependencies of an Enropean power would not be interfered with by the United States - means eolonies or dependeneies then existing, with their limits as then existing. So it has been invariably construed, and so it must contimue to be eonstrued unless it. is to be depriver of all vital force. Great Britain cannot be deemed a South American state within the purriew of the Monroe doetrine, nor, if she is appropriating Venezuelan territory, is it. material that she does so by advancing the frontier of an old colony instead of by the planting of a new eolony. The difference is matter of form and not of substance and the doctrine if pertinent in the one case must be in the other also. It is not. admitted, however, and therefore cannot be assumed, that Great Britain is in fact usurping dominion over Venezuelan territory. While Venezuela charges snch usurpation, Great Britain denies it, and the United States, until the merits are anthoritatively aseertained, can take sides with neither. But while this is sowhile the United States may not, under existing cireumstances. at least, take upon itself to say which of the two parties is right. and whieh wrong - it is certainly within its right to demand that the truth shall be ascertained. Being entitled to resent and resist any sequestration of Venezmelan soil hy Great Britain, it is necessarily entitled to know whether such sequestration has occurred or is now going on. Otherwise, if the United States is without. the right to know and have it determined whether there is or is not British aggression upon Venezuelan territory, its right to protest against or repel such aggression may be dismissed from consideration.

The right to act mon a fact the existence of which there is no right to have aseertained is simply illusory. It being clear, therefore, that the United States may legitimately insist upon the merits of the bomdary question being detrrmined, it is equally clear that there is but one feasible mode of determining them, viz, peaceful arbitration. The impracticability of any conventional arjustment has been often and thoroughly demonstrated. Even more impossible of comsicleration is an appeal to arms - a mole of settling national pretensions mulappily not yet 
wholly obsolete. If, however, it were not condemnable as at relic of barbarism and a crime in itself, so one-sided a contest could not be invited nor even accepted by Great Britain without distinet disparagement to her chararter as a civilized state. Great Britain, however, assumes no such attitule. On the eontrary, she both admits that there is a controversy and that arbitration should be resorted to for its arljustment. But, while np to that point her attitude leaves nothing to be desired, its luactical effect is completely nullified by her insistence that the suhmission shall cover but a part of the controversy - that, as a condition of arbi. trating her right to a part of the disputed territory, the remainder shall be turned over to her. If it were possible to point to a bomdary which both parties had ever agreed or assumed to be such either expressly or tacitly, the demand that territory conceded by such line to British Guiana should be held not to be in dispute might rest upon a reasonable basis. But there is no such line. The territory which Great Britain insists shall he eerled to her as a condition of arbitrating her claim to other territory has never been admitted to belong to her. It has always and con. sistently been claimed by Venezuela.

Upon what principle - except her feebleness as a nation - is she to be denied the right of having the elaim heard and passerl upon by an impartial tribunal? No reason nor sharlow of reason appears in all the voluminous literature of the subject. "It is to be so beeause I will it to be so" seems to be the only justification Great Britain offers. It is, indeed, intimated that the British claim to this particular territory rests upon an ocrupation, which, whether acquiesced in or not, las ripened into a perfect title by long continuance. But what preseription affecting territorial rights can be said to exist as between sovereign states? (1), if there is any, what is the legitimate consequence? It is not that all arbitration should be denied, but only that the submission should embrace an additional topric, namely, the validity of the asserted prescriptive title cither in print of law or in point of fact. No different result follows from the contention that as matter of principle (ireat britain cannot be asked to subnit and ought not to submit to arbitration her politionl and sovereign rights over territory. This contention, if applien to the whole or to a rital part of the possessions of a sovereign state, need not be controverted. To hold otherwise might be equivalent to holding that a sovereign state was bomol to arbitrate its very existence.

But Great Britain has herself shown in rarions instances that the principle has no pertineney when either the interests or the territorial area involved are not of controlling magnitulle and her 
loss of them as the result of an arbitration cannot appreciably affect her honor or her power. Thus, she has arbitrated the extent of her colonial possessions twice with the United States, twice with Portugal, and once with Germany, and perhaps in other instances. The Northwest Water Boundary arbitration of $18 \% 2$ between her and this country is an example in point and well illustrates both the effect to be given to long-continued use and enjoyment and the fact that a truly great power saerifices neither prestige nor dignity by reconsidering the most emphatic rejection of a proposition when satisfied of the obvious and intrinsic justice of the case. By the award of the Emperor of Germany, the arbitrator in that case, the United States aequired San Juan and a number of smaller islands near the coast of Vanconver as a consequence of the decision that the term "the channel which separates the continent from Vanconver"s Island," as used in the treaty of Washington of 1846 , meant the Haro channel and not the Rosario channel. Yet a leading contention of Great Britain before the arbitrator was that equity required a judgment in her faror because a decision in favor of the United States wouk deprive British subjects of rights of navigation of which they had had the habitual enjoyment from the time when the Rosario Strait was first explored and surveyed in 179S. So, though by virtue of the award the United States acquired San Juan and the other islands of the group to which it belongs, the British Foreign Secretary had in 1859 instrueted the British Minister at Washington as follows:

"Her Majesty"s Government must, therefore, under any ciremmstances, maintain the right of the British Crown to the Island of san Juan. The interests at stake in connection with the retention of that Island are too important to admit of compromise and Your Lordship will consequently bear in mind that, whatever arrangement as to the boumdary line is finally arrived at, no settlement of the question will be accepted by Her Majesty's Gorermment which does not provirle for the Island of San Juan being reserved to the British Crown."

Thus, as already intinated, the British demand that her right to a portion of the disputed territory shall be acknowledged before she will consent to an arbitration as to the rest seems to stand upon nothing bnt her own ipse dixit. She says to Veneznela. in substance: "You can get none of the debatable land by fore, because you are not strong enough; you can get none by treaty, becanse I will not agree; and you can take your chance of gretting a portion by arbitration, only if you first agree to aban- 
don to me such other portion as I may lesignate." It is not perceived how such an attitude ean be defended nor how it is reconcilable with that love of justice and fail play so eminently characteristic of the English race. It in effect deprives Temezure of her free agency and puts her moler virtual duress. Territory aequired by reason of it will be as mum wrested from her by the strong hand as if occuplied by bitish troops or covered by bitish fleets. It seems therefore quite impossible that this pusition of Great Britain should be assented to hy the Lnited states. or that. if such position be arhered to with the result of enlarging the bounds of British Guiana, it should not he regarderl as anomnting. in substance, to an invision and conquest of Venezuelan terejtory.

In these circumstances, the duty of the Plesident appears to him unmistakable and inperative. Great britain's assertion of title to the disputed territory combined with her refinal to have that title investigated being a substantial aploundation of the territory to her own use, not to protest and give warning that the transaction will be regarded as injurions to the interests of the people of the United Sitates as well as opluessive in itsolf wonld be to ignore an established policy with which the homol and welfare of this comntry are elosely identitied. While the measures necessary or proper for the vindication of that polier. are to be determined by another branch of the covermment, it is clearly for the Executive to leave nothing molome which may tend to render such determination muneressary.

You are instructed, therefore, to lnesent the formoing views to Lom Salisbury ly reading to him this commmication (leavinn with him a copy should he so desires), and to reinforec them hy such pertinent considerations as will doubtless oreme to won. They call for a definite derision mom the print whether fireat Britain will eonsent ol will declime to sulnuit the Venezurlan boundary question in its entirety to inpartial arlitration. It is the earnest hope of the President that the endrehsion will lu on

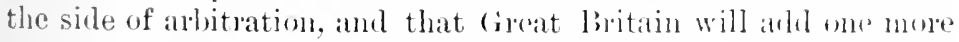
to the conspienous precedents she has alrouly fumished in favol of that wise and just mode of adjusting international disputes. If he is to be clisaplointed in that hope, howerer-a result not to

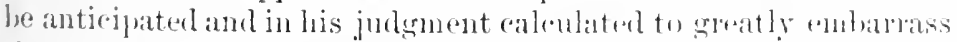
the future lelations betweren this romentry and lireat bitain - it is his wish to le marle areguabuterl with the fact at such waly dato as will emable him to lay the whole subjere befose comeress in his next annual messare.

I an, sir, your obedicnt servant,

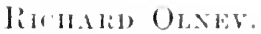




\section{Lord Salisbury to Sir Julian Panncefote.}

No. 189.]

Folieiga Office,

November $26,1895$.

Sir, On the 7 th August I transmitted to Lord Gough a copy of the despatch from Mr. Olney whieh Mr. Bayard had left with me that day, and of which he had read portions to me. I informed him at the time that it could not be answered until it had been carefully considered by the Law Officers of the Crown. I have therefore deferred replying to it till after the recess.

I will not now deal with those portions of it which are concerned exclusively with the controversy that has for some time past existed between the Republie of Venezuela and Her Majesty's Govermment in regard to the boundary which separates their dominions. I take a very different view from Mr. Olney of various matters upon which he touches in that part of the despatch; but I will defer for the present all observation upon it, as it coneerns matters which are not in themselves of first-rate importance, and do not directly coneern the relations between Great Britain and the United States.

The latter part however of the despateh, turning from the question of the frontiers of Veneznela, proceeds to deal with principles of a far wider character, and to advance doetrines of international law which are of considerable interest to all the nations whose dominions include any portion of the western hemisphere.

The contentions set forth by Mr. Onney in this part of his despatch are represented by him as being an application of the political maxims which are well known in American disenssion under the name of the Monroe doctrine. As far as I an aware, this dortrine has never been before advanced on behalf of the United States in any written communication acklressed to the Government of another nation; but it has been generally adopted ancl assumed as true by many eminent writers and politieians in the United States. It is said to have largely influeneed the Govemment of that country in the conchuct of its foreign affairs: thongh Mr. ('layton, who was Secretary of State under P'resident Taylor, expressly stated that that Administration had in no way adopted it. But during the period that has elapsed since the Message of President Monroe was delivered in 1S:3, the doetrine has undergone a very notable development, and the aspeet which it now presents in the hands of Mr. Olney differs widely from its character when it first issued from the pen of its author. The two propositions which in effect President Monroe laid down 
were, first, that America was no longer to be looked upon as a field for Emopean colonization: and, secondly, that Eunper must not attempt to extend its political system to America, ol to (o)ntrol the political condition of any of the Imerican communtes who had recently declared theil indeprendence.

The dangers against which l'resident Monroe thourht it right to guard were not as imaginary as they would seem at the pursint day. The formation of the Holy Alliance: the Comgresses of Laybach and Verona; the invasion of Syain by Frane for the purpose of forcing upon the spanish people a form of government which seemed likely to disappear, unless it was sustained hy external aid, were incidents fresh in the mind of l'resident Monroe when he pennel his celebrated Hessage. The system of which he speaks, and of which he so resolutely deprenates the application to the American Continent, was the system then adopted by certain powerful states upon the Continent of Euroue of combining to prevent by fore of arms the adoption in otlere countries of political institutions which they dislikerl, and to uphold by extermal pressme those which they approver. Varims portions of Sonth America har recently declated their inderendence, and that independence had not been lepognized by the Governments of Finin and Portugal, to which, with small exorption, the whole of Central and south America were nominally subject. It was not an imaginary tanger that he foresaw, if he feared that the same spirit whinh hat lietated the French expedition into spain might inspire the more purerful Governments of Europe with the idea of imposing, by the forre of Enopean arms. upon the south American rommunities the form of government and the political connection whioh they hat thrown off. In declaring that the United states would lesist any such ruterpuise if it was contemplated, I'resident Momme adopted a poling whivh received the entire sympathy of the English Government of that date.

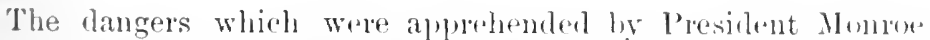
have no relation to the state of things in which we live at the present day. There is no langer of any lloly Mllinne impusins its system upon any portion of the Inerican Continent, and there is no danger of any linnpean state treating any pat of the American Contiment as a fit objort for Eumperan colomization. It is intelligible that Mr. Olney shomld invoke, in delenes of the views on which he is now insisting. an anthority which onjoys so high a popmlarity with his own ledlow-omutrymen. lint the ris-

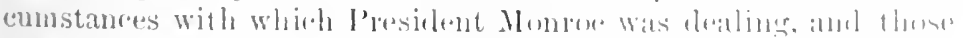
to which the present Amerean Government ss athlessing itsell, 
have very few features in common. Great Britain is imposing no "system" upon Venezuela, and is not concerning herself in any way with the nature of the political institutions under which the Venezuelans may prefer to live. But the British Empire and the Republic of Venezuela are neighbours, and they have differed for some time past. and continue to differ, as to the line by which their dominions are separated. It is a controversy with which the Cnited States have no apparent praetical concern. It is difficult, infeed, to see how it ean materially affect any State or community ontside those primarily interested, except perhaps other parts of Her Majesty's dominions, such as Trinidad. The disputed frontier of Venezuela has nothing to do with any of the questions dealt with by Presilent Monroe. It is not a question of the colonization by a Europrean lower of any portion of America. It is not a question of the imposition upon the commumities of South America of any system of government devised in Europe. It is simply the determination of the frontier of a british possession which helonged to the Throne of England long before the Republic of Venezuela came into existence. But even if the interests of Venezuela were so far linked to those of the Cnited states as to give to the latter a locus standi in this controversy, their Government apparently have not formed, and certainly do not express, any opinion upon the actual merits of the dispute. The Government of the United States do not say that Creat Britain, or that Venezuela, is in the right in the matters that are in issue. But they lay down that the doctrine of President Monroe, when he opposed the imposition of European systems, or the renewal of European colonization, confer's upon them the right of demanding that when a European Power has a frontier difference with a South American community, the European Power shall consent to refer that controversy to arbitration; and Mr. Ohey states that mless Her Majesty's fovernment accede to this demand, it will "greatly embarrass the future relations between (ireat Britain and the United states."

Whaterer may be the anthority of the doctrine laid down by l'resinkent II moe, there is mothing in his language to show that he ever thought of claining this novel prerogative for the United ritates. It is admitted that he dirl not seek to assert a Protectoraterer Mexico, or the States of rentral and South America. Such a dain wonk have inposed upon the Lnited States the duty of answering for the conchet of these States, and consequently the responsibility of controlling it. Ilis sagacions foresight would have led him energetically to deprecate the addition of so serious 
a burden to those which the Rulers of the Cnited States have to bear. It follows of necessity that if the ciovermment of the United States will not control the conduct of these communities, nether can it undertake to protect them from the conserquences attaching to any misconduct of which they may be guilty towards other nations. If they violate in any way the rights of anothes' State, or of its subjects, it is not alleged that the llonroe doctrine will assure them the assistance of the Enited States in escapiner from any reparation which they may lie homb by international law to give. Mr. Olney expressly disclaims such an inference from the principles he lays down.

But the claim which he fomds npon them is that, if any independent American state adrancess a demand for territory of which its neighbour claims to be the owner, and that neighbour is the colony of a European state, the Enited states have a right to insist that the European State shall submit the demand, and its own impugned rights to arbitration.

I will not now enterinto a discussion of the merits of this method of terminating international differences. It has proved itself ralnable in many cases; but it is not free from lefects, which often operate as a serious drawback on its value. It is not always easy to find an Arbitrator who is competent, and who, at the same time, is wholly free from hias; and the task of insuring compliance with the Award when it is made is not exempt from difficulty. It is a mole of settlement of which the value varies much according to the nature of the controversy to which it is applied, and the character of the litigants who apyeal to it. Whether, in any larticular case, it is a snitable methorl of procedure is generally a delicate and difficult question. The only fruties who are competent to decide that question are the two parties whose rival contentions are in issule. The raim of a third nation, which is unaffected by the controwers, to impose this partionlar procedure on either of the two others, camnot be rasonably justified, and has no foumdation in the law of nations.

In the remarks which I have made, I have alloged on the theory that the Honroe doctrine in itself is somml. I must mot.

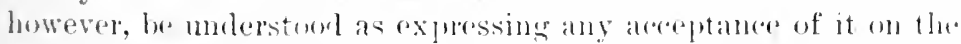
jart of Her llajesty's forerninent. It mist al ways be nentioned with respect, on areoment of the distingushod statesuran 10 whom it is due, and the errat nation who have gemerally aldepted it. But international law is founded on the senemal ansent of nations; and no statesman, howeren eminent, and no nations however powerful, are anderent to insert inte the corle ol intermittonal law a novel principle wheh was never recongued before, 
and which has not since been aceepted by the Government of any other comntry. The United States have a right, like any other nation, to interpose in any controversy by which their own interests are affected; and they are the julge whether those interests are touched, and in what measure they should be sustained. But their rights are in no way strengthened or extended by the fact that the controversy affects some territory which is called American. Mr. Olney quotes the case of the recent Chilean war, in which the United States declined to join with France and England in an effort to bring hostilities to a close, on aecount of the Monroe doctrine. The United States were entirely in their right in declining to join in an attempt at pacification if they thought fit; but Mr. Olney's principle that "Ameriean questions are for American rlecision," even if it receive any countenance from the langulage of President Monroe (which it does not), cannot be sustained by any reasoning drawn from the law of nations.

The Government of the United States is not entitled to affirm as a universal proposition, with reference to a number of inderendent states for whose conduct it assumes no responsibility, that its interests are necessarily coneerned in whatever may befall those states simply because they are situated in the Western Hemisphere. It may well be that the interests of the United States are affected by something that happens to Chile or to Peru, and that that eiremustance may give them the right of interference; but such a contingeney may equally happen in the ease of China or . Japan, and the right of interference is not more extensive or more assured in the one cisse than in the other.

Though the language of President Monroe is direeted to the attainment of objects which most Englishmen would agree to be salutary, it is impossible to anlmit that they have been inscribed by any adequate anthority in the code of international law; and the danger which such almission would involve is sufficiently exhibited both by the strange development which the doctrine has received at Mr. Olney's hands, and the arguments by which it is supported, in the despatch under reply. In defence of it he siays:

That distance and 3,000 miles of intervening ocean make any permenemt political uniom betreen " Enropean amd an American Strete unmetural amd imoxpediont will havily be denied. But physical and geographical considerations are the least of the objections to such a mion. Europe has a set of primary interests which are peculiar to herself; Amerina is not interested in them, and onght not to be rexed or complustat with them. 
And again :

Thus far in our history we lave been spared the burdens and evils of immense standing armies and all the other aceessories of huge warlike establishments; and the exemption has highly contributed to our national greatness and wealth, as well as to the happiness of every citizen. But with the Pouers of Enroper por manently encrmped on imericun soil, the ideal conditions we have thus far enjoyed cannot be expected to continue.

The necessary meaning of these words is that the mion hetween Great Britain and Canala; between (ireat Britain and Janaica and Trinidad; between Great Britain and British Honduras or British Guiana ale "inexpedient and umatural." President Monroe disclaims any such inference from his doctrine; but in this, as in other respects, Mr. Olney develops it. He lays down that the inexpedient and mnatural character of the mion between a Emropean and American State is so obvions that it "will hardly be denied." Her Majesty's Government are prepared emphatically to deny it on behalf of both the British and American people who are subject to her Crown. They maintain that the union between Great Britain and her territories in the Western Hemisphere is both natural and expedient. They fully concur with the view which President Monroe apluarently entertained, that any disturbance of the existing territorial distribution in that hemisphere by any fresh acquisitions on the part of any European State would be a highly inexpedient change. But they are not prepared to admit that the reconition of that experlieney is clotled with the sanction which belongs to a doctrine of international law. They are not prepared to almit that the interests of the United States are necessarily concerned in every frontier dispute which may arise between any two of the States who possess dominion in the Western II'misphere; and still less "an they aecept the doctrine that the United States are entitled to claim that the process of arbitration slall be applied to any demand for the surrender of territory which one of those states may make against another.

I have commented in the above remarks only mon the general aipect of $\mathrm{Mr}$. Olney's doctrines, apart from the spreeial consirlerations which attale to the controversy between the United Kingdom and Venemela in its present phase. This eontroversy has undonbtedly been marle more difficult by the inconsiderate aldion of the Venezuelan Government in hraking off relations with Ifer Majesty's 'Government, and its settloment has bern colrespondingly delayed; but Her Majesty's Government have not surem- 
dered the hope that it will be adjusted by a reasonable arrangement. at an early date.

I request that yon will read the substance of the above despatch to Mr. Olney, and leave him a copy if he desires it.

S.

President Cleveland in submitting the above correspondence to Congress concluded his message as follows :-

Without attempting extended argument in reply to these positions, it may not be aniss to suggest that the doctrine upon which we stand is strong and sound because its enforcement is important to our peace and safety as a nation, and is essential to the integrity of our free institutions and the tranquil maintenance of our distinctive form of government. It was intended to apply to every stage of our national life, and cannot become obsolete while our Repuhlic endures. . . .

In the belief that the doctrine for which we contend was clear and lefinte, that it was founded upon substantial considerations and involved our safety and welfare, that it was fully applicable to our present conlitions and to the state of the world's progress, and that it was directly related to the pending controversy and withont any conviction as to the final merits of the dispute, but anxious to learn in a satisfactory and conclusive manner whether Great Britain somght, under a claim of homdary, to extend her possessions on this continent withont right, or whether she merely somght possession of teritory fairly included within her lines of ownership, this Government proposed to the Govermment of Great Initain a resurt to arbitration as the proper means of settling the question to the end that a rexations boundary dispute between the two contestants might be dutermined and our exact standing and relation in respect to the controversy minl be made clear.

It will he seen from the correspondence herewith submitted that this proposition has been leclined by the British Government, upon grounds which in the circumstances seem to me to be far from satisfactory. It is deeply disappointing that such an alleal actuated by the most friendly feelings towards both nations directly conremed, addressed to the sense of justice and to the magnanimity of one of the great powers of the world and touching its relations to one compratively weak and small, should have promeed no better results.

The comse to be pursued by this Government in view of the present comblition does not appear to almit of serions donbt. Having labored fathfully for many years to induce Great Britain 
to submit this dispute to impartial arbitration, and having been now finally apprized of her refusal to do so, nothing remains but to accept the situation, to recognize its plain requirements and deal with it actordingly. Great Britain's present proposition has never thus far been regarled as admissible by renezuela, though any adjustment of the bombiary which that comntry may deem for her advintage and may enter into of her own free will cannot of course be objected to ly the ['nited States.

Assuming, however, that the attiturle of Venezuela will remain unchanged, the dispute has rearcherl such a stage as to mitke it now incumbent upon the United states to take measures to letermine with sufficient certainty for its justification what is the true divisional line between the Republic of Venezuela and British Guiana. The incruiry to that emb should of course be conducted earefully and judicially, and due weight shonld be given to all avaliable evilence, recorts, and facts in support of the claims of both parties.

In order that such an examination should be prosecuted in a thorough and satisfactory manner I suggest thit the compress make an aleyuate apnropriation for the expenses of a Commission, to be appointed by the Executive, who shall make the necessary investigation and report upon the matter with the least possible delay. When such report is made and anepted it will in my opinion be the duty of the Cnited states to resist by every means in its power, as a wilful angression upon its lights and interests, the approputiation by Great liritain of any lands or the exercise of governmental juristiction orer any territory which after investigation we have detemined of right belongs to Venezuela.

In making these recommentations I an fully alive to the responsibility incurred and keenly realize all the conserpences that may follow.

I am nevertheless firm in my comviotion that while it is a grievous thing to contemplate the two great English-speaking peoples of the world as being otherwise than frimolly conjuetitors in the onward march of eivilization, and stremons and wortly. rivals in all the arts of peare, there is no calamity which a great nation can invite which equals that which follows a supines submission to wrong and injustice and the consedpent loss of national self-respect and homor, beneath which are shielded and defended a people's safety and greatness.

After a short controversy Congress provided for the appointment of an American Commission of Jurists to inves- 
tigate the territorial claims of Venezuela and Great Britain in order to enlighten the government upon the question as to whether Great Britain's action in South America should be acepted by the execntive as an extension of European dominion on the Ameriean continent. The President therefore appointed a commission "to investigate and report upon the true divisional line between the republic of Venezuela and British Guima." In asking Congress for an appropliation to defray the expenses of such an investigating hoard, the President said: "When such report is made and accepter, it will, in my opinion, be the duty of the United States to resist by every means in its power, as a wilful aggression upon its right and interest, the appropriation by Great Britain of any lands or the exercise of governmental jurisdiction over any territory which after investigation we have determined of right belongs to Venezuela.

"In making these recommendations, I am fully alive to the responsibility incurred, and keenly realize all the consequences that may follow."

The commission at once entered upon the arduous labor of examining a voluminoms mass of documentary evidence furnished by Venezuela and somewhat good-naturedly by England, but before the final conclusion of their task had been reached, the British Government yielded to the repeated solicitations of the United States, and agreed to arbitrate with Venezuela. For that purpose a treaty was drawn up in Washington and afterward signed (February 12, 1897) by the British and Venezuclan representatives. By this convention a tribunal of arbitration was appointed, consisting of two English judges, two American judges, and a president of the tribunal who should be selected by the four members of the court already designated.

In June, 1899, the commission assembled in Paris. It consisted of Professor Martens, the distinguished Russian anthority upon international law, the Chief Justice of the Inited States, Justice Brewer of the United States Supreme C'ourt, Baron Russell, Lord ('hief Justice of England, and Sir lichard Collins, Lord Justice of Appeals of Great Brit- 
ain. The Venezuelan ease was presented ly ex-Presilent Harrison, Gen. B. F. Tracy, M. Mallet-Prevost, and the Marquis de Raljas. The British ease was comrlueted by Nip Richard Webster, Sir Robert Reid, and others. A verdiet was rendered on Octuber :3, which was of a compromise nature.

The rendering of this award elosed an incislent of Ameriean intervention in support of the principles of the Monroe Doetrine which has been consiclered fortunate by malny, only in so far as its ending was a halpy one. British feeling had been greatly aroused against the linited States by what appeared to be an mwarranted meddling in an affair belonging only to Great Britain and Venezuela. On the other hand, the belief had been general in the Lnited States that England's unwillingness at first to arbitrate the dispnte gave evidenee of her aggressive designs in Sonth Americal. The positive tone of Mr. Olney's letter's and of President Cleveland's messages indicated that Inglo-American affairs were nearing a crisis, and that the two great powers were perilously elose to an open rupture. When the moment for sober thought arrived, it was generally conceded that a war so appalling in its probable consequences between these two nations of one language and of a common purpose in the advancement of eivilization and eonstitutional liberty would have been totally unjustified by the circumstances in the ease. It has since been freely said that the wise resolntion of Great Britain to yield was prompted by the wishes of the Queen, who cherished a desire to peserve peace during her reign between the two great nations of kindred race.

\section{XIII}

The eourse of the ('leveland administration in using the Monroe Doctrine as a means for compelling (ireat Britain to arbitrate her differences with Venconela called forth much eriticism. The opponents of Mr. Olney 's rallacal position argued that the Monroe Doctrine hatving been establisherl to meet a eertain end, it harl aleomplished its purposes and was 
now functus officio. It being at best but a domestic policy, its olservance conld not properly be enforced against foreign nations. It had no place in international law, and consequently it was unreasonable to expect other powers to reeognize it. Indeed, it was not even an established principle of Ameriean diplomacy, for it had upon many oceasions been disregarded when it might with propriety have been appealed to; whenever proclaimed, it had been accepted by the comntry as merely the expression of a poliey which imposen no obligation upon the government to enforce it. Finally, it was insisted that the occupation by Great Britain of some hundreds of miles of comparatively worthless territory in Sonth America, theretofore considered as belonging to Venezuela, in no mamner affected the rights or interests of the United States. On the contrary, some critics rather openly hinted that the settlement of the dispnted area by British subjects would give to the territory better clances for development under an assured good govermment, and that England's ocenpation of the traet would therefore inme to the advantage of American trade. So far as the wilds of the upper Orinoco were capable of civilized occupation, it would be better for the eommercial interests of the world if they were under British jurisdiction than under the uncertain rule of a nation whose weak and faltering government has been throughout its history subject to constant revolution. American trarle with Great Britain and with British possessions far exceeded the slender volume of Anerican commerce with V'nezmela. Indeed, to have imperilled even for a year the five hundred millions of trade with Great Britain for the sake of the ammal two or three millions with Veneznela would have been a quixotic proceeling. This suspected expansion of British territory in South America involved no danger to the safety of the United States. England already possessed Canarla with a contignous boundary line of nearly $: 3000$ miles. The islands of Newfomdland, Belmula, the Bahamas, Jamaica, together with mumerous smaller islands of the Lesser Antilles and Trinidad, already formed a chain of English narial posts along the eoast of 
the United States. Belize and British Guiana supplemented these outposts, and all of these English possessions, barring the last, are nearer to the Cnited States than is the territory in dispute, - indeed, a direet line from the southermmost point of Florida to the mouth of the Orinoco River is abont 1600 miles. The addition of this tract of land to existing English possessions in the Western IIemisphere would have been, after all, a matter of little consequence. The country was a tropieal jungle, where the maintenance of military forces would be impossible, on aceount of its extremely unhealthy elimate; and such military posts as England would be likely to establish thereabouts would be located in her existing Guiana colony. I'nder these ciremmstances, the danger to the United States arising out of British oecupation appeared to be wholly imaginary. If british arcquisition of this disputed territory lying so far distant could be justly regarled as threatening the safety of the Liniterl States, by similar process of reasoning, to what deplorable condition of helplessness is the Amerian Govermment reduced by the cordon of English possessions, naval stations, and fortified positions which have threatened it for one hundred years :

Whatever may have been the dangers of Enropean colonization in 1823, that danger hat ceased to exist. English liberty is as well guaranteed as American liberty. The English colonist is as jealous of his rights and as determined in the support of hmman freedom as is the American. Wherever he or his descendants go, industry, trade, commeree, civilization, and religion go with them. In reality, the English Government in its artual arministration more nearly approximates that of the Cnited sitates than rloes the Government of Venezuela.

Finally it was asked, If British ocenpation of the disputed territory entailed such rlisastroms consequences upon the United States that the risk of war wre better, would not the nation's safety have demanded at the start a positive denial of British rights in the premises, and a refusal to consent to the arbitration of the bounclary lines? 'To insist 
upon Great Britain's acceptance of arbitration, to institute an ex parte commission to determine British rights and to dictate the course she was to follow in the settlement of this dispute, was as much an effront as peremptorily to order the British (rovernment to withdraw its pretensions from Venezuelan territory. In either ease the United States assumed a high degree of anthority which Great Britain refused to acknowlerlge; in either case, war was a possible ontcome. In short, therefore, the olponents of the administration policy held simply that the Enited States was not threatened in any way by british advances in Veneznela, and therefore the circumstances in the case did not justify the country in going to the extremity of a war with England.

Those who defended the stand taken by the administration asserted that while the occupation of a portion of Venezmela by Great Britain did not in itself endanger American interests, it violated a well-established policy of the American people. This cardinal prineiple of American diplomacy had been so long revered it shonld be maintained at all hazards. To abandon the Monroe Doctrine at that particular time would be to open the entire South American continent to the rapacious and land-hungered nations of Europe.

After all is said on both sides of the controversy there is but one point which merits serious consideration. That one point determines the applicability of the doctrine in every ease, - that is, the safety of the Lnited States.

Self-defence is an essential principle of existence. It is a law of nature that no rules of society can accurately define. Because the Monroe Doctrine was an invocation of this great principle of whieh Mr. Momroe was in no wise the anthor, beeanse it came opportunely, because it was so ably expressed, becanse it met with enthusiastic approval at the time, it lass lived and obtained a permanence in American politics as thongh it were a principle purely American and of American discovery. In reality it is only a special or a new name for a principle of life that is as old as the existence of man. The new name has supplanted the old in the Ameri- 
can mind, and whenever a threat, real or fancied, has come in the shape of aggression in the Mestern Ilemisphere, the Lnitel states Government hats asserted its right to interpose - the right of self-protections. hut called instead the Monroe Doetrine. The phrase " Mombe Doctrine" has been preferred, and in the consese of three-phaters of a century it has wonght a weird and enchanting influence on the Amerien intellect. The mind herones imbned with a vague sense of past traditions resulting in a confusion of sentimental ioleas which imprite the powers of discrinination, and thus the original purpose of the Momroe boetrine and the defensive grinciples which it represents are often lost sight of. Inteed. the cireumstanees nuder whith the Doctrine was originally enmuciated, as well as the condition of American political life previous to 18:0;, were of a nature to give Mr. Monloces declatation a peenliar signifieance. Fear of European aggression in the Americas was the particular langer that gave the "-loctrine" birth. The Lnited States was companatively a weak nation, its system of gorermment was experinental, and it was in ennflict with the monarehical principles of Enrope: and jealous Enrope was feared. The spanish possessions were in revolt, and offered a tempting field for the exploitation of Empopean arms. The American penple were impressed with the danger that lurked in every European advance; the Momroe Doctrne voiced the apprehension in a manner that satisfied every Anerican citizen.

The American nation is no longer weak; its system of government is no experiment. Absolutism in Enrope lias almost disajpearerl, and liberal constitutional monaredies and republics have taken its place. There is no holy alliance, there is no selome to subrert repmblican forms of gorernment, but the people of the Cuiterl states latre not pet ontlived the inherited fears of their grandfathers. and they still cherish the apprehensions they bequeathed. They eling to the words that proclaimert their fears, the worts which Mr. Monroe anmonucer. Thus to-rlay the simme ary of alatrm of three generations ago is still uttered; the . Ionre l bectrine 
has become a magic symbol, and an idol for national worship. Thus it comes about in course of time, after that doctrine lats undergone numerous modifications, after it has been distorted in various ways to meet the requirements of party polities, that it has lost, to some extent, its original meaning. The "doetrine" is supported on other grounds than those of self-protection; admittedly British occupation of certain tracts of land in Venezuela conld not conceivalbly endanger the reace, safety, and integrity of the United States, yet the Monroe Doctrine seemed to call for action to prevent such oceupaney.

The position may be maintained with considerable force that when a political principle obtains a superstitious hold upon a nation that compels its blind observance regardless of comsequences it is time to cast it aside. To consign the Mompe loctrine to its alpropriate place of political signiticance in American history is by no means to deprive the American people of self-protection. It is only to rid the mind of a disturbing factor in the determination of foreign questions - to leave the julgment free to measure danger by the exigencies of the present, and not the remembrance of the fears which are of the past.

'The acquisition of the Philippine Islands necessarily opens new fields of diplomaey to the Enited States Govermment. To some axtent at least the oller policy of political isolation must give way to that of a more intimate comnection with foreign powers; it is therefore all the more important that every habit of thought should he suppressed which prevents clear and reasonable eonsideration of all diplomatic questions.

Thre need be no apprehension lest the people of the United States will always be alert and watchful of their own interests. A higler principle than revotion to the Monroe Doetrine will gnide-principles of an organic law upon which the Monroe Doctrine is founded, and of which the Momoe Doctrine was but a single expression. 
THE NORTHEAST COAST FISHERIES 


\section{V \\ THE NORTHEAST COAST FISIIERIES}

Oxe of the most perplexing problems which the Government of the Lnited states has been called upon to meet, in eonnection with its foreign relations, is the northeastern tishery question. It formerly eoncerned the rights of American eitizens to catch fish within the territorial waters of Canada and Newfoundland, and to use the shores of these provinces either for the purpose of drying and curing their fares or to procure bait. The consideration of these rights necessarily involved a host of incidental legal questions - such as the nature of territorial jurisdiction over the ocean within the three-mile limit of shore, the doctrine of headlands and the rights of vessels mnder local laws of commerce and navigation. It involved also the interpretation of mumerous treaty stipulations, some of them more or less ambignous; and these interpretations, furthermore, were too often distorted by the exigencies of party politics. Since the beginning of our national existence this question lias bronght almost eonstant eare and vexation to both Anerican and English statesmen, and thus far it seems to have defied all efforts at permanent and satisfactory arljustment. Bricf respites have been found in the alwards of arbitration tribumals, while new conventions and treaties hatve suffieed temporarily to allay irritation; but after all, the old quarrel of the fishermen eonstantly recurs in some form no less angrialvating and threatening than before.

The circunstanees which have given this guestion eminent importance hatve been of a nature to renter its solution peconl. ianly difficult. The great economic value of the fisheries, both in the matter of providing employment for thomsands of men and in the matter of furnishing to the world a 
staple article of food, has excited the earnest solieitude of the govermments of both Great Britain and the United States. Each has neeessarily sought to seeure for its respective subjects the greatest possible adrantage in the lnosecution of so important an industry.

These tishing operations on the part of Americans have required in the past not only the occupancy of Canadian waters, but equally the oceupancy and use of Canadian shores; ant as a quid pro quo for granting these privileges British subjects have natmally demanded as large remunerations as they could reasonably obtain. On the other hand, Imerican fishermen have always desired, and sometimes clemander as a national right, the privilege to follow their game into British territorial waters, and the United States Government has always sought to obtain for them these important privileges on terms least objeetionable and onerous to the nation at large. In pursuit of their vocations, American and Canadian fishermen have necessarily been brought sirle by side into direct personal contact, thus affording occusion for the breeding of jealousies and litter feelings of resentment for real and fancied wrongs. It is not remakable that collisions from time to time have resulted, which have always served to complicate the settlement of the publie issnes involved.

It has heen said that fishermen are the "wards of nations." They enjoy eertain special immunities in times of war, and in many respeets they receive from their governments all the fostering are and protection required at the hands of a guardian. Formerly they were specially eneomraged and protected both lig lingland and the Enited States, on the gromel that the chandeter of their alling peculiarly fitted them for the naval service. From this mantical sehool the hardiest and hest sailon's have been drafterl. In this connection it is interesting to note the fears of an English writer, expressed as early as 1670, who viewerl with alatm the growth of the col-fisheries in the New World. He wrote: "New England is the most prejullicial plantation in this kingdom, . . . of all the American plantations. Mis Majesty has none so apt. 
for building or shipping as New England, nor any comparatively so qualified for the breeding of seamen, - prineipally by reason of their cod and mackerel fisheries, and, in my opinion, there is nothing more prejudieial, and in prospect more dangerous, to any mother kingdom, than the increase of shipping in her colonies, plantations, or provinces." sir Joshua Child's ntterance proved prophetic. Thus were the govermments of England and of the United States stimulated to nurtmre with greatest care the industry that furnished their best naval reserves.

The chief diffieulty in the way of a permanent and satisfactory settlement of this question lats been to discover some suitable return to the Canadians for the privileges asked by American fishermen, to wit: the right (should the necessity (lemand), to fish in Canalian territorial waters, and ummolested to secure bait and smpplies ashore. No compensation yet devised for such privileges has remained mutually satis. factory for more than a few years. The partial reduetion of tariff duties or the total omission to tax specified artieles in favor of Canadian trade has been tried with but indifferent success. The American probluers of artirles whenever brought thus into active eompetition with ('analian products, have invariably raised their roices in angry disilpproval, - chictly upon the gromul that they were being sacrificed for the benefit of fishernen in whose sureess or failure they had no interest whaterer. Congress has always been compelled sooner or later to abandon this schene of settlement as impracticable. The atmission of Camadian fish free of dluty into lnited States ports has alwalys been regarded by Camala as the proper prive for her fishery concessions to the Lnited States, but this seemingly rational method of adjustment has been at all times most rigorously opposed by our own fishermen. They insist that the benefits to the nation of a free fishery are general, and that the burdens of its maintenanee shomld be equally so; moleover, they stoutly maintain that they camot steresinflly compete with their Canadian brethren in the Cnited states narkets withont the same tariff protection accorded to other inclus- 
tries. Therefore a solution which seems on its face to be perfectly just and rational has always come eventually to be abancloned as impracticable.

The payment of a lump sum or an amnual license tax to Canala has at times been considered as a hopeful adjustment of the question, but this means of settlement has always met with a determined opposition from the agricultural classes thronghout the country.

Thus it is that, abounling in difficulties, aggravated by frequent encounters of the fishermen, - especially cluring periods of ill feeling between England and the United States, - complicated by private claims and confused by numerous minor issues, the fishery question has remained an unsolved problem for nearly a century and a quarter.

\section{I}

The most valuable food fishes inhabit the cold waters of northern seas. A great ocean river, having its origin in the polar" seas, and known as the "Labrador Current," sweeps to the sonth along the entire shore of British America, past Newfoundland, and down the New England coast. Rounding Cape Cod, and following thence a southern course, it plunges downward, to pass beneath the warmer and lighter waters of the Gulf Stream, and is finally lost in the abyssal depths of the middle Atlantic. 'The presence of this boty of cold water near the coast greatly influences the climate of Labrador and Newfoundland, rendering their shores bleak and desolate, while it prolongs the rigorous winters of New England. As a seeming recompense for so much of cheerless cold and gloom, it brings to these maritime provinces the conditions necessary for a marrellous wealth of marine life, which has proved of almost incalculable value to their inhabitants. 'The coastal waters of these provinces teem with cod, herring, mackerel, and a variety of other fish of great commercial value.

Of the various kinds of food fish taken in these waters, the first in importance is the cod, which remarkable fish ex- 
ceeds in commercial value any other product of the ocean, possibly excepting the herring, which, in northern Europe, forms the basis of a colossal industry. The natural home of the cod is in the shore waters extending from Greenland to Massachusetts, but they are taken in small numbers as far south as Hatteras. They frequent the coast waters of moderate depths, having no definite migratory habits other thin during certain seasons to pass to and from somewhat deeper water offshore, in order to find a temperature more appropriate, or perhaps necessary to their existence. The largest and best cod are those which betake themselves from the shore stations to the more suitable conditions that seem to be offered by those "elevated tablelands" of the Atlantic, those great submarine plateaux that lie to the south and east of Newfoundland, and to the east of Nova Scotia and New England, and which are known as the "Banks." Here, at a depth of fifty to four hundred feet, they are found in comtless numbers. Notwithstanding the fact that for several hundred years the Banks have furnished to the fishermen millions of cod, the supply seems to be but little less abundant than when first discovered. On shore stations their decreasing numbers may be attributed to the exhaustive rails made upon the smaller species of fish which serve the larger ones as food, rather than to the direet eatch of shore cod. On the Maine and Massachusetts coasts cod have long since ceased to exist in quantities snfficient to warrant extensive operations as are now carried on by the fleets of American vessels employed on the banks. Bantholontew Gosnold, in 1602, arriving at Cine Cod, reported that the fish were so abmulant that they "did vex the ship." With due allowance for Gosnold's enthusiasm, the prevalence of cod in New England in enlonial days is evidenced by the flourishing business carried on along its shores by the early settlers, even so late as the revolutionary era. The decline was felt, however, even before that period, and it continued in increasing ratio on accomnt of the steady development of manufacturing interests in New Englant. The damming of rivers to secure water power for machinery 
to a great extent destroyed the spawning grounds of the fish. Cod, however, still exist all along the New England shores in varying quantities, though the supply is scarcely sufficient some seasons to meet the demands of local markets.

Every portion of the fish is of use. The flesh, as a staple article of food, forms the basis of an enormous export trade to all parts of the world; the entrails, head, and bones, are extensively used for fertilizing lands; the swimming bladder is employed in the manufacture of gelatine, and the oil extracted from the liver is well known as a valuable agent in the materia medica; the skin is utilized in the manufacture of glue.

A number of cities on the Maine and Massachusetts coasts are famous as rendezvous for large fleets of fishing vessels which make their annual cruises to the Banks for the purpose of gathering the harvests of the sea. Many of these cities owe both their origin and their prosperity to the energy, industry and success of their fishermen. The business is probably of less relative importance to-day, although the number of men employed in 1900 was about 35,000 , the catch $162,218,921$ pounds, and its value $\$ 4,385,102$.

The method of fishing on the Banks is from small boats with hand lines and trawls, the latter being long lines upon which are attached several hundred hooks. They are anchored and buoyed at both ends, and left out during the night. In the morning the trawl is brought up, the fish that have feasted unwisely are removed, and the hooks are rebaited to repeat the operation. The bait used is the soft-shell clam, the eapelin (a small fish from the bays of Newfoundland), and the squid (a mollusk of the euttle-fish order, which is prineipally taken in Newfoundland waters). When the American fishermen use clams as bait they take a supply, iced or salterl, from the United States, being enabled thereby to avoid the neecssity of tourhing the Dominion coast; in former times, however, a call at some Canadian or Newfoundland port was made imperative for obtaining supplies of capelin or squid, neither of which occurs abundantly in the United States. A class of Canadian longshoremen followed 
the business of eatching and providing these articles of luait to American fishermen, the rates being abont $\$ 1$ a barrel, though it sometimes happened, in the confusion of their misunderstandings, that the Canadians declined to supply their rivals with the necessary bait.

Formerly, when fishing on the coast stations, the corl were taken ashore, eleaned, split open, and spread out to dry in the sun upon "stages," or rndely ennstructed woorlen platforms. Thus prepared, the fish will keep indefinitely. bank fishermen never resort to this means of eming their fish, the run into port consuming too much valuable time. The fish are carefully salted or iced, and patied away in the holds of the ressels, and thus bronght home. The decline of shore fisheries for cod. and the substitution in late years of a better class of Bank fishing vessels earrying ice, has materially changed the relations of American and Canadian eod-fishermen. The former maintain they are inderendent of all privileges the Canatians might seek to offer them, yet the fact remains that shore privileges in Newfomndlum are still considered viluable for purposes of transshipment of cargo, refitting, purehase of bait, ice, and provisions.

The mackerel is a pelagic free-roving fish, appearing at times in rast numbers within the shore waters from the (inff of St. Lawrence to Cape Hatteras. They appear and disalppear suddenly, and withont known reason, to the joy or despair of the masters and erews of a large fleet of American mackerel schooners. The eaprieiousness of this excellent food fish is liable to bring to its pursuers either very great profit, or eomplete disappointment. (rovernor Winthrop, in 16999, relates: ". There was such a store of exceeding large and fat mackerel upon onr coasts this season as wats a great benefit to all onr plantation, sinee one boat with thres men wonkl take in a week ten hogsheark, which were sold at Connectient for three pommols ten shillings a logesheal." Ameriean fishing schooners lave loug frequented Canarlian territorial waters in the prosecution of the mackerel fishery, and many disputes have arisen between the two governments concerning the value to Anerican eitizens of this privilege. 
The uncertain nature of the fish renders all calculations respecting future eatches virtually impossible; hence, it is the more difficult to agree upon regulations for future seasons to govern the mackerel fisheries.

When the mackerel first appear in the early summer months along the New England coasts, the fleet of American fishermen set out in pursuit, following the school of fish into the Gulf of St. Lawrence, where they remain throughout the summer. As the mackerel frequent shallow water, the American fishermen, having no right to do so, are often tempted to approach the shore and carry on their operations within the forbidden territorial waters of Canada. This has been even recently one of the principal grievances of the Canadian fishermen. The method employed by Amerieans in the mackerel fishery is the "purse seine." This mode of fishing is attended with many difficulties and dangers in the shallow waters of the Gulf of St. Lawrence, where violent squalls are frequent, yet as a method of eapturing fish it is most effective. The Canadians object to the use of the purse seine, even when employed outsicle the three-mile limit of their jurisclictional waters, for, they maintain, it "vexes" the fish, interferes with their breeding, and tends to drive them away altogether from the Gulf. For this reason they hold - on the seore of contra bonos mores - that the Americans have no right to use this kind of seine in the Gulf of St. Lawrence. In asserting their right to fish as they choose upon the high seas, the attitude of American and Canadian fishermen is the exact reverse of the positions assumed by their respective govermments in relation to pelagic sealing in Bering' Sea. 'The most serious difficulties of the fishery question to-day are connected with the rights and privileges of the American mackerel fleet.

The herring fisheries of the United States, mntil within recent years, have occupied a relatively subordinate place. In northern Europe this industry is carried on with great vigor, the anmal yield sometimes reaching the extraordinary number of 2,500,000,000 fish. The herring on the west side of the Atlantic lave their range within the limits of the 
Labrador current. They swarm in comntless numbers on the Banks, and indeed throughout the Canadian and Newfoundland shore waters, but they were not formerly pursued by Americans with the energy and zeal justified by their value as an artiele of food. By treaty with England, American fishermen obtained the right to cateh herring abont the Magdalen Islands, and in 1839, just after the commencement of the fishery, a record is given of 146 American sehooners "taking nearly 700 barrels each." A generous estimate of $1,000,000$ barrels of herring taken ammualiy from Dominion and Newfoundland waters has been given by Professor IIinds. A large part of these were taken, however, for fertilizing purposes.

As earried on to-day the herring is largely a shore fishery. The young herring swim in vast schools close along the margin of the water, having eertain definite comrses which they follow. The fishermen construet "weirs" or pocket-like traps, extending ont from the land and crossing the track of the fish. In these labyrinths, the herring become inprisoned in great numbers. They form the basis of a rapidly growing "sardine" eaming industry in New England. The herring, being practically a shore fishery, does not figure prominently in the disputes between the two govermments.

In a lesser degree, pollock, haddock, hake, halibut and other species of fish, of more or less eommercial value, figure in the comprehensive phrase "Northeast Coast Fisheries"; but the greater importance of the cod and mackerel over other varieties of fish included within the term, warrants the omission of all others from a historical review of the subject.

As early as 1415 English fishermen resorted to Iceland to catch eod. There is evidence tending to prove that before the voyages of Columbus, the colfishery of the Newfomdland Banks was known to the Basque and Normandy fisher- 
men. This supposition is supported by the fact that, as early as 1504 , only seven years after the discovery of Newfoundland by the Cabots, Basque fishermen are known to have risited the Banks, and in 15.57 their fishing operations in the New World had increased in extent to the employment of some fifty or more vessels.

The English do not seem promptly to lave followed up the adrantages gained for them by the discoveries of Cabot in 1497. Possibly the superior naral forces of her enemies detered her at that time from asserting jurisdiction over the waters of North America. These waters had been reportel. first by Cabot, and soon after by other English voyagers, as marvellonsly rich in fish. For nearly a century England made no attempt to colonize the newly discovered territories. The French were more alert in grasping the importance of the new industry thus diselosed to the world, and during the early and middle portions of the sixteenth century, enterprising merchants of Dieppe, St. Malo and Ronen, sent their ressels to the Banks in annually increasing numbers. By the year 1540, they had established fishing stations on the shores of Newfoundland, and in 1577 their fleet mustered 150 ships. At that time Spain and Portugal were also well represented on the Banks, but the thirst for gold, which eonsmed the Spanish adventurers of that period, soon lured away her fishermen to the West Indies; and the Portuguese soon found more eongenial fields for exploration in Brazil. By the end of the century Spanish and Portuguese ships disalpeared almost entirely from the fishing grounds.

English ressels, fitted out in London and Bristol, came to Newfomelland as early as 1540 , and continued yearly to visit the region, though their operations were not carried on with the vigor that chalaterized the efforts of the French fishermen of that period. Verranzo, Chabot, Cartier, Roberal de la lioehe and other voyagers of the sixteenth century were conspicuous in establishing the supremaey of France in this part of the New Worde; and Champlain, who founded Quebec in 1608, gave his country a still firmer hold on these shores, 
- a hold that took the English a century and a half to loosen. The prineipal, if not the sole object of acquiring territory in northeastern America at this early period, was to obtain a control of the fisheries which were regarled by both English and French as far the most valuable possession of the New World. It was not until 1583, however, that England fully awakened to the necessity of protecting her interests in America. In that year sir IImphrey Gilbert. with a royal patent from Queen Elizaheth, landed at St. Johns, Newfoundland, for the purpose of establishing a colony. 'To a motley group of fishermen of varions nationalities, who happened to be gathered in the harbor, he read a proclanation, setting forth the intention of his sovereign to assmme control of the waters about Newfomnland to the distance of 200 leagues. 'This order was enforeed, notably in one instance, when that redoubtable old sea rover, Sir Francis Drake, eruising thereabonts some years later, seized several Portuguese fishing ressels as prizes; and although his captures were made many miles from land, he appropriated to his own use their eargoes of fish and oil. This tardy effort at colonization, followed by an attack on the right of free fishery, was not an unqualified suceess, though there is little doubt that it gave a great impetus to English fishing interests in North America. Nir IImmphey's settlement languished, and in 1610 another attempt to colonize the forbidding shores of Newfommland was marle by John Guy of Bristol. Sir liancis bacon was a patron of this seheme, and lis pophetie uttermee that the fisheries of Newfomdland would prove more valuable tham all the mines of Peru, has been amply rerified ly time.

John Guy"s colony reaped a harvest of sorrows, but it gave another lease of life to Enghish fishery interests. Five years later (1615) 250 Eughlish vessels, employing over 10,000 men, were engaged in fishing along the coast, and profits anising therefrom grew apace. In $162:$ another colonizing schene in Newfomdland was earried out by Sir George Calvert, afterward Lord Baltimore, the fomnder of the enlony of Maryland. He was granted by King Jannes a large tract of land 
extending from Trinity Bay to Placentia, which he named "Avelon." Baltimore's hardy followers were beset and harassed by the French who, from their strongholds on the mainland, were determined to possess Newfoundland, hoping thereby to secure to themselves the control of the fisheries.

By the middle of the seventeenth century, the resident population of Newfoundland had increased to 2000, the greater part of which followed fishing for a livelihood. Besides them, several thousand fishermen from France and England came annually in the spring season to her shores, returning in the autumn to their homes across the Atlantic with full fares of fish and oil.

This already extensive and rapidly growing industry of the English soon fell into the lands of a number of merchants and shippers who resided in London and in the west coast cities of England. These men having ample means, fitted out numbers of superior vessels, and mamning them with skilful crews, began a systematic exploitation of the Newfoundland fisheries. It naturally came to pass that the interests of these English fishermen and of those who had settled permanently as colonists in Newfoundland came into conflict. The former sought the most desirable harbors and shore stations for erecting their stages to cure and prepare their fish, and the resident colonists naturally selected these arlvantageous coast situations as places for permanent settlement; and thus a petty warfare between settlers and sailors took place every summer on the southern Newfoundland coast. The interests of the English merchants were paramount in the estimation of the sovereign, it being coneeived that the only real value of the desolate island of Newfoundland to the mother country consisted in its control of the fisheries, for which control a mere nominal possession of the island was quite sufficient.

Legislation at London accorded precedence and preëminence to the rights of fishermen over those of the Newfoundland settlers. Laws enacted by the English Parliament between 1630 and 1640 proved to be oppressive and highly injurious to the colonists, and the enforcing of many cruel 
and unjust regulations, under the plea that the fisheries must be preserved to England, both as a means of profit and as a nursery for her seamen. eovered a period of more than a hundred years. The building of houses and cultivation of the soil were prohibited within six miles of the shore, and numerous other barriers to prospective colonization gave great amnoyance to existing settlers. In fact, the London Board of Trade, in whose hands the regulation of the English fisheries had been placed, pursued its radieal policy so far as to send Sir John Berry to Newfoundland in 1670 with orders to burn and destroy all dwellings, and drive the wretched owners from the island. Under such adverse conditions, British colonization in Newfommlland dwindled into insignifieance in the presence of a proteeted interest of predominant importanee. At that dark period of her history, Newfoundland was generally regarded beyond the Atlantic as "a great English ship moored near the Banks during the fishing season for the convenience of English fishermen."

The era of oppression upon the Newfoundland settlers reached its eumination in the passing of the statute. 10 and 11 William and Mary (1698), entitled: "An act to eneomage the trade of Newfoundland," which was, in reality, an aet to discourage immigration aud to foster the interests of fishermen alone. By one of the provisions of this statute, referred to as "infamous" in the anmals of Newfoundland, a judlieial system was established for the eolony, to be administered by the "fishing admiral." 'This system abolisher the plan of dispensing justice, already in vogue in the eolony, and created in its stead a form of impromptu eourts, held by the eaptains of the English fishing vessels whenever they happened in port. The eaptain arriving first in a harbor was constituted "Armiral of the Port," the second, "Vice-Armiral," etc., in whom was vested the exereise of all judicial functions. The rule of these generally ignorant, and too often vicions, men soon brought all semblanee of law and order into eontempt, and resulted in conditions bordering on anarehy. This statute remained in foree many years, and did much to retard the growth of the colony. Indeed, it may reasonably 
be questioned whether Newfoundland has ever fully recovered from the many sacrifices she has been forced to make in preserving the monopoly of the fisheries to her mother country. The wealth of her large bays and coastal waters may be said to have brought to the island benefits and damages in about equal proportions.

The history of the fisheries, from the early part of the seventeenth century to the treaty of 1763 , is merely the story of Euglish and French conflicts for mastery in the regions lying about the Gulf of St. Lawrence, and south on the mainland of Massachusetts, - the primary object of these many encounters being to secure control of the inexhanstible riches of the neighboring seas.

Throughont the sixteenth century, the flags of France were the more numerous on the fishing grounds; and after the disappearance of the Spanish, the French remainet for many years a formidable rival of the English. They clung tenacionsly to the shore stations they had established in Newfoundland during the sixteenth century, and were always ready to fight for the maintenance of their full rights on the Banks. In 1577 they employed no less than 150 vessels, and about this time the fisheries were deemed of sufficient importance to be placed under the protection of the French Govermment.

Seeking a permanent base of operations on the continent, the French set up a elaim to Nova Scotia, which, together with Cape Breton, New Brumswick and a part of Maine, constituted a great tract of comntry known later as Acadia. Basing their rights upon early diseovery and upon a grant of llenry IV of France to Pierre de Gast, Sienr de Morts, in 1603, the French ocempied this territory, built Port Royal, and established a thriving fishery at Canso. It was the intention of the French monarels to found a colony at some point accessible to the Banks, from which, as a base, the husiness might be easily and sucessfully conducted. Cod was becoming a necessity as a food in France, and was especially suitable for use on the many religious fast days of that periol. 'The settlement of Acadia fulfilled all the needs of 
this desire to secure the bank fisheries for his own suljeets. The first Fench emigrants to this eountry, howerer, eame into immediate collision with English subjects, who, taking shelter behind a royal patent from the English sorereign to Sir Willian Alexamler, in 1621, set up a chim of their own to the greater part of the territory constituting Acadia. Here, then, hegan in earnest the fuarrel that, lasting more than a century, terminated only in the total cxtinction of Frenel sovereignty in Canada. Charles I of England, having married a French princess, was prevailed upon to abandon all settlements in Canala, Nora Seotia and Cape Breton oeeupied hy his subjects : and by the treaty of St. Germains (16:32) the French were matle secure in their possession of Acarlia.

With so favorable a base for aggressive operations, the Freneh began at once to extend their fisheries and to endarge their dominion. They boasted that they would eventually drive English colonists into the sea. Within three yoars they obtained privilegres from the English Government for drying their fish on the southern shore of Newfoumbland ly payment of a duty of 5 per cent on the produet. In twenty-five years more, by seizing the chance of an olportme noment, they established a colony at I'lacentia, on the large hay of that name (south shore of Newfommlland). In a short time, and apparently through the faror and sympathy of the English sovereign, they were relieved from the 5 per eent duty which had been previonsly exarted of then in return for shore privileges. Growing bolder hy snceess, they arried their sphere of intluence along the entiresonthern coast of Newfoumbland, establishing here and there fishing stations and small settlements - meeting only occasional cherks in their pogress from the English settlers on the islinnt.

Cromwell seized Acadia in 16ijt, during a period of perfect peate between the two mations, on the allegerl gromm that its transfer to the Feench by ('harles I in 16:-2: was framblent and tratorous: lut num the restoration of the Stmarts this valuable territory was again restored to Fiance (treaty of Brela, 16iti), to the intense lisigust of all Eurr- 
lish fishermen, and other English subjects who had borne the brunt of conflict with the ambitious and aggressive Frenchmen of North America.

The New England colonists south of Acadia, who, by this. time, were becoming sensible of their increasing vigor and strength, and who, moreover, were acquiring a degree of selfconfidence inspired by their trimphs over the many difficulties. attending their early settlements, looked upon the growth of French power in the New World with bitter jealousy, intensifierl as well by local conflict of interest. Not only as British subjects with the usual antipathy against Frenchmen, but in defence of their own colonial interests and welfare, they opposed, whenever opportunity offered, the development of French power and influence in Acadia or elsewhere in North America.

After the breaking out of hostilities between France and England, on the accession of William and Mary to the throne, Sir William Phips of Massachusetts, with a band of hardy fishermen, made a successful attack on Port Royal (1690), and took formal possession of all Acadia in the name of ling William. Phips' victory resulted in the alleged annexation of that great province to Massachusetts. Similar attempts were made upon Newfoundland, and among them a desperate effort to dislodge the French from Placentia; but in retaliation St. Johns was successfully besieged by a French fleet. The peace of Ryswick (1697) closed hostilities, leaving the Frencli in the New World in full possession of their previous elaims, and Acarlia was specifically restored to. them. Their right to Placentia and to a considerable extent. of the Newfoundland shores was confirmed. The indignation of the English colonists in America, aroused by this. surrender of Acadia, was very great. It readily occurred to. these people that the mother country attached but little value to her Anerican possessions, or else had consented to sacrifice her interests here as mere pawns on the ehessboard of European politics.

The new governor of Acadia, Villabon, announced, soon after the treaty of 1697 , that he had received orders from his. 
home government to arrest any foreign vessels found trespassing on the French shores, the southern limit of which he placed at the Kennebec River. The way was now openerl to the goal of French ambition in Ameriea, and Villabon set about to secure full and immediate control of the fisheries. French fishing vessels, some five hundred in number, and many of them well armed, soom practically enjoyed a monopoly of the fisheries along the eoasts and in the Gulf of St. Lawrence, the returns proving exceelingly remuncrative. In order better to maintain this monopoly, he inaugurated a military campaign in Newfoumlland, the full possession of which was ever dear to the Freneh. Success attenderl their arms, and in a very short time nearly every desirable settlement, port and harbor in the island fell into their hands, and Newfoundland became virtually lost to England. French enterprise had secured to them an almost absolute monopoly of the fisheries, and they held besicles the territory from Maine to Labrador, inchuding Newfoundland.

The hostilities incident to this great advance of French interests were terminated by the treaty of Utrecht in 171:, which very considerably altered the political situation in the North, and may be said to have inserted a wedge that ultimately rended and destroyed French prestige and monopoly of the fisheries in North American waters. By this famous compact the stronghold of l'acentia was yelded by Finnee, and all Newfoundland restored to England. A reservation was made, however, securing to the French a concurpent and equal right of fishery with English subjects along the coast of Newfoumdland, from Bona Vista to Cape liehe by the north, and of using the shores for curing, etc. A "arlia again beeame English territory, France retaining only the island of Cape Breton. An instance is given in this treaty of a nation establishing by agreement its exclusive sovereignty over a wide expanse of high seas, for ly one of its articles the French were prohibited from approathing within thinty leagues of the coast of Nova Scotia.

The French were by no means discomaged by such re. verses, and continued to press their fishing operations with 
their aceustomed vigor. On the Newfoundland coast, within . the area allotted to them, where they enjoyed concurrent fishing rights, they at once began to assert an absolute and exclusive right, and forbade the settlement of the region by English subjects. In Cape Breton, where their fishing fleet of some 400 sail rendezroused, they constructed the famous fortress of Louisburg. 'This position was maintained with a sort of desperate determination as the last barrier against English adrance. It was designed and considered by the French Government to be absolutely impregnable. It required twenty-five years to build, at a cost of $\$ 5,000,000$. Lpon its great walls were placed 200 pieces of heary artillely, which gave defiance to all assault. Within these massive fortifications reposed a city with full complement of public edifices, churches, parks and the homes of several thousand fishermen, by whose persevering industry the city was made prosperous. In the building of this fortress, - "the Dunkirk of America," - upon a low sandy spot in a desolate island, a mere outpost in the vast wilderness of a new country, one finds a glaring example of the ill-juctged policy that has so generally characterized French colonial operations. The splendid scale upon which this great fortress was built measures the earnest and extraoldinary interest felt by the French at that period in the northeastern fisheries.

Lomishurg was regarded by British subjects in America, and especially in Massachusetts, as both an insult and a menace. The aggressiveness of the French in prosecuting the fisheries; their unreasonable and exaggerated claims on the Newfoundland coast, combined with the measiness and jealonsy prorluced by the contemplation of their position of vantage and strength in Cape Breton, greatly irritated and inflaned the colonists. They believed that French chicanery and effrontery had aceomplished what her arms had failed to achieve, and it was thoromghly believed and constantly asserter that there could be no lasting peace in America until Gallic influence had been extirpated from the continent.

In 17tt war again broke ont between England and France, and the long-cherished plan of striking a blow at 
Louisburg was immediately set on foot in New Englanrl. Massachusetts colony organized an expedition with l'puerrell, a merehant of Kittery, Maine, at its head. With some English ships as allies he maintained a siege under many difficulties for nearly two months, and was finally rewarded by the eapitulation of the fortified city on .June 16, 17ti. The eapture of Lonisburg was an event of great importance. Smollett refers to it as "the most important achievement of the war of $1744, "$ as it aecomplished much toward balancing English reverses across the Atlantic. Pepperell was mate a baronet, and all the expenses of the camplign which had been borne by Massachusetts were subsequently repaid to the colony. The English colonists were jubilant over the success of their expedition, hut they were as sudrlenly disalppointed and chagrined when the English surrentered Cape Breton with a restoration of Lomisburg only three years later in the peace of $\mathrm{Aix}$ la Chapelle. Again had the mother country profited by the valor of her American subjects in furthering her ends in Europe, and again had the French reaped trimmph from defeat in North Anerica.

Louisburg was promptly rebuilt and strengthened, and a vigorous effort was matle by France to revive her fishing industries, which had suffered severely by the war. It is estimated that of the 560 French fishing vessels employed at the beginning of the wal of $17+4$, only about 100 remained after the fall of Lonisburg; these carried on their operaltions almost entirely on the Newfoundland eoast. Although the French were reaching the period of decline in the prosperity of their North American fishing interests, yet despite all discouragements they har no intention of allandoning the valuable industry. Reinstated in ('ale Breton, the French at once resumed their old system of agraression. The ancient quarrels, involving questions of boumdary and of fishing rights, were revived. Secmingly incapable of peaceful relations with others, when their interests were tonehed, they began to renew their attatks on Newfomulland, and to make hostile raids into Nova Seotia. War again broke out between Englaud and France in 1756, one of the eauses of which was 
these French aggressions upon Nova Scotia and Newfoundland; and it gave the British subjects in America the opportunity they especially desired - to remove, if possible, the humiliation brought on them by the disgraceful peace treaty of Aix la Chapelle. A strong British fleet commanded by Lord Amherst, with the gallant Wolfe second in command, and supported by nearly one-third of the fighting strength of Massachusetts, again captured Louisburg in 1758, and razed its battlements to the ground; the following year Wolfe marched into Canada and captured Quebee. With the fall of these two strongholds, French power in the New World was broken, and Great Britain became mistress of her possessions in North America.

It was during this same war that the attempt was made by the British authorities in Nova Scotia to remove from that colony all vestiges of Latin influence, by foreibly expelling the French settlers from the land. The execution of this harsh and eruel poliey furnishes the saddest chapter in the somewhat romantie history of Acadia. Thousands were deported to the Virginia and New England colonies, where they found a scant weleome, and many hundreds perished miserably through exposure and want. The pathetic ineidents connected with the depopulation of the French village of Grand Pré, conducted by the unwilling Lieutenant Winslow, who declared the duty "very disagreeble to my natural make and temper," gave to longfellow the theme for "Evangeline." If the chroniclers of the time are reliable, the natives of Grand l'ré were not altogether the simple-hearted, peaceloving people depieted by the poet, but were rather a troublesome and somewhat vicious colony of fishermen who lost no opportmity to infliet injury upon the New England skippers who eame in eontact with them. Candor, however, compels one in forming estimates of the moral qualities of the French and English fishermen of the seventeenth and eighteenth centuries, to divide honors about equally between them. If the French in Nova Seotia were sullen and undyly under English dominion, and if they enjoyed harrying New Englanders when they came to the Bay of 
Fundy, they probably found ample justifieation for their misdeeds in the bad treatment they had themselves reeeived.

In drawing up the treaty of peace which was concluded in Paris in 1763, much difficulty was encountered by the plenipotentiaries in adjusting the fishery question which appears to have elamed consideration beyom all other topies. France, driven to extremities, stemed willing enough to lose all of Canada, lut she insisted upon the retention of some parcel of territory as a hasis from which to earry on her fisheries. Strong opposition to any fishing concessions manifested itself in England, it being earnestly eontended that the fisheries alone were worth more than possession of all Canada. It was finally agreed that France should continue her use of the shores of Newfoundland from Bona Vista to Cape Riche, as had heen previomsly stipulated in the treaty of Utrecht. French fishermen were not allowed to fish elsewhere within three leagnes of the shore; and along the eoast of Cape Breton an interdiction of fifteen leagues was placed against them. The islands of St. Pierre and Miquelon were celed to France in full right, to serve as shelter to its fishermen, and the French engaged not to fortify or to effect permanent settlements upon the same.

The Freneh fishery interests had again suffered severely by these wars, although after the treaty of Paris, through generous bounties and every kind of govermmental encomragement, they slowly revived, and in combe of time recorered a share of their former prestige. France having sirled with the American colonists in their war of indepentence, suffered the loss of St. Pierre and Miquelon, but ly the treaty of Versailles in 1783, these islands were restored, together with an extension of privileges theretofore grantert on the shores of Newfoundland, giving them an area of shore line for curing, from Cape St. John to Cape Ray. The phraseology of this treaty, defining the nature of the rights of France on the Newfoundland shore, furnisherl another subjeet of eontention to English and French statesmen, until a true meaning was agreed upon in 1881, nearly a century 
later. The French insisted upon their exclusive right to oceupy the shore areas allotted to them, even as against British settlers.

Despite continned ill-feeling between French and English fishing interests, both have nevertheless prospered, and the friction between them has gradually diminished ever since.

\section{III}

In seeking a home for themselves and their posterity, the Pilgrim Fathers were largely influenced in their ehoice of a place of settlement by the value they attached to the fisheries of New England. Enthusiastic descriptions of the abundance of eod in that region had reached them in England. The reports of Gosnold in 1602; of Pring, who explored the harbors of Maine in 1603; of Waymouth in 1605; of Popham and Cilbert who settled in Maine in 1608; and of the romantic Joln Smith who caught 47,000 cod at Monhegan in 1614, and who devoted pages "writ with his oune hande " to the wealth of the fisheries in the New World, and especially in New England, - all of these had been read and considered by the Puritans before making their exodus to the West. Before abandoning forever the shores of the Old World, they exeeuted contracts with certain merehants in England, to whom they agreed to furnish fish, hoping thereby to defray the expenses of their voyage. In his history of Virginia, John Smith takes eredit to himself for having been largely instrumental in inclueing the Pilgrims to come to the New World on account of his favorable representations regarding the New England fisheries. In a discomrse on the trials of the New England colonists and their wonderful industry in fishing, he enmmerates the English ships that had made "exceeding good voyages" to the coasts, and continuing, says, "at list, mon these inducements, some well-disposed lirunists [Puritans], as they are termed, with some gentlemen and merchants of Leyden and Amsterdam, to save eharges, wonld try their omne conclusions, though with great losse and much miserie." He 
refers later to the prosperity of the little band in $1634-$ "since they had made a salt worke wherewith they preserv all the fish they take, and have fraughted this yeare a ship' of an hundred and four score tun."

The Pilgrims lost no time in entering upon the business of fishing. Within ten years after their landing at Plymouth Roek, they earried on an export fish trade with English and Dutch settlers in New York; indeed, fishing becane the principal occupation and chief source of revenue of the people of New Plymouth, and the rapid settlement of Massachusetts after the founding of that colony was greatly promoted by the great profits arising from the fishing interests on its coast. The colonists at Plymouth founcl remunerative oceupation, while English ressels at Monhegan and other points along the coast of Maine reported fish in great abundanee.

It was during the infancy of the Massachnsetts colony that Salem, Gloucester and Marblehead were foumlerl, ambl they soon beeame centres of great importanee for fishing and other associated interests. The first Massachusetts ship visited the Banks of Newfomndland in 1645-a pioneer destined to have an abmulant following. Some frietion between the fishermen of Plymonth and Boston manifesterl itself, but all such differences were finally aljusted by uniting the two colonies in 1692, and the fisheries of the greater Massachusetts flourished more extensively than ever. At the elose of the seventeenth century, the merehants of Boston exported to Portugal, Spain and Italy about 100,000 quintals of cod, worth $\$ 400,000$ annually.

In 1731 the fisheries of this colony employed abont 6000 men. Ten years later the cod fishery had hecome exceedingly prosperous; the annual product being about 230,000 quintals, valued at $\$ 700,000$. One hundrerl and sixty fifty-ton vessels were owned at Marbleliearl alone; and it is estimated that in all Massachusetts comnted about 400 fishing vessels, together with multiturles of smaller fishing eraft operating along New England shore stations.

A variety of causes contributed to the deeline of the New 
England fisheries from 1740 to $176 \%$. As already noted, the struggles between the French and English in Nova Scotia, Cape Breton and Newfoundland were espeeially acute at that period, and the New Englanders, as British subjects, were expected to answer repeated calls to arms. Fishermen were impressed into the royal nary, or were drafted into military expeditions by land against the traditional foe; and, as is usual in war, inclustrial pursuits languished.

After the final capitulation of Louisburg and the fall of Quebec, the fishing interests of the British colonies revived, and the coast towns of New England would have greatly increased in population and wealth, but for the threatening controversies which soon led to the American Revolution, and the final separation of the thirteen colonies from the mother country. The commencement of actual hostilities of course suspended all fishing operations until the restoration of peace in 1783 .

The important rôle played by the fisheries in the causes that led to the Revolutionary War does not appear to be fully appreciated. Other eauses assumed greater and more general prominence in popular discussion because they affected interests more extended in their nature, and exerted an influence on a greater number of the colonists. England had watched with jealous eyes the steadily growing trade - the expanding commerce and the rapilly increasing marine power of the New England colonies. This colonial trade latd alrearly extended to the ports of Europe and South Ameriea, and to the Spanish, French and English West Indies as well, where Ameriean fish found ready malket to be paid for in sugar, molasses, rum, bullion and bills of exthange payable in European cities. The commercial prestige of New England lugan to interfere in no slight degree with the foreign trade of English merchants, and the excellent nantical training acquired by New England fishermen and sailors began to arouse the apprehension of Englishmen who demanded exclusive dominion in all that pertains to British industries.

The policy of curtailing American commerce by legislative 
enactment began with the restoration of the Stuarts, and was maintained by a series of more or less stringent navigation laws which imposed the most injurious and oppressive burdens upon the eolonists. In 1733 Parliament placed a duty in New England on rum, sugar and molasses imported from the islands of the West Indies other than British, the aim being to eheek the prosperous trade that had sprung up between Boston and the French, Duteh and Spanish islands. This measure, along with other measures restricting export trade from New England, tended to work great injury to the fishing interests. The merchants of Boston complained bitterly, saying that the fisheries were their mainstay of life, and that to prevent trade with the West Indies was to do no less than render their fisheries of little value - in short, to convert their gold into dross. An English fleet was sent over to enforce the tariff law, but its commander reported, "ye fishermen to be stubberne fellowes," and in spite of his vigilanee, the West Indian tradle eontinued as before, in defiance of Parliamentary action. The act of $17: 39$ was renewed in 1764 , and the vigilance of the authorities doubled. The jurisdiction of the armiralty comrts was enlarged, and determined efforts were male by the officers of the crown to eollect the duties. For this purpose eommanders of the English men-of-war were commissioned to act as revenue eollectors.

The field having just been cleared of the annoying competition of French fishermen, the Americans were about to enter upon an era of great prosperity. Their fishing stations were loeated at Canso, in the bay of Chaleur, and extended along the Labrador eoast, and a tertain renewal of former sncesses was just in sight. The navigation laws of Engrand, however, operated so adversely to American interests that the English fishermen, untrammelled by these exactions, soon regained a monopoly in the fishing husiness. Many New England skippers beeane diseouriged and took their vessels and outfits abroad, where they sold them to their more fortunate rivals. By evasions of the law, lowever, many of the merchants and fishermen of Buston, Salem and Gloncester 
still managed to maintain themselves, but only at the cost of frequent collisions with the king's officers.

The effeet upon the fisheries, caused by the renewal of the navigation laws of 1764 , is well set forth in the petition of the common council of Massachusetts to the House of Commons for their abrogation. It recites that the importation of molasses from the West India Islands is of the greatest importance, not merely beciuse it is a valuable and useful commodity, but, _ - If the trade, for many years carried on for foreign molasses ean no longer be continued, a vent camnot be found for more than one-half the fish of inferior quality which are caught and enred by the inhabitants of the province, the French not permitting fish to be carried by foreigners to any of their islands unless to be bartered or exchanged for molasses; that if there be no sale of fish of inferior quality, it will be impossible to continue the fishery; the fish usually sent to Enghand will then cost so dear that the French will be able to undersell the Enghish in all the European markets." Thus it will be seen that the fisheries, which formed the basis of New England eommerce, and which may be said to have been the very life-blood of all its commereial enterprise, lad a most intinate relation to the canses that soon brought about the dismemberment of the empire.

The final act of Great Britain in its policy toward New England, and which at last brought on the war, was aimed directly against the fisheries, its purpose being to starve the rebellions colonists into submission by destroying their most importint industry. Pending the discussion of the bill in the English Parliament "to restrain the trade and commerce of the provinces of Massaeluusetts Bay and New IIampshire, the colonists of Connecticut and Rhode Island and Providence plantation, in North America, to Great Britain, Ireland, and the British Islands in the West Indies; and to prohibit such provinces and colonies from carrying on any fisheries on the banks of Newfonmbland or other places therein to be mentioned, under certain conditions, and for a time to be limited," an examination of witnesses from Massachnsetts by a committee of I'arliament elicited the statements that the enforce- 
ment of such an act would deprive over sixty-two hundred inhabitants of Massachusetts of the means of livelihood, and throw out of employment ten thousand persons. An expert witness from Nantucket declared that the great number of people then engaged in the fisheries in New England, if deprived of the right of following their calling, conlel only subsist "perhaps three months."

After a stormy debate in both Houses of Parliament, the bill was passed March 21, 1775. The passage of this act, so well calculated to destroy the fisheries of the New England colonies, was soon followed by a motion of Lord North, then the British Premier, that the "House do resolve itself into a committee of the whole to consider the encouragement proper to be given to the fisheries of Great Britain and Jreland.'

During the entire period of the war, the fisheries of New England as a business ceased, and the fishermen took an active part in the conflict. In the negotiations of the colonies with France, seeking her aid againsi England, a proposition was advanced to attempt jointly the eapture of Canada and Newfoundland, and if suceessful, to divide between Fince and the United States all fishing privileges acerning therefrom. The plan was never seriously entertained by France, and was lost sight of in the Lnited States, anid the stirring events of the Revolution.

Although systematic prosecution of work was necessarily abandoned during the war, the importance and value of the fisheries were steadily kept in view, and after the termination of the conflict the necessity of preserving these interests is evidenced by numerous resolutions of Congress, and is further indicated in the debates of various state legislatures (especially in New England), and in frequent utteranees of the public men of the times. It seems to lave been belicred by many American statesmen of that day that becanse New England fishernen harl eontributerl their share of blood and treasure in the joint struggles against France for the purpose of securing fishery rights in the Canatian waters, it followed as a natural and legal consequence that Americaus must have a perfect right to their contimued enjoyment quite irrespective 
of any territorial changes, - in whieh respect it made no difference whether Canala and Newfoundland should remain under the sovereignty of England or pass to the United States at the conclusion of hostilities. In the light of a better understanding of the public law on this subject, it now seems elear that the fishery rights must attach to and adhere to the ownership of and sovereignty over the territories in whose waters the fish are found. Americans should have been left free to fish on the Banks, for they lie wholly without the limits of territorial marine jurisdietion, and are therefore free to the world, - but the right to eatch fish in Canadian waters, that is, within the three-mile limit of ordidary marine jurisdiction, was wholly a different matter. In the one case (the Bank fishery) no fear's should have been entertained at any time tonching the question of American rights. The public law settles this matter, and gives all nations the right to fish outside territorial waters. In the other ease, a continuance of inshore fishing by Amerieans in Canadian territorial waters, as enjoyed by them while British eolonists, conld not have been allowable as an international right, nor could such right have been legally based on the relations of the parties existing prior to the peace of 1783 . The apprehensions of the statesmen of the period lest Great Britain should attempt in a spirit of retaliation to perpetuate the interdictions of Lord North's Bill and thus seek, perhaps by force of arms, to cut off Americans from all participation in the northern fisheries, were possibly well founded. It was determined, at all events, to make the question of the fisheries a prominent subject of the treaty of peace with England. The fishery interests of the comntry were supposed to be so intimately assoediated with its eommereial prosperity that no conditions interfering with their full development could be tolerated ; indeed, it was urged in many quarters that their importance warranted a eontinuance of the war, if need be, to preserve them inviolate.

The firm purpose of Congress to insist upon a full recognition of these fishing rights as a sine qua non of commereial relations with England was supported by all its members, 
barring certain delegates from the extreme South. These legislators represented constituents who had never participated in the fisheries, and who therefore felt their importance less keenly. Mr. Gerry, of Massachusetts, replied to their protests against making free fishery an important feature of the coming peace negotiations: "It is not so much fishing as enterprise, inclustry, employment. It is not fish merely, which gentlemen sneer at, - it is gold, the product of that arocation. It is the employment of those who would otherwise be idle, the food of those who would otherwise be hungry, the wealth of those who would otherwise be poor, that depend on your putting these resolutions into the instructions of your minister."

After a lengthy debate (1779) Congress instructed John Adams, who was then in Europe acting in a diplomatic capacity, and to whom had been entrusted the responsibility of negotiating a treaty of peace with England, "that the common right of fishing would in no case be given up "; "that it is essential to the welfare of all the United States that the inhabitants thereof, at the expiration of the war, should continue to enjoy the free and undisturbed exercise of their common right to fish on the Banks of Newfomndland, and all other fishing hanks and seas of North America, preserving inviolate the treaties letween France and the sald States"; "that our faith be pledged to the several states that without their unanimous consent no treaty of commeree shall be entered into, nor any trade or commerce whatever carried on with Great Britain, without the explicit stipulation hereinafter mentioned. You are, therefore, not to consent to any treaty of commerce with Great Britain without an explicit stipulation on her part not to molest or disturb the inhabitants of the Uniter States of America in taking fish on the Banks of Newfonndland, and other fisheries in the American seas, anywhere except within the distance of three leagues of the shores of the territories remaining to Great Britain at the close of the war. If a nearer distance cannot be obtained by negotiations, you are to exert your most strenuous endearors to obtain a nearer distance in the 
Gulf of St. Lawrence, and particularly along the shores of Nova Seotia; as to which latter, we are desirous that even the shores may be occasionally used for the purpose of carrying on the fisheries by the inhabitants of those states."

Before aetual negotiations for a treaty of peace with England were entered upon, innumerable difficulties had arisen to dishearten American legislators, and these diffieulties tencled to weaken the obligatory foree of previous congressional resolutions on the subject. The war dragged on remorselessly, exhausting the slender resourees of the eountry and disconraging the brave men who were saerifieing their all in the cause of freedom. 'To-day peace was in sight, tomorrow it seemed farther away than ever; and the disheartened patriots realized too well that the English ministry was firm in its determination to withhold any fishery concessions. Other important coneessions besides the fisheries had to be secured from England, and form a part of any treaty of peace-such as the navigation of the Mississippi River, the delimitations of boundaries, indemnities, ete. ; but first, and above all, independence, the primary object of the war, was to be obtained at any and all eost. The yielding of this eoneession alone, in the judgment of Congress, would be so distasteful to the mother conntry that it might not be well to jeopartize the treaty by making other demands searcely less distasteful to England. Might it not prove unreasonable, or at least impolitie, to prolong a war begun for freedom, simply to keep inviolate a single eommereial privilege which might be as well seeured by subsequent treaty? In a gloomy mood Congress therefore cleclared that, "although it is of the utmost importance to the peace and commerce of the United States that Canala and Nova Seotia should be eeded, and more partienlarly that their equal common right to the fisheries should be guaranteed to them, yet a desire of terminating the war has indneed us not to make the aequisition of these objects an ultimatum on the present oceasion." It was thus that in July, 1781, the instructions to Mr. Adams of 1779 were overruled, much to the chagrin of that zealous patriot. 
In addition to the obstacles in the way of a probable retention of full fishing rights ahealy mentioned, others of a most serious character suddenly presented themselves from an unexpected source. France had given to the strugghing colonists not only moral support, but that substantial and material aid without wheh a successful issue of the war for independence would have been next to impossible. American friendship for France was sincere and profound. Confidence in her motives was without suspicion and undisturbed by doubt. Ameriean gratitucle recognizer the full measure of obligation due to an act of disinterested beneficence and kindness. In the progress of efforts towarl peace, the disagreeable and startling fact became apparent that our ally entertained some schemes of self-interest hardly compatible with the generous motives which had been originally ascribed to her. Traces of French reserve in the proposed adjustment of questions growing out of the war were first detected in the matter of the fisheries; but the benefit of presumed innocence was for some time accorded to the action of the French fovernment, and its motives were ascribed to the acemplishment of ends not prejurlicial to American interests. It subseguently came to light, however, that Count de Vergennes, the astute Minister of State at Paris, had earefully mapper out a course of action relating to the fisheries, in the erent of Ameriean intependence, which looked to the enjoyment of a monopoly of this valuable industry by France and spain to the entire exclusion of the Americans. This seemingly inconsistent attitule of the French premier toward his ally across the oecan may be fully understood when consinlered in consection with the grand scheme he had plamned for so shaping the destinices of the new republic as to hold them permanently under French influence. The people of Anericat were to have "liberty," of course, but liberty unler French domination. In no event did he propose to permit the growth of the new nation to interfere with the interests of his own eomutry, it being his intention, on the contrary, to train his poutege into a subservient and useful ally of France. According to De 
Vergennes, the territorial limits of the United States were to be confined to a narrow strip along the Atlantic seaboard; they were to be "circumscribed," he wrote, "with the greatest exactness, and all the belligerent powers [England, France, and spain] must bind themselves to prevent any transgression of them." In the furtherance of his project to perpetuate the glory of France on the Western continent, and to humiliate his Anglo-Saxon enemy, he flattered himself upon having made an excellent beginning. By timely aid to the United States in its period of distress he had won the gratitude and confidence of the young nation, and it needed but the exereise of vigilance and political sagacity to guide its future steps in paths of his own making. As a guardian it was necessary to gain control of the nation's diplomatic bureau, and for himself to negotiate for his ward its treaty of peace with Great Britain. The young eagle's wings were to be clipped at once.

French diplomatic agents in Philadelphia exerted all their influence over Congress to bring about this end, and with such skill, be it said, that in July, 1781, Congress instructed the peace commission (now to be enlarged by the appointment of Jay, Franklin, Jefferson, and Laurens), to take no initiative in the coming negrotiations for peace without the knowledge and consent of the king of France, and, "ultimately to govern ourselves by their advice and opinion, cndeavoring in our whole conduct to make him sensible how much we rely on His Majesty's influence for effectual support." Madison bitterly denomeed this resolution of Congress as a "sacrifice of the national dignity." About one year later an intercepted letter of Marbois, a French diplomat in the United States, to De Vergennes, when made publie, aroused great and well-merited indignation, as it furmished the first real proof of French duplicity toward the United states. It had a wholesone effeet in determining the course of action to be followed by the peace commissioners in Paris.

The letter is in part as follows :-

But Mr. Samuel Adams is using all his endeavors to raise in the State of Massachusetts a strong opposition to peace if the 
Eastern States are not thereby admitted to the fisheries, and in particular to that of Newfoundiand . . . and if the states should agree relative to the fisheries, and be certain of partaking of them. all his measures and intrigues would be directed toward the conquest of Canada and Nova Scotia; but he could not have used a fitter engine than the fisheries for stirring up the passions of the eastern people, by renewing the question which has lain dormant during his two years absence from Boston. He has raised the expectations of the people to an extravagant pitch. The public prints hold forth the importance of the fisheries. The reigning toast in the East is "May the United States ever maintain their rights to the fisheries." "It has often been repeated in the deliberations of the General Courts, "no peace without the fisheries." However clear the principle may be in this matter, it would be useless, and even dangerous, to attempt informing the preople through the public papers. But it appears to me possible to use all means for preventing the consequences of success to Mr. Samuel Adams and his party; and I take the liberty of submitting them to your discernment and indulgence.

Jefferson did not act upon the peace commission, and Laurens did so only at its elose. Jay, who was then Minister at Madrid, had resided long enough abroad to become thoroughly imbned with a distrust in the genuineness of Freneh and Spanish friendship toward his comtry, and he deprecated his instructions to abide by the wishes of any European sovereign. Joln Arlams fairly blazed with indignation at the huniliating conditions placed by Congress upon himself and his associate commissioners, and he determined to rebel against the meddling interference of the French court, whose treachery to the United States tonehing the fisheries he thoroughly understood. Franklin, then United States Minister at Paris, had grown more complaisant to French intrigues, or possibly lie feared them less than did his colleagrues, lout he nevertheless yielded to the proposals of $A$ dams and Iay, and the negotiations were consequently carried on by the three American peace eommissioners entirely upon their own responsibility, and without the aid or arvice of De Vergennes or of the French comrt.

The firmness of these men in adhering to their ultimatnm that a fishery elause granting ample rights to Americans 
was one of the conditions of peace with England, and their courage in ignoring French interference, though done in open defiance of instructions from Congress, secured the excellent foundation npon which have rested all the fishery rights and privileges the United States has since enjoyed in Canadian waters. To John Adams especial credit is due. His steadfastness of purpose inspired his colleagues to share with him the risk of disobeying legislative commands in so important a matter, and of assuming the responsibility incurred in slighting the French court at a critical moment when foreign sympathy could ill be spared.

The diseussions of the commissioners concerning the fisheries were long and tedious, and the opposition of the English to any satisfactory form of concession in relation to them was only gradually and with great difficulty overcome. Iad the fishery interest been the only one involved, the matter might have been settled after a comparatively easy diplomatic struggle, but to retain the fisheries deprived the American negotiators of eapital to draw upon in payment for the other equally valuable concessions which they demanded.

On one occasion, when the phraseology of the fishery clause was under discussion, an English commissioner objected to the word "right" of fishing instead of liberty, as a term olmoxious to his countrymen, to which Mr. Adams replied: "Gentlemen, is therc or can there be a clearer right? In former treaties - that of Ltrecht and that of Paris - France and England have elaimed the right to use the word. When God Nhighty made the banks of Newfoumdland, at three humbled leagnes distant from the people of Ameriea, and at. six humber leagues distant from those of France and England, dirl He not give as good a right to the former as to. the latter? If Heaven, at the ereation, gave a right, it is ours at least as much as it is yours. If occupation, use, and possession give a right, we have it as elearly as you. If war and blood and treastre give a right, ours is as good as yours. We have been contimually fighting in Canada, Cape Breton, and Nova Scotia for the defence of this fishery, and 
have expended beyond all proportion more than you. If, then, the right eamnot be denied, why should it not be acknowledged and be put out of dispute? Why should we leave room for illiterate fishermen to wrangle and chicane?"

As finally signed on September 3, 1783, Article III of the treaty of Paris stands as follows:-

It is agreed that the people of the United States shall continue to enjoy unmolested the right to take fish of every kind on the Grand Bank, and on all the other hanks of Newfomdland; also in the Guph of St. Lawrence, and at all other places in the sea, where the inhabitants of both comntries used at any time heretofore to fish; and also that the inhabitants of the United States shall have the liberty to take fish of every kind on such part of the eoast of Newfommland as British fishermen shall use (but not to dry or cure the same on that island); and also on the coasts, bays and creetss, of all other of His British Majesty's dominions in America; ant that the American fishermen shall have the liberty to dry and ane fish in any of the mosttled bays, harbours and creeks of Nova Scotia, Magrlalen Islands, and Labrador, so long as the same shall remain unsettled; luat so soon as the same, or either of them shall be settled, it shall not be lawful for the said fishermen to dry or cure fish at sueh settlement, without a previous agrement for that purpose with the inhabitants, proprietors or possessor's of the gromil.

It will be observed, then, that in regard to the fisheries, very few privileges enjoyed by the American colonists (as British subjects) were (lenied to them as American citizens by the treaty of Paris. The bank fishery was recognized by England to be beyond her legislative control, and therefore open and free to the world ; likewise the fishery of the rulf of St. Lawrence. The treaty rights to take fish in the inshore waters of Camarla were ample; all that marine area, including the bays and creeks of the I)ominion coast, was left free to Ameriean fishermen. Two restrietions only were placed upon them, first, that they should not use the Newfoundland shores for purposes of drying or curing their fish, - and second, they should not, mon all the balance of the British-American coast (where such privileges were granted), so locate their stages as to molest or annoy the 
inhabitants. This latter restriction was a proper and wise one, and could have called for no reasonable complaint. The withlolding from American fishermen of the Newfoundland shores for the purpose of curing fish was regarded as unfortunate, for these being nearer the Banks were more convenient for the establishment of shore stations. Had American eitizens been accorded this one additional right to the others acquired by the rtreaty, there would virtually have been no distinction drawn between American and English fishermen in their freedom of morements in Canadian territorial waters or on Canadian soil.

At the close of the Revolutionary War, the fisheries were substantially amnihilated, and their restoration to a condition of vigor was neither immediate nor rapid. An order issned by proclanation (July, 1783) in London, prohibited the importation of American fish into British West Indian ports. 'This action was a telling blow to the greatly weakened American industry, and adverse tariff regulations in various foreign markets added to the eanses that retarded its growth. To offset these depressing foreign influences, efforts were marle by Congress to stimulate the languishing fisheries by means of bonnties. In 1789 an act was passed allowing a bounty of five cents per quintal on all dried, and five eents a barrel on all pickled (salted) fish exported, and, at the time, imposing a duty on fish imported into the United States. Even this encouragement seems to have been insufficient, for the fishermen of Gloneester soon after presented a petition to Congress setting forth a grievons story of their losses, with a prayer for further measures of relief.

The necessity of reviving the fisheries seems to have been generally accepted by the legislator's of the period. The reasons given were not simply that the industry was in itself a valuable one and promised wealth to its followers, but higher considerations of national ntility were advanced for its eneouragement. President Washington, in 1790, an- 
nounced that "our fisheries and the trunsportation of our own produce offer us abuulant means for guarding ourselves against depending upon foreign vessels." The views of Congress are refleeted in its reply to the President's message: "The navigation and the fisheries of the Lnited States ane objects too interesting not to inspire a disposition to promote them by all the neans which shall appear to us consistent with their natural progress and permanent prosperity."

The fishermen's appeal was answered, and in 1792 a new law was created abolishing the bounties on exported fish, and in lieu thereof a specitic tomage allowance was made to all Ameriean vessels engaged in the fisheries. This law was more or less altered by sulsequent legislative acts, until finally all bounties and allowanees to tishermen were abolished in 1854. These various hounty acts had ahwass met more or less opposition on constitutional grounds. A generation later, Senator Benton opposed them with all the vigor and strength which that parlinnentary learler possessed. Further legislative measures were taken to improve the condition of the fishermen by the aet of 179:) authorizing the customs officials to grant to tishing vessels licenses " to touch and trade" at any foreign port or place. The ohject of this act was to enable the fishermen to purchase in foreign ports, - and free of all duties, - needful supplies of salt, provisions, fishing gear, etc. This privilege wats certainly of great benefit to the fishermen, who avalerl themselves of it to carry on regular trading operations in Newfoundland and in Canadian ports. Thus it soon led to abuses that later ushered in a series of cliplonatie eomplications, and added to the "fishery question" new elements of controrersy.

Despite these earnest efforts to infuse new life into the crippled fisheries, they rallied lont slowly from the shork of war. Statistics of the yearly catches from 1789 to 1812 indicate a wavering increase in ressels and tommage employod, but the fishermen harl nevertheless reason to rejoiee in fairly bright prospects for renewal of the prosperity they had enjoyed before the Revolution. Whan their hopes were about to be realized, the sharlow of the alphoneling politioal 
erises of 1812 depressed the fisheries. Jefferson's Embargo measures brought great distress to the fishermen, and the advent of war soon after drove them from the Banks, and completely paralyzed their industry.

Immediately following the withdrawal of the British forees from the Uniter States at the elose of the Revolutionary War, a strong lislike was manifested for the "Tories," or those who had remained loyal to England throughout the struggle for independenee. Numbers of these disaffeeted people emigrated to Nova Seotia and to Canada ; not a few of them established homes in Newfoundland. These disappointed men, no doubt nurturing feelings of resentment, regarded with jealous interest the operations of Ameriean fishermen in Canadian waters. As loyal emigrants making new settlements on the coasts of New Brunswiek and Nova Seotia, they were naturally loath to reeognize the rights of American fishermen unler the treaty of 1783 , namely, to use British shores for drying and emring their fish; and they were in a mood to record eagerly any transgression of privileges by their old enemies as they were always vigilant to deteet them in misteeds of any kind. These unfriendly settlers along the Canadian shores were largely instrumental, it is known, in causing the British colonies in 1807 to make protests to their home government against the eonduct of the Americans; later, upon the outbreak of hostilities between England and the United States, and the eonsequent abrogation of all former treaties between those powers, they took the opportunity to urge upon the British Government a refusal to renew any fishing privileges whatever in their waters. These appeals, backed by many representations of the pernicious moral influences exerted by New England fishermen over the inhalitants of Nova Seotia and Iabrador, through their evasions of enstom duties, illicit trading, ete., soon convinced the British ministry that England had been far too generous for her own grood in granting such extended 
and valuable fishery rights to her seceded colonists. Accordingly, at the close of the War of 1812 (though before the battle of New Orleans). when the American peace commissioners arrived in (ihent for the purpose of making a new treaty with England, they were met at the outset by the assertion of the British commissioners that " it was thought proper in candor to state, that in relation to the fisheries, although it was not intended to contest the right of the United States to them, yet so far as respected the concessions to land and dry fish within the exchusive juriscliction of the British, it was proposed not to renew that without an equivalent," and further, that " the British Govermment did not intend to grant to the United States gratnitously the privileges formerly granted by treaty to them, of fishing within the limits of the British sovereignty, and of using the shores of the British territories for purposes connected with the British fisheries." John Quincy Adams, speaking for the Ameriean commissioners, replied that they har not intender to mention the subject of fisheries, that question not being one of the subjects of difference in the war just concluded.

Althongh it had beeme alparent before 1812 that different conceptions of the force and character of the third article of the treaty of Paris were ledd in England and the United States, then for the first time, the opposing views, as to the exact nature of American chims to the inshore fisheries as expressed by that article, came face to face.

The English held that the liberties accorded the Americans by the third article of the treaty of 1783 to fish within the territorial waters of Great Britain and to land on the shores of Nova Seotia, to dry and eure fish, were in the nature of a grant or a concession, and were liable, as are all such treaty rights and privileges, to alorogation by subsequent war hetween the parties. The British commissionels assumed, therefore, that these inshore privileges harl been terminated by the $W_{\text {ar }}$ of 1812 , and that should the United States desire a renewal or modification of them, such eonld only be obtained through new treaty stipulations. They drew a distinction, however, between the fisheries on the Banks (or in 
all waters lying without the marine jurisdiction of Great Britain) and those fisheries that were proseeuted within such marine jurisdiction (vaguely regarded then as all waters lying within three leagues of the shore). The former, they were willing to concede, belonged equally to all nations, - as fixed and permanent a right as the navigation of the high seas ; the latter, the inshore fisheries, belonged to England alone, and any transfer of privileges to other nations by treaty to participate therein was necessarily in the form of a contract, - and contracts between nations are cancelled by war.

The American commissioners took a radically different view of the situation. It will be remembered that in 1782 , when the treaty of Paris was being negotiated, John Adams, supported by the opinions of many prominent men of New England, had stoutly contended that these inshore fisheries of Canada, together with all landing privileges to cure fish, belonged to Americans, in equal right, as well as they belonged to England. They had fonght and bled for them, and as American eitizens they were entitled to them quite as much as were the Canadians who had ehosen to remain British subjects. Mr. Livingstone, Secretary of State, in writing of the bank fisheries to Benjamin Franklin, January 7, 178:, said:

The arguments on which the people of America found their claim to fish on the banks of Newfoundland arise, first, from their having once formed a part of the British Empire, in which state they always enjoyed, as fully as the people of Britain themselves, the right of fishing on these banks. They have shared in all the wars for the extension of that right, and Britain could with no more justice have exchuded them from the enjoyment of it (even supposing that one nation could possess it to the exclusion of another), while they formed a part of the empire, than they conld exclude the people of London or Mristol. . .

Upon the same prineiple that Mr. Livingstone supported the Aneriean right to the bank fislery, namely, previous enjoyment of them as British subjeets, Mr. Adams and his colleagues elaimed the inshore fisheries of Canada. He 
maintained that these natural rights, enjoyed as British subjects before the Revolution, had never been yielded or lost by the war of independence, nor forfeited by the resulting changes in sovereignty over Canalian waters. As "tenants in common" with Great Britain, the Americans held all fishery rights in northeastern waters, both open and teritorial, and by the "partition" of the territory of North America, effeeted in the treaty of 178.9 , these fishery rights were in no manner destroyed or abridged. He wrote some years later $(18: 2)$ : -

The inhabitants of the United States har as clear a right to every branch of the fisheries, and to enre fish on land, as the inhabitants of Canada or Nova Scotia. . . . the citizens of Boston, New York, or Philadelyhia had as clear a right to these tisheries, and to eure fish on land, as the inhabitants of London, Liverpool, Bristol, Glasgow or Dublin; fourthly, that the third article was demanded as an ultimatum, and it was declared that no treaty of peace should be made without that article. And when the British ministers found that peace could not be made withont that article, they consented, for Britain wanted peace, if yossible more than we did; fifthly, we asked no favor, we requested no grant, and would accept none.

Following the same line of argument, Rufus King, in addressing the Senate in 1818, said that the fisheries "on the coasts and bays of the provinces eonquered in America from the French were acquired by the common sword, and mingled blood of Amerieans and Englishmen - menbers of the same empire, we, with them, had a common right to these fisheries; and, in the division of the empire England confirmed our title without condition or limitation; a title equally irrevocable with those of our boundaries or of our independence itself.'

In a celebrated pamphlet on the "Fisheries and the Mississippi," in which this controversy over Anerican fishery rights is discussed at great length, John Quincy Adams said:

As a possession it was to he held by the people of the Cnited States as it had been held before. It was not, like the land parti- 
tioned out by the same treaty, a corporeal possession, but, in the technical language of the English law, an incorporeal hereditament, and in that of the civil law a right of mere faculty, consisting in the power and liberty of exercising a trade, the places in which it is exercised being occupied only for the purposes of the trade. Now, the right or liberty to enjoy this possession, or to exercise this trate, could no more be affected or impaired by a declaration of war than the right to the territory of the nation. The interruption to the exereise of it, during the war, could no more affect the right or liberty than the occupation by the enemy could affect the right to that. The right to territory conld be lost only by abandonment or renunciation in the treaty of peace, by agreement to a new boundary line, or by acquiescence in the occupation of the territory by the enemy. The fishery liberties could le lost only by express renunciation of them in a treaty, or by acquiescence, on the principle that they were forfeited, which would have been a tacit renunciation.

Again :-

... in consenting by that treaty [178:3 that a part of the North American continent should remain subject to the British jurisdiction, the people of the United States had reserved to themselves the liberty, which they hat ever before enjoyed, of fishing upon that part of the coasts, and of drying and coring fish upon the shores, and this reservation hat been agreed to by the other contracting party.

In substance, then, the Ameriean position at Ghent, as regards the inshore as well as the open sea fisheries, was: that the people of the United States had done as mueh as the English to win and proteet the fisheries; that as British subjeets they hal always enjoyed them; that at the close of the Revolutionary War a treaty (1783) liad been marle recognizing the independence of the Uniterl States and making a partition of the territory of North Ameriea; that so far as the fishery rights were concerned, they were simply incorporeal hereditanents owned alike by England and the United States, as tenants in eommon in North America; that the third article of the treaty of l'aris reeognized this to be the ease, and by its terms simply defined those rights and recorded them, but did not create nor grant them to the United States; that all these fishery rights belonging to the 
United States' eitizens as a natural heritage of their former allegiance to Great Britain (and being in no wise a eoncession from England) were by nature ferpetual, and not liable to revoeation by war between England and the United States, - and therefore they harl not been lost by the Wir of 1812. Consequently, American fishery rights were not a proper subject for discussion or negotiation at that time.

The American eommissoner's went still farther to substantiate their contention that the inshore fisheries of Canada and the right to use Canadian shores for curing and drying fish belonged to the United States as an inviolable right. They maintained that as these liberties of fishing were not created but merely defined and recorded by the third article of the Paris treaty, that article, like all treaty clauses pertaining to matters of partition or boundaries or territory, was of that particular class of treaty articles which is permanent and not affected by subsequent suspension of fricndly relations between the parties. Thus they eonsidered their position doubly strengthened, and beyond question correct.

The arguments of Mr. Adams and the members of the commission who supported him were elenrly unsound. While British colonists, the Americans certainly possessed all the rights of other English subjeets in British territorial waters, and shared with them the obligations and duties which such possession imposed. These obligations had ealled for the protection of the fisheries against French agrgressions, and the American colonists answered the eall as a duty, and performed it well. After the war of independence, England retained Nova Scotia, Newfomdland, and labrator, and as an inseparable condition, the jurisclietion over their marginal belts of ocean; the Americans ceased to be British subjects, and were at onee relieved of all duties and olligations to defend English territory or protect English waters, and in a like mamer they were certainly deprived of the privileges of ownership over such alien territory and waters. Haul the contention of Mr. Adams been sound, the United States with equal justice conld have pressed a elaim for possession of Quebec or Inalifax, for by the "common sword and min- 
gled blood of Americans and Englishmen "those strongholds were won and defended. By the same argument the English could have claimed the right to navigate the Mississippi River, which had been conceded to them by the treaty of 1783, and which Mr. Clay (one of the commissioners at Ghent) declared to be forfeited by the War of 1812 .

Again, had the United States an inherent and natural right to the inshore fislieries of Canada, and to the perpetual use of its shores, why had these shore privileges been limited by the treaty of l'aris? Why had the United States accepted the privilege of curing and drying fish in Nova Scotia and Labrador, and relinquished it in Newfoundland? If American citizens had been entitled as of right to use a part of the Canadian coast, they were equally entitled to use all of it. On the Newfoundland coast, where shore privileges were most desired, and where long usage would have set up an easement or prescriptive title fully as well as to the Nova Scotia or Labrador coast, Americans had been denied all landing privileges.

Furthermore, a review of the instructions of Congress to the commissioners, who negotiated the treaty of Paris, develops the fact that it had not been the intention or object of the United States Government to insist upon a continuance of the inshore fisheries which had formerly been enjoyed as a right. Congress did insist on the right to fish on the "Banks of Newfoundland and other fisheries in the American seas, anywhere excepting within the distance of three leagues of the shores of the territory remaining to Great Britain at the close of the war, if a nearer distance cannot be obtained by negotiation." A full expression of the policy of the govermment in 1782 is given in a report of a committee of Congress on certain resolutions adopted by the legislature of Massialnusetts touching the fisheries (1781). An eliborate argument is there set forth to demonstrate the freedom of the ligh seas, and to prove that the Bank fishery may not be properly appropriated by any power. These Banks, "the nearest point of which is thirty-five leagnes distant from Cape lace, are too far advanced in the Atlantic 
to be a dependence of the shores." Thus a distinction was at that time made between the Bank and the shore fishery. All expressions of Congress signifying a determination to retain the fisheries, at all hazards, refer only to the open sea fisheries; for at that period of uncertainty it was feared that England might even refuse to yield her pretended sovereignty over the Banks. The spirit of Joln Arlans' instructions in 1782, as gathered from congressional actions previously taken upon the subject, was to insist as a right upon the freelom of the high seas for American fishermen, and to secure for them by negotiation the largest possible inshore privileges. Finally, it will be noted that in the third article of the treaty itself the word "right" is used in comnection with the Bank and deep sea fishery, and the word "liberty" with reference to the shore fishery.

Failing to make good the doctrine that Canadian inshore fisheries belonged to the United States, not by treaty stipulation, concession or grant, but by natural and inherent right, the second contention of our commissioners at Ghent was equally bound to fail, namely, that the third article of the treaty of Paris belonged to that elass of treaty obligations which are exempt from abrogation by war. 'The second proposition is in a measure a eorollary to the first. It will readily be seen that all treaty stipulations must belong to one or the other of two clisses. Those covering atknowledgments of independence, cessions or partitions of territory, delimitations of boundaries, acknowledgments of preëxisting rights and stipulations male in contemplation of war, - all of which may be regurded as exeented stipulations, - are not subjeet to abrogation by war. All such ats include mere grants of privileges, or rights, may be regirded as executory stipulations, and are necessarily terminated by war between the parties. Mr. Adams and his colleagues at Ghent chung persistently to the idea that the fishery clanse of the l'aris treaty belonged to the first class of treaty stipulations mentioned, and therefore that this in the same mamer as the first article of that treaty (acknowledging the inclependence of the United States), and in the same manner as the seeond 
article (defining the bomndaries of the United States), stood inviolate and unaffected by the war that had just been concluded between the parties. In defending his position he afterward wrote:-

In case of a cession of territory, when the possession of it has been delivered, the article of the treaty is no longer a compact between the parties, nor can a subsequent war between them oprerate in any manner npon it. So of all articles, the purport of which is the acknowlergment by one party of a preëxisting right belonging to another. The engagement of the acknowledging party is consummated by the ratitication of the treaty. It is no longer an executory contract, lut a perfeet right mited with a rested possession, is thenceforth in one party, and the acknowledgment of the other is in its own nature irrevocable. As a bargain the article is extinct; but the right of the party in whose faror it was made is complete, and camnot be affected by a subsequent war. A grant of a facultative right or incorporeal hereditament, and specifically of a right of fishery, from one sovereign to another, is an article of the same deseription. It is analogous to a cession of territory, and is in fact a partial and qualified cession. The right is consummated by the ratification of the treaty. The possession is rested by the exercise of the faculty.

So that whether the third article of the treaty of 1783 be considered as an acknowledgment of preëxisting liberties or as a grant of them, to be exercised within British jurisdiction, it was in its nature permanent and irrevocable.

Only on the assmmption that the treaty article in question createrl no new privileges but merely recognized an existing one, ean Mr. Adams' somewhat ingenious argument be accepted as somud. Howerer, as it is miversally agreed that a nation has full jurisdiction over its marginal waters, Mr. Adams' contention must be regarded as wholly mitenable. With a mind minflueneed or clouded by considerations of the national needs and popular elamors of a period, one may often look back over the distance of years and olutain a clearer view of political conditions and of international questions than was possible to the men who were callerl upon to grapple with them. 'The very nearness to difficulties oceasionally distorts the vision of great men and 
leads them into absurdities of reasoning that afterwards seem almost inexensible. John Quiney Adams was probably less influenced by the popular clamor of the day than by a certain family tradition in regard to the North Ameriean fisheries. His father, at Paris in 178-2-8:, hat defied the consequences of disoberlience to his country commancls, and harl staked his reputation as a patriot in order. to wrest from Great Britain those very fishery rights that he, the son, thirty-one years later at (ihent, found himself called upon to proteet. As a New Linglander he was saturated with the belief that the fisheries constitnted the most valuable American industry. It was the alling which for generations his comntrymen and their ancestors had followed almost withont interruption. The fisheries formed the very basis of the great commercial interests of his own New England. Under no circumstances must they be forfeited through neglect or fault of his. Their loss meant to his people the greatest of ealamities. Thus may one appreeiate the mental attitude that permitted in John Quney Adams so decided a warp in his reasoning upon this subject.

A satisfactory adjustment either of the fisheries, or the navigation of the Mississippi River, proved to be impossible, and it was finally agreed to sign a treaty that should remain silent on these two important subjects. Hence it is that no mention whatever is made of the fisheries in the treaty of Ghent (181t).

\section{II}

The inability to reach an understanding at Ghent, in regard to the fisheries left that question in a most unsatisfactory condition. The war clousk of 1812 hat no sooner blown away than the New England fishemen appeared in forec in Canadian waters. A series of eollisions with the Canadians immediately took place. English authorities, assuming that all American fishery privileges in british waters had lapsed by the war, arrested numbers of lioston and (iloncester $2 \kappa$ 
schooners on various eharges of trespass, and eondemned them as prizes in the Halifax courts. The disputed question of American fishery rights was frequently left to the rude arbitrament of American fishermen and the Dominion police, resulting in a severe strain upon the reeently restored amicable relations between Great Britain and the United States. In the Lnited States, where Mr. Adams' doetrine that American fishery rights har survived the war still obtained, feelings of anger and lostility to Great Britain grew more and more intense. Fortunately the tension was soon relieved by the Convention of 1818 , wherein a eompromise of the troublesome fishery question was effected. The first article of this treaty, the one relating to the fisheries, is as follows :-

Whereas differences have arisen respeeting the liberty claimed by the United states for the inhabitants thereof, to take, dry, and cure fish on certain coasts, bays, harbors and creeks, of His Britamnie Majesty"s dominions in America, it is agreed between the high eontracting parties, that the inhabitants of the United States shall have forever, in common with the subjeets of His Britannic Majesty, the liberty to take fish of every kind on that part of the sonthern coast of Newfoundland which extends from Cape Ray to the Ramean Islands, on the western and northern coast of Newfoundland from the said Cape Ray to the Quirpon Islands; on the sonthern shores of the Magdalen Islands, and also on the coasts, bays, harbors, and ereeks, from Mount Joly, on the southern eoast of Lilnrador, to and through the streights of Belleisle, and thence northwarlly indefinitely along the eoast, without. prejudice however, to any of the exehusive rights of the Hudson Bay Comprany and that the Amerien fishermen shall also have liberty forever, to dry and emre tish in any of the unsettled bays, harbors, and creeks of the sonthern part of the coast of Newfommlland hereabove deseriber, and of the coast of Labrador; but so sonn as the same, or any portion thereof, shall be settled, it shall not be law ful for the said fishermen to dry or eure fish at such portion so settled. withont previons agreement for sueh purposewith the inhabitants, proprietors, or possessors of the ground. And the United States hereby renounce forever, any liberty heretofore enjoyed or clained by the inhabitants thereof, to take, dry, or cure fish on, or within three marine miles of any of the coasts, bays, creeks, or harbors of His Britannie Majesty's do- 
minions in America, not inchuded within the above-mentioned limits. Provided, however, that the American fishermen shall be permitted to enter such bays or harbors for the purpose of shelter and of repairing damages therein, of purchasing wook, anct of obtaining water, and for no other purpose whatever. lint they shall be under such restrictions as may be necessary to prevent their taking, drying or curing fish therein, or in any manner abusing the privileges hereby reserved to them.

It will be observed that under this new arrangement Americans were permitted to fish in all waters falling within British marine juriscliction, on the south eanst of Newfomndland between Cape Ray and the Ramean Islands, and on the west and north eoasts thereof between Cape liay and the Quirpon Islands; on the sonthern shores of the Magdalen Islands and upon the Labrador coast from Mount Jolly northward indefinitely. The coasts of Nova Seotia, New Brunswick, Lower Canada, Cape Breton, more than half of the south coast, and all of the east eoast of Newfoumdland, were excepted from this grant of fishery privileges. It must he borne in mind that the bank and all open sea fisheries were entirely free to the world, for at this time no nation pretencled to control the high seas.

The privileges of landing for the prupose of euring and drying fish were withlueld from the Uniter States, exeept upon the south shores of Newfoundland from Cape liay to the Rameau Islands, and except upon the coast of Lablactor, - and here the right was only granted within unsettled bays and harbors. In all other bays or harbors of the lominion, American fishermen were fully privilegen to enter for certain designated purposes,__ "shelter," "repairing damages," "purchasing wood," and "obtaining water," but for no other purpose whatever.

The arloption of these regulations was ealled in the United States a "compromise," because American statesmen still eontended that the Cnited States owned the Camadian fisheries by a title as groorl as that of freat Britain, and that by the relinquishing of jurisdictional privileges over certain parts of the Canadian coast, and accepting England's recogni- 
tion of them on other parts of the coast, a genuine compromise had been effected. It is curious to note the light in which this fishery clause was regarded by eminent statesmen of the period, and indeed by many since. Never abandoning the idea of John Quincy Adams that the United States possessed and always had possessed an inherent and natural right to the inshore fisheries, a right that had survived the operation of war, they firmly believed, and as solemnly argued that, by the convention of 1818, England granted no fishery privileges to the United States, no rights of landing to cure fish or to obtain supplies, but, on the contrary, the United States had simply consented to certain restrictions on those rights and privileges always possessed. This erroneous conception of the spirit of the convention might be dismissed as an innocent historical or legal eurio, had it not vitally affected the interpretation of the words, and later given rise to much nisunderstanding between England and the United States.

The adherents to this view found proof of their contentions in that part of the fishery clause wherein the United States expressly "renounces forever any liberty," ete. They urged that in the use of these words Great Britain acknowledged those preëxisting and natural rights. The insertion of that phrase had been insisted upon by our eommissioners, Messrs. Rush and Gallatin, and was reluctantly allowed by the British representatives, who were actuated by a strong desire to settle the troublesome quarrels of the fishermen as quickly as possible, and to remove the whole question from diseussion. This fallacious theory of a "natural and inherent right" has never entirely lost its influence, even to the present day. It has been defended by the ponderous arguments of many legal writers, as it eolored the deliberations of govermment oftieials.

With the promulgation of the new rules and regulations of 1818, the future of Ameriean fishermen seemed partienlarly bright. Congress eneouraged them the following year with increased bounties. The fisheries had suffered greatly through the vicissitudes of war. Blissfully ignorant of, 
and probably caring little for, the diplomatic wrangles over the legal nature of their rights, the fishermen took immediate advantage of the privileges just opened to them, and sought to restore their inclustry to a laying basis. In the course of a few years, howerer, a harest of new and unforeseen troubles ripened to confound the nen who had fishing interests in charge. Fresh quarrels grew alarmingly, and in the course of some years reached a degree of intensity that forboded anotler war with Great Britain. Happily such a calamity was arerted in time, though not before the "Fishery (question" had given evidence of its liability sooner or later to embroil the nation in armed confliet.

In 1819, Parliament emacted a statute to carry out the provisions of 1818. This statute authorized local regulations to declare it unlawful for foreign vessels to take, dry, or cure fish within three marine miles of any coast, bays, creeks, or harbors in any part of His Majesty's dominion in America, not included in the limits of the treaty. It defined with particularity the privileges of American vessels in all such bays, ereeks, harbors, etc., -i.e., to enter only for the purpose of obtaining shelter, repairs, wood and water, - and it provided that if any vessels were eanght violating, or preparing to violate, those laws, or that refused to depart from such bays, ete., wher ordered to do so, they should be liable to certain emmerated punishments and fines. No objection could be found to this act itself, but in alleged conformity to it, and for the purpose of carrying ont its provisions, the provincial legislatures of British Ameriea, from time to time, enacted series of laws relating to the fisheries that were far more stringent and rigid in their nature than justified by the original parliamentary act. These provincial regulations manifested a spirit of unfriendliness, and it was often asserted that they were executed with a severity and in a manner wholly unwaranted and improper. By the narrowest construction of the terms of the treaty they restricted the rights of Americaus in every possible way. In accordince with these laws, the Canadian police authorities detained 
American fishermen upon the most shadowy pretexts, and otherwise rexatiously harassed them, sometimes confiscating their vessels upon the merest suspicion of offence. While these burdensome regulations were unnecessarily severe, and perhaps maliciously enforced, it is more than probable that American fishermen were not always guiltless of the offences charged to their account.

A new form of fishery was at that period rapidly developing which brought into Canadian waters conclitions entirely novel, and which, not having been anticipated by those who framed the convention of 1818 , were not provided for in that instrument. Mackerel had appeared in vast quantities, and with them, in close pursuit, a large fleet of American sclooners. The modus operandi of the mackerel fishery is entirely different from that of the cod fishery. The latter, even at that day, was carried on for the most part on the Banks, or in localities generally well removed from the debatable waters of British sorereignty. The men who confined themselves to cod fishing had less oceasion to seek shore stations, either for bait or shelter. The mackerel fishery, on the other hand, constantly lured its followers within the three-mile limit of the Nova Scotia and New Brunswick shores, for it is the habit of these fish to hover about the shallower reaches of the sea near land. Large quantities of bait were cast upon the waters to tempt the fish within range; this process, of course, necessitated frequent landing at Canadian ports to procure fresh bait supplies; besides this, the nets employed in taking makerel demanded for their proper preservation necasional drying upon shore. Now neither of these acts fell within the list of privileges guaranteed to American fishermen in Nova Scotia or New Brunswick loy the treaty of 1818. As American fishermen were perlates not overconscientions in these matters, disputes between them and the Canalians grew more and more frequent, and the situation soon became painfully acute. Numbers of New England vessels were held on elarges of "fishing within the prescribed limits"; "hovering within shore during calm weather withont ostensible cause, having on board 
ample supplies of wool and water"; "lying at anehor and remaining inside of bays to elean and pick tish " ; " selling goods and buying supplies" ; "landing and transhipping" cargoes of fish.'

The fishermen of the Lnited states were privilegerl hy the treaty to take fish of every lind on the southern shores of the Magdalen Islands. This involved the herring fishery, and herring are certainly included in the comprehensive term "fish of every lind." From the peculiar mode of taking this kind of fish, resort to the shore was necessary for hauling seines and construeting weirs, but the Canadian authorities remained inflexible in their determination to prevent such landing. It is true that on these islands no landing privileges were expressly gruaranteed in the treaty, hut it was eontencled in Washington that as the fishery of the Magdalen Islands was prineipally for herring. - a mole of fishery carried on from the shore, - the right to prosecute it at all must of necessity presuppose the right to use the shore. At all events, whether or not landing privileges are inseparable from the right to take lerring, Ameriean fishermen eontinued to land on the Magdalen Islands, despite the opposition of the natives. A petty warfare resulted that kept full the measure of ill-feeling hetween New England and Canada.

A subject that provoled much discord, and that soon involved the two powers in another diplomatic controversy, arose from opposing theories entertained in Great Britain and the United States concerning the line of "three-mile limit" as applied to the bays and harbors of British Anerica. Several Ameriean vessels, including the Washington in 184:?, had been seized within the bay of Fundy and other "bays" " of the coast, at a greater distance than three marine miles from the shore. The Canalian authorities, to make sure of their position in thus seizing foreign vessels ontsille a threemile line from the shore, had appealed to the crown lawyers at London to ascertain definitely whether Anericans had a right, under the treaty of 1818 , to fish in the bays of Findy and of Chaleurs, or to navigate the Strait of Canso; or, in 
other words, to learn whether the doctrine of "Headlands" applied to these great bodies of water. The reply of the queen's counsel assured them of their undoubted right to exclude all foreign vessels from fishing in any of the larger bays of British America. "Except," they wrote, "within certain defined limits, to which the query put to us does not apply, we are of opinion that, by the terms of the treaty, American citizens are excluded from the right of fishing within three miles of the coast of British America; and that the prescribed distance of three miles is to be measured from the headlands or extreme points of land next the sea of the coasts, or of the entrance of the bays, and not from the interior of such bays or inlets of the coast; and consequently that no right exists on the part of American citizens to enter the bays of Nova Scotia, there to take fish, although the fishing, being within the bay, may be at a greater distance than three miles from the shore of the bay, as we are of opinion that the term 'Ineadland' is used in the treaty to express the part of the land we have before mentioned, excluding the interior of the bays and inlets of the coasts."

Althongh the term "healland" does not appear in the instrument referred to, the British interpretation of the "three-mile limit," as applied to all harbors, bays, or indentations of the coast, was made clear by this decision of the royal counsel.

It was held in the United States that the phrase "within three marine miles of any of the coasts, bays, creeks, or harbors," indicated an imaginary line three miles distant from and following the sinuosities of the shore. Thus all bays over six miles wide at their entrances would be free to their fislsermen, except, of conse, within three miles of shore. This question becane a pressing one about 1840, and preeipitated a lengthy disenssion between Washington and London. Theoretically, the question of "headlands" has never been definitely settled, and the many authorities in international law furnish as yet no fixed rule for guidance. In general it may be said that the tendency of the law of nations is to restrict the extent of marine juriscliction. In the matter 
of harbors and bays, international usage has long established the propriety of reserving within the limits of national jurisdiction bodies of water, or arms of the sca, the entrances to which from the ocean may exceed six miles in width. Many examples of this can be found in England and France; in the United States no one doubts the legality of our claim to the full jurisdiction over Chesapeake ant Delaware bays, and over Long Isliund Somnd, all of whose entrances from the open sea measure more than six miles from headland to headland. An approximate rule only may be formulated respecting the length of the line from hearlland to headland that may reasonably be claimed to form a divisional line between the open ocean and juristictional waters. 'This may be somewhat vaguely stated as double the length of a cannon shot; or, in other words, all bays, recesses of the sea, or inland waters comneeted with the ocean, whose entrinces may be clefended by cannon placed upon the opposing hearlands, are properly subject to the juriscliction of the nation possessing their shores.

The English construction of the terms "three marine miles of any of the coasts, bays," etc., was moloubterly correct, so far as that principle governs the smaller indentations of the seacoast, but the gross error in their eontention laty in the effort to include within the definition of "bays" such great bodies of water as the Bay of Fundy or the biay of Chaleurs. The distances from hearland to headland at the entrances of these great estuaries measure no less than sixty miles, clearly excepting them from the most liberal designation of cloned seas.

The British Government, however, showed some signs of relenting, though not of recerling from the position it had taken regarding the elosed natmre of the bay of fiundy. In $18+5$ Lord Aberdeen announced that ont of comsiderations of courtesy Great Britain would yield to the Lnited States the right of her fishermen in that hay, "provided they do not approach, except in the cases specified in this treaty of 1818 , within three miles of the entrance of any bay on the const of Nova Scotia or New Brunswick." Mr. Everett, the Ameri- 
can Minister to the court of St. James, very properly declined to receive this privilege as a faror, but reiterating the Ameriearr claim, he explained that it was "not for the sake of detracting from the liberality evinced by Her Majesty's Govermment in relaxing from what they regarded as their right, but it would be placing his own government in a false position to accept as a mere faror that for which they had so long and so stremously contended as due them from the convention."

The eolonists of Nora Seotia and New Brunswick were greatly disturbed by Lord A berdeen's proposed "concession." Fearing it indicated a weakening in the face of Ameriean contentions, and that it might perhaps presage a more general yielding of all the large bays of the Dominion to the operations of foreign fishermen, they hurriedly despatched an envoy to London, who appeared before the colonial office with representations "of the injurious consequences certainly to result to Her Majesty"s Ameriean subjects, were the negotiations with Mr. Everett to be coneluded on the basis proposed." The policy of the colonial seeretary was accordingly abandoned, and the bay of Fundy was again declared to be a closed sea. The rexatious shipping regulations of the Dominion were even more strictly enforced than before; seizure of American ressels was continued; and the animosity which had been smouldering in New England against its northern neighbor's nearly blazed into war.

The Canadians, on their sille, were thoroughly indignant at what they considered the persistent lawlessness on the part of American fishermen, and they displayed their resentment in still another form. 'The Strait of Canso, between Nora Seotia and Cape Breton, affords a shorter and safer route to vessels making the Gulf of St. Lawrence from the sonth. This narrow passige is in eertain places not more than a mile in wirth. When the navigation of two seas is free, the navigation of a channel connecting them should also be free, although it may for certain reasoms be made subject to a toll regulation. The Cinalians insisted that the Strait of Canso fell within the deseription of territorial waters, and they conseguently denied the right of passage through it to 
American fishing vessels. American fishermen were not justified in tarrying in the strait or fishing therein, but its prohibition merely as a channel of communieation was distinetly an unfriendly act.

The affair of the Washington had not been forgotten ; claims for indemnity were presented by her owners and the matter was laid before the British authorities. In 1852 this claim along with others was referred to a commission in London. By decision of an umpire, the Bay of Fundy was declared not to be a mare clausum within the meaning of the treaty of 1818. In this matter, then, the American contention was sustained, and one of the unhappy subjects of controversy growing out of the fisheries was laid at rest.

About this time (1847-54) commercial relations with the Canadian provinces were beginning to develop along new lines. The free-trade policy of England had opened her ports to the world's trade, and this to a large extent had deprived the Dominion of her most valuable markets; and her merchants holefully turned to the United States. 'To enter American markets with their products became to them an object of prime importance. In 1847 overtures were made to Congress for reciprocity, Canada promising full freedom to American fishermen in return for a remission of tariff duties upon her fish. For several years Congress refused to consider the question, and the colonies vented their displeasure by an inereased naval foree to patrol their waters and terrorize American fishermen. It was soon suspected that there was a method in this marlness of a $D_{0}$ minion navy, and the attempt. smpposed or real, to eoerce the United States into a reciprocity treaty, by annoying hor fishermen, provoked an anmated disenssion in Congress. Mr. Hamlin, of Maine, declared that the semrling of a naval force to the fishing gromuds, pending negotiations, was "notling more nor less than to compel the United States to legislate under duress," and to this he, for one, was moilling to submit. A growing sentiment manifested itself to despatch to Canadian waters a naval force of equal proportions. Mr. Webster promised the people of Massachusctts that the 
administration would protect the fishermen, "hook and line, bob and sinker." An American war vessel was sent to the seene; the relations of the two countries became most critieal and war was again predicted. When popular excitement was rumning high, the Governor General of Canada, Lord Elgin, eame to Washington (1854) for the purpose of making a commereial treaty with the United States. It was a most inopportune time for the suceess of his mission, not only on account of the ill-feeling throughout the East toward Canada and the deeided opposition in Congress to any form of reeiprocal trade relations with her, but it was also the moment when political parties in the United States were alsorbed in a desperate struggle over the Kansas-Nebraska Bill, and were too deeply agitated by the threatening aspect of the slavery question to give willing heed to less important affairs. Notwithstanding these obstaeles, Lord Elgin succeeded. In the short space of a fortnight, a treaty " Extending the Right of Fishing and Regulating Commerce and Navigation between the United States and the British possessions in North America," was signed (June 5, 1854).

\section{VII}

Up to this point in the history of the fisheries, the discussions relative to the rights and liberties of eitizens of the United States in Canadian water's, and all negotiations looking toward larger British eoncessions, had been almost wholly free from entanglement with the many coneurrent diplomatic questions between Great Britain and the United States. With the exception of that famous dispute concerning the navigation of the Mississippi River, which had been for a time associated with it, the fishery question was fought out alone, and wyon its own merits. liy the year 1854, the most important of the legal points involved in the old eontroversy had been disposed of. Although the doctrine of "inherent and natural right" to the fisheries still found its supporters, those notions had been praetieally abandoned, and the rights of Ameriean eitizens in Canadian waters were admittedly 
based upon the eonvention of 1818 . Fngland had receded from her eontention of mare clausum in regard to the Bay of Fundy. Barring some minor disputed points, there existed between the two governments a fairly good understanding as to the broad principles of law mnderlying the question. In future, American rights in the inshore waters, and upon the shores of Canadi, were to become matters of purchase, and the whole fishery question, with its record of strife and contention, was transferred from the domain of law to that of politieal eeonomy. What are the fisheries worth to New England, and what will be a suitable quid pro quo were the queries to be answered. The compensation Canada nost desired for the freedon of her shore water's was eommereial favors. The fisheries, therefore, became associated with commercial reeiprocity, and the two questions lave beteome so thoroughly associated, that to-rlay they cannot well be eonsidered separately. Although those larger and more serious disagreements which had formerly characterized all negotiations eoncerning the fisheries, and which had rendered their suecessful termination so diffieult, were removed, minor issues of a legal nature were yet to appear, and to produce at times a high degree of irritation.

The treaty of 1854 permitted a free exchange of nearly all the land and sea products of Cinada and the Cnited States. The first article relating to the fisheries is as follows : -

It is agreed by the high contracting parties that in addition to the liberty seeured to the United States fishermen by the above-

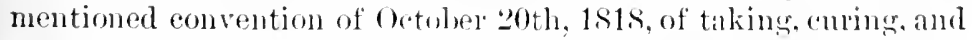
drying fish on certain coasts of the British Torth American Colonies therein defined, the inhabitants of the United States shall have, in common with the suljerets of Hor Britamic Majesty, the liberty to take fish of arey kind, exerpt shell fish, on the seacoasts and shores, and in the lays, harbors, and crecels of Canadio. New Brunswiek, Nova Seotia, l'rince Edwad's Island, and of the several islands theremento aljacent, witlont being restrictexl to any distance from the shore. With permission to land upon the roasts and shores of those (olonies anm the islands therenf, and also upon the Magdalen Islanils, for the purpose of drying their nets and 
curing their fish; provided that, in so doing, they do not interfere with the rights of private property, or with British fishermen, in the peaceable use of any part of the said coast in their occupancy for the same purpose.

By the second article, Canadian fishermen were accorded similar privileges in American waters north of latitude $36^{\circ}$.

With the sole exception of taking "shell fish," the Americans were practically placed upon the same footing with British subjects in the prosecution of the fisheries in Canadian waters. By the fifth article it was stipulated that the treaty " is to remain in force for ten years and further, until the expiration of twelve months after either party shall give notice of a wish to terminate the sime."

The effeet of this agreement upon American fishermen was almost magical. Their disputes were immediately forgotten, and harmony reigned. In Canada, where formerly the American fishermen had been regarded as enemies, they were now weleomed as the best of friends. The Canadians rejoiced in the new and extensive markets opened to their produce, and their trade soon quadrupled. Nova Scotia and New Brunswiek entered upon a period of extraordinary prosperity, and their fisheries leaped at a bound from conditions of adversity to those of great prosperity. But such delightful tranquillity upon the fishing grounds was not destined to last many years; a viriety of canses led to the abrogation of the treaty of $185+$ by the United States at the end of the stipulated ten years. 'The first note of alarm was sounded by the Maine and Massachusetts fishermen themselves, who began to complain that the free admission of Canadian fish into the United States crippled their own industry. Owing to eheaper labor, and their greater proximity to the fisheries, the Canadians were enahled to undersell the New England fishermen in the Boston markets. The extent of the free list of Canadian products was so great that it largely curtailed the revenues the government needed. Senator Sherman estimated this loss mon the single item of lumber to be $\$ 5,000,000$ a yeur. It soon became evident that the price being paid Camala for the freedom of her fisheries was too great. 
Notwithstanding these very urgent reasons for altering the laws at the end of the stipulated ten yeir's, it is probable that the regulations would have continued in force for a longer period had it not been for the Rebellion in the United States. At the begimning of the Civil war trade conditions in the United States materially ehanged. The neeessary increase of taxes, together with radical changes in eurreney values, producing inereased eost of labor, enabled the Canarlian farmer to supplant the American in his own markets. The unfriendly attitude of the Canadians toward the Govermment during the civil confliet furnished an additional ineentive to withdraw the advantages which the treaty of 1854 concededly gave them. The Canadians had exhibited a marked disposition to profit by the diffieulties of the Lnited States; Montreal and Quebec harbored the most virulent enemies of the Northern eause, and at one time the Provinces were suspected of contemplating the seizure and annexation of Maine.

Notice was given in March, 186in, and the following year the treaty was terminated. With the abrogation of the reeiprocity treaty, the provisions of the agreement of 1818 again came into foree, the stipulations contained in the treaty of $185 t$ having been based upon and declared to be "in addition to those of the eonvention of 1818." Therefore the old seheme of restricting Ameriean fishermen to certain limited areas of inshore waters of Newfoundland, to the coastal waters of Labrador and to the southern shores of the Magdalen Islands, together with contracted landing privileges, was revived.

The Canadians were greatly disappointed by the recession of the reciprocity treaty. The largely inereased volume of their export trade and the gratifying prosperity of their fisheries, both direetly resulting from the freedom of the Ameriean markets, immediately declined and withered. Referring to economic conditions in Nova Scotia, the editor of the Halifax Chronicle said that from the abrogation of the reciprocity treaty, "we have retrograded with the most frightful rapillity." litter complaints of the "selfish policy" of the United States arose from every side. 
With the return to those conditions which had existed prior to 1854 , the same old quarrels and encounters among the fishermen reappeared. Lord Monck, the Canadian Governor General, promptly issued notice to Americans that inasmuch as their general fishery rights had ceased, any infractions of the laws relating to them would forthwith be severely punished. Trouble began to threaten even before the close of the first fishing season. The Canadians thereupon adopted a license system granting full fishery privileges to American schooners on payment of an amnual tax. New England skippers generally arailed themselves of this arrangement, but each succeeding year the price of licenses was increased ( 50 eents a ton in $1866, \$ 1.00$ in 1867 , and $\$ 2.00$ in 1868), until by the year 1869 the duty lad virtually become prohibitive, and American fishermen refused to pay it.

The various provinces of Canada having consolidated into the Dominion of Canada, the Parliament at Ottawa, in 1868, issued in reference to the fisheries a new code of laws which was thought by Americans to be needlessly severe. Canadian maritime officials redoubled their vigilance; as a result a large number of New England fishing smacks were captured, and they generally suffered the penalty of forfeiture. The fishermen's quarrels assumed constantly increasing violence, and so much bitterness was aroused in the New England States that open rupture with England again seemed probable. In evident desperation an order was issued in 1870 by the Governor General of Canala to the effeet "that henceforth all foreign fishermen shall be prevented from fishing in the waters of Camada." To enforce this questionable edict, the Dominion assumed the expense of fitting out cruisers to patrol the waters of Nora Scotia, especially those waters in and abont the Bay of Fundy, where, it was alleged, American captains purchased bait and supplies in open violation of the law. Four hundred Amerienn vessels were boarder, and of these fifteen were detained and afterward condemned. When the situation had become most threatening, the fishery question was onee more set at rest by the treaty of Washington (1871). 


\section{VIII}

In 1870, a number of Anglo-Ameriean claims growing ont of depredations committed during the war had acemulated, and were pressing for adjudication. These claims were gathered together and by the agreement of a joint high commission were referred to rarions bourds of arbitration. It was an opportune moment to settle the fishery dispute, which, true to its old-time traditions, had reawakened and demanded an immediate settlement. It therefore fell in with the other issues under diseussion at that time and the subject was included in the eomprehensive Anglo-Ameriean treaty of 1871 .

The eighteenth artiele of this latter instrument renewed the provisions of Article 1 of the reciprocity treaty of 18.54. it being further stipulated in the treaty that it shonld remain in force for a period of ten years. and for two years after notice of its termination by either party ; Article 19 extended the privileges of fishing in the territorial waters of the United States as far down as the 39 th clegree of hatitude: Article 21 provided for the free admission into Ameriean and Canadian ports of fish and fish oil. During the negotiation of the treaty, the Inited States commissioners offered to pay to Canada the smof of $\$ 1,0(10.000$ in return for full American privileges in their inshore tisheries in perpetuity. This sum was thought hy the eommissioners tentering it to be greater than the real value of these inshore fisheries, but the amount was probably not too great for a positive guarantee of freedom from further molestation. 'The offer was deelined by the English commissioners as insufficient in amount, but the rliseuscion of a money consideration led to the insertion in the instrument of the following artiele $(221):-$

Inasmueh as it is asserted by the Gorermment of Her Britamice Majesty that the privileges aremerled to the ritizens of the Cuiterl States uncer Article 18 of this treaty ale of serater value than those accorded by Articles 19 and 21 of this treaty to the subjerts of Her Britannic Majesty, and this assertion is not andmitted by 
the Government of the United States, it is further agreed that commissioner's shall be appointed to determine. having regard to the privileges accorded by the United States to the subjects of Her Britannic Majesty, as stated in Articles 19 and 21 of this treaty, the amount of any compensation which, in their opinion, ought to be paid by the Government of the United States to the Government of Her Britannic Majesty in retum for the privileges accorled to the citizens of the United States under Article 18 of this treaty: and that any sum of money which the said commissionel's may so award shall be paid by the United States Government, in a gross sum, within twelve months after snch award shall have been given.

Article 29 provided that the three commissioners proposed in the previous clause should be appointed, one by the President of the United States, one by the queen of England, and the third conjointly by the two; though in case they failed to agree upon some one within three months, the ehoiee of the third commissioner should then fall to the Austrian Ambassador in London.

It will therefore be observed that by this treaty the Canadians secured one of their most eherished desiderata, - the abolition of all United States customs duties upon the products of their fisheries. The American fishermen in return gained perfect freedom in Canadian inshore waters, - though at what seemed to them to be a ruinous cost, i.e. free Canadian fish; they had alrealy realized their inability to compete successfully upon even terms with Canadian fishermen.

Believing that their government had given too great a price for a free Canadian fishery, the New England fishermen thonght it simply preposterous that the United States Govermment should be willing to pay in addition, a money consideration.

The agreement to leave to an Austrian (under certain conditions) the choice of a member of this proposed board was unfortmate. It might reasonably have been feared that a selection from Viemna would have been prejudiced, as the ambitions of the house of Hapsburg had but recently been frustrated by the United States in the threat to expel 
Maximilian and his Freneh army from the Western continent. The United States Govermment realized the blunder too late, and in the attempt to free itself from the mistake of its commissioners, it fell into even greater difficulties. The aeting Secretary of State, Mr. J. C. Bancroft Davis, proposed to the British Govermment the names of a number of foreign ministers in Washington whose knowledge of the English language qualified any one of them to act as the third commissioner in question. The name of Mr. Delfosse, the Belgian Minister, had been purposely onitted from the list, for the reason that the intimate political relations between England and Belgium (strengthened by the ties of close kinship) in their royal families) seemed to disqualify any belgian from acting in such a diplomatie eapacity. Lord de Grey, one of the British commissioners who had signed the treaty of Washington, had given it as his opinion that Belgium and Portugal need not be considered in this comnection, for their treaty arrangements with England "might be supposed to incapacitate" their representatives from acting upon such a commission. A desire beame evident on the prirt of the British Minister in Washington to delay the choice of a third arbitrator until the end of the stipulated period, when the selection would fall into Austrian hands. Finding that the United States entertained objections to Mr. Delfosse, the English Govermment aceordingly offered him as their choice, no doubt anticipating a lengthy discussion which would waste time. Upon further request to name some other person for neutral member of the board, the british premier suggested that the American and British Ministers at The IIgue should seleet jointly some Duteh subject, but the recently appointed Ameriean Minister to that capital felt his inability, through a lack of acquantance with the people, to make an intelligent choice: so that scheme was abandoned. Mr. Thornton, the British Minister in Washington, wrote that circumstances seemed to point either to the selection of Mr. Delfosse or to the alternative provisled for in the treaty. 'The three months' allotted time was about to expire, and there appeared to be no escape from an appointment by the 
Austrian. An extension of time, however, was agreed upon, for Canada, still anxions for reciprocity, had sent proposals to Washington for a new treaty of commerce and fisheries which would do away with the proposed board of arbitration, and entirely dispense with all additional compensation for the freedom of her fisheries. A draft of treaty was presented, the provisions of which almost totally remover protective duties from Canadian products, but guaranteed in return perfect freedom to American fishermen. The proposition was submitted to the Senate in 1874, and met with an unfavorable report the following year. The matter of the unselected commissioner accordingly revived.

The stipulated time as extended had passed, and in 1875 the British premier requested an identical note to the Austrian Ambassator in London, asking him to name the third commissioner. For various reasons the correspondence dragged on for over a year without results, but at length the Secretary of State, finding himself between Seylla and Charybdis, and being exeeedingly desirous of closing the matter as quickly as possible, decided that Mr. Delfosse"s selection would likely prove the lesser evil of the two; he accordingly suggested to the British authorities, in 1877, that the United States would not oppose the appointment of the Belgian if the British Government still desired his selection. It was agreed, however, upon a request from London, that in conformity with the treaty stipulations, Count beust, the Austrian Ambassador at London, should name Mr. Delfosse, - which he proceeded to do. at once.

Thus the United States was placed in the unfortunate and wholly false attitude of having requested Mr. Delfosse's appointment, and was therefore all the more hopelessly estopped from afterward excepting to any rewarl he might see fit to. make. Much adverse eriticism was expressed in the United States when all the correspondence was published, which. bronght to light the clever diplomatie tactics of Great Britain in taking advantage of the American commissioners' blunder 
(1871) in thus leaving the choice of the thirel arbitrator to one whose feelings towarl the Lnited states might be unfriendly.

Both Count Beust and Mlr. Delfosse were probably maware of the proeedings that had taken place between the English premier and $\mathrm{Mr}$. Fish, relative to the selection of a third commissioner. The former would doubtless have evineed some delieacy in venturing to propose Mr. Delfosse; and the latter, had he felt that he was persona non yrata in this comnection, would certainly have declined to serve.

The board convened at Halifax, Jme 15, 1877. The commission was composed of Sir Alexander Galt (British), E. H. Kellogg (American), and Mr. 1)elfosse as the neutral member. Secretaries, official reporters, and a host of elerieal assistants, together with an array of counsel, combined to make an imposing gathering.

Newfoundland at once presented a claim for compensation to the amount of $\$ 14.880,000$, for privileges enjoyed by Ameriean fishermen in her waters and upon her shores during the past twelve years, but the argment in sulport of this elaim was met by the answer that such demands were fully covered by the remission of Ameriean tariff duties upon her fish. The American eounsel further insisted that the juriscliction of the board wats restricted to the duty of ascertaining how much mose valuable, if more valuable at all, free ('anatian fisheries were to the Inited States than similar privileges in American waters eombined with free importation of Canadian fish into the Lnited States were to the Canadians. On November 2:3 of the same year the award was found, the following verdict being rendered, together with the dissenting opinion of the American commissioner:-

The commissioners appointed, etc. . . A Aard the sum of five millions five hondred thousand dollars in gold to be paid by the government of the United States to the government of Iler liritamnic Majesty in aceordance with the provisions of the said treaty.

Signed at llalifax, ete. . .

MaUiage Delause.

A. 'T. Galt. 
The United States Commissioner is of opinion that the advantages accruing to Great Britain under the treaty of Washington are greater than the advantages conferred on the United States by said treaty, and he cannot therefore concur in the conclusions announced by his colleagues.

And the American commissioner deems it his duty to state further that it is questionable whether it is competent for the board to make an award under the treaty except with the manimons consent of its nember's.

\section{E. H. KellogG,}

Commissioner.

News of the award was received in the United States with astonishment, the feeling being general that the eountry had been wronged. The sum was grossly excessive. It was estimated that the remission of duties on Canadian fish cost the govermment about $\$ 3,50,000$ yearly, and this added to the sum awarded at Halifax made the total cost of Canadian fisheries for twelve years abont $\$ 10,000,000$. The true value of the fisheries of Canala was computed to be worth about $\$ 25,000$ a year. The Senate committee on foreign affairs chafed under the injustice of the decision, and its members began to consider the suggestion in Mr. Kellogg's dissenting opinion that a majority decision alone was insufficient to bind the United States. A disposition was quite manifest to evade, if possible, the payment of so mureasonable a sum. However, the feeling finally prevailed that it was a debt of honor, and the award was paid. A resolution was immediately taken to abrogate the treaty at the "earliest period consistent with Article 33 " of that instrument.

The treaty of Washington had gone into effect July 1 , $187: 3$; notice was given at the end of the stipulated ten years, and the treaty articles referring to the fisheries were terminated on .July 1, 1885-two years later. 'Thus the status of the fishery question reverted for the third time to the conditions of the convention of 1818 .

Before the abrogation of the fishery clanses of the treaty of Washington, an incident oecurred in Canadian waters (Januiry 6,1878 ), that brought to the attention of the 
State Department a new difficulty commected with the subject. One Sunday some American fishermen were hanling their herring seines near the settlement of Long Harbor in Newfoundland. "It appears that a local statute was in force forbidding such desecration of the Sabbath. A native mob, whose religious, scruples had leen offended, set upon the luckless Americans and drove them from the region. This adventure brought to light the variance between the imperial law and loeal regulations. The question at once arose - Which are paramount, treaty rights or local ordinances? The British Foreign Office at first contended that the treaty was marle sulject to all local laws or harbor regulations that affected all people alike, but ultimately acknowledged the supremacy of treaty rights, and consented to have all local laws at variance with them suspenterl. The Secretary of State, Mr. Evarts, urgerl that "this govermment conceives that the fishery rights of the United ates conceded by the treaty of Washington, are to be exrrised wholly free from the restraint and regulations of the atutes of Newfoundland." The matter was closed by Great britain paying the sum of $\$ 75,000$ damages to the outraged American fishermen.

\section{IX}

With the alorogation of the treaty of Washington in 1885 , and the consequent revival of the numerous restrictions inposed by the convention of $1 \varsigma 18$, it was fully expected that the quarrels of the fishermen wonld begin anew. To mitigate the losses the Amerieans would undonbtedly suffer by the sudden withdrawal of privileges they had enjoyed in the midst of a fishing season, an agreement was made with Canada to continne in operation the fishery chauses of the Washington treaty during the remainler of the season 1885. The Dominion eherisher the hope that as as "e procity treaty would soon be made, and negotiations wes once entered upon with that ohject in view. President c'ler. land in his annual message of December 8, 1885 , proposed in 
the interests of "good neighborhood," that a joint high commission should be appointed, "charged with the consideration and settlement npon a just, equitable, and honorable basis, of the entire question of the fishery rights of the two govermments and their respective eitizens on the coasts of the United States and British North America." The fishery interests, he insisted, were intimately related to other general questions dependent upon contiguity and intercourse. This of course pointed lirectly to reeiprocity, but the New England fishermen protested so londly against any ehange of arrangements, that the P'resident's recommendations to Congress were adversely considered.

To mnderstand clearly the opposition of American fishermen in 1885 to any change in the regulations of 1818 that placed upon them so many disabilities, and against which they had so steadily clamored for years, a glance at the changing character of the fisheries becomes necessary. In the earlier part of the century, American fishermen were almost wholly dependent upon their shore privileges, both for the purpose of refitting, obtaining supplies and bait, and for drying and curing their cateh. The fishing grounds along the Maine coast, having long before become practically exhausted, the Canadian inshore waters were next exploited, and the most liberal privileges to fish in such waters were songht by the Americans. Gratually, however, American cod fishermen withdrew to the richer fisheries of the Banks, employing larger vessels and taking with them the necessary supplies of salted or iced bait to last the entire cruise. 'Thus they became more and more independent of the shore privileges they had formerly songht. The drying and curing proeess laving also been abandoned for better methods, the necessity for landing on Canadian soil was again lessened.

The sudden rise of the mackerel fishery (abont 1850), again made inshore privileges of vahe to a class of fishermen that followed it exelusively, for, as already observed, this business was for the most part earried on within British territorial waters. Even before this time (1885), the use 
of the purse seine had smpplanted the old method of " chmmming" for mackerel. 'This was carried on in deeper water, and without the use of bait. Malibut fishing in the vicinity of the provineial shores was at one time profitable, but it, too, was found to yield better results in offsliore waters. Herring alone remained in $18 \mathrm{~s}$ a a purely inshore fishery, but its importance was relatirely small; owing to constant disagreements with the natives, with whom this ocempation brought our men in close contact, the practice of purchasing herring from the provincial fishermen gradnally ame to be adopted. Thus in 1ss.5 the shore privileges, for which American statesmen hat so strenuonsly eontented, hat become of comparatively little value to Anerican fishermen. But the privilege of entering Canarlian ports for certain murposes was still desirable, for all the contingencies of long voyages and lengtly sojourn upon the Banks conld not always be provided against before departure fiom home. Continued boisterons weather often prevaled, and on. account of the delays anued thereby, together with accidents that are likely to ocur in such exposed stations, the: right to enter any nearly harbor to retit or purehase fresh supplies was useful thomgh mot perhats ahsolutely necessary. These privileges were alrearly provided for by the treaty

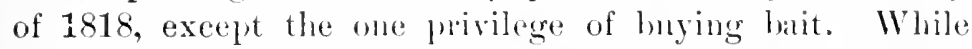
this single privilege was less important in some respects than the others, it was still eomsillered to be worth a price, though not so great a priec as the remission of luty njom Canadian fish. Asirle from the guarels in which these fishermen so often fomml themselves involved when they visited Camadian ports, Anerian skiplers found other good reasons for alostaining, as far as possible, fom the necessity of making port doring the fishing season. A roun ashore consumed valuable time, and invariably demoralized their crews; the more frequent the calls in port the less efficient became their men. Not a few of the shreweler captains of "bankers" would have quietly welcomed the excuse to offer their men that all law ding on ('analian shores was prohibited.

It will be remembered that the treaty of 1818 gave the 
right to American fishermen to enter any of the harbors of British America for the purposes of shelter, repairing damages, purchasing wool and obtaining water, but "for no other purposes whatever." 'The Dominion Govermment interpreted this phrase technically and strietly. The seizure of the American vessel David J. Adams in 1)igby Harbor, Nay 7, 1886, for landing and purchasing'bait and ice, was followed soon after by screral other seizures upon the same charge. The trial of these alleged enlprits brought to the front the linitation of privileges in Canadian ports which was imposed upon Americans by the Dominion laws as based upon the treaty of 1818 .

The Lnited States contended that while it was perfectly true that the right to purchase bait in Canadian harbors, and also the right to enter such harbors for any other purposes than shelter, repairs, and to obtain wood and water, had been expressly denied in the treaty of 1818 , nevertheless, subsequent lexgislation on the pant of hoth Camada and the L'nited States had so far modified that clause of the treaty that a liberal interpretation of the phrase in question would give full freedom to New England fishing vessels to purchase all needful supplies in Camarlian ports, and in general, to perform, withont let or hinclance, all acts necessary for refitting. It was contemled that in 1818 , when the treaty was made, commereial vessels of the Lnited States were absolutely prohibited from British Ameriean ports, and the privileges granted to tishing vessels in that year were exceptions to the rigid navigation laws of Great Britain. Since then, and notably by an act in 1830, and by the Imperial Shipping and Navigation A.t of 1849 , these restrictions upon Ameriean tommercial vessets were removed. With the removal therefore of all former disabilities upon trading vessels, were not the few remaining disabilities upon fishing vessels (imposer by the treaty of 1818) also removed? Gleat Britain replied that these disabilities had not been removed, as she had then drawn, and did now draw, a distinction between fishing and tratiung vessels. The former, she contented, had no commereial privileges whatever; and 
only with the understanding that they would not transport merehandise, they were aceorled, by most divilized nations, certain speeial immunities from larbor and port regulations. They carry no clearance papers or manifests, and are tree to eome and go at will. Trading vessels, on the other hand, are strietly held to these formalities. For the protection of revenue laws and to prevent illicit tracle, all tommercial vessels are obliged to eary ships papers that indicate clearly their ports of departme and destination, and an inventory of eirrgo as well. These laws are very stringent, and therefore if American fishing ressels desire to become merchant ressels also, they must comply with the usual regulations imposed upon merchant vessels.

For obvious reasons the eaptains of fishing schooners were unwilling to be burdened with ships grapers. The nature of their calling mate their movements more or less moertain, and to be obliged by their clearances to call at I Ialifax when St. John's halpened to be the more convenient port, womhl be an intolerable nuisance. The Druid of (iloncester, in 1886, furnished an eximple. With supplies for the Ameriean mackerel fleet she took ont clearance papers for Ilarbor de Bar in the Magdialen Islands: but finding later that the fleet she sought wats oft' l'rince Edward Island, she proceerled to that point, and disposing of her cargo of provisions, put into the nearest port, - which happened to be Malpecque, -

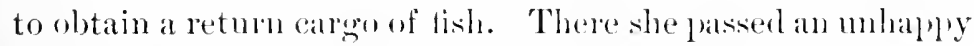
week in the toils of the revenue officials of that port.

As alleady mentioned (page 457). Comgress harl passed an aet in 1793 anthorizing fishing vessels to take out licenses to "toueh and trate" at any foreign jort, and to make purchases necessary for their own use withont heing suljected to the customs regulations of the Inited States. The form of this permit was not the silne as a elearance, lint was a doewment to be shown to rostoms olficers of home ports. in order to exempt the holiler from certinin customs luse. The argmment that the "tonch and trale" licenses were understoor as "conferring and receive on homel a rareno of merehamelist in the sane 
manner as if she were not engaged in the fisheries" was scarcely sound.

On the trial of the David .J. Adams, charged with purchasing bait and ice in contravention of the terms of the treaty of 1818 , the athiralty court in Halifax found some difficulty. because the Imperial Act of 1819, enforcing the provisions of the treaty of 1818, prescribed no penalty for such purchases, the only penalties mentioned being for "fishing and preparing to take fish" within the prohibited waters. To hold that buying bait was necessarjly for the purpose of "preparing to fisls" within prohibited waters was seireely logieal.

The real grievance of American fishermen, however, was in the aggrarating and needlessly severe port regulations of the Dominion, and also in the harsh mamer of their execution. One of these statutes was so framed that the captor was entitled to one-half the profits of confiscation, and the hurden of proof to show innocence practically fell upon the defendant captains. The pratice of purchasing bait and landing to transship cargoes, and the doing of numerons other acts necessarily comnected with the refitting of a ship, such as purchasing new water casks, material for mending nets or sails, were declared illegal. For these reasons, and often upon very slight pretexts, American vessels were detained to the great discomfiture and annoyance of the fishermen. It was rather, then, to the strained and unfriendly spirit manifested in the interpretation of their laws than to the laws thenselves that the Americans directed their complaints.

The camatians, on the other hand, charged that the Americans somphit, contrary to kaw, to use their ports as a base for fishing operations, and thus to exereise and enjoy in common, privileges which they woll knew had not been conceded to then. Having exhansted their own fisheries by overexploitatiom, replierl the Canalians, the Americans had demanded all the privileges of British subjects in Canadian waters, and furthermore they actually assumed and used them in defiance of treaty pohilitions, amb in perfeet contempt of all local 
regulations. The seizures of their ressels were comparatively few and far between, considering the persistency with which the Amerieans riolated their laws. For all privileges granted them, the Americans were unwilling to make any return. The Canadians reiterated their willingness to remove at any time the regulations so obnoxious to the American fishermen, and to grant them the fullest liberties in their ports, if the United States would but compensate them for sneh concessions. Their price, they saicl, was free Canadian fish into the Cnited States. but this the Amerieans who sought favors of them opposed with all their influenee in Congress.

A treaty with England was signed in Washington, February 15, 1888, providing for a eommission to designate and describe the British waters in which the Lnited States should enjoy full right to fish, and in like mamer to enumerate and state specifieally the harbor's and other waters in which such rights would thenceforth be rlenied. One artiele recited that whenever the Cnited States Govermment should remove the tariff duty upon the products of the Canadian fishery, then the privilege of entering all ports, harlwors, etc., of the Dominion coasts wonld be accorded Americans for the following purposes, namely :-

"1. The purehase of provisions, bait, ice, seines, lines, and all other supplies and ontfits.

"2. Transshipment of eatch, for tramsport by any means of conveyance.

"3. Shipping of crews."

The draft of treaty went to the Senate strongly reeommended by Presirlent ('leveland, but failed to betome law. Pending action by Congress, the following Modus Vivendi was agreed npon in February, $18 x-$, which by tateit consent has continuer to remain in foree by renewal eate year to the present time :-

1. For a period not exceeding two years from the present dite, the privilecere of entering the baves and harbors of the Atlantic

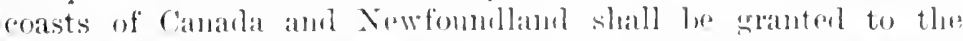
Uniter States fishimer vessels ly ammal licenses at a fee of s1.no per ton - for the following purposes: - 
The purchase of bait, ice, seines, lines, and all other supplies and outfits.

Transshipment of catch and shipling of crews.

2. If, during the continnance of this arrangement, the United States should remove the duties on fish, fish oil, whale and seal oil (and their coverings, prackages, etc.), the said licenses shall be issued free of charge.

3. Uniterl States fishing vessels entering the bays and harbors of the Athantic coasts of Canada or of Newfomdland for any of the four purposes mentioned in Article 1 of the convention of Gotober 20, 1s18, and not remaining therein more than twentyfour hours, shall not be recpuired to enter or clear at the custom house, proviling they do not commmicate with the shore.

4. Forfeiture to be exacted only for the offences of fishing or preparing to fish in territorial waters.

5. This arrangement to take effect as soon as the necessary measmres can be completed by the Colonial anthorities.

For the past twelve rears, therefore, the regulations governing the Canadian fisheries are those of the convention of 1818, as modified by the words of the Modus Vivendi of 18s. The arrangenent did not prove altogether satisfactor' at first to either party, and the continued suceessful operation of the plan depended largely upon the good-will and forbearance of both.

\section{$\mathrm{X}$}

Changing conditions in the methods of fishing have operated more largely in the last ten years to do away with the troublesome " fishery question" than have a century of diplomatic skirmishes. At the present moment those chronie differences of the fishrrmen seem to be almost forgotten, and until new and unforeseen complications arise, the whole matter will grobably remain at rest. The liability to further rupture with ('andala concerning these rights lies to-rlay rather in associated diplomatic questions still mosetthed betwen the two powers and in the adjustnent of which the fishery regulations are likely to be utilized in the shifting game of international prolities. The fishermen at least are satisfied with present conditions. Each year since 1888, and including the last, the Modus Vivendi has been renewed; 
and under its provisions American captains desiring the nse of Canadian ports for purposes of procuring bat, tramsshipping cargoes, purchasing provisions, refitting, ete., may purchase licenses at the cost of $\$ 1.50$, multiplied by the registered tomnage of the vessel. ${ }^{1}$

But each year the value of such privileges to our fishermen has been diminishing, and the rast majority of United states fishing vessels do not eare to avail themselves of them. In 1898, out of 1427 New England sehooners engaged in fishing, only 79 took ont lieenses, and the year before only to hought the right to enter Camadian ports for the purposes mentioned in the Modus Vivendi.

The inshore cod fishery of Cinadi, though still prosecuted by Canadians, has been wholly abandoned by Americans. The entire Ameriean fleet, which is equipled for cod and other "ground" fish, follows the Bank fishery. The nse of larger, faster and better equipped vessels, the earying of ice to pack away the cateh, the nse of ieed or salted bait, has almost totally obriated the necessity of tonehing at Canadian ports, and our fishermen dechare themselves to be

1 The form of license is as follows:-

(Name) (Master or Owner) of the

United states Fishing ressel tons recister, of having paid to the undersigneel, collector of Customs at the port of the sum of $\mathrm{S}$ , being one lollar and fifty entits per registered ton, the privilere is hereby cranted to said fishing vessel to enter the bays and harbours of the Atlantic coatsts of Canara, for the purchase of bait. ice, seines, lines and all othersuplies and outfits. and the transshipment of eateh, and slipping of erews.

This license shall contimue in foree for the year and is issued in pul-

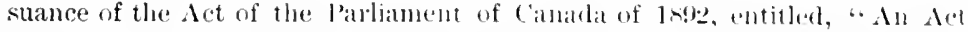

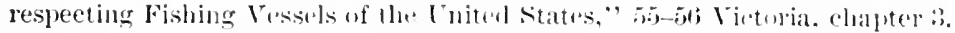

This license, while oonferring the alowe-mentioned privilenes, does now dispense with a due observanes by the holere, or any ofler persoll. of the laws of Canada, and will become null and roid. and forfeited forthwitl, and the vessel will heeome ineligible to oluain a lieense in future, if any unkms on supplies, or other alvantaces obtuinel heremuler are sold or transferred to any United States fishiuer vessel that has not ubtained a license.

Dated this day of

1.1. 1 . 89

Collector of customs at the l'ort of

For Minister of Marine and Fisheries. 
entirely independent of the rights or privileges which the Canadians have to offer.

By freezing their fares they are enabled to bring them home and to cure their fish upon American soil, thus doing away with one of the most aggravating causes of dispute in former years. Those American fishermen who resort more particularly to the Banks adjacent to Newfoundland admit the convenience of a license for using Canadian ports, especially in the contingency of prolonged unfavorable weather; but whatever may be the value of such privileges - even if male general and open to all — the fishermen are unanimous in the belief that they are not worth the price of free American markets to Camalian fish and fish products. Rather than suffer the great injury to their business, which they say free eompetition with the Canalians would cause, they woukl cheerfully forego the benefits given them by the Modus Vivendi.

As heretofore shown, the chief difficulties arising out of the fisheries in the last few years have been produced by the use of the purse seine. This method of fishing for mackerel was extensively followed by American skippers in the shallow waters of the Gulf of St. Lawrence, but the employment of these large nets was denounced by the Canadians upon the smpposition that it tended to scatter the seliools of fish, to interfere with their habits of breeding, and to cause them ultimately to abandon those waters. They alleged, therefore, that the use of this seine constituted an act contra bonos mores. Whether the Canadians were justified in those apprehensions or not, the Americans nevertheless continterl the prictice, basing their right to do so (beyom three miles from shore) upon the broad rights of mare libirum.

These proints of difference offered an excellent foundation for future diplomatic disturbances, but two causes happily apleared which no dombt prevented the matming of these seasonal quarrels into a mole serions international disagreement. The American fishermen legan of their own volition to abankm the use of the purse seine, and to retmon to the 
more primitive, but after all the more effective. method of "chumming"; secondly, the mackerel hegan to disappear from Canadian waters, in consequence of which, eateh succeeding year has found fewer American vessels in the Gulf of St. Lawrence. Since 1886, indeed, the matrerel have almost wholly aluandoned their former hamts in the (inlf of St. Lawrence, althongh reports of the present year give evidences that they are renewing their anmul migrations to the more northern station. However, the alnandonment of the purse seine has removed the prime anses of discord, and if the American mackerel fleet shomld resmme operations in - the Gulf, there is no speecial likelihood of conflict.

The northeast coast fisheries are in a most prosperous and flombing combition, as may be realized from the fatt that in 1899 the number of "ground fish" from the Banks (roxl. haddock, hake, ete., exchuling mackerel) landed at loston and Gloncester, amomited to $15.5,367.808$ pomols, valued at $\$ 3,525,268$. A substantial increase is thus shown over the business of the previons year, which amounted to 12.8.084.245 pounds, with estimated vatue of 2.55 .5010 . Reports for 1900 indicate that the fislueries are stealily ineleasing in value.

It is greatly to be hoped that the present regulations may continue in operation mulisturbed by the intrusion of other diplomatic issmes. 'Therein lies the chief danger of a perpetuation of this stubborn pritrrel of at century between the United States and Camala.

At last the American fislerman seems to be satisfierl, and the Canalian fisherman is equally withont antse of (omplaint. Time has reconciled disputes which the wistom of statesmen failerl to adjust, and it has suecessfully (romposed those questions which diplomacy conld not premanenty sulve. And thus the lesson is once more tanght that war postponed is the heginning of peace. Let it he hoperl that the eordial relations between the two great nations in interest thus cemonterl by time, may continne as long as time itself may last. 



\title{
The Peace Conference at the Hague and its Bearings on International Law and Policy
}

\author{
By FREDERICK W. HOLLS, D.C.L., \\ A Member of the Conference from the l'nuted State's of Amercia.
}

8vo Cloth $\$ 3.00$

Edward Everett Hale in The Forum says:-

"Mr. Holls's closing chapter is of profoumel interest and importance. In twenty pages, quite too few, he states "the bearings of the cinference upon International Law and Policy.' . . This masterly chapter should be studied not only in schools of law, but in all schools of the higher edlucation. fin we must all take care that the generation which created the Ilaguc conference shall comprehend its purpuse, and know what are its achievements. Mr. Holls truly says that it is most encouraging that on the continent of Europe the governments are in ackance of public opinion on the entre subject. In this country we must afl see to it that public opinion shall he thoroughly informed as to what has been done, and as to what is still pussible. For such a purpose we are already larsely melebted to the distinguinhed members of the conference, making their repurts each un his own way, Thus country and the world are vervesreatly indebted to Mr. llolls for the arlmira. ble narrative which we have severely condensed. which is destmed to take an important place in the written history of the civilized workt."

The London Times says:-

"No one was better qualified than Mr. F. W. IIolls to be the historian of the Peace Conference at the IIague. He has many qualifications for the task, being known in the Linited states as a contekential aclviser of Mr. YleKinley in regard to delicate questions of forcign affairs. The showed, as one of the American delegates at the llague, rare tact and ability. Reputations were made and unmale there. One of the few who distinctly increased the estimation in which they were held was the author of this rolume. Amoms the few defects in his history of the leace (onference at the llague is the fact that it does not make the reader molerstaml the large part which he himself took in the proceedings. . . But every one ought to le grateful for the elear statement of the course of the discussion and the cffect of the cunclusions."

The Outlook says :-

"This is a book of reference which the sturent of International Law must put in the tirst rank. Mr. Ilolls writes so interestingly, huwever, that the book is not too technical for the generai realer. Since the beginning of the Boer war much has been said pessimistically alout the resulis of the l'eace Conference at the Hague. It is now well to emphasize what the cunference did accomplish - in the corditication of the laws of war, in the building up of the body of international haw, above all, in the binding tegether of the nations into a federation for justice. The establishment of a permanent internationai court of arlitration is the great munument which will commemorate the Hague Conference. It will dissipate many prevalent misconceptions."

\section{THE MACMILLAN COMPANY}




\title{
THE CITIZEN'S LIBRARY OF ECONOMICS, POLITICS, AND SOCIOLOGY
}

\author{
UNDER THE GEXERAL EDITORSHIP OF \\ RICHARD T. ELY, Ph.D., LL.D. \\ Director of the School of Economics and Political Science; Professor \\ of Polntical Economy at the University of IVisconsin \\ 12mo. Half Leather. \$1.25, net, each
}

Tlonopolies and Trusts. By Richard T. Ely, Ph.D., LL.D.

"It is admirable. It is the soundest contribution on the subject that has appeared." - Professor Johx R. Commons.

"By all odds the best written of Professor Ely's work." - Professor Simon 1. Pattex, Lnizersity of Pennsyluania.

Outlines of Economics. By Richard T. Ely, Ph.D., LL.D., author of "Monopolies and Trusts," etc.

The Economics of Distribution. By JoHN A. HoBson, auther of "The Evolution of Modern Capitalism," etc.

World Politics. By Paul S. Reinsch, Ph.D., LL.B., Assistant Professor of Political Science, University of Wisconsin.

Economic Crises. By Edward D. Jones, Ph.D., Instructor in Economics and Statistics, University of Wisconsin.

Government in Switzerland. By John Martin Vincent, Ph.D., Associate Professor of History, Johns Hopkins University.

Political Parties in the United States, $1846=1861$. By Jesse MACr, LL.D., Professor of Political Science in Iowa College.

Essays on the Monetary History of the United States. By Charles J. Bullock, Ph.D., Assistant Professor of Economics, Williams College.

Social Control: A Survey of the Foundations of Order. By Eugar Aisworth Ross, Ph.D.

\section{THE MACMILLAN COMPAKY}

66 FIFTH AVENUE, NEW YORK 



University of British Columbia Library

\section{DATE DUE}

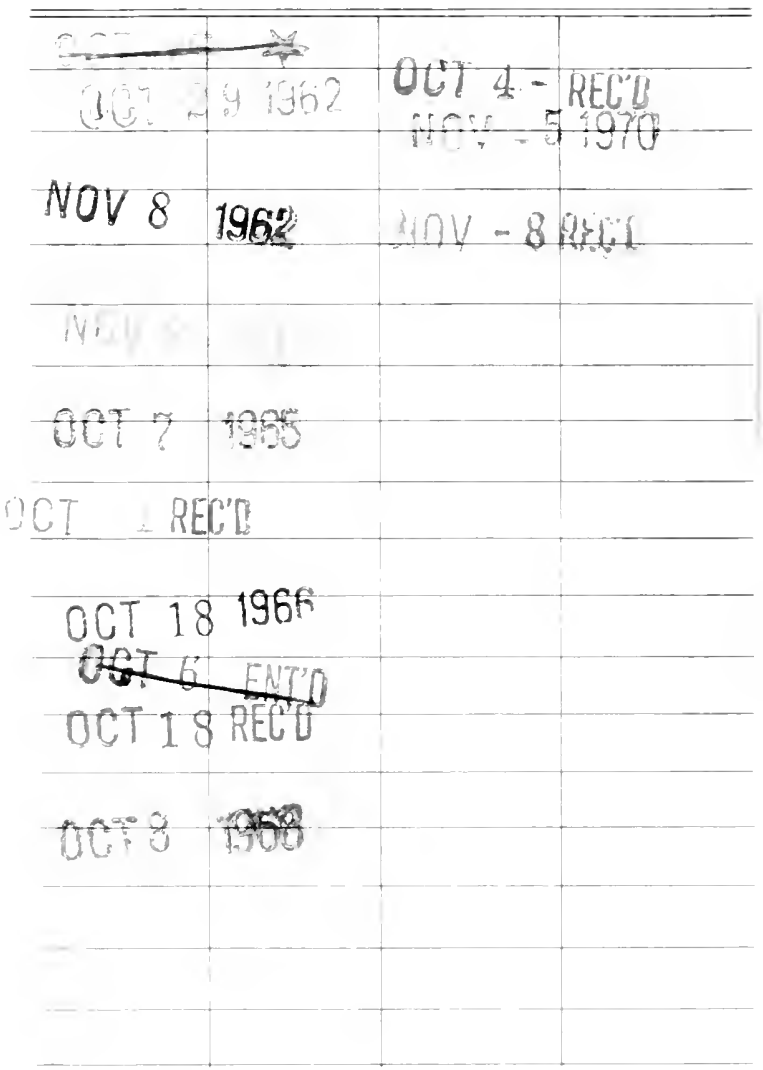

FORM No 310 

fis (2)

(19.

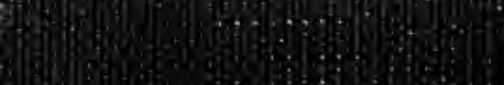

4.

Q

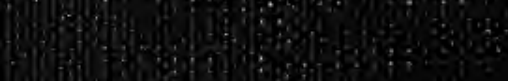

60

(1)

(4)

(2)

(1)

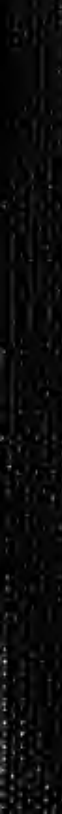

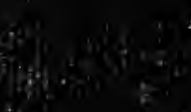

